\title{
Contested Justice
}

The Politics and Practice of

International Criminal Court

Interventions

Edited by Christian De Vos,

Sara Kendall and Carsten Stahn 


\section{CONTESTED JUST ICE}

The International Criminal Court emerged in the early twenty-first century as an ambitious and permanent institution with a mandate to address mass atrocity crimes such as genocide and crimes against humanity. Although designed to exercise jurisdiction only in instances where states do not pursue these crimes themselves (and are unwilling or unable to do so), the Court's interventions, particularly in African states, have raised questions about the social value of its work as well as its political dimensions and effects. Bringing together scholars and practitioners who work closely on the ICC, this collection offers a diverse account of its interventions: from investigations to trials and from the Court's Hague-based centre to the networks of actors who sustain its activities. Exploring connections with transitional justice and international relations, and drawing upon critical insights from the interpretive social sciences, it offers a novel perspective on the ICC's work in practice.

CHRISTIAN DE vos is an advocacy officer with the Open Society Justice Initiative.

SARA KENDALL is a lecturer in international law at the University of Kent, Canterbury. She also co-directs Kent Law School's Centre for Critical International Law.

CARSTEN STAHN is Chair of International Criminal Law and Global Justice at Leiden University and Programme Director of the Grotius Centre for International Studies, The Hague. 


\title{
CONTESTED JUST ICE
}

The Politics and Practice of International Criminal Court Interventions

\author{
Edited by \\ CHRISTIAN DE VOS, SARA KENDALL \\ AND CARSTEN STAHN
}




\section{CAMBRIDGE \\ UNIVERSITY PRESS}

University Printing House, Cambridge CB2 8BS, United Kingdom

Cambridge University Press is part of the University of Cambridge.

It furthers the University's mission by disseminating knowledge in the pursuit of education, learning and research at the highest international levels of excellence.

www.cambridge.org

Information on this title: www.cambridge.org/9781107076532

(c) Cambridge University Press 2015

This work is in copyright. It is subject to statutory exceptions and to the provisions of relevant licensing agreements; with the exception of the Creative Commons version the link for which is provided below, no reproduction of any part of this work may take place without the written permission of Cambridge University Press.

An online version of this work is published at

[http://dx.doi.org/10.1017/CBO9781139924528] under a Creative

Commons Open Access license CC-BY-NC 4.0 which permits re-use, distribution

and reproduction in any medium for non-commercial purposes providing appropriate credit to the original work is given and any changes made are indicated. To view a copy of this license, visit https://creativecommons.org/licenses/by-nc/4.0.

All versions of this work may contain content reproduced under license from third parties. Permission to reproduce this third-party content must be obtained from these third-parties directly.

When citing this work, please include a reference to the DOI 10.1017/CBO9781139924528

First published 2015

A catalogue record for this publication is available from the British Library

Library of Congress Cataloguing in Publication data

Contested justice : the politics and practice of the International Criminal Court interventions / edited by Christian De Vos, Sara Kendall, Carsten Stahn.

pages $\mathrm{cm}$

Includes papers presented at a conference 'Post-Conflict Justice and Local Ownership' at The Hague in May 2011. - Asknowledgments.

ISBN 978-1-107-07653-2 (hardback)

1. International Criminal Court. 2. International criminal courts. 3. Criminal justice, Administration of. I. Vos, Christian M. de, editor. II. Kendall, Sara, editor. III. Stahn, Carsten, 1971- editor.

KZ7312.C658 2015

$345^{\prime} .01-\mathrm{dc} 23$

2015026746

ISBN 978-1-107-07653-2 Hardback

Cambridge University Press has no responsibility for the persistence or accuracy of

URLs for external or third-party internet websites referred to in this publication, and does not guarantee that any content on such websites is, or will remain, accurate or appropriate. 


\section{CONTENTS}

List of contributors page viii

Foreword by Ruti G. Teitel xv

Acknowledgements xviii

Citing this work $\mathrm{xx}$

Introduction 1

CHRISTIAN M. DEVOS, SARA KENDALL

AND CARSTEN STAHN

PART I Law's shape and place 21

1 In whose name? The ICC and the search for

constituency 23

FRÉDÉRIC MÉGRET

2 Justice civilisatrice? The ICC, post-colonial theory, and faces of 'the local' 46

CARSTEN STAHN

3 The global as local: the limits and possibilities of integrating international and transitional justice

85

DAVID S. KOLLER

4 Bespoke transitional justice at the International Criminal Court 106

JAYA RAMJI-NOGALES

5 A synthesis of community-based justice and complementarity 122

MICHAELA. NEWTON 
PART II Reception and contestation 145

6 In the shadow of Kwoyelo's trial: the ICC and complementarity in Uganda 147 STEPHEN OOLA

7 A story of missed opportunities: the role of the International Criminal Court in the Democratic Republic of Congo 171 PASCAL KALUME KAMBALE

8 The justice vanguard: the role of civil society in seeking accountability for Kenya's post-election violence 198 NJONJO MUE AND JUDY GITAU

9 'They told us we would be part of history': reflections on the civil society intermediary experience in the Great Lakes region 219

DÉIRDRE CLANCY

PART III Practices of inclusion and exclusion

10 Challenges and limitations of outreach: from the ICTY to the ICC 251 MATIAS HELLMAN

11 'We ask for justice, you give us law': the rule of law, economic markets and the reconfiguration of victimhood 272

KAMARI MAXINE CLARKE

12 Refracted justice: the imagined victim and the International Criminal Court 302

LAUREL E. FLETCHER

13 Reparations and the politics of recognition PETER J. DIXON

14 Beyond the restorative turn: the limits of legal humanitarianism 
PART IV Politics and legal pluralism 377

15 All roads lead to Rome: implementation and domestic politics in Kenya and Uganda 379

CHRISTIAN M. DE VOS

16 Applying and 'misapplying' the Rome Statute in the Democratic Republic of Congo 408 PATRYK I. LABUDA

17 Beyond the 'shadow' of the ICC: struggles over control of the conflict narrative in Colombia 432 JENNIFER EASTERDAY

18 Between justice and politics: the ICC's intervention in Libya 456 MARK KERSTEN

19 Peace making, justice and the ICC 479 JUAN E. MÉNDEZ AND JEREMY KELLEY Index 496 


\section{CONTRIBUTORS}

DÉIRDRE CLANCY serves as the humanitarian expert for the UN Monitoring Group on Somalia and Eritrea. She was previously the co-director and co-founder of the International Refugee Rights Initiative (IRRI), headquartered in Kampala, Uganda. Prior to founding IRRI she held positions at Human Rights First in New York, the Council of Europe and the Irish Refugee Council. Deirdre holds an LLB from Trinity College and a master's degree in Human Rights and Democratisation (University of Padova, Italy/Robert Schumann University, Strasbourg, France).

KAMARI MAXINe ClaRke is Professor at Carleton University in

Global and International Studies. Her research explores issues related to legal institutions, religious nationalism, human rights and international law, the interface between culture, power and globalization, and their relationships to history, politics and power. Her many publications include Fictions of Justice: The International Criminal Court and the Challenge of Legal Pluralism in Sub-Saharan Africa (Cambridge University Press, 2009), as well as Mirrors of Justice: Law and Power in the Post-Cold War Era (Cambridge University Press, 2014), a collection co-edited with Mark Goodale. She has held numerous prestigious fellowships, grants and awards, including grants from the Ford Foundation (2003), the Wenner-Gren Foundation and a highly competitive grant from the National Science Foundation (2012).

C H R I S T I A N DE V O S is an advocacy officer with the Open Society Justice Initiative. Previously, he was a $\mathrm{PhD}$ researcher at the Grotius Centre for International Legal Studies and a law clerk with the Legal Affairs Office of the United States Court of Appeals for the Second Circuit. He has also held research positions with the United States Institute of Peace and the War Crimes Research Office. Christian received his $\mathrm{PhD}$ from Leiden University and his JD from the American University Washington College of Law. He is a member of the bar of the State of New York and a term member of the Council on Foreign Relations. 
PETER DIX ON is a fellow at the Harvard Humanitarian Initiative. He is a $\mathrm{PhD}$ candidate in sociology at the University of California, Berkeley, from which he also received his MA. Previously, he worked as a research fellow in monitoring and evaluation at the International Criminal Court's Trust Fund for Victims and conducted dissertation research in The Hague and the Democratic Republic of the Congo.

Jennifer easterday is a PhD researcher for the 'Jus Post Bellum' project at Leiden University. She is also a trial monitor and consultant for the Open Society Justice Initiative and previously worked for several international NGOs working on issues of international justice and human rights. Jennifer received her JD from the University of California, Berkeley School of Law, and is a member of the California State Bar.

LA UREL E. FLetCher is Clinical Professor of Law at the University of California, Berkeley, School of Law. Before joining the Berkeley Law faculty in 1998, she practised complex civil litigation, including representing plaintiffs in employment discrimination class actions. Her work focuses on transitional justice and humanitarian law, as well as globalization and migration. She is Co-Editor-in-Chief of the International Journal of Transitional Justice, author of numerous articles and lead-author of The Guantanamo Effect (2009), together with Eric Stover.

JUDY GITAU currently works as Technical Advisor on Transitional Justice for a Justice Sector Development Project in Somaliland. She previously worked as a programme officer with the Kenyan Section of the International Commission of Jurists managing projects that promoted and improved human rights protection in Kenya and the Eastern Africa region. She is an Advocate of the High Court of Kenya and a member of the Kenyan Chartered Institute of Arbitrators. She read Law at the University of Nairobi and holds an LLM in International Human Rights Law from Oxford University.

matias hellman is External Relations Adviser at the Presidency of the International Criminal Court, where he facilitates the Court's high-level interaction with states, international organizations and civil society. He was the first field outreach officer recruited to the International Criminal Tribunal for the Former Yugoslavia (ICTY) and later conducted outreach activities as Registry Liaison Officer in Bosnia and Herzegovina and in Serbia; in 2008 he was appointed the ICTY's first Legacy Officer. Hellman holds an LLM (with distinction) in International Human Rights Law from the University of Essex and 
an MA in Slavic Languages and Cultures from the University of Helsinki.

PASCAL KA M B ALE is Senior Advisor in the Open Society Foundations' Africa Regional Office and leads its international justice work. He previously served as Deputy Director of the Open Society Foundations' Africa Governance, Monitoring and Advocacy Project and, from 1999 to 2005, as International Justice Counsel with Human Rights Watch. A former member of the Congolese Law Reform Commission and of the Commission of Investigation into PostElection Violence in Kenya, Kambale was called to the Kinshasa Bar in 1989. He is a graduate of the University of Kinshasa and Harvard Law School.

JEREMY KELLEY currently clerks for Honourable Thomas O. Rice on the US District Court for Eastern District Washington. He graduated magna cum laude from the American University Washington College of Law in 2013.

SARA KENDALL is Lecturer in International Law at the University of Kent, where she co-directs the Centre for Critical International Law. She holds a doctorate from the University of California, Berkeley. She has previously taught at the University of Amsterdam and at Leiden University, where she participated in a multi-year research project on the ICC at Leiden's Grotius Centre for International Legal Studies. Her research draws upon insights from the humanities and the interpretive social sciences to explore the work of the international legal order, and her publications have addressed issues in international criminal law and efforts to address state violence through international law more broadly.

MARK KERSTEN is a researcher, consultant and teacher at the London School of Economics and the School of Oriental and African Studies. He has worked with a number of organizations focused on international justice, including the Refugee Law Project, Lawyers for Justice in Libya and Justice Africa. He is currently consulting for the Wayamo Foundation on a project pertaining to the domestic prosecution of international and transnational crimes in Kenya. Mark is also the creator and author of the blog 'Justice in Conflict'.

DAVID KOLLER is Legal Officer with the UN Management Evaluation Unit in the Office of the Under-Secretary-General for Management. He previously served as Special Assistant to Presidents Philippe Kirsch and Sang-Hyung Song of the International Criminal Court and as Legal Officer in the ICC Appeals Chamber. David holds a JD from 
New York University School of Law and is a member of the bar of the State of New York.

PATRYK LABUDA is a PhD candidate at the Graduate Institute of International and Development Studies in Geneva. He previously worked as a research fellow in Sudan and South Sudan for the Max Planck Institute for Comparative Public Law and International Law (currently the Max Planck Foundation for International Peace and the Rule of Law) and, before that, with the European Union's Police Mission in the Democratic Republic of Congo. Patryk holds an LLM from Columbia Law School and degrees in law and history from Adam Mickiewicz University.

FRÉDÉRIC MÉGReT is Associate Professor at the Faculty of Law, McGill University. He also holds the Canada Research Chair in the Law of Human Rights and Legal Pluralism and is affiliated with the McGill Centre of the same name. Since September 2012 he has been Associate Dean for Research. He holds an LLB from King's College London, a DEA from the Université de Paris I and a PhD from the Graduate Institute of International Studies (Geneva), as well as a diploma from Sciences Po Paris. His work focuses on some of the theoretical dimensions of international law, international criminal justice, international human rights law and the laws of war.

JUAN E. MÉNDEZ is Visiting Professor of Law at the American University Washington College of Law and the author (with Marjory Wentworth) of Taking A Stand: The Evolution of Human Rights (2011). As of November 2010, he serves as the UN Special Rapporteur on Torture and Other Cruel, Inhuman and Degrading Treatment or Punishment. He was Special Advisor to the Prosecutor of the International Criminal Court. He was also CoChair of the International Bar Association Human Rights Institute from 2010 to 2011. Until May 2009, he was President of the International Center for Transitional Justice (ICTJ). Concurrent with his duties at ICTJ, the Honourable Kofi Annan named Méndez his Special Advisor on the Prevention of Genocide, a task he performed from 2004 to 2007.

N JONJO MUE is a program advisor to Kenyans for Peace with Truth and Justice. He previously worked as Africa Deputy Director for the International Center for Transitional Justice and Head of Advocacy at the Kenyan National Commission on Human Rights. He is an advocate of the High Court of Kenya, having read law at the University of Nairobi and Oxford University. 
michael a. New ton is Professor of the Practice of Law at Vanderbilt University Law School. He has published more than 80 books, articles and book chapters. He formerly taught at the United States Military Academy at West Point and at the Judge Advocate General's School and Center. He has written extensively about use of force issues, international jurisprudence and the enforcement of international law. STEPHEN Oola heads the Conflict, Transitional Justice and Governance Program at the Refugee Law Project (RLP), based at the Makerere University School of Law, Kampala. He previously headed the Research and Advocacy Department at RLP from 2010 to 2012 and led the drafting of Uganda's proposed National Reconciliation Bill, in addition to participating in drafting the proposed African Union Transitional Justice Policy Framework. He is currently a member of the Advisory Committee for the African Commission on Human and Peoples' Rights Transitional Justice Study in Africa. Stephen holds an LLB (Hons) degree from Makerere University and an MA in International Peace Studies from the University of Notre Dame.

Jaya Ramji-nogales is I. Herman Stern Professor of Law and CoDirector of the Institute for International Law and Public Policy at Temple University's Beasley School of Law. Her transitional justice scholarship focuses on process and institutional design. She received her JD from the Yale Law School, her LLM with distinction from Georgetown University Law Centre and her BA with highest honours and distinction from the University of California at Berkeley.

CARSTEN STAHN is Professor of International Criminal Law and Global Justice at Leiden University and Programme Director of the Grotius Centre for International Legal Studies (The Hague). He has previously worked as Legal Officer in Chambers of the International Criminal Court (2003-2007) and as Research Fellow at the Max Planck Institute for Comparative Public Law and International Law (2000-2003). He is the author of The Law and Practice of International Territorial Administration: Versailles to Iraq and Beyond (Cambridge University Press, 2008/2010), which received the Ciardi Prize 2009 of the International Society for Military Law and the Law of War. He has edited numerous collections in the field of international criminal justice and directs research projects on 'Jus Post Bellum' and 'PostConflict Justice and Local Ownership', funded by the Netherlands Organization for Scientific Research (NWO).

RUti teitel is Ernst C. Stiefel Professor of Comparative Law at New York Law School, where she serves as Chair of the Global Law and 
Justice Colloquium and co-directs the Institute for Global Law, Justice and Policy. She is also a visiting professor at the London School of Economics. She is the author of Globalizing Transitional Justice (2014), Humanity's Law (2011) and Transitional Justice (2000), as well as numerous articles on comparative law, human rights, international law and constitutionalism. She has taught at Yale, Fordham and Tel Aviv's law schools as well as at Columbia University's Politics department and School of International and Public Affairs, where she is currently a distinguished research scholar. She is a life member of the Council on Foreign Relations. A graduate of Georgetown University, she received her JD from Cornell Law School. 


\section{FOREWORD}

This timely, perceptive book brings together leading scholars and practitioners to reflect on the field of international criminal justice through focusing on a singular institution: the International Criminal Court (ICC). Drawing on a range of experience, empirical work, and normative theory, it seeks to come to grips with a remarkable development - the creation of a permanent, international court meant to adjudicate mass crimes - through assessing the ICC's work in practice, given now more than a decade of experience to explore.

The ICC is a clear innovation in global governance. A relatively new legal institution, it was intended as an evident departure from past exceptional tribunals associated with particular conflicts. Generally created post-conflict, and therefore lacking the regularity of the rule of law, these tribunals were different in kind from the ICC - ad hoc, temporary, and often criticized as 'victors justice'. Moving beyond the either/or dichotomies of the last century, one can see that the Court - through its Trust Fund for Victims as well as its concern for victim participation also presages a move from the single-minded focus on grave human rights violations to broader issues of security and care provision. In a number of chapters, the volume shows the ways that the ICC's goals extend beyond remedying human rights violations by also responding to human suffering.

Characteristic of this global phase of justice, we have seen a normalizing of 'judicialization' - at once non-exceptional, yet also designed to be independent from regular domestic institutions of judgment associated with and supported by political communities. Given these twin changes of adjudicatory processes that are increasingly pervasive, but also the centralizing of international judgment in one body - how are we to understand the meaning of an institution like the ICC, a new permanent international actor? How are we to evaluate its contribution to broader justice projects? And what are we to make of the proliferation and ongoing judicialization of transitional justice under way, where courts 
and legal processes increasingly appear to be at the field's normative centre?

This broader question could be seen as one of the questions this book seeks to answer. Its aim, as the Introduction sets out, is to 'pay attention to the effects that international judicial interventions have had upon the communities and the structures where grave crimes have occurred'. It reviews the phenomena in depth and in a way that has not yet been done. For while there have not yet been a large number of completed trials at the ICC, this book does not limit itself to judgment alone; rather, it addresses the panoply of forms that judicial interventions may take, moving the reader from initial phases of intervention involving 'politics and legal pluralism' to 'reception and contestation'.

What this volume illuminates is that neither the Court's purposes nor its parameters seem to be purely or quintessentially international, in the sense of an institution that regulates interstate relations. Rather, it is more ambitiously global, an example of globalized justice associated with political change in the contemporary moment. Indeed, as the Introduction makes clear, what is remarkable about the ICC is that there is an openness, a porousness to its work - from the many actors that are part of its operation, to its presence in multiple contexts - that is unique. Added to this is the critical jurisdictional feature known as complementarity, an admissibility criterion with the normative objective of accounting for state sovereignty. From the start, then, the ICC was designed to have a more fluid relationship with the domestic than any prior international court or tribunal.

This volume takes up some of the most difficult cases for complementarity, including Colombia, which has been operating its own justice mechanisms for some time, and Libya, which faces its own increasingly difficult transition. Often the authors conclude with a preference for the local, but the book's ambition - to understand the ICC in context means this is not in just one place but rather in the multiple countries in which the Court operates, for multiple audiences, and with multiple aims. The Court's goals may sometimes be harmonious with these ends, but other times they may equally clash. From what perspective, then, are we to evaluate what the ICC is doing? Domestic, regional or international security? The needs of the political transition, of conflictaffected communities, or of 'local' priorities more broadly? It is clear that the turn to the Court is not a static matter; however, the goal is less about judging the ICC than about understanding what its interventions contribute to a post-Cold War, global world. 
In addition to responsiveness to context, we need to understand the ways in which the Court and its legal discourse have themselves become part of the global security context. From the UN General Assembly's referral of North Korea to Palestinian ratification of the ICC, one can see that we need to address the changing law and politics on offer and recognize that, at a time of ongoing transition and conflicts with global impact, there is a heightened demand for accountability and a shared discourse of legality. Indeed, some might say these dimensions reflect the globality that allows us to best comprehend the ambition of the Court's goals as well as the nature of the problems it has confronted.

This volume - through its self-reflexivity and its self-consciousness about this new institutional engagement with justice - offers a critical perspective on these developments. Ultimately, the research presented here can be seen to redirect scholars and practitioners in international law and transitional justice. Its insights will surely help transform the questions currently being raised regarding the normative role of international criminal justice, as mediated by bureaucratic and political actors, in foreign affairs today. Seen from this reconceived vantage point, international punishment constitutes more than one remedy or instrument among many - rather, it offers processes, institutions and a language of the rule of law by which to balance diverse goals and to attempt to reconcile political upheavals and social transformations. This appeals in a global world that lacks political integration, but where law and legality are increasingly its lingua franca.

As this insightful book works through its diverse case studies, its illustration of the many ways in which the ICC operates may ultimately function as a hermeneutic for revealing the unique character of this institution in context. But it also enables a reframing, where one can see the space that the Court occupies in international affairs and the shared normativity it offers, in the evolving language of international law and politics. 


\section{ACKNOWLEDGEMENTS}

This volume is the result of a collaborative research project on the social and legal effects of the work of the International Criminal Court. Based at Leiden University's Grotius Centre for International Legal Studies, the project analyses the impact and effects of ICC interventions through drawing upon insights from multiple scholarly fields. Some of the contributions to this volume are based on discussions held at the project's inaugural conference, 'Post-Conflict Justice and Local Ownership', which took place in The Hague in May 2011. The conference and the project were made possible with the generous support of the Netherlands Organization for Scientific Research (NWO).

We would like to thank the contributors to this collection for their efforts to rethink existing narratives and conventional presumptions in international criminal justice. We also wish to express our gratitude to the many interlocutors who gave generously of their time and wisdom in Kenya, Uganda, the Democratic Republic of Congo, and the Netherlands, including several of the volume's contributors. Their insights into the workings of the ICC in practice helped to inform many of the claims contained here. Although our debts to individuals are too numerous to list, particular thanks are due to Josephine Atim, Maria Kamara, George Kegoro, Sarah Kihika, Betty Murungi, Godfrey Musila, Sharon Nakandha, Gabriel Oosthuizen, Michael Otim, Ronald Slye, Muthoni Wanyeki and Marcel Wetsh'okonda Koso.

This work would not have been possible without the support of the Grotius Centre for International Legal Studies, which hosted the project. Valuable insights from Larissa van den Herik and Marieke Wierda, both Leiden colleagues and project collaborators, have contributed to shaping the work contained in this volume. We also wish to thank the members of the project's steering committee - Barney Afako, Phil Clark, Refik Hodzic, Sally Engle Merry, Juan Mendez, Victor Peskin, Eric Stover and Ruti Teitel - who have followed this work since the project's inception. We are particularly grateful to Luca Ferro, Madeleine Gorman, 
Teodora Jugrin and Yang Xie for their valuable editorial assistance in the finalization of the manuscript.

At Cambridge University Press, we would like to thank Finola O'Sullivan, Elizabeth Spicer and Richard Woodham for supporting this project and ensuring publication of the volume.

We hope that this work will contribute to broader discussions about the work of international criminal law across scholarly disciplines.

The Editors 


\section{CITING THIS WORK}

As per the provisions of section 3.a.I.A.i of the CC BY-NC license, when attributing this work, we request that you reproduce the following elements in your citation: De Vos, Kendall and Stahn (eds.), Contested Justice: The Politics and Practice of the International Criminal Court Interventions (Cambridge University Press: 2015) and the URL http://dx.doi.org/10.1017/CBO9781139924528. If a derivative, you should acknowledge this fact. Although we cannot legally enforce it under the license, we would be grateful if you would summarise any changes made in a derivative. 


\title{
Introduction
}

\author{
CHRISTIAN M. DE VOS, SARA KENDALL AND CARSTEN STAHN
}

International criminal law and its institutions have expanded dramatically over the past two decades, a growth that has been reflected in the related fields of international human rights law and transitional justice. Much early writing on the field of international criminal law focused on its growing body of jurisprudence and its institutional developments, yet less attention has been paid to the effects that international judicial interventions have had upon the communities and state structures where grave crimes have occurred. Similarly, while claims have proliferated among proponents and observers that the field contributes to certain normative goods - the lessening or prevention of conflict, the re-establishment of the rule of law and the alleviation of suffering within conflict-affected communities - few of these ambitious claims have been subjected to grounded inquiry or critical analysis.

Over the past decade, however, an emerging body of literature has sought to situate the work of international criminal law in historical, political and cultural contexts, with critical interventions from scholars in related fields, including socio-legal scholars, political scientists and anthropologists. Much of this scholarship has focused on the work of the ad hoc tribunals for the former Yugoslavia (International Criminal Tribunal for Former Yugoslavia; ICTY) and Rwanda (International Criminal Tribunal for Rwanda; ICTR),

${ }^{1}$ For studies on the impact of ICTY, see, e.g.,S. Ivković and J. Hagan, Reclaiming Justice: The International Tribunal for the former Yugoslavia and Local Courts (Oxford: Oxford University Press, 2011); B. Swart, A. Zahar, and G. Sluiter (eds.), The Legacy of the International Criminal Tribunal for the Former Yugoslavia (New York: Oxford University Press 2011); D. Orentlicher, That Someone Guilty Be Punished: The Impact of the ICTY in Bosnia (New York: Open Society Justice Initiative, 2010); L. Nettelfield, Courting Democracy in Bosnia and Herzegovina: The Hague Tribunal's Impact in a Postwar State (Cambridge: Cambridge University Press, 2010). On the ICTR, see M. Drumbl, Atrocity, Punishment, and International Law (New York: Cambridge University Press, 2007); K. Moghalu, Rwanda's Genocide: The Politics of Global Justice (New York: Palgrave MacMillan, 2005); E. Stover and H. Weinstein (eds.), My Neighbor, 
both now nearing the end of twenty-year trajectories, as well as the Special Court for Sierra Leone, ${ }^{2}$ which ceased active operations in 2013. Scholars have also begun to focus critically on the work of the International Criminal Court (ICC), the sole permanent body where genocide, war crimes and crimes against humanity are judged and punished. ${ }^{3}$

This volume builds upon this body of literature by offering a grounded critique that focuses exclusively on the institutional site of the ICC and its work in situation countries. Drawing upon field- and practice-based accounts that illustrate the effects of the Court's interventions, it brings together contributions from scholars and practitioners within and outside the field of international criminal law to offer a sustained focus on the work of the ICC, with a particular emphasis on its work in domestic contexts. With this emphasis, the collection seeks to unsettle the predominantly 'Hague-centric' view of the production of international criminal justice where doctrine and jurisprudence have been at the normative centre by critically reflecting on the ICC's multiple and competing constituencies, its translation and reception at national and local levels and the sociopolitical effects of its work in the states and communities where it has intervened.

\section{The ICC's novelty}

Established in 2002, the ICC is often read as a novel development in the field of international criminal law. As a treaty-based institution, it has the

My Enemy: Justice and Community in the Aftermath of Mass Atrocity (Cambridge: Cambridge University Press, 2004). For an account of state cooperation in relation to both tribunals, see V. Peskin, International Justice in Rwanda and the Balkans: Virtual Trials and the Struggle for State Cooperation (Cambridge: Cambridge University Press, 2009).

2 C. Jalloh (ed.), The Sierra Leone Special Court and Its Legacy: The Impact for Africa and International Criminal Law (Cambridge: Cambridge University Press, 2014); T. Kelsall, Culture Under Cross-Examination: International Justice and the Special Court for Sierra Leone (Cambridge: Cambridge University Press, 2009).

${ }^{3}$ S. Nouwen, Complementarity in the Line of Fire: The Catalysing Effect of the International Criminal Court in Uganda and Sudan (Cambridge: Cambridge University Press, 2013); C. Schwöbel (ed.), Critical Approaches to International Criminal Law: An Introduction (London: Routledge, 2014). Literature from outside the field of international criminal law that has taken up more critical perspectives on the ICC includes: D. Bosco, Rough Justice: The International Criminal Court in a World of Power Politics (Oxford: Oxford University Press, 2014); A. Branch, Displacing Human Rights: War and Intervention in Northern Uganda (Oxford: Oxford University Press, 2011); K.M. Clarke, Fictions of Justice: The International Criminal Court and the Challenge of Legal Pluralism in Sub-Saharan Africa (Cambridge: Cambridge University Press, 2009); T. Allen, Trial Justice: The International Criminal Court and the Lord's Resistance Army (London: Zed Books, 2006). 
potential to exercise territorial jurisdiction in all states that accept its authority, in addition to the exceptional jurisdiction it enjoys through referrals from the UN Security Council. The Rome Statute, the Court's founding treaty, grants it subject-matter jurisdiction over 'the most serious crimes of international concern', a number of which are defined by the Statute in unparalleled detail. Furthermore, unlike its ad hoc predecessors for Rwanda and the former Yugoslavia, which enjoyed primacy over domestic jurisdictions, the ICC is designed to complement domestic investigations and prosecutions. Referred to as 'complementarity', this constraint on admitting situations before the ICC is a defining feature of the Court's architecture. It results from a number of factors, including the Court's institutional design, its limited resources and the acknowledged role of domestic legal orders in bringing more proximate forms of criminal accountability.

While complementarity is technically understood as an admissibility principle, 'positive' complementarity is a more expansive conception that calls upon the Court and other actors to encourage and assist national legal bodies in investigating and prosecuting crimes of an international character. ${ }^{4}$ The vision is illustrated by the first prosecutor Luis MorenoOcampo, who notably argued that ' $\mathrm{t}]$ ] he effectiveness of the International Criminal Court should not be measured by the number of cases that reach the Court. On the contrary, the absence of trials by the ICC, as a consequence of the effective functioning of national systems, would be a major success. ${ }^{5}$ This has aroused debate as to whether the ICC, rather than states, should be called upon to develop domestic capacity for trying international crimes.

The mandates of judicial institutions often encompass a variety of goals and objectives; however, the ICC's are particularly ambitious. The Court's intended relationship with conflict-affected communities is another aspect that distinguishes its work: as an ICC guidebook explains, 'victims at the ICC enjoy rights that have never before been incorporated

${ }^{4}$ On the evolution and various interpretations of complementarity, see C. Stahn and M. El Zeidy (eds.), The International Criminal Court and Complementarity: From Theory to Practice (New York: Cambridge University Press, 2011).

5 'Paper on some policy issues before the Office of the Prosecutor', ICC Office of the Prosecutor, September 2003, 4. On 'positive complementarity', see W.B. White, 'Proactive Complementarity: The International Criminal Court and National Courts in the Rome System of International Justice', Harvard International Law Journal, 49 (2008), 53-108; C. Stahn, ' Complementarity: A Tale of Two Notions', Criminal Law Forum, 19 (2008), 87-113. 
in the mandate of an international criminal court'. ${ }^{6}$ Towards this end, the Statute attempts to provide greater recognition to communities through a complex regime of victim participation and the prospect of reparations. The Court's affiliated Trust Fund for Victims is also mandated with implementing Court-ordered reparations, as well as with supporting medical and livelihood assistance programs to conflict-affected communities. The Court's work extends beyond judgment and punishment, and it seeks to incorporate restorative dimensions that bring it more explicitly into a relationship with the field of transitional justice.

The ICC's institutional structure is designed with a degree of porousness that is unusual for a criminal court: civil society actors as well as conflict survivors are brought into its formal operations, and domestic judicial activity plays a role in determining whether or not cases are admissible. ${ }^{7}$ Spaces of discretion are built into the Rome Statute as well. The Court's ability to assesses whether a state is 'able or willing' to prosecute those individuals brought before it, or the prosecutor's ability to take into account 'the interests of justice' in determining whether to investigate or prosecute, provides important openings to contextual and extra-legal considerations.

Finally, the network of actors drawn into the ICC's orbit is uniquely expansive. Its work engages international political entities such as the UN Security Council; the Assembly of States Parties, the Court's governing body of member states; and a vast array of civil society actors, ranging from international non-governmental organisations (INGOs) to domestic and local community-based organisations. The Court's decisions and policies also have implications that intersect with those of donor states, UN bodies, and NGOs working in post-conflict responses, development and domestic institutional reform. The multiple ways in which the Court's jurisdiction can be triggered - through state referral, UN Security Council resolution and the prosecutor's exercise of proprio motu powers - further engage a broad set of actors and institutions involved in practices of global governance.

The diverse actors who interact with and influence the work of the Court form broader assemblages of agency, affecting the terms and institutions through which conflicts are addressed and expanding the

${ }^{6}$ See ICC, 'Victims Before the International Criminal Court: A Guide for the Participation of Victims in the Proceedings of the Court'.

7 F. Jessberger and J. Geneuss, 'The Many Faces of the International Criminal Court', Journal of International Criminal Justice, 10 (2012), 1081-1094. 
role of international criminal law in the global imagination. ${ }^{8}$ But how do the various aspects of the Court's architecture operate in practice? Does the ICC actually supplement national jurisdictions, as is often described, or might it instead supplant them? Does it defer to domestic initiatives, or does it seek to influence the terms and institutional forms through which they are carried out? To what extent - and with what effects - does the Court rely upon in-country actors to sustain its work? How does the ICC operate as a site of normative production, disseminating views and values concerning what an appropriate response to conflict should entail? How does it influence the legal discourse of criminal justice, as well as national political priorities in the states where it intervenes?

\section{ICC interventions and their effects}

While political dimensions of the Court's work are frequently downplayed in ICC discourse and practice, ${ }^{9}$ many of its actions and policies can be interpreted in light of how they allocate and diffuse different forms of power. In some situations the Court exercises what might be termed 'compulsory power'. The most classical example of this is the exercise of direct control by the ICC over individuals, including the detention of persons or efforts to protect witnesses and victims. In these areas, ICC authority appears as a surrogate of state power and is most vulnerable to criticisms that include the violation of human rights norms or the lack of democratic accountability. Yet in practice the Court is highly dependent upon states and other entities to assist it in executing arrest warrants and carrying out its in-country work.

The Court has developed alternate channels of authority and control, deploying multiple forms of institutional power. In many contexts, the ICC justifies or maintains its power through formalised responses, practices and policies of interaction. ${ }^{10}$ Decisions or claims to authority are translated into technical legal documents or institutionalised in order to cultivate acceptance of ICC actions or to mitigate criticisms of the Court. The turn to institutional power is most visibly reflected in the expansion

${ }^{8}$ See S. Sassen, Territory, Authority, Rights: From Medieval to Global Assemblages (Princeton: Princeton University Press, 2008).

9 See generally S. Nouwen and W. Werner, 'Doing Justice to the Political: The International Criminal Court in Uganda and Sudan', European Journal of International Law, 21 (2010), 941-965.

${ }^{10}$ On the role of 'practice' in the ICC, see J. Meierhenrich, 'The Practice of International Law: A Theoretical Analysis', Law \& Contemporary Problems, 76 (2014), 1-83. 
of the Court's regulatory framework, the development of procedures of interaction with domestic authorities and victims and the adoption of policy and 'expert' papers on core issues of concern to the Court, including complementarity, the 'interests of justice', victims and sexualand gender-based violence. ${ }^{11}$ This practice has gradually extended the Court's normative space of operation as well as its claim to authority by re-casting political choices as formalised policies.

Many of the effects of ICC interventions are also influenced by relationships with other actors. The Court relies on these dynamics to justify its authority or to reinforce its impact. This structural power involves forms of subordination as well as cooperation, including the Court's relationship to collective security and the role of the Security Council; ${ }^{12}$ its interaction with state authority; ${ }^{13}$ and its relationship to individuals, which serves as the basis of some of the most important claims of the Court's authority. Indeed, as a number of the chapters in this volume suggests, ICC actions, policies and language have had a transformative effect in spaces where the Court intervenes. They may alter social realities through discursive practices and processes: through labelling certain acts as crimes, through stigmatising perpetrators, and through the bestowal or denial of victim status as a legal category. Some of the resulting effects of Court interventions are calculated and intended, as when the ICC's actions generate political pressure to comply with its decisions. But in many situations, ICC interventions have produced unintended effects, such as the alteration of conflict narratives and ICC-centric law reform practices, some of which may ultimately run counter to the Court's objectives. ${ }^{14}$

${ }^{11}$ See OTP, Informal Expert Paper, 'The principle of Complementarity in Practice' (2003); OTP, 'Policy Paper on Interests of Justice', September 2007; OTP, 'Policy Paper on Victims' Participation', April 2010; OTP, 'Policy Paper on Sexual and Gender-Based Crimes', June 2014.

12 See L. Arbour, 'Doctrines Derailed? Internationalism's Uncertain Future', 28 October 2013, http://www.crisisgroup.org/en/publication-type/speeches/2013/arbour-doctrinesderailed-internationalism-s-uncertain-future.aspx.

${ }^{13}$ On acculturation, based on 'sanction' and 'reward' schemes in international law, see R. Goodman and D. Jinks, Socializing States: Promoting Human Rights through International Law (Oxford/New York: Oxford University Press, 2013).

${ }^{14}$ A vivid illustration of the Court's contested transformation of social reality appears in Judge van den Wyngaert's critical note on the judicial construction of ethnicity in the Katanga case. See Prosecutor v. Germain Katanga, Jugement rendu en application de l'article 74 du Statut, ICC-01/04-01/07, Trial Chamber II, 7 March 2014, Minority Opinion of Judge Christine van den Wyngaert, ICC-01/04-01/07, para. 258. 
This volume critically engages with the effects of ICC interventions. It begins from the normative premise that the Court should be more responsive to the contexts in which it works. The Court's Outreach Unit has claimed that it 'aims to give [conflict-affected] communities ownership over the Court, rendering it an institution that works for them and in their name'. ${ }^{15}$ While the Court and its proponents have occasionally invoked the language of 'local ownership', responsiveness and contextual sensitivity may offer more realistic standards for its work in practice. In their pioneering contribution to the field of socio-legal scholarship, Philippe Nonet and Philip Selznick argued that 'a responsive institution retains a grasp on what is essential to its integrity while taking account of new forces within its environment. To do so, it builds upon the way integrity and openness sustain each other even as they conflict'. ${ }^{16}$ In the context of the ICC, 'integrity' is provided by the Court's governing documents and continuing dialogue over the interpretation of the laws and rules that bind it, and the ICC's responsiveness is thus restricted by what is possible within the confines of the Rome Statute and its interpretation. By contrast, the normative call to 'openness' admits the social and political contexts in which international criminal law operates, and suggests a continuing dialogue between the Court's institutional form and the settings in which it carries out its work.

This collection places particular emphasis on the Court's work in context, such as its relationship with domestic constituencies and actors. It thus seeks to foreground critical considerations of how and for whom the ICC operates. While some scholars have addressed the turn to 'the local' in the field of transitional justice, ${ }^{17}$ there has been relatively little analysis of how international criminal justice interventions are received domestically and locally - that is, what shape their domestic uptake has assumed and the degree to which these interventions have been developed by local actors. Echoing Nonet and Selznick's views on responsive law, transitional justice literature has traced a shift towards 'the local' in

15 'Outreach Report 2009', ICC Public Information and Documentation Section, 28.

16 P. Nonet and P. Selznick, Law \& Society in Transition: Toward Responsive Law (New York: Harper and Rowe, 1978), 77.

17 See, e.g., P. Clark, The Gacaca Courts and Post-Genocide Justice and Reconciliation in Rwanda: Justice Without Lawyers (Cambridge: Cambridge University Press, 2010); R. Shaw, L. Waldorf, and P. Hazan (eds.), Localizing Transitional Justice: Interventions and Priorities after Mass Violence (Stanford: Stanford University Press, 2010); A. Hinton, Transitional Justice (New Brunswick, NJ: Rutgers University Press, 2011); K. McEvoy and L. McGregor, Transitional Justice from Below: Grassroots Activism and the Struggle for Change (London: Hart Publishing, 2008). 
transitional justice mechanisms, arguing for 'more responsive forms of place-based engagement and broader understandings of justice'. ${ }^{18}$ In a similar vein, this volume takes up the question of whether an analogous shift has happened in the field of international criminal law, and if so, with what effects at the ICC's sites of reception.

\section{Contributions to the volume}

This collection brings together scholars and practitioners to reflect upon the ways in which ICC interventions have been taken up, developed and contested by a range of actors, including states, civil society organisations, sections of the Court and conflict-affected communities. Contributions are divided among four sections, each with a distinct unifying theme: Law's Shape and Place, Reception and Contestation, Practices of Inclusion and Exclusion, and Politics and Legal Pluralism. Tracking the Court's selective geography, the volume predominantly focuses on the ICC's effects in African states, beginning from its early state-referred interventions in Uganda and the Democratic Republic of Congo (DRC) and continuing through its proprio motu investigations in Kenya and its UN Security Council-referred work in Libya. Yet it also considers the domestic uptake of preliminary examinations in states like Afghanistan and Colombia, where the Court's presence has shadowed state- and community-based accountability efforts. Throughout the contexts considered, the work of the ICC has been 'vernacularised' to varying degrees, circulating among alternate and often competing conceptions of what qualifies as an appropriate response to mass atrocity. ${ }^{19}$

\section{Law's shape and place}

The section begins by considering international criminal law as a legal form: how does it relate to the field of transitional justice, and to what extent is it seen to complement domestic justice initiatives? Read together, the chapters offer multiple perspectives on the degree to which the work of the Court can be tailored towards domestic and local concerns. The volume's first section thus brings the work of the ICC into dialogue with broader themes from the field of transitional justice and, in particular,

18 Shaw, Waldorf, and Hazan (eds.), Localizing Transitional Justice, 5.

19 On 'vernacularisation' and legal language, see S.E. Merry, Human Rights and Gender Violence: Translating International Law into Local Justice (Chicago: University of Chicago Press, 2006). 
on the possibility and desirability of prioritising local considerations within international legal institutions. Some ICC proponents regard it as falling within the 'transitional justice' paradigm, operating as a post-conflict mechanism that would help to facilitate societal recovery. But for many states, a key constituency of the international legal order, these institutions have been and remain instruments of international politics.

The first chapter by Frédéric Mégret departs from the question of who the beneficiaries of international criminal justice are in practice, arguing that the issue of constituency has remained marginal in scholarship on international criminal justice to date. Rather than asserting a claim about the empirical reality of the ICC's constituency, the chapter instead focuses on the ways that claims to particular constituencies produce the field of international criminal law's 'symbolic economy'. In whose name is international criminal law carried out, and how do these various claims work to shore up the legitimacy or authority of institutions such as the ICC? By tracing various ways in which constituencies are invoked - such as 'justice' itself, a universalist notion of humanity, the victims of international crimes, future generations or the 'international community' - Mégret shows how constituency-building, a rhetorical feature of the international criminal justice project, reveals a broader politics of 'speaking for', or a politics of representation. Mégret concludes that the plurality of diverse and at times contested - constituencies invoked by the Court suggests that its main constituency may in fact be 'nothing but itself.

Carsten Stahn's chapter examines the divide between the international and the local in ICC policies and practice. It argues that ICC justice is different from historical 'civilizing' projects, yet it remains vulnerable to some of the dilemmas that other liberal and emancipatory projects face in their engagement with 'the local', such as paternalistic and missionary features, perpetuation of structural inequalities and the distorting effects of de-localisation. It discusses different faces of the 'local' in the ICC context: as 'the other', as object, as subject and, finally, as a pattern of justification. It claims that a certain degree of de-localisation is unavoidable in international justice, and that there is some virtue in the ability of the ICC to override domestic choice (e.g., to counter claims of superiority inherent in criminal conduct). But it pleads against artificial 'mainstreaming' of ICC justice and an instrumentalist vision of 'the local' that blends out the disempowering effects and contradictions of ICC justice.

David Koller's chapter revisits the well-travelled tension between law and politics, but with a view to understanding how the relation between the global and the local might bear upon it. This third chapter critically 
reflects on international justice as a form of what Gerry Simpson has called 'juridified diplomacy', ${ }^{20}$ questioning whether the mandates of international tribunals, particularly the ICC's, have been stretched too far in the quest to accommodate local priorities and demands. It argues that the support of donor states for international criminal institutions playing a transitional justice role remains limited. While the integration of transitional justice and international politics may be desirable in the long-term, the hesitation of states to fully embrace this paradigm suggests limitations to that vision in the short-term. Koller ultimately cautions against viewing international courts and tribunals as working in the interests of local communities given their inherent constraints as transitional justice mechanisms, arguing that they are more properly regarded as 'instruments of a legitimised international politics'.

Contrasted with Koller's emphasis on the role of states, Jaya RamjiNogales's chapter begins from a more community-based view regarding the possibilities of orienting the field of international criminal law towards the ends of transitional justice. Articulating a theory of what she terms 'bespoke transitional justice' at the ICC, Ramji-Nogales suggests principles to support the legitimacy of the source, procedure and substance of accountability mechanisms, as well as the desirability of using evidence-based and locally grounded methods to implement them. In offering a normative theory of 'bespoke' justice, the chapter concludes that the Court should be more responsive towards local demands, even if this entails refusing to intervene in situations where the objectives of transitional justice may not be met through criminal prosecutions. Ramji-Nogales contends that contextual considerations and local priorities should serve as the normative starting point of the Court's work, which would align its objectives more clearly with the field of transitional justice.

Michael Newton's final contribution to the section builds upon RamjiNogales's normative argument by asking what a more communityfocused form of justice might look like in legal practice. He contends that Article 53 of the Rome Statute offers an under-explored avenue for incorporating domestic understandings of justice. The text of the article specifies that the prosecutor must consider the 'interests of justice' when initiating an investigation and requesting prosecution. Through a reading that seeks to incorporate local understandings of justice as a

${ }^{20}$ G. Simpson, Law, War \& Crime: War Crimes, Trials and the Reinvention of International Law (Cambridge: Polity Press, 2007), 1. 
counterforce to international criminal law's terms, Newton draws upon his own experience advising domestic transitional processes in Afghanistan and Uganda to show how 'the interests of justice' can be broadly construed to incorporate alternate values beyond criminal accountability.

\section{Reception and contestation}

The second section takes up specific situations where the ICC has intervened to consider its political effects and its interaction with state officials, NGOs and 'intermediaries' - individuals or groups working on the Court's behalf. All contributors write from direct experience of working in the African Great Lakes region, and their chapters document the complex and often fraught circumstances in which Court interventions unfold.

Stephen Oola's chapter focuses on how the principle of complementarity has been marshalled by domestic political actors in Uganda. As he argues, the attempted prosecution of former LRA member Thomas Kwoyelo before the International Crimes Division (ICD) of Uganda's High Court has been hailed by many advocates and international donors as an example of complementarity 'in practice', yet the case raises disturbing questions about an executive branch that has skilfully used the Court's intervention to shore up its own dominance. The chapter focuses, in particular, on the emergence of the ICD as a post-Juba priority for international donors and asks to what degree Kwoyelo's prosecution of former LRA members signals an increasing attempt by the government to control and manage the country's incipient transitional justice process.

Oola's attention to the dark sides of complementarity - the way in which ICC interventions can reinforce state power - finds resonance in the DRC as well. There the government also 'invited' the Court to investigate the commission of international crimes post-2002: these investigations have focused only on rebel movements operating within the country, rather than the regime itself. Pascal Kambale examines the ICC's record in this regard and elucidates several critical areas - investigations, capacity building, information sharing - where cooperative arrangements between the ICC's Office of the Prosecutor (OTP) and Congolese officials were overlooked or ignored, despite the prosecutor's repeated calls to harness ICC interventions in the service of 'positive complementarity', that is, to actively encourage and strengthen domestic accountability efforts. While the concept of 'positive complementarity' has resonance among the representatives of international human rights 
organisations, Kambale contends that its implementation in the DRC was frustrated by the strategy of the OTP prosecutor, which valorised state cooperation and cost-savings over the needs of conflict-affected communities and the duty to conduct thorough investigations.

The ICC's intervention in Kenya stands apart from Uganda and the DRC insofar as it was the prosecutor's first investigation proprio motu, following the failure of domestic authorities to establish a special tribunal after the post-election violence of 2007-2008. As Njonjo Mue and Judy Gitau's chapter details, Kenyan civil society has been at the vanguard of the Court's intervention, which resulted in the issuing of arrest warrants for Uhuru Kenyatta, who later became president, and William Ruto, who became deputy president. The prosecutor's initiation of an investigation fundamentally reoriented domestic politics in Kenya, uniting former political rivals and shaping a discourse that increasingly casts the ICC as a neo-colonial project, with civil society as its conduits. ${ }^{21}$ In the face of these growing attacks, Mue and Gitau detail the brave efforts of domestic NGOs to shore up the Court's work, ranging from developing an informal system of witness protection to litigating the enforcement of ICC warrants in Kenyan courts. Their descriptive account highlights the catalytic role the Court has played in orienting the work of domestic human rights advocates, notwithstanding the OTP's collapsing cases and the government's further retreat from accountability for grave crimes.

Such attacks on civil society in situation countries have raised questions about the work civil society does on the ground, and about the appropriate limits and regulation of respective mandates. Returning to similar themes raised by Kambale, Déirdre Clancy's chapter illustrates the risks that many country nationals assume on behalf of the Court ranging from the OTP to defence counsel - often with little if any formal support. She examines the ICC's practice in this regard through the lens of so-called intermediaries, locally situated individuals and organisations who provide a variety of vital services in support of the Court's core functions. The chapter argues that while civil society has always had an active and visible advocacy role around the ICC and international justice, much of the work of NGOs in support of Court operations, in the field, has unfolded largely in the shadows. Furthermore, Clancy contends that, as with its investigations, the OTP in particular has taken a cavalier

${ }^{21}$ For an account of the Court's effects upon domestic politics in Kenya, see S. Kendall, "UhuRuto" and Other Leviathans: The International Criminal Court and the Kenyan Political Order', African Journal of Legal Studies, 7 (2014), 399-427. 
approach to its work with and reliance upon intermediaries. Reflecting on several experiences to date, the chapter highlights some of the challenges with which both civil society and the ICC must grapple.

\section{Practices of inclusion and exclusion}

In addition to an institutional response to grave crimes, the ICC can be viewed as a set of practices and discourses that produce certain forms of legal subjectivity, ways of speaking and inclusions and exclusions. Based largely on empirical study of different ICC practices - outreach, victim participation, the assistance mandate of the Court's affiliated Trust Fund for Victims and reparations - the chapters gathered in the volume's third section examine the production of these forms amongst conflict-affected communities. As noted, many commentators have praised the ICC for incorporating the interests of these communities more explicitly than previous tribunals. For example, it includes outreach activities in its general budget, and its founding statute formalises victims' participatory rights. In attempting to reach out to conflict-affected individuals and communities as part of its broader constituency, however, the Court must make decisions about how to distribute its resources and personnel, invariably producing exclusions and marginalisations even as it seeks greater inclusion.

Matias Hellman's chapter focuses on outreach practices at the ICC through drawing comparisons to past work he carried out as an outreach officer at the ICTY. Hellman's cautiously optimistic contribution charts how the ICC sought to draw upon lessons from previous international criminal tribunals in establishing its Public Information and Documentation Section, a permanent section of the Court with a dedicated budget. By now there is a broad consensus on the importance of effective outreach in a court's work and a growing recognition of the limits of the first and second waves of international tribunals in this regard. Outreach activities at the ICC reflect a more settled part of tribunal practice, with increased funding and institutional attention paid to the local population as an audience of tribunal proceedings.

Nevertheless, these developments are beset by new tensions: for example, Shaw, Waldorf and Hazan have argued that transitional justice 'has undergone a shift towards the local' while also claiming that its current phase 'is frequently marked by disconnections between international legal norms and local priorities and practices.. ${ }^{22}$ Relatedly, Hellman's

22 Shaw, Waldorf, and Hazan (eds.), Localizing Transitional Justice, 4 and 3. 
chapter notes how outreach frequently becomes an exercise in 'managing expectations', where ICC personnel must explain that the desires of conflict-affected communities may not be reflected in the outcomes of the Court's work. It argues that while a robust outreach program is a necessary component of international criminal proceedings, the active engagement of courts in socio-political processes should be avoided, since their legitimacy as judicial entities ultimately depends on their independence and impartiality. Viewed in this light, the Court's integrity is valued as much if not more than its openness.

The ICC's legal regime for victim participation offers another possibility for greater inclusion of conflict-affected communities, and it remains unique amongst international criminal tribunals. It has the potential to more profoundly engage the ICC's relationship with post-conflict priorities in situ because it conceives of local actors as agents of the court's work. As the OTP noted in its 'Policy Paper on Victims' Participation', victims bring a 'necessary perspective to the ICC['s] activities', one in which they are engaged as 'actors of international justice rather than its passive subjects' ${ }^{23}$ Participation before the ICC extends beyond the role of witness-participant commonly reserved for victims in criminal proceedings. Victims may participate as witnesses before the Court, but, crucially, the purpose animating the Rome Statute conceives of them as more than instruments for evidence gathering.

While the participation of victims may offer a site for engagement with the local, there are numerous challenges. First, who qualifies as a victim? Rule 85 of the ICC's Rules of Procedure and Evidence defines 'victims' as natural persons who have suffered harm, but - assuming that an individual can first overcome the formidable process of applying for recognition as a victim - this definition must necessarily be linked to one of the relevant charges brought by the OTP. ${ }^{24}$ Thus there will be hundreds, if not thousands, of victims in situation countries who suffered harm as a result of crimes other than those charged by the OTP who will be excluded from participation before the Court.

The following four chapters provide more critical accounts of the Court's potential for inclusivity. Legal anthropologist Kamari Maxine Clarke begins by historicising the turn to victims' participatory rights in international criminal law, noting its imbrication with neoliberalism in

23 See OTP, 'Policy Paper on Victims' Participation'.

${ }^{24}$ See The Prosecutor v. Thomas Lubanga Dyilo, Judgment on the appeals of The Prosecutor and The Defence against Trial Chamber I's Decision on Victims' Participation of 18 January 2008, ICC-01/04-01/06, The Appeals Chamber, ICC, 11 July 2008, para. 62. 
the turn of the twenty-first century and its attendant discourses of the 'rule of law' and 'good governance'. Clarke's contribution highlights the narrowing of conceptions of justice by routing them through criminal law and notions of legal accountability, which she theorises as 'legal encapsulation': the erasure of political and economic realities of violence by subjecting them to judicial logics. The field of possible victims is substantially narrowed by purported institutions of redress such as the ICC, which fail to account for socio-economic crimes and structural violence while focusing instead on violations against the human body. Drawing upon an ethnographic account of the ICC's work in the Great Lakes region, Clarke contends that even the court's 'restorative mandate' fails to account for the structural needs of victims.

In a related vein, legal scholar Laurel Fletcher takes up a critique of victim-related discourse at the ICC, drawing upon critical theoretical accounts of identity and language to argue that the institution constructs and relies upon an 'imagined victim' to help legitimate its work. In line with Mégret's observations, Fletcher claims that victims are but one of many constituencies for the ICC, and the field of international criminal law itself prioritises retributive over restorative justice. Through a reading of the ICC's case against Thomas Lubanga, Fletcher shows that the Court responds to victims within its own juridical logics, obscuring the 'juridical switch from normative to distributive concerns' through the figure of the imagined victim. Whereas actual victims of crimes may seek more distributive forms of justice, the imagined victim is constructed as seeking retributive justice, thus serving a legitimating function for the Court itself and ICL more broadly. While eschewing concrete policy prescriptions, Fletcher calls for more modest claims from the ICC regarding victim redress.

Sociologist Peter Dixon addresses similar concerns of inclusivity at the Court, highlighting the relationship between reparations and categorisations of harm. He argues that for international criminal reparations, the targeted distribution of assistance to vulnerable groups is a particularly risky and complex process - as material manifestations of legitimate categories of crime, reparations can 'mark' and potentially stigmatise individuals. Drawing on lessons from development and humanitarian assistance projects, the chapter highlights both the challenges of targeting reparations to victims of crimes as well as the need to carefully balance individual and collective reparations within a community-based decision-making model. Dixon illustrates how his claims bear out in Court practice by 
addressing two categories of crimes that have featured prominently in the ICC's first trials: the use of children in armed forces and acts of sexual and gender-based violence.

The section's final chapter by Sara Kendall contends that the restorative practices of the ICC - including victim participation, medical and livelihood assistance for conflict-affected communities and reparations ought to be read in the broader context of humanitarianism rather than through the more limited frame of international criminal law. Arguing that such practices at the ICC can be understood as forms of 'legal humanitarianism', which seeks to address conflict-related suffering through law, Kendall reads international criminal law's restorative turn in relation to existing critiques of humanitarianism in other disciplines. Drawing upon observations from Uganda and Kenya, she considers how the ICC's constraints do not necessarily mark institutional failings of the Court itself, but instead highlights the inherent tension in re-crafting a retributive field towards restorative objectives. The chapter thus builds upon the critiques by Clarke and Fletcher to illustrate the erasures and exclusions performed by international criminal law when it engages in concrete projects of post-conflict redress.

\section{Politics and legal pluralism}

The fourth section considers the relationship between the ICC and domestic legal systems. Its contributions trace the uptake of international criminal law through domestic implementation of the Rome Statute, admissibility challenges and contestations around the meaning of 'complementarity', and the relationship between the ICC and other postconflict responses. Considering the phenomenon of legal pluralism, or the relationship between 'multiple legal spheres, which may be equal but are in conflict with each other', ${ }^{25}$ contributors reveal how the interaction between the law of the ICC and other legal forms may produce contestations as well as complementarity.

Christian De Vos examines the implementation of the Rome Statute in the domestic jurisdictions of Kenya and Uganda. He challenges the dominant narrative that the ICC itself catalysed these implementation efforts; rather, implementation of the Statute in both countries was accelerated in order to 'perform' complementarity for predominantly international audiences. In Uganda, the state's role as host of the 2010

${ }^{25}$ Clarke, Fictions of Justice, 24. 
ICC Review Conference propelled the passage of legislation that had long stagnated, while in Kenya the desire to publicly demonstrate an immediate departure from the post-election violence 'fast-tracked' implementation there. De Vos argues that this acceleration was enabled by the rise of a growing 'transnational expert community' that sees implementation as an increasingly disciplinary exercise: it privileges conformity with the Statute over legal pluralism. In both countries, however, these truncated politics glossed over deeper fissures about the desirability of importing international criminal law as a framework for domestic accountability. Moreover, the outsized role of external actors in pushing domestic implementation legislation raises questions about the African continent's equal and consensual participation in the creation of this body of law.

Offering a more positivist reading, Patryk Labuda's chapter explores the impact and 'misapplication' of the Rome Statute in the Democratic Republic of Congo. In addition to examining political debates within the Congolese parliament over implementation of the Rome Statute in the country's civilian judicial system, Labuda considers the fate of a proposed bill to establish a special hybrid tribunal in the wake of the UN's 2010 Mapping Report. He also examines the direct application of the Rome Statute by Congolese military courts, highlighting instances in which military court judges have specifically used the Statute to adjudicate serious crimes. This account of attempted legislative changes and the development of international criminal jurisprudence at the domestic level reveals a political dimension of legal pluralism in the institutional and jurisprudential sites where international criminal law and Congolese law come into contact. Seemingly technical legal modifications transpire within a broader social and political context, which in turn influences their uptake and translation into the Congolese legal order.

Moving from the ICC's focus on the African continent, Jennifer Easterday considers the domestic effects of the ICC's preliminary examination in the Colombian context, where prosecutions and practices of memorialisation and reparations are carried out in the 'shadow' of the Rome Statute system. Easterday's chapter examines whether and how these examinations can affect domestic justice process, even in the absence of the conduct of international trials or, indeed, of formal investigations as such. In particular, the chapter examines the creation and implementation of Colombia's Justice and Peace Law, and the extent to which the ICC played a role in shaping the legal and practical application 
of that law. As with other contributions from Oola, Kambale and De Vos, Easterday's chapter illustrates the role of the state in managing and contesting the work of the Court.

In his chapter on the ICC's engagement in Libya, Mark Kersten explores the political dimensions of ICC interventions in situations where the Court's jurisdiction has been triggered by virtue of a UN Security Council referral. He considers the unique set of cooperation and admissibility challenges that confront the Court where, as in Sudan, it acts under the umbrella of collective security. ${ }^{26}$ Kersten further highlights the risks of mixing 'military' and 'justice' interventions, and the controversies over the locality and normative space of international justice in the immediate aftermath of civil war. Particular attention is paid to the UN Security Council referrals, which have generated substantial political controversy regarding the exercise of ICC jurisdiction, as well as the subsequent distancing from the Court by Security Council members following the fall of the Qaddafi regime.

The final chapter, by Juan Méndez and Jeremy Kelley, returns to some of the open questions and broad themes raised in the first section of the volume. It considers the ways in which the ICC, and international courts more broadly, may work towards establishing and maintaining peace, noting how faith in criminal law's deterrent capacities continues to animate the international criminal justice project. The chapter argues that justice can contribute to peace and prevention when it is not conceived instrumentally - that is, as a lever than can be turned on and turned off - but rather from the certainty of the law's application over a period of time. This view presents a (qualified) optimism about the ICC, affirming law's emerging, if not yet enduring, place within the broader order of peace making.

\section{Contested justice}

Building upon Martti Koskenniemi's insights into the dynamics of the international legal field, the contributions in this volume contend that the ICC and its body of law oscillate between deference to (state) power on the one hand, and openness to more inclusive and cosmopolitan visions of justice on the other. ${ }^{27}$ These tensions are built into the very

${ }^{26}$ For an account of the Court's role in Sudan, see Nouwen, Complementarity in the Line of Fire.

${ }^{27}$ M. Koskenniemi, From Apology to Utopia: The Structure of International Legal Argument (Cambridge: Cambridge University Press, 2006). 
architecture of the Rome Statute system, which provides the prospect of deferring to domestic jurisdictions or delaying proceedings, while at the same time re-inscribing the authority of institutions like the UN Security Council, opening spaces for non-state parties to influence a Court to which they are not bound. The form of justice on offer at the ICC is thus deeply contested, raising questions as to what constituencies it serves, in whose name it acts, and what other avenues may be foreclosed as the reach of international criminal law extends.

The volume's diverse set of contributions illustrates these contestations, showing how the role of the ICC has extended far beyond the juridical practices of judgment and punishment. Like many international actors in other professional fields, the Court has taken on an increasing range of issues that venture beyond a classical focus on the adjudication of crime. Through the development of concepts and practices, such as complementarity, victim participation or the 'interest of justice', the Court actively shapes global justice policies. This may be one of its most visible traces. By mandating that state action should largely mirror ICC action in the context of admissibility challenges, ${ }^{28}$ the ICC has also placed itself at the centre of the international justice system, with domestic systems at the periphery. This trend is reinforced through the promotion of specific agendas in judicial findings and in the formulation of Court policies.

The ICC's development is thus symptomatic of the transformation of international institutionalism since the end of the Cold War, and its critiques. ${ }^{29}$ Like other global human rights or justice institutions, the practice of the Court suffers from its own contradictions. It has considerably widened its telos and reach for the sake of justice and accountability, but this expansion of authority has not always been accompanied by sufficient attention to the responsibilities, needs, and duties of care that such a transformation requires.

Further, as a particular form of justice-as-accountability, international criminal law's disciplinary reach risks eliding different understandings of

28 See, e.g., Prosecutor v. Gaddafi and Al-Senussi, Judgment on the appeal of Libya against the decision of Pre-Trial Chamber I of 31 May 2013 entitled 'Decision on the admissibility of the case against Saif Al-Islam Gaddafi', ICC-01/11-01/11, The Appeals Chamber, ICC, 21 May 2014, para. 73

${ }^{29}$ See, e.g., D. Kennedy, The Dark Side of Virtue: Reassessing International Humanitarianism (Princeton: Princeton University Press, 2004); M. Barnett, Empire of Humanity: A History of Humanitarianism (Ithaca: Cornell University Press, 2011); R. Paris, At War's End: Building Peace after Civil Conflict (Cambridge: Cambridge University Press, 2004). 
justice. Scholars such as Kamari Clarke have noted the growing 'tribunalization of violence' ${ }^{30}$ - the turn to legal frameworks as a primary means of responding to intractable conflict. In a similar vein, Mark Freeman argues that the 'permanent ICC ... has come to define' our current moment in the 'global fight against impunity', potentially crowding out other approaches, while Samuel Moyn asks, 'How has international criminal justice ascended so quickly, and so high, even as social justice is increasingly marginalized, undermined from within at home and eroded through the victory of the free market on the world stage? ${ }^{31}$ In relation to the ICC's understanding of complementarity, Sarah Nouwen argues that 'the promotion of one value often compromises another': ${ }^{32}$ the view that mass atrocity requires legal accountability may foreclose other responses, such as negotiated political settlements or nonretributive transitional justice mechanisms. More critically, it may also displace attention from other structural causes of violence in a globalised world of increasing inequality.

The expansion of international criminal law is thus itself contested. As the contributions to this volume illustrate, the ICC's work is refracted through domestic politics, competing conceptions of accountability, and local priorities that accompany its interventions on the ground. The particular vision of justice agreed to in Rome often looks quite different in practice, as it plays out in relation to other sets of priorities and interests that reshape its content as well as its form. The extent to which the ICC is capable of a responsive orientation towards the social, political and legal contexts where it intervenes remains one of the central challenges of the Court's work, and more broadly, for international criminal law as an emerging field of global governance.

${ }^{30}$ Clarke, Fictions of Justice, 45.

${ }^{31}$ M. Freeman, Necessary Evils: Amnesties and the Search for Justice (Cambridge: Cambridge University Press, 2009), 4; S. Moyn, 'Of Deserts and Promised Lands: On International Courts', Human Rights and the Uses of History (London: Verso, 2014), 54. See also S. Nouwen and W. Werner, 'Monopolizing Global Justice: International Criminal Law as Challenge to Human Diversity', Journal of International Criminal Justice, 13 (2015), 157-176.

32 Nouwen, Complementarity in the Line of Fire, 414. 


\section{P A R T I}

\section{Law's shape and place}




\title{
In whose name?
}

\author{
The ICC and the search for constituency
}

FRÉDÉRIC MÉGRET

\section{Introduction}

Who is international criminal justice imagined as being rendered for? Who are the beneficiaries or at least recipients of its work? And, relatedly, who is the 'we' in international criminal justice? ${ }^{1}$ Specifically, who is imagined as being the symbolic authority behind the International Criminal Court's (ICC) work? Is the authority behind the ICC the same as its beneficiaries, or are they distinct? These questions are rarely addressed directly, but they go to the heart of the project of international criminal justice, especially as it conceives of itself as a project of intervention, one whose legitimacy is constantly in need of buttressing.

In this respect, studies of the legitimacy of international institutions and international criminal tribunals sometimes look at these subjects from the outside in, rather than from the inside out. In other words, they are interested in the extent to which legitimacy can be granted by something external (by focusing on issues of mandate or accountability, for example) rather than how its legitimacy may be produced, at least in part, by international institutions themselves through a range of choices and strategies. All theories of the legitimacy of international institutions - theories based on mandate/consent, charisma, rule adherence or results - can nonetheless be reframed as something that tribunals do not simply inherit or obtain but deliberately seek to activate, as agents of their own legitimacy. ${ }^{2}$

1 The question of the 'we' of international criminal justice has been explored in more detail by Immi Tallgren. See I. Tallgren, 'We Did It? The Vertigo of Law and Everyday Life at the Diplomatic Conference on the Establishment of an International Criminal Court', Leiden Journal of International Law, 12 (2004), 683. This chapter is less directly interested in this 'we' than it is in its implicit 'them', but the two are obviously related.

2 See generally M.C. Suchman, 'Managing Legitimacy: Strategic and Institutional Approaches', Academy of Management Review, 20 (1995), 571. 
The main hypothesis of this chapter is that constituency building and invocation is a key part of the Court's search for legitimacy. There is by now a rich emerging literature on the legitimacy of international criminal tribunals, focusing, for example, on their ability to adhere to noble founding principles ${ }^{3}$ or to be responsive to the populations whose decisions they affect. ${ }^{4}$ However, this chapter is less interested in the issue of legitimacy as such than it is in a number of practices of legitimacy that international tribunals engage in because they apparently feel compelled to. In that respect, I am interested in the fact that legitimacy is something that actors seek to produce actively and it does not simply derive unproblematically from their existence. I also deliberately leave aside the question of whether such practices actually make international tribunals more or less legitimate; I merely focus on the fact that it makes them what they are. The point is to investigate how the appeal to certain constituencies - their production through discourse and narrative - helps to construct a particular role and identity for the ICC. 'Speaking in the name of may or may not boost international criminal tribunals' legitimacy, but ultimately it speaks more through questions of legitimacy - to an ongoing sense of identity and place in the world. It is, in other words, constitutive of international criminal justice, regardless of whether it is also legitimising of it.

This chapter is therefore interested in the way practices of legitimacy are inherently tied up with the ability to 'speak for' or 'speak in the name of, to occupy a certain space in international interventions of 'standing in' for something bigger than oneself. This is not the same thing as consent theories, in that I do not claim that external constituencies have actually given their consent to (or 'authorised') the ICC's intervention (they may have, but that is not the problem). Indeed, the ability to 'speak in the name of is not the same thing as 'speaking with a mandate from' or even 'having spoken to'. 'Speaking in the name of may be the exact opposite of these things in that one is not specifically authorised to do so by those involved, and one may even speak for them without ever having meaningfully interacted with them. Rather, following Sara Kendall and Sarah Nouwen's lead, ${ }^{5}$ I am interested in practices of

3 A. Fichtelberg, 'Democratic Legitimacy and the International Criminal Court: A Liberal Defence', Journal of International Criminal Justice, 4 (2006), 765.

${ }^{4}$ M. Glasius, 'Do International Criminal Courts Require Democratic Legitimacy?', European Journal of International Law, 23 (2012), 43.

5 S. Kendall and S. Nouwen, 'Representational Practices at the International Criminal Court: The Gap Between Juridified and Abstract Victimhood', Law and Contemporary Problems, 76 (2014), 235. 
representation without consent, or where the consent is at best imagined. Indeed 'speaking in the name of' often refers to a type of legitimacy that is produced in the eyes of a third party or oneself, rather than necessarily the agent one is speaking for. For example, one could 'speak in the name of victims' but not particularly interact with them, as some theories of the legitimacy of international criminal justice insist is vital.

In the process, I hope to make a contribution to our understanding of international criminal justice's politics of representing itself as a complex exercise in which strategies of discursive representation compete with and may even, over time, undermine each other. While practices of representation have garnered increasing attention, the existing scholarship has focused mostly on how representation relates to victims. Without denying the importance of that particular constituency (which is discussed in the final section), this chapter stresses that victims are only one possible constituency and representation strategy among others. Moreover, assessing the current centrality of victims as a source of symbolic legitimacy for the ICC entails an understanding of what particular void victims end up filling, and what their existence owes to the challenges involved in constructing alternative constituencies.

In that respect, the debate on the constituencies of international criminal justice mirrors and charts - although it never fully overlaps with - two similar debates. The first is the domestic debate on for whom criminal justice is rendered. As is well known, a traditional focus on the state and public order has occasionally ceded space to a view of criminal justice as having a more societal function or as directed primarily at victims. ${ }^{6}$ Such debates have had a profoundly structuring effect on criminal justice: they are both manifestations of its changing nature and causes of it. The second is the old international debate on who the ultimate beneficiaries of international law are. Again, a traditional focus on the state has long been challenged by a view of international legal institutions operating for the benefits of peoples or individuals. Although these debates will not be addressed as such here, it is unsurprising that the debate on international criminal justice - as the ultimate hybrid between both international and criminal justice - echoes these separate conversations.

${ }^{6}$ F. Carrington and G. Nicholson, 'The "Victims" Movement: An Idea Whose Time Has Come', Pepperdine Law Review, 11 (1983), 1.

7 J. Spiropoulos, 'L'individu et Le Droit International', Recueil des cours de l'Académie de droit international de La Haye, 31 (1929), 191-270. 
Specifically, this chapter will characterise the debate on the implicit beneficiaries of international criminal justice as the product of a tension between a propensity to imagine a number of ideal recipients and a countervailing temptation to concede who the actual patrons of the project are. The more abstract the imagined recipients of international criminal justice, the easier it becomes to claim things in their name, although also the more artificial the move may appear to be; the more concrete the 'patrons' of international criminal justice, the easier it becomes to claim political backing, but the more it risks appearing as merely their object. This idea draws on the work of Martti Koskenniemi and his identification of the oscillation between apology and utopia as the inevitable fate of international legal argumentation. ${ }^{8}$ However, it reconceptualises this oscillation as embedded in actual institutional practices of representation, rather than simply legal-doctrinal discourse. In between these extremes, the chapter argues that a 'local turn' in the justificatory strategies of the ICC is discernible, one focusing on 'societies', 'communities' and 'victims'. The strength of this strategy is that it appears to ground itself in both the reality and dignity of actual suffering. However, as I will argue, this is a difficult strategy to execute in conditions where victims' aspirations may be quite at odds with those of the Court.

\section{Imagining the ICC's ideal recipients}

Doubts about the legitimacy of international criminal justice in a world of states may lead to a degree of rhetorical flight. In a context where international criminal justice cannot prevail itself of the backing of a world sovereign, the temptation may be to move beyond sovereignty altogether. At the most abstract level, the ICC may perceive itself, or be perceived as, working for 'Justice'. This is a fairly traditional conceit, one that foregrounds the value of an idea as antecedent to the institutions seeking to incarnate it. This reference to a disincarnated, a priori form of justice is certainly present in the discourse. For example, Amnesty International has supported the notion of 'prosecuting crimes in the name of international justice. ${ }^{9}$ International criminal tribunals are conceptualised as the embodiment of a certain idea. This sort of discourse is never far but its fragility is all too obvious. Justice is an appealing ideal,

${ }^{8}$ M. Koskenniemi, From Apology to Utopia: The Structure of International Legal Argument (New York: Cambridge University Press, 2005).

9 'Prosecuting Crimes in the Name of International Justice', Amnesty International, www. amnestyusa.org/our-work/issues/international-justice/international-criminal-court. 
but it is hard to think of it as an operative principle and even less as a constituency. Moreover, appeals to international justice are easily suspected of having ulterior motives. ${ }^{10}$

A more concrete cosmopolitan defence of international criminal justice might emphasise the degree to which it is being pursued 'for the sake of humanity. ${ }^{11}$ Such ideas have a venerable pedigree, starting with the notion that there is such a thing as 'crimes against humanity', which reminds us of the extent to which humanity is sometimes largely constructed negatively, through its breach. ${ }^{12}$ The Rome Statute itself nods to this notion in its preamble by emphasising 'that all peoples are united by common bonds, their cultures pieced together in a shared heritage, and concerned that this delicate mosaic may be shattered at any time'. Such references are reminiscent of an earlier age when the existence of a civitas maxima was taken for granted. The emergence of the notion of crimes against humanity is very much seen as one of the most evident moments of genesis of a cosmopolitan law, transforming the idea of humanity from a 'regulative idea into a substantive reality. ${ }^{13}$ It represents the culmination of successive processes of abstraction from actual victims - for example, the hardly evident idea that the Holocaust is not primarily 'the culmination of the history of anti-Semitism' or 'the history of racism at its worst' but a 'crime against the human condition', which manifests 'the cosmopolitanisation of political life'. ${ }^{14}$

The ICC, in this context, might be seen as 'act[ing] in the name of humanity, to protect the interests of humanity. ${ }^{15}$ The beauty of such a reference is that it bypasses states altogether and portrays international

${ }^{10}$ Consider, for example, Paul Kagame's typical assertion to the African Union that 'It is evident that political bias, control and flawed methodology are being deployed in the name of International Justice.' Paul Kagame, 'Statement by H.E Paul Kagame, President of the Republic of Rwanda at the 21st Ordinary Session of the Assembly of the Union' (Addis Ababa, 26 May 2013).

11 R. Teitel, Humanity's Law (New York: Oxford University Press, 2011).

12 R.A. Wilson, 'Crimes against Humanity and the Conundrum of Race and Ethnicity at the International Criminal Tribunal for Rwanda', in I. Feldman and M. Ticktin (eds.), In the Name of Humanity: The Government of Threat and Care (Durham: Duke University Press, 2010), 28.

13 R. Fine, 'Crimes against Humanity: Hannah Arendt and the Nuremberg Debates', European Journal of Social Theory, 3 (2000), 293.

${ }^{14}$ D. Levy and N. Sznaider, 'The Institutionalization of Cosmopolitan Morality: The Holocaust and Human Rights', Journal of Human Rights, 3 (2004), 143, 144.

${ }^{15}$ W. Driscoll, J.P. Zompetti, and S. Zompetti, The International Criminal Court: Global Politics and the Quest for Justice (New York: International Debate Education Association, 2004), 53. 
criminal justice as operating directly and radically for the benefit of a sort of cosmopolitan audience. It is part and parcel of the invention of a constitutive humanity as the very basis of international institutions of justice and further officialises the idea of certain matters as inherently public concerns, as opposed to part of states' 'private' affairs. ${ }^{16}$ The existence of 'humanity', moreover, opens the way to the exercise of an international form of sovereignty superseding states within which the ICC presumably has a central role to play in the impartial ascription of suspicion and guilt. It builds on several strands in international law, including a long and infamous tradition of bombing in the name of humanity. ${ }^{17}$

This sensitivity is quite present in the discourse. As Ilana Feldman and Miriam Ticktin have shown in their book-length treatment of the ability to speak 'in the name of humanity', the fact that every universalistic claim may hide a quite particular viewpoint does not change the potency of the claim that something is universal. ${ }^{18}$ Theories of cosmopolitanism that emphasise its roots in experience (particularly the Holocaust) rather than Enlightenment-type philosophising ${ }^{19}$ provide at least an air of plausibility to the notion that 'humanity' is affronted by certain crimes. The ICC might be seen as a leading artisan in the cultivation of sentiments extolling its own role as a vanguard of the historical emergence of humanity in international politics. There is at least superficial plausibility that 'humanity' - either as a community or an essence - is harmed whenever thousands of people are slaughtered.

Nonetheless, it is a strategy that has some evident weaknesses. There is a degree of abstraction in the notion that, for example, the Rwandan genocide was primarily committed against 'humanity', when its perpetrators were surely only interested in massacring Tutsis qua Tutsis. To see genocides as essentially identical crimes against the diversity of

${ }^{16}$ Indeed that process may be reminiscent of earlier efforts at imagining 'society' as an existing whole justifying intervention in its name. B. Beck, 'The Politics of Speaking in the Name of Society', Social Problems, 25 (1977), 353.

${ }^{17}$ G. Abraham and K. Hopkins, 'Bombing for Humanity: The American Response to the 11 September Attacks and the Plea of Self-Defence', South African Law Journal, 119 (2002), 783; F. Harhoff, 'Unauthorised Humanitarian Interventions - Armed Violence in the Name of Humanity?', Nordic Journal of International Law, 70 (2001), 65; N.D. White, 'The Legality of Bombing in the Name of Humanity', Journal of Conflict and Security Law, 5 (2000), 27.

${ }^{18}$ I. Feldman and M. Ticktin, In the Name of Humanity: The Government of Threat and Care (Durham: Duke University Press, 2010).

19 Levy and Sznaider, 'The Institutionalization of Cosmopolitan Morality'. 
humankind may be to put too philosophical (and perhaps too Western) a spin on offences that have very localised dynamics. Indeed, whilst the Rwandan government has drawn on the cosmopolitan moorings of the notions of crimes against humanity and genocide, going to great lengths to ensure that what happened in 1994 was directly traceable to the Holocaust, it has also at times shunned the cosmopolitan consequences that would ensue, notably in the form of a dispossession of the case load for the benefit of the international community. When it suited its needs, the Rwandan government was adamant that these were crimes committed primarily against Tutsis or the Rwandan nation, not humanity. There may even be a risk of moral trivialisation of atrocity crimes when their particular gravity is seen as a function of how they affect the whole of mankind or the idea of mankind, rather than crimes of flesh and blood.

Moreover, there must be a difference between the existence of a general, abstract hostility to crimes against humanity and support for the ICC as a peculiar institution, not to mention actual ICC policies. It may be hard, in fact, to argue that there is considerable cosmopolitan support for the ICC independent of particular successes the Court may or may not be able to claim for itself. Although public opinion in countries that have joined the ICC is generally supportive of the Court, that is not always true of countries that have been the target of investigations. A fortiori beyond states parties, public opinion may be indifferent or hostile to the ICC's interventions (except as they may, very exceptionally, indirectly affect them or some of their allies). All of this belies the idea that 'humanity' speaks with one voice in its condemnation of international crimes.

In effect, the prioritisation of cosmopolitan ambitions over local demands, from Uganda to Libya, is easily faulted for being disconnected from where the true locus of justice should be. It has been repeatedly assailed not only for its lack of realism but, more pointedly and painfully for cosmopolitans, for its inherent unfairness, thus weakening the matter-of-courseness of the cosmopolitan case. As Adam Branch puts it, for example,

[W] hen international prosecution is not in solidarity with local demands, then the idea that any part of humanity is entitled to punish those guilty of 'crimes against humanity' necessarily entails a rejection of others' autonomy and self-determination. The decision, on the one hand, to seek justice through punishment or, on the other, to forgo punishment in favor of justice through reconciliation, is a decision that must be made by the 
concrete community that is the victim of the crimes and that will have to live with the consequences of the decision. 'Humanity' is too thin a community upon which to base a universal right to punish. ${ }^{20}$

It is quite clear that international criminal tribunals are aware of these arguments - regardless of their ultimate merit - and wary of pushing the cosmopolitan argument too far, lest they appear too disconnected from the reality of international and local politics.

A rather more grounded variant of the appeal to 'humanity' is the notion that the ICC is working for international civil society more generally. There is certainly much evidence that the Court would not be what it is without the support of a number of NGOs actively involved in the last two decades - but particularly in the run-up to and at the Rome conference - in promoting its principles. ${ }^{21}$ More importantly, the Court has gone on to treat NGOs as a serious constituency, hosting, for example, regular meetings with civil society representatives in The Hague. This reliance on civil society is also a feature of some well-known critiques of the Court. ${ }^{22}$ As Emily Haslam has argued, the reliance on formal transnational advocacy networks loosely representing 'victims' has, in addition to objectively benefitting the ICC, ironically helped to muzzle the voices of actual victims. ${ }^{23}$

One of the problems is that civil society cannot easily stand in for humanity or be equated with the world's population. The NGOs present at the Rome conference may well have had a crucial degree of expertise, but it would be very hard to see them as a substitute for real democratic engagement. Moreover, it is one thing to say that the ICC was created thanks to, and is supported by, civil society, but another to say that international criminal justice is rendered in its name. Such a basis for the legitimacy of the Court would run into all of the typical critiques that have been made of civil society's claims to represent different constituencies. This is all the more so since civil society happens to be divided on many issues concerning international

20 A. Branch, 'International Justice, Local Injustice', Dissent, 51 (2004), 22, 25.

${ }^{21}$ M. Glasius, The International Criminal Court: A Global Civil Society Achievement (London/New York: Routledge, 2006); M. Glasius, 'Expertise in the Cause of Justice: Global Civil Society Influence on the Statute for an International Criminal Court', in M. Glasius, M. Kaldor and H.K. Anheier (eds.), Global Civil Society Yearbook (Oxford: Oxford University Press, 2002), 137.

22 S. Sur, 'Vers Une Cour Pénale Internationale: La Convention de Rome Entre Les ONG et Le Conseil de Sécurité', Revue générale de droit international public, 1 (1999), 103.

23 E. Haslam, 'Subjects and Objects: International Criminal Law and the Institutionalization of Civil Society', International Journal of Transitional Justice, 5 (2011), 221. 
criminal justice and therefore does not offer an unambiguous support base. In the African context, civil society has been found on both sides of the debate. Again, what matters is less whether international criminal tribunals are actually working for civil society than the perception within the tribunals that these arguments can only be pushed so far on both empirical and normative grounds.

\section{Acknowledging the ICC's patrons}

If the invocation of ideal constituencies turns out to be too abstract, the ICC can opt for another strategy: acknowledging the extent to which it is working for a number of 'patrons' who cannot be equated with humanity. For example, a classical way of seeing international criminal justice is as being rendered by and for the international community, which is itself understood less as a global community of mankind than as the society of states. This is what one might view as a 'Grotian' imagination of the constituency of international criminal justice, one focused on sovereigns, but only insofar as they transcend their sovereignty through belonging to a social whole. Again, a rhetorical inclination to invoke the international community is evident in much literature on the ICC and the Court's own discourse. A sensitivity to this more grounded view is evident, for example, in the way in which the ICC is constructed and presented as conducive to international peace and security - surely a widely shared goal of the international community - and as the heir to some of the narrower earlier projects of international criminal justice incarnated by the ad hoc tribunals. The recognition of the Security Council's power to defer investigations is recognition of this fact.

There are, however, evident problems with this view. The ICC's operations may be in tension with some more traditional concerns of the international community, such as the ability to use tools like amnesties. The international community's deep divisions when it comes to the role of international criminal justice in international affairs may end up belying the notion that there is much of a community to speak of. Or, it will come together briefly to support international criminal justice, in ways that suggest that its interest in supporting the ICC is merely tactical and instrumental. In other words, while the ICC may portray itself as conducive to international criminal justice generally and 'sell' its more general justice mandate on that count, the international community may be interested in it only to the extent that it is conducive to international 
peace and security. ${ }^{24}$ The relative enthusiasm with which the Security Council once referred the situations of Sudan or Libya to the Court as part of the management of complex crises suggests precisely such an instrumentalism. ${ }^{25}$

More importantly, the idea that the ICC is working for the international community as a whole' only works if one thinks of the Court as being quasi-universal or at least as having a recognised vocation to be. ${ }^{26}$ However, this view seems blind to the reality that prospects for universal ratification are extremely dim at present and even in decades to come. A less generous view would see the ICC as merely the Court of a particular club, bringing together European, South American and African states. There is a clear and lasting 'exterior' to the Court that belies its view as 'naturally' tending towards universality. The international criminal law regime is not the laws of the sea regime, or even the laws of war regime, whose quasi-universality align them naturally with concepts of international community. This is most evident in the rapport between the ICC and the United Nations (UN), the one organisation that can make a good claim to being universal. The integration of the Security Council within its functioning suggests a certain mutual recognition but, in fact, the Rome Statute allows the UN to do something that in all likelihood it could have done anyhow. Adding insult to injury, the UN has considered that the Rome Statute gives it privileges but few obligations; in particular, the Security Council has refused to consider that it ought to finance the very investigations that its referrals have mandated. ${ }^{27}$

If not really an emanation of the international community at large, the ICC might be seen as a sort of avant-garde, acknowledging that it is working directly only for some states (typically state parties), but at least creating a positive externality (peace, justice) for the entire international community. For example, Sara Kendall has shown the success of a view of

${ }^{24}$ See further Chapter 3 by Koller in this volume.

${ }^{25}$ See further Chapter 18 by Kersten in this volume.

${ }^{26}$ The idea that the ICC is destined to eventually become universal runs deep in the discourse. For example, the Coalition for the International Criminal Court (CICC) insists that 'In order for the International Criminal Court to succeed in its universal project, it needs an increasing majority of the world's nations to join the Rome Statute.' See 'A Universal Court with Global Support', Coalition for the International Criminal Court, www.iccnow.org/?mod=universalcourt.

27 S/RES/1593 (2005), 31 March 2005, para. 7 (Darfur referral). W.M. Reisman, 'On Paying the Piper: Financial Responsibility for Security Council Referrals to the International Criminal Court', American Journal of International Law, 99 (2005), 615. 
states parties as the primary 'shareholders' of the ICC, at least in the discursive strategies deployed by the Prosecutor. ${ }^{28}$ There may be something disingenuous, however, about the idea that the ICC is working for the international community at large, despite the fact that there seems to be nothing temporary about non-states parties' refusal to join, and their quite principled reasons for not doing so. At any rate, the idea that states parties 'sacrifice' themselves for the greater good, in that they expose themselves to international criminal justice at least partly for the sake of others, is not very plausible.

A somewhat more grounded view would acknowledge that the ICC's more direct constituency is its states parties, and only really those states parties. This has the advantage of classicism: at least in strict public international law, an international institution is only working 'for' its members, whatever benefits it may more or less accidentally yield are for its periphery. This view, in other words, would emphasise the extent to which the ICC is a states parties' 'thing', an institution working, albeit diffusely, for their collective interest. In effect, the 'we' in international criminal justice is often heavily associated with states parties rather than the international community at large. ${ }^{29}$

The Assembly of States Parties (ASP) could be seen as the central manifestation of this inward-looking constituency of the Court. It has been quite boldly described as the ICC's 'legislative body ${ }^{30}$ (as if the ICC were a sort of democracy). Effectively, it has the ability to adopt norms such as the Rules of Procedure and Evidence (which states parties specifically did not want to be left entirely to praetorian judicial creation), the Elements of Crimes and the addition of new crimes, including the definition of 'aggression'. The ability to elect judges and prosecutors (and, symmetrically, to remove them) shows that this is evidently a prerogative of states, which also take the 'risks' associated with Court membership. Finally, the ASP is at least theoretically the final stop for the Court when dealing with non-cooperation by a state party, and it has recently shown its ability to reform the rules of the Court to

28 S. Kendall, 'Commodifying Global Justice: Economies of Accountability in the International Criminal Court', Journal of International Criminal Justice, 13 (2015), 113.

${ }^{29}$ See, e.g., 'Ceremony for the Solemn Undertaking International Criminal Court', Statement by the President of the Assembly of States Parties Ambassador Tiina Intelmann, 12 December 2013. 'The Statute reflects our determination to put an end to impunity' [emphasis added].

${ }^{30}$ ICC Fact Sheet on the Assembly of States Parties, available at www.icc-cpi.int/en_menus/ asp/publications/factsheet/Documents/ASP-Factsheet-2013-v4-ENG-web.pdf. 
accommodate certain state interests. ${ }^{31}$ One can conceptualise the Assembly as a form of permanence of the political interests that gave rise to the creation of the ICC, with a certain power to monitor its activities and set a loose framework for its work.

There are, nonetheless, several problems with this view. First, the idea that the ICC works unmistakably for the interests of its members may be denied (occasionally vigorously) by some states parties themselves. There is in other words a difference, and sometimes quite a wide gap, between states' initial adherence to the Rome Statute and the actualisation of their national interest in various circumstances, one that may lead them to express frustration, disappointment or anger with the Court. Several African states parties have been less than moderate in their efforts to contain African Union initiatives to limit the power of the ICC; they have at times seemed to join the enemies of the Court, as for example when they accepted the possibility of excusal from presence at trial for highranking officials. ${ }^{32}$ Ensuring that states parties behave as supportively as they might be expected has become a deliberate goal of international civil society. ${ }^{33}$

In this context there may be something disingenuous about saying that international criminal justice is exercised for the benefit of state parties in the face of flagrant denials by actual states parties that this is the case. At any rate, the ability of states parties to control or influence the ICC, although greater than that of non-states parties, remains somewhat limited. For example, the ASP is only tasked with management oversight of the administration of the Court and not, for example, prosecutorial decisions. The ICC involves a 'high degree of delegation' compared to other international institutions. ${ }^{34}$ This means that if the Court can claim that it is working 'for' states parties, it must be able to do so despite some member states' denial that this is the case and complaints about the Court's lack of responsiveness to their needs. The ICC therefore cannot

31 Article 134 of the Rules of Procedure and Evidence was amended, largely at Kenya's behest, so that defendants who have 'extraordinary public duties at the highest national level' and who are not the subject of an arrest warrant can be exempted from attending their trial, as long as they are represented.

32 'Justice at Risk: States Parties to the ICC Statute Concede to Political Pressure', FIDH (28 November 2013).

33 'Call for African ICC States Parties to Affirm Support for the ICC at the Assembly of States Parties Session', Human Rights Watch (12 November 2013).

${ }^{34}$ C.A. Bradley and J.G. Kelley, 'The Concept of International Delegation', Law and Contemporary Problems, 71 (2008), 1, 22. 
be equated with states parties' interests, since the latter's interests vary considerably.

Moreover, the idea of international criminal justice as foregrounding the interests of ICC states parties may sacrifice too much in terms of ideals. It often seems key to the rhetoric of the ICC that it is not merely a privately run, inward-looking project but one that is more generally in the global or cosmopolitan interest. Moreover, if the ICC is really run in the interests of its members, then it is hard to avoid the conclusion that its members should have some sort of right of veto against particular investigations or prosecutions that are not seen as conducive to their actualised national interest. Although this is close to what some states have sought, becoming a member of the ICC has almost always been understood as involving at least a theoretical risk to states parties in the form of unexpected and adverse investigations/prosecutions.

Yet, an even more grounded view might see international criminal justice as rendered for the benefit of those particular states that have referred cases to it. Here the view of the ICC might be of a sort of 'international public service' of justice, ready and willing to render services to states in need. This view is at least consonant with the evolution of the notion of complementarity, less as a form of discipline against recalcitrant states than as a vector of transmission of cases to The Hague, through the practice of so-called self-referrals. The element of global justice, international ordre public and top-down enforcement is thereby radically relativised, if not exactly trivialised. The Court acts as a service provider when for some reason states decide that it would be in their interest to have a supranational jurisdiction deal with sensitive cases for them.

It may well be that the Court has become exactly such an annex to states' designs. However, ICC proponents have also argued that the Court will not simply allow itself to become a puppet of sovereigns' designs. Moreover, this view of referring states as the constituency of international criminal justice has been amply criticised as sovereignconsensual: the ICC is so in line with states' interests as to be virtually indistinguishable from it. ${ }^{35}$ In short, rather than the ICC having states as a constituency the Court risks becoming a pawn of the states.

Finally, an extreme realist view might see the ICC as always having been in a sense subservient to big power interests, notably as a tool of

35 W.A. Schabas, 'Complementarity in Practice: Some Uncomplimentary Thoughts', Criminal Law Forum, 19 (2008), 5. 
influence for European middle powers, ${ }^{36}$ and perhaps even the United States. Here, the element of groundedness is impeccable, and an argument may be made that the ICC was always more or less darkly conceived as an instrument to express a certain civilisational domination over the African continent, or something even more tactical linked, for example, to the possibility of the use of force. However, such a view raises problems of plausibility: surely the Court escapes big powers' calculus at least occasionally, if only because their interests must be at odds at least sometimes. Moreover, it raises considerable normative problems: although the ICC is sometimes denounced as a puppet of big powers, it is almost never defended as such precisely because to do so would undermine its very claim of being an institution of justice. For example, it is notable that the option that the Court operates entirely at the whim of the Security Council was excluded early on in negotiations.

\section{The 'local turn': of societies, communities and victims}

The challenge, then, seems to be to find constituencies that do not appear eerily abstract at the risk of undermining international criminal justice's authenticity and power, nor so grounded as to associate it with merely the use of force. The classical vehicle for doing so is of course international law itself, and international criminal law might very much appear to serve that role. International criminal justice might be understood as merely an instrument of 'the law'. This form of representation - international criminal tribunals as natural steps somehow mandated by the existence of international law and expressing that ideal's actuality in history - is quite common, even if not always quite as conscious. The idea of international law is often complemented with the idea of a universal rule of law, of which international criminal tribunals are a natural, perhaps even essential, element.

The strength of such an appeal is that international law already incorporates its own compromises between apology and utopia, and comes with an already stabilised identity. It confers upon international criminal justice an aura of indisputable historical pedigree, portraying international criminal tribunals as the latest and perhaps most promising attempt in setting up a universal rule of law. The personification of the law - its idea as a living, even thinking and acting, force of progress in

36 'ICC a European Tool, Libya Says', News24, 28 June 2011. 
history $^{37}$ - is one of the most powerful rhetorical tropes conceived by the legal imagination. Such personification also powerfully reinforces a particular professional constituency, that of international criminal lawyers.

The idea of international criminal justice as merely a slave of the law is both aggrandising and depoliticising, since major dilemmas of interpretation can be understood as merely part of professional exercises of competence. Nonetheless, such an appeal remains problematic. It is too abstract because 'international law' is hardly a constituency; it is more of an idea or a project. Or it risks being too grounded if the law is effectively reduced to the interests of a particular profession, which is surely an unappealing option. At any rate, it is quite clear that nothing in international law compels the creation of international criminal tribunals and that, moreover, blind following of international criminal law might lead to deeply problematic results in terms of legitimacy. Appeals to the law serve to partly legitimise the practice of international criminal justice but they cannot ground its existence.

One characteristic of both 'lofty' and 'grounded' constituencies of international criminal justice is that they both seem ultimately rooted in traditional understandings of the international. On the one hand, justice, natural law and humanity; on the other hand, international public order, states and sovereignty. Both types of appeals thus play out in quite predictable and somewhat circular ways. As has been shown, each 'descending' appeal risks being denounced as excessively apologetic, as renouncing too much in terms of what makes international criminal justice recognisable to its proponents; conversely, each 'ascending' appeal risks undermining the sovereign basis of international criminal justice needed to make the enterprise both credible and legitimate. Hence the temptation of trying to bypass the state/international community dichotomy by more radically piercing the sovereign veil (not without irony, since this is precisely what international criminal justice is otherwise supposed to be about). Much of the work of the ICC, in particular, can be seen as developing at least a symbolic societal, communitarian and victim constituency. I say symbolic because, in the end, whether that constituency exists, or exists quite the way it is imagined, is relatively independent of the belief that it does.

The idea that the ICC works for the societies whose individuals it prosecutes is one that has some resonance. The rhetorical frame of

37 T. Skouteris, The Notion of Progress in International Law Discourse (The Hague: T.M.C. Asser Press, 2010). 
reference is at least clearly more often societal than statist. For example, a communiqué of the International Federation for Human Rights (FIDH) describes the Ruto and Sang trial as a 'historical opportunity' for Kenyan society to 'face the truth and find justice'. ${ }^{38}$ In this sense, the goal of international criminal justice is less an international legal goal of reining in states than the transitional justice goal of helping societies shift to forms of governance that minimise the likelihood of recurrence of international crimes. The real or imagined support of 'societies' has thus become a key prong in the struggle for legitimacy between international criminal justice and state elites. ICC supporters may even seek to portray society as, in some respect, against the state when it opposes international criminal justice, and the state as no longer having a monopoly on the representation of its society. Conversely, democratic legitimacy, when it is forthcoming, will be heralded by the state as evidence that the government has an unassailable claim to be equated with society.

That international criminal justice is rendered for particular communities is less explicitly touted, but it is sometimes implicit as part of the pro-victim rhetoric. It is less explicit because it might render international criminal justice vulnerable to accusations of partiality and as merely doing one group's bidding. Nonetheless, international criminal justice is hardly foreign to the notion that 'not all communities are equal': in armed conflict or following atrocities, some have clearly suffered a disproportionate burden. The claim that justice is rendered for particular communities, rather than for society at large, is sometimes present in the rhetoric, although often as a criticism (as in the suggestion that Rwanda is organising a form of 'Tutsi justice'). ${ }^{39}$ Rather than communities per se, it is communities of victims that have emerged as one of the most explicit imagined constituencies of the ICC. ${ }^{40}$ The idea of victim communities meshes well with the notion, now quite broadly accepted, that reparations will ultimately have a broad collective character.

The emphasis currently placed on victims at the ICC can be partly explained by the weaknesses and precariousness of other constituencies. The more general focus on victims is now something that is quite well documented. Kendall and Nouwen, for example, have shown the

38 'Beginning of ICC Trial against Ruto and Sang Is a Historical Opportunity for Victims and for the Kenyan Society to Face the Truth and Find Justice', FIDH (9 September 2013) (FIDH, 'Beginning of ICC Trial').

39 D. Orrin Butare, 'Hutus in Horror Jails Await Tutsi "Justice", The Independent, 1 May 1995.

40 See further Chapter 11 by Clarke in this volume. 
ICC's near obsession with 'victims and the justice they deserve' as the 'sole raison d'être of the ICC'. ${ }^{41}$ They suggest that whilst 'juridified' victims have become an ever-narrower category, the 'abstract' victim has become an almost deified entity, which they boldly describe as the 'absent "sovereign" of international criminal law'. ${ }^{42}$ The invocation of victims serves to silence dissent and to make international criminal justice unimpeachable (who, after all, will dare being against victims?). ${ }^{43}$ The ICC seems content to let go of all its other potential constituencies for the benefit of this one. Contra 'society' or 'communities', victims are a category rather than a specific group. They may not even think of themselves as bound by anything other than the chance of having been victimised by the same individuals who are facing charges before the ICC. The emphasis on victims is evident both in what has become a historically relatively generous victim participation regime, and in the increasing focus on reparations as the ultimate outcome of the trial. ICC authorities have undertaken explicit efforts to court victim communities, engaging in significant outreach activities and touring affected regions, all in an attempt to obtain the sort of local support that is seen as indispensable to the enterprise's success.

Although different, these potential victim constituents provide similar advantages for the Court. First, they avoid the dangers characteristic of arguments about international criminal justice as either too concrete or too abstract. As such, international criminal justice avoids the danger of clinging to too statist a vision of itself by following (only with probably more urgency) the path of many domestic criminal justice systems that have sought, notably through a greater emphasis on victims, to redefine themselves as having a more social function. Simultaneously, the ICC avoids the accusation of excessive abstraction because victims are in a sense as concrete as can be, whilst avoiding the suspicion of excessive groundedness, for victims are not presumed to have any particular political agenda outside of justice.

Second, talking directly to/for societies, communities and victims can be a way of forging alliances that bypass the state altogether and empower the Court against recalcitrant sovereigns. In effect, the ICC deemphasises the state element in its interventions in favour of a societal emphasis - the international community, states, humanity - that is portrayed as being

${ }^{41}$ Kendall and Nouwen, 'Representational Practices', 239, citing the ICC Prosecutor.

${ }^{42}$ Ibid. ${ }^{43}$ Ibid., 255. 
directly in touch with particular intra-state groups. ${ }^{44}$ Victims also come endowed with an inherent dignity and respectability that is hard to question politically without incurring the ever-present suspicion of revisionism, which can help silence dissent. As Kamari Clarke puts it, 'the pursuit of justice invoked through privileging claims of victim subjectivity is a technique that manifests aspirations of justice as both real and justified. ${ }^{45}$

Third, references to 'society' or 'victims' share with references to 'humanity' or 'the international community' the fact that these are diffuse constituencies, in whose name it is therefore all the easier to speak. Societies, communities and victims are less likely to forcefully and at least univocally protest an ICC intervention than are states or the organised variants of international civil society. At any rate, the relative lack of organisation of these diffuse constituencies may create opportunities for a forceful outside intervener to try to articulate their needs in lieu of them. The distinction between actual victims and abstract victims routinely invoked by international criminal tribunals, ${ }^{46}$ or the emphasis on organised advocacy NGOs purporting to act as intermediaries rather than real victims, is also what makes it possible to, in a sense, claim 'the victims' voice', even against actual victims' voices. In effect, the faceless victim comes very close to an invocation of 'humanity', for it is in the name of the victim's abstract humanity that international criminal justice is invoked.

Nonetheless, there are evident problems with the investment in these diffuse constituencies, and the idea that they constitute facile (or even unmistakably helpful) refuges from more classical international constituencies. All are more fractured entities than their ordinary invocation suggests, and the ICC's invocation of them is a recurring story of being confronted with the messiness and ambiguity of reality. In fact, it is often the ICC itself that will have to give up implicit claims about the more or less unitary character of societies as ultimately implausible. Confronted with claims that 'Kenyan society' or 'Sudanese society' or 'Ugandan society' wants certain things (typically something other than what the

44 This draws attention away from the problematic inter-state distributive dimensions of the ICC's work. The 'Why Africa?' question, for example, can be marginalised by an appeal to 'this is what these victims here want'.

${ }^{45}$ K.M. Clarke, Fictions of Justice: The International Criminal Court and the Challenges of Legal Pluralism in Sub-Saharan Africa (New York: Cambridge University Press, 2009), 21.

${ }^{46}$ Kendall and Nouwen, 'Representational Practices'. See further Chapter 12 by Fletcher in this volume. 
ICC would want ${ }^{47}$ ), and the consequent marginalisation of those who seek to cooperate with it, the Court has been forced to problematise the notion that there is such a thing as a unified society speaking with one voice.

Instead, the ICC will seek to highlight that those who speak 'for' society may only speak for certain quarters of it, and at any rate not necessarily for victim communities and individual victims. They will designate certain groups (typically those that are supportive of its actions) as having similar or better claims to representing 'society' or to be doing it a service by locally upholding the cause of international criminal justice. ${ }^{48}$ If nothing else, they will emphasise the existence (as the case may be) of majoritarian support for the ICC. ${ }^{49}$ In other words, the Court will engage in its own politics of calling the bluff of those who speak for others.

Furthermore, even though the ICC may invoke all of the above quite freely, states are constantly in competition to represent them. The recalcitrant state will also invoke society, communities and victims and may have more powerful tools to do so (national allegiance, a propaganda machine, etc.). Indeed, there will be nothing that a state might appreciate more than the opportunity to remind the world that, even if hated or contested by part of its population, it better represents the demos. In this context, the precariousness of the representation claims of the ICC is that they emanate not from a broad mandate from populations, but from an ability to satisfy their peculiar demand for justice, an ability that is severely limited by the Court's powers and constraints - of fairness to the accused, adherence to the international rule of law - that it would not want to easily shake off.

47 The Sudanese minister for foreign affairs, Al-Samani al Wasilah, is reported to have pointed out that 'the Sudanese judiciary should be given the opportunity to complete its task in accordance with the conditions of the Sudanese society which is more interested in the reconciliations system and cordial solution than the judicial one'. See A. Al-Awsat, 'No Dialogue with ICC- Sudanese Minister', Asharq Al-Awsat, 23 July 2008.

48 'The unsung heroes of these proceedings are the victims and witnesses who, despite a difficult and sometimes threatening environment, have committed themselves to the search for truth and justice. Their engagement will benefit the whole Kenyan society.' FIDH, 'Beginning of ICC Trial'.

49 See G. Oteino's memo from Kenyans for Peace with Truth and Justice (KTPJ), 'The ICC has always enjoyed high public support in Kenya; as of January 2013, 66\% of Kenyans said they supported the ICC prosecutions. Surely $66 \%$ is of far greater significance than the figure cited by Kamau as evidence of "overwhelming support" of the indictees.' 'KPTJ Memo Responding to Kenyan Ambassador's Letter to the UNSC on ICC Cases, Africa Centre for Open Governance', 7 May 2013, available at www.africog.org/content/kptjmemo-responding-kenyan-ambassadors-letter-unsc-icc-cases. 
Finally, and perhaps more importantly, societies, communities and victims may have or develop the ability to speak in their own name. Indeed, they will occasionally protest ICC interventions, belying the idea that such interventions are being carried out for their sake. As Laurel Fletcher argues convincingly, the practice of international criminal justice constantly exposes a gap between 'real' and 'imagined' victims, the latter being used to implicitly exclude the former. ${ }^{50}$ At the very least, they will routinely complain about the partiality, slowness and insensitivity to local needs of international prosecutions. This was clear in Uganda, for example, where some victim communities tended to act as arbiters of international justice, faulting it for being too focused on the Lord's Resistance Army rather than the Ugandan military, in effect being too committed to a sovereign constituency. ${ }^{51}$

The reality and legitimacy of the ICC's efforts to represent victims was also called into question: 'How can you try to right a wrong, when you have not spoken to those who were wronged?' asked one Ugandan victim. ${ }^{52}$ In the Darfur case, a number of Sudanese citizens even managed to make submissions as amicus curiae to the Court opposing admissibility. In a sense, therefore, the ICC calls attention to victims at its own risk: if they are pliant and supportive, then the Court's legitimacy will be enhanced; if they are invoked too freely, its bluff may be exposed. Challenges to the legitimacy of the ICC coming from victims have thus arguably hurt it most, and have been perceived as a potentially mortal wound. If international criminal justice is not even for victims, given how much it has invested in that idea, then it becomes hard to imagine what its justification could be.

Ultimately, the claim to represent societies, communities and victims' aspirations, even against their clearly stated frustrations (or straightforward opposition), will end up weakening the ICC's own quasi-democratic ethos. It will drive the Court into a posture of paternalism in which it claims to know better what is good for victims than they do; into a flight of abstraction, invoking 'justice' and 'humanity'; or a descent into concreteness, invoking the mandate given by referring states. If these contradictions are exposed, the very legitimacy of the exercise of speaking for victims will be exposed as highly questionable, if not outright fraudulent.

${ }^{50}$ See Fletcher (Chapter 12).

${ }^{51}$ F. Ogola, 'Uganda Victims Question ICC's Balance', Institute for War and Peace Reporting, ACR Issue 261, 14 June 2010. See further Chapter 6 by Oola in this volume.

52 I. Wairimu, 'Uganda: Victims Waiting for ICC Justice', The Independent, 3 February 2012. 


\section{Conclusion}

This chapter has sought to examine the extent to which the legitimacy, identity or authority of the ICC can be understood as a function of who its constituents are understood as being, and who the Court can more or less successfully claim to 'speak for'. More importantly, invocations of justice or 'humanity' show the Court as the servant of an ideal and depoliticise it. On the negative side, such appeals may fail to convince many beyond a small core of activists or other interested parties. Seeking to ground the ICC in something more tangible comes with distinct advantages. The Court cannot be dismissed as irrelevant or utopian. It has powerful patrons and knows what it is doing.

But this grounding comes with its own set of dangers as well. The greater the perception of the ICC as anchored in sovereign consent and will, the more the Court risks being viewed as sacrificing some of its sacred justice mission. The invocation of societies, communities and victims has thus emerged as a sort of ideal middle ground, one that bypasses a few of the tensions inherent in basing legitimacy on some variant of the international argument but that also has its pitfalls. Victims, in particular, may be a prized constituency, although it is not evident that the ICC is willing to do what it takes to represent actual victims as opposed to a highly idealised version of them.

Three more general lessons seem to emerge. First, in the discourse of international criminal justice, 'who?' and 'for whom?' are questions that are intimately related. For example, if justice is perceived as being rendered 'for X', then the suggestion may be that it is X that is, if not actually rendering justice, the authority that gives the ICC the symbolic or moral power to do so. $\mathrm{X}$ will be imagined as both the beneficiary downstream and the implicit authority upstream. Even if the authority for international criminal justice and its constituents are not envisaged as the same (as in 'the international community rendering justice for vic$t^{t i m s} s^{53}$ ), they will be seen as coterminous or closely related. This particular circularity (international criminal justice rendered 'by and for X'), then, reinforces the status of international criminal justice by underlining the congruence between subject and object and reducing anxiety about appropriation or instrumentalisation.

Second, the politics of 'speaking for' can be understood as responsive to a number of needs and constraints. Questions of identity and

53 Kendall and Nouwen, 'Representational Practices', 256. 
authenticity evidently matter, and 'speaking for' is not only ever an instrumental exercise. Understanding whom one thinks of oneself as speaking for is a way of understanding what international criminal justice practitioners and institutions think they are doing. Invoking certain constituencies is also a way of seeking to capture some of their legitimacy for the international criminal project, and perhaps for certain directions in which the project seeks to orient itself. Which constituency is invoked at any given junction will depend on a range of exogenous and endogenous factors, the degree and strength of resistance that the ICC faces and what its particular tactical and strategic goals are in any given circumstance. In that respect, some constituencies may be prized for what one can say in their name, and the relative ease with which those things can be said. Imagining highly abstract beneficiaries has the advantage that it is hard to go wrong or at least to disprove the usefulness of international criminal justice. Who is to say, in the end, whether 'humanity' will be well served by the actions of the ICC?

Third, it is important to note that the constituencies of international criminal justice - victims, states and the 'international community' itself are both imagined and real. They are to a degree imagined as collectives existing at times through nothing else than the rhetorical force of the spokespersons of the project. In that respect, constituency discourse is constitutive of constituencies, rather than the other way around. ${ }^{54}$ However, representation is not a one-way process and the reaction of those on behalf of whom one speaks (or who can legitimately make a claim to being those in whose name international courts speak) is a significant factor in assessing strategies of representation. International criminal justice does not have a monopoly over the creation of its constituencies, who are likely to have an ability to 'speak back' to those who claim to speak in their name.

In the end, practices of 'speaking for' typically oscillate between many constituencies based on what the ICC can realistically get away with and what politics it is seeking to promote. Local support may be the default preference and it certainly is ideal from the point of view of international criminal justice's legitimacy and effectiveness in particular settings in a context where a number of alternative grand narratives - a 'world state', 'humanity', 'global peace' - are clearly on the defensive. However, when

${ }^{54}$ See Ian Clark's recent work on the 'international social practice of the vulnerable' and the way in which it serves to constitute the notion of an 'international society'. I. Clark, The Vulnerable in International Society (Oxford: Oxford University Press, 2013), 2. 
that support is not forthcoming, several retreat strategies are available, buttressing either the sovereign credentials of international criminal justice or its long-term legacy for future generations. Ultimately, every constituency can be mobilised against any other constituency: the state can be faulted for letting down 'humanity' and its own population, not to mention its own commitment to international criminal law and justice; the abstraction of cosmopolitan references can be compensated by local moorings; and the idiosyncrasy of local desire can be offset by the universalism of cosmopolitan horizons. In that respect, it only makes sense to speak of constituencies in the plural, because each constituency in a sense compensates for the inherent weaknesses of the others.

Yet, if the ICC can only have its way by successively mobilising a series of constituencies that are inherently in tension with each other, what remains is the feeling that the Court's ultimate constituency is nothing but itself. The 'absent sovereign', then, is not any of international criminal justice's many constituencies (not even victims), but the agent that is capable of articulating the successive prominence and effacement of these constituencies. The ICC itself is a leading contender for that role and this chapter has shown that it is capable of deploying the rhetoric of constituency in highly sophisticated ways. Ultimately, 'humanity', 'civil society', 'state parties', 'societies', 'communities' or 'the international community' are all signifiers that international criminal tribunals invoke for their own ends. 


\title{
Justice civilisatrice?
}

The ICC, post-colonial theory, and faces of 'the local'

\author{
CARSTEN STAHN
}

\section{Introduction}

In past decades, local-based approaches have gained increased attention in humanitarian action. The focus on 'the local' is a natural counterpoint to internationalism and globalisation in international affairs. Its ambiguity is its strength. There is no unified local. 'The local' has many faces. Depending on context, 'the local' may mean a country, a community, a group, a neighbour and so on. In contemporary discourse, the notion of 'the local' is mostly used as a structural argument. It is popular in the field of development, where the notion of 'local ownership' became a central concept to reduce the divide between external interference and domestic capacity in development action. ' 'Local ownership' was initially associated with 'national ownership'. ${ }^{2}$ Its meaning has evolved over time. It has been associated with broader policy objectives governing interaction of stakeholders, such as inclusiveness, consultation and participation of domestic political, social and community actors in processes of transition and emancipatory rationales. ${ }^{3}$ After the Brahimi Report, ${ }^{4}$

${ }^{1}$ See OECD, Development and Assistance Committee, 'Development Partnerships in the New Global Context', May 1995; B. Pouligny, Supporting Local Ownership in Humanitarian Action, Humanitarian Policy Paper Series (Berlin: Global Public Policy Centre, 2009); T. Donais, Peacebuilding and Local Ownership: Post-conflict ConsensusBuilding (London: Routledge, 2012).

${ }^{2}$ Ownership is not strictly tied to powers of possession. It includes 'different components of local involvement, participation, capacity, accountability and empowerment'. See Pouligny, Ownership, 9.

3 See generally O. Richmond, 'Emancipatory Forms of Human Security and Liberal Peacebuilding', International Journal, 62 (2007), 459-478.

${ }^{4}$ See Report on the Panel on United Peace Operations, UN Doc. A/55/305, S/2000/809, 21 August 2000. 
'local ownership' became a key component of UN peacebuilding and transitional justice doctrine. ${ }^{5}$ The need to pay greater attention to local priorities was presented as one of the 'lessons learned' from the shortcomings of multidimensional peace operations in the seminal 2004 report of the UN Secretary-General on the Rule of Law and Transitional Justice. ${ }^{6}$ The concept was meant to mitigate certain criticisms of liberal peacebuilding (e.g., paternalism, norm entrepreneurship, lack of sustainable 'exit' strategies ${ }^{7}$ ), and leave space for context-sensitive justice responses (e.g., hybrid courts, communitybased reconciliation). ${ }^{8}$ But it remained underdeveloped conceptually, ${ }^{9}$ and has been subject to various critiques (e.g., indeterminacy, circularity). It provides a discursive space to a accommodate divide between 'inside' and 'outside' in the struggle over political authority and legitimacy.

In other fields, 'the local' has developed into a lens to analyse and evaluate action and to critically study its effects. Local interests and perceptions have gained greater importance in the fields of transitional justice, ${ }^{10}$ restorative justice ${ }^{11}$ and peacebuilding, ${ }^{12}$ and perception-based

${ }^{5}$ S. Chesterman, 'Ownership in Theory and in Practice: Transfer of Authority in UN Statebuilding Operations', Journal of Intervention and Statebuilding, 1 (2007), 3; T. Donais, 'Empowerment or Imposition? Dilemmas of Local Ownership in PostConflict Peacebuilding Processes', Peace \& Change, 34 (2009), 3.

${ }^{6}$ See UN Secretary-General, Rule of Law and Transitional Justice in Conflict and Postconflict Societies, UN. Doc. S/2004/616, 3 August 2004, para. 17.

7 See R. Paris, 'International Peacebuilding and the "Mission Civilisatrice", Review of International Studies, 28 (2002), 637.

8 D. Roberts, Global Governance and Liberal Peacebuilding: Beyond the Metropolis (London: Routledge, 2011).

9 See D. Sharp, 'Addressing Dilemmas of the Global and the Local in Transitional Justice', Emory International Law Review, 29 (2014), 71, 73.

10 A. Hinton (ed.), Transitional Justice: Global Mechanisms and Local Realities after Genocide and Mass Violence (New Brunswick, NJ: Rutgers University Press, 2010); L. Waldorf, R. Shaw, and P. Hazan (eds.), Localizing Transitional Justice: Interventions and Priorities After Mass Violence (Stanford: Stanford University Press, 2010); P. Lundy and M. McGovern, 'Whose Justice: Re-Thinking Transitional Justice from the Bottom Up', Journal of Law and Society, 35 (2008), 265; E. Baines, 'The Haunting of Alice: Local Approaches to Justice and Reconciliation in Northern Uganda', International Journal of Transitional Justice, 1 (2007), 91; P. Vinck and P. Pham, 'Ownership and Participation in Transitional Justice Mechanisms: A Sustainable Human Development Perspective from Eastern DRC', International Journal of Transitional Justice, 2 (2008), 398.

${ }^{11}$ See M. Findlay and R. Henham, Transforming International Criminal Justice (London: Routledge, 2012); J. Doak and D. O'Mahoney, 'In Search of Legitimacy: Restorative Youth Conferencing in Northern Ireland', Legal Studies, 31 (2011), 305-325.

12 G. Millar, An Ethnographic Approach to Peacebuilding Understanding Local Experiences in Transitional States (London: Routledge, 2014). 
research more generally. ${ }^{13}$ In these contexts, 'the local' provides a counter-perspective or reaction to top-down approaches and processes of bureaucratisation and technocratisation in humanitarian action, such as mainstreaming, ${ }^{14}$ programming, packaging and so on. The local perspective places greater emphasis on narratives, experience, empathy and perception of international action. It enquires how such action affects local collectivities or individuals, and how it is perceived. This focus on 'the local' may serve as a parameter to consider the legitimacy of an institution, or it may trigger a different vision of goals or success or failure of action. $^{15}$

In international criminal justice, local perspectives have thus far only received limited attention. ${ }^{16}$ Localisation of international justice has been discussed in specific contexts, such as institutional decentralisation, ${ }^{17}$ rule of law reform ${ }^{18}$ or court management (in situ proceedings). ${ }^{19}$ But local approaches are mostly regarded with suspicion from an accountability perspective. They are typically assessed through a universal lens, criticised in light of international standards (e.g., duty to investigate and

13 See e.g., P. Pham et al., Forgotten Voices: A Population-Based Survey on Attitudes about Peace and Justice in Northern Uganda (New York and Berkeley, CA: Center for International Transitional Justice and Berkeley Human Rights Center, 2005); P. Pham et al., When the War Ends: A Population-Based Survey on Attitudes about Peace, Justice, and Social Reconstruction in Northern Uganda (New York and Berkeley: Center for International Transitional Justice and Berkeley Human Rights Center, 2007); P. Vinck et al., Living with Fear: A Population-Based Survey on Attitudes about Peace, Justice, and Social Reconstruction in Eastern Democratic Republic of the Congo (Berkeley: Human Rights Center, 2008).

${ }^{14}$ M. Koskenniemi, 'Human Rights Mainstreaming as a Strategy for Institutional Power', Humanity, 1 (2010), 47.

15 A good example is the development of localised peace indicators. See R. MacGinty, 'Indicators+: A Proposal for Everyday Peace Indicators', Evaluation and Program Planning, 36 (2013), 56.

${ }^{16}$ See H. Weinstein and E. Stover (eds.), My Neighbor, My Enemy: Justice and Community in the Aftermath of Mass Atrocity (Cambridge: Cambridge University Press, 2004); M. Glasius, 'What is Global Justice and Who Decides? Civil Society and Victim Responses to the International Criminal Court's First Investigations', Human Rights Quarterly, 31 (2009), 496; M. Saul, 'Local Ownership of the International Criminal Tribunal for Rwanda: Restorative and Retributive Effects', International Criminal Law Review, 12 (2012), 427.

17 W. Burke-White, 'Regionalization of International Criminal Law Enforcement: A Preliminary Exploration', Texas International Law Journal, 38 (2003), 729.

18 See Open Society Justice Initiative, International Crimes, Local Justice (New York: Open Society Foundations, 2011).

19 See S. Ford, 'The International Criminal Court and Proximity to the Scene of the Crime: Does the Rome Statute Permit All of the ICC'S Trials to take Place at Local or Regional Chambers?', John Marshall Law Review, 43 (2010), 715. 
prosecute, procedural fairness, proportionate sentencing) or accepted as a 'necessary evil'. ${ }^{20}$ International criminal justice often blends out social realities, since it is predominantly focused on crimes and perpetrators, rather than on the underlying social crisis. ${ }^{21}$ Local effects are sidelined. The Statute of the International Criminal Court (ICC) contains certain balancing factors, through its increased focus on complementarity, victims and reparation. The Kampala Review Conference considered a '[t]urning' of 'the lens' on victims and affected communities in the context of its stocktaking exercise. ${ }^{22}$ But this review was centred on narrow institutional dimensions, and is at best still in its infancy. The ICC thus navigates between institutional self-interest (e.g., preservation of institutional autonomy and independence, integrity and efficiency of proceedings) and justification of action through vindication of the rights of 'others'. Local dimensions are typically considered through a vertical lens, which places the 'international' at the centre and uses it as a benchmark against regional, domestic or local responses. Domestic societal concerns are reflected indirectly, namely through the filter of specific institutional goals, such as complementarity, ${ }^{23}$ completion $^{24}$ or procedural mechanisms (victim participation, reparation). ${ }^{25}$

${ }^{20}$ On gacaca, see P. Clark, The Gacaca Courts and Post-Genocide Justice and Reconciliation in Rwanda: Justice without Lawyers (Cambridge: Cambridge University Press, 2010). On amnesties, see M. Freeman, Necessary Evils: Amnesties and the Search for Justice (Cambridge: Cambridge University Press, 2009).

${ }^{21}$ See D. Rothe, J. Meernik, and T. Ingadóttir (eds.), The Realities of International Criminal Justice (Leiden/Boston: Martinus Nijhoff, 2013); C. Schwöbel (ed.), Critical Approaches to International Criminal Law (London: Routledge, 2014).

22 ICC, 'Turning the Lens: Victims and Affected Communities on the Court and the Rome Statute System', RC/ST/V/INF.2, 30 May 2010, at www.icc-cpi.int/iccdocs/asp_docs/ RC2010/Stocktaking/RC-ST-V-INF.2-ENG.pdf; Assembly of States Parties, 'The Impact of the Rome Statute on Victims and Affected Communities', RC 11 (2010), at www.icccpi.int/iccdocs/asp_docs/RC2010/RC-11-Annex.V.a-ENG.pdf.

${ }^{23}$ S. Nouwen, Complementarity in the Line of Fire (Cambridge: Cambridge University Press, 2013); C. Stahn, 'Taking Complementarity Seriously: On the Sense and Sensibility of "Classical", "Positive" and "Negative" Complementarity', in C. Stahn and M. El Zeidy, The International Criminal Court and Complementarity: From Theory to Practice (Cambridge: Cambridge University Press, 2011), 233-281.

${ }^{24}$ See K.J. Heller, 'Completion', in Luc Reydams, Jan Wouters, and Cedric Ryngaert (eds.), International Prosecutors (Oxford: Oxford University Press, 2012), 886-925.

${ }^{25}$ S. Kendall and S. Nouwen, 'Representational Practices at the International Criminal Court: The Gap Between Juridified and Abstract Victimhood', Law and Contemporary Problems, 76 (2014), 235; A. Sagan, 'African Criminals/African Victims: The Institutionalised Production of Cultural Narratives in International Criminal Law', Millennium - Journal of International Studies, 39 (2010), 3. 
This chapter examines the 'international/local' divide in ICC policies and practice. It draws on insights from post-colonial theory ${ }^{26}$ to discuss the relationship between justice intervention and ownership. It argues that the ICC is vulnerable to some of the dilemmas that other liberal and emancipatory projects face in their engagement with 'the local', such as paternalistic and missionary features, perpetuation of structural inequalities or distorting effects of de-localisation. ${ }^{27}$

Engagement with 'the local' is based on a fundamental paradox. The ICC defines itself partly in opposition to 'the local' in the exercise of its core criminal mandate, and derives justification from this distinction. But it needs local 'buy in' and support to realise some of its long-term objectives, that is, to leave a lasting footprint for domestic societies, to ensure that 'justice is seen to be done' or to contribute to justice in everyday life. Narratives and representations of 'the local' shift in the course of proceedings. While functionalist and utilitarian approaches prevail in the framing of situations and case-related litigation, specific community-based and local perspectives gain some attention in the closure of cases (e.g., reparation) and situations (e.g., exit strategy).

This chapter starts with an examination of the dilemmas of the ICC as an agent. It then discusses different faces of 'the local' in the ICC context: (i) 'the local' as 'other', (ii) 'the local' as object, (iii) 'the local' as subject

${ }^{26}$ Post-colonial theory has a long tradition. It is grounded in humanitarian, economic, political or religious critiques of colonial and imperial forms of power (i.e., relationships of oppression, domination, inequality and dependence), and their continuing manifestation in contemporary society. See E. Said, Orientalism (New York: Vintage, 1978); L.S. Rukundwa and Andries G. van Aarde, 'The Formation of Postcolonial Theory', Theological Studies, 63 (2007), 1171; R. Young, Postcolonialism: An Historical Introduction (London: Blackwell, 2001); D. Ivison, Postcolonial Liberalism (Cambridge: Cambridge University Press, 2002). Post-colonial legal theory draws on the intellectual legacy of colonialism to examine divides and asymmetric power relations within domestic, international and global contexts. See E. Darian-Smith, 'Postcolonial Theories of Law', in R. Banakar and M. Travers (eds.), An Introduction to Law and Social Theory (Oxford: Hart, 2nd ed., 2013), 247; A. Anghie, 'The Evolution of International Law: Colonial and Postcolonial Realities', Third World Quarterly, 27 (2006), 739; B. Rajagopal, International Law from Below: Development, Social Movements and Third World Resistance (Cambridge: Cambridge University Press, 2003). 'TWAIL' scholarship is one strand of postcolonial research. See J. Gaathi, 'TWAIL: A Brief History of Its Origins, Its Decentralized Network, and a Tentative Bibliography', Trade, Law and Development, 3 (2011), 26.

27 On missionary features, see A. Anghie and B.S. Chimni, 'Third World Approaches to International Law and Individual Responsibility in Internal Conflict', Chinese Journal of International Law, 2 (2003), 77, 91; C. Nielsen, 'From Nuremberg to The Hague: The Civilizing Mission of International Criminal Law', Auckland University Law Review, 14 (2008), 81. 
and (iv) 'the local' as pattern of justification. It shows that ICC justice produces certain forms of influence and domination that bear synergies with dilemmas articulated in post-colonial discourse, that is, centreperiphery divides, artificial constructions of 'otherness', disparities of knowledge, logics of imitation and structural dependencies. It cautions against an instrumentalist vision of 'the local' that blends out such effects and contradictions.

\section{The ICC and dilemmas of agency}

The ICC is an entity with multiple identities. It is partly a judicial actor and partly an executive agent, with certain humanitarian or human rightsrelated functions. In official discourse, the Court refrains from branding itself as a humanitarian or development actor. Like other agents, the ICC seeks to de-politicise its action. It typically stresses its mandate as independent judicial actor when its role in conflict is discussed. ${ }^{28}$ ICC actions are typically presented under the inconspicuous label of justice. But the judicial nature of activities does not absolve the Court from tensions of protectionism and agency that are inherent in its mandate.

\section{ICC justice and protection}

As highlighted later in this volume by Kamari Clarke ${ }^{29}$ and Sara Kendall, ${ }^{30}$ the exercise of justice has certain transformative features that share synergies with other articulations of power in the humanitarian space. ${ }^{31}$ ICC interventions differ from classical humanitarian action. ${ }^{32}$ This distinction is reflected in Pictet's famous dictum that one cannot be a champion of 'charity' (compassion) and 'justice' at the same time. ${ }^{33}$ It

${ }^{28}$ See Chapter 3 by Koller in this volume. ${ }^{29}$ See Chapter 11 by Clarke in this volume.

${ }^{30}$ See Chapter 14 by Kendall in this volume, analysing dilemmas of restorative justice through the lens of humanitarian discourse.

31 On the concept of 'humanitarian space', see D. Thürer, 'Dunant's Pyramid: Thoughts on the "Humanitarian Space", International Review of the Red Cross, 89 (2007), 47.

32 Classical humanitarianism is grounded in the application of the principles of humanity (e.g., alleviating human suffering), impartiality (no discrimination as to nationality, race, religious beliefs, class or political opinions), neutrality (no involvement in conflict or taking sides for a party) and independence (e.g., autonomy). See proclamation of the Fundamental Principles of the Red Cross, at www.icrc.org/eng/resources/documents/ misc/fundamental-principles-commentary-010179.htm.

33 See J. Pictet, Commentary on the Fundamental Principles of the Red Cross (Geneva: International Federation of Red Cross and Red Crescent Societies, 1979), 22-23. 
applies to a certain extent to the ICC. ICC action is selective by nature and geared to take side for a specific cause, namely to combat 'impunity'. It is justified by legal obligation, rather than empathy, and aimed at providing judgment on violations. But as Clarke and Kendall show later in this volume, ICC interventions are part and parcel of a broader protective movement geared at remedying harm and restoring rights of victims of conflict.

Some of these interventionist features result from the fact that ICC justice is related to global protection schemes, such as the 'Responsibility to Protect'. ${ }^{34}$ The Court is used as an actor to promote security, prevention or protection and connected to peacebuilding strategies, such as 'capacity-building. ${ }^{35}$ ICC engagement is associated with certain transformative goals, such as producing a 'catalytic' effect on domestic law reform (e.g., implementing legislation) or institution-building. In human rights discourses, ICC frameworks and definitions are presented as a model for domestic justice, sometimes with a pull towards over-compliance. ${ }^{36}$ The Court is viewed as a saviour for all types of societal problems, ranging from the protection of civilians to electoral politics, as well as for remedying gender biases or specific patterns of victimisation.

The flip side of this trend is rarely investigated. Conflicts with domestic choices are swept aside by formal reliance on state consent. The broader conditions, under which this consent emerged, are rarely critically reflected. ${ }^{37}$ The assumption that the Court can create 'domestic capacity' has a patronising quality. This normative embedding makes ICC justice vulnerable to criticisms from different strands of thought, such as Third

34 The 2009 Report of the Secretary-General branded the Rome Statute expressly as 'one of the key instruments relating to the responsibility to protect.' See Report of the SecretaryGeneral, 'Implementing the responsibility to protect', UN. Doc A/63/677, 12 January 2009, para. 19.

${ }^{35}$ For a critique of the term, see Pouligny, Ownership, 7. On the ICC context, see M. Bergsmo, O. Bekou, and A. Jones, 'Complementarity After Kampala: Capacity Building and the ICC's Legal Tools', Göttingen Journal of International Law, 2 (2010), 791.

${ }^{36}$ See F. Mégret, 'Too Much of a Good Thing? Implementation and the Uses of Complementarity', in Stahn and El Zeidy, Complementarity, 361, 364-376.

37 See N. Krisch, 'The Decay of Consent: International Law in an Age of Global Public Goods', American Journal of International Law, 108 (2014), 1. Weiler argues that 'the consent given by [most] "sovereign" states is not much different to the "consent" that each of us gives, when we upgrade the operating system of our computer and blithely click the "I Agree" button on the Microsoft Terms and Conditions.' See J. Weiler, 'The Geology of International Law - Governance, Democracy and Legitimacy', Zeitschrift für ausländisches öffentliches Recht und Völkerrecht, 64 (2005), 547, 557. 
World Approaches To International Law (TWAIL) critiques ${ }^{38}$ or humanitarian critiques. ${ }^{39}$ The Court is easily perceived as an entity that serves as an instrument of foreign power, or as a mechanism that markets and exports a cosmopolitan vision of justice. ${ }^{40}$

Some of these tensions are inherent in the Court's role and mandate. ICC action creates certain relationships of power. The use of crime labels and the choice of sites of intervention produce certain stigmas and narratives. ICC intervention entails certain forms of coercive action, vis-à-vis states, individuals or groups, and certain paternalistic features that are part of protective action. It interferes with the liberty of action of collectivities and individuals, and overrides individual agency in the name of a broader good (e.g., collective values, protection needs and interests of humanity). ${ }^{41}$ In some cases, individual choice is restricted directly through coercion. In other cases, ICC action restricts choice indirectly or gradually, through the use of 'soft powers' or incentives that create dependencies. Some of the coercive dimensions or effects may be non-intended, or even unwarranted by the Court.

Court action involves conflicts of agency. The Court needs to satisfy conflicting imperatives. It requires distance from the site of conflict, in order to be perceived as impartial. But it must at the same be sufficiently close to local reality and actors, in order to be able to speak credibly on behalf of others. This dilemma runs through ICC activities, from

38 See, e.g., the Statement by Palitha Kohona (Sri Lanka), General Assembly, Thematic Debate on International Criminal Justice, 11 April 2013, UN. Doc. GA/11357, arguing that the current international criminal justice system 'only pays lip service to the cultural backgrounds of the rest of the world.' On TWAIL critiques, see Anghie and Chimni, 'Third World Approaches', 89-92.

39 See e.g., D. Kennedy, The Dark Sides of Virtue: Reassessing International Humanitarianism (Princeton, NJ: Princeton University Press, 2004); M. Barnett, Empire of Humanity: A History of Humanitarianism (Ithaca, NY: Cornell University Press, 2011); B. Leebaw, 'The Politics of Impartial Activism: Humanitarianism and Human Rights', Perspectives on Politics, 5 (2007), 223; D. Rieff, A Bed for the Night: Humanitarianism in Crisis (New York: Simon \& Schuster, 2003).

40 G.M. Gordon, 'The Innate Cosmopolitan Tradition in International Law', Cambridge Journal of International and Comparative Law, 2 (2013), 906; P. McAuliffe, 'From Watchdog to Workhorse: Explaining the Emergence of the ICC's Burden-Sharing Policy as an Example of Creeping Cosmopolitanism', Chinese Journal of International Law, 13 (2014), 259.

${ }^{41}$ See also A. Branch, Displacing Human Rights: War and Intervention in Northern Uganda (Oxford: Oxford University Press, 2011). On forms of paternalism (hard v. soft, broad v. narrow, weak v. strong, pure v. impure), see G. Dworkin, 'Paternalism', The Monist, 56 (1972), 84; M. Barnett, 'International Paternalism and Humanitarian Governance', Global Constitutionalism, 1 (2012), 485. 
preliminary examination to judgment. A prime example is the role of intermediaries. The Court requires intermediaries to gather information, carry out outreach or provide public information in countries. But the use of intermediaries enhances risks of misconduct and interference, as demonstrated by Déirdre Clancy later in this volume. ${ }^{42}$ The Court has struggled to accommodate this tension. In the Lubanga case the outsourcing of investigations nearly led to a collapse of the trial, in light of undue witness coaching. ${ }^{43}$ The Court further struggles with mediation problems. They emerge by definition in the operation of victim participation, which forms part of the constituent features of the Court. The Court must give voice to victims (Art. 68 (3) ICC Statute). But it is at the same time required to mediate that voice through representation, in order to be able to run proceedings. The Court is still in search of a model that reconciles individualised recognition of victimhood with the need for collective representation. ${ }^{44}$ In particular those victims who fall outside the scope of charges brought by the prosecutor remain marginalised. ${ }^{45}$

ICC justice poses ethical dilemmas for the relationship between agent and protected subject. ICC intervention creates expectations of help and protection. It derives empathy and support from the idea of humanitarian crisis. But as with other types of crisis response, the responsibility that follows protecting is often neglected. Attention shifts quickly to other sites of crisis. The response remains ICC centred. Little is done to provide continuing protection of witnesses and victims when situations and cases are dropped. ${ }^{46}$ There are no direct forms of accountability between agent and protected subject.

42 See Chapter 9 by Clancy in this volume.

43 C. De Vos, 'Prosecutor v Lubanga: "Someone who comes between one person and another": Lubanga, Local Cooperation and the Right to a Fair Trial', Melbourne Journal of International Law, 12 (2011), 217.

${ }^{44}$ S. Vasiliev, 'Victim Participation Revisited: What the ICC is Learning About Itself, in C. Stahn (ed.), The Law and Practice of the International Criminal Court (Oxford: Oxford University Press, 2015), 1133.

${ }^{45}$ See, e.g., ICC, Judgment on victim participation in the investigation stage of the proceedings in the appeal of the OPCD against the decision of Pre-Trial Chamber I of 7 December 2007 and in the appeals of the OPCD and the Prosecutor against the decision of Pre-Trial Chamber I of 24 December 2007, ICC-01/04 OA4 OA5 OA6, 19 December 2008, para. 58. See also Kendall and Nouwen, 'Representational Practices', 244-245.

${ }^{46}$ On witnesses, see E. Stover, The Witnesses: War Crimes and the Promise of Justice in The Hague (Philadelphia, PA: University of Pennsylvania Press, 2005). 


\section{Justice civilisatrice}

Many of these problems are not new or unique to the ICC. They have arisen in other contexts, such as decolonisation or development action. ${ }^{47}$ They may not be entirely solvable. ${ }^{48}$ They involve trade-offs whatever choice the Court makes. But it is fundamental to analyse and understand the underlying frictions and risks. Otherwise, ICC practice will reflect binaries and stigmas that may render justice suspect in the eyes of those in whose interests it is carried out.

There is a danger that ICC practice repeats some of the pitfalls that have been associated with internationalism throughout the twentieth century. Traditional discourses of civilisation ${ }^{49}$ have been largely banned from official UN vocabulary in relation to states; ${ }^{50}$ but they re-emerge in different forms today, that is, in the social or political organisation of domestic societies, including societies in transition. ${ }^{51}$ International justice has been associated with narratives of civilisation since its inception. At Nuremberg and Tokyo, international justice was justified in the name of civilisation. ${ }^{52}$ In the heroic pioneering phase of UN ad hoc tribunals, former ICTY president Cassese qualified the project of international criminal law as 'the only civilized alternative to ... desire for revenge'. ${ }^{53}$ Today, there is a fear that international justice may develop into a new benchmark to 'divide and judge the world'. ${ }^{54}$ Through the push for

47 D.P. Fidler, 'The Return of the Standard of Civilization', Chicago Journal of International Law, 2 (2001), 137; F. Mégret, 'From "Savages" to "Unlawful Combatants”: A Postcolonial Look at International Humanitarian Law's "Other"', in A. Orford (ed.), International Law and Its Others (Cambridge: Cambridge University Press, 2006), 265-317. On progress, see T. Skouteris, The Notion of Progress in International Law Discourse (The Hague: TMC Press, 2010).

48 D. Robinson, 'Inescapable Dyads: Why the ICC Cannot Win', Leiden Journal of International Law, 28 (2015), 323.

49 See e.g., Article 22 of the Covenant of the League of Nations ('sacred trust of civilisation').

50 Article 78 UN Charter bans trusteeship in relation to UN member states.

51 See B. Bowden, The Empire of Civilization: The Evolution of an Imperial Idea (Chicago, IL: University of Chicago Press, 2009).

52 See Nielsen, 'Civilizing Mission', 105.

53 See the First Annual Report of the International Tribunal for the Prosecution of Persons Responsible for Serious Violations of International Humanitarian Law Committed in the Territory of the Former Yugoslavia since 1991, UN Doc, A/49/342, S/1994/1007, 29 August 1994, para. 15; A. Cassese, 'Reflections on International Criminal Justice', Journal of International Criminal Justice, 9 (2011), 271 ('criminal justice is among the most civilized responses to ... conflict').

54 See in relation to human rights, D. Otto, 'Subalternity and International Law: The Problems of Global Community and the Incommensurability of Difference', in E.-D. Smith and 
universality of the Rome Statute and context-neutral mainstreaming, ICC justice may easily turn into a modern form of justice civilisatrice. ${ }^{55}$ This critique is distinct, and in some respects more difficult to discard than the traditional victor's justice argument, ${ }^{56}$ since it questions the foundations of individual criminal responsibility and its use as global concept.

The ICC differs formally from hegemonic projects of the nineteenth and twentieth centuries, which were grounded in the idea of superiority of Western state authority. ${ }^{57}$ The Court has increasingly countered the perception that it is dependent on the authority of a few powerful states. ${ }^{58}$ It is rather a success of the power of small states in international law and the cardinal role of civil society movements. It particularly empowers the role of individuals as holders of rights against oppression. ${ }^{59}$ In this sense, the project of the ICC reflects a certain democratisation in international relations. The Statute avoids clear lines of hierarchy and domination. The idea that justice rendered by the ICC is superior to other forms of justice was intentionally mitigated by the drafters of the Rome Statute through various mechanisms, such as the choice for complementarity rather than primacy, the lack of a firm statutory legal duty to implement core crimes into domestic jurisdictions (preamble), the conduct and process-based conception of admissibility (Art. 17 and 20), the space left for variety of penalties at the domestic level (Article 80) or the possibility for the Court not to act 'in the interests of justice'. The Statute is visibly aimed at preserving diversification of legal traditions. ${ }^{60}$ But these ideals are difficult to maintain in practice.

P. Fitzpatrick (eds.), Laws of the Postcolonial (Ann Arbor: University of Michigan Press, 1999), 145-180.

55 On 'mission civilisatrice', see A.L. Conklin, A Mission to Civilize: The Republican Idea of Empire in France and West Africa 1895-1930 (Stanford, CA: Stanford University Press, 1997); M. Koskenniemi, Gentle Civilizer of Nations: The Rise and Fall of International Law 1870-1960 (Cambridge: Cambridge University Press, 2002), 105.

${ }^{56}$ On victor's justice, see e.g., William A. Schabas, 'Victor's Justice: Selecting “Situations" at the International Criminal Court', John Marshall Law Review, 43 (2010), 535.

57 See E. Jouannete, 'Universalism and Imperialism: The True-False Paradox of International Law', European Journal of International Law, 18 (2007), 379.

58 For a critique, see M. Mamdani, 'Responsibility to Protect or Right to Punish?', Journal of Intervention and Statebuilding, 4 (2010), 53, 60-67.

59 See Report of the Special Rapporteur on the promotion of truth, justice, reparation and guarantees of non-recurrence, A/HRC/21/46, 9 August 2012, para. 30.

60 See E. van Sliedregt and S. Vasiliev (eds.), Pluralism in International Criminal Law (Oxford: Oxford University Press, 2014). 
Many of the Court's first operational steps suggest that ICC practices entail a strong degree of influence and control over domestic choices and a risk to silence alternative approaches. Unlike in colonial projects of the past, this role is not exercised through direct territorial control or formal legal subjugation. It emerges incrementally, through more subtle forms of threats and incentives, and pressures created through informal channels and networks (e.g., multilateral diplomacy, NGOs, institutional interconnectedness). The ICC does not directly proscribe how domestic justice should look like, nor does it have the power to enforce such a vision through regulatory action. But it actively shapes such choices, through narratives, policies and procedures. It translates underlying problems into procedure. In some cases, it steers inequalities inadvertently, not so much through positive action, but rather through inaction. This entrenches fears of double standards and perceptions of injustice that have fuelled discontent.

Certain policies and mechanisms have emancipatory or missionary features. The Rome Statute establishes a treaty-based system of justice. Through its outreach policy, and in particular its projected claim towards universality, the Court has actively sought to push the boundaries of this regime. This is reinforced by efforts in UN practice to mainstream international justice in UN policies. ${ }^{61}$ But little groundwork has been done to substantiate shared communality. ${ }^{62}$ In particular, the promotion of the global 'fight against impunity' has taken on certain missionary features. The concept is a double-edged sword. Due to its action-related framing ('fight') and its substantive ambiguity, it can be used as a pretext for a government to justify any type of repressive measure (e.g., prosecution of political opponents for corruption), rather than equal prosecution for core crimes. More cynically, appeal to this notion empowers a global justice industry versus grassroots-driven approaches. ${ }^{63}$ It induces pressures of compliance and emergence of justice mechanisms that are oriented towards global priorities. ${ }^{64}$ Coupled with socio-economic incentives, this approach may create strong discrepancies between

${ }^{61}$ Critically in relation to human rights, see Koskenniemi, 'Mainstreaming', 51-54.

${ }^{62}$ For a defence of universalism, based on 'anthropological human identity' and re-appropriation, see D. Tladi, 'The African Union and the International Criminal Court: The Battle for the Soul of International Law', South African Yearbook of International Law, 34 (2009), 57, 66.

63 See C. Schwoebel, 'The Market and Marketing Culture of International Criminal Law', in C. Schwoebel (ed.), Critical Approaches to International Criminal Law - An Introduction (London: Routledge, 2014), 264-275.

${ }^{64}$ See S. Nouwen and W. Werner, 'Doing Justice to the Political: The International Criminal Court in Uganda and Sudan', European Journal of International Law, 21 (2010), 941; 
'ordinary' justice and elitist international justice regimes - which ultimately run counter to the objective of effective and long-term justice enforcement. A too close alignment of the ICC with the global 'impunity' movement may thus create frictions with statutory objectives. As noted in critical scholarship, there is a risk that the expansion of the ICC as global accountability project may effectively narrow or reduce, rather than broaden, the options of justice. ${ }^{65}$

Moreover, the de-contextualisation of social reality through criminal procedures produces certain frictions. It focuses on 'the local' predominantly as a site of conflict, evil and violence. This creates a particular stigma that may perpetuate sentiments of inferiority and exclusion. ${ }^{66}$ This dilemma is reinforced by the selectivity of ICC justice. The ICC is focused on mass atrocity and leadership responsibility, which foster certain asymmetries. The broader influence of economic and political policies of Western leaders and corporations on conflict is rarely explored. ${ }^{67}$ The failure to address these underlying factors may ultimately constrain the effectiveness of international justice. ${ }^{68}$ It also stands in contrast with the premise to prevent atrocities. In many contemporary conflicts, violence does not emanate from state power, but from non-state armed groups that challenge state authority, governance and territorial control through externally backed force and popular appeal. Blending out the external influences on conflict fails to address underlying problems, such as the emergence of illicit power structures or recourse to violence. ${ }^{69}$

Some of the weaknesses are illustrated by the rhetoric in relation to the ICC's engagement in Africa. ${ }^{70}$ In 2005, Sudan employed a critical

S. Kendall, 'Donor's Justice: Recasting International Criminal Accountability', Leiden Journal of International Law, 24 (2011), 585.

65 S. Nouwen and W. Werner, 'Monopolizing Global Justice: International Criminal Law as Challenge to Human Diversity', Journal of International Criminal Justice, 13 (2005), 157, 163; M. Drumbl, Atrocity, Punishment, and International Law (Cambridge: Cambridge University Press, 2007), 122.

${ }^{66}$ For instance, in the controversy over the ICC and the African Union, Kenya did not want to be seen as a state that is subject to an Article 16 deferral, and thus portrayed as a 'threat to international peace and security'.

67 See W. Schabas, 'The Banality of International Justice', Journal of International Criminal Justice, 11 (2013), 549-550.

68 See Anghie and Chimni, 'Third World Approaches', 91.

69 See D. Beswick, 'The Challenge of Warlordism to Post-Conflict State-Building: The Case of Laurent Nkunda in Eastern Congo', The Round Table, 98 (2009), 333, 342-343.

${ }^{70}$ See generally K. Mills "Bashir is Dividing Us": Africa and the International Criminal Court', Human Rights Quarterly, 34 (2012), 404; A. Branch, 'Uganda's Civil War and the Politics of ICC Intervention', Ethics and International Affairs, 21 (2007), 179. 
position that had been developed elsewhere by TWAIL scholars to oppose ICC action. It rejected the referral of the Security Council to the Court inter alia on the ground that

the [International] Criminal was originally intended for developing and weak States, and that it is a tool for the exercise of the culture of superiority and to impose cultural superiority. It is a tool for those who believe that they have a monopoly on virtues on this world, rife with injustice and tyranny. $^{71}$

These points later were later echoed by Jean Ping, former president of the Commission of the African Union, who argued that the ICC is discriminatory since it focuses on Africa and disregards crimes perpetrated by 'Western powers' in states such as Iraq, Afghanistan and Pakistan.

These statements must be read with some caution. ${ }^{73}$ They are (i) overassertive in their assumption of discriminatory intent, guided by specific geo-strategic motives, and (ii) reductionist in their presentation of nonWestern (e.g., African) views, which differ considerably. Criticising the Court for geographical discrimination in selection strategy is only a slogan version of a more sophisticated post-colonial critique. The core of the argument goes deeper. It lies in deeper structural factors underlying the reach and orientation of international criminal justice and contested impact and effects of international courts and tribunals, such as marginalisation of claims, perpetuation of inequalities or, at worst, the validation of injustice. It is these factors that merit closer analysis.

The 'international/local' lens provides an important perspective to analyse and unpack these risks and divides. As noted before, ICC practice is built on a paradox. In its own discourse, the Court relies on complementarity, integrative procedures and dialogue with 'local' actors, in order to mitigate concerns of justice export or imposition. All organs of the Court seek to avoid that the ICC is perceived as 'gentle civilizer' of justice systems. But the institutional architecture of the Court, and the

${ }^{71}$ See statement of Mr Erwa (Sudan), Security Council, 5158th meeting, Thursday, 31 March 2005, UN. Doc. S/PV.5158, at 12.

72 See Associated Press, 'African Union calls on Member States to Disregard ICC Arrest Warrant against Libya's Gadhafi', 2 July 2011, at www.foxnews.com/world/2011/07/02/ african-union-calls-on-member-states-to-disregard-qaddafi-arrest-warrant/.

73 Their weaknesses and internal contradictions have been exposed elsewhere. See Tladi, 'African Union'; M. du Plessis, A. Louw, and O. Maunganidze, African Efforts to Close the Impunity Gap, ISS Paper 231 (ISS Africa, 2012) at www.issafrica.org/uploads/ Paper241.pdf. 
framing of cases, creates a drive for de-contextualisation, and homogenisation that stands in contrast to this imperative. It embraces a functional logic, with different narratives and representations of 'the local'.

\section{Us vs. them: 'the local' as other}

The ICC is vulnerable to arguments of division and exclusion, ${ }^{74}$ since it tends to encourage abstractions and certain binary visions of justice. Although the Court seeks to mitigate divides ('us vs. them') through dialogue and certain managerial techniques (e.g., outreach and prospects of local proceedings ${ }^{75}$ ), it requires a certain distance to 'the local'. This distinction emerges incrementally through proceedings, namely analysis and judicialisation, which rely on abstraction and fiction. ${ }^{76}$

\section{Periphery vs. centre}

The 'us vs. them' divide is rooted in deeper frictions relating to the relationship between periphery and centre. ${ }^{77}$ Formally, the ICC is a treaty regime, based on consent. Unlike other global order treaties, such as the UN Charter, ${ }^{78}$ it does not contain an express universalising mandate. But willingly or unwillingly, the Court is frequently moved to the heart of the accountability debate, be it for strategic, activist or apologetic reasons. Where the Court is not taking this role on its motion, it is placed into this position by other actors who pursue specific rationales and interests (e.g., states who associate certain benefits with ICC activity, civil society actors or, at times, the Security Council). The ICC is thus put at the centre of accountability strategies. This move is driven by an urge for immediate response. But it neglects underlying tensions. The ICC is put 'at the

74 See Nielsen, 'Civilizing Mission', 103.

75 See ICC, Prosecutor v. Bosco Ntaganda, Trial Chamber VI, Recommendation to the Presidency on holding part of the trial in the State concerned, ICC-01/04-02/06, 19 March 2015.

76 On fiction, see K. Clarke, Fictions of Justice (Cambridge: Cambridge University Press, 2009).

77 On 'periphery' and 'centre' in post-colonial theory, see D. Chakrabarty, Provincializing Europe: Postcolonial Thought and Historical Difference (Princeton, NJ: Princeton University Press, 2000); Darian Smith, 'Postcolonial Theories', 252.

78 According to Art. 2 (6) of the UN Charter, the UN 'shall ensure that states which are not Members of the United Nations act in accordance with these Principles so far as may be necessary for the maintenance of international peace and security'. The ICC Statute lacks such a provision. 
forefront of the fight against impunity', although it is 'not ... necessarily the most liberal regime of criminal justice. ${ }^{79}$

The ICC regime is ab initio built on a certain structural inequality. ${ }^{80}$ ICC jurisdiction is geared at atrocity violence. The statutory mandate steers ICC action towards intervention in fragile conflict and post-conflict settings. These crimes are less likely to occur in stabilised societies. When they are committed by major Western powers, they often occur in the context of protective or military action in foreign states. The ICC as such is neither the source (i.e. the cause) of this discrepancy, nor does it apply unequal standards per se. But ICC intervention may entrench existing divides, that is, consolidate or create deeper distinctions between developed and less developed states. In cases where the Court does not act, the model of justice that it represents may be seen as unduly limited in choice. ${ }^{81}$ These dynamics are at the heart of discontents voiced against ICC justice.

Once the ICC machinery is brought into action, it tends to portray conflict in specific categorisations. ICC procedures involve choices of prioritisation and distinction to separate sites of intervention from sites of inaction. This operation entails a (i) move towards centralisation of justice and (ii) a process of abstraction that simplifies and reconstructs social reality. Both processes create a distance between the ICC and 'the local'. Court action becomes essentially an engagement with the 'other'. This opens ICC justice to a range of critiques that have been articulated against other international judicial mechanisms, such as (i) marginalisation of claims, (ii) de-contextualised knowledge production, (iii) perpetuation of structural inequalities or (iv) even validation of outcomes that are perceived as 'unjust' locally. ${ }^{82}$

\section{Centralising features of ICC action}

The Rome Statute was meant to create a greater space for domestic justice options. But the existence of the Court as justice mechanism centralises justice discourse to the detriment of other approaches to mass conflict. There is a stark contradiction between reality and perception. Although

\footnotetext{
79 See Mégret, 'Implementation', 389, fn. 80. ${ }^{80}$ See Nielsen, 'Civilizing Mission', 107.

${ }^{81}$ Drumbl, Atrocity, 143.

82 On global judicialisation, see B. Kingsbury, 'International Courts: Uneven Judicialization in Global Order', in J. Crawford and M. Koskenniemi (eds.), Cambridge Companion to International Law (Cambridge: Cambridge University Press, 2012), 203-227.
} 
the Court's institutional capabilities are limited, the role of the ICC is often regarded as central. This centralisation is not necessarily driven by the Court itself, but rather by the movement behind it. As noted by Adam Branch:

there is a vast regime of institutions and organizations engaged in a massive pedagogical project trying to build support for the ICC as the exclusive arbiter of global justice. It is precisely through the ICC's mechanisms for victims' 'participation' and 'empowerment' that the Court restricts people's concepts of injustice and justice to those provided by the ICC and thus to put entire forms of domination, violence, and inequality beyond the scope of justice. ${ }^{83}$

There is a thus certain irony in the way in which centralisation operates. It may even occur against the Court's will.

When the ICC itself takes action, it applies certain formal lenses that shape its focus of enquiry. Patterns of conflict are first of all analysed in terms of jurisdictional parameters. This logic requires the Court to look at local reality through an abstract lens, namely territoriality or nationality. ${ }^{84}$ Both concepts are tied to the state. This lens creates a rift between the ICC and 'the local'. The latter is categorised, if not subsumed, by affiliation to the state. Local culture and identity are largely blended out. The relationship between the 'international' and the 'national' forms the focus of enquiry.

Where justice choices are contested, this contestation remains largely dependent on the state. Both states and defendants can challenge the admissibility of proceedings. ${ }^{85}$ But the ultimate choice on the forum of justice is made on the basis of the action, will and capacity of the state, as determined by the Court. ${ }^{86}$ 'The local' is thus essentially treated as the 'national'. Local issues are subsumed into national processes. If a state is unwilling or unable to act, an individual defendant cannot reverse ICC engagement.

When investigation starts, the focus shifts quickly to the other end of the spectrum, namely the individual. ICC investigations and prosecutions are predominantly concerned with determination of individual criminal responsibility. This focus has particular attraction. It prevents

\footnotetext{
${ }^{83}$ See A. Branch, 'What the ICC Review Conference Can't Fix', 11 March 2010, at http:// africanarguments.org/2010/03/11/what-the-icc-review-conference-can\%E2\%80\%99tfix/.

${ }^{84}$ For legal analysis, see M. Vagias, The Territorial Jurisdiction of the International Criminal Court (Cambridge: Cambridge University Press, 2014).

85 Art. 19 (2) ICC Statute. ${ }^{86}$ Art. 19 (1) ICC Statute.
} 
formal assignment of responsibility to collectivities, such as whole ethnic and religious groups. This may ultimately prevent resentment, hatred and frustration caused by feelings of collective guilt. But it also has downsides. The turn to individual responsibility makes it more difficult to capture structural dimensions of violence. It privileges punishment of individuals over enquiry into the causes of atrocity. ${ }^{87}$ The role of collectivities and groups is brought in through quantitative and qualitative nexus assessment in the context of contextual elements of crimes or linkage factors. But it is examined through the perspective of individual responsibility. One of the dangers of a strict focus on individualised guilt in institutional responses is that it 'may contribute to a myth of collective innocence'. ${ }^{88}$

Collectivities as such rarely have a voice; their interests are typically mediated. They are mainly reflected in collective forms of victim representation ${ }^{89}$ or indirectly in prosecutorial strategies, namely in determinations whether individual cases represent major patterns of victimisation in conflict or the role and involvement of groups in crimes. One direct option for consideration of community interests is the interest of justice' clause under Article 53 of the Rome Statute. ${ }^{90}$ It is framed in negative terms. It allows the ICC to take a decision not to proceed in the interests of justice'. This clause provides an entry point for consideration of local justice approaches. Consideration of the 'interests of justice' involves enquiry into the interests of victims (Article 53 (1)(c)). In its policies, the Office of the Prosecutor (OTP) has presented this provision as a means to conduct a 'dialogue' with victims and representatives of local communities. ${ }^{91}$ In the first ICC situations (e.g., Uganda and Democratic Republic of Congo), the OTP has formally engaged a wide range of actors in this discourse, namely intermediaries and 'local leaders (religious, politically, tribal)', as well as 'other states, local and international intergovernmental and nongovernmental organizations. ${ }^{92}$

This methodology is slightly contradictory. The openness towards consultation and local input seems to suggest that ICC justice can be

${ }^{87}$ For a critique, see Nielsen, 'Civilizing Mission', 99.

88 See L. Fletcher and H. Weinstein, 'Violence and Social Repair: Rethinking the Contribution of Justice to Reconciliation', Human Rights Quarterly, 24 (2002), 573, 580.

89 See Rule 90 (2) of the ICC Rules of Procedure and Evidence.

90 See Chapter 5 by Newton in this volume.

91 See OTP, Policy Paper Interests of Justice (September 2007), 6, at http://icc-cpi.int/ iccdocs/asp_docs/library/organs/otp/ICC-OTP-InterestsOfJustice.pdf.

92 Ibid. 
negotiated. But the normative space for dialogue is in fact very limited. In its 2007 Policy Paper, the OTP has made it very clear that there is a 'presumption in favour of investigation or prosecution' under the Statute, and that the Prosecutor would use Article 53 'only in exceptional circumstances'. ${ }^{93}$ The office used a rather authoritative rhetoric to justify this approach. It denied freedom of choice, arguing that:

a new legal framework has emerged and this framework necessarily impacts on conflict management efforts. The issue is no longer about whether we agree or disagree with the pursuit of justice in moral or practical terms: it is the law. ${ }^{94}$

This argument leaves hardly any room for contest and persuasion, since it implies that there can be no 'neutral' debate on the issue of accountability. The OTP conceded in a footnote that the concept of 'justice' in Article 53 'must be broader than criminal justice. ${ }^{95}$ But it failed to acknowledge that 'other forms of justice decided at the local level' could serve as a bar to ICC proceedings under Article 53. It merely stated the need for a 'comprehensive approach' under which ICC justice and local justice mechanisms are 'as complementary as possible'. ${ }^{96}$ These statements are framed in the language of legal pluralism. But they have an underlying centralising effect on justice discourse. They divide the world into an accountability universe of the ICC ('us'), and a parallel system of 'other forms of justice', pursued locally ('them'). This juxtaposition itself has strong effects on conflict dynamics. It presents ICC justice as idealised framework of reference. ICC policy remains strongly one-directional. As has been rightly suggested by Priscilla Hayner, ' $[w]$ hat may be missing is a process by which the prosecutor could more comfortably evaluate the likely impact and timing of her actions in each different national context. ${ }^{97}$

\section{De-localisation and social engineering}

ICC proceedings entail a significant degree of de-localisation and social engineering. This process occurs incrementally, in multiple segmented steps. It involves different steps: dislocation, disaggregation, translation

93 Ibid., 3

94 For a different narrative on the state of the art, see Freeman, Necessary Evil.

${ }^{95}$ OTP Policy Paper, Interests of Justice, 8, fn. 13. ${ }^{96}$ Ibid., 8.

97 See Priscilla Hayner, 'Does the ICC Advance the Interests of Justice?', 4 November 2014, at www.opendemocracy.net/openglobalrights/priscilla-hayner/does-icc-advance-interests-of-justice. 
and reconstruction. The steps are shaped by different filters applied in the analysis.

\section{Methods}

Like other criminal tribunals, the ICC analyses historical events mainly through the lens of crimes. ${ }^{98}$ Historical context informs the contextual elements of crimes or narratives of conflict in pleadings. In proceedings, facts and events are filtered through the rationality of the law. The legal process seeks to bring order into chaos. It is geared at clarifying and simplifying social reality. It relates facts, conduct and events to legal concepts and tangible normative constructs. It analyses human conduct through certain ordering structures, hierarchies and chains of causation, and it uses constructed knowledge and fictions to fill gaps. ${ }^{99}$

Typically, domestic conflict and violence are branded in specific language and judicial vocabulary. Atrocities are translated into crimes labels that form part of the ICC's jurisdiction. The very use of these labels might influence dynamics. Specific incidents and patterns of victimisation serve as a sample for enquiry. This is followed by (i) the framing of the situation that forms the subject of enquiry (preliminary examination), (ii) the initiation of international investigation and prosecutions, (iii) the shaping and identification of the identity of the 'case' and (iv) recognition of specific victims through the regime of victim participation. In this context, social reality is disaggregated, and then reconstructed, based on evidence available.

This process involves friction, and at times contradiction, with domestic narratives. There is a certain virtue and necessity for the ICC to override domestic articulations and justification of conduct. As argued by Damaška, a message appropriate orbi need not be appropriate urbi:

Circumstances exist in which global horizons of concern clearly should prevail. International judges should not be swayed by hostile local responses to their decisions if they are generated by values or attitudes whose transcendence is the pedagogic aim of international criminal justice. $^{100}$

98 On history and trials, see L. Douglas, The Memory of Judgement: Making Law and History in the Trials of the Holocaust (London: Yale University Press, 2000). R.A. Wilson, Writing History in International Criminal Trials (Cambridge: Cambridge University Press, 2011).

99 See M. Damaška, 'What Is the Point of International Criminal Justice', Chicago-Kent Law Review, 83 (2008), 329.

100 Id., at 348. 
At pre-trial as well as at trial, this information is presented through the lens of multiple agents that pursue different, and sometimes conflicting, interests (prosecution, defence, victims, judges, state representatives, NGOs, etc.). This culminates in different narratives.

Each of these steps (dislocation, disaggregation, translation and reconstruction) involves a certain degree of de-localisation. It entails multiple layers of abstraction and knowledge production, geared at providing judgment. The process of judicialisation rationalises the view on facts and conduct. But it also entails risks and negative side effects.

\section{Global/local dilemmas}

De-localisation creates certain structural paradoxes from the perspective of the goals of justice. In the eyes of 'the local', the very trial of perpetrators in The Hague may not be seen as punishment but as a reward. The ICC is bound by higher human rights standards than certain domestic jurisdictions. The ICC might thus appear as 'justice light' in terms of punishment and sentencing in comparison to domestic proceedings. This paradox became apparent in the context of Rule 11bis proceedings at the ad hoc tribunals where some of the defendants pleaded that they were high-level, rather than medium- or low-level, perpetrators, in order to be tried in The Hague rather than locally. ${ }^{101}$ Similar claims were made in the ICC context. In the Libyan situation, Saif Al-Islam Gaddafi and Abdullah Al-Senussi expressly requested surrender to the Court. ${ }^{102}$ The Gaddafi Defence supported ICC admissibility, arguing that '[j]ustice [would] not be served by domestic proceedings', since they are 'so ineliminably tainted by violations of domestic law that ... proceedings will go down in history as a manipulated spectacle of victor's revenge'. ${ }^{103}$ The Al-Senussi Defence adopted a similar line, invoking 'recognised standards of due process under international law. ${ }^{104}$ In both cases, the

101 O. Bekou, 'Rule 11 BIS: An Examination of the Process of Referrals to National Courts in ICTY Jurisprudence', Fordham International Law Journal, 33 (2009), 729.

102 Gaddafi and Al-Senussi, Situation in Libya, Defence Response on behalf of Mr Abdullah Al-Senussi to 'Application on behalf of the Government of Libya relating to Abdullah Al-Senussi pursuant to Article 19 of the ICC Statute', ICC-01/11-01/11-356, 14 June 2013, para. 11.

103 Gaddafi and Al-Senussi, Situation in Libya, Public Redacted Version of the 'Response to the "Libyan Government's further submissions on issues related to admissibility of the case against Saif Al-Islam Gaddafi"', ICC-01/11-01/11-281-Red2, 18 February 2013, para. 11.

104 See Prosecutor v. Saif Al-Islam Gadaffi and Abdullah Al-Senussi, Document in Support of Appeal on behalf of Abdullah Al-Senussi against Pre-Trial Chamber I's 'Decision on the 
preference for ICC justice over 'local' trials was visibly shaped by the absence of the death penalty in ICC sentencing.

Second, de-localisation produces certain tensions in relation to knowledge production. A judicialised way of reading conflict may produce reconstructions of reality that are at odds with local perspectives. One particular problem is the representation of the role of non-state actors. In many contexts where atrocity crimes occur, the state is at best one among many actors influencing people's lives. International criminal justice goes beyond the state-centric logic of general international law or peacebuilding strategies, by highlighting accountability of non-state actors in both classical civil war contexts and conflicts between opposing armed groups. But it struggles with a representation of non-state violence. It uses certain social ideal types (i.e., ideas of organisation, formation of plan and policy, use of command) to categorise this violence, which may not always offer a proper fit. The underlying picture is often constructed through mediated knowledge, that is, information from states, NGOs or international organisations that have a normative interest in the use of specific labels and their connotations.

At the ICC, these epistemological dilemmas became evident in the Katanga case. ${ }^{105}$ The judgment rested on the theory that Katanga contributed to a campaign by Ngiti fighters to 'wipe out' out the village of Bogoro and its Hema population, since it occupied a strategic position for the Union des patriotes congolais (UPC) in the Ituri conflict. ${ }^{106}$ But key foundations of this theory, such as the concept of 'militia', ethnic foundations or an 'alleged anti-Hema ideology', remained underdeveloped. The weaknesses were outlined in the Minority Opinion of Judge Christine van den Wyngaert. Van den Wyngaert questioned key categorisations of organisational violence. She argued that the judgment failed to explain 'with any level of precision how the so-called militia of the Ngiti fighters of Walendu-Bindi was structured or how it supposedly operated', ${ }^{107}$ or "how and when the "thousands" of individual members of the Ngiti fighters of Walendu-Bindi would have adopted the alleged common

admissibility of the case against Abdullah Al-Senussi', ICC-01/11-01/11-474, 4 November 2013, para. 3.

105 See C. Stahn, 'Justice Delivered or Justice Denied: The Legacy of the Katanga Judgment', Journal of International Criminal Justice, 12 (2014), 809.

${ }^{106}$ ICC, Prosecutor v. Germain Katanga, Jugement rendu en application de l'article $74 \mathrm{du}$ Statut, ICC-01/04-01/07-3436, 8 March 2014.

107 Minority Opinion of Judge Christine Van den Wyngaert, ICC-01/04-01/07-3436-AnxI, 8 March 2014, para. 205. 
purpose to attack the Hema civilian population'. ${ }^{108}$ She claimed that 'so little is known about how, when and by whom most of the crimes against civilians were actually carried out that it is totally impossible to form any opinion about the systematic nature of it'. ${ }^{109}$

Her critique attacks the trend to present and construe the world through pre-fabricated legal constructs. Van den Wyngaert cautions against the risks of undue categorisation and oversimplification, including the 'danger of treating entire populations, or vast categories within a population, as abstract entities with a mind of their own'. ${ }^{110} \mathrm{Her}$ argument goes to the heart of the limits and risks of global knowledge production in a judicial context:

it is factually wrong to reduce this case, and especially the reasons of the different Ngiti fighters and commanders for participating in the operation against the UPC, to ethnic fear and/or hatred. Such oversimplification may fit nicely within a particular conception of how certain groups of people behave in certain parts of the world, but I fear it grossly misrepresents reality, which is far more complex. It also implicitly absolves others from responsibility. ${ }^{111}$

Ultimately, such reliance on social ideal types might produce narratives that are seen as perpetuating injustice at the local level. ${ }^{112}$

Third, de-localisation entrenches certain knowledge disparities. In post-colonial and critical scholarship, global institutionalism is often criticised for its technocratisation and bureaucratisation, that is, the application of standardised or self-serving decision-making processes or forms of organisation to complex societal structures. ${ }^{113}$ This critique applies in a different form to judicialisation. When a case is pursued before the ICC, it triggers a multiplicity of judicial decisions and motions. The sheer amount of materials created through pleadings and proceedings makes it very hard to follow the case. The Court speaks to some extent in its own language. ICC proceedings introduce specific vocabulary and technical procedures that are often difficult to understand by outsiders. Various organs of the Court represent different voices, while differences between procedures and the justification of certain judicial

108 Ibid., para 207. ${ }^{109}$ Ibid., para. 274. ${ }^{110}$ Ibid., para. 258. ${ }^{111}$ Ibid., para. 318.

112 See generally A. Branch, 'International Justice, Local Injustice', Dissent, 51 (2004), 22.

113 See U. Baxi, 'Postcolonial Legality', in H. Schwarz and S. Ray (eds.), A Companion to Postcolonial Studies (Oxford: Blackwell, 2000), 540, 551-552; M. Barnett, 'Humanitarianism as Scholarly Vocation', in M. Barnett and T. Weiss (eds.), Humanitarianism in Question: Politics, Power, Ethics (Ithaca, NY: Cornell University Press, 2008), 235, 255; Kennedy, Dark Sides, 26-28. 
outcomes are not always clear. This creates risks of misrepresentation and misunderstanding that cannot be solved by mere translation and interpretation. ${ }^{114}$ It also has certain disempowering effects. It ultimately implies that knowledge, expertise and professionalisation relating to the adjudication of international crimes develop mostly internationally, rather than domestically or locally. ${ }^{115}$ This creates a vicious cycle. It fosters a spin towards a monopolisation of justice that forecloses local input and might remain unresponsive to local needs and particularities.

\section{'The local' as object}

Although the ICC Statute is systemically open to pluralism, the functioning of the Court remains self-centric. 'The local' is predominantly an object. ICC practice does not repeat stereotyped versions of civilising discourse as reflected in the Covenant of the League of Nations or Article 38 of the ICJ Statute, that is, formal distinctions between advanced and primitive nations as well as between the civilised and the savage. ${ }^{116}$ Access to the Rome Statute is not subject to a determination of the ability and standards of a domestic system. The Statute avoids formal claims of superiority over domestic justice. ${ }^{117}$ It is also less vertical than other international justice mechanisms (e.g., the 'primacy'-based ad hoc tribunals). ${ }^{118}$ It does not impose clear-cut substantive justice standards. It judges domestic action in terms of processes and outcomes. But it represents an instrumentalist logic that exposes the Court to similar criticisms as other 'global governance' actors. ICC action has caused

114 On dilemmas of acquittals, see J. Clark, 'Courting Controversy: The ICTY's Acquittal of Croatian Generals Gotovina and Markač, Journal of International Criminal Justice, 11 (2013), 399.

115 For democratisation of access to information, see M. Bergsmo, Complementarity and the Challenges of Equality and Empowerment, FICHL Policy Brief Series No. 8 (2011), 3-4.

116 Article 38 para. 1 lit. c. of ICJ Statute refers to 'general principles of law recognized by civilized nations' as one of the sources of international law. See G.W. Gong, The Standard of 'Civilization' in International Society (Oxford: Clarendon Press, 1984), 3; L. Obregón, 'The Civilized and the Uncivilized', in B. Fassbender and A. Peters (eds.), The Oxford Handbook of the History of International Law (Oxford: Oxford University Press, 2012), 917.

117 In colonial policy, decolonisation implied that 'a society first had to be educated to be civilized' and to gain access to self-determination before its recognition as an equal sovereign. See N. Matz, 'Civilization and the Mandate System under the League of Nations', Max Planck Yearbook of International Law, 9 (2005), 47, 61.

118 F. Mégret, 'In Search of the "Vertical": Towards an Institutional Theory of International Criminal Justice's Core', in C. Stahn and L. van den Herik (eds.), Future Perspectives on International Criminal Justice (The Hague: TMC Asser Press, 2010), 178. 
resentment since it entails features of disempowerment and emancipatory rationales. Two factors are of key importance in this regard: (i) the ICC regime fosters a (re-)orientation of the domestic realm towards the international, and (ii) it pushes certain forms of emancipation and dependency.

\section{Marginalising choice}

The mandate of the Court is geared at limiting choice. This is inherent in its mandate of ensuring accountability that prioritises legal justice. There is widespread agreement on the underlying rationale of accountability. But the way it is implemented has given rise to concern.

There is a fear that ICC policies marginalise domestic agency and foster ICC-centric imitation. ${ }^{119}$ The principle of complementarity offers a basic choice that is now largely uncontested in international justice: A state must either investigate or prosecute crimes, or leave space for another forum to take action if it fails to do so. This can be either the ICC or another state ('horizontal complementarity'). This commitment itself is rarely challenged on ideological grounds. ${ }^{120}$ But its application has come under criticism.

The ICC has adopted a rather strict approach towards the required degree of symmetry between domestic and ICC action. The 'case' before the ICC serves as main point of comparison. States must adjust their criminal strategy to this focus of enquiry and model their own action after ICC proceedings, in order to be able to challenge admissibility successfully. ${ }^{121}$ It is this structural dependency that causes unease from a critical perspective. The very idea that a state must construct its accountability approach after a pre-set international case policy evokes certain parallels to historical critiques of international justice. ${ }^{122}$ At Tokyo, the Indian judge Pal famously branded the trial as an imperial

119 See K. Clarke and M. Goodale (eds.), Mirrors of Justice: Law and Power in the Post-Cold War Era (Cambridge: Cambridge University Press, 2014).

${ }^{120}$ But see Nielsen, 'Civilizing Mission', 108, arguing that the choice under the complementarity model as such is 'imperialistic', since 'the "other" is brought within the universal standards of civilization set by international criminal law'.

121 See R. Rastan, 'What Is a "Case" for the Purpose of the Rome Statute?', Criminal Law Forum, 19 (2008), 435.

122 See L. Varadarajan, 'The Trials of Imperialism: Radhabinod Pal's Dissent at the Tokyo Tribunal', European Journal of International Relations, 21 (2015), first published on 10 December 2014 as doi:10.1177/1354066114555775; Y. Totani, The Tokyo War Crimes Trial (Cambridge, MA: Harvard University Press, 2009). 
project by Allied Powers, ${ }^{123}$ geared at creating 'an international legal community in their own image'. ${ }^{124}$ The ICC glanced over these sensitivities. It expressly used the 'mirror' imagery to determine complementarity. It held that admissibility requires a 'judicial assessment of whether the case that the State is investigating sufficiently mirrors the one that the Prosecutor is investigating.'

This language is unfortunate. It evokes fears that complementarity is a concept with missionary features, geared at domestic replication. ${ }^{126}$ In its jurisprudence, the Court accepted that domestic investigations and prosecutions must not necessarily use the same crime labels as the ICC. ${ }^{127}$ But it restricted flexibility through an 'incident'-specific interpretation of the 'sameness' of the case. It held that it is 'hard to envisage a situation in which the Prosecutor and a State can be said to be investigating the same case in circumstances in which they are not investigating any of the same underlying incidents'. ${ }^{128}$ This leaves de facto limited space for deviation.

The strict focus on congruence between the ICC and the domestic case has critical repercussions. It has been vividly challenged by Kenya and Libya. Kenya argued that this symmetry approach leaves virtually no prospects for domestic justice, 'since a national jurisdiction may not always have the same evidence available as the Prosecutor and therefore may not be investigating the same suspects as the Court'. ${ }^{129}$ Libya

${ }^{123} \mathrm{Pal}$ argued that the tribunal would be an ideological cloak, intended to disguise the vested interests of the interstate sphere and [...] serve as a first line for their defence'. See IMTFE, Dissentient Judgment of Justice Pal (Kokusho Kankokai, Tokyo, 1999), 117.

124 E. Kopelman, 'Ideology and International Law: The Dissent of the Indian Justice at the Tokyo War Crimes Trial', New York University Journal of International Law and Politics, 23 (1991), 373, 375.

125 Gaddafi and Al-Senussi, Situation in Libya, Judgment on the appeal of Libya against the decision of Pre-Trial Chamber I of 31 May 2013 entitled 'Decision on the admissibility of the case against Saif Al-Islam Gaddafi', ICC-01/11-01/11 OA 4, AC, ICC, 21 May 2014, para 73 ('Gaddafi Appeals Judgment'); in the same vein Gaddafi and Al-Senussi, Situation in Libya, Judgment on the Appeal of Mr Abdullah Al-Senussi against the decision of Pre-Trial Chamber I of 11 October entitled 'Decision on the admissibility of the case against Addullah Al-Senussi', ICC-01/11-01/11 OA 6, AC, ICC, 24 July, para. 119 ('Al Senussi Appeals Judgment').

126 On 'mimicry' as a feature of post-colonial critique, see D. Robinson, Translation and Empire: Postcolonial Theories Explained (Manchester: St Jerome Publishing, 1997), 1920; Darian Smith, 'Postcolonial Theories', 253.

127 Al-Senussi Appeals Judgment, para. $119{ }^{128}$ Gaddafi Appeals Judgment, para. 72.

129 See Appeals Chamber, Judgment on the appeal of the Republic of Kenya against the decision of Pre-Trial Chamber II of 30 May 2011 entitled 'Decision on the Application by the Government of Kenya Challenging the Admissibility of the Case Pursuant to Article 19(2)(b) of the Statute', ICC-01/09-02/11 O A, 30 August 2011, para. 42. 
submitted that it conflicts with the need to '[empower] national jurisdictions in challenging transitional situations'.

Existing jurisprudence runs the risk of entrenching inequalities in international society, that is, differences between developed and developing states and between stable and unstable democracies. It makes it even harder for conflict-torn societies to take justice in their own hands. It provides limited weight to a more cooperative-oriented approach towards justice, that is, the idea that 'the overall goal of the Statute to combat impunity can also be achieved by the Court through means of active cooperation with the domestic authorities. ${ }^{131}$ This contradiction has been aptly identified by Judge Ušacka:

Instead of complementing each other, the relationship between the Court and the State would be competitive ... such an approach could potentially preclude a State from focusing its investigations on a wider scope of activities and could even have the perverse effect of encouraging that State to investigate only the narrower case selected by the Prosecutor. ${ }^{132}$

Ultimately, a strict admissibility jurisprudence might deprive a domestic society from an indigenous process of trial and error.

\section{Ethics of emancipation}

A second dilemma in the agent-object relationship relates to the ethics of emancipation. The idea of complementarity as such carries a certain emancipatory impetus. Legally, states are not forced to model their own justice system after the ICC. But the ICC framework provides an incentive for legal adaptation through the 'unability' and 'unwillingness' exception. States might need to adjust and strengthen their national jurisdiction in order to avoid being found 'unable' or 'unwilling'. Complementarity thus creates incentives for structural reform, such as perfecting the state, encouraging accountability and transparency and strengthening civil society.

These dynamics open the Court to emancipatory dilemmas known from (post-)colonial discourse. ${ }^{133}$ States need to adopt certain

${ }^{130}$ Gaddafi Appeals Judgment, para. 76.

131 Gaddafi Appeals Judgment, Dissenting Opinion of Judge Anita Usacka, ICC-01/11-01/1 1-547-Anx2 (OA 4), para. 65.

132 Ibid., paras. 52 and 55.

133 On legal hybridity in colonial and post-colonial relations, see J. Comaroff and J. Comaroff (eds.), Law and Disorder in the Postcolony (Chicago, IL: University of Chicago Press, 2006); Darian Smith, 'Postcolonial Theories', 255. 
international narratives and structural measures in order to gain 'ownership' over justice. Practice in some of the first ICC situations (e.g., Uganda, DRC) has shown that the logic of complementarity has certain distorting side effects. As illustrated in this volume by Christian De $\operatorname{Vos}^{134}$ and Patryk Labuda, ${ }^{135}$ there is a risk that states implement international standards primarily to satisfy international audiences, such as the ICC itself, international donors and NGOs. ${ }^{136}$ External incentives and pressure for quick solutions encourage a move towards targeted institutional responses that satisfy international audiences, but remain exceptional in the domestic context. One example is the creation of the International Crimes Division (ICD), a special division of the High Court of Uganda. ${ }^{137}$ It has had a curious career. It was initially deemed to be part of the comprehensive peace agreement with the Lord's Resistance Army, but has re-branded itself "as a court of "complementarity" with respect to the International Criminal Court', in order to '[fulfill] the principle of complementarity stipulated in the preamble and Article 1 of the Rome Statute'. ${ }^{138}$ It dealt with only one 'core crimes' case, the Kwoyelo case. ${ }^{139}$ This case was hampered by controversies between the Constitutional Court and the Supreme Court over the effects of Ugandan amnesty legislation. ${ }^{140}$ When Dominic Ongwen was arrested in 2015, ICD proceedings were not even considered. Nor did the ICD look into violations committed by the Uganda People's Defence Force. It has thus remained a partly artificial construct, as Stephen Oola's chapter in this volume examines in greater detail.

In other contexts such as Kenya and Libya, complementarity has triggered an action/response game. Domestic accountability measures were adopted. But they were geared at avoiding ICC intervention, rather than appropriating accountability regimes. For instance, Libya adopted a

134 See Chapter 15 by De Vos in this volume.

135 See Chapter 16 by Labuda in this volume.

136 See also S. Kendall, 'Commodifying Global Justice: Economies of Accountability at the International Criminal Court', Journal of International Criminal Justice, 13 (2015), 113.

137 See Nouwen, Complementarity, 223.

138 See International Crimes Division, at www.judicature.go.ug/data/smenu/18/ International_Crimes_Division.html.

139 On the Kwoyelo case, see Chapter 6 by Oola in this volume.

140 The Constitutional Court directed the ICD to cease the trial in light of the existing amnesty legislation. In April 2015, the Supreme Court held that the trial of the respondent by the International Crimes Division of the High Court is proper and should proceed'. See Supreme Court, Uganda versus Kwoyelo, Constitutional Appeal No. 01 of 2012, [2015] UGSC 5, 8 April 2015, at www.ulii.org/ug/judgment/supreme-court/ $2015 / 5$ 
draft decree, incorporating international crimes into domestic law, and a decree on reparation for victims of sexual violence, in order to strengthen its admissibility challenges. ${ }^{141}$ This is likely to produce artificial results. If states strengthen domestic systems primarily for the sake of adjudicating specific cases domestically, reform efforts are geared towards ICC priorities rather than long-term domestic interests. This adjustment of national systems based on case-related strategic considerations may ultimately run counter to the objective of the Rome Statute, that is, to create a sustainable 'system of justice' and replicate failures of development policy (e.g., norm export, legal transplantation). ${ }^{142}$

\section{'The local' as subject}

The view of 'the local' as subject offers a counter-narrative to fears of disempowerment through ICC justice. The ICC embraces this vision. It differs formally from classical emancipatory projects where the interests of 'the local' were conveyed through state-based mediaries. ${ }^{143}$ It stands in the tradition of liberal justice, which seeks to counter forms of organisation, domination or submission inherent in the commission of crimes and formal structures supporting their entrenchment in society. As Pablo de Greiff put it:

criminal justice can be interpreted as an attempt to provide recognition to victims by denying the implicit claim of superiority made by the criminal's behaviour through a sentence that is meant to reaffirm the importance of norms that grant equal rights to all. ${ }^{144}$

ICC justice serves as both a shield for individuals and as a platform to voice the grievances of victims. It recognises the significance and value of persons in a dual capacity: as victims and as holders of rights. Both aspects are typically invoked as progress by supporters of international

141 On the draft decree, see Application on behalf of the Government of Libya pursuant to Article 19 of the ICC Statute, ICC-01/11-01/11, 1 May 2012, para. 84. On justice and Libya, see International Crisis Group, 'Trial by Error: Justice in Post-Qadhafi Libya', Crisis Group Middle East/North Africa Report Nº140, 17 April 2013; see Chapter 18 by Kersten in this volume.

142 On legal transplants and colonisation, see B.S. Cohen, Colonialism and Its Forms of Knowledge (Princeton, NJ: Princeton University Press, 2006), 58-75.

143 On the petition system of the League, see A. Momirov, 'The Individual Right to Petition in Internationalized Territories: From Progressive Thought to an Abandoned Practice', Journal of the History of International Law, 9 (2007), 203.

144 See Report Special Rapporteur, para. 30. 
justice. But they create certain new dilemmas in their approach towards the victim as subject. ${ }^{145}$

\section{Tensions of a rights-based approach}

In past decades, there has been a large turn to a rights-based approach towards victims' claims. ${ }^{146}$ This trend towards individualisation has its origin in the recognition of the rights of victims to an effective remedy. ${ }^{147}$ It has been enshrined in multiple UN documents, such as the UN Basic Principles and Guidelines on the Right to a Remedy and Reparation for Victims of Gross Violations of International Human Rights Law and Serious Violations of International Humanitarian Law. ${ }^{148}$ It has merits in the domestic adjudication of claims or in civil claims proceedings. But it cannot be transposed in an automatic fashion to international criminal justice. In a criminal process, adjudication of victims' claims remains an annex function to the process of judgment. This involves a typification of victims' claims and a certain instrumentalisation of their interests. Judicial action in support of victims is portrayed as an improvement of local interests, but the two do not necessarily coincide. Individualised victim protection does not necessarily correlate with improvement of local conditions and collective interests.

At the ICC, the rights-based approach towards victims entails strong tensions between individual and collective interests. Applications for participation and reparation are individualised. ${ }^{149}$ The Court is mandated to provide significant attention to individualised factors, such as whether 'personal interests' of victims are affected by proceedings or individualisation of harm. But adjudication remains closely tied to the nexus to the prosecutor's case, including choice of perpetrators, incidents and localities and crimes charged (participation), as well as the link to the offender (reparation). This type of litigation may easily increase victim

145 See also Chapter 11 by Clarke and Chapter 12 by Fletcher in this volume.

146 On similar trends in humanitarian action, see P. Benelli, 'Human Rights in Humanitarian Action and Development Cooperation and the Implications of RightsBased Approaches in the Field' (ATHA, June 2013).

147 See Velasquez Rodriguez Case, Judgment of 29 July 1988, Inter-Am.Ct.H.R. (Ser. C) No. 4 (1988), para. 176.

148 UN Basic Principles and Guidelines on the Right to a Remedy and Reparation for Victims of Gross Violations of International Human Rights Law and Serious Violations of International Humanitarian Law, Adopted and proclaimed by General Assembly resolution 60/147 of 16 December 2005, para. 15 .

149 See Chapter 13 by Dixon and Chapter 14 by Kendall in this volume. 
fatigue with the Court, struggles between individuals over identity and group affiliation or feelings of exclusion. In key decisions, that is, the trial judgment or decisions on sentencing and reparation, accountability is expressed towards victims collectively. In many instances, formal recognition of victimhood and expressivist or symbolic justice may be the only realistic prospect of proceedings. ${ }^{150}$ The focus on individual rights and claims in the judicial process stands at odds with this outcome. The Court often struggles to relate this judicial outcome back to individual claims.

The rights-based approach provides a breeding ground for contestation. It may create new forms of hierarchy in the conceptualisation of 'the local'. The ICC system creates at least three different classes of victims: a broader category of victims whose general victimhood is testified in abstract terms (e.g., victims of situation-related violence), victims of the case (whose status is individualised) and victims entitled to reparation as a result of harm suffered by the convicted person. ${ }^{151}$ This judicialisation of victimhood may cause new grievances among collectivities ${ }^{152}$ or forestall a sense of closure with the past. It coincides with different types of benefits. While victims with a sufficient link to the conviction benefit from Court-ordered reparations under Article 75 (i.e. individual reparation, collective reparation or both), ${ }^{153}$ other victims are at best eligible to come within the ambit of the Trust Fund's 'assistance mandate', which is humanitarian in nature. ${ }^{154}$

These tensions became apparent in the debate over the appropriate form of reparations in the Lubanga case. The Trust Fund for Victims argued that

individual [reparations] awards which are dependent on successful applications to participate may not be the most appropriate approach in the

150 See Prosecutor v. Thomas Lubanga, TC I, Decision on the Defence request for leave to appeal the Decision establishing the principles and procedures to be applied to reparations, ICC-01/04-01/06, 29 August 2012, para. 23.

151 On the hierarchisation of victims through ICC proceedings, see Kendall and Nouwen, 'Representational Practices', 241-252.

152 See M. Findlay, 'Locating Victim Communities within Global Justice and Governance', in A. Crawford (ed.), International and Comparative Criminal Justice and Urban Governance: Convergence and Divergence in Global, National and Local Settings (Cambridge: Cambridge University Press, 2011), 109-139.

153 Prosecutor v. Thomas Lubanga, Judgment on the appeals against the 'Decision establishing the principles and procedures to be applied to reparations' of 7 August 2012, ICC-01/ 04-01/06 A A 2 A 3, Appeals Chamber, 3 March 2015 (AC Reparations Judgment), para. 65.

154 AC Reparations Judgment, para. 183; Regulation 50 of the Regulations of the Trust Fund. 
present case, given only a small number of victims are currently participating and they are not necessarily representative of the wider group of victims. ${ }^{155}$

It added that 'community discontent' with the Trial Chamber's verdict 'could lead to former child soldiers and their families to refuse individual awards of reparations due to a fear of reprisals from within their own communities.' ${ }^{156}$ The Trial Chamber sought to reduce such risks by endorsing 'a community-based approach' towards reparations. ${ }^{157}$ This approach was partly reversed by the Appeals Chamber, which noted that any reparation to a community requires the establishment of a sufficient link between the harm suffered by community members and the crimes of the convicted person. ${ }^{158}$

This jurisprudence illustrates the shadow side of a 'rights-based' conception of victims. It creates distinctions between 'privileged' and 'less privileged' victims. This legal categorisation may implicitly fuel claims of superiority among victims, cause resentment on the part of marginalised victims or neglected local groups or even lead to embarrassment by affected victims, as Peter Dixon explores in his contribution to this volume. As one voice put it in the Kenyan context:

I am concern[ed] of what to tell my community. How do I explain that you selected few victims? Many victims will be left aside of this process. Everyone I know would like to have a say in this process. ${ }^{159}$

\section{Archetypes of victimhood}

The second danger of the ICC's approach towards victims as a subject is related to the construction of subjectivity. ${ }^{160}$ In the context of mass atrocity crimes, the victim is rarely regarded as he or she is, but is rather tailored and trimmed to fit certain roles and expectations. Victimhood is shaped by the social patterns of atrocity violence, and then framed and specified by case theory and Court discourses. In this context, personal

155 Prosecutorv. Thomas Lubanga, Decision establishing the principles and procedures to be applied to reparations, ICC-01/04-01/06, Trial Chamber, 7 August 2012 (TC Reparations Decision), para. 44.

156 Ibid. ${ }^{157}$ Ibid., para. 274. ${ }^{158}$ AC Reparations Judgment, para. 212.

159 See ICC, 'Turning the Lens', 5.

160 On imagined subjectivity in post-colonial theory, see T. Mahmud, 'Postcolonial Imaginaries: Alternative Development or Alternatives to Development?', Transnational Law \& Contemporary Problems, 9 (1999), 25; T. Ruskola, 'Legal Orientalism', Michigan Law Review, 101 (2002), 179, 200 et seq. 
harm and suffering is of secondary importance. Subjectivity is a means to an end, that is, related to a cause. The individual victim becomes to some extent a 'universalised victim' that is emblematic of the harm and suffering caused to the international community as a whole. ${ }^{161}$ There is a strong tendency to rely on archetypes of victimhood in order to mobilise empathy and support.

Victimhood becomes part of the identification of the Court. ${ }^{162}$ This process transforms subjectivity and stresses particular narratives and features; there is an element of drama. Charging strategy and expressivist features of ICC justice focus on spectacular events and certain specific categories of victims (e.g., child soldiers, victims of sexual violence), as Kamari Clarke's work has shown, ${ }^{163}$ rather than victims of everyday violence. There is interest in the 'victim' because of its extraordinary position. Victimhood is associated with certain characteristics, such as vulnerability, powerlessness, disadvantages, abuse and fear. This limits the space for contestation and contributes to the perception of justice as a heroic response. Representation of types of violence or policies is often a product of Western culture. It involves a certain degree of voyeurism, that is, viewing the drama of others, ${ }^{164}$ and exhibitionist features. The discourse disregards that the label of victimhood has also certain disempowering effects. Some individuals do not want to be seen as (passive) victims but as individual subjects or agents who overcame atrocities they had suffered. ${ }^{165}$ Cultivating a culture of victimhood is thus not always in the best interest of conflict-affected persons.

Paradoxically, this construction of victimhood has some parallels to the contradictions of guardianship in historical practice. ${ }^{166}$ There is a

161 On victims as constituency of international justice, see also Chapter 1 by Mégret in this volume.

162 See Clarke (Chapter 11).

163 See K. Clarke, 'The Rule of Law Through Its Economies of Appearances: The Making of the African Warlord', Indiana Journal of Global Legal Studies, 18 (2011), 7; Clarke, Fictions of Justice, 105-109.

${ }^{164}$ In the late nineteenth and early twentieth centuries, exhibitions of native people and traditions were a popular means of entertainment in Europe. See Matz, 'Civilization', 66.

165 See M. Mutua, 'Savages, Victims and Saviors: The Metaphor of Human Rights', Harvard International Law Journal, 42 (2001), 201; F. Ní Aoláin and D. Haynes, 'The Compatibility of Justice for Women with Analysis', in C. Stahn, J. Easterday, and J. Iverson, Jus Post Bellum: Mapping the Normative Foundations (Oxford: Oxford University Press, 2013), 161, 164.

166 Critics have argued that the mandates and trusteeship system were geared at maintaining power. See A. Anghie, Imperialism, Sovereignty and the Making of International Law (Cambridge: Cambridge University Press, 2005). 
certain conflation between self-interest and the protected subject. ICC justice promises more equality, freedom and justice through judicial intervention. This cause attracts input from and acceptance of the role of victims, but is partly a means for the Court to maintain its own power.

\section{Us as them: the 'local' as pattern of justification}

The turn to 'the local' as structural justification becomes particularly evident in the context of exit and disengagement strategy. At this stage, 'them' turns into 'us'. The relationship with national jurisdiction(s) and affected communities turns into a central tenet of ICC policy. The Court uses different types of connections to 'the local' to validate its mission.

In the context of non-engagement or exit from situations, considerable emphasis is placed on synergies between ICC intervention and the strengthening of domestic jurisdictions. Complementarity forms a main postulate of disengagement strategy. This transforms the perspective towards 'the local'. 'National ownership' becomes an important justification of ICC justice.

This lens is reflected in the Court's strategy towards 'Completion of ICC activities in a situation country. ${ }^{167}$ The strategy differentiates between 'completion', that is, progressive conclusion of investigative, prosecutorial and judicial activities, ${ }^{168}$ and 'legacy'. This involves 'longterm post-completion projects, which begin prior to the institution's closure, such as outreach and institutional and capacity-building efforts, aimed at leaving a lasting positive impact on affected communities and their criminal justice systems'. ${ }^{169}$

Underlying policies reflect some of the transformative ethos of the ICC. Completion involves 'assessments of what assistance is needed to enable the relevant country's judicial system to handle any residual issues could be seen part of the exit strategies'. ${ }^{170}$ Completion is treated in connection with the goal of 'legacy', which is defined by the Court as 'lasting impact on bolstering the rule of law in a particular society, by conducting effective trials to contribute to ending impunity, while also strengthening domestic judicial capacity'. ${ }^{171}$

The Court's legacy vision is centred on global implications and virtual symmetry between the ICC and domestic jurisdiction. ${ }^{172}$ It imagines a

167 Report of the Court on complementarity: Completion of ICC activities in a situation country, ICC-ASP/12/32, 15 October 2013.

168 Ibid., para. 19. ${ }^{169}$ Ibid., para. 17. ${ }^{170}$ Ibid., para. 26. ${ }^{171}$ Ibid., para. 27.

172 Ibid., para. 32. 
natural continuum between ICC action and domestic action according to which 'national authorities should already be fully ready to pick up and effectively continue work', when 'the Court is exiting a given country'. ${ }^{173}$ It operates on the premise that there are 'gaps' between international and domestic justice that can be filled through 'capacity building initiatives. ${ }^{174}$ It relies on consultation ${ }^{175}$ and the 'willingness of a given State ${ }^{376}$ to address this vacuum. But it says very little about what 'national ownership' would entail.

Success or failure of cases is often explained with a reference to an 'ideal type' of victim. The focus shifts between 'global' and 'local' victims. Reference is made to the 'global' in order to mobilise sympathy and appeal. For instance, in Lubanga the OTP used 'the global child' as archetype. It defended the relatively low sentence of fourteen years as 'a symbol of hope' and 'an important step towards bringing an end to the suffering of tens of thousands of children still forced to fight, to kill and to die in conflicts around the world'. ${ }^{177}$ An even broader notion of 'global victim' was used in order to limit concern about inaction in relation to ISIS. ${ }^{178}$ The OTP emphasised 'our collective duty as a global community to respond to the plight of victims whose rights and dignity have been violated'. ${ }^{179}$ Here, 'us' and 'them' appear to have merged.

Divisive actions or outcomes are often defended with reference to an ideal type of 'local victim'. This strategy was particularly visible in the Katanga and Ndgudjolo Chui cases. When the Appeals Chamber confirmed Ndgudjolo Chui's acquittal, the OTP defended ICC proceedings by the abstract recognition of victimhood relating to the Bogoro attack. It noted that ' $\mathrm{t}$ ] he decision does not negate the fact that crimes were committed in Bogoro or the suffering of the victims' in order to limit hostile local response. ${ }^{180}$ In Katanga, the OTP used the interests of

173 Ibid., para. 36. ${ }^{174}$ Ibid., para. 33. ${ }^{175}$ Ibid., para. $35 .{ }^{176}$ Ibid., para. 34.

177 Statement of the Prosecutor of the International Criminal Court, Fatou Bensouda, following the Appeals Chamber decision on the verdict and sentence in the Lubanga case: Protecting children means preserving the future, 2 December 2014.

178 On the ICC and ISIS, see C. Stahn, 'Why the ICC Should Be Cautious to Use the Islamic State to Get Out of Africa: Part 1', at www.ejiltalk.org/why-the-icc-should-be-cautiousto-use-the-islamic-state-to-get-out-of-africa-part- $1 /$.

179 Statement of the Prosecutor of the International Criminal Court, Fatou Bensouda, on the alleged crimes committed by ISIS, 8 April 2015.

180 Statement of the Prosecutor of the International Criminal Court, Fatou Bensouda, following the Appeals Chamber decision upholding the acquittal in the Ngudjolo Chui case, 27 February 2015. 
victims as pattern of justification for the withdrawal of the appeal against the judgment. It justified agreement with the Defence on the ground that 'Germain Katanga has [...] played a part in addressing the need for accountability and justice as expressed by the victims', by 'acknowledging his participation in these crimes and in expressing his regret'. ${ }^{181}$ The alleged interests of 'local victim' served as justification to mitigate criticism concerning the outcome of the judgment, that is, the thin basis of conviction and evidentiary problems regarding sexual and gender-based charges. ${ }^{182}$ A similar strategy was invoked to explain the end of proceedings against Kenyatta. The Prosecutor noted:

the hurdles we have encountered ... delayed and frustrated the course of justice for the victims in this case ... it is my firm belief that today's decision is not the last word on justice and accountability for the crimes that were inflicted on the people of Kenya in 2007 and $2008 .{ }^{183}$

This strategy illustrates the instrumentalist use of the 'the local' in ICC practice. The ICC is sold as a project for 'locals'. But there is hardly meaningful engagement with 'the local'. The 'local' is portrayed in a onedimensional way, namely through the lens of the ICC. In its own discourse, the Court uses ideal types of 'victims' and 'locals', that is, those who cannot protest, as illustrated by Laurel Fletcher's analysis of the 'abstract victim' in this volume. ${ }^{184}$

Protection of 'the local' is a driving factor for ICC action. But what comes after ICC intervention is often less important. Victims are easily dropped after the end of the case. There is limited aftercare or psychosocial support. This burden is shifted back to the 'national', the 'local community' or the family. General assistance is outsourced to the nonjudicial mandate of the Trust Fund, which is limited in scope. ${ }^{185}$

\section{Conclusions}

Civilising discourse has been part of international justice since its inception. It is a double-edged sword. It is used to glorify international action or to discredit it. The ICC is sometimes unfairly equated to an imperial

181 Statement of the Prosecutor of the International Criminal Court, Fatou Bensouda, on Germain Katanga's Notice of Discontinuance of his Appeal against his Judgment of Conviction, 25 June 2014.

182 See Stahn, Katanga, 821, 833-834.

183 Statement of the Prosecutor of the International Criminal Court, Fatou Bensouda, on the withdrawal of charges against Mr Uhuru Muigai Kenyatta, 5 December 2014.

184 See Fletcher (Chapter 12). ${ }^{185}$ See Dixon (Chapter 13). 
project. It is in many ways an antidote to classical imperial or colonial forms of domination and subordination. But it raises equality and justice dilemmas that cannot merely be swept aside by reference to its noble cause. They do not arise in the form of traditional hierarchies or emancipatory claims relating to all spectrums of life ('mission civilisatrice'), but in a novel and more subtle way. Post-colonial theory, and its critique of constructed subjectivity, emancipation, asymmetric power and inequality, ${ }^{186}$ provides a lens to reflect on these tensions, including the relationship between the ICC and 'the local'.

ICC justice offers protection against abuse and oppression, but it also involves assertion of power. This power might not always be directly perceived or experienced as coercive. ${ }^{187}$ It is often exercised with some form of consent, or through soft, informal or indirect means. But it creates similar fears as other global institutions (e.g., international financial institutions, administrative standard-setting bodies). ICC actions and procedures create certain effects that divide and shape the world. While seeking to protect individuals from mass atrocity crime, they create new forms of international 'ownership', that is, ownership over narratives, knowledge production or branding of 'otherness', and structural dependencies. This occurs incrementally, that is, through practice.

Categorisations and notions used in the process of rendering justice produce certain binaries and distinctions that are easily perceived as stigma. For instance, the unreflected use of concepts, such as 'complementarity' or 'capacity-building', may steer distinctions between the 'able' and the 'unable', the 'knowing' and the 'unknowing', the 'progressive' and the 'regressive' and so on. This has disempowering effects. Similar tensions arise in relation to the use of the notion of victims. This label may have certain patronising implications for affected groups or individuals. It evokes images of vulnerability and passivity that may not always coincide with social reality or self-perception.

Moreover, there is an implicit risk that ICC interventions may encourage certain forms of justice that do 'not come from within', but are externally driven. Practices such as the strict application of the admissibility test and the use of the 'mirroring' imagery produce action/response schemes that may stifle or weaken domestic justice. They incentivise

186 See above note 26.

187 As noted by Mamdani: '[T]he colonial experience for most natives was one of rule mediated through one's own.' See M. Mamdani, 'Historicizing Power and Responses to Power: Indirect Rule and Its Reform', Social Research, 66 (1999), 859, 870. 
domestic responses that are geared and construed to meet short-term policy objectives of the ICC, or serve as encouragement to dump the burden of investigations and prosecutions on the Court. Both approaches stifle creativity.

The 'local' as structural argument provides a certain counter-perspective to such tendencies. It highlights that social reality is more complex, and often more messy, than articulated in the language of law and justice. The 'local' is a concept with many faces. It forces the ICC to look at very different spectrums of its interventions, that is, regional implications; impact on states; effects on communities, groups, individuals; and so on. It thus provides a necessary balance to the mainstreaming of international justice in institutional politics. It implies that the benefits of ICC justice cannot be taken for granted, but must be constantly articulated, assessed and re-adjusted, if necessary.

Some of the paternalising and disempowering features of ICC justice cannot be solved. But they might be handled more constructively, with closer consideration of the faces of 'the local'. The ICC may legitimately override domestic preferences, or present alternative narratives or choices in specific contexts. But structurally, 'the local' is more than a means to an end.

Many of the complex historical and social realities of conflicts cannot be understood through short-term intervention. There is a need for deeper engagement with locality in ICC practice. This is crucial in the early part of proceedings, for example, as part of preliminary examination analysis, investigation and the framing of the case, rather than merely at trial (e.g., in situ hearings) or in the reparation phase. Initiatives to re-connect to the 'local' through field presences or outreach are likely to have limited impact, once the ICC case has been detached too far from local societies.

Where ICC action discards domestic or local interests, such action should be adequately reasoned and explained. ${ }^{188}$ Its acceptance may depend on a number of factors: the way in which it was formed and conveyed; its grounding in knowledge and expertise, including local and regional expertise (rather than the presumptive superiority of 'the international'); and its verification and openness to challenge.

Finally, more attention needs to be paid to the negative or unintended side effects of ICC interventions, including the potential inequalities and injustices they produce. Among other things, this requires sensitivity to

188 See Damaška, 'What's the Point', 387. 
the forms of power and dependencies created through ICC action, attention to the injustices of inaction and caution in the use of the notion of victim. Existing contradictions will be less striking if the ICC shows greater responsibility towards its objects of care. It is these features that need to be addressed to counter fears of justice civilisatrice. 


\title{
The global as local
}

\author{
The limits and possibilities of integrating international \\ and transitional justice
}

DAVID S. KOLLER

\section{Introduction}

It has become increasingly popular in recent years to focus on the contributions of international criminal courts and tribunals (ICTs) to transitional or post-conflict justice and to assess the impact of ICTs in terms of their ability to promote justice locally in societies undergoing transition or emerging from conflict. ${ }^{1}$ Yet this description only captures part of the story. These very same institutions have also been described as tools of international realpolitik or, in a more nuanced form, what Gerry Simpson calls 'juridified diplomacy', which largely serve political rather than legal aims and which generally operate globally rather than locally. In Simpson's words, 'juridified diplomacy' is '[t]he phenomenon by which conflict about the purpose and shape of international political life (as well as specific disputes in this realm) is translated into legal doctrine or resolved in legal institutions.'

This chapter elaborates these two competing paradigms of transitional justice and juridified diplomacy and examines the extent to which, and the reasons why, they have been reflected historically in different ICTs. This historical analysis leads to three observations. First, the origins of international criminal law lie firmly within the paradigm of juridified diplomacy and not in that of transitional justice. Second, despite these origins, ICTs have increasingly taken on characteristics that resemble the

${ }^{1}$ See, e.g., R. Shaw et al. (eds.), Localizing Transitional Justice: Interventions and Priorities after Mass Violence (Stanford, CA: Stanford University Press, 2010); Report on the Rule of Law and Transitional Justice in Conflict or Post-Conflict Societies, UN Doc. S/2004/616 (2004) ('Rule of Law Report').

${ }^{2}$ G. Simpson, Law, War and Crime: War Crimes Trials and the Reinvention of International Law (Cambridge: Polity Press, 2007), 1. 
transitional justice paradigm. Third, and perhaps most surprising, this apparent turn towards transitional justice can to a large extent be explained by reasons grounded in the juridified diplomacy paradigm. On the basis of these conclusions, this chapter explores the possibility and desirability of ICTs becoming instruments of transitional justice in the future. Ultimately, it concludes that, while further moves towards a transitional justice mandate may be possible in the short-term, this could ultimately undermine the effectiveness of ICTs as instruments of both paradigms. In contrast, focusing on the juridified diplomacy mandates of ICTs may increase their beneficial impacts if appropriate caution is exercised.

\section{The two paradigms}

ICTs are established through complex processes involving negotiations among a wide array of individuals and organisations with diverse interests. They do not reflect the working out of coherent conceptual frameworks defined ex ante. Rather, observers have constructed such frameworks or paradigms ex post in order to describe, to understand and to test assumptions about ICTs. ${ }^{3}$ To date, two rival and ostensibly incompatible paradigms - transitional/post-conflict justice and international politics/juridified diplomacy - have emerged as the dominant frameworks for understanding ICTs. Neither paradigm in itself captures the complexity of ICTs or indeed of international diplomacy or transitional justice. Rather, they serve as rough conceptual frameworks for understanding these institutions and processes. This section describes these two paradigms and examines to what extent they are contradictory or complementary means of understanding ICTs.

\section{Transitional/post-conflict justice}

The UN Secretary-General's 2004 Report on the Rule of Law and Transitional Justice in Conflict or Post-Conflict Societies describes transitional justice generally as 'compris[ing] the full range of processes and mechanisms associated with a society's attempts to come to terms with a legacy of large-scale past abuses, in order to ensure accountability, serve justice and achieve reconciliation'. ${ }^{4}$ Ruti Teitel more precisely defines

3 See D. Koller, 'The Faith of the International Criminal Lawyer', New York University Journal of International Law and Politics, 40 (2008), 1019, 1020-1021.

${ }^{4}$ Rule of Law Report, 8. 
'transitional justice' as 'the conception of justice associated with periods of political change, characterized by legal responses to confront the wrongdoing of repressive predecessor regimes'. While these broad descriptions may encompass a wide variety of views as to what specifically transitional justice should entail and precisely how ICTs may contribute to its realisation, ${ }^{6}$ two fundamental characteristics underlie the paradigm.

First, justice is an important goal to be pursued. Justice within this paradigm has a specific sense related to the rule of law and legal processes, and a claim to justice is one that must be phrased in legal terms. ${ }^{7}$ In this sense, justice is opposed to politics as usual. Indeed, justice may not be the only or even the ultimate goal; it may exist alongside or as an intermediary to other goals such as peace or reconciliation. ${ }^{8}$ However, justice is a significant and relevant good. As such, the manner in which institutions contribute to justice, the extent to which they do so and the particular conceptions of justice they serve become defining characteristics.

As a consequence, ICTs are perceived within this paradigm as mechanisms for the delivery of a highly formalised and individualised justice in the form of the criminal trial. They are, in this fundamental respect at least, indistinguishable from national criminal courts. Together, international and national or local criminal courts are thought to form a 'system' or 'community' of courts working to enforce accountability for international crimes for the benefit of societies undergoing transition or recovering from conflict. ${ }^{9}$ They are thus distinguished from other justice-related mechanisms such as truth commissions or lustration mechanisms, all of which are contrasted with political (i.e. non-legal) processes. ${ }^{10}$

Second, transitional justice interventions tend to operate more locally, with their effects felt on the society undergoing a transition or recovering from conflict. ${ }^{11}$ The precise borders of this society may vary; they can be

${ }^{5}$ R. Teitel, Transitional Justice (New York: Oxford University Press, 2000), 69 (citations omitted).

${ }^{6}$ Rule of Law Report, 5.

7 See K. McEvoy, 'Beyond Legalism: Towards a Thicker Understanding of Transitional Justice', Journal of Law and Society, 4 (2007), 411.

8 Rule of Law Report, 39.

9 See, e.g., W. Burke-White, 'A Community of Courts: Toward a System of International Criminal Law Enforcement', Michigan Journal of International Law, 24 (2002-3), 1.

${ }^{10}$ See, e.g., Teitel, Transitional Justice.

11 R. Teitel, 'Preface', in Shaw et al., Localizing Transitional Justice, viii; M. Osiel, Mass Atrocity, Collective Memory, and the Law (New Brunswick, NJ: Transaction Publishers, 2000), 1. 
conceived in a more communitarian or more individualistic manner, and the views of the society's members may be given more or less weight in the design of particular justice mechanisms. However, the key point is that all justice mechanisms, including ICTs, should be evaluated in terms of the benefits they bring to particular defined societies in transition or post-conflict. The paradigm is inapplicable, however, to societies that have not yet entered into transition or that remain in the midst of conflict. ${ }^{12}$ Furthermore, the international audience, which transcends the borders of particular societies, is given at most secondary consideration after the concerns of local populations. ${ }^{13}$

\section{Juridified diplomacy}

Counterpoised to the transitional justice paradigm, critical scholars have put forth an alternative vision that largely conceives of ICTs as instruments of international politics. ${ }^{14}$ This paradigm - building on Simpson's notion of 'juridified diplomacy' - is constructed upon premises that at least appear fundamentally opposed to those that underlie the transitional justice paradigm.

First, within this paradigm, ICTs are not primarily instruments of law and of justice but of diplomacy and of politics. ${ }^{15}$ They are set up by states to achieve their political purposes rather than for the pursuit of an idealised notion of justice. These purposes may reflect self-interest in a narrow, cynical sense or more broadly conceived, such as a general interest in maintaining international peace and security. As instruments of politics, they fulfil these purposes primarily through influencing the calculus or perceptions (short or long term) of political actors, ${ }^{16}$ although interaction with ICTs may also have a normative effect on the

12 See Teitel, Transitional Justice, 5.

${ }^{13}$ See N. Kritz, 'Progress and Humility: The Ongoing Search for Post-Conflict Justice', in M. Bassiouni (ed.), Post-Conflict Justice (Ardsley, NY: Transnational Publishers, 2001), 59.

14 Simpson, Law, War and Crime; See also P. Hazan, Judging War, Judging History: Behind Truth and Reconciliation (Stanford, CA: Stanford University Press, 2010), 145; F. Mégret, 'The Politics of International Criminal Justice', European Journal of International Law, 13 (2002), 1261; M. Koskenniemi, 'Between Impunity and Show Trials', Max Planck Yearbook of United Nations Law, 6 (2000), 1.

15 See G. Bass, Stay the Hand of Vengeance: The Politics of War Crimes Tribunals (Princeton, NJ: Princeton University Press, 2002).

${ }^{16}$ See Hazan, Judging War, Judging History, 137; J. Maogoto, War Crimes and Realpolitik: International Justice from World War I to the 21st Century (Boulder, CO: Lynne Rienner Publishers, 2004), 8-9. 
interests of states in the long term. ${ }^{17}$ The key point is that the fact that ICTs conduct criminal trials is considered at most an accidental or secondary characteristic of such institutions. ICTs have much more in common with other mechanisms of international diplomacy, such as the threat or imposition of sanctions or military intervention, than they do with national courts. ${ }^{18}$

Second, defining ICTs as mechanisms of diplomacy also situates them within a particular community of practice, namely the international diplomatic community. This community may be defined narrowly to include only states or more broadly to account for a wide range of nonstate actors. Local actors may even have a role within this community. The defining aspect of this community, however, is that it transcends particular societal borders; by contrast, borders provide the context for the transitional justice paradigm. Moreover, as instruments for effecting political change, international criminal courts and tribunals are not limited to operating within post-conflict or transitional situations. Rather, they are explicitly intended to bring about such changes and potentially bridge conflict and post-conflict societies. ${ }^{19}$

\section{Competing or complementary paradigms?}

As described before, the two paradigms reflect premises defined in opposition to each other and that superficially appear to be irreconcilable. One considers transitional justice as the triumph of law and legal processes over politics. The other regards judicial mechanisms as coopted for political purposes and rendered subservient to political aims. One defines itself as operating within particular national or societal borders, and the other as operating only across such borders.

On closer look, however, these paradigms depend on each other for their respective existences and cannot be easily separated. Indeed, they are mutually constitutive: the decision to pursue justice through legal mechanisms is itself a political decision, whilst this decision is justified

${ }^{17}$ See Koller, 'The Faith of the International Criminal Lawyer'.

18 See T. Farer, 'Restraining the Barbarians: Can International Criminal Law Help?' Human Rights Quarterly, 22 (2000), 90; D. Scheffer, 'International Judicial Intervention', Foreign Policy, 102 (1996), 34.

19 Madoka Futamura describes such institutions as existing at the 'critical juncture' between 'how war ends' and 'how peace starts'. M. Futamura, War Crimes Tribunals and Transitional Justice: The Tokyo Trial and the Nuremberg Legacy (Abingdon: Routledge, 2008), 6. 
through appealing to legal norms and implemented through legal mechanisms. And while the focus of transitional justice is on one particular society, that society's claims to justice are often articulated in presumptively universal norms that reject its past practices. Yet as Ruti Teitel notes, despite the appeal to the universal, what constitutes justice is determined not from an idealized archimedean point but from the transitional position itself. ${ }^{20}$ Thus, it is impossible to separate one paradigm entirely from the other. As Frédéric Mégret observes, 'all attempts at prioritizing one over the other seem destined to fail, as the excluded paradigm comes back to haunt the dominant account'. ${ }^{21}$

These two paradigms of transitional justice and juridified diplomacy constitute ideal types, each representing a distinct set of contradictory but also mutually constitutive values in dialogue with each other: the local and judicial contrasted with the international and political. International criminal law is a contested field in which states and other policy-makers are constantly articulating and mediating between values such as law and politics, realism and idealism, individual and collective, local and international and so forth. ${ }^{22}$ As the debate between the competing values represented by each paradigm plays out over time, support for one or the other set of values ebbs and flows among those in a position to influence the development of ICTs and manifests in differences within and between these institutions over time. The next section of this chapter looks at why and to what extent the values represented by one or the other paradigm have come to dominate in different ICTs.

\section{Historical development of international courts and tribunals}

This section traces the historical evolution of international criminal law (ICL) through the five ICTs established to date: the International Military Tribunal ('Nuremberg Tribunal'), the International Military Tribunal for the Far East Tribunal ('Tokyo Tribunal'), the International Criminal Tribunal for the Former Yugoslavia (ICTY), the International Criminal Tribunal for Rwanda (ICTR), and the International Criminal Court (ICC). It excludes hybrid mechanisms and purely domestic institutions (criminal and otherwise) dealing with international crimes. The same contestation between contradictory but mutually constitutive paradigms

20 Teitel, Transitional Justice, 224.

${ }^{21}$ Mégret, 'The Politics of International Criminal Justice', 1281.

${ }^{22}$ See, e.g., D. Robinson, 'The Identity Crisis of International Criminal Law', Leiden Journal of International Law, 21 (2008), 925. 
takes place at all levels of the transitional justice/international criminal law debate. Similar observations could be made at national or local levels or among other transitional justice mechanisms, although the different actors and different interests will lead the processes to play out differently. This chapter limits itself to exploring how this process of contestation has played out at the sites of construction of ICTs.

\section{Nuremberg and Tokyo tribunals}

The establishment of the Nuremberg and Tokyo tribunals emerged not out of a commitment to deliver justice to affected communities but rather as part of broader efforts to achieve the overarching political aims of ending the war and establishing peace. The founding documents of the Nuremberg and Tokyo tribunals rooted these institutions, respectively, in the 1943 Moscow and 1945 Potsdam Declarations, sweeping political documents setting out the Allies' aims and intentions with respect to the conduct and termination of hostilities and the establishment and maintenance of peace and security after the war. ${ }^{23}$ The Moscow Declaration situated a call for punishment alongside such broad political aims as continuing the war, disarming the Axis powers, establishing what was to become the United Nations and regulating armaments in the post-war period. ${ }^{24}$ The Potsdam Declaration, occurring nearer to the end of the war, listed the need to mete out 'stern justice' among the comprehensive terms for Japanese surrender. ${ }^{25}$

The threat of punishment contained in the Moscow and Potsdam Declarations did not, however, necessarily reflect any commitment to criminal justice as understood within the transitional justice paradigm. The Moscow Declaration reserved the question of how major war criminals would be punished for a future decision of the Allies, ${ }^{26}$ and it was equally contemplated that they could be summarily executed without trial or following only the most cursory 'show trial', as opposed to following a full trial. ${ }^{27}$ The decision to punish these individuals - already denoted as 'war criminals' - through the mechanism of a criminal trial

23 Joint Four-Nation Declaration ('Moscow Declaration'), Moscow, 30 October 1943, The Avalon Project; Proclamation by the Heads of Governments, United States, China and the United Kingdom, Terms for Japanese Surrender ('Potsdam Declaration'), Berlin, 26 July 1945, 3 Bevans 1204.

${ }^{24}$ Moscow Declaration. ${ }^{25}$ Potsdam Declaration. ${ }^{26}$ Moscow Declaration.

27 See A. Kochavi, Prelude to Nuremberg: Allied War Crimes Policy and the Question of Punishment (Chapel Hill: University of North Carolina Press, 1998), 63-79. 
came much later, long after the decision to inflict individual punishment on the authors of atrocities had been taken. ${ }^{28}$ The Tokyo Tribunal largely followed its influential predecessor. Thus, while the Nuremberg prosecutor Robert Jackson referred to the decision to subject those responsible for Nazi atrocities to criminal trials as 'stay[ing] the hand of vengeance', ${ }^{29}$ at their roots, these tribunals represented the threat of individual violence to be inflicted directly on the Allies' political opponents. The decision to opt for criminal trials instead of summary executions merely channelled and did not substitute for such threats of individualised violence.

The nature of the crimes the tribunals were to address further reflected the primary concern of their creators with matters of international politics and not transitional justice. The main focus of the creators and proponents of the tribunals was the launching of an aggressive war, a crime that affected primarily the interests of states. ${ }^{30}$ War crimes, which also implicated primarily the interests of states and their militaries, were of lesser but significant concern. ${ }^{31}$ Far less significance was attached to crimes against humanity, the one category of crimes that most reflects the concerns motivating the more recent transitional justice paradigm. ${ }^{32}$

Over time, the Nuremberg and Tokyo tribunals increasingly took on apparent characteristics of the transitional justice paradigm. As mentioned earlier, criminal trials triumphed over the prospect of summary executions, crimes against humanity were eventually included in the tribunals' charters, and trials were carried out even after the Allies' war aims had been achieved. However, the extent of these developments should not be exaggerated. The legality of trials was sharply contested. ${ }^{33}$ Prosecutions were highly selective. The tribunals not only focused exclusively on German and Japanese defendants, but also spared those German and Japanese officials who could serve useful political purposes. ${ }^{34}$ The tribunals' jurisdiction over crimes against humanity was restricted to crimes committed in execution of or in connection with the

${ }^{28}$ See Report of Robert H. Jackson, US representative to the International Conference on Military Trials (1945), The Avalon Project; Kochavi, Prelude to Nuremberg; B. Smith, The Road to Nuremberg (New York, NY: Basic Books 1981).

29 R. Jackson, 'Opening Address at the Nuremberg Tribunal', reprinted in U.S. Chief of Counsel For Prosecution of Axis Criminality, Nazi Conspiracy and Aggression (Washington, DC: United States Government Printing Office,1946), vol. I, 98-99.

30 Ibid. (referring to the launching of an aggressive war as the 'supreme crime').

${ }^{31}$ Koller, 'The Faith of the International Criminal Lawyer', 1035-1036. ${ }^{32}$ Ibid.

33 See Judge R. Pal, 'Dissenting Opinion to the Tokyo Judgment', in B. Röling and C. Ruter (eds.), The Tokyo Judgment (Amsterdam: University Press Amsterdam, 1977), 541-551.

${ }^{34}$ Maogoto, War Crimes and Realpolitik, 100-104. 
war. $^{35}$ Though the war may have ended, trials were seen as serving the broader purpose of delegitimising Nazism and Japanese imperialism and establishing the ideological foundations of the post-war order.

Thus, to the extent that the Nuremberg and Tokyo tribunals took on apparent characteristics of transitional justice, they did so primarily for reasons of international politics, not out of concern among policymakers as to their domestic effects on transitional societies. The decision to reject summary executions in favour of criminal trials had little to do with the impact of these trials on Germany or Japan. Rather, to impose punishment on individuals without trial was considered by international decision-makers to be an affront to shared international values. ${ }^{36}$ Similarly, the incorporation of crimes against humanity came only after pressure from non-governmental organisations who appealed not to a particular society's need for justice but to a common sense of humanity perceived to be shattered by these crimes. ${ }^{37}$ In short, the tribunals were tools of diplomacy: in Simpson's words, they 'pursue[d] political ends through jurisprudential means' ${ }^{38}$

\section{ICTY/ICTR}

Like their Nuremberg and Tokyo predecessors, the ICTY and ICTR bear many of the hallmarks of juridified diplomacy. They were established by an overtly political body - the UN Security Council - in the exercise of a political mandate - Chapter 7 of the UN Charter - with a view to achieving an overtly political aim: the restoration and maintenance of international peace and security. ${ }^{39}$

In both cases, the establishment of the tribunals followed an escalating series of Security Council resolutions and presidential statements, beginning with expressions of general concern about or condemnation of the ongoing violence and continuing through the imposition of arms embargoes, calls to respect humanitarian law, the deployment of peacekeepers and, penultimately, the establishment of commissions to investigate allegations of international crimes. ${ }^{40}$ Only after the failure of these actions to

${ }^{35}$ Article 6 of the Charter of the International Military Tribunal.

36 See the discussion in Koller, 'The Faith of the International Criminal Lawyer', 1040-1046.

37 Ibid., 1038-1039 ${ }^{38}$ Simpson, Law, War and Crime, 24.

39 UN Doc. S/RES/827 (1993) (establishing the ICTY); UN Doc. S/RES/955 (1994) (establishing the ICTR).

40 In relation to the ICTY, see UN Docs S/RES/713 (1991); S/RES/721 (1991); S/RES//724 (1991); S/RES/727 (1992); S/RES/740 (1992); S/RES/743 (1992); S/RES/749 (1992); 
achieve their intended aims of restoring peace and security did the Security Council turn to the establishment of tribunals. In these circumstances, threatening individualised violence against perpetrators of crimes was seen as a more forceful action that could be taken either without going so far as to intervene militarily in the case of the former Yugoslavia ${ }^{41}$ or to make up for having failed to intervene adequately in the case of Rwanda. ${ }^{42}$

The primary political function of the ICTY and ICTR was further reflected in the debate, or more properly the lack of debate, concerning their features. Echoing the relationship between the Moscow Declaration and the establishment of the Nuremberg Tribunal, the decision to establish the ICTY preceded any consideration of the means by which it would operate. ${ }^{43}$ Meanwhile, as with the Tokyo Tribunal, the ICTR's Statute largely replicated that of its sister institution.

As was the case with the Nuremberg and Tokyo tribunals, states targeted and labelled as 'criminals' those individuals whom they intended the ad hoc tribunals to prosecute long before they had been established, let alone having begun any investigations or trials. ${ }^{44}$ To the extent that states expressed views on the possible features of the ICTY, at least some influential states advocated features inimical to the concept of fair and independent justice, such as placing it under the control of the Security Council. ${ }^{45}$ Once established, the ICTY and ICTR also found their ability to carry out their mandates frustrated by a lack of support by states, suggesting that the interest of states in using the political threat of punishment outweighed their support for adjudicating crimes committed in the regions. ${ }^{46}$

S/RES/752 (1992); S/RES/757 (1992); S/RES/758 (1992); S/RES/760 (1992); S/RES/761 (1992); S/RES/762 (1992); S/RES/764 (1992); S/RES/771 (1992); S/RES/780 (1992). In relation to the ICTR, see UN Docs S/RES/912 (1994); S/PRST/1994/21 (1994); S/RES/918 (1994); S/RES/935 (1994).

${ }^{41}$ See K. Anderson, 'The Rise of International Criminal Law: Intended and Unintended Consequences', European Journal of International Law, 20 (2009), 331, 334; R. Kerr, The Internal Criminal Tribunal for the Former Yugoslavia: An Exercise in Law, Politics and Diplomacy (Oxford/New York: Oxford University Press, 2004), 38.

42 See Maogoto, War Crimes and Realpolitik, 185; M. Mutua, 'Never Again: Questioning the Yugoslav and Rwanda Tribunals', Temple International \& Comparative Law Journal, 11 (1997), 167, 176.

43 UN Doc. S/RES/808 (1993), 2.

${ }^{44}$ See 'U.S. Names Figures it Wants Charged with War Crimes', The New York Times, 17 December 1992; Letter dated 28 September 1994 from the Permanent Representative of Rwanda to the United Nations Addressed to the President of the Security Council, UN Doc. S/1994/1115 (1994).

45 Mégret, 'The Politics of International Criminal Justice', 1275.

${ }^{46}$ Bass, Stay the Hand of Vengeance, 215-216; D. Hirsh, Law against Genocide: Cosmopolitan Trials (London: The Glass House Press, 2003), 75-76. 
Notwithstanding their firm roots in international political concerns, the ICTY and ICTR showed increasing affinity with the transitional justice paradigm. Both tribunals were established, at least formally, not only to restore peace and security, but also to hold accountable those responsible for serious violations of international humanitarian law ${ }^{47}$ and, in the case of the ICTR, to contribute to national reconciliation and the strengthening of national courts. ${ }^{48}$ Their jurisdictions were extended from the Nuremberg and Tokyo tribunals to include genocide, war crimes committed in non-international armed conflict and crimes against humanity when committed in non-international armed conflict (ICTY) or even independent of any nexus to armed conflict (ICTR), ${ }^{49}$ and they were given broad jurisdiction over all sides to the conflicts. Suggestions to subordinate the judicial process to political supervision were rejected, ${ }^{50}$ the independence of the tribunals was guaranteed $^{51}$ and cooperation and support was eventually forthcoming with the overwhelming majority of suspects surrendered to the tribunals.

As they grew, the tribunals began to develop and to articulate their own conceptions of their roles as instruments of transitional justice and of reconciliation, and to move themselves in these directions. ${ }^{52}$ Outreach to local populations was accepted, if belatedly, to be an important component of the tribunals' practices, and the tribunals gradually began to work more closely with national courts and other organisations engaged in transitional justice. ${ }^{53}$

As with Nuremberg and Tokyo, the ICTY and ICTR's transitional justice mandates were not universally accepted, ${ }^{54}$ and the extent to which they have contributed to local justice remains limited. They have been accused of impartiality for not prosecuting all sides to the conflicts

47 See UN Doc. S/Res/827 (1993); UN Doc. S/Res/955 (1994).

${ }^{48}$ UN Doc. S/Res/955 (1994).

49 Articles 3-5 ICTY Statute, Annex to UN Doc. S/25704 (1993); Articles 2-4 ICTR Statute, Annex to UN Doc. S/RES/955 (1994).

${ }^{50}$ Mégret, 'The Politics of International Criminal Justice', 1275.

51 See Articles 12 and 16 ICTY Statute, Annex to UN Doc. S/25704 (1993); Articles 11 and 15 ICTR Statute, Annex to UN Doc. S/RES/955 (1994).

52 See, e.g., Report of the ICTY, UN Doc. A/49/342-S/1994/1007 (1994), at 15-16.

53 See, e.g., Seventeenth Annual Report of the ICTY, UN Doc. A/65/205-S/2010-413 (2010), at 8, 80-84 and 87; Fifteenth annual report of the ICTR, UN Doc. A/65/188-S/2010/418 (2010), at 53-55, 60-65.

54 See statements of Mr Kovanda (Czech Republic) and Mr Keating (New Zealand) in UN Doc. S/PV.3453 (1994). 
despite having the jurisdiction to do so. ${ }^{55}$ More importantly, an immense gulf (or 'impunity gap') persisted between the activities of the ad hoc tribunals and demands for punishment of those responsible for atrocities. Ten years after the establishment of the ICTR, thousands remained in Rwandan jails awaiting trial ${ }^{56}$ and it was not until 2011 that the tribunal approved the transfer of suspects for trial in Rwanda on the basis of 'international standards' (namely, opposition to capital punishment), which was prioritised over calls for more local accountability. ${ }^{57}$

While the tribunals themselves and their staff may have developed and acted on their own conceptions of the ICTY and ICTR as instruments of transitional justice, support among states for the apparent turn towards this paradigm can be explained to a large extent in light of international political concerns. More specifically, two sorts of international influences normative and instrumental - led to states supporting efforts by the ICTY and ICTR to take on apparent characteristics of transitional justice.

First, as with Nuremberg and Tokyo, international values shaped both the structure and the operations of the ad hoc tribunals. Suggestions to subject them to the political control of the Security Council were rejected as inconsistent with international values, ${ }^{58}$ and it was considered 'axiomatic' that the tribunals' procedures should be consistent with internationally recognised human rights. ${ }^{59}$ The international nature of the tribunals, including in particular the composition of their judiciaries and their location outside situation countries, was seen as means to safeguard their international legitimacy. ${ }^{60}$ When international and national values clashed, such as over the location of the tribunals, the primacy of the tribunals over national courts or the prohibition of the

55 See, e.g., A.-S. Massa, 'NATO's Intervention in Kosovo and the Decision of the Prosecutor of the International Criminal Tribunal for the Former Yugoslavia Not to Investigate: An Abusive Exercise of Prosecutorial Discretion?' Berkeley Journal of International Law, 24 (2006), 610; P. Erlinder, 'The UN Security Council Ad Hoc Rwanda Tribunal: International Justice or Juridically-Constructed "Victor's Impunity"? DePaul Journal for Social Justice, 4 (2010), 131.

56 See K. Moghalu, 'Reconciling Fractured Societies: An African Perspective on the Role of Judicial Prosecutions', in R. Thakur and P. Malcontent (eds.), From Sovereign Impunity to International Accountability: The Search for Justice in a World of States (Tokyo: United Nations University Press, 2004), 197.

57 See J. Mujuzi, 'Steps Taken in Rwanda's Efforts to Qualify for the Transfer of Accused from the ICTR', Journal of International Criminal Justice, 8 (2010), 237.

58 Mégret, 'The Politics of International Criminal Justice', 1275.

59 UN Doc. S/25704 (1993), at 106.

${ }^{60}$ See UN Doc. S/25704 (1993), at 131. See also T. Franck, Fairness in International Law and Institutions (Oxford: Oxford University Press, 2002), 280. 
death penalty before the ICTR, it was the international that won out, even though encouraging national values could arguably contribute more to transitional justice.

Second, states came to support the transitional justice mandate of these tribunals for more instrumental reasons. As international public opinion paid increasing attention to the unfolding atrocities and support for accountability measures grew, it became in the interests of states to be seen as defenders of the international rule of law and to provide the ICTY and ICTR with necessary cooperation and support. ${ }^{61}$ The same states also quickly realised that the international legitimacy bestowed by fair and independent judicial processes could further their own political aims. The issuance of arrest warrants for Radovan Karadžić and Ratko Mladić provided an objective basis for excluding them from negotiations on the future of Bosnia-Herzegovina, thereby enabling diplomats to deal with their preferred interlocutor, Slobodan Milošević. ${ }^{62}$ Later, the perception of Milošević as a war criminal, even before an indictment was issued, eased the acceptance for the ongoing bombing of Kosovo by NATO forces. ${ }^{63}$ This recognition of the possible convergence between states' political interests and the legitimacy bestowed by independent judicial bodies constituted a significant development in the practice of ICTs and was to be of relevance for the ongoing negotiations on the establishment of the ICC.

\section{International Criminal Court}

To some extent, the adoption of the Rome Statute of the International Criminal Court in 1998 can be seen as continuing the trend of increasing recognition of the transitional justice paradigm. It may even be described as, to that point, a high-water mark in the development of ICTs qua transitional justice mechanisms. The ICC has broad jurisdiction over crimes against humanity outside of situations of armed conflict as well as war crimes committed in non-international armed conflict. ${ }^{64}$ The

${ }^{61}$ Mégret, 'The Politics of International Criminal Justice', 1273. See also G. McDonald, 'Problems, Obstacles and Achievements of the ICTY', Journal of International Criminal Justice, 2 (2004), 558, 560-567.

62 See Kerr, An Exercise in Law, Politics and Diplomacy, 156 (citing R. Holbrooke, To End a War (New York, NY: Random House, 1999), 315-316, 338).

63 P. Williams and M. Scharf, Peace with Justice? War Crimes and Accountability in the Former Yugoslavia (Lanham, MD: Rowman and Littlefield, 2002), 207-208.

${ }^{64}$ Articles 7-8, Rome Statute. 
exercise of this jurisdiction is subject to the principle of complementarity, ${ }^{65}$ suggesting a preference for domestic proceedings that are closer to affected populations. Victims have unprecedented rights to participate in proceedings and to obtain reparations, rights that make sense only within the transitional justice paradigm. ${ }^{66}$ Most importantly, its jurisdictional regime puts fundamental determinations of where and when the ICC will act in the hands of an independent prosecutor and judges guided by objective criteria set out in the Statute. ${ }^{67}$

One should not be too hasty, however, in celebrating the ICC as an unqualified victory for the premises of transitional justice. As noted by Judge Philippe Kirsch, the first president of the ICC and former chairman of the committee that elaborated the ICC's Statute,

The ICC did not create itself. It was created by states for the fulfilment of certain objectives stated by them and as provided in the ICC statute: to put an end to impunity for the perpetrators of the most serious crimes that threaten the peace, security and well-being of the world; to contribute to the prevention of such crimes, and to guarantee lasting respect for the enforcement of international justice. ${ }^{68}$

Originally conceived as 'a "facility" for states - something of which they might avail themselves if they thought it useful or expedient to do so, ${ }^{69}$ the ICC may be triggered by states referring situations (individually or via the Security Council), and the Statute accords privileged status to these referrals. Not only may the prosecutor investigate such situations without first awaiting judicial approval as he must in the case of investigations proprio motu, ${ }^{70}$ but the referring state or Security Council may also challenge a decision of the prosecutor not to investigate or prosecute. ${ }^{71}$

The early years of the ICC have seen states seize it in circumstances that recall the establishment of previous ICTs. Uganda and the Central African Republic referred situations on their own territory, specifically targeting individuals opposed to the governing regime in their referrals. ${ }^{72}$

65 Preamble and Article 17, Rome Statute. ${ }^{66}$ Articles 68(3) and 75, Rome Statute.

67 Articles 15 and 73, Rome Statute.

68 Statement of President Kirsch, 11th Diplomatic Briefing, 10 October 2007, 4.

69 C. Warbrick, 'The United Nations System: A Place for Criminal Courts?' Transnational Law and Contemporary Problems, 5 (1995), 237, 243.

70 See Articles 13-15, Rome Statute. ${ }^{71}$ Article 53(3)(a), Rome Statute.

72 See Letter from Prosecutor Moreno-Ocampo to President Kirsch on 17 June 2004, Annex to Decision Assigning the Situation in Uganda to Pre-Trial Chamber II, Situation in Uganda, ICC-02/04, Presidency, ICC, 5 July 2004; Letter referring the situation in the Central African Republic to the ICC Prosecutor, reproduced in annex 19 to Communication par la Défense des copies de documents référenciés dans les notes de 
Much as it did in establishing the ICTY and ICTR, the Security Council referred the situation in Darfur, Sudan, only following the failure of a series of increasingly stringent measures, including the establishment of a commission of inquiry, to achieve peace and security. ${ }^{73}$ In an action that recalls the earlier origins of ICTs in the 1943 Moscow Declaration, the Security Council referred the situation in Libya in the context of a broader resolution aimed at stemming a conflict. ${ }^{74}$ In each of these cases, the threat of punishment was seen as a tool for achieving a political end - the resolution of conflict - and this threat could be withdrawn through legal processes or promises of non-cooperation if withdrawal would further those ends. ${ }^{75}$ In these circumstances, the principle of complementarity represents not so much a preference for national or local trials but rather deference to states that may choose to relinquish the exercise of jurisdiction to the ICC. ${ }^{76}$

Even the proprio motu powers of the prosecutor and his or her discretion in deciding to investigate situations or cases can be fully explained within the juridified diplomacy paradigm. States undoubtedly realised, from the experience of the ICTY, that the ability of the ICC to influence political developments would depend on its perceived legitimacy. By creating an independent prosecutor, states have 'outsourced' difficult decisions as to when and where to intervene judicially with two potential benefits.

bas de pages de sa requête en contestation de la recevabilité, The Prosecutor v. Jean-Pierre Bemba Gombo ('Bemba'), ICC-01/05-01/08, 15 March 2010. Even the referral of the situation in the Democratic Republic of the Congo can be seen as an expression of selfinterest. See W. Burke-White, 'Complementarity in Practice: the International Criminal Court as Part of a System of Multi-Level Global Governance in the Democratic Republic of the Congo', Leiden Journal of International Law, 18 (2005), 557, 565.

73 UN Doc. S/RES/1593 (2005). For a brief overview of the steps leading to the referral, see R. Cryer, 'Sudan, Resolution 1593, and International Criminal Justice', Leiden Journal of International Law, 19 (2006), 195, 198-203.

${ }^{74}$ UN Doc. S/RES/1970 (2011).

75 See Cable from US Embassy, London to US Secretary of State: 'Sudan/ICC: UK Prepared to remain Initially Flexible in the Face of New Indictments', 11 July 2008; Cable from US Embassy, London to US Secretary of State: 'Sudan/ICC: UK Strategy with Potential Bashir ICC Indictment',15 July 2008; 'Deal Could See Gaddafi Escape Prosecution', Belfast Telegraph, 29 March 2011; David Bosco, 'The Libya Resolution: Prosecution as Bargaining Chip?', Foreign Policy, 27 February 2011.

76 See Corrigendum to Judgment on the appeal of Mr Jean-Pierre Bemba Gombo against the decision of Trial Chamber III of 24 June 2010 entitled 'Decision on the Admissibility and Abuse of Process Challenges', The Prosecutor v. Jean-Pierre Bemba Gombo, ICC-01/0501/08, Appeals Chamber, ICC, 19 October 2010; Judgment on the Appeal of Mr Germain Katanga against the Oral Decision of Trial Chamber II of 12 June 2009 on the Admissibility of the Case, The Prosecutor v. Germain Katanga and Mathieu Ngudjolo Chui, ICC-01/04-01/07, Appeals Chamber, 25 September 2009. 
First, it increases the legitimacy of international action if judicial intervention is triggered or led by an independent prosecutor, rather than a handful of possibly self-interested states. Second, there may be situations where states wish international action to be taken but would not be willing to incur the political costs of referring a situation to the Court. By feeding information to the prosecutor, they may anonymously contribute to the opening of an investigation. In exchange for these benefits, states had to accept the risk of an independent prosecutor and judges who may act against their interests. However, it should be recalled that such independence, as a practical matter, is not unlimited. The whole ICC system is, at its core, entirely dependent on the support and cooperation of states. ${ }^{77}$ In particular, without the arrest of suspects, the ICC may be prevented from carrying out trials. As such, states retain significant control over the effectiveness of the ICC.

That the ICC can be largely explained within the juridified diplomacy paradigm - as a means of routing political interests through legal forms does not necessarily negate its role as an instrument of transitional justice. The two could be complementary. It could also be that the two paradigms have converged in the recognition that justice and peace must, in the words of UN secretary-general Ban Ki-Moon, go 'hand in hand'. ${ }^{78}$ In 2010, states parties to the ICC Statute held a conference to review the Statute, during which they devoted a significant portion of time to a 'stocktaking' of international criminal justice as it currently stands. ${ }^{79}$ While they emphasised that justice is 'a fundamental building block of sustainable peace', ${ }^{80}$ their discussions reflected a limited commitment to a view of the ICC as an instrument of transitional justice. Its ultimate impact was considered primarily in terms of its contribution to peace; ${ }^{81}$ its impact on victims and affected communities was treated as a secondary or incidental effect. ${ }^{82}$

77 See Parts IX-XII, Rome Statute.

${ }^{78}$ Ban Ki-Moon, 'Op-Ed: We Must Get Justice', New Vision Online, 28 May 2010.

${ }^{79}$ Official Records of the Review Conference of the Rome Statute of the International Criminal Court, Part I, at 22-30.

${ }^{80}$ Kampala Declaration, 1 June 2010, RC/Decl.1, Official Records of the Review Conference of the Rome Statute of the International Criminal Court, Part II, 23, at 3.

${ }^{81}$ See Stocktaking of International Criminal Justice (Peace and Justice): Moderator's Summary, Official Records of the Review Conference of the Rome Statute of the International Criminal Court, Annex V(b), at 2a, 8-26, 32.

${ }^{82}$ Stocktaking of International Criminal Justice (The impact of the Rome Statute System on Victims and Affected Communities): Final Report by the Focal Points (Chile and Finland), Official Records of the Review Conference of the Rome Statute of the International Criminal Court, Annex V(a), at 8. 
Furthermore, when it came to closing the so-called impunity gap between national jurisdictions and the ICC, states made clear that the ICC had a very limited role in strengthening national jurisdictions. In their view, it should rather focus on its 'core mandate and function', whilst '[a]ctivities aimed at strengthening national jurisdictions ... should be carried forward by States themselves, together with international and regional organizations'. ${ }^{83}$

\section{Towards the integration of transitional justice and international politics}

In light of the arguably increasing acceptance by states of ICTs as instruments of transitional justice, the question is whether and to what extent ICTs may play such a role in the future. This section considers the extent to which it is practical and desirable for ICTs to engage more directly with the objectives of transitional justice.

\section{Integrating transitional justice and juridified diplomacy in practice}

The history of ICTs, as depicted earlier, demonstrates that it is possible to render these institutions more responsive to transitional justice concerns. States have increasingly recognised that the legitimacy provided by independent judicial bodies can contribute to the advancement of their own political interests. They have accordingly accepted and even supported the independence and judicial nature of ICTs and provided them with necessary support. This interest of states has also opened the opportunity for ICTs to develop their own identities and for 'outsiders', most notably non-governmental organisations, to also influence their direction. $^{84}$

By arguing that the legitimacy of ICTs depends on such factors as the fairness of trials and the effectiveness of cooperation or outreach, advocates of transitional justice have sought to move ICTs in this direction. To date, states have shown greater receptivity to arguments concerning the

83 Assembly of States Parties, Report of the Bureau on stock-taking: complementarity, ICCASP/8/51 at 4 .

${ }^{84}$ The growing role of civil society has had the added consequence that the ICC must justify its legitimacy not only to states but also to civil society. M. Glasius, 'What Is Global Justice and Who Decides? Civil Society and Victim Responses to the International Criminal Court's First Investigations', Human Rights Quarterly, 31 (2009), 496, 497. 
'justice' aspect of the transitional justice paradigm, that is, to ensuring the fairness of judicial proceedings, than to its 'transitional' component, that is, its benefit to societies undergoing transition.

Any effort to render ICTs more responsive to transitional justice concerns will encounter two significant challenges. First, as reflected earlier, support of states for the transitional justice mandate of ICTs remains limited. A considerable increase in state support would be needed to effect a significant shift in the role of ICTs towards transitional justice. Second, turning ICTs into comprehensive instruments of transitional justice would require incredible investments. In the case of Rwanda, for example, the ICTR issued indictments against eighty individuals, yet approximately 120,000 persons remained in jail as of $2004{ }^{85}$

The complementarity challenges in the situations before the ICC are similarly daunting. ${ }^{86}$ Promoting effective and comprehensive transitional justice will require longer-term involvement in societies and a broader approach to criminality than that currently employed by any ICT. Even only moving international courts and tribunals partially towards closing the 'impunity gap' would significantly change the functioning of these institutions. In this context, the questions remain whether, to what extent and in what form further expanding the transitional justice role of ICTs would be desirable.

\section{The desirability of integrating transitional justice and juridified diplomacy}

Given the limited support of states and the significant investments likely to be required, prudence is merited in any effort to enhance the contributions of ICTs to transitional justice. Demanding too much too quickly risks creating unrealistic expectations that courts and tribunals will be unable to fulfil. Such failures in the short term could significantly impair enthusiasm for broader transitional justice initiatives in the long term. Moreover, a backlash may emerge if states see the mandates of these institutions being stretched too far beyond what they are willing to

${ }^{85}$ Moghalu, 'Reconciling Fractured Societies', 203.

${ }^{86}$ See E. Witte, Putting Complementarity into Practice: Domestic Justice for International Crimes in DRC, Uganda and Kenya (New York, NY: Open Society Foundations, 2011); G. Mattioli and A. van Woudenberg, 'Global Catalyst for National Prosecutions? The ICC in the Democratic Republic of Congo', in N. Waddell and P. Clark (eds.), Courting Conflict? Justice, Peace and the ICC in Africa (London: Royal African Society, 2008), 55. 
support. ${ }^{87}$ Emphasising the contributions of ICTs to transitional justice goals may also lead to a diminution of support and cooperation, to the extent that states do not see these goals as being in their interests. In contrast, stressing the contributions of ICTs to international peace and security increases the likelihood that states will see their interests reflected and provide the support and cooperation necessary for ICTs to function as instruments of both transitional justice and juridified diplomacy. ${ }^{88}$

In addition, there is a potentially significant loss incurred in transforming ICTs into more effective instruments of transitional justice. ICTs are beginning to emerge as potentially powerful tools of specific deterrence and conflict resolution. ${ }^{89}$ Burdening ICTs with the responsibility to deliver comprehensive transitional justice could significantly curtail the flexibility and freedom of action that, arguably, enables them to make these contributions. To the extent that it is desirable to pursue transitional justice, it may be preferable to heed the lessons of the 2010 ICC Review Conference stocktaking exercise and to focus on developing national capacities to promote transitional justice while preserving the more selective, targeted role of international courts and tribunals as instruments of juridified diplomacy - bearing in mind that many of the same challenges of contestation of values will be replicated at national and local levels.

Focusing on the juridified diplomacy role of ICTs is not without its own dangers. Leaving ICTs as instruments of international politics risks opening them to the cynical manipulation of states, thereby undermining not only their limited contributions to transitional justice but also their legitimacy, which provides their added value within the juridified

${ }^{87}$ Suggestions that international criminal law will radically evolve on its own against the interests of states are largely overstated. See A. Kapur, 'Conceptual Distinctions Between the ICJ Project and Its Constituent Processes: A Reply to Brad Roth and Ken Anderson', EJIL Talk!, 11 May 2010.

${ }^{88}$ See, T. Franck and S. Yuan, 'The United States and the International Criminal Court: Unilateralism Rampant', New York University Journal of International Law and Politics, 35 (2003), 519, 555-558.

${ }^{89}$ See, e.g., N. Grono and A. O'Brien, 'Justice in Conflict: The ICC and Peace Processes', in Waddell and Clark (eds.), Courting Conflict? Justice, Peace and the ICC in Africa, 15-16; see also International Crisis Group, 'Northern Uganda Peace Process: The Need to Maintain Momentum', Africa Briefing No. 26, 14 September 2007; Mattioli and van Woudenberg, 'Global Catalyst for National Prosecutions?'; M. Glasius, 'Global Justice Meets Local Civil Society: The International Criminal Court's Investigation in the Central African Republic', Alternatives: Global, Local, Political, 33 (2008), 413, 428; B. Cooper, 'The Limits of International Justice', World Policy Journal, 91 (2009), 98. 
diplomacy paradigm. It is crucially important - even within this paradigm - that states are aware of the substantial damage that can result from undermining the legitimacy, independence or effectiveness of ICTs, or of failing to provide them with the necessary support and cooperation.

Even minor instances of non-cooperation or infringement on the perceived independence or legitimacy of ICTs can have significant effects because, as Thomas Franck has observed with respect to international law more broadly, '[i]n a community whose rules are so largely derived from the persistent patterns of its members' conduct, each action is judged by all states in terms of its projected effect it all were to act similarly'. ${ }^{90}$ It is therefore vital that states make every effort to refrain from interfering with, and provide full support to the conduct of, independent judicial processes before ICTs. In those limited cases where states may consider it absolutely necessary to withhold support or otherwise to interrupt the judicial process, every effort should nevertheless be made to preserve the integrity of ICTs.

\section{Conclusion}

As much as signifying acceptance of the promise of transitional justice, the evolution of ICTs can be understood as reflecting growing recognition of states of the importance of legitimacy in international politics. By creating and supporting independent criminal courts and tribunals guided by neutral, objective criteria, states have been able to draw on these institutions' legitimacy for their own purposes. This independence has, at the same time, enabled these institutions, with the support of civil society and others, to develop their own identities as instruments of transitional justice within the limits of the tolerance of states and other policy-makers.

Nevertheless, the support of states for ICTs playing a transitional justice role remains limited. While the integration of transitional justice and international politics may be desirable and achievable in the longterm, the hesitation of states to fully embrace the transitional justice paradigm, at least insofar as ICTs are concerned, suggests that caution is due in the short-term. To expect ICTs to perform the functions or to fulfil the purposes ascribed to them within the transitional justice paradigm is to ask these institutions to play many roles, perhaps more than

90 T. Franck, The Power of Legitimacy Among Nations (New York: Oxford University Press, 1990), 152. 
any one institution can bear. The ICC's own struggle as a court of both retribution and reparations is instructive in this regard. ${ }^{91}$

The extent to which ICTs contribute to the realisation of the aims of transitional justice should not be taken as measures of their overall effectiveness, and the failure to 'achieve' transitional justice, broadly construed, should not be laid at the feet of these institutions. The evaluation of ICTs should be done on the basis of the political context and constraints in which they operate, not on the basis of what one might wish them to do under ideal circumstances. Thus, with respect to the ICC - whose future development is at the centre of this evolution - it may be preferable to continue to explore and to focus on its contributions as an instrument of a legitimised international politics, mindful of the potential for its political manipulation by states. At a minimum, efforts to render the ICC more responsive to the concerns motivating the transitional justice paradigm must acknowledge the risks and challenges of doing so.

91 See Chapters 12-14 by Fletcher, Dixon and Kendall in this volume. 


\title{
Bespoke transitional justice at the International Criminal Court
}

\author{
JAYA RAMJI-NOGALES
}

This chapter grapples with the question of whether the International Criminal Court (ICC) should be conceptualised as a mechanism of transitional justice. Most theorists insist that transitional justice is either an inappropriate or an unrealistic goal for the Court. Some scholars have proposed that the Court might more accurately be theorised as seeking to achieve political goals through 'juridified diplomacy'. Others suggest that the Court should speak to a global, rather than local, audience. A third school of thought criticises international criminal law as insufficiently focused on the preferences of societies affected by mass violence. Going one step further, some theorists suggest that the Court should be set aside in favour of mechanisms that are more responsive to local preferences. Although the incorporation of the ICC into a locally owned transitional justice paradigm faces substantial challenges, this chapter draws on a theory of 'bespoke transitional justice' to suggest ways in which this knotty relationship might be better designed.

This chapter proceeds in three parts. It begins by laying out three alternate theories by which we might explain the purpose of the ICC: global justice, 'juridified diplomacy' and transitional justice. Each of these theories is held up to scrutiny by exploring the limits of its explanatory power and accuracy. The chapter then presents a theory of bespoke transitional justice that I have presented in greater detail elsewhere, but with particular attention to the role of the ICC in 'locally owned' transitional justice efforts. ${ }^{1}$ In particular, I expand upon definitions of 'local'; that is, who are the local stakeholders in transitional justice situations and how do we define their interests and priorities? I also elaborate upon concepts of 'ownership'; that is, what does it mean to have a stake in the

1 J. Ramji-Nogales, 'Designing Bespoke Transitional Justice: A Pluralist Process Approach', Michigan Journal of International Law, 32 (2010), 1. 
Court's work? The chapter ends with concrete suggestions as to the potential role of the ICC in locally owned transitional justice efforts.

In short, a bespoke transitional justice approach to the ICC reminds us that international prosecutions may not be appropriate in all contexts, and argues that the views of members of conflict-affected societies should play a central role in determining whether or not the Court should intervene in a given situation. This means that the Office of the Prosecutor (OTP) should carefully study the appropriateness of prosecution in specific cultural and societal contexts before proceeding. If international prosecution will aid some of the affected society's transitional justice goals, it may be appropriate to open a case.

But international justice proponents, including those who speak on behalf of the OTP, should recognise the limitations of the Court in meeting all transitional justice goals and manage expectations accordingly. This entails clearly communicating the circumscribed nature and impact of Court interventions and, where appropriate, working alongside other transitional justice mechanisms that may better achieve goals enumerated by members of the society that has suffered mass violence. Moreover, in cases in which such intervention does not respond to local interests, international prosecution should not be pursued.

\section{Conceptualising the ICC's purpose}

The theoretical aims of the ICC are deeply contested, with at least three different schools of thought struggling for prominence. The first theory, which I will label 'global justice', defines the goals of the Court as creating international legal standards aimed at ending impunity for the crimes laid out in the Rome Statute. ${ }^{2}$ Theorists in this school by and large view the Court as a legal entity that is above the political fray. In their view, the central aim of the ICC is to establish international norms of criminal justice; repairing conflict-affected societies is a secondary goal. This might be labelled the 'trickle-down' approach to international justice;

2 See, e.g., M. Cherif Bassiouni, 'International Criminal Justice in Historical Perspective: The Tension Between States' Interests and the Pursuit of International Justice', in A. Cassese (ed.), The Oxford Companion to International Criminal Justice (Oxford: Oxford University Press, 2009), 131, 131; A. Cassese, 'The Rationale for International Criminal Justice', in A. Cassese (ed.), The Oxford Companion to International Criminal Justice (Oxford: Oxford University Press, 2009), 123, 127; W.A. Schabas, The UN International Criminal Tribunals: The former Yugoslavia, Rwanda and Sierra Leone (New York: Cambridge University Press, 2006), 68. 
proponents suggest that once these norms take root on the international level, they will be adopted, enforced and complied with on the national level. To the extent that the Court's efforts benefit members of the conflict-affected society, they are thought to prioritise the interests of victims. $^{3}$

The second theory by which the role of the ICC might be conceptualised is that of 'juridified diplomacy', a phrase coined by Gerry Simpson and described in greater detail by David Koller in this volume. ${ }^{4}$ Theorists of this school suggest that the Court's goals are to achieve international peace and security and, in some cases, political self-interest. According to this theory, the ICC is inherently political and works primarily as an instrument of international diplomacy. The role of the Court is therefore not to empower national institutions. It aims instead to assist in resolving conflicts through the use of referrals as a threat of punishment. The independent prosecutor can also be viewed as a route for domestic elites to outsource difficult political decisions. ${ }^{5}$ This theory focuses on the global political impact of the Court rather than on local outcomes. Following this approach, domestic political elites would be the main local beneficiaries of the Court's efforts.

The third possible conceptual approach to the ICC's role is the theory of transitional justice. As discussed in more detail in the next section, scholars of transitional justice view the Court's central goal as repairing societies that have suffered mass violence. Rather than situating the Court entirely within the political or legal realm, a transitional justice approach views the Court as a legal institution enmeshed in a field of political interests. From this starting point, theorists of this school think about how to manage the political dimensions of the Court in a way that prioritises the interests of rank-and-file members of the affected society (as opposed to local political elites). This theory gives precedence to local

${ }^{3}$ For an incisive critique of the concept of victimhood before the ICC, see S. Kendall and S. Nouwen, 'Representational Practices at the International Criminal Court: The Gap between Juridified and Abstract Victimhood', Law and Contemporary Problems, 76 (2014), 235.

${ }^{4}$ See further Chapter 3 by Koller in this volume, citing G. Simpson, Law, War and Crime: War Crimes Trials and the Reinvention of International Law (Cambridge: Polity Press, 2007), 1.

${ }^{5}$ For a thoughtful exploration of how this phenomenon has played out in Uganda and Sudan, see S. Nouwen and W.G. Werner, 'Doing Justice to the Political: The International Criminal Court in Uganda and Sudan', European Journal of International Law, 21 (2010), 941. 
perceptions of the Court's legitimacy over international legal or political outcomes.

This schematic highlights the different ways in which these three schools of thought define the purposes of the ICC:

\begin{tabular}{|c|c|c|c|c|}
\hline & Goals & Focus & $\begin{array}{l}\text { Source }(s) \text { of } \\
\text { legitimacy }\end{array}$ & $\begin{array}{l}\text { Societal } \\
\text { beneficiaries }\end{array}$ \\
\hline $\begin{array}{l}\text { Global } \\
\text { justice }\end{array}$ & $\begin{array}{c}\text { International } \\
\text { criminal } \\
\text { standards }\end{array}$ & Legal & $\begin{array}{l}\text { International legal } \\
\text { community }\end{array}$ & Victims \\
\hline $\begin{array}{l}\text { Juridified } \\
\text { diplomacy }\end{array}$ & $\begin{array}{c}\text { International } \\
\text { peace and } \\
\text { security }\end{array}$ & Political & $\begin{array}{l}\text { International } \\
\text { diplomatic } \\
\text { community }\end{array}$ & $\begin{array}{c}\text { Political } \\
\text { elites }\end{array}$ \\
\hline $\begin{array}{l}\text { Transitional } \\
\text { justice }\end{array}$ & $\begin{array}{l}\text { Repairing } \\
\text { affected } \\
\text { societies }\end{array}$ & $\begin{array}{l}\text { Legal and } \\
\text { political }\end{array}$ & Local society & $\begin{array}{l}\text { General } \\
\text { populace }\end{array}$ \\
\hline
\end{tabular}

In practice, the ICC does not wear any of these mantles well. None of the theories is a perfect fit; they each have significant descriptive and explanatory flaws. The Court's efforts to create international legal norms have been foiled by politics, the outcomes of its political interventions have been unpredictable and its record on addressing the needs of local populations has been decidedly mixed.

The global justice theory has proved incapable of contending with the inescapably political nature of the ICC. The Court is engaged in deeply politicised situations and requires substantial political support on many fronts in order to succeed. The politics of the Court must be addressed head-on in any serious effort to theorise its goals. ${ }^{6}$ Perhaps because many of its actors view themselves and their work as above the political fray, the Court has struggled to control the narrative around its work, particularly in Kenya and Sudan. Political elites in both of those countries have managed to depict the ICC, at least in some quarters, as a neocolonialist tool that prosecutes only African defendants. Setting to one side the question of whether this depiction is fair, the fact that it has gained traction with at least some local audiences stymies efforts to create international criminal law norms.

${ }^{6}$ Ibid., 946. Nouwen and Werner argue that analysts of the ICC must begin by understanding and acknowledging its inherently political nature. 
The Court's individualist and adversarial approach to complex political situations creates further problems for the adoption of the international standards it promulgates. ${ }^{7}$ Given their zero-sum nature, international criminal trials are not well suited to situations of mass violence in which the 'truth' is violently disputed. Those who disagree with the Court's selection of winners and losers may simply reject the trials as 'victor's justice'. ${ }^{8}$ This depiction of the Court's work may resonate deeply with portions of the affected society, who will similarly reject the international criminal law standards the Court is intent upon promoting. Moreover, the ICC's focus on individual criminal accountability overlooks the broader structural roots of mass violence, both national and international. ${ }^{9}$ Again, local populations, who may have a much more nuanced perception of the causes of conflict, may be sceptical of ICC decisions that appear to be divorced from the broader context. Some segments of the affected society may, on this basis, refuse to accept the Court's pronouncements, as Hellman's contribution to this volume recounts. The 'global justice' theory is therefore limited by its failure to engage sufficiently with the political aspects of the Court's work.

The juridified diplomacy theory recognises the political nature of the ICC, focusing on its role in promoting international peace and security. Its flaws lie in the messy and unpredictable nature of international political outcomes. The idea that the ICC can be used as a tool to resolve conflicts assumes that the Court's impact on a given conflict can be forecast and measured with some accuracy. The Kenya situation provides an example of the unexpected and complicated outcomes of Court interventions. ${ }^{10}$ The prosecutor's proprio motu investigation into the mass violence surrounding Kenya's 2007 election led to the laying of charges against six individuals, including Uhuru Kenyatta and William Ruto, now president and deputy president, respectively, of the country as of the time of writing. Kenyatta and Ruto had been political rivals during the 2007 elections, but became allies soon after they were indicted in 2011. In December 2012, they formed a coalition

7 See, e.g., M. Drumbl, Atrocity, Punishment, and International Law (New York: Cambridge University Press, 2007), 32.

${ }^{8}$ See, e.g., M. Damaška, 'What Is the Point of International Criminal Justice?' Chicago-Kent Law Review, 83 (2008), 329, 336-337, 345.

9 See, e.g., M. Koskenniemi, 'Between Impunity and Show Trials', Max Planck Yearbook of International Law, 6 (2002), 1.

10 See S. Kendall, "UhuRuto" and Other Leviathans: The International Criminal Court and the Kenyan Political Order', African Journal of Legal Studies, 7 (2014), 399. 
party unified around opposition to the ICC prosecutions. Presenting themselves as a party of reconciliation, Kenyatta and Ruto won the 2013 elections. This outcome underscores the point that the effects of ICC interventions are impossible to predict.

Perhaps the only predictable consequence of outsourcing difficult political decisions to the prosecutor is that it will enable political elites to manipulate the ICC to suit their interests. ${ }^{11}$ In the case of Uganda, President Yoweri Museveni requested Court intervention to issue arrest warrants against the Lord's Resistance Army (LRA) in 2003. Needing Museveni's assistance to hunt down indicted LRA leaders, the prosecutor has not yet sought - and is unlikely ever to seek - to prosecute the Ugandan military (Uganda People's Defense Force or UPDF). The Court's decision sent the message that the UPDF was not responsible for the many atrocities it committed during its decade-long conflict with the LRA. ${ }^{12}$ This manoeuvre also helped Museveni's government to obtain military aid and international legitimacy. Uganda thus became a 'golden child' of the international criminal law community, hosting the first review conference for the Rome Statute in 2010. But in 2013, Museveni decided that the Court was no longer a valuable political tool, vocally opposing the prosecution of Kenyatta and Ruto and threatening withdrawal from the Rome Statute. ${ }^{13}$

Given the unpredictable nature of political outcomes, the goal of international peace and security becomes problematic. This term means different things to different people, and the debate over the best methods to achieve it is highly politicised. Even if one could say with any certainty what the impact of ICC interventions might be, it is not clear that external intervention in the form of expressed international criminal norms is sufficient to stabilise a society recovering from mass violence. Attention must also be paid to methods of creating sustainable peace within affected communities.

The transitional justice theory prioritises the preferences of local populations in determining when, and how, the ICC should intervene. A central problem with this approach is the question of measurement of

11 See further Koller (Chapter 3); Kendall and Nouwen, 'Representational Practices'.

${ }^{12}$ For a critique of this claim, see A. Branch, Displacing Human Rights: War and Intervention in Northern Uganda (New York: Oxford University Press, 2011).

${ }^{13}$ L. Akande, 'How Nigeria, Others Averted AU's Withdrawal from ICC', Nigerian Guardian, 16 October 2013, reprinted by Open Society Foundation for South Africa, South African Foreign Policy Initiative, available at www.safpi.org/news/article/2013/ how-nigeria-others-averted-au-s-withdrawal-icc. 
these preferences. As the Kenya example demonstrates, population preferences shift over time - even over a relatively short period of time. As late as December 2010, nearly 80 percent of Kenyans supported the Court's investigation of the perpetrators of post-election violence. ${ }^{14}$ Just over two years later, Kenyans voted two of those indicted perpetrators, Kenyatta and Ruto, into their country's two highest public offices. In part, these shifts occur because local populations are composed of many different groups with many different, and often competing, preferences. It is a tall order to understand and represent these different preferences in decisions in determining whether to proceed with prosecutions.

A locally driven transitional justice process also presents two major risks: elite capture and domination. Much like a juridified diplomacy approach that prioritises the political, a transitional justice approach celebrates 'the local' risks being captured by local elites, whose priorities may be quite different from those of the general populace. Such a process must take measures to prevent elites from using transitional justice mechanisms, including ICC proceedings, to further their own political ends. An approach that relies on local population preferences to determine when the Court should intervene risks entrenching societal patterns of domination and exclusion. ${ }^{15}$ Significant time and effort must be devoted to ensuring that the voices of marginalised groups are heard and included in decision-making processes.

\section{Bespoke transitional justice: a focus on local ownership}

This chapter presents a theory of bespoke transitional justice, namely that effective accountability mechanisms are those that successfully reconstruct local social norms opposing mass violence. ${ }^{16}$ The process of repairing extant norms and creating new norms must be performed within and throughout the affected society in order to fully take root. ${ }^{17}$ As a result, transitional justice must be primarily locally driven and

14 'The Kenya National Dialogue and Reconciliation Monitoring Project, South Consulting Review Report April 2011', Annex I, National Baseline Survey, 7. The December 2010 survey used a nationwide multi-stage cluster sampling methodology, with a random selection of households and respondents. The sample size was 9,200 and the survey was conducted in all forty-seven counties of Kenya.

15 D. Sharp, 'Addressing Dilemmas of the Global and the Local in Transitional Justice', Emory International Law Review, 29 (2014).

16 Ramji-Nogales, 'Designing Bespoke Transitional Justice', 11.

17 The term 'affected society' refers to the society primarily affected by the mass violence; that is, the society in which the mass violence occurred. 
precisely tailored to particular events and societies; hence, bespoke. Though the ICC has faced significant criticism for failing to adequately account for local perspectives in practice, the Court itself is not inconsistent with a theory of bespoke transitional justice.

This chapter defines transitional justice as any mechanism that accounts for mass violence, thereby beginning the process of reconstituting justice, broadly defined, within the society affected by such atrocities. ${ }^{18}$ Mass violence, the widespread commission of criminal acts throughout a society, is enabled by the manipulation of social norms by an insurgent power structure. ${ }^{19}$ In order to adequately address mass violence, then, a transitional justice mechanism must restore upended social norms that oppose mass violence.

The process of norm reconstruction will be most successful if societal stakeholders view the norms promulgated by the transitional justice mechanism as legitimate. Though legal legitimacy, which equates lawfulness with legitimacy, is important, this chapter affords primacy to sociological legitimacy, which requires that the relevant public perceive an institution as worthy of respect 'for reasons beyond fear of sanctions or mere hope for personal reward'. ${ }^{20}$ When a transitional justice mechanism achieves sociological legitimacy, members of the relevant society internalise the social norms it promulgates. In other words, these norms begin to define how societal stakeholders conceive their own interests. ${ }^{21}$ Such internalised compliance is the most effective method of building a law-abiding society, particularly in transitional societies, where enforcement mechanisms are likely to be weak. ${ }^{22}$

Disaggregating the concept of the 'relevant society', at least three groups of internal stakeholders should perceive an institution as

18 See, e.g., R. Teitel, Transitional Justice (New York: Oxford University Press, 2000); R. Mani, Beyond Retribution: Seeking Justice in the Shadows of War (Cambridge: Polity Press, 2002).

19 Drumbl, Atrocity, Punishment, and International Law, 32. This contrasts with domestic crimes, the perpetrators of which violate social norms established by a stable power structure.

${ }^{20}$ R.H. Fallon, Jr., 'Legitimacy and the Constitution', Harvard Law Review, 118 (2005), 1787, 1795.

${ }^{21}$ I. Hurd, 'Legitimacy and Authority in International Politics', International Organization, 53 (1999), 379, 388.

22 See, e.g., D. Bodansky, 'The Concept of Legitimacy in International Law', in R. Wolfrum and V. Röben (eds.), Legitimacy in International Law (Berlin: Springer, 2008), 309, 310; T.R. Tyler and J.M. Darley, 'Building a Law-Abiding Society: Taking Public Views About Morality and the Legitimacy of Legal Authorities into Account When Formulating Substantive Law', Hofstra Law Review, 28 (2000), 707, 714-717. 
legitimate for it to be considered effective: victims of the mass violence, perpetrators of the atrocities and societal elites. At least one group of external stakeholders, international justice proponents who offer financial and technical support for transitional justice projects, must also find the institution acceptable. Of course, the perceptions and preferences of these groups are likely not only to differ but also to conflict, giving rise to difficult questions of prioritisation.

Victims of mass violence are likely the first group of stakeholders that comes to mind when envisioning a transitional justice process. In order to successfully reconstruct social norms, such mechanisms must incorporate the perspectives of these victims. To be sure, the preferences of victims within a particular society will differ. Several factors might impact these variations, including how directly the victims suffered from the violence and how stark the disparities were between the victims' socioeconomic positions prior to the violence. ${ }^{23}$ Nonetheless, transitional justice mechanisms should at least acknowledge the victims' various perspectives, even if they are not able to fully address each preference. This is a task to which the ICC is not particularly well suited, given legal relevance restrictions on the scope of testimony, not to mention the cost and effort involved in bringing victims before the Court.

The widespread nature of mass violence may make it difficult to distinguish clearly between victims and perpetrators. The same individual who was subject to violence may also have perpetrated violence, in some cases because their participation was coerced or forced, and in other cases simply because of the broad societal participation in these crimes. ${ }^{24}$ The interests of these individuals must also be incorporated into a successful transitional justice process.

The same holds true for perpetrators of mass violence. Any institution that hopes to shift social norms must ensure the participation of as many

${ }^{23}$ See, e.g., H. Weinstein, L.E. Fletcher, P. Vinck, and P. Pham, 'Stay the Hand of Justice: Whose Priorities Take Priority?', in R. Shaw et al. (eds.), Localizing Transitional Justice: Interventions and Priorities after Mass Violence (Stanford, CA: Stanford University Press, 2010).

${ }^{24}$ For example, in a study of the attitudes of judges and prosecutors in Bosnia to war crimes trials, Laurel Fletcher and Harvey Weinstein found that all participants identified their national group as a victim group. L. Fletcher and H.M. Weinstein, 'Violence and Social Repair: Rethinking the Contribution of Justice to Reconciliation', Human Rights Quarterly, 24 (2002), 602. See also Post-Conflict Reintegration Initiative for Development and Empowerment (PRIDE) and the International Center for Transitional Justice, 'Ex-Combatant Views of the Truth and Reconciliation Commission and the Special Court in Sierra Leone' (2002), 11, 13. 
perpetrators as possible. ${ }^{25}$ There are many challenges inherent in engaging perpetrators, including denial or justification of criminal acts and significant conflict with victim preferences. Yet, a transitional justice mechanism that excludes perpetrators' interests will be incomplete and unstable. $^{26}$

Perpetrators have unique knowledge of the commission of atrocities that is crucial in creating a complete historical record. Perhaps most importantly, if most perpetrators reject the legitimacy of such a mechanism, a post-conflict society will face duelling social norms, supporting and opposing mass violence. This will likely exacerbate divisions created by the conflict, and impede the reconstruction of society. Similarly, perpetrators must be reintegrated in order to shift social norms effectively; if they are to denounce their prior participation in mass violence, they must view as legitimate the relevant transitional justice mechanism and the norms it propounds. To date, ICC indictments and prosecutions have favoured one side of a conflict over the other; they have generally failed to represent the perspective of multiple perpetrators.

Political elites in the affected society must also perceive the accountability institution to be legitimate. If they do not, they may capture, undermine or reject the transitional justice process. These elites may use a mechanism to gain political advantage over competitors or enemies, as the above example from Uganda demonstrates. ${ }^{27}$ They may support the mechanism in part but aim to prevent themselves and/or their allies from being tried. If public acceptance is low, elites may try to increase their own political power by denouncing the mechanism's legitimacy. In order to forestall the various methods through which elites may stymie a transitional justice mechanism, a fine balancing act is required. In some cases, it may simply not be possible to eliminate elite meddling in the process.

These significant challenges should not deter efforts to ensure elite perceptions of legitimacy, which, even if imperfect, will increase a mechanism's effectiveness. There is much room for improvement on this front on the part of the ICC. Simple recognition of, and engagement

25 See, e.g., J.N. Clark, 'Genocide, War Crimes and the Conflict in Bosnia: Understanding the Perpetrators', Journal of Genocide Research, 11 (2009), 421.

${ }^{26}$ See, e.g., R. Shaw, 'Linking Justice with Re-integration? Ex-Combatants and the Sierra Leone Experiment', in Shaw et al. (eds.), Localizing Transitional Justice, 11, 131-132.

27 Drumbl, Atrocity, Punishment, and International Law, 13; J. Ku and J. Nzelibe, 'Do International Criminal Tribunals Deter or Exacerbate Humanitarian Atrocities?', Washington University Law Review, 84 (2006), 777, 817-819. 
with, the political nature of the Court's work may improve its track record, but a more sophisticated strategy must be implemented in order to minimise elite interference as far as possible.

Finally, a successful transitional justice mechanism must be viewed as legitimate in the eyes of at least one group of external stakeholders international justice proponents. This term is used here to refer to international organisations with great investment and participation in transitional justice efforts. This group includes international advocacy and funding groups such as Amnesty International, Human Rights Watch and the Open Society Foundations, as well as UN staff and some scholars of international law. Most international justice proponents focus on procedural fairness questions - fairness, impartiality, transparency and independence - that at times conflict with the interests of domestic populations. While these concerns are valid and important, they must be carefully balanced with the perspectives of internal stakeholders to ensure that as many actors as possible view the transitional justice mechanism as legitimate.

The ICC generally receives high marks on this front, which is an important consideration for 'local ownership' theorists. Though the Court has shortcomings in its ability to address local needs, it draws with it a great deal of international recognition, not to mention funding. While it may be tempting to write off the Court as a transitional justice failure, such an approach may be short-sighted. Engagement with the Court through a bespoke approach to transitional justice can harness its power and make it more responsive to local preferences.

Given that stakeholder perspectives are likely to conflict, a theory of transitional justice must offer a framework for prioritising among competing preferences. Most importantly, a theory of bespoke transitional justice aims to ensure that as many voices as possible are heard, and that prioritised preferences do not repeat past patterns of domination. A pluralist process approach eschews universal truths in favour of institutions and procedures that resolve conflict fairly. ${ }^{28}$ While accepting a broad range of beliefs, this approach limits behaviours, specifically the imposition of a substantial conception of justice through domination. ${ }^{29}$ Domination can be defined as the illegitimate exercise of power to

28 S. Hampshire, Justice is Conflict (Stanford, CA: Stanford University Press, 2000), 40.

29 Ibid., 41; I. Shapiro, Democratic Justice (New Haven, CT: Yale University Press, 1999), 234; I. Shapiro, 'Group Aspirations and Democratic Politics', in I. Shapiro and C. HackerCordón (eds.), Democracy's Edges (Cambridge: Cambridge University Press, 1999), 210, 220 . 
'shap[e] agendas, constrain ... options, and ... influenc[e] people's preferences and desires. ${ }^{30}$ In order to avoid domination, an inclusive process is helpful, but must include specific protections designed to ensure that the voices of particularly vulnerable groups are heard and prioritised. ${ }^{31}$

\section{Designing bespoke transitional justice at the ICC}

To be successful as a transitional justice mechanism, non-elite local populations must perceive the ICC as legitimate. Perceptions of institutional legitimacy derive from at least three factors: the source from which it has been constituted, the procedure by which it has been adopted and the substance of the rule itself. ${ }^{32}$ From this theory, we can draw out three principles and three methods for increasing the perceived legitimacy of the Court. ${ }^{33}$

Beginning with principles, in order to strengthen the legitimacy of the source of the ICC's authority, it should affirm norms opposing mass violence that are endogenous to the affected society. The Court can improve the legitimacy of its constitutive procedure by making it participatory and inclusive. It should, for example, take perpetrators' perspectives into account, so they are not marginalised, and delve into atrocities committed by all parties, not just those who are on the losing end of the conflict. Finally, offering realistic goals to an affected population could improve the legitimacy of the substance of the norms that the Court presents. Recovery from mass violence is a slow and difficult process; the ICC is but one component of a long-term effort, not an immediate remedy. Effective public education campaigns are an essential component of achieving that goal.

The first two principles - affirming community norms and offering an inclusive design process - should be implemented through concrete methods that aim to successfully incorporate local perspectives and authorities into ICC interventions. Relevant norms and stakeholder

${ }^{30}$ I. Shapiro, The State of Democratic Theory (Princeton, NJ: Princeton University Press, 2003), 4.

${ }^{31}$ D.L. Markell and T.R. Tyler, 'Using Empirical Research to Design Government Citizen Participation Processes: A Case Study of Citizens' Roles in Environmental Compliance and Enforcement', University of Kansas Law Review, 57 (2008), 1, 33; Shapiro, The State of Democratic Theory, 36.

${ }^{32}$ Hurd, 'Legitimacy and Authority in International Politics', 381.

${ }^{33}$ Ramji-Nogales, 'Designing Bespoke Transitional Justice', 61-67. 
interests are difficult to discern, and may be manipulated in ways that undermine, rather than strengthen, the legitimacy of the Court. A threepronged approach should be used to gain a comprehensive and nuanced understanding of these norms and preferences: empirical surveys of the perceptions of local populations, studies of local moral traditions and the participation of local moral leaders. ${ }^{34}$

Empirical population surveys, or 'stakeholder assessments', should be performed at least three times during the lifespan of an ICC intervention at the investigation phase, during the prosecution and after the verdict - to measure the preferences of local populations regarding accountability. Given its neutral position, the Registry would likely be the appropriate entity within the Court to conduct such surveys. Whichever body undertakes such surveys will face numerous challenges in ensuring accurate and reliable measurement given the cross-cultural context. As a result, deep cultural knowledge is a crucial component not only in crafting surveys, but also in determining when the Court should intervene.

Country experts may be able to determine how the Court can incorporate local norms and practices, or how these can work alongside an ICC prosecution. They can also prevent potential conflicts with local norms in the Court's work. Finally, indigenous moral authorities should be included in the process of determining whether the ICC should play a role in transitional justice efforts. Cultural experts should assist in determining the identity of such leaders and identifying patterns of domination. The ICC can play an important role in limiting domination and corruption, and increasing capacity throughout the transitional process.

At this point, these suggestions are little more than a vision, as the OTP currently employs few of these methods to measure local preferences prior to initiating an investigation. ${ }^{35}$ In practice, however, a bespoke transitional justice approach for the ICC would prioritise the careful and thoughtful selection of situations. It would begin from the premise that societies impacted by mass violence are unique and therefore require differentiated approaches to accountability. As described before, the

${ }^{34}$ For further discussion of the inclusion of traditional leaders with moral authority in transitional justice mechanisms in ways that minimise domination and replace a singleminded focus on law as moral authority, see Ramji-Nogales, 'Designing Bespoke Transitional Justice', 66.

35 The OTP does engage in some discussion with local populations before deciding whether to undertake an investigation, but such efforts could be more scientific and systematic, and focused more on the perspectives of non-elite members of the affected society. See, e.g., 'Report on Preliminary Examination Activities', The Office of the Prosecutor, International Criminal Court (13 December 2011). 
Court would undertake serious efforts to gauge local preferences concerning its intervention. In addition, it would measure baseline levels of capacity and assess the need for international involvement from the perspective of strengthening local institutions. ${ }^{36}$ The Court would likewise collaborate with local moral authorities to situate its work within a broader transitional justice context, determining how international prosecutions might be sequenced alongside other mechanisms.

The Court's reparations decision in the Lubanga case offers an example of how local preferences might be incorporated. ${ }^{37}$ In assessing reparations, the Court approved a five-step implementation plan proposed by the Trust Fund for Victims (TFV). According to this plan, the TFV, along with the Registry, the Office for Public Counsel of Victims, and a group of experts, is responsible for selecting the areas involved in the reparations process. In those areas, the TFV will be responsible for a process of consultation and the team of experts will undertake a harm assessment. The TFV will then hold discussions in each area to engage the public in the reparations process with an eye to managing victim expectations. Finally, each locality will develop proposals for collective reparations to be presented by the TFV to the Chamber for its approval.

Though the inclusiveness of the process is to be commended, it would benefit from a more scientific and systematic investigation of local preferences, as well as more specific requirements of deep cultural knowledge among the experts group (rather than simply 'representatives of the DRC', who might represent political elites with little moral authority in the affected communities). ${ }^{38}$ The importance of engagement with alleged perpetrators should be underscored in order for reparations efforts to take root in the DRC. Moreover, the Court's engagement with efforts should begin much earlier in the lifecycle of a case. ${ }^{39}$

As David Koller notes in his contribution to this volume, it is impossible for the ICC to be single-handedly responsible for all transitional justice efforts in an affected society. Situating the Court within a bespoke

36 M. Sirleaf, 'The Truth About Truth Commissions: Why They Do Not Function Optimally in Post-Conflict Societies', Cardozo Law Review, 35 (2014), 2263.

37 Decision establishing the principles and procedures to be applied to reparations, The Prosecutor v. Thomas Lubanga Dyilo, ICC-01/04-01/06, Trial Chamber I, ICC, 7 August 2012, paras. 281-286.

38 Ibid., para. 264.

39 Ibid., paras. 263-266. The Court envisions engagement with a variety of experts at the reparations phase pursuant to Rule 97 (2) of the ICC's Rules of Procedure and Evidence; such engagement should begin much earlier in the process and prioritise the participation of experts with deep understanding of the relevant cultural context. 
transitional justice lens does not mean, however, that all transitional justice expectations should be placed upon the Court in countries in which a case is opened. If local perspectives indicate that international prosecution is necessary or useful, the limited role of the Court in achieving expressed societal goals should be clearly communicated by Court staff and other transitional justice actors. International prosecution may be a useful approach in certain situations, and it may create political space for other transitional justice efforts. ${ }^{40}$ But the ICC by no means possesses the entire tailor's kit; expectations and strategies should be managed accordingly.

A bespoke transitional justice approach also suggests that the ICC should not intervene in societies in which local populations prioritise issues other than criminal justice. Population preference surveys might reveal greater concern around questions of development, including jobs, education and infrastructure, or establishing a historical record, including discussion of the root causes of conflict.

While even a generous reading of Article 17 of the Rome Statute might not support such an approach, the realities of the Court's limited resources suggest that such factors could be included in strategic decisions about which prosecutions to pursue. ${ }^{41}$ The prosecutor might also look to Article 53's 'interests of justice' provision in situations where societal preferences suggest international prosecutions would not be appropriate, though, similarly, this approach does not fit well with current practice. ${ }^{42}$ Yet if the ICC were to undertake such a bespoke transitional justice approach, its decision not to prosecute certain situations after carefully considering the factors above may well afford the Court greater legitimacy in the eyes of local populations. ${ }^{43}$

${ }^{40}$ See, e.g., J. Ciorciari and J. Ramji-Nogales, 'Lessons Learned from the Cambodian Experience with Truth and Reconciliation', Buffalo Human Rights Law Review, 19 (2012), 193.

41 ICC Statute Article 17, focused on admissibility, requires that the Court decline cases in which the state with jurisdiction over that case is investigating or prosecuting the case, or has decided not to prosecute the case.

42 Article 53 of the ICC Statute requires the prosecutor to determine whether 'taking into account the gravity of the crime and the interests of the victims, there are nonetheless substantial reasons to believe that an investigation would not serve the interests of justice'. The OTP has stated in that a decision not to investigate under this provision is a 'course of last resort'. See 'Policy Paper on the Interests of Justice' Office of the Prosecutor, International Criminal Court (September 2007), 9.

43 A. Greenawalt, 'Complementarity in Crisis: Uganda, Alternative Justice, and the International Criminal Court', Virginia Journal of International Law, 50 (2009), 117. 


\section{Conclusion}

Most scholars of the ICC claim that it is not and should not be a mechanism of transitional justice. This chapter argues that such theories have significant descriptive limitations. A 'bespoke transitional justice' theory affords a more accurate understanding of the Court and prescribes methods for better aligning its efforts with the preferences of local populations. Such an approach prioritises the reconstruction of social norms in societies recovering from mass violence, and recognises the numerous challenges in doing so. It suggests that the Court should affirm community norms and utilise an inclusive design process by undertaking empirical population surveys several times during the lifespan of a case and by engaging with cultural experts and local moral authorities.

The challenges of domination and exclusion must be anticipated and addressed. Expectations of the Court's role in transitional justice efforts should also be managed; it is important to recognise that international criminal prosecution cannot meet all transitional justice needs. This might mean that the Court works alongside other mechanisms, and, in some situations, chooses not to intervene based on the preferences of the local population. It is not an easy task to conceptualise the ICC as a transitional justice mechanism, but the 'bespoke transitional justice' method can be used to redesign the relationship between the Court and the populations most affected by mass violence. By increasing perceptions of the Court's legitimacy in such societies, such an approach offers the potential to more effectively entrench the norms it seeks to promulgate and promote peace and security in conflict-affected societies. 


\title{
A synthesis of community-based justice and complementarity
}

\author{
MICHAEL A. NEWTON
}

\section{Introduction}

The International Criminal Court (ICC) operates as the conceptual pinnacle of an interlocking system, one in which supranational and domestic court systems are meant to operate as a cohesive whole. ${ }^{1}$ The Rome Statute was designed to address the 'most serious crimes of international concern' but to do so in line with the fundamental norm that the Court at all times and in all cases 'must be complementary to national criminal jurisdictions.' Thus, while it operates within the milieu of international politics and power, the Court's very raison d'être is to seek justice for the most consequential crimes against the backdrop of an interconnected and often interdependent relationship with domestic criminal justice systems. Localised efforts to achieve justice for violations of societal norms are as desirable as they are inevitable.

'Justice' is, however, a far less straightforward concept than is commonly acknowledged, and often means different things to different people depending on their relationship to the crimes committed and the relevant cultural norms within the affected community or group. ${ }^{3}$ The concept of 'justice' may be a vital need for refugees, victims and affected communities, but its multidimensional nature and subjective shape makes it a far more nuanced aim than is always possible through a formalised prosecution and punishment of

1 Articles 12-19, Rome Statute.

2 Ibid., Article 1. See also M. Newton, 'The Quest for Constructive Complementarity', in C. Stahn and M. El Zeidy (eds.), The International Criminal Court and Complementarity: From Theory to Practice (Cambridge: Cambridge University Press, 2011).

${ }^{3}$ J.N. Clark, 'Peace Justice and the International Criminal Court: Limitations and Possibilities', Journal of International Criminal Justice, 9 (2011), 521, 523 (discussing the varying reactions of Bosnian Serbs and Muslims to the arrest of ICTY fugitive Radovan Karadžić in July 2008, as well as the diversity of responses to the release of convicted Lockerbie bomber Abdelbaset Ali al-Megrahi in 2009). 
responsible perpetrators. ${ }^{4}$ Community-based dispute mechanisms can thus have a central role alongside formalised trials, to the extent that localised processes embody a culturally meaningful blend of restorative and retributive elements. There is often a corresponding value to seeing the Rome Statute offences through the metric of localised goals, since such offences may be widely seen as affairs between competing communities and sub-state actors; hence, the legitimacy of 'justice' turns on its societal resonance. Communities affected by hostilities also have legitimate interests in finding a balance between appropriate punitive procedures and a deliberate dimension of reintegration, especially insofar as community leaders may become the guarantors of a lasting and sustainable peace. By logical extension, the ICC must be open to these perspectives.

This chapter seeks to articulate an affirmative posture for the field of international criminal law and its institutions to adopt towards traditional justice processes. Based on his own experience in the transitions to peace in Kosovo and Timor-Leste, Lakhdar Brahimi strongly advocated local ownership and involvement in institutional reforms - an approach known as the 'light footprint' - by which capacity building emphasised the most limited international presence possible in conjunction with as many local staff as possible. ${ }^{5}$ Brahimi's involvement in the early phases of post-Taliban Afghanistan adopted the 'light footprint' approach as a guiding model. Apart from the deeply held beliefs of communities most affected by hostilities, traditional justice mechanisms are also tinged with political importance because they often operate against the backdrop of peace negotiations and the recurrence of tensions raised by domestic amnesty provisions.

In making this argument, the chapter first describes the interface between the concept of complementary and localised systems, and then details the ICC's authority under Article 53 - particularly that of the

4 There was extensive debate during the drafting of the Elements of Crimes for the International Criminal Court over the relative merits of the terms 'perpetrator' or 'accused'. Though some delegations were concerned that the term 'perpetrator' would undermine the presumption of innocence, the delegates to the Preparatory Commission (PrepCom) ultimately agreed to use the former in the Elements after including a comment in the introductory chapter that 'the term "perpetrator" is neutral as to guilt or innocence'. See UN Doc PCNICC/2000/INF/3/Add.2 (2000), in K. Dormann, Elements of War Crimes under the Rome Statute of the International Criminal Court (Cambridge: Cambridge University Press, 2002), 14.

${ }^{5}$ S. Chesterman, You, The People: The United Nations, Transitional Administration, and State-Building (New York: Oxford University Press, 2004), 8. 
Office of the Prosecutor (OTP) - to seek the larger 'interests of justice'. Article 53 has been a neglected dimension of the Court's power, particularly in its underdeveloped relationship to the complementarity regime. The following section examines recent trends in localised efforts to seek post-conflict stability in two situation-specific contexts - Uganda and Afghanistan - with a view towards illustrating the need for a holistic and comprehensive approach that balances formalised criminal systems with more community-based approaches. In the final section, the chapter articulates four specific recommendations designed to guide the Article 53 discretion of the ICC's prosecutor and pre-trial chambers. These recommendations offer a series of affirmative steps that the Court could take to consciously implement a more consistent approach to incorporating local perspectives within its work.

Phrased another way, this chapter describes specific statutory changes that would permit a productive interface between ICC investigations and efforts by affected communities to achieve lasting peace. Taken together, the recommendations seek to ensure a cooperative and constructive relationship between a maturing Court and situation states, as well as with communities affected by conflict. Public articulation of standards for assessing the 'interests of justice' would provide needed consistency within the larger context of the complementarity regime and would shield the Court from charges of excessive politicisation in relation to controversial case dispositions. Indeed, a more developed understanding and subsequent implementation of the Court's prerogatives under Article 53 could substantially strengthen its institutional aspiration to serve as a permanent supranational body that purports to advance the 'interests of justice'.

\section{Complementarity and community-based justice}

Though it is the fulcrum that prioritises the authority of domestic forums, the precept of complementarity does not of itself logically lead to a homogenised system of national and supranational concurrent jurisdiction with a shared vision of 'justice'. The ICC was not created to impede domestic processes or to impose its dominance over the prosecutorial practices and priorities of states with developed systems and demonstrated adherence to the rule of law. ${ }^{6}$ The ICC does not have

6 The irony of this truth is that the actual prosecution of Saddam Hussein and other leading Ba'athists took place in an internationalised domestic forum precisely because, inter alia, 
authority to take a case to trial until the issues associated with domestic jurisdiction and the admissibility criteria have been analysed and resolved in accordance with the framework of the Rome Statute. Properly understood and implemented, the admissibility regime is thus best conceived as a tiered allocation of authority to adjudicate. The creation of a vertical level of prosecutorial authority that operates as a permanent backdrop to the horizontal relations between sovereign states in large part depended on a delineated mechanism for prioritising jurisdiction while simultaneously preserving sovereign rights and serving the ends of justice.

Complementarity is designed to serve as a pragmatic and limiting principle, rather than as an affirmative means to target the nationals of states who are hesitant to embrace ICC jurisdiction and authority. The provisions of the Rome Statute preserve a balance between maintaining the integrity of domestic adjudications and authorising a supranational court to exercise power where domestic systems are inadequate. In preserving this balance, complementarity is best viewed as a restrictive principle rather than as an empowering one; while the ICC has affirmative powers as a supranational court, the textual predicates necessary to make a case admissible are designed to constrain the power of the Court. Hence the operative language in Article 17 mandates that 'the Court shall determine that a case is inadmissible' where the criteria warranting exclusive domestic authority are met as specified in the Statute itself. ${ }^{7}$

The appropriate power of the ICC prosecutor will be sustained only by a relationship based on respect and an authentic partnership with sovereign authorities. As one Ugandan minister told me in confidence, 'I think the ICC would be helpful if they cooperated with us.' The text of Article 18 implicitly places control of investigations with states, unless the prosecutor can otherwise show that such a decision does not serve the interests of justice because the domestic investigation is automatically given primacy unless the prosecutor submits an application to the PreTrial Chamber. ${ }^{8}$ The language is unequivocal: 'the Prosecutor shall defer to the State's investigation of those persons unless the Pre-Trial Chamber, on the application of the Prosecutor, decides to authorize the investigation. ${ }^{9}$ The burden thus lies with the prosecutor to prove that the

Iraqis saw grave injustice arising from prosecuting only the subset of crimes committed after 1 July 2002, as required by the jurisdictional limitations of the Rome Statute. M.A. Newton and M.P. Scharf, Enemy of the State: The Trial and Execution of Saddam Hussein (New York: St Martin's Press, 2008), 76-80.

7 Article 17 (1), Rome Statute. ${ }^{8}$ Ibid. ${ }^{9}$ Ibid. 
state processes are insufficient. This structure implements state primacy by making the state investigation the default response of the Court. If the prosecutor wants to proceed with the case, he or she must do so only based on the affirmation of the Pre-Trial Chamber by demonstrating that the state's investigation is inadequate.

The reliance on formal investigative and prosecutorial processes in these provisions is understandable but also inadequate, in the sense that the dominant needs of affected communities become tertiary. Indeed, neither domestic prosecutors nor international tribunals have the capacity to punish every perpetrator for every offence; in any event, the gravity threshold explicitly preserves space for domestic formal and informal authority in all cases 'that are not of sufficient gravity to justify further action by the Court'. ${ }^{10}$ The evolving discipline now termed 'international criminal law' has been described as 'the gradual transposition to the international level of rules and legal constructs proper to national criminal law or national trial proceedings'. ${ }^{11}$ States around the world have implemented domestic legislation to provide the basis in criminal law for punishing perpetrators of grave crimes. This is important because the era of accountability is well under way, and it is transpiring through an interrelated system of domestic and international forums. The complementarity regime is therefore a pragmatic necessity that will disappoint local leaders and innocent civilians who expect courts to 'severely punish all war criminals with harsh prison sentences and to have a significant impact at the level of their communities'. ${ }^{12}$ Empirical accounts demonstrate that survivors and victims in post-conflict environments 'expected to be able to go about their daily lives without encountering people whom they claim are guilty of war crimes'. ${ }^{13}$ Formalised processes that are centralised at the supranational level will almost always be inadequate to achieve this result. In fact, sustainable peace may depend on a synergy between formalised trials and a broader set of actions by local actors that are firmly rooted in sociological legitimacy.

${ }^{10}$ Article 17 (1)(d), Rome Statute.

11 A. Cassese, International Criminal Law (Oxford: Oxford University Press, 2003), 18. Mark Osiel has correctly noted that prosecutors in international forums have divergent professional and career motivations than domestic prosecutors. The divergent incentives and perspectives make the process of complete 'coherence' between international and domestic systems quite unattainable. M. Osiel, Making Sense of Mass Atrocities (New York: Cambridge University Press, 2009), 169-185.

12 J.N. Clark, 'The Limits of Retributive Justice: Findings of an Empirical Study in Bosnia and Hercegovina', Journal of International Criminal Justice, 7 (2009), 463, 467.

13 Ibid. 
The complementarity structure is thus necessarily strengthened by traditional justice mechanisms, subject to two important caveats. First, the provisions are framed in the context of official, formalised investigations or prosecutorial action and worded entirely in the present or past tense. There should be no space within this universalised body of international criminal law for personal vengeance or community vigilantism. Second, just as it is reasonable for the Court to require proof of good faith investigations and prosecutions by domestic authorities, one must be careful not to romanticise community-based processes. Localised alternatives to prosecution may well be under the control of persons who exercise inappropriate or undue influence. Community-based traditional mechanisms can enable corruption and human rights violations or further victimise individuals along local ethnic, religious or political divisions. To reiterate, the Court would be well served to develop concrete standards for assessing the efficacy of local processes to guide dialogue and decision-making of both Court and domestic criminal officials.

\section{Article 53 and the 'interests of justice'}

\section{The conceptual roots of integrating community-based efforts into the Court}

In light of the inspiring growth of the field of international criminal law since World War II, it is often forgotten that the Moscow Declaration specifically favoured punishment through the national courts in the countries where the crimes were committed. ${ }^{14}$ The military commissions established in the Far East also incorporated the principle that the international forum did not supplant domestic mechanisms. ${ }^{15}$ The UN secretary-general is persuaded that 'no rule of law reform, justice reconstruction, or transitional justice initiative imposed from the outside

14 IX Department of State Bulletin No 228, 310, reprinted in Report of RH Jackson United States Representative to the International Conference on Military Tribunals (Department of State Publication 3080, 1945), 11. The Moscow Declaration was actually issued to the Press on 1 November 1943. For an account of the political and legal manoeuvering behind the effort to bring this stated war aim into actuality, see P. Maguire, Law and War: An American Story (New York: Columbia University Press, 2000), 85-110.

15 'Persons whose offenses have a particular geographical location outside Japan may be returned to the scene of their crimes for trial by competent military or civil tribunals of the local jurisdiction.' Regulation 5 (b), Regulations Governing the Trial of War Criminals, General Headquarters, United States Army Pacific, AG 000.5 (24 September 1945). 
can hope to be successful or sustainable'. ${ }^{16}$ For example, very few experts believe that a system of 'justice' can be effectively imposed upon a recalcitrant regime in conflict settings. ${ }^{17}$ The complementarity regime is predicated on precisely this principle because 'justice' is most legitimate and ultimately effective when it is most responsive to the demands of the local population.

As a moral and practical imperative, permitting external actors to supersede the established set of domestic punishments and cultural traditions, would be a modern form of legal colonialism that would undermine international prosecutions. ${ }^{18}$ Rather, the relative priorities of people affected by conflicts can be best gauged and addressed at more local levels. For some, justice means the retrieval of family remains from mass graves and the right to conduct a culturally appropriate burial. For others, disputes over property vacated under threat of imminent danger are the most pressing concern, while in other contexts the needs of refugees and religious leaders to seek restitution and reparations for damage done by former neighbours will predominate. In other words, community leaders and local political authorities deserve the frontline role in serving the needs of those whose interests they represent, but they should not be forced to subvert their own legal traditions as the price for gaining international support and assistance. Traditional mechanisms may well provide for their psychological, social and economic needs far better than any formalised prosecution.

Article 53 of the Rome Statute recognises this implicit relationship as a third dimension of justice alongside the formalised processes of the domestic state or the complexities of ICC authority; it is implicated only in circumstances where a case or situation is properly subject to the jurisdiction of the Court. The plain language requires the prosecutor to initiate an investigation unless he or she determines that there is not a 'reasonable basis to proceed'. ${ }^{19}$ As a logical extension, grounds for

16 Report of the UN Secretary-General, 'The Rule of Law and Transitional Justice in Conflict and Post-Conflict Societies', UN Doc S/2004/616 (23 August 2004), 17.

17 B. Crocker, 'Iraq: Going it Alone, Gone Wrong', in R.C. Orr (ed.), Winning The Peace: An American Strategy for Post-Conflict Reconstruction (Washington, DC: Center for Strategic and International Studies, 2004), 281.

${ }^{18}$ For a detailed account of the Cold War politics and unravelling of wartime unity that doomed the effort to convene a second International Military Tribunal after World War II, see D. Bloxham, Genocide on Trial: War Crimes Trials and the Formation of Holocaust History and Memory (Oxford: Oxford University Press, 2001), 28-37.

19 Article 53 (1), Rome Statute. This language parallels that of Article 15, which governs the proprio motu powers of the Prosecutor, and provides that such proprio motu authority to 
declining an investigation exist when there is no reasonable basis to believe that a crime within the jurisdiction of the Court has been or is being committed (i.e. a formal investigation is unwarranted), or the case would be inadmissible under the complementarity regime (i.e. domestic authorities are engaged in formalised judicial or investigative processes). The most significant aspect of Article 53 stands in contrast to the formalised processes by permitting the prosecutor to defer investigation when 'Taking into account the gravity of the crime and the interests of victims, there are nonetheless substantial reasons to believe that an investigation would not serve the interests of justice. ${ }^{20}$

Notably, the text of Article 53 is silent regarding a duty to consult with victims, domestic officials, religious leaders or prosecutors in a situation state. This stands in sharp contrast to the rights afforded the Security Council, as well as other states parties and political officials who are entitled by the Statute to an explanation of 'his or her conclusion and the reasons for the conclusion'. In short, the communities most affected - who should be entitled to consultation or coordination when the prosecutor's decision not to investigate or to prosecute is premised on the interests of justice' - are omitted. This disparity is puzzling in part because the affected communities are often able to assess the 'interests of justice' and have the most access to available information related to the perceived legitimacy of case dispositions, as well as insights into the most advisable order for bringing charges against perpetrators. Furthermore, in another ironic twist, although states parties that refer a situation (or the Security Council, in the case of an Article 13 referral) may request review when the prosecutor declines to investigate or prosecute based on the interests of justice, victims, domestic officials and affected communities have no basis for seeking such review. ${ }^{21}$ Article 53 only stipulates that the Pre-Trial Chamber may review the prosecutor's 'interests of justice' determination on its own initiative and that in 'such a case, the decision of the Prosecutor shall be effective only if confirmed by the Pre-Trial Chamber. ${ }^{22}$

open an investigation is discretionary, rather than mandatory. At least one eminent authority has surmised that Article 53 only applies to situations that have been referred to the Court either by states party or by the Article 13 action of the United Nations Security Council. W. Schabas, The International Criminal Court: A Commentary on the Rome Statute (New York: Oxford University Press, 2010), 659.

20 Article 53 (1)(c), Rome Statute. ${ }^{21}$ Ibid., Article 53 (3)(a).

22 Ibid., Article 53 (3)(b). 


\section{The prosecutor's current policy on the 'interests of justice'}

Article 53 requires a synthesis of perspectives and goals within which the ICC and local communities share information and strive towards shared objectives. In a policy paper issued in September 2007, the OTP unsurprisingly noted that 'The issue of the interests of justice, as it appears in Article 53 of the Rome Statute, represents one of the most complex aspects of the Treaty. It is the point where many of the philosophical and operational challenges in the pursuit of international criminal justice coincide (albeit implicitly), but there is no clear guidance on what the content of the idea is. ${ }^{23}$ As Juan Mendez memorably observed, 'justice contributes to peace and reconciliation when it is not conceived as an instrument to either'. ${ }^{24}$

Despite this complexity, the policy paper did not take the opportunity to clearly frame the role of formalised international justice as an interconnected and additive dimension of local needs and desires. It finds that the provisions of the Rome Statute 'clearly favour the pursuit of investigations and cases' when they meet the necessary predicates of jurisdiction and admissibility, and thus specifies that, 'Taking into consideration the ordinary meaning of the terms in their context, as well as the object and purpose of the Rome Statute, it is clear that only in exceptional circumstances will the Prosecutor of the ICC conclude that an investigation or a prosecution may not serve the interests of justice. ${ }^{25}$ However, unlike the objective criteria specified in the Statute for assessing admissibility of a particular case, the Court can never implement a wholly monopolistic interpretation of the 'interests of justice'. This is because the subjective valuations of the affected community or situation state will always be relevant when weighing the merits of investigations and prosecutions, when warranted by the evidence and circumstances.

Two important applications follow from this generalised philosophical construct. First, focusing on the narrowly conceived view of the ICC as the

23 'Policy Paper on the Interests of Justice', Office of the Prosecutor, ICC (September 2007), 2 (OTP, 'Policy Paper on the Interests of Justice'). This approach clearly reflects the input received from Human Rights Watch, which noted that the term was not 'precisely defined', and urged a narrow construction 'most consistent with the object and purpose of the Rome Statute'. 'The Meaning of "The Interests of Justice" in Article 53 of the Rome Statute', Human Rights Watch Policy Paper (June 2005).

24 J.E. Mendez, 'Justice and Prevention', in C. Stahn and M. El Zeidy (eds.), The International Criminal Court and Complementarity: From Theory to Practice (Cambridge: Cambridge University Press, 2011), 33, 36.

25 OTP, 'Policy Paper on the Interests of Justice', 3. 
instrument of international accountability, the policy paper pledges to work 'constructively with and respect the mandates of those engaged in other areas' but insists that the 'judicial mandate' operates 'independently' and implicitly superior to other considerations arising from community perspectives. While expressly noting the 'complementary role that can be played by domestic prosecutions, truth seeking, reparations programs, institutional reform and traditional justice mechanisms in the pursuit of a broader justice, ${ }^{26}$ the paper omits any mention of specific measures to accomplish such a synergy between formalised prosecutorial efforts and the larger efforts to achieve justice within a given society and situational context. There is no affirmative vision that postulates the OTP's vision of the factors that could, in the aggregate, warrant a finding that the interests of justice' mitigate against further investigation or prosecution. Indeed, the paper expressly sets forth the aspects that the prosecutor will not consider when weighing the 'interests of justice', but there is nothing explicit in the policy that leads to a cohesive sense of what factors can, and should be, considered as serving justice. Hence, affected states and communities are left to guess what factors might or might not be determinative.

Second, and more controversially, the OTP's paper juxtaposes the 'interests of justice' criteria against the more problematic controversy surrounding the appropriate role for the ICC as an instrument of international diplomacy. The policy states in its introduction that 'there is a difference between the concepts of the interests of justice and the interests of peace and that the latter falls within the mandate of institutions other than the Office of the Prosecutor ${ }^{27}$ In fact, the secretary-general of the United Nations has stated that 'Justice, peace and democracy are not mutually exclusive objectives, but rather mutually reinforcing imperatives. ${ }^{28}$ Nevertheless, official OTP policy remains at the time of this writing that a broad conception of the Article 53 mandate would violate the very object and purpose of the Rome Statute. This argument assumes that the formalised trials in the Court play an irreplaceable role as the sole arbiter of international justice, which itself contravenes the well-established complementarity framework. This is even more problematic when read in light of Richard Goldstone's caution that 'the word "justice" is demanding ... yet few would aver that it is "demanding" in the sense that it is always retributive. ${ }^{29}$ The OTP policy makes no allowance for a situation state

${ }^{26}$ Ibid., 5. ${ }^{27}$ Ibid., 1. ${ }^{28}$ Report of the UN Secretary-General, para. 49.

29 R. Goldstone and N. Fritz, "In the Interests of Justice" and Independent Referral: The ICC Prosecutor's Unprecedented Powers', Leiden Journal of International Law, 13 (2000), $655,662$. 
to represent the human interests of its citizens, apart from filing formal challenges to admissibility under the procedures of Article 19. Finally, it bears noting that the narrowest possible framing of Article 53 reflected by the OTP policy is absolutely unsupported by the diplomatic history. As William Schabas has noted, 'an amendment to article 53(1)(c) to the effect that "the interests of justice shall not be confused with the interests of peace" would "surely not have met with consensus". 30

In sum, rather than setting out an affirmative and powerful vision of a synergy between formalised prosecutions, whether at the domestic or international level, and the far more common usage of community-based justice mechanisms, the current OTP policy paper provides little clarity for the future. This represents an intentional trade-off of overall legitimacy and efficacy in favour of expediency. At the time of writing, there is also no authoritative statement from the Court regarding the conditions or circumstances in which domestic action would warrant abeyance of supra-international ICC authority in a particular case. This is a significant concern for two reasons: 1) it permits allegations that a particular approach to a particular perpetrator is ad hoc and that future decisions are not taken in the context of a consistent and defensible policy, and 2) it clouds the relationships with domestic officials, victims and affected communities in ways that hinder effective investigations and movement towards both sustainable peace and justice.

\section{Local ownership for localised objectives: Uganda and Afghanistan}

Justice that benefits from a sense of local-level ownership is actually a mosaic of prosecutions, accountability, reconciliation, reparations, institutional reform, reintegration, truth-telling and retribution. The artificial polarisations between peace and justice have clouded debates about the most appropriate ways to address conflict and its aftermath, implying either/or choices when combinations of these elements often better reflect popular perceptions and lead to more effective practical strategies. As framed by the aspiration of a leading Ugandan lawyer, the creation of a modern holistic system of accountability for international crimes should serve as the interface of the ICC and domestic processes that 'link together in an inseparable synergy the restorative/traditional, official and international justice mechanisms. ${ }^{31}$

${ }^{30}$ Schabas, The International Criminal Court, 663.

${ }^{31}$ F. Okumu-Alya, 'The International Criminal Court and Its Role in the Northern Uganda Conflicts - An Assessment', Uganda Living Law Journal, 4 (2006), 16, 48. 


\section{Uganda}

In response to accusations from the ICC that the use of communitybased justice practices actually reinforce impunity in Uganda, a leading local NGO expert claimed that if you are pursuing peace then justice is not optional, it is an integral part of peace. Done wrongly (as we would argue has happened in northern Uganda), the pursuit of international justice can undermine the pursuit of peace, but done correctly' using 'a whole array of transitional justice approaches, the pursuit of peace and the pursuit of justice should and can go hand in hand'. ${ }^{32}$ The singleminded and mechanical pursuit of punitive justice by the ICC in complex situations like Uganda, where victims want an immediate end to their anguish, has been described by local actors as iniquitous, especially in the presence of more pragmatic efforts like peace negotiations' ${ }^{33}$ The current ICC Article 53 policy paper seems to reaffirm this single-minded focus on prosecution as the only viable option for achieving justice.

The controversies over the role of the ICC in Uganda, which led in a linear fashion to the policy paper on Article 53, arose from the history of the conflict and the structure of the Juba Accords themselves. The Lord's Resistance Army (LRA) rampaged across northern Uganda for nearly two decades, in the process abducting children, murdering families and terrorising villages across northern Uganda. On 21 January 2000, Uganda adopted an Amnesty Act providing unconditional amnesty for anyone who had engaged in armed rebellion against the government since the '26th day of January 1986' and who agreed to renounce and abandon such rebellion. ${ }^{34}$ The act subject to amnesty was broadly conceived, ${ }^{35}$ amidst the declaration that 'amnesty means a pardon, forgiveness, exemption or discharge from criminal prosecution or any other form

${ }^{32}$ C. Dolan, 'Imposed Justice and the Need for Sustainable Justice in Northern Uganda', Presentation to the Beyond Juba Project/AMANI Forum training in Transitional Justice for Parliamentarians (18 July 2008).

${ }^{33}$ S. Oola, 'Bashir and the ICC: The Aura or Audition of International Justice in Africa?' Oxford Transitional Justice Research Working Paper Series (27 February 2009).

34 The Amnesty Act, 2000.

${ }^{35}$ Ibid., para. 2 (1):

(1) An amnesty is declared in respect of any Ugandan who has at any time since the 26th day of January, 1986, engaged in or is engaging in war or armed rebellion against the government of the Republic of Uganda byactual participation in combat; collaborating with the perpetrators of the war or armed rebellion; committing any other crime in the furtherance of the war or armed rebellion; or assisting or aiding the conduct or prosecution of the war or armed rebellion. 
of punishment by the State'. The Ugandan Constitutional Court has since held that even a former child soldier who rose to become a senior LRA commander and who was captured by government forces remains constitutionally entitled to amnesty for his criminal acts even though he failed to claim amnesty until after his detention. ${ }^{36}$ At the time of writing, nearly 27,000 individuals have received amnesty pursuant to the act, and Uganda is more or less at peace.

The Agreement on Accountability and Reconciliation (commonly referred to as the 'Juba Accords') was consciously negotiated in light of the complementarity framework of the Rome Statute, and shaped by the refusal of LRA leaders to submit to the authority of the ICC. What observers have commonly termed the 'Spirit of Juba' actually represented the kind of sophisticated synthesis that one might well have expected to arise from a formal OTP policy with respect to the Article 53 interests of justice' criteria. The preamble of the Agreement (the Annexure has no preamble) sets out the purpose of the Agreement to prevent impunity, to promote redress to promote reconciliation and to achieve peace. The second paragraph also clarifies that the goal is 'lasting peace with justice' - evidently a nod to the peace versus justice debate triggered by the ICC warrants of arrest against LRA leadership. ${ }^{37}$

The Juba Accords contain a number of different mechanisms, which often explicitly or implicitly subsume the language of the Rome Statute, and the complementarity framework in particular. According to Clause 1, the term 'alternative justice mechanisms' covers not only traditional mechanisms but also any mechanism that is 'not currently administered in the formal courts' of Uganda. Clause 5.3 of the Agreement provides that the alternative justice mechanisms shall consist of traditional justice mechanisms, as well as 'alternative' mechanisms or features within the formal proceedings, such as 'alternative sentences'. In addition, the term 'formal' appears in several places, for example in Clause 4.2, which speaks of 'prosecutions and other formal accountability proceedings.' This is culturally significant due to the wide variation between regional practices within the situation state. ${ }^{38}$

36 Thomas Kwoyelo alias Latoni v. Uganda (Const. Pet.No. 036 Of 2011(reference)) [2011] UGCC 10 (22 September 2011). Article 28 (10) of the Ugandan Constitution states, 'No person shall be tried for a criminal offense if the person shows that he or she has been pardoned in respect of that offense.'

37 On this debate, see Refugee Law Project's statement on the ICC investigation in northern Uganda (5 August 2004).

38 See J. Latigo, 'The Acholi Traditional Techniques of Conflict Management', Uganda Living Law Journal, 4 (2006), 1, and J.F. Adong, 'Restorative Justice as a Strategy for 


\section{Afghanistan}

The Afghan Ministry of Justice continues to implement a halting and conflicted process of determining the optimal blend of localised mechanisms amidst a revitalised but fragile formal justice system. Approximately 80 per cent of the private civil and criminal disputes in Afghanistan are resolved through some form of community-based dispute resolution process, rather than in a courtroom or, in the case of most rural communities, the district office. ${ }^{39}$ This has led many analysts to describe Afghanistan as having two justice systems: a 'formal' (state-run) judicial sector and an 'informal' (community-based) judicial sector. Where they do exist, locals generally view the formalised processes as corrupt, slow, expensive, inept and less legitimate than the long-standing customary practices emphasizing local resolution of disputes. ${ }^{40}$ In a recent survey, Afghan citizens complained that interactions between the citizen and the state resemble a bazaar economy, where corruption has become the nation's new currency. ${ }^{41}$ These factors - corruption in the public judicial process and widespread acceptance of customary practices - explain why community justice is such a vital institution in Afghanistan.

The 'informal' system is comprised of local dispute resolution councils, which are led by community elders and are convened on an ad hoc basis to resolve specific disputes arising between members of a community as well as between different communities. More than just a customary practice, Jirga is 'an historical and traditional institution and gathering of the Afghans, which over the centuries, has resolved our nation's tribal and national political, social, economic, cultural and even religious conflicts by making authoritative decisions'. ${ }^{42}$ When reliable evidence, in the form of either witness testimony or documentation, is unavailable, jirgamaran render islahi decisions - or 'equity-based' decisions - to keep peace within the community. ${ }^{43}$

Achieving Lasting Peace, Justice and Reconciliation in the Northern and North Eastern Uganda', Uganda Living Law Journal, 5 (2007), 27.

39 Progress in Peace Building: Afghanistan, United States Institute of Peace (February 2011).

40 T. Barfield, N. Nojumi, and J. Their, 'The Clash of Two Goods: State and Non-State Dispute Resolution in Afghanistan', in D. Isser (ed.), Customary Justice and the Rule of Law in WarTorn Societies (Washington, DC: United States Institute of Peace, 2011), 159-193, 160.

${ }^{41}$ M. Gardizi, K. Hussmann, and Y. Torabi, 'Corrupting the State or State Crafted Corruption?', Afghanistan Research and Evaluation Unit (June 2010), 3.

42 A. Wardak, 'Jirga - Power and Traditional Conflict Resolution in Afghanistan', in J. Strawson (ed.), Law After Ground Zero (London: Glasshouse Press, 2002), 187, 190.

43 D.J. Smith and S. Manalan, 'Community-Based Dispute Resolution Processes', Bamiyan Province, Afghanistan Research and Evaluation Unit - Case Study Series (December 2009), 41. 
The continued vitality of community-based justice in post-Taliban Afghanistan owes largely to the elders, or jirgamaran, who resolve disputes; they are widely trusted by the community, and as such are thought of by community members as being 'just' and having the wider community's interest in mind. ${ }^{44}$ As one villager who has served as a jirgamaran put it, the elders who are selected to locally resolve disputes 'are familiar to us and respected by the people - and they should resolve our disputes and problems honestly and respect the rights of the villagers' ${ }^{45}$ These local elders possess a type of authoritative power that derives not from any formal affiliation with the state or its ability to physically enforce its directives, but rather from their longevity and the perception that their judgments are an organic part of community life. ICC officials seldom share these perceptions in situation states.

Furthermore, a categorical distinction between an 'informal' and 'formal' justice sector contains several inaccurate assumptions: (1) that these two modes of dispute resolution are separate, distinct and unconnected in practice; (2) that the existence of one sector undermines the legitimacy and efficacy of the other and (3) that policymakers and military analysts should work towards the creation of one dominant sector to serve as Afghanistan's primary modality for both public and private dispute resolution. ICC officials also commonly voice these perspectives.

It would be a mistake, however, to presume that public and private institutions in modern Afghanistan operate either in isolation or in tension. For many Afghan citizens, the interface of traditional and formal processes permits the freedom to turn to one where the other has not succeeded or would be predictably inappropriate. Many Afghans consider a variety of factors in choosing which forum to resolve their disputes, such as the preference for local resolutions by arbiters who have a deep knowledge of them, their dispute and their community; the desire for speedy resolution of disputes and the emphasis on restoring communal stability over retribution. ${ }^{46}$ Thus, while a cleavage between 'formal' and 'informal' justice may be superficially appealing, it ignores the nuanced interaction between state justice institutions, administrative bodies and local dispute resolution councils, as well as the role customary

${ }^{44}$ D.J. Smith, 'Community-Based Dispute Resolution Processes', Nangarhar Province, Afghanistan Research and Evaluation Unit - Case Study Series (December 2009), 11.

${ }^{45}$ Ibid. ${ }^{46}$ Ibid., 30. 
practices have played in creating political stability in areas of the country where formal governmental authority has been undermined. ${ }^{47}$

\section{Proposals for reimagining the ICC's role}

In his inaugural address, the first ICC prosecutor was correct in noting that, 'As a consequence of complementarity, the number of cases that reach the Court should not be a measure of its efficiency. On the contrary, the absence of trials before this Court, as a consequence of the regular functioning of national institutions, would be a major success. ${ }^{38}$ The provisions of the Rome Statute provide for a triangular relationship whereby three sets of actors should operate in a productive tension with each other: the local actors who will directly benefit from the restoration of the rule of law; the sovereign authorities that are responsible for protecting the human rights of the population, but also for creating the conditions of societal stability; and the appropriate role of the ICC alongside the domestic judiciary.

Yet the relationship between the 'interests of justice' under Article 53 and the larger admissibility regime remains largely undeveloped, even though the relationship between the efforts of the ICC and domestic institutions may well represent the most definitive measure of success over the long-term life of the Court. After all, the existential imperatives for the formation and costs of the supranational court lie in the overarching goal of creating a productive relationship with local accountability efforts that makes genuine progress towards the commonly proclaimed goal of 'ending impunity for the most serious crimes of concern to mankind'. This section offers a series of specific considerations that might well be incorporated into an amended ICC policy with respect to the 'interests of justice'.

\section{Specific rationales for determining the 'interests of justice'}

In the first place, a revised Article 53 policy should clearly articulate a set of factors that help to determine the deference that should be accorded to traditional processes. In effect, this is a two-level problem whereby domestic prosecutors must make a similar determination vis-à-vis

47 D.J. Smith, 'Examining Community-Based Dispute Resolution Processes', Podcast, Afghanistan Research and Evaluation Unit (3 November 2010).

${ }^{48}$ L. Moreno-Ocampo, 'Statement made at the Ceremony for the Solemn Undertaking of the Chief Prosecutor of the International Criminal Court' (16 June 2003). 
traditional mechanisms, even as the ICC undertakes its own independent analysis of the 'interests of justice' within the meaning of the Rome Statute. Afghanistan provides a good example of traditional processes for seeking justice and resolving disputes that function to fill a necessary void in state authority. Nevertheless, there have been many instances when the traditional processes have been co-opted by Taliban influences. A revised Article 53 policy should thus acknowledge that any process demonstrably controlled by a specific religious, tribal or other informal faction should be entitled to less deference than purely communal processes. Phrased another way, when traditional processes provide a functional substitute for the conduct of hostilities, they ought to be substantially discounted, if not disregarded.

Second, the very nature of conflict may well have altered the distribution of power within a region or village, or indeed between competing clans or sects. For instance, where local processes have been hijacked, they may well be seen as counterproductive to the twin interests of lasting stability and reconciliation. If local processes have been overcome by intrinsic corruption to the degree that they have lost the communal power of reconciliation, they should also be entitled to less deference. Traditional authorities will generally be the most sensitive to shifts in the power relationships within a region, and the corollary relationships between domestic prosecutors and local populations should be informed by these shifts. As a logical extension, when local accountability mechanisms operate to entrench gender inequalities or to subvert established internationally recognised human rights, they cannot be presumed to represent the 'interests of justice' simply by virtue of their 'local' provenance.

A revised Article 53 policy should also require that a specific set of factors be developed in conjunction with prosecutors and local authorities in every case where the prosecutor moves towards initiation of an investigation. This would have the effect of making the 'interests of justice' a regular and required consideration, albeit one that would commonly be insufficient to warrant abeyance of an investigation. The criteria listed in Article 53 itself are intended neither to be dispositive nor to deny a more comprehensive consideration of the circumstances of each offence. A revised policy paper could state, for example, that, 'the choice of forum for the adjudication of any particular case shall depend, amongst other considerations, on the nature and gravity of the offending conduct, the age and interests of the victims, and the role of the alleged perpetrator in that conduct'. In particular, such determinations should be required to rest upon an individualised assessment of the alleged offences in light of the assessed operation of 
other domestic courts, traditional justice mechanisms and any process for national truth-telling or historical documentation. A determination not to proceed with a particular case, and the reasons warranting such a determination, should be prepared in writing and provided to the Pre-Trial Chamber's pro forma. Similarly, the ICC should provide such determinations to national or local prosecutorial authorities upon request.

In reaching these determinations, the ICC should clearly articulate the factors within each case and the charges under consideration that indicate what interests are served (or in many cases left unprotected) by the interaction of traditional justice mechanisms as an alternative to formalised prosecutions. These factors would include: ensuring accountability for those perpetrators whose prosecution is deemed essential, promoting truth-telling and contributing to the historical record of wrongdoing, facilitating reparations and providing available redress for victims of international crimes and human rights violations and facilitating reconciliation within the affected communities and in the situation state more generally.

These written determinations could go a long way towards dispelling arguments that the ICC prosecutor's decisions hinge on an inappropriately politicised rationale, personal vendetta or other inappropriate factors. Lastly, a new deliberative policy with designated criteria could well serve to provide specific legal rationale for the declination of prosecutorial action. This demonstration of the 'interests of justice' might well have a beneficial effect on traditional processes, and would at a minimum strengthen the triadic relationship between the ICC, domestic authorities and local actors as one based on transparency, mutual respect and comity.

\section{Closer cultural coordination}

A revised prosecutor's policy should clearly establish coordination mechanisms for feedback and consultation with both domestic justice officials and community leaders. This would be achieved through the designation of a formal point of contact and clear timelines for communication within the policy. A formal process of consultations is vital to ensure mutual understanding. Nor should linguistic difficulties be overlooked: in Uganda, for instance, the concepts of 'amnesty', 'forgiveness', 'reconciliation' and cessation of criminal punishments are not conceptually distinct in the Lwo language. ${ }^{49}$ Similarly, loose dialogue of

49 Tim Allen offers the example of the word timo-kica, which means reconciliation/doing forgiving, but is often used by people who are simultaneously enthusiastic for 
'forgiveness' may also mean different things to different communities; therefore, communication between the ICC and affected communities should be strong and constant. Finally, Court representatives must have absolute granularity regarding the circumstances of each particular perpetrator and the related but distinct goals of reconciliation or atonement at the individual and the collective levels.

In practice, culturally sensitive communication accompanied by a clear set of guidelines can help focus investigative efforts in ways that serve the 'interests of justice'. The traditional models of justice in Afghanistan seek restitution rather than retribution, 'compensation for the wrong done and social reconciliation, not the punishment of the perpetrator. ${ }^{50}$ Yet formalised prosecutions may well be needed to achieve those purposes. The phrase 'after full accountability' is also used in the Juba Accords in the definitions of all the traditional mechanisms, but there is no correlative explanation of the interaction of those terms. Hence, formalised prosecutions might well be appropriate for perpetrators who participate in traditional systems involuntarily, who do not follow through on promised restitution or whose expression of remorse was demonstrably insincere. Similarly, traditional processes that do not serve inter-communal interests or lasting social cohesion should be entitled to less deference. If a traditional process fails to adequately address inter-communal gaps, then the overlay of actual prosecution might well transcend the communal divide. These often countervailing interests must be carefully balanced in practice through clear and consistent communications channels.

\section{Addressing amnesty}

The role of amnesties in the context of situation states remains controversial because even selective grants of amnesty have the potential to (re)ignite a false dichotomy between peace and justice. Some large-scale, so-called blanket, amnesties have been implicitly accepted as a matter of state practice. ${ }^{51}$ There is scant empirical support for the proposition that amnesty for the class of crimes within the jurisdiction of the Rome Statute will predictably lead to a culture of impunity that incentivises

prosecutions and punishments. T. Allen, Trial Justice: The International Criminal Court and the Lord's Resistance Army (London: Zed Books, 2006), 13.

${ }^{50}$ Barfield et al., 'The Clash of Two Goods', 167.

${ }^{51}$ L. Mallinder, Amnesty, Human Rights and Political Transitions: Bridging the Peace and Justice Divide (Portland: Hart Publishing, 2008). 
violence. $^{52}$ The suggestion of the Special Court for Sierra Leone that a domestic amnesty is prohibited as a matter of customary international law and can never have preclusive effect is at best unsupported, and at worst corrosive, to the harmonised system of cooperative synergy that provides the conceptual model underlying the Rome Statute. ${ }^{53}$ One scholar has thus concluded that the combination of amnesty with some form of broader truth-seeking 'largely defines state practice - massively and pervasively, throughout the world'. ${ }^{54}$ Indeed, in Afghanistan, as in other conflict settings, discussion of the appropriate role for amnesties, and the conditions precedent for achieving a lasting peace have been a persistent thread over the past decade of conflict.

The current OTP Article 53 policy provides no guidance over the circumstances in which the authority of the ICC might be secondary to an ongoing domestic amnesty process. It is also conceptually possible that ICC prosecution might in certain circumstances be entirely appropriate to supersede domestic amnesty in suitable circumstances. While the premise that the Court may assert jurisdiction even in the face of a domestic amnesty (as warranted by the particular circumstances of a particular perpetrator) is incontrovertible, a revised policy could nevertheless contribute to a consistent set of criteria for assessing when the 'interests of justice' warrant supranational prosecution. Factors that should provide guidance with respect to the relationship between domestic amnesties and the circumstances of a particular perpetrator might include:

- Whether the perpetrator has complied with any conditions attached to the amnesty, such as restitution or active efforts to eliminate intracommunity tensions;

- Whether there is any other state that could exercise criminal jurisdiction over a particular subset of the offences otherwise subject to amnesty;

52 L. Sadat, 'Exile, Amnesty, and International Law', Notre Dame Law Review, 81 (2006), 955, 966.

53 Decision on Challenge to Jurisdiction: Lomé Accord Amnesty, Prosecutor v. Morris Kallon, SCSL-2004-15-AR72(E), and Prosecutor v. Brima Bazzy Kamara, SCSL-200416-AR72(E), Appeals Chamber, SCSL, 13 March 2004. The decision notes that states are free to grant amnesties to be governed exclusively by domestic law that have no binding effect on institutions governed by international law.

${ }^{54}$ Conversely, amnesty itself provides no obvious path towards reintegration or reconciliation. Some recipients of amnesty can also become a visceral focal point within a community, one that reminds citizens of the past and serves to re-victimize others. Osiel, Making Sense of Mass Atrocities, 233. 
- Whether the amnesty itself was a central imperative to ending hostilities or a self-serving afterthought;

- Whether a perpetrator holding amnesty from domestic prosecution has nevertheless become a focal point of tension within a community or is re-victimising civilians;

- Whether the amnesty operates in tandem with other accountability measures, such as truth-telling or traditional community processes;

- Whether the amnesty was enacted through democratic procedures and lengthy debates, or imposed by authoritarian decree; ${ }^{55}$ and

- Whether prosecution in the domestic state might be permitted by the terms of the amnesty, but foreclosed by other aspects of the domestic criminal procedure.

\section{Adding reciprocal rights to Articles 53 and 93}

Despite its complexity, the Rome Statute nowhere specifies a regime for requiring a harmonisation between the investigative and prosecutorial efforts of the ICC and those of domestic states. The OTP is obligated to notify 'all States Parties and those States which, taking into account the information available, would normally exercise jurisdiction' prior to proceeding with a proprio motu investigation. This obligation is subject to limitation based on the needs of confidentiality and the preservation of evidence, but is notably not accompanied by any obligation to assist a state that is both willing and able to prosecute or investigate a perpetrator. There is no correlative process accompanying notification for actually providing assistance to those states that are willing and able to initiate investigations and prosecutions, where appropriate, using the applicable domestic procedures. In addition, neither the prosecutor nor the Pre-Trial Chamber is obligated to consult with state or local officials when considering whether to suspend investigation or decline prosecution based on the interests of justice.

This gap in the Rome Statute structure creates a one-sided scheme whereby states parties must comply with their obligations to cooperate but the Court need not reciprocate. This gap is especially prominent in the context of Article 53, in which the process of ascertaining the interests of justice' should always involve a collaborative discourse. Simply put, the use of traditional or customary mechanisms that might well serve

55 C.P. Trumbull IV, 'Giving Amnesties a Second Chance', Berkeley Journal of International Law, 25 (2007), 283, 320. 
to sustain the conditions of a lasting peace need not be facilitated by the Court. The Statute therefore creates an imbalance that, at best, undermines the rights of states to exercise complementarity, and at worst creates barriers to the effective and efficient use of domestic forums that are capable of assisting the efforts of the Court to create a comprehensive system of criminal accountability. To effectuate a productive collaboration, Article 93 (10)(a) should be amended to impose an affirmative duty on the Court, such that:

The Court shall, upon request, cooperate with and provide assistance to a state party conducting an investigation into or trial in respect of conduct which constitutes a crime within the jurisdiction of the Court or which constitutes a serious crime under the national law of the requesting state.

In addition, Article 54 (3)(c) should permit the prosecutor to interface with community leaders and organisations in making the interests of justice' assessment and should be amended to read as follows: 'Seek the cooperation of any State, local, or intergovernmental organization or arrangement in accordance with its respective competence and/or mandate; in particular when analysing whether there are substantial reasons to believe that an investigation would not serve the interests of justice within the meaning of Article 53. ${ }^{56}$

These basic changes, while textually minimal, would signal a profound shift of the Court's current approach towards domestic states and local communities. They would better harmonise communication between states parties and the ICC, specifically regarding investigations. Amending Article 93 would help foster a climate of trust and cooperation between states and the Court. These amendments balance the operational aspects of a viable complementarity regime by providing for the sharing of information in both ICC and domestic investigations. Conversely, Article 53 (3) should add a textual basis for affected states, victim groups and community leaders to provide informed input to the OTP in its assessment of the 'interests of justice'. Improving the constructive dynamic between the Court, domestic prosecutors and local leaders would help to harmonise decision-making with respect to each perpetrator under the specific circumstances of each charge.

56 Proposed additions indicated in italics. 


\section{Conclusion}

The pursuit of 'justice' is socially and politically complex. The decade plus of practice since the entry into force of the Rome Statute reveals that the Court's institutional role will be contested by families, communities and victims affected by conflict. Just as the nature of the relationship between the state and the supranational court is evolving, the balance among prosecutions, reintegration, forgiveness, reparations, truth-telling and apology is itself a delicate process, often in flux. Although the complementarity regime focuses exclusively on formalised processes in allocating power between the ICC and situation states, the external interference of the Court may well be a controversial and complex aspect of 'justice' from the perspective of victims and community leaders. Furthermore, to ameliorate what will be a recurring problem as it begins its second decade of operation, the ICC needs to develop a consistent and analytically defensible framework for understanding community-based mechanisms in light of the 'interests of justice' analysis permitted under Article 53.

If the ICC ploughs new jurisprudential pathways by imposing its determinations on domestic systems in a manner that undermines local preferences and overrides local conceptions of the rule of law, it will continue to be subject to charges of legal neo-colonialism in violation of its own central tenets. These are not idle fears. Early in its existence, the Court has already been presented with an array of complexities and challenges that underscore its inability to serve as the sole forum for 'international justice'. The Court's long-term viability thus depends upon sustaining a cooperative synergy with domestic jurisdictions, both states parties and other states, which leads to a sense that the Court and local jurisdictions share a common objective. What I term a 'cooperative synergy' entails a well-crafted and consciously implemented approach to incorporating local perspectives in the pursuit of international criminal accountability. 


\section{P A R T I I}

\section{Reception and contestation}




\title{
In the shadow of Kwoyelo's trial
}

\author{
The ICC and complementarity in Uganda
}

\author{
STEPHEN OOLA
}

\section{Introduction}

The coming into force of the International Criminal Court (ICC) opened new possibilities for the promise of a global justice institution and, with it, a new lexicon of 'complementarity.' 'Broadly defined, 'complementarity' means that the ICC should be a court of last resort: it intervenes where a responsible state is either unwilling or unable to investigate and prosecute crimes of war, genocide and crimes against humanity committed within its jurisdiction. ${ }^{2}$ In a strictly legal sense, complementarity operates as a principle of admissibility, limiting the situations and cases that may appear before the ICC. ${ }^{3}$ In practice, however, and in the name of complementarity, the ICC has become an international crimes policeman: a key player in many conflicts, post-conflicts and transitional contexts where serious international crimes are suspected, especially within Africa.

Indeed, complementarity, or 'positive' complementarity as it is often called, has been broadly interpreted to mean all manner of productive developments attributable to The Hague-based Court: catalysing judicial norms, legal trainings, local trials, outreach initiatives, legal reforms, peace agreements and even regime change. ${ }^{4}$ Yet the ICC and its

${ }^{1}$ Even though the concept of complementarity is as old as international law and international human rights systems, it was not until the ICC's establishment that the term became more commonly used. See M. El Zeidy, The Principle of Complementarity in International Criminal Law: Origin, Development and Practice (Leiden: Martinus Nijhoff Publishers, 2008).

${ }^{2}$ See C.M. Bassiouni, The Statute of the International Criminal Court: A Documentary History (Ardsley: Transnational Publishers, 1998), 793; 'Delivering on the Promise of a Fair, Effective and Independent Court', Coalition for the International Criminal Court.

3 S.M.H. Nouwen, Complementarity in the Line of Fire (Cambridge: Cambridge University Press, 2013).

${ }^{4}$ See 'Report of the International Criminal Court to the UN General Assembly', A/60/1771, August 2005. 
proponents in different situations provide little recourse or accountability where its interventions, ostensibly made in the name of impartiality, have the practical effect of condoning impunity. ${ }^{5}$ This may happen either indirectly or directly, when complementary gets hijacked in the service of other objectives, or when it undermines other forms of much-needed social and political accountability. ${ }^{6}$

This chapter discusses problematic aspects of complementarity within the context of Uganda. Drawing upon my extensive experience working for the Refugee Law Project (RLP), a civil society organisation with a long-term presence in northern Uganda, and my role as a member of the defence team for Thomas Kwoyelo, the first defendant brought before Uganda's domestic war crimes court, I consider in this chapter some of the domestic effects of the ICC's intervention. ${ }^{7}$ This chapter places the ICC's intervention in the broader context of an over two-decade-long civil war between the Lord's Resistance Army (LRA) and the Ugandan government in order to consider its impact on subsequent political solutions and domestic transitional justice processes. ${ }^{8}$ Furthermore, by examining Uganda's first domestic war crimes trial, which has been hailed by many ICC advocates and international donors as an example of the positive impact of complementarity, the chapter explores how states and interest groups can marshal, or even hijack, international and domestic accountability processes, while in fact perpetuating other forms of impunity. ${ }^{9}$

The chapter ultimately argues that understanding the broader implications of the Court's work requires viewing it in relation to domestic transitional initiatives, political factors and the work of other actors in the

5 See, e.g., A. Branch, Displacing Human Rights: War and Intervention in Northern Uganda (Oxford: Oxford University Press, 2011).

${ }^{6}$ See, e.g., S.M.H. Nouwen and W.G. Werner, 'Doing Justice to the Political: The International Criminal Court in Uganda and Sudan', European Journal of International Law, 21 (2011), 952.

7 The Refugee Law Project (RLP) is an outreach project of the School of Law, Makerere University, Kampala. Established in 1999, RLP has over the years grown to become the leading centre for justice and forced migrants in the region with cross-cutting interventions working with refugees, asylum seekers, internally displaced persons and conflictaffected communities in the pursuit of durable solutions, peace, justice, healing and reconciliation through research, documentation, accountability, memory and memorialisation initiatives.

${ }^{8}$ See N. Waddell and P. Clark (eds.), Courting Conflict? Justice, Peace and the ICC in Africa (London: African Royal Society, 2008).

9 On the notion of 'hijacked justice', see J. Subotic, Hijacked Justice: Dealing with the Past in the Balkans (Ithaca, NY: Cornell University Press, 2009). 
Ugandan context. In so doing, it first offers a broad historical background for understanding the ICC's impact in Uganda, including the place of amnesty in the country's approach to transitional justice and the Juba peace process. The chapter then considers the trial of Kwoyelo in greater detail, before reflecting on its broader effects on Uganda's transitional justice discourse and the influence of the ICC in that regard. My intention here is not to discredit the ICC as an institution, but rather to contribute to its development by exposing what were, in my view, mistakes the Court has made in Uganda, in the hope of influencing future investigations and prosecutorial strategies.

\section{The ICC in Uganda}

Uganda was amongst the first African countries to ratify the Rome Statute. In 2003 it also became the first country to come before the ICC when President Yoweri Museveni referred the situation concerning the LRA to the Court (later renamed the 'situation in northern Uganda'), arguing that because the LRA was operating mainly from Sudan, Uganda lacked the ability to arrest and prosecute the perpetrators, even though the state itself appeared to be able and willing. As it turned out later, there is in fact evidence that the then prosecutor, Luis Moreno-Ocampo, had earlier requested Uganda to refer the situation in the north to the Court. ${ }^{10}$ This was followed by several discussions within Uganda and with ICC officials on what such a referral would mean in practice.

Prior to the referral, a key concern to the government was the role of its soldiers in the atrocities committed, including its failure to protect children and civilians abducted by the LRA and the creation of camps for internally displaced persons as a military strategy, an act prohibited under international law. ${ }^{11}$ As has been well documented, these camps almost decimated the Acholi ethnic group, from which Joseph Kony, the LRA leader, hailed, and within whose territory the war was fought longest and in its most brutal form. ${ }^{12}$

${ }^{10}$ See P. Clark, 'Chasing Cases: The ICC and the Politics of State Referral in the Democratic Republic of Congo and Uganda', in C. Stahn and M. El Zeidy (eds.), The International Criminal Court and Complementarity: From Theory to Practice (Cambridge: Cambridge University Press, 2010).

11 See 'Behind the Violence: Causes, Consequences and the Search for Solutions to the War in Northern Uganda', Refugee Law Project Working Paper No. 11 (March 2004) (RLP, 'Behind the Violence').

12 See C. Dolan, Social Torture: The Case of Northern Uganda 1986-2006 (New York: Berghahn Books, 2009). 
The circumstances of the ICC's referral resulted in political consequences bearing upon who would be investigated and subjected to arrest warrants. Even before investigations were conducted, it was clear that only a few key perpetrators would be sought by the ICC, and that state actors within Uganda may never find themselves before the Court for their own role in the atrocities that were committed. ${ }^{13}$

In July 2004, the ICC prosecutor launched formal investigations. The OTP soon found evidence of war crimes and crimes against humanity committed by the LRA, and in October 2005, the Court unsealed warrants of arrest against five top LRA commanders for war crimes and crimes against humanity: Joseph Kony, Vincent Otti, Okot Odhiambo, Raska Lukwiya and Dominic Ongwen, the latter of whom was apprehended and surrendered to the ICC in early $2015 .{ }^{14}$ During its investigations, the OTP was accused of turning a blind eye to atrocities committed by government forces. ${ }^{15}$ In fact, ICC investigators were accompanied by state agents on their missions, including operatives of the Chieftaincy of Military Intelligence, a special investigative unit of the Uganda People's Defence Force (UPDF), known for its high-handed methods of 'investigation', including torturing suspects and holding them in 'safe houses'. ${ }^{16}$

From the beginning, the Court's intervention faced opposition from victims groups, conflict-affected communities and much of Ugandan civil society, with the notable exceptions of victims directly supported by the ICC Trust Fund for Victims and NGOs funded by pro-ICC donors. The unsealing of the arrest warrants caused particular controversy as they came amidst promising peace talks between the Ugandan government and the LRA, under the mediation of the former vice president of South Sudan, Dr Riek Macher. The timing of the ICC's intervention thus drew criticism and re-ignited the long-standing 'peace versus justice' debate, as well as contention over the meaning of complementarity. ${ }^{17}$

${ }^{13}$ See Nouwen and Werner, 'Doing Justice to the Political'.

${ }^{14}$ Ongwen's confirmation of charges hearing before the ICC has been postponed until January 2016.

15 'Ambiguous Impacts: The effects of the International Criminal Court investigations in northern Uganda', RLP Working Paper No. 22 (October 2012).

16 US Department of State Report on Uganda Human Rights Record, available at www.state. gov/documents/organization/160149.pdf.

17 See S. Oola, 'Bashir and the ICC: The Aura or Audition of International Justice in Africa', Oxford Transitional Justice Research Network Working Paper (2008) (Oola, 'Bashir and the ICC'). 
This debate, which centred on how to foster legal accountability for crimes without further escalating the costs of war, was unfortunately portrayed as a contest between Western conceptions of punitive justice versus African understandings of restorative justice. As an organisation, RLP sought to decry the simplistic manner in which many Western academics and practitioners were framing the issue. ${ }^{18}$ Some commentators viewed the Ugandan situation rather simplistically, as a contest between amnesty and justice, yet, such a view neglects the fact that 'justice' is a highly contextual norm; depending on how it is perceived, amnesty could in fact be the form of justice sought by conflict-affected communities in situations like northern Uganda, a conflict characterised by mass abductions, lack of civilian protection and an attendant humanitarian catastrophe. ${ }^{19}$ As the following section illustrates, the conflict between the LRA and the Ugandan government involved the commission of atrocities on both sides, whereas the ICC's intervention has, to date, furthered a narrow and one-sided interpretation of the conflict.

\section{The LRA conflict}

The LRA is a rebel group that has fought the government of President Museveni since he captured power in $1986 .^{20}$ Spanning twenty-nine years, the group operated largely in northern Uganda (Acholi and Lango sub-regions) until 2006, when it crossed briefly into Teso subregion $^{21}$ in 2003 following 'Operation Iron Fist'. ${ }^{22}$ To date, the LRA continues to abduct children and displace civilians in some parts of the Central African Republic (CAR), Democratic Republic of Congo (DRC), and occasionally South Sudan. ${ }^{23}$ Alleged members of the LRA are

18 See M.C. Okello, 'The False Polarisation of Peace and Justice in Uganda, International Conference: Building a Future on Peace and Justice', Expert Paper Workshop 2 (Nuremberg, 25-27 June 2007).

19 See 'Peace First, Justice Later', RLP Working Paper No. 17 (2006).

${ }^{20}$ To understand the root causes and the context of the LRA insurgency and Uganda's political crisis see RLP, 'Behind the Violence'.

${ }^{21}$ See 'The Day they Came: Recounting the LRA Invasion of Teso Sub-Region through Obalanga Sub-County in 2003', JRP Field Note (September 2012).

22 Launched on 18 December 2008, Operation Iron Fist was a code name to the joint surprise attacks against the LRA bases in Garamba, launched by the Uganda Peoples Defence Forces, Sudanese Peoples Liberation Army and the forces of the Democratic Republic of Congo following Joseph Kony and the LRA's refusal to sign the Final Juba Peace Agreement.

${ }^{23}$ See L. Cakaj, 'The Lord's Resistance Army of Today', Enough Project Report (2010). 
accused of committing serious crimes including widespread abductions, mass killings, arson, forceful enslavement and mutilations.

In fighting the LRA, however, the government's counter-insurgency strategy resulted in over 1.8 million civilians being moved into squalid camps for internally displaced persons (IDPs), with barely any protection provided against the LRA's ongoing insurgency. ${ }^{24}$ This has had catastrophic effects on the culture and morale of the people and created one of the world's worst humanitarian situations. Indeed, it is estimated that more people died as a result of the unbearable conditions living in IDP camps than from direct-armed violence. ${ }^{25}$ For the LRA, the IDP camps became a one-stop abduction point: to replenish its fighting forces, it simply raided one of the (un)protected camps. $^{26}$

There is still no official inquiry or acknowledgement of the cost in terms of human lives; however, estimates are well over one million deaths and between 30,000 to 66,000 abductees, approximately half of whom were under the age of $18,{ }^{27}$ and less than half of whom have returned or been accounted for ${ }^{28}$ Moreover, the UPDF, which was mandated to protect Ugandan civilians, sometimes turned its guns on them on suspicion of collaborating with 'the enemy'. ${ }^{29}$ The UPDF raided people's cattle, raped women, destroyed properties and tortured thousands during its counter-insurgency operations. Several hundreds of civilians were caught in the crossfire and many lives were lost in places like Alero, Awach, Mukura, Namukora ${ }^{30}$ and Buu Coro. ${ }^{31}$

Conflict-affected communities therefore apportion responsibility to both the LRA and the UPDF for atrocities committed. A 2007 survey on victims' perceptions of justice and accountability following the conflict found that a majority of respondents blamed the government and demanded accountability for both the LRA and the UPDF in equal

24 See Branch, Displacing Human Rights; RLP, 'Behind the Violence'.

25 See Dolan, Social Torture: The Case of Northern Uganda. ${ }^{26}$ Ibid.

27 'The Dust Has Not Yet Settled: Victims' Views on the Right to Remedy and Reparation A Report from the Greater North of Uganda', Uganda Human Rights Commission and United Nations Office of the High Commissioner for Human Rights (2011).

28 See 'Uprooted and Forgotten: Impunity and Human Rights Abuses in Northern Uganda', Human Rights Watch, 17:12 (September 2005).

29 See 'Uganda: Army and Rebels Commit Atrocities in the North: ICC must investigate Abuses on Both Sides', Human Rights Watch (September 2005).

30 See 'Occupation and Carnage: Recounting Atrocities Committed by the NRA's $35^{\text {th }}$ Battalion in Namukora Sub-County in August 1986’, JRP Field Notes (2014).

31 Ibid. 
measure. $^{32}$ The government was also accused of contributing to the length of the war, through aiding and abetting its continuation for political and economic motives. Politically, the war was important to destroy National Resistance Army/Movement (NRM) ${ }^{33}$ opposition from the north, consolidate the government's power bases in the west and other parts of the country and destroy what Museveni called the Acholi's chauvinisms. The government further used the conflict as an excuse to bloat the army's budget and avoid scrutiny. Indeed, it received large sums of money and military support from the international community to fight the war; as a result, it had little interest in ending it. ${ }^{34}$ At the height of the war, the army payrolls were filled with ghost soldiers and their salaries were diverted. ${ }^{35}$

\section{A legacy of violence}

Beyond the LRA, Uganda has also endured years of conflict and gross human rights violations dating back to colonial times, pre-independence struggles and certainly the better half of the years since attaining political independence. ${ }^{36}$ The country remains highly divided, with a weak sense of national identity, low solidarity amongst local constituencies, a lack of information and transparency about historical events and little accountability for past wrongdoing. Previous attempts yielded little, including two commissions of enquiries in the early 1970s and 1980s. The work of both commissions was hampered by numerous challenges, and their recommendations were seldom implemented.

Furthermore, the Ugandan state is characteristically oppressive, corrupt, nepotistic and intolerant to alternative groups and dissenting opinions. ${ }^{37}$ In the past fifty years, eight different presidents have ruled

32 See 'When the War Ends: A Population Based Survey on Attitudes about Peace, Justice and Social Reconstruction in Northern Uganda', Human Rights Centre and ICTJ (December 2007).

33 The NRM is a political wing of the National Resistance Army led predominantly by Banyakole, Bakiga and Buganda politicians led by Museveni and built around removing President Obote and northerners from power.

${ }^{34}$ See 'Northern Uganda: Understanding and Solving the Conflict', International Crisis Group African Report No. 77 (April 2004).

35 See O.C. Bichachi, 'From Ghost Soldiers to Ghost Investors', The Observer, 4 May 2012.

${ }^{36}$ See T.P. Ofcansky, Uganda: Tarnished Pearl of Africa (Boulder, CO: Westview Press, 1996).

37 See, e.g., A.M. Tripp, Museveni's Uganda: Paradoxes of Power in a Hybrid Regime (Boulder, CO: Lynne Rienner Publishers, 2010). 
Uganda and the country has yet to witness a peaceful transfer of power from one to another. The legacy of these episodes of coups and associated violence is a country deeply divided along ethnic lines, in which one's ethnicity inherently defines one's access to power, sense of belonging and opportunities in life. As a result, large sections of the population feel permanently victimised and marginalised. ${ }^{38}$

Sadly, however, the ongoing transitional justice debate within Uganda remains largely premised on the LRA violations and focused on 'complementing' international responses, as opposed to addressing the country's broader conflict legacies. ${ }^{39}$ RLP's efforts to map and document the key transitional justice issues in Uganda from the perspective of victims and affected communities - as part of a national reconciliation and transitional justice 'audit' - documented over forty-four armed conflicts and more than 125 other violent conflicts in Uganda. ${ }^{40}$ These conflicts have affected different parts of the country and, if they remain unaddressed, will continue to have negative impacts on the future. The majority of these grievances fall outside the jurisdiction of the ICC and cannot be addressed by courts, yet no effort is being made to address them in the current national discourse.

The RLP's National Reconciliation and Transitional Justice Audit also revealed that, when it comes to dealing with legacies of violence, 'expertise' resides in every corner of the country. This means that rather than a top-down approach, 'positive complementarity' should require international justice systems to learn from local actors and mechanisms. As

38 See F. Golooba-Mutebi, 'Collapse, War and Reconstruction in Uganda: An Analytical Narrative on State-Making', Makerere Institute of Social Research Working Paper No. 27 (Development as State-Making) (January 2008).

39 See S. Oola, 'The Coalition for Reconciliation in Uganda: Important Lessons for Proactive Civil Society Engagement in Catalysing Transitional Justice Discourse', Paper presented at the ATJRN Workshop on Advocating Justice: Civil Society and Transitional Justice in Africa (30-31 August 2010).

40 The National Reconciliation and Transitional Justice Audit was a two-year research to document and map conflicts and their legacies from a community perspective in different parts of Uganda. It was conducted by the Refugee Law Project from 2011 to 2012 to document from a community perspective all post-independence and post-1986 conflicts in Uganda (that they were aware of) and to identify and assess what outstanding reconciliation and transitional justice needs were related to each of these conflicts. The audit also aimed to reflect on the merits of possible mechanisms and processes to address these needs. It included sixty-five focus group discussions and over eighty key informant interviews in twenty traditional districts of Uganda, equally distributed in all regions of the country. It is the most comprehensive and in-depth study of Uganda's transitional justice issues and needs; its findings will be presented in a forthcoming volume. See www. beyondjuba.org/NRTJA/index.php for more information. 
Chris Dolan has observed, 'When it comes to understanding the structural underpinnings of violence, ordinary citizens are the match of international experts, and when it comes to connecting the dots between poverty, violence and the form that justice needs to take if it is to deliver sustainable peace, they readily outstrip the mainstream policy debate. ${ }^{31}$ With complementarity in Uganda, however, it is the reverse: complementarity has been (mis)understood as copying international standards and practices and pasting them into the Ugandan context.

As a result, international 'experts' with limited in-country experience have replaced local chiefs in the 'traditional justice component' of the transitional justice policy debate. Moreover, as discussed further below, these 'experts' were appointed, seconded or compensated by pro-ICC donors to advise the Ugandan government's transitional justice processes in order to promote complementarity, a practice first developed during the peace talks in Juba, and which ultimately contributed to their failure.

\section{The Juba peace process}

In 2006, the LRA and the government again entered into peace negotiations in Juba, this time with much brighter prospects following the signing of the Comprehensive Peace Agreement in Sudan and the establishment of a semi-autonomous government in the south. ${ }^{42}$ With ICC arrest warrants hanging over the top leadership of the LRA, complementarity soon took centre stage in the process. Fearing that the Court's warrants might pose a major obstacle to the talks, the Acholi Religious Leaders Peace Initiative - joined by RLP, other civil society organisations, victims groups and local leaders from the war-affected sub-regions appealed to the ICC to suspend its warrants for at least one year to facilitate the talks. The Ugandan government also requested the ICC to defer the LRA warrants to enable it to handle the matter domestically, as it saw a peace dividend resulting from the LRA's withdrawal from northern Uganda into southern Sudan's border with the DRC. ${ }^{43}$

The ICC prosecutor rejected the request, however, given the importance of the cases to the Court, but also because the international attention focused on the peace process likely gave it a platform for establishing

${ }^{41}$ See C. Dolan, 'Foreword to the Compendium of Conflicts in Uganda 1960-2012' (2015).

${ }^{42}$ See 'Northern Uganda: Seizing the Opportunity for Peace', International Crisis Group Africa Report No. 124 (26 April 2007).

${ }^{43}$ See F. Ahimbisibwe and P. Jaramogi, 'Uganda to appeal to ICC for LRA leaders', New Vision, 30 August 2006. 
its international reputation as a mechanism of 'global justice'. Seizing the opportunity, Prosecutor Moreno-Ocampo repeatedly made public statements dismissing the requests for withdrawal, and reminding the Ugandan government of its commitment to cooperation by arresting and handing over the LRA leaders.

This contemptuous attitude continued throughout the peace talks, often drawing anger from conflict-affected communities and local leaders. Many domestic actors regarded the Court as a 'peace spoiler'. Norbert Mao, the Gulu district chairman at the time, repeatedly criticised the ICC's indifference to the plights of the IDPs, and appearing at a local radio station one morning, he publicly announced the vehicle number plate of an ICC outreach vehicle in Uganda. ${ }^{44}$ Coupled with limited outreach and knowledge of the ICC, the local communities in LRAaffected areas initially thought the Court was just a single man: Luis Moreno-Ocampo. Indeed, a story is told of how, when the ICC outreach office in Uganda went for a meeting in a remote part of Gulu (now Amuru District), an old man carrying an axe stormed the meeting asking, 'Where is this ICC man stopping our abducted children from coming home?' He was wrestled down by local authorities and security agents and calmed down after learning that the ICC was, in fact, a Court and that these were just its Uganda-based employees who were trying to educate people about its work. Such hostilities towards the Court continued throughout the peace process.

Nevertheless, the peace talks continued and all of the agreed agenda items for discussion were ultimately passed: cessation of hostilities; comprehensive solutions to the conflict; accountability and reconciliation; and permanent ceasefire and disarmament, demobilisation and reintegration. While the first two agenda items were quickly agreed upon, observers predicted that the third agenda item - accountability and reconciliation - would be the key sticking point. Many feared that the LRA would not accept any form of criminal sanctions, which was understood to be mandatory for the ICC complementarity test to be satisfied.

In fact, there was a legal amnesty in place within Uganda since 2000, which all LRA combatants were entitled to upon renouncing rebellion against the government. But a few legal experts advising the Juba process (and paid by Western governments financing the talks) were tasked with crafting a 'complementary' domestic transitional justice framework

44 See Oola, 'Bashir and the ICC'. 
acceptable to both the ICC and the LRA. To many people's surprise, the accountability and reconciliation agenda was quickly discussed and concluded, embracing a range of formal and non-formal accountability and reconciliation measures. According to Haruna Ndema, a peace delegate who represented the LRA in Juba, when the draft text of the principal agreement was presented to Kony and Otti, they both welcomed it and demanded that any domestic trial process should be credible, and should involve both LRA and government forces. ${ }^{45}$

In the principal accountability and reconciliation agreement, both parties acknowledged for the first time that they had committed atrocities in the course of the conflict. The LRA demanded accountability and reconciliation, but the government rejected this position on the basis that the LRA was entitled to amnesty and the UPDF had its own 'accountability system' laid out in the country's domestic military code. Contrary to many predictions, this became the sticking point in Juba: whether the UPDF and other state actors should be subjected to the special accountability measures envisaged under the draft agreement.

After protracted negotiations, the parties signed the Agreement on Accountability and Reconciliation (AAR) in June 2007. It provided, in part, that, 'Formal criminal and civil justice measures shall be applied to any individual who is alleged to have committed serious crimes or human rights violations in the course of the conflict. Provided that, state actors shall be subjected to existing criminal justice processes and not to special justice processes under this Agreement. ${ }^{46}$ It also added that traditional justice principles shall constitute a central pillar in all formal and informal justice processes. ${ }^{47}$ After the signing, both delegations embarked on a countrywide consultation to seek Ugandans' views on how to implement the AAR. The views expressed countrywide, and in particular by the affected communities, demanded comprehensive reparations, establishment of a national truth-seeking and reconciliation mechanism and, where needed, accountability by both state and non-state actors through specially established justice mechanisms. ${ }^{48}$

When talks resumed in Juba, an implementation agreement set out a comprehensive transitional justice framework for Uganda providing for the establishment of a number of mechanisms, including a body to conduct proper truth-seeking and promote truth-telling and memorialisation;

45 Author's interview with Haruna Ndema (Arua Town, 15 April 2014).

46 Agreement on Accountability and Reconciliation between the Government of Uganda and the Lord's Resistance Army, signed 29 July 2007, para. 4.1.

47 Ibid. ${ }^{48}$ Dr R. Marchar, 'Final Report of the Chief Mediator to the LRA' (2008). 
a special division of the High Court of Uganda to try individuals alleged to have committed serious crimes during the conflict; and a unit for carrying out investigations and prosecutions in support of the trials and other formal proceedings. It also determined that necessary arrangements should be made for providing reparations to victims of the conflict, and it determined that traditional justice should form a central part of the AAR framework. $^{49}$

The Juba agreements thus provided a wide-ranging template for postconflict transitional justice that was more comprehensive than subsequent initiatives. Nevertheless, the government delegates, with instruction from Kampala, rejected any attempt to subject the UPDF to accountability, including the proposed special division of the High Court. The LRA was also given the impression at the talks that, upon signing the AAR, the ICC would be persuaded to drop its charges or suspend its arrest warrants. As a result, the LRA demanded the withdrawal of the warrants before signing the Final Peace Agreement (FPA).

Ultimately, fearing a fate not unlike that of former Liberian president Charles Taylor, the LRA leaders shunned the signing ceremony and postponed it several times without appearing. Shortly thereafter, on 14 December 2008, the government of Uganda launched coordinated military strikes (dubbed Operation 'Lightning Thunder') against LRA assembly points, which it carried out with intelligence gathered during the peace talks and with the backing of some Western observers. The LRA eluded the strikes and scattered into southern Sudan and the CAR, where it continues to operate as of the time of writing.

\section{Establishment of the War Crimes/International Crimes Division}

The FPA provided that, 'A Special Division of the High Court of Uganda shall be established to try individuals who are alleged to have committed serious crimes during the conflict. ${ }^{50}$ The Principal Judge of Uganda's High Court accordingly (and quickly) established a War Crimes Division (later renamed the International Crimes Division or ICD) of the High Court of Uganda in July 2008. Four judges were immediately appointed to the WCD with support staff trained on international 'best practices'. Following the WCD's establishment, the

49 The Annexure to the Agreement on Accountability and Reconciliation was signed on 19 February 2008, following extensive national consultations within Uganda.

${ }^{50}$ Ibid. 
Ugandan Parliament passed - on the eve of the 2010 Kampala Conference - the International Criminal Court Act (ICC Act) to domesticate the Rome Statute, and to provide for full cooperation with the ICC.

Notably, in order to pre-empt any attempt to defer ICC proceedings, the Court's Pre-Trial Chamber sought, proprio motu, to determine whether the creation of the domestic war crimes court would satisfy the complementarity test. While not obliged to do so in the absence of a challenge from the Ugandan state itself, the Court ruled that the Juba framework was not yet sufficient to satisfy the Rome Statute's requirements: 'pending the adoption of all relevant legal texts and the implementation of all practical steps', the cases remained admissible. ${ }^{51}$ This decision arguably signalled to the LRA leadership that the ICC's warrants would not be dropped or suspended, and that the domestic AAR process was unlikely to involve the UPDF or other state actors.

Although the LRA did not sign the FPA, the Ugandan government made it clear that it would fulfil its commitments and proceeded to implement the Juba agreements to the fullest extent possible. In fact, shortly before the failed signing, the government established a 15-member transitional justice technical working group within the Justice, Law and Order Sector (JLOS) in order to think through the ramifications of the peace deal. The JLOS Transitional Justice Working Group (TJWG) became a coordinating forum through which international donor support, money and influence were extended in the design and implementation of the Ugandan transitional justice agenda. While initially the RLP and the International Center for Transitional Justice, two leading transitional justice voices in the country, were invited to represent civil society at the forum, they were gradually sidelined. Instead, and again in the name of complementarity, international experts and technical assistants from abroad were preferred to support JLOS.

\section{Amnesty Act}

The practice of amnesty in Uganda is deeply rooted in cultural and religious conceptions of forgiveness and reconciliation. Before the complementarity issue was introduced, forgiveness had played an important

51 Decision on the Admissibility of the Case under Article 19(1) of the Statute, Situation in Uganda, The Prosecutor v. Joseph Kony, Vincent Otti, Okot Odhiambo, Dominic Ongwen, ICC-02/04-01/05, Pre-Trial Chamber II, ICC, 10 March 2009; see para. 52 (emphasis added). 
role in conflict resolution and the socio-political transformation of Ugandan society. After attaining independence in 1962, neither the British nor their colonial agent were held to account; they were largely 'forgiven' for their transgressions. Indeed, throughout the political turmoil that followed independence - marred as it was by violent changes of government, liberation struggles, coups and insurgencies - amnesty and forgiveness have played a central role in Uganda. Even before the LRA's insurgency, when Museveni's NRM captured power in 1986, it declared amnesty for all agents of the former regimes. In 1989, the National Resistance Council enacted an amnesty statute for all armed groups fighting the government within Uganda.

But the amnesty that emerged from the government's conflict with the LRA was unique insofar as it was the affected communities themselves, led by their religious and cultural leaders, who began to call upon the government to abandon its hard-line military approach, enact an amnesty law and negotiate with the rebels. President Museveni was initially opposed to this approach, but with international attention increasingly drawn to the worsening humanitarian situation, and with religious and cultural leaders from the Acholi mobilising victims' demonstrations, the regime conceded and tabled an amnesty bill in parliament.

The Parliament of Uganda passed the Amnesty Act in 2000. The act provided amnesty for any person or group who had been fighting the government since January 1986 and was conditional only upon their renouncing rebellion. The act was aimed at ceasing hostilities, encouraging defections and finding a peaceful resolution to the conflict. According to the Honourable Dick Nyai, a former legislator who was part of the drafting process, the act was one of the most popular enactments at the time. ${ }^{52}$ Initially, the Amnesty Act was only meant to last for six months, but it has been extended several times - most recently in 2012 - in light of its contributions to the peace process. Since its passage, well over 27,000 combatants from over twenty-eight different armed groups have renounced rebellion and benefitted from the process. Only about half of those amnestied were from the LRA.

With the ICC's intervention, however, the Amnesty Act soon came under scrutiny. The pro-ICC lobby in the country condemned the law without appreciating its uniqueness. Although there are clear conditions within the law that must be fulfilled before one can be granted amnesty,

52 Author's interview with the Hon Dick Nyai (Arua Town, 15 April 2014). 
the law was demonised as promoting impunity by providing unconditional, or 'blanket', amnesty. To receive amnesty in Uganda one must renounce rebellion and not be a second-time offender. Furthermore, a 2006 amendment provided the Minister of Internal Affairs with powers to exclude certain individuals from amnesty. ${ }^{53}$ The amendment, however, did not specify the criteria by which individuals may not be considered eligible for amnesty, nor did it make ineligibility a legal determination. Consequently, the power to declare an individual ineligible for amnesty remained at the political discretion of the minister and parliament.

Because of the popularity of the law, it is worth noting that the antiamnesty debate in Uganda has, until recently, largely been academic: the anti-amnesty group could hardly face the general population, particularly in the north of the country. ${ }^{54}$ Indeed, because of amnesty's popularity within Acholiland, most anti-amnesty consultations were conducted outside the sub-region; when Acholis were invited, representatives were carefully selected. The ICC Act also reflects this fact: even with principles that would arguably contradict some provisions of the Amnesty Act, repeal of the legislation was not even contemplated. ${ }^{55}$ Notably, however, when the Constitutional Court halted the ICD's celebrated 'complementarity' trial of former LRA colonel Thomas Kwoyelo in 2011, pro-ICC groups did attempt to dismantle the act. The following section turns to Kwoyelo's trial.

\section{The trial of Thomas Kwoyelo}

In July 2011, Colonel Thomas Kwoyelo, a former LRA fighter and child soldier who himself had been abducted, became the first war crimes suspect to face trial before Uganda's renamed ICD. ${ }^{56}$ Kwoyelo, forty

53 See Uganda Amnesty Act 2000 as amended in 2006. Under Section 2 of the Amnesty (Amendment) Act 2006 (Uganda), a person shall not be eligible for the grant of amnesty if he or she is declared not eligible by the Minister of Internal Affairs by a statutory instrument made with the approval of Parliament.

${ }^{54}$ In one such consultative workshop, jointly organised by RLP, OHCHR and UN Women in Kitgum, some of the organisers were visibly embarrassed and disappointed that the participants strongly supported the continuation of the amnesty law. In another such meeting, organised by the same partners, the title and agenda for discussions were altered in the eleventh hour without informing RLP. Similar accusations were levelled against the Uganda Law Society and Avocats San Frontiers, alleging that the published version of a consultative report was doctored to reflect lawyers' opposition to the law.

55 See International Criminal Court Act (2010).

${ }^{56}$ Kwoyelo was captured in March 2009 in Ukwa, a northeastern part of the DRC during a joint military operation and as part of 'Operation Lightning Thunder', which was launched in December 2008, following the failed Juba peace process. 
years old at the time, pleaded not guilty to the 12 initial counts of war crimes and an additional fifty-three alternative charges (included in an amended charge sheet) that alleged kidnap with intent to murder, wilful killing, attack on civilian villages and aggravated robberies under Uganda's Penal Code Act and the Geneva Conventions. ${ }^{57}$ No charge was brought under the ICC Act of 2010 because all the crimes Kwoyelo allegedly committed took place before that legislation came into force.

It was alleged that Kwoyelo 'committed his offences in the context of an international armed conflict that existed in northern Uganda, southern Sudan and north-eastern Democratic Republic of Congo between the LRA (with the support of and under the control of the government of Sudan), fighting against the government of the Republic of Uganda as by law established, between 1987 and 2008 ${ }^{58}$ According to the indictment, all attacks by the LRA - which took place in Kilak County, Amuru District, between 1987 and 2005 - were either commanded by Kwoyelo or were carried out with his full knowledge and authority. It further alleged that all property and persons were protected under the Fourth Geneva Convention and that Kwoyelo was aware of the factual circumstances that established such protected status. ${ }^{59}$ Kwoyelo's indictment also contained allegations of murdering Alfred Bongomin, a prominent pro-government operative whose murder had previously been blamed on two senior opposition politicians from northern Uganda. ${ }^{60}$

While Kwoyelo's trial is the closest Uganda has yet come to testing complementarity in terms of an actual criminal proceeding, it stalled from the beginning. His legal team raised several legal questions in the first instance, such as whether the armed conflict between the LRA and the government of Uganda qualified as an international armed conflict under the Geneva Conventions, about the alleged torture of war crimes suspects during investigations ${ }^{61}$ and about the criminal liability of a

57 See JLOS Annual Report, 72.

${ }^{58}$ Uganda v. Thomas Kwoyelo alias Latoni, HCT-00-ICD-Case No. 02/10.

${ }^{59}$ In his defence, the lead defence counsel Caleb Alaka raised a preliminary objection on a point of law; namely that Kwoyelo, as a junior commander, is entitled to amnesty, which has been granted to his senior commanders, including Brigadier Kenneth Banya and Sam Kolo. He further maintained that charging Kwoyelo under the Geneva Convention Act contravenes the 1995 Uganda Constitution and finally that the prosecution failed to disclose evidence that exonerates or mitigates Kwoyelo's culpability to his defence.

${ }^{60}$ See 'Uganda: Key Opposition Politicians Arrested', Human Rights Watch (28 April 2005).

${ }^{61}$ Kwoyelo had alleged that he was tortured and held in 'safe houses' before he was produced in court and the defence had demanded compensation for such cruel and degrading treatment. 
victim-turned perpetrator. ${ }^{62}$ The central question however - whether Kwoyelo was entitled to amnesty, and whether the Amnesty Act itself was constitutional - effectively removed Kwoyelo's case from the ICD's jurisdiction. In fact, for all the preparation and financial commitments made to the court, the ICD only had three sessions with Kwoyelo. It never had the opportunity to hear any witnesses or to interrogate the merits of the government's accusations. It only dealt with preliminary legal objections and then a request by the defence for referral to Uganda's Constitutional Court on the question of amnesty, which the ICD granted.

In November 2011, the Constitutional Court halted Kwoyelo's trial on the grounds that it was unconstitutional. ${ }^{63}$ The court ruled that Kwoyelo had applied for amnesty, which he was entitled to under the law. In a unanimous judgment, the court said that the Amnesty Act was constitutional and that Kwoyelo was entitled to its benefits. The court further held that Uganda's amnesty was unique from other amnesties given the circumstances of its enactment, and that it was not, in fact, a blanket amnesty, as it excluded state actors who committed atrocities and required applicants to renounce rebellion. The court further found that by initially refusing to grant an amnesty certificate to Kwoyelo, the Director of Public Prosecutions (DPP) had denied Kwoyelo equal treatment and protection under the law. Kwoyelo's trial was to be stopped immediately and his file returned to the ICD 'with a direction that it must cease the trial of the applicant forthwith'. ${ }^{64}$

In response, JLOS quickly issued a public statement that was critical of the Constitutional Court's decision. ${ }^{65}$ The DPP also issued a public statement rejecting the ruling and vowing not to implement the court's order. Key players in the transitional justice project in Uganda were disappointed, as it seemed that JLOS was undermining the very rule of law it was mandated to promote. As with all public matters where the president's official position is not known, different government officials were reluctant

${ }^{62}$ See Constitutional Court of Uganda, Constitutional Petition No.036/11, 22 September 2011.

${ }^{63}$ See Constitutional Court Ruling, Thomas Kwoyelo alias Latoni v. Uganda (Const. Pet. No. 036 of 2011 (reference)).

${ }^{64}$ See 'Constitutional Court Halts Kwoyelo's Trial', RLP Court Update, available at www. refugeelawproject.org/others/kwoyelo_ruling_summary.pdf.

65 An edited version of the press statement has since been modified in language and tone and published on JLOS website as a report. See 'Justice at Cross Roads: A Special Report on the Thomas Kwoyelo Trial', JLOS, available at www.jlos.go.ug/index.php/documentcentre/news-room/archives/item/200-justice-at-cross-roads?-a-special-report-on-thethomas-kwoyelo-trial. 
to comment on the court's verdict; where they did, they issued contradicting statements with few commitments. The ICD judges, however, complied with the Constitutional Court's decision and halted Kwoyelo's trial, with the directive that he should be issued an amnesty and released.

When Kwoyelo applied for execution of the court order, the attorney general controversially filed a late appeal to the Supreme Court (a higher appellate court), challenging the Constitutional Court's decision. At the time, however, the Supreme Court had no quorum, meaning that it could not hear the appeal and that it would take another year before Kwoyelo's case could be heard. The Ugandan Supreme Court stayed the Constitutional Court's ruling in March 2012. Kwoyelo's lawyers applied to the Court of Appeal for bail, an interim remedy to safeguard his liberty as he awaited the Supreme Court's decision. He argued that since the Constitutional Court had found in his favour, he stood a better chance of prevailing at the Supreme Court, and thus was entitled to bail, pending the outcome. The Court of Appeal agreed and ordered that Kwoyelo be released on bail. Again the DPP ignored the ruling, ${ }^{66}$ thus forcing Kwoyelo to apply to the High Court for a writ of mandamus, ordering the DPP to perform its duty as a public officer.

In a dramatic turn of events, the Supreme Court convened a special one-hour sitting (without a quorum) to hear the attorney general's request to stay the orders of the lower courts ordering Kwoyelo's release. Led by Chief Justice Benjamin Odoki ${ }^{67}$ the court heard the appeal, which it granted without any deliberations. In October 2012, Kwoyelo petitioned the African Commission on Human and Peoples' Rights, challenging his continued detention as arbitrary and as a violation of his right to be free of arbitrary detention. ${ }^{68}$ Meanwhile, the appeal against the Constitutional Court's decision on the Amnesty Act was heard before the Supreme Court in April 2014. One year later, in the first judicial determination of an individual's ineligibility for amnesty in Uganda, the Supreme Court overturned the Constitutional Court's decision, bringing Kwoyelo's case back before the ICD to begin again. ${ }^{69}$

${ }^{66}$ See M.C. Kane, 'The Indefinite Detention of Thomas Kwoyelo', Jurist Forum, 18 February 2013.

${ }^{67}$ Controversially known within the circles as the 'chief of injustice', Justice Odoki is alleged to have been Museveni's ally within the judiciary, affecting the integrity and development of the judiciary.

68 The commission has since seized itself of the matter, pending further determination.

${ }^{69}$ See Supreme Court Ruling, Constitutional Appeal No. 1 of 2012, Uganda v. Thomas Kwoyelo, 8 April 2015; S. Nakandha, 'Supreme Court of Uganda Rules on the Application of the Amnesty Act' (16 April 2015), www.ijmonitor.org/2015/04/supreme-court-ofuganda-rules-on-the-application-of-the-amnesty-act/. 


\section{Uganda's justice dilemmas: the 'Shadow' of the ICC and Thomas Kwoyelo}

Kwoyelo's trial highlights the extent to which the discourse of justice-asaccountability has come to dominate the Ugandan context, as well as its attendant political pressures. From the beginning, the trial was characterised by international support and domestic opposition. When Kwoyelo was first captured, he was held by Ugandan military intelligence for almost six months in secret detention. He was then charged with murder in the Chief Magistrate Courts at Buganda Road and committed to the High Court. At this stage, the ICD had not been fully established; however, pro-ICC groups and several international human rights agencies were lobbying the Ugandan government and JLOS to delay his trial until the court was ready. In this sense, JLOS used the bait of Kwoyelo's custody to lobby financial support in support of the ICD.

JLOS received significant donor money in support of expediting the trial and, with it, pressure to abandon its earlier roadmap towards a more comprehensive transitional justice process. The sector secured over UGX $400 \mathrm{~m}$ (US $\$ 160,000)$ to initiate the Kwoyelo trial alone. ${ }^{70}$ Before its focus shifted exclusively to prosecution and its financial dividend, JLOS TJWG had set up a robust and highly inclusive technical sub-committee to study and advise the government on the development of an appropriate and comprehensive transitional justice framework for Uganda. ${ }^{71}$ The four thematic sub-committees comprised: formal criminal justice; truthseeking; traditional justice and integrated justice committees. A number of civil society actors, including RLP, had researched and engaged victim communities and consulted widely on key issues to be addressed in such a comprehensive framework. JLOS had even conducted its own consultations around the country, the findings of which validated previous civil society reports. ${ }^{72}$

Initially, there was a strong working relationship between the TJWG and civil society; at this time, Justice James Ogoola was in charge as principal judge. Indeed, the TJWG had initially agreed that the proposed civil society draft of a National Reconciliation Bill and the International Criminal Court Bill (then of 2009) would both be presented together

70 See 'Annual Performance Report 2010/2011', JLOS, 72.

${ }^{71}$ See 'Transitional Justice in Uganda', JLOS, available at www.jlos.go.ug/index.php/201209-25-13-11-16/2012-09-28-06-56-14/transitional-justice.

72 See 'Transitional Justice Archive', JLOS, www.jlos.go.ug/index.php/document-centre/ document-centre/cat_view/10-transitional-justice. 
before parliament, in order to generate a comprehensive national discussion on Uganda's justice needs. Both draft laws were discussed with JLOS and key stakeholders, including a training of parliamentarians on the laws conducted by RLP, under its Beyond Juba Project. ${ }^{73}$ The National Reconciliation Bill was likewise reviewed by Justice James Ogoola and a number of JLOS officials. The bill was officially handed over to JLOS with a promise that both laws would be submitted to cabinet.

When JLOS approached its funders, however, to conduct a national consultation on the bills before their submission to cabinet, donor governments supporting JLOS - who were strongly in favour of the ICC and similar accountability efforts - made it clear that they would not fund the process if it included the National Reconciliation Bill. To them, it was important for JLOS to fast-track the ICC legislation - in part to enable Uganda to win its bid to host the ICC Review Conference in $2010^{74}$ - and to prosecute Kwoyelo. International lawyers from an international legal consulting group were even flown in to help JLOS enact such a law, despite their lack of familiarity with Uganda's legal terrain. ${ }^{75}$ As a result, the ICC Act that passed in 2010 was rushed through parliament with little consultation and without much-needed acknowledgment of the domestic legal reality, given the existence of the Amnesty Act. Nevertheless, pro-ICC groups and lobbyists celebrated it as a step towards complementarity.

Furthermore, to the ICC's advocates, Kwoyelo's trial was an example of putting complementarity 'into practice'. Little attention was thus paid to the politics, procedure or merits of the case. Internationally, an indictment for war crimes appears to erode the presumption of innocence, at least in the court of public opinion. Indeed, prosecutors and sometimes judges play more to public opinion and political interests than to the merits of a case, or even to the applicable law. ${ }^{76}$ In Kwoyelo's case,

73 For more information on RLP Beyond Juba Project activities, see www.beyondjuba.org.

74 See S. Oola, 'Global Justice! The 2010 ICC Review Conference and the Future of International Justice in Africa', Beyond Intractability Project, University of ColoradoUSA (February 2010).

75 In one joint consultation organised by RLP and the Public International Law \& Policy Group (PILPG) on the two bills, held at the Imperial Royale Hotel in Kampala, RLP walked out following particularly disparaging and patronising remarks made by an American lawyer hired by PILPG.

76 This is evident in the reluctance to grant Kwoyelo such interim judicial remedies as bail, and the refusal to execute repeated court orders for his release. For a similar argument, see D. Robinson, 'The Identity Crisis of International Criminal Law', Leiden Journal of International Law, 21(4) (2008). 
even before the case had commenced, a sitting judge within the ICD, Judge Anup Singh Choudry, issued a letter condemning the planned trial as unconstitutional and as a perversion of justice. ${ }^{77}$ He alleged that the trial was a mere sham given that the bench had been briefed and directed on how long the trial should last, as well as on the expected verdict.

The challenge for JLOS from the beginning was institutional. As a donor organ pioneered by a consortium of donor agencies, its role was to strengthen the rule of law by coordinating actors within the 'access to justice' chain. JLOS's understanding of transitional justice was limited to prosecution, however, and many of the advisors recruited to advise JLOS had only learned of 'transitional justice' because Justice Ogoola played a key role in the establishment of the (then) WCD. (RLP's interactions with JLOS insiders during the TJWG meetings also revealed that many had little to no knowledge of the contents of the other Juba peace agreements.) As a result, to many JLOS actors, the end of Kwoyelo's trial was understood as signifying an end to transitional justice in Uganda.

\section{From amnesty to 'accountability'}

Nowhere were tensions with JLOS more acute than over the Amnesty Act, as that was the basis on which Kwoyelo's trial had been stopped. Led by JLOS - with financial and ideological backing from UN Women and the UN Office of the High Commission of Human Rights, and in coordination with several local organisations in the Lango and Teso sub-regions Kwoyelo's proceedings thus dovetailed with the development of a new narrative against amnesty, one that presented it as unfair to 'innocent' civilian abductees as compared to those who were conscripted into the LRA. While this narrative was pushed heavily by JLOS, it reflected the donor agenda of many pro-ICC international actors.

Tensions over the act came to a head within government in early 2012, when the media reported that Jacob Oulanyah, the Deputy Speaker of Parliament, announced in Gulu that the Honourable Hilary Onek, then Minister of Internal Affairs, had extended the amnesty for another two years. This came as a shock to JLOS, and was again understood as symbolising an end to transitional justice in Uganda (rather than functioning as part of it). When JLOS read the news, it asked then Chief Justice Odoki - who was also Chair of the JLOS Leadership Committee - that Part II of the act be terminated, as a way to bring pressure on Minister Onek.

77 'Judge faults Ugandan war crimes court', New Vision, 5 July 2011. 
The chief justice (who, as noted, was also the head of the Supreme Court before whom Kwoyelo's appeal was then pending) called Minister Onek and instructed him not to gazette the law he had apparently signed. According to Onek, the chief justice told him that the Amnesty Act was unconstitutional and that he and the attorney general had agreed that only those parts of the law concerning reintegration should be extended. ${ }^{78} \mathrm{~A}$ few days later, a revised statutory instrument was gazetted, extending only part of the law and lapsing the most important provision: Part II, which provided for the grant of amnesty.

The lapsing of Part II angered many victims and leaders from the conflict-affected sub-regions in northern Uganda. Local leaders and civil society actors petitioned the Speaker of Parliament, condemning the illegal and unconstitutional manner in which the amnesty provision had been removed and demanding its reinstatement. Under the act, the decision to renew or lapse any part of the law is clearly at the discretion of the minister, not the chief justice or attorney general. ${ }^{79}$

The Speaker referred the matter to the Defence and Internal Affairs Committee to consult with the various stakeholders and report on its conclusions and recommendations. With support from Barney Afako - a well-known human rights lawyer who had advised the Juba peace process and was himself instrumental in drafting the 2000 act - and RLP, the committee conducted extensive consultations with all key stakeholders in the conflict-afflicted sub-regions, including the UPDF and victims groups. All of the groups were strongly in favour of reinstating the law. According to the committee chairperson, only JLOS and a few international NGOs and pro-ICC donors were against the reinstatement. ${ }^{80}$

Ultimately, in its report to the Parliament, the committee recommended immediate reinstatement of the law. This recommendation was debated and unanimously adopted. In May 2013, the full Amnesty Act was reinstated by Parliament, a move many victims groups and civil

78 Author's interview with the Hon Felix Okot Ogong, Chairperson of the Greater North Parliamentary Forum; author's phone conversation with the Hon Hilary Onek (Kampala, 23 May 2012).

79 See 'The Status of Amnesty in Uganda (part 2)', JLOS, available at www.jlos.go.ug/index. $\mathrm{php/document-centre/news-room/archives/item/211-the-status-amnesty-in-}$ ugandapart2.

${ }^{80}$ Author's interview with a Committee Chairperson during the CSO Consultation with Committee on Defence and Internal Affairs (Grand Imperial Hotel, Kampala, 16 April 2013). The Committee's report is available at www.parliament.go.ug/new/index.php/ documents-and-reports/committee-reports/category/31-committee-on-defence-andinternal-affairs\#. 
society actors welcomed, and that again drew harsh criticism from JLOS and other pro-ICC partners. ${ }^{81}$ Unfortunately, those who advocated for the reinstatement of the law were branded as 'pro-impunity' groups. ${ }^{82}$

\section{Conclusion}

Although the LRA is just one of several armed groups to have fought President Museveni's government, with untold legacies, the predominant focus of the ICC's complementarity 'work' in Uganda - newly visible with the recent arrest and surrender of Dominic Ongwen to The Hague - has overshadowed larger gaps in accountability and justice. The domestication of the Rome Statute may have foregrounded international crimes like genocide and war crimes, but it changed little in terms of practical commitment. ${ }^{83}$ Instead, it jeopardised a prospective peace agreement in Juba, one that could have ended a generational conflict and brought both parties to account. The ICC's warrants of the top LRA leadership further placed prosecution at the top of the justice agenda for northern Uganda, whereas amnesty and a preference for traditional reconciliation rituals had previously held sway. The ICD became popular and received large sums of money, given the widespread support for domestic trials to complement the ICC.

For its part, the Ugandan government has hidden under the veil of complementarity to prosecute one side to the conflict, shy away from truth-seeking, deny immediate reparatory measures to victims and avoid acknowledgement of its responsibility and needed institutional reforms. All of this has contributed to silencing a majority of the victims of Uganda's conflicts. The ICC's intervention, in part, has enabled this one-sided focus. For instance, the ICC outreach office in Uganda continues to organise regular trainings for local officials within Uganda. The OTP also availed its investigation file to the prosecutors in Uganda, upon which they based some of their evidence against Kwoyelo. ${ }^{84}$ The OTP equally provided information regarding the whereabouts of potential

81 At the time of writing, the Amnesty Act's reinstatement was to remain in effect through May 2015.

82 At one public event organised at Makerere University shortly after the law's reinstatement, a donor representative reproached RLP for 'stabbing' JLOS in the back. In another meeting in Entebbe, a JLOS staff member told an RLP colleague, 'You guys have taken TJ away from us.'

${ }^{83}$ See Oola, 'Bashir and the ICC'.

${ }^{84}$ In fact, one of the preliminary objections initially raised by Kwoyelo's defence attorney at the opening of the trial was that some exculpatory evidence in the original ICC investigation file had been redacted. 
witnesses against Kwoyelo to Ugandan prosecutors. But even with all of this support, Kwoyelo's case raised significant questions regarding whether Uganda was ready to prosecute international crimes and whether prosecution was even appropriate.

Finally, JLOS, largely driven by financial motives, has hijacked the transitional justice efforts initiated by civil society and survivors, excluded critical civil society voices and replaced local interest groups and stakeholders with international technical advisors and experts, all in the name of complementarity. By stigmatising the amnesty law and exploiting the opportunities within the law to craft its version of 'positive' complementarity, JLOS and its allies have sparked what David Oulanyah has rightly called 'judicial instability', to the detriment of a more comprehensive transitional justice approach. ${ }^{85}$ The ICC and its supporters have thus been deceived by their own narrow focus on prosecutions. They are celebrating a symbolic trial without substance, just as Ugandan transitional justice policies have been carefully calculated to condone state impunity, and to deny victims their opportunity to reckon with the country's past in a comprehensive manner.

${ }^{85}$ See D. Lumu, 'Oulanyah Warns Judiciary on Kwoyelo Case', New Vision, 6 November 2013. 


\title{
A story of missed opportunities
}

\author{
The role of the International Criminal Court \\ in the Democratic Republic of Congo
}

PASCAL KALUME KAMBALE

\section{Introduction}

I left Dakar, Senegal, in March 2001 with a heavy heart. A three-judge panel of the Cour de cassation, the highest appeal court of Senegal, had just quashed the criminal case against Hissein Habré, president of Chad from 1982 to 1990, and now living in exile in Senegal. I had been the main lawyer acting for a group of victims of the bloody repression perpetrated by agents of Habré's government throughout his eight years in power. All had gone well until the Cour de cassation ruling. A year earlier, a Senegalese investigative judge who examined the victims' complaint indicted Habré on several counts of torture and crimes against humanity under the UN Convention against Torture and the Senegalese penal code. On Habrés appeal, however, the court nullified the indictment on the grounds that the Torture Convention could not be applied in Senegal in the absence of legislation determining which particular Senegalese court had jurisdiction over acts of torture committed abroad. ${ }^{1}$

What this legalistic interpretation meant in concrete terms was that nine years of meticulous and risky efforts by the Association des victimes des crimes de répression politique au Tchad (Chadian Association of Victims of Crimes of Political Repression) to document crimes committed by Habrés regime were, for a time, swept away, ${ }^{2}$ ironically

1 The ruling rendered meaningless both the provision of the Torture Convention providing for states ratifying it to prosecute the offences it describes wherever they have occurred, and the clause in the Senegalese Constitution giving international conventions ratified by the state direct application in national law.

2 The International Court of Justice later found that by failing to make immediately a preliminary inquiry into the facts relating to the crimes allegedly committed by Habré, Senegal breached its obligations under the Torture Convention and that it 'must, without 
enough, by judges of the country that was the first in the world to ratify the Rome Statute. I returned to my country, the Democratic Republic of Congo (DRC), to devote myself to education in a small Catholic university in the north-eastern city of Butembo, which was occupied at the time by Ugandan troops.

It is in this small town and in the most unlikely circumstances that I rediscovered my faith in international justice. As I left a classroom for a break, I was approached by an old woman who wanted to know if I was the local boy who had gone on to prosecute a powerful president in a foreign land. She then handed me a bulky dossier related to the murder of her husband by the leader of a local rebel group supported by Uganda. Her daughter had told her that the local lawyer whom she had heard speaking on the radio regarding the Habré case was back and would be able to help in prosecuting the people who assassinated her husband and father. I was soon to devote a great part of my time to listening to victims of torture and parents of people killed or 'disappeared' by rebel and occupying forces in the DRC. I quickly realised that the faith in a vague 'international justice' to which all these people wanted to bring their cases was as contagious as their personal stories were painful to hear. A few months after I completed my teaching assignment, the DRC government ratified the Rome Statute, thus giving the International Criminal Court (ICC) jurisdiction over crimes like those described in the dossiers I was given in Butembo. I wondered, 'Would the ICC fulfil the hope of the people I met in Butembo and so many across the country?'

This chapter exposes the means by which, in my view, the Court betrayed this hope. As I argue, this betrayal is largely due to a defective prosecutorial strategy: the various wrong turns taken by the Office of the Prosecutor's (OTP) strategy in Congo could have been avoided if its first prosecutor, Luis Moreno-Ocampo, had given a more attentive ear to the numerous criticisms and to the advice that was given to him by representatives of national and international organisations who were at the outset among the Court's most enthusiastic supporters. ${ }^{3}$

further delay, submit the case to its competent authorities for the purpose of prosecution, if it does not extradite him'. Questions relating to the Obligation to Prosecute or Extradite (Belgium v. Senegal) [2005] ICJ Rep., 20 July 2012, para. 122.

3 Investigation in the cases discussed in this chapter had been completed by the time Moreno-Ocampo stepped down as prosecutor and Deputy Prosecutor Fatou Bensouda took over as chief prosecutor on 15 June 2012. Immediately after taking office, Prosecutor Bensouda embarked on a thorough review of the OTP's operating procedures and structures, including its investigations policies. This resulted in a new strategic plan, which acknowledges some of the limitations of the OTP's investigations policies 
As I argue, the failure of the OTP under Prosecutor Moreno-Ocampo's tenure to extend such an ear resulted in a prosecutorial strategy that prioritised political expedience over thorough investigations, resulting in the pursuit of relatively 'small fish', frustrating a fuller accounting of the full scope of the DRC conflict, and jeopardising the OTP's independence. Moreover, rather than strengthen domestic accountability efforts, the OTP's investigations did them some measure of harm. The following critical analysis of the actions of the ICC in the DRC is grounded in the belief that criminal justice has an important expressive role to play - truthtelling, building a historical narrative - in the efforts to achieve political reconstruction in post-conflict societies. ${ }^{4}$ While the prosecutor's early theory of 'positive complementarity' contained the broad outline for such a role, he ultimately failed to apply his own theory in the context of the DRC.

\section{A fertile ground for international justice}

The conflict in Congo has gone through a succession of different phases since 1996. The first and shortest phase of the conflict lasted from November 1996 to May 1997 and was instigated by a rebel movement known as the AFDL (Alliance des forces démocratiques pour la libération du Congo) against the national army, President Mobutu's Forces Armées Zairoises. The support the AFDL enjoyed from Ugandan and Rwandan troops gave the conflict its international dimension. It ended with the ousting of Mobutu in May 1997 and his replacement with the AFDL leader Laurent-Désiré Kabila. The second phase of the conflict started in August 1998 when Rwanda and Uganda turned their back on Kabila to support a dissident rebel movement, RCD (Rassemblement congolais pour la démocratie), and many other splinter groups, all aiming to unseat President Kabila who, for his part, received the support of troops from Angola, Namibia and Zimbabwe, in addition to creating and arming self-defence groups (the so-called Mayi-Mayi) in the RCD-controlled territories. ${ }^{5}$

highlighted in this chapter. It is too early to assess how the important changes announced in the plan impact the quality of the OTP's investigations and prosecutions strategies. See 'OTP Strategic Plan June 2012-2015', Office of the Prosecutor, International Criminal Court (11 October 2013).

${ }^{4}$ See M. Drumbl, Atrocity, Punishment and International Law (New York: Cambridge University Press, 2007).

${ }^{5}$ For further history, see John F. Clark (ed.), The African Stakes of the Congo War (New York: Palgrave, 2002); G. Nzongola-Ntalaja, The Congo from Leopold to Kabila. A People's History (London and New York: Zed Books, 2002); T. Turner, The Congo Wars: Conflict, Myth and Reality (London and New York: Zed Books, 2007). 
At the time of my return in early 2001, the DRC was thus in the throes of a long political crisis. The signing of a comprehensive peace agreement in Pretoria, South Africa, in December 2002 formally put an end to the national and international dimensions of the conflict and paved the way for a transition period led by a national unity government. However, it also resulted in more localised conflicts in eastern territories in a third and ongoing phase of the conflict that pits the government of Kinshasa against several armed groups scattered across the vast national territory. ${ }^{6}$

By any measure, the violence wrought by the conflict has been devastating. All the belligerent forces, national and foreign, have indulged in brutal attacks against the civilian population. It is estimated that 5.4 million were numbered dead as the direct or indirect consequence of the war that raged from August 1998 to April 2007. ${ }^{7}$ A little more than 2 million were officially recorded as dead after the signing of the agreement that formally ended the war in $2002 .^{8}$

In the DRC, the dichotomy between peace and justice has not played out at the same level of complexity as has been the case in other situation countries. Partly due to the excessive brutality of the war and the apparent absence of any political rationality in the belligerent's motives, it quickly appeared to numerous Congolese that efforts to put an end to the conflict should include the establishment of justice mechanisms. But the national justice system, undermined by corruption and weakened by lack of resources, was too limited to achieve this goal. A turn to international justice mechanisms was therefore seen as necessary.

In the Ituri District, a reconciliation process at the grassroots level had started in September 2003, spearheaded by traditional leaders from the Hema and Lendu communities, whose members were most affected by the successive waves of the conflict. Most actors of these reconciliation efforts understood the need to complement and support the process with a justice component. There was strong popular support for the Programme pour la restauration rapide de la justice en Ituri ('Program

${ }^{6}$ On the history of these more 'localised conflicts', see Séverine Autesserre, The Trouble with the Congo: Local Violence and the Failure of International Peacebuilding (Cambridge: Cambridge University Press, 2010).

7 'Mortality in the Democratic Republic of Congo: An Ongoing Crisis', International Rescue Committee (2007). Data in this report were later challenged in a Human Security Report Project, available at www.hsrgroup.org/human-security-reports/20092010/overview.aspx.

8 Prior to his voluntary surrender to the ICC in March 2013, Bosco Ntaganda was involved in one such armed group, the Rwanda-backed CNDP (or 'National Congress for the Defence of the People'), created in 2007, which later metamorphosed into M23. 
for the Urgent Restoration of the Justice System in Itruri'), a donor-supported program launched in December 2003 whose objective was to enable the criminal justice system to recover its capacity to prosecute serious crimes and thus contribute to fostering criminal accountability in Ituri. ${ }^{9}$

Civil society groups across the country issued communiqués, prepared reports and held workshops in support of the idea that crimes committed in the past five to six years of civil war must be prosecuted before some kind of international tribunal. Although the concept of such a mechanism varied from organisation to organisation, there was broad agreement on the need to not leave unpunished the authors, foreign and national, of the gravest crimes of the war, including those committed before the Rome Statute's entry into force. ${ }^{10}$

One of the five commissions established under the Inter-Congolese Dialogue (ICD) ${ }^{11}$ the Commission on Peace and Reconciliation, was tasked with recommending measures to ensuring lasting peace within the national borders and security in the region. Members of the commission

9 'Making Justice Work: Restoration of the Legal System in Ituri, DRC', Human Rights Briefing Paper, Human Rights Watch (HRW, 'Making Justice Work', 2004). The program later expanded both geographically (to the rest of the eastern territories) and thematically (to embrace other aspects of justice provision beyond criminal justice) under the name of REJUSCO (Restauration de la Justice à l'Est du Congo), which ran from 2007 to 2010. See K. Tekilazaya, D. Fataki Wa Luhindi and M. Wetsh'Okonda Koso, 'République démocratique du Congo: Le secteur de la justice et l'Etat de droit', AfriMAP/Open Society Initiative for Southern Africa (2013), 140.

10 NGO participants in a May 2001 seminar convened by the DRC office of the International Human Rights Law Group recommended the creation of a special international criminal tribunal that 'should be of a hybrid or mixed character (its judges and prosecutors should consist of both Congolese and non-Congolese nationals)'. They also recommended the creation of 'a national Truth Commission, the establishment of a grassroots-level reconciliation process, and reinforcing the capacity of the Congolese judicial system'. In October 2001, the Centre pour la Paix en Afrique Centrale (CIPAC) issued a report entitled 'Pourquoi une juridiction spéciale pour la RDC?', which discussed different options for a mechanism to try the most serious crimes committed since 1996. The report recommended the creation of a special tribunal with both Congolese and international judges, and set to apply both national criminal law and international humanitarian law. The August-October 2002 issue of 'Le Scrutin', a newsletter published by LINELIT, a Kinshasa-based civic education organisation, ran an article under the headline 'Quelles juridictions pour la répression des crimes internationaux commis pendant les guerres en RDC de 1996 à 2001?', which recommended the creation of a special tribunal following the model of the International Criminal Tribunal for Rwanda.

11 Efforts to bring an end to the second cycle of war in Congo that had flowed throughout the country since 1998 led to the convening in 2002 of peace talks, known as the InterCongolese Dialogue (ICD), in Sun City, South Africa. In December 2002, participants in the ICD reached a Global and Inclusive Accord (or 'Accord Global et Inclusif'), which set a timetable for a two-year transition government leading to democratic elections. 
were clear about the fact that restoring lasting peace would be conditional on establishing dedicated justice mechanisms to prosecute war crimes. Their recommendations regarding the establishment of a truth and reconciliation commission and an international special tribunal for war crimes in the DRC were adopted by all 359 delegates to the ICD, ${ }^{12}$ rather than being referred to the upcoming transitional parliament as most 'contentious' recommendations were. ${ }^{13}$

The transitional government formed in July 2003 engaged in an internal debate on the implementation of the recommendations of the ICD's 'Global and Inclusive Accord'. On 25 September 2003, the transitional government approved a decision to refer to the ICC war crimes and other international crimes committed throughout the territory of DRC and to request the creation by the UN Security Council of an international special tribunal for the DRC to deal with crimes that would fall outside the jurisdiction of the ICC. ${ }^{14}$ Remarkably, this decision was reached by a government composed of leaders of armed groups and factions whose own conduct would be the subject of investigations by any international criminal tribunal.

Prosecutor Moreno-Ocampo deserves a great deal of credit for having actively sought a dialogue with Congolese authorities on the scope and impact of the referral. Either through direct contacts with Congolese government and judicial authorities or through consultation with a broad network of individuals and international agencies, the prosecutor sought advice and guidance on a range of issues, from the geographic scope of his investigations to their impact on the peace process and the role of national justice mechanisms. The content of the state referral was among several issues discussed with Congolese authorities. Following the decision by the transitional government on 25 September 2003, the referral was formally made in March $2004 .{ }^{15}$

$12 \mathrm{P}$. Bouvier et F. Bomboko, Le Dialogue intercongolais, anatomie d'une négociation à la lisière du chaos, Cahiers africains No 63-64 (Paris: L'Harmattan, 2004), 177-178.

13 R. Minani Bihuzo, 1990-2007, 17 ans de transition politique et perspectives démocratiques en RDC (Kinshasa: CEPAS/RODHECIC, 2008), 68.

14 Although the first part of this decision was followed through, as detailed later in this chapter, for reasons that remain unclear, the government failed to follow up on request for the creation of an international special tribunal for the DRC.

${ }^{15}$ In the letter, President Kabila refers 'the situation that has been unfolding in my country since July 1,2002 , in which it appears that crimes that fall within the competence of the International Criminal Court have been committed, in order to determine if one or more persons should be charged with the commission of these crimes'. 'Letter of Referral from President Joseph Kabila to Prosecutor of the ICC', ICC-01/04-01 /06-32-US-Exp-AnxAl 12-03-2006 1/1UM, 3 March 2004. 


\section{A good start: devising the theory of 'positive complementarity'}

At the outset, the then prosecutor took concrete and positive steps, demonstrating his willingness to make the best use of complementarity mechanisms provided for in the Rome Statute. Moreno-Ocampo organised the OTP so as to give complementarity issues the prominence they deserve. In addition to the Investigations and Prosecutions Divisions, he created a Jurisdiction, Complementarity and Cooperation Division (JCCD), which was given the task, among other things, to look into issues of admissibility and advise the prosecutor on the proper balance between national prosecutions and the role of the ICC. The JCCD was to foster a practical division of labour between the ICC and national courts, based on the principle of 'a positive approach to complementarity, encouraging genuine national prosecutions wherever possible. ${ }^{16}$

In the DRC situation, the prosecutor envisaged a clear division of labour whereby the ICC would prosecute a handful of individuals among those bearing the greatest responsibility, while the Congolese justice system, with the support of the international community, would take on other cases. Elements of such a division of labour were outlined in the following paragraph from the letter the prosecutor sent to President Kabila to seek his referral of the situation in DRC:

Since the International Criminal Court will not be in a position to try all the individuals who may have committed crimes under its jurisdiction in Ituri, a consensual division of labour could be an effective approach. We could prosecute some of those individuals who bear the greatest responsibility for the crimes committed, while national authorities, with the assistance of the international community, implement appropriate mechanisms to deal with others. This would send a strong sign of the commitment of the Democratic Republic of the Congo to bring to justice those responsible for these crimes. In return, the international community may take a more resolved stance in the reconstruction of the national judiciary and in the re-establishment of the rule of law in the Democratic Republic of the Congo. ${ }^{17}$

The OTP's theory of complementarity found a positive echo in the DRC as it gave concrete meaning to the national consensus achieved at the Inter-Congolese Dialogue around the need for a special international tribunal, and to the idea that a division of labour between international

16 'Report of the International Criminal Court to the UN General Assembly', A/60/177, 1 August 2005, para. 28.

17 'Letter from Prosecutor Luis Moreno-Ocampo to H.E. Joseph Kabila, President of the Democratic Republic of Congo', 25 September 2003 (on file with author). 
justice bodies and the Congolese judicial system was desirable. The highest-ranking leaders linked to the most serious crimes, including foreign nationals, would appear before international justice mechanisms, given the incapacity of the Congolese justice system to prosecute them. The Congolese justice system would use the respite gained in order to reform its internal structures as well as to prosecute people in lowerranking positions.

Former minister of justice Ngele Masudi articulated this vision in his opening remarks at a meeting on the ICC in October 2002. Before a gathering of lawyers, law professors, senior members of the judiciary, human rights activists and representatives of civil society organisations, he indicated that the government's strategy to address war crimes was based on the principle of complementarity, by which he meant that the DRC would leave to the ICC the task of prosecuting those in the top leadership of armed groups who bore the greatest responsibility for crimes under the ICC jurisdiction, whereas the Congolese justice system would deal with the lower-ranking perpetrators and the less-complex crimes. This was the background, Minister Ngele explained, against which the government had ordered the overhaul of the legal framework for military justice so as to give military courts jurisdiction over crimes under the Rome Statute. He added that the same rationale was the basis for the government's request to the United Nations for the creation of a specific international criminal tribunal for the DRC.

The announcement by then prosecutor Moreno-Ocampo in June 2004 of the formal opening of investigations in the DRC seemed to reinforce the idea of an ideal division of work between the Congolese justice system and an international court. In the communique announcing the opening of the investigation, the prosecutor highlighted the fact that his office would focus its investigation so as to target 'serious crimes' committed in the DRC territory from 1 July 2002 and only those 'people that bore the highest responsibility' for the crimes. ${ }^{18}$

In the following months, however, the opposite happened. At the end of what appeared to be only a cursory investigation, the Court issued arrest warrants for people hardly thought of as bearing the highest responsibility for crimes committed. Indeed, the crimes for which the prosecutor sought early convictions were not among the most serious committed in Ituri. The strategy the OTP was implementing in the DRC

18 'The Office of the Prosecutor of the International Criminal Court opens its first investigation', ICC-OTP-20040623-59, Press Release, 23 June 2004. 
seemed to be moving away from the basic principles that it had previously outlined.

\section{Targeting small fish: Thomas Lubanga}

Very few among the Congolese legal community and civil society expected the ICC prosecutor to go as high up as he later did in the Sudan case. Though he was the person bearing the greatest responsibility for crimes committed in Darfur, the issuance of an arrest warrant against President Bashir was rightly criticised for its potentially adverse implications to the peace process that was taking place at the time the warrant was issued. The DRC situation was different: there was no shortage of individuals other than heads of state who bore a much greater responsibility for crimes in Ituri than those for whom the prosecutor later sought arrest warrants.

The first disillusionment came with news of Thomas Lubanga as the first person to be charged by the ICC. Lubanga was prosecuted for crimes consisting of 'conscripting and enlisting children under the age of 15 ' and forcing them 'to participate actively in hostilities in Ituri, from September 2002 to 13 August 2003'. ${ }^{19}$ Both the choice of individual and the crime he was charged with would irreparably damage the effectiveness of the division of labour between the Court and the Congolese justice system.

For most Congolese, Thomas Lubanga did not fit into the category of persons bearing 'the greatest responsibility' for the crimes committed during the second phase of the Congolese war. A mid-level actor in the conflict in Ituri, Lubanga started his criminal career as an aide to Mbusa Nyamwisi, leader of the armed group RCD-ML (Rassemblement Congolais pour la Démocratie - Mouvement de Libération), which controlled Ituri between 1999 and 2002 with the support of Uganda. A large percentage of the crimes committed in Ituri were committed by the RCD-ML, but Lubanga was only one among several 'ministers' in the group. Only in the beginning of 2003 did he create his own militia, the Union des Patriotes Congolais (UPC) - with the support and at the initiative of officers of the Ugandan army, the Uganda People's Defence Force (UPDF) - although he quickly switched sides and pledged allegiance to the Rwanda Defence Force, which provided him with arms, training and operational capability

19 Decision on the Prosecutor's Application for Warrants of Arrest, Situation in the Democratic Republic of the Congo, ICC-01/04, Pre-Trial Chamber I, ICC, 10 February 2006, para. 37 (Arrest Warrant, Lubanga, 10 February 2006). 
for the greater part of 2003. As was the case with most of the militia in Ituri, however, the UPC's operations were under the effective strategic control of the Ugandan army and later the Rwandan army, whose officers retained command and control of military operations, including those during which crimes were committed against the civilian population.

Moreover, many in the DRC found it deeply disturbing that, after two years of investigations, conscription of child soldiers was all that the OTP was able to point to as being among 'the worst crimes' committed in Ituri. Loud expressions of indignation would quickly be heard in the media and among the human rights community. Most of the journalists invited by the ICC in November 2006 to cover the Court's hearing on the confirmation of charges against Lubanga expressed their bewilderment at the fact that Lubanga was not prosecuted for more serious crimes. It did not make sense to the Congolese media that the ICC prosecutor would identify and describe 'the instigators of the conflict in Ituri' and yet refrain from pursuing them. According to John Lwamba, director of the Kinshasa daily L'Echo des Grands Lacs, 'We criticise the work of the Court for only targeting the small fish. ${ }^{20}$

By the OTP's own admission, it appears that the decision to prosecute Lubanga on the charges of enlisting and conscripting children under fifteen was based not on the gravity of the crime but rather on which crime investigators could quickly gather evidence on in order to secure an arrest warrant. According to a report issued weeks before Lubanga's confirmation hearing, the OTP's investigation of Lubanga initially included a wider range of crimes with the aim of representing a broad range of criminality. ${ }^{21}$ At the same time Lubanga was the subject of another investigation in the national courts: on 19 March 2005 a Congolese military prosecutor had ordered him into preventive detention on different counts of war crimes and crimes against humanity. However, the prosecutor suddenly dropped the investigation of a wider range of crimes upon learning from the Congolese investigative magistrates that they might have to grant Lubanga's release if by 19 March 2006 they could not gather enough evidence to charge him. The prosecutor thought it urgent to prevent such release so he decided to focus his investigation on the more manageable crime of enlisting and conscripting children under $15 .^{22}$

${ }^{20}$ D.I. Kazadi, 'Procès Lubanga - la CPI critiquée par les médias congolais', Le Phare, Kinshasa, 15 April 2008.

21 'Report on the activities performed during the first three years (June 2003-June 2006)', 22 Office of the Prosecutor, ICC, 12 September 2006, 8, 12. Ibid. 
In August 2006, the ICC also issued an arrest warrant against Bosco Ntaganda, former chef d'état-major général adjoint ('Deputy Chief of the General Staff), responsible for overseeing military operations of Thomas Lubanga's militia, the UPC. ${ }^{23}$ Again, Ntaganda was charged with the same crimes as his former boss: conscription of children of less than fifteen years old, although the OTP would later add more serious charges in an additional application for warrant of arrest in $2012 .^{24}$

Human rights NGOs and victims' associations across the country began questioning the ICC's motives. Some warned that not taking into account the most serious crimes risked the Court's credibility in the DRC. In the months following the arrest of Thomas Lubanga and his surrender to the Court, a group of twenty-five Congolese women's and human rights organisations met in Beni, North Kivu, to discuss the status of the ICC prosecutions in the DRC. In a strongly worded statement, these organisations expressed their 'deep regret' that the only charge brought against Lubanga pertained to the enlistment and conscription of child soldiers. They stressed that Lubanga's UPC had committed 'several other crimes falling under the jurisdiction of the ICC, of which the details have been submitted to the OTP by national and international NGOs'. More specifically, the groups thought it was the ICC's responsibility to address 'the widespread commission of rape and other forms of sexual violence by the UPC'. They concluded their statement with a warning that a failure to add more serious charges would result in 'offending the victims and strengthen the growing feeling of mistrust of the work of the ICC in the DRC and of the work of the prosecutor especially'. ${ }^{25}$

The Congolese National NGO Coalition for the ICC, which claimed membership of more than a hundred leading human rights organisations, joined a group of international human rights NGOs in sending a letter to the ICC prosecutor in which they expressed their disappointment 'that two

23 Warrant of Arrest, The Prosecutor v. Bosco Ntaganda ('Ntaganda'), ICC-01/04-02/06, Pre-Trial Chamber I, ICC, 22 August 2006.

24 The prosecutor's application for a second arrest warrant against Ntaganda on 14 May 2012 included charges of (1) crimes against humanity of murder, rape/sexual slavery and persecution based on ethnic grounds; and (2) war crimes of murder, intentional attacks against civilians, pillaging and rape/sexual slavery. See Decision on the Prosecutor's Application under Article 58, Ntaganda, ICC-01/04-02/06, Pre-Trial Chamber II, ICC, 13 July 2012, para. 5 ('Article 58 Decision, Ntaganda, 13 July 2012').

25 'Obtaining further charges in the opening case against Thomas Lubanga', Statement by women's rights and human rights NGOs of the DRC on the prosecutions by the ICC, Beni, 16 September 2006 (on file with the author). 
years of investigation by your office in the DRC have not yielded a broader range of charges against Mr. Lubanga'. While acknowledging the seriousness of the charges related to enlisting of child soldiers, they cited concrete examples of the UPC's involvement in the commission of far more serious crimes, such as the killing of 350 persons in the course of a military operation, which also resulted in the 'complete destruction' of more than twenty villages in February and March 2003. They also concluded that the failure to include additional charges for the most serious crimes in the case against Lubanga 'could undermine the credibility of the ICC in the DRC'.

\section{A partial story: Katanga and Ngudjolo}

The credibility of the ICC was indeed seriously undermined. The much more serious charges of war crimes and crimes against humanity brought against two other militia leaders of Ituri, Germain "Simba" Katanga and Mathieu "Chui" Ngudjolo, in July 2007 were too late to do much to restore the Court's standing. Katanga and Ngudjolo were arrested and surrendered to the ICC in connection with crimes committed in the course of a brutal attack jointly launched by their respective militia on the Ituri village of Bogoro on 24 February 2003. They were eventually charged with war crimes (consisting, amongst other things, of attacks against the civilian population, intentional murders, and sexual slavery and rape) and crimes against humanity (consisting of murders, rapes and sexual enslavement). ${ }^{27}$

However, according to Godefroy Mpiana of the human rights organisation Justice Plus of Bunia, 'the procedure [against Germain Katanga] was very delayed. The court had really spent its credit here on the ground. ${ }^{28}$ Moreover, as with the prosecution of Lubanga, the ICC's arrest of Ngudjolo and Katanga appeared in the eyes of many Congolese to be the result of a mix of opportunism and a public relations operation having little to do with a genuine effort to punish the leaders of crimes committed in Ituri. In particular, the fact that the case against

26 The other signatories of the letter of 31 July 2006 are: Avocats Sans Frontières, the Center for Justice and Reconciliation, International Federation for Human Rights (FIDH), Human Rights Watch, International Center for Transitional Justice (ICTJ), Redress, and Women's Initiative for Gender Justice.

27 Warrant of Arrest, The Prosecutor v. Germain Katanga, ICC-01/04-01/07, Pre-Trial Chamber I, ICC, 2 July 2007, and Warrant of Arrest, The Prosecutor v. Mathieu Ngudjolo Chui, ICC-01/04-02/07, Pre-Trial Chamber I, ICC, 6 July 2007, respectively.

28 'Germain Katanga, deuxième Congolais transféré à la CPI', http://sites.rnw.nl/pdf/ijt/ IJT76_VF.PDF. 
Katanga was already before the Congolese courts, as explained below, on charges of genocide, war crimes and crimes against humanity under Congolese law, meant that its removal to the ICC had the effect of weakening national efforts at justice, while doing nothing to take on those who were their superiors. ${ }^{29}$

The commander of a small armed group, the FRPI (Forces de résistance patriotique de l'Ituri), Germain Katanga had been appointed a general of the national army of Congo in December 2004 with six other warlords from Ituri, over the protests of the victims' organisations and the human rights activists who gave evidence of their implication in criminal acts in Ituri. Ngudjolo, meanwhile, occupied a lower post in the leadership chain of an allied group, the FNI (Front des nationalistes intégrationnistes). He had joined the Congolese army at the same time as Katanga, and was arrested by the ICC in January 2008, while attending an army officer-training course in Kinshasa. Floribert Njabu, the president and co-founder of the FNI-FRPI, was held in a prison in Kinshasa at the time of the transfers of Katanga and Ngudjolo to the ICC, but was not himself transferred to The Hague. Even if the FNIFRPI was a movement of lesser scale than the RCD-ML, for example, Floribert Njabu better matched the profile of 'persons bearing the largest responsibility' for crimes committed by this armed group than either Katanga or Ngudjolo. It was not until November 2010, after the prosecution's case was closed, that Njabu was called to testify by the defence for Germain Katanga, along with two other militia leaders, Pierre Mbodina Iribi and Sharif Manda Ndadza, who were also in detention in Kinshasa. ${ }^{30}$

Moreover, evidence produced in the Ngudjolo and Katanga cases indicated that the governments of Uganda and the DRC, in conjunction with a larger armed group, the RCD-ML, supplied the FNI-FRPI with military support for, and jointly planned, several attacks, including the

29 By the time of his transfer to the Court, Katanga was in the custody of the Congolese military justice and was awaiting the commencement of his trial in the case Auditeur militaire c. Germain Katanga et Crts, No RDP 001/05, before the Haute cour militaire of Kinshasa, in connection with different attacks on civilians and the murder of nine UN peacekeeping troops in Ituri on 25 February 2005.

30 After they had completed their testimony in which they implicated the Kinshasa government, including President Joseph Kabila personally, in the attack on Bogoro, the three witnesses applied for asylum in the Netherlands, citing fear for their security if they were to return to prison in the DRC. Their asylum applications have since been denied and they were returned to the DRC. See J. Easterday, 'Three Defense Witnesses Blame the DRC for Bogoro Attack, then Seek Asylum in the Netherlands', 6 June 2011 at http:// www.ijmonitor.org/2011/06/three-defense-witnesses-blame-the-drc-for-bogoro-attackthen-seek-asylum-in-the-netherlands/. 
Bogoro attack in connection to which Katanga and Ngudjolo were also charged. For example, the chamber in Ngudjolo was provided extensive evidence of numerous meetings that Ngudjolo, Katanga and other FNIFRPI leaders held with senior Congolese and Ugandan government and military leaders, including President Kabila and President Museveni and their emissaries, prior or subsequent to these attacks. Meetings with General Kale Kayihura, overall commander of the UPDF occupying forces in Ituri, were particularly detailed. ${ }^{31}$ The evidence in Katanga was that the attack on Bogoro was planned in Beni by the EMOI ('Integrated Operational Head Command') commanding structure operated by the government of Kinshasa and the RCD-ML armed group, which provided arms and training of FNI-FRPI combatants in preparation for the attack on Bogoro. ${ }^{32}$

This prosecution strategy was never likely to allow the ICC to tell the full story of the conflicts in Ituri, and less still in the DRC as a whole. The relatively minor role that the individuals who have been brought to court in The Hague played in the Ituri conflict means that the OTP deliberately left the most important actors - all of the national political and military leaders in DRC, Uganda and Rwanda - in the shadows. ${ }^{33}$ The Court has thus been unable to place the crimes that it prosecutes in their full historical context and so fails to contribute to the uncovering of the truth. As one analyst noted, the Court deliberately chose not to respond to the following important questions: 'Who provided the weapons? Who supported the militia leaders? Where are the political leaders that are behind these crimes? ${ }^{34}$ By choosing not to deal with these and other similar questions, the OTP presented evidence that was so weak and incomplete that, in the words of the dissenting judge in Katanga, 'we will never fully understand

31 Judgment pursuant to article 74 of the Statute, The Prosecutor v. Mathieu Ngudjolo, ICC01/04-02/12, Trial Chamber II, ICC, 18 December 2012, paras. 474-475, 493-494, 500 ('Judgment, Ngudjolo, 18 December 2012').

32 Jugement rendu en application de l'article $74 \mathrm{du}$ Statut, The Prosecutor v. Germain Katanga, ICC-01/04-01/07, Trial Chamber II, ICC, 7 March 2014, paras. 635; 643-644; 651 ('Judgment, Katanga, 7 March 2014').

33 According to Human Rights Watch, during the period in which the crimes of which Katanga, Lubanga and Ngudjolo are accused were committed, Ituri was 'the battleground for the war between the governments of Uganda, Rwanda and the DRC, which have provided political and military support to local armed groups despite abundant evidence of their widespread violations of international humanitarian law' and who, therefore 'share responsibility for these crimes'. Human Rights Watch, 'Ituri: "Covered in Blood." Ethnically Targeted Violence in Northeastern DR Congo', Human Rights Watch Report, 15:11(A) (2003), 2.

34 'Germain Katanga, deuxième Congolais transféré à la CPI', Radio Nederland Wereldomroep, 21 October 2007. 
what happened on 24 February 2003 and especially who did what to whom and why. ${ }^{35}$

The narrative that better fit this prosecutorial strategy was one that presented the conflict in Ituri as being predominantly of an ethnic nature. The OTP first worked on describing crimes committed in Ituri as the direct consequence of a deliberate policy 'of attacking the Lendu and other non-Hema population throughout the territory of Ituri', in order 'to seek Hema political and military domination over Ituri' ${ }^{36}$ Prosecutor Moreno-Ocampo then presented a situation of all-out ethnic conflict between the Hema, the Lendu and the Ngiti. ${ }^{37}$ This narrative was a distortion of history: it deliberately ignored important elements of the historical context, including the fact that the implication of the governments of the DRC, Rwanda and Uganda was motivated by the desire to control political space and natural resources. ${ }^{38}$ It left the impression that the alleged crimes were motivated only by ethnic identity and thus reinforced the Western media's lazy and inadequate image of 'tribal warfare', without spending the time to learn about the political and economic causes of those wars. As Judge Christine Van den Wyngaert rightly observed in her dissenting opinion:

It is factually wrong to reduce this case ... to ethnic fear and/or hatred. Such oversimplification may fit nicely within a particular conception of how certain groups of people behave in certain parts of the world, but I fear it grossly misrepresents reality, which is far more complex. It also implicitly absolves others from responsibility. ${ }^{39}$

\section{A one-way street: failure to support national prosecutions}

The prospect of a division of labour between international and national justice and the promise of international support to the reconstruction of

35 Minority Opinion of Judge Christine Van den Wyngaert, Judgment, Katanga, 7 March 2014, para. 261.

${ }^{36}$ Article 58 Decision, Ntaganda, 13 July 2012, para. 23.

37 Decision on the confirmation of charges, The Prosecutor v. Thomas Lubanga Dyilo, ICC01/04-01/06, Pre-Trial Chamber I, ICC, 29 January 2007, para. 4; Decision on the confirmation of charges, The Prosecutor v. Germain Katanga and Mathieu Ngudjolo Chui, ICC-01/04-01/07, Pre-Trial Chamber I, ICC, 30 September 2008, para. 4.

38 See United Nations, 'Final report of the Panel of Experts on the Illegal Exploitation of Natural Resources and Other Forms of Wealth of the Democratic Republic of the Congo', S/2002/1146, 16 October 2002.

39 Minority Opinion of Judge Christine Van den Wyngaert, Judgment, Katanga, 7 March 2014, para. 318. 
the national justice system were among the factors that made the ICC so attractive to most in the Congolese legal community. The October 2004 cooperation agreement between the ICC and the government of the DRC included a specific commitment for the OTP to 'cooperate with the [Congolese] courts and provide assistance to them for ... investigations, prosecutions, and any eventual trials for crimes that fall within the competent jurisdiction of the International Criminal Court'; the ICC prosecutor also committed to, 'as far as possible, facilitate such assistance by third parties' ${ }^{40}$ Immediately after the signing of the cooperation agreement, the Congolese Procureur général de la République (the chief public prosecutor) established a section in his office with a team of senior prosecutors in charge of the implementation of the cooperation mechanisms provided under the agreement.

This cooperation mechanism, however, has worked as a one-way street in favour of the ICC. While the ICC prosecutor has enjoyed unlimited access to the judicial proceedings before national courts in accordance with Article 36 of the ICC-DRC agreement, no Congolese court has been given information in the ICC's possession relevant to crimes being prosecuted in national courts. ${ }^{41}$ Moreover, the ICC has not provided national courts with the much-needed training in prosecution of complex mass crimes, even though national prosecutors and judicial police officers have consistently identified such training as a prerequisite for a more efficient fight against impunity. ${ }^{42}$ Nor has the prosecutor's commitment to helping with international assistance for the rebuilding of the Congolese justice system materialised.

In fact, the ICC has hindered progress towards the rebuilding of a functioning Congolese justice system by taking cases away from national courts. As an initial matter, it should be noted that the OTP began its investigations in Ituri, a region where the domestic criminal justice system was in comparably better condition than other conflict-affected regions. Indeed, the announcement by the OTP of the beginning of investigations in Ituri coincided with the piloting of donor-funded Programme pour la restauration rapide de la justice en Ituri ('Program for the urgent restoration of the criminal justice system in Ituri'), with the aim of putting an

40 'Judicial Cooperation between the Democratic Republic of the Congo and the Office of the Prosecutor of the International Criminal Court', Article 37, Kinshasa, 6 October 2004.

${ }^{41}$ Interviews with senior military judges (Kinshasa, August 2009).

${ }^{42}$ Mission multi-bailleurs de l'audit du système judiciaire en RDC, 'Rapport final des ateliers et du séminaire pour un programme cadre de la justice en RDC', Kinshasa, 15 November 2004 ('Mission multi-bailleurs, Rapport final'). 
end to impunity for serious crimes in the region. As the first ICC investigative teams were being deployed, local prosecutors supported through the program were making progress on their first prosecutions, which included cases against prominent leaders of local armed groups, among them Mathieu Ngudjolo. ${ }^{43}$

Most militia leaders currently in the ICC's custody were being prosecuted or had been indicted by Congolese courts at the time of their transfer to the ICC. Two of them, Lubanga and Katanga, had been arrested following the murder of nine UN peacekeepers in February 2005 and charged by Congolese military prosecutors on different counts of looting, crimes against humanity and war crimes. Until his surrender to the ICC on 17 March 2006, Lubanga had been in the custody of the prosecutor of the Kinshasa Haute Cour Militaire ('Military High Court'), the country's highest military court, though he had not yet appeared before it. Katanga had been arrested in March 2005 and an investigative judge had opened a formal investigation file against him and seven other militiamen. ${ }^{44}$

During their appearance before Congolese investigative judges on 17 June 2004 and 20 January 2006, respectively, Ngudjolo and Katanga were asked specific questions in relation to crimes committed during the attack on Bogoro in 2003 - with which they were eventually charged at the ICC. ${ }^{45}$ Six months prior to his surrender to the ICC in October 2007, Germain Katanga had appeared before the Haute cour militaire in Kinshasa, which ruled on his application for conditional release by directing the military prosecutor to complete his investigations and bring the case to trial without further delay. ${ }^{46}$ Katanga was eventually transferred to the ICC before the investigative magistrate could complete his investigation. The long delay in bringing his and Lubanga's cases to trial since they were arrested in 2005 was in part due to lack of training on the part of military investigative magistrates in investigation of complex crimes of an international nature. ${ }^{47}$ Nonetheless, the initial work in their

${ }^{43}$ HRW, 'Making Justice Work', 4.

${ }^{44}$ Haute cour militaire, File RMP No. 0121/0122/NBT/05 in the case against Germain Katanga, Goda Sukpa, Ndjabu Ngabo, Pitchou Mbodina Iribi, Masudi bin Kapinda, Lema Bahat Pelo, Philémon Manono and Bede Djokaba Lambi.

45 Judgment, Ngudjolo, 18 December 2012, para. 455; Transcripts of the pre-trial hearing in the case The Prosecutor v. Germain Katanga and Mathieu Ngudjolo Chui, 22 October 2007, ICC-01/04-01/07-T-5-ENG [22Oct2007 WT] 1/31 NB PT, 18.

${ }^{46}$ Haute cour militaire, Auditeur militaire c/ Germain Katanga et Crts, Aff. RDP 001/05, jugement du 10 avril 2007.

47 Interview with a senior investigative magistrate (Kinshasa, August 2009). 
cases had already been completed, enabling the ICC to take credit for bringing new cases without doing the hard graft of investigation that should have established the basis for charges.

Ngudjolo, meanwhile, had been charged with the kidnapping and murder of a UPC sympathiser in September 2003 and prosecuted before a civilian court of first instance in Ituri. His acquittal on 3 June 2004 was mainly due to the Congolese and UN security agencies' failure to protect the prosecution's witnesses from threats by FNI supporters, which led to the witnesses' refusal to appear in court to give evidence. ${ }^{48}$

The failure of these cases to be successfully prosecuted before national courts is but one example of opportunities the OTP missed to make good use of the prosecutor's stated vision of complementarity. Prosecutor Moreno-Ocampo could have used the cooperation and complementarity mechanisms set out in the Rome Statute and the DRC-ICC agreement to help the Congolese justice system address key obstacles to effective prosecution of war crimes in DRC: the lack of trained investigators and the lack of adequate national legislation defining the relevant crimes. ${ }^{49}$ Participants to the November 2004 national seminar on the reconstruction of the justice system in the DRC had hoped for such help, but it was not forthcoming. ${ }^{50}$

The Pre-Trial Chamber deciding on the first application for warrants of arrest against Lubanga and Ntaganda was therefore right to point out that,

[S]ince March 2004 the DRC national judicial system has undergone certain changes, particularly in the region of Ituri where a Tribunal de Grande Instance has been re-opened in Bunia. This has resulted inter alia in the issuance of two warrants of arrest by the competent DRC authorities for Mr Thomas Lubanga Dyilo in March 2005 for several crimes, some possibly within the jurisdiction of the Court ... Moreover, as a result of the DRC proceedings against Mr Thomas Lubanga Dyilo, he has been held in the Centre Pénitentiaire et de Rééducation de Kinshasa since 19 March 2005. Therefore, in the Chamber's view, the Prosecution's general statement that the DRC national judicial system continues to be unable in the sense of article 17 (1) (a) to (c) and 3, of the Statute does not wholly correspond to the reality any longer. ${ }^{51}$

${ }^{48}$ HRW, 'Making Justice Work', 8.

${ }^{49}$ For example, under the October 2004 Judicial Cooperation Agreement with the DRC, the ICC prosecutor committed to 'cooperate with national jurisdictions and provide assistance to them for those investigations, prosecutions, and any eventual trials for crimes that fall within the competent jurisdiction of the International Criminal Court'.

${ }^{50}$ Mission multi-bailleurs, Rapport final.

${ }^{51}$ Arrest Warrant, Lubanga, 10 February 2006. 
Thus, the ICC simply took over the prosecution of crimes allegedly committed by these middle-level perpetrators instead of helping the Congolese judiciary address these prosecutions directly. It sent the message that individuals and institutions involved in efforts to rebuild the Congolese justice system had no reason to speed up the pace of the reforms as long as the ICC could substitute its jurisdiction for that of national courts. It was not surprising, therefore, that to justify the Court's jurisdiction, the Congolese minister of justice (the very person in charge of implementing reforms in the justice sector) made vague reference to the 'difficulties' of completing investigations, without having to face questions as to the reasons for such difficulties. ${ }^{52}$

\section{Hit-and-run investigations}

The ICC's failure to bring charges against high-ranking commanders and for the most serious crimes was also a direct result of the OTP's strategy of conducting quick investigations with the lowest cost possible. From the outset, the OTP invested only in low-intensity and short investigations in Ituri, relying on the cooperation of the Congolese government and the UN mission in Congo, rather than on collecting direct victim testimony or using the material already collected by local NGOs for information on crimes and analysis of the cases. This system would eventually form the default operating protocol in the OTP and lead to investigative disasters elsewhere in the DRC and other countries. ${ }^{53}$

It would appear that investigations were never at the top of the ICC prosecutor's agenda from the time of the establishment of the office. While Moreno-Ocampo devoted considerable efforts and resources in establishing the impressively bureaucratic JCCD, he also put in place administrative operations and policies that had the consequence of undermining the importance and professionalism of the Investigations Division. In December 2003, for example, the prosecutor told a group of international NGOs that the investigative teams deployed to the field would be composed almost entirely of temporary staff. It is only after strong objections from some of those NGOs and senior staff in his office

52 'Statement by the DRC Government in opposition to Germain Katanga's challenge to the admissibility of his case before the ICC on the ground that he has already been the subject of proceedings by Congolese courts for the same facts', 1 June 2009, available at www.icccpi.int/iccdocs/doc/doc711960.pdf.

53 See C. De Vos, 'Investigating from Afar: The ICC's Evidence Problem', Leiden Journal of International Law, 26 (2013), 1009-1024. 
that he agreed to reconsider this initial plan. ${ }^{54}$ Among arguments put forward to counter these initial plans was the experience of other international tribunals: expertise in field investigation and proper analysis of information and evidence, which is the foundation of a sound prosecution strategy, would not be easily obtained through lightweight, undersized investigative teams.

However, the prosecutor did not completely back down from his vision of light-touch investigations. Although he eventually integrated permanent staff into the investigative teams in the DRC, his cost-efficient approach to investigations meant that investigators were sent to the field for short periods of time. Other elements of the strategy included the OTP's over-reliance on indirect evidence and the absence of nationals in the investigative teams. ${ }^{55}$ In a 15 July 2004 meeting with NGOs, the prosecutor highlighted his vision of 'a short and focused investigation' aiming at eliciting 'a limited number of witnesses'. As he explained, this investigation strategy would 'simplify witness protection' while furthering the OTP's policy of seeking 'more evidence from States, less from witnesses' and advancing his vision of 'short trials with few charges'. At the same meeting, he stressed other benefits of the strategy, including the fact that it would minimise the need for having local people in the investigative teams, thus helping avoid situations where impartiality is questionable. $^{56}$

To be fair, cost efficiency was part of the agenda that major state contributors were pushing both bilaterally and through the Assembly of States Parties to the ICC, with some threatening to withhold or cut contributions unless clear cost-efficient policies were articulated by the OTP and other organs of the Court. The principle of an independent prosecutor, however, means that such efforts by states parties to the Rome Statute could only concern decisions of a non-judicial nature. ${ }^{57}$ Indeed, in making the case for his hit-and-run investigations policy, the prosecutor was careful not to over-emphasise the cost-efficiency argument, insisting instead on a range of other factors, such as security on the

${ }^{54}$ Interviews with senior investigators in the OTP (January-March 2005).

55 'Investigative Management, Strategies, and Techniques of the International Criminal Court's Office of the Prosecutor', American University Washington College of Law War Crimes Research Office (October 2012), 1016.

56 Personal notes of a meeting with the prosecutor and the OTP officials (The Hague, 15 July 2004).

57 According to Article 112 (2) (b) of the Rome Statute, the Assembly of States Parties 'shall ... provide management oversight to the Presidency, the Prosecutor and the Registrar regarding the administration of the Court'. 
ground, quality of analysis of the situation and the value of state cooperation.

In a meeting in March 2005, for example, Moreno-Ocampo brushed aside objections from NGOs by insisting that, 'even with a small team, we can do a good investigation'. A participant in the meeting conveyed the view that the humanitarian NGO community in Ituri blamed the slow pace of investigations on the undersized investigative teams and the short periods of time they spent on the ground. The prosecutor immediately countered that 'the problem in DRC is not the size of the [investigative team], but that factions are killing each other and killing peacekeepers and witnesses'. He offered the situation in northern Uganda as proof that his strategy was working, since 'in a few months, we have had a fast and efficient investigation in Uganda with a small team of twelve..$^{58}$

In addition to security conditions, the prosecutor also thought state cooperation was more important than the size of the investigative teams or the time they spent on the ground. 'What we learned in comparing Uganda and Congo', Moreno-Ocampo explained, 'is that our life was different in Uganda because the government was more involved. We have worked longer in Congo and have less information, we need to improve cooperation [with the DRC State]. ${ }^{59}$ Since the DRC government and other state institutions, such as the newly integrated army, were populated with some of the individuals who potentially bore the greatest responsibility for the crimes committed in Ituri, such a strategy was a recipe for failure.

Two years into the investigation - as donor states, human rights groups and victims' associations impatiently waited for the first cases to be brought - the cooperation with the DRC on which the OTP had relied was so poor that it could not, by the prosecutor's own admission, elicit enough quality information on the most serious crimes committed in Ituri to bring solid charges against those most responsible. The investigative teams assigned to the Ituri situation were too undersized and too short term to generate good analysis of the intricately entangled criminal activities in this bloody part of Congo. Local NGOs and activists, who had more raw intelligence on the crimes than any other entity, were deliberately sidelined and their invaluable expertise not fully integrated into the investigative process. In such a situation the OTP was left with no

58 Personal notes of a meeting between the ICC prosecutor and NGOs (New York, 4 March 2005).

59 Personal notes of a meeting with the prosecutor and OTP officials (The Hague, 15 July 2004). 
other choice than to bring the most 'manageable' charges for the short prosecution he envisioned. Thus, to some extent, the situation was also a reaction to the growing impatience among the major states supporting the ICC, the human rights community and victims to see some movement at the Court in the form of arrests and trials.

This difficult position led to the investigators having to rely on intermediaries' for the identification of potential witnesses and the generation of contextual analysis. Much of the delay of Lubanga's trial was due to the heated debates between the prosecution and the defence over the credibility of evidence generated through intermediaries. ${ }^{60}$ The Court dismissed some of the evidence produced through the intermediary system as weak and full of contradictions. In the end, therefore, what was meant to be a short and cost-effective investigations strategy ended up causing unnecessary delays and almost caused the prosecution's case to be thrown out.

Indeed, the OTP's case against Ngudjolo was thrown out, in part after the chamber determined that the prosecutor had failed to conduct a more thorough investigation, 'which would have resulted in a more nuanced interpretation of certain facts, a more accurate interpretation of some of the testimonies and ... an amelioration of the criteria used by the Chamber to assess the credibility of various witnesses'. ${ }^{61}$ For example, as the chamber noted, the OTP failed to perform such basic investigative tasks as visiting the location where Ngudjolo lived and where the preparations of the attack on Bogoro allegedly took place. The prosecution was thus unable to provide the Court with such basic information as the distances between the relevant sites and the conditions of the roads, all elements that 'would have been useful in clarifying several witness testimonies, thereby promoting a better understanding $a b$ ovo and a more accurate assessment of the various statements' ${ }^{62}$

\section{Questioning the prosecution's independence}

All but one individual currently in ICC custody in relation to the conflict in the DRC are Congolese, although the crimes with which they have been charged were committed on territory that was at least partially under the military occupation of Uganda and by armed groups

${ }^{60}$ A detailed account of the debates is provided in C. De Vos, "Someone Who Comes Between One Person and Another": Lubanga, Local Cooperation and the Right to Fair Trial', Melbourne Journal of International Law, 12 (2011), 1.

${ }^{61}$ Judgment, Ngudjolo, 18 December 2012, para. 123. ${ }^{62}$ Ibid., para. 118. 
manipulated by the Congolese, Ugandan and Rwandan governments. President Museveni had referred the situation in the north of Uganda to the ICC only some months after Moreno-Ocampo announced his interest in investigating the crimes perpetrated in Ituri. ${ }^{63}$ The investigation of crimes committed in the Uganda-occupied district of Ituri thus unfolded during the same period as the investigation of the situation in northern Uganda, for which the OTP received the support of the Ugandan government. This support consisted, in particular, of the provision of intelligence on the Lord's Resistance Army (LRA) by the Ugandan army, which was itself implicated in the crimes in Ituri.

It has been suggested, quite convincingly, that President Museveni used the referral to, among other objectives, confer a moral ground status to the Ugandan government, to attract international support 'for a legitimate government, committed to international justice, fighting a hostis humani', and to 'make the ICC's Prosecutor dependent on the cooperation of the Ugandan government' so that 'he might hesitate to jeopardize such cooperation by charging his cooperative friends with crimes committed in neighbouring DRC ${ }^{64}$ Indeed, the Ugandan government wasted little time in signalling its intention to use the credibility it had gained on matters related to international justice to influence ICC investigations in Ituri, as well as in northern Uganda. One month after the beginning of investigations in Ituri was announced, President Museveni asked for the intervention of the UN Secretary-General for the suspension of these investigations until progress in the peace process in Ituri was irreversible. ${ }^{65}$

The investigations in Ituri and in Uganda thus became entangled with each other by a series of linked events, which, added together, made the ICC vulnerable to the charge of political manipulation by the Ugandan authorities. For several months, the Congolese press dwelt on the idea of an ICC prosecutor who 'across the board, has a selective vision of the facts and of who is guilty', justifying proceedings 'against President Bashir of Sudan, when nothing disturbs the peace enjoyed by Presidents Yoweri Museveni

63 On 16 July 2003, ICC prosecutor Luis Moreno-Ocampo announced his office had selected the conflict in Ituri, DRC, as 'the most urgent situation to be followed'. In December 2003, Ugandan president Yoweri Museveni referred the situation concerning the LRA to the ICC prosecutor.

${ }^{64}$ S. Nouwen and W. Werner, 'Doing Justice to the Political: The International Criminal Court in Uganda and Sudan', The European Journal of International Law, 21 (2010), 950.

65 'Letter from President Yoweri Katuga Museveni to H.E. Kofi Annan, Secretary General of the U.N., Re: Integration of Ituri Armed Groups', 3 July 2004 (copy on file with author). 
of Uganda and Paul Kagame of Rwanda, although both were instigators of rebellions responsible for the deaths of 6 million Congolese. ${ }^{66}$

The OTP's own strategy documents had clearly identified the risk that its efforts to secure cooperation could pose to its independence. For example, in a restatement of its policy on preliminary examinations, the OTP vowed to guard itself against the possibility that its decisions are 'influenced or altered by the presumed or known wishes of any party, or in connection with efforts to secure cooperation'. ${ }^{67}$ At the same time, however, the OTP had repeatedly indicated its preference for state referral over the use of the prosecutor's proprio motu power to initiate an investigation. This preference has been based on the assumption that a state referral is a strong indication of the state's 'political will to provide [the Prosecutor] with all the cooperation within the country that it is required to give under the Statute' ${ }^{68}$ Having candidly anticipated the likelihood of a risk to its independence from state cooperation, it is beyond understanding that the OTP did not contemplate the possibility of a state referring a situation to the Court in order to better control the investigations by a cooperation-obsessed prosecutor. ${ }^{69}$ Yet, that is exactly what seems to have happened with its very first investigation.

As the prosecutor launched parallel investigations in northern Uganda and the Uganda-occupied Congolese district of Ituri, the relations between the two countries were already bad, the DRC having sued Uganda before the International Court of Justice (ICJ) for acts of armed aggression perpetrated on the DRC's territory. The decision rendered by the ICJ made some factual findings, which should have been directly relevant to the OTP's investigation of crimes committed in Ituri. For example, the ICJ found,

[C]redible evidence sufficient to conclude that the UPDF troops committed acts of killing, torture and other forms of inhumane treatment of

66 A. Kasele, 'Quand la Cour Pénale Internationale se disqualifie', direct.cd, 27 January 2009. See 'Lubanga plaide non coupable, accuse Jospeh Kabila', Le Nouvel Observateur (daily), Kinshasa, 28 January 2009; S. Tisseyre, 'Le procès Lubanga, ou la fabrique de la justice internationale', Afribone, 28 January 2009.

67 'Policy Paper on Preliminary Examinations', OTP, ICC (November 2013), 7.

68 'Paper on Some Policy Issues before the Office of the Prosecutor - Annex', OTP, ICC (September 2003).

${ }^{69}$ Other scholars have argued that the OTP deliberately 'chased' these cases, in search of state referrals. See P. Clark, 'Chasing Cases: The ICC and the Politics of State Referral in the Democratic Republic of Congo and Uganda', in C. Stahn and M. El Zeidy (eds.), The International Criminal Court and Complementarity: From Theory to Practice (Cambridge: Cambridge University Press, 2010). 
the civilian population, destroyed villages and civilian buildings, failed to distinguish between civilian and military targets and to protect the civilian population in fighting with other combatants, incited ethnic conflict and took no steps to put an end to such conflicts, was involved in the training of child soldiers, and did not take measures to ensure respect for human rights and international humanitarian law in the occupied territories. ${ }^{70}$

In other words, it was highly likely that the Ugandan occupying troops were involved in the planning, preparation, incitement and execution of the very crimes the OTP was investigating in Ituri. Yet not a single one of the charges brought by the OTP in relation to the situation in Ituri made reference to the ICJ decision.

There was no shortage of heinous and extremely violent incidents in Ituri from which the prosecutor could build strong cases. It appears, however, that only those incidents in which Ugandan army officers played the least decisive role were picked. This looked like a trade-off: Ugandans would be shielded from prosecution over their role in crimes committed in Ituri in exchange for their cooperation in the investigation against the LRA.

A similar dynamic drove the prosecutor's approach in the DRC. In Ngudjolo, for example, the chamber was provided with sufficiently detailed evidence that the defendant was more clearly involved in the planning and organising of attacks on Mandro and Bunia on 4 and 6 March 2003, ${ }^{71}$ respectively, than he was for the attack on Bogoro on 24 February 2003. ${ }^{72}$ In addition, evidence of Ngudjolo's seniority in the command structure of the FNI Lendu militia was more detailed at the time of the Mandro and Bunia attacks than it was at the time of the Bogoro attack. At first sight, therefore, the attacks on Mandro and Bunia - both of which resulted in massacres of civilians and other Rome Statute crimes - presented the OTP with much greater chances of securing Ngudjolo's conviction than the attack on Bogoro. Yet, the OTP chose to build its case on the Bogoro attack. It was not surprising, therefore, that the chamber was later unable to establish beyond reasonable doubt that Ngudjolo 'was one of the military commanders who held

70 Congo v. Uganda), [2005] ICJ Rep., 19 December 2005, para. 211.

71 Launched two days apart, the two attacks were aimed at driving Thomas Lubanga's UPC out of its positions in these two cities. They were launched by a coalition of FNI combatants, RCD-ML's APC ('Armée Patriotic Congolaise') rebels and UPDF troops, and resulted in dozens of deaths among the local civilian populations.

72 Judgment, Ngudjolo, 18 December 2012, paras. 496-499. 
a senior position among the Lendu combatants' at the time of the attack on Bogoro. ${ }^{73}$ It is further worth noting that while there was no strong evidence of the UPDF's direct involvement in the attack on Bogoro, the chamber established that its participation in the 6 March 2003 attack on Bunia was uncontested. ${ }^{74}$

\section{Conclusion}

All good faith advocates of international justice in the DRC understood that the ICC's intervention in Congo would have limitations and face challenges of politics, infrastructure and other obstacles. One of the greatest issues in such situations has always been the management of too high expectations among different constituencies. As this chapter has sought to illustrate, however, the DRC investigation offered the ICC a unique set of potential assets for the assertion of the young institution's legitimacy. The Congolese legal community's predisposition and desire to cooperate meant that the ICC had an opportunity to develop and creatively implement a doctrine of complementarity based on a positive division of labour with national courts. Faith in international justice from ordinary people like the woman who approached me as I was walking between two classrooms in Butembo meant that ICC investigators could rely on cooperation from victims and integrate their stories into the broader narrative of the crimes committed in the DRC.

Yet, the prosecutorial strategy implemented led Prosecutor MorenoOcampo to give priority to the views of states and the demands of international organisations over the needs of the victims. The concept of 'positive complementarity' has resonance in the West among the representatives of international human rights organisations. However, its implementation was frustrated by an obsession with the need to obtain the cooperation of the states where the ICC's investigations were taking place. The idea to set up small investigation teams and to deploy them for short periods was applauded by contributing states and international agencies impatient to see the beginning of the trials. Yet the emphasis on cost saving prevented the ICC's investigators from spending essential time with the victims and reigniting their faith in the international justice system.

Prosecutor Bensouda has signalled her intention to operate a radical reversal of this approach to investigations. Among important changes

73 Ibid., para. $501 \quad{ }^{74}$ Ibid., para. 452. 
announced in the OTP's new strategic plan are the replacement of focused investigations with in-depth, open-ended investigations; the enhancement of the OTP's analytical capabilities, including through a set of guidelines currently being developed for NGOs wanting to assist the office in the area of investigations; the increase of its field presence wherever possible and the enhancement of complementarity and cooperation in support of national efforts under preliminary examination or investigation. ${ }^{75}$ These new changes were announced in October 2013, as the OTP was preparing for the confirmation of charges hearing in the case against Bosco Ntaganda, who surrendered himself to the Court in March 2013. Ntaganda's trial will thus provide the OTP the opportunity to test its commitment to more in-depth and open-ended investigations aimed at collecting trial-ready evidence, which presents crimes committed in the DRC in a broader, more complex context than has been the case.

75 See OTP Strategic Plan, June 2012-2015 (strategic goals 1, 2, 4). 


\section{The justice vanguard}

The role of civil society in seeking accountability for Kenya's post-election violence

NJONJO MUE AND JUDY GITAU

\section{Introduction}

A key feature of the International Criminal Court's (ICC) intervention in Kenya has been the critical role played by civil society organisations (CSOs) in promoting accountability following the election violence of 2007-2008. ${ }^{1}$ Kenyan civil society has been historically known for enabling political, legislative and institutional reform. ${ }^{2}$ By way of trade unions, religious bodies and non-governmental and human rights organisations, civil society in post-independence Kenya has actively checked the excesses of the national government and provided an alternative voice where the government constrained the opposition, both in law and in practice. ${ }^{3}$

Accountability for these violations has been particularly important in light of the continued history of electoral violence in Kenya. ${ }^{4}$ This history owes to many factors, including a raft of amendments to Kenya's Independence Constitution, which had effectively created an imperial presidency. ${ }^{5}$ Politicians therefore increasingly campaigned on an ethnic

${ }^{1}$ C. Bjork and J. Goebertus, 'Complementarity in Action: The Role of Civil Society and the ICC in Rule of Law Strengthening in Kenya', Yale Human Rights and Development Journal, 14 (2011), 205.

2 See, e.g., M. Mutua (ed.), Human Rights NGOs in East Africa: Political and Normative Tensions (Philadelphia: University of Pennsylvania Press, 2009).

${ }^{3}$ D. Throup and C. Hornby, Multi-Party Politics in Kenya: The Kenyatta and Moi States and the Triumph of the System in the 1992 Election (Oxford: James Currey Publishers, 1998).

${ }^{4}$ Kenya had previously experienced electoral violence in 1992, as well as in 1997. See M.S. Kimenyi and N. Ndungu, 'Sporadic Ethnic Violence Why Has Kenya Not Experienced a Full-Blown Civil War?' in P. Collier and N. Gambanis (eds.), Understanding Civil War: Africa (Washington, DC: The World Bank, 2005).

${ }^{5}$ Commission of Inquiry into Post-Election Violence, 'Report of the Commission of Inquiry into the Post-Election Violence' (October 2008) ('CIPEV Report'). 
platform, rallying supporters into ethnic blocs for their community's 'turn' at the helm and access to resources. Those who attained power maintained the status quo using state agencies to suppress dissenting voices, ${ }^{6}$ or through outsourcing violence to militia gangs of unemployed youth to terrorise the opposition. ${ }^{7}$ Those who had not attained power turned to communal mobilisation of violence. A culture of impunity was thus entrenched, as 'the beneficiaries of the violence had no incentive to give it up and every incentive to avoid the consequences of past violence by holding onto power'. ${ }^{8}$

The post-election violence of 2007-2008 was a culmination of this political culture in Kenya. With the election results incredibly close, the violence was the worst on record: 1,133 persons were recorded killed, over 900 sexually violated, 650,000 physically displaced from their homes and countless others suffered grievous physical harm. Scholarly accounts have attributed the underlying causes to multiple factors, such as privatised, diffused extra-state violence; ethnic clientelist parties; and the highstakes prize of an imperial presidency. ${ }^{9}$ An uneasy calm was restored in the country following the intervention of the international community. The visit of President John Kufuor, the then Chair of the African Union, to Kenya in January 2008 resulted in the creation of a Panel of Eminent African Personalities to assist Kenyans in finding a peaceful solution to the crisis. Under the auspices of the panel, President Mwai Kibaki's Party of National Unity (PNU) and Raila Odinga's Orange Democratic Movement (ODM) started negotiations on 29 January 2008 through the Kenya National Dialogue and Reconciliation Committee (the KNDR or 'National Dialogue'). ${ }^{10}$

Owing to the international alarm caused by the nature and the magnitude of the violence, there was political will to facilitate reform for institutions and put in place transitional justice measures. However, there was little likelihood of the government establishing an accountability mechanism for the violations, and efforts to establish such a

${ }^{6}$ D. Waweru, 'DIY Violence is Corrosive for Nationhood', Oxford Transitional Justice Research: Debating International Justice in Africa (OTJR Collected Essays, 2008-2010), 92 (Waweru, 'DIY Violence').

7 D. Branch, 'The Normalisation of Violence', Oxford Transitional Justice Research: Debating International Justice in Africa (OTJR Collected Essays, 2008-2010), 90; CIPEV Report.

${ }^{8}$ Waweru, 'DIY Violence'.

9 See generally S.D. Mueller, 'The Political Economy of Kenya's Crisis', Journal of Eastern African Studies, 2 (2008), 185; Waweru, 'DIY Violence'.

10 'National Accord Agenda', National Dialogue \& Reconciliation. 
measure were strongly opposed. Human rights organisations therefore took on the multifaceted role of collecting and collating information regarding the violence for possible future legal action, generating social discourse concerning options for justice for the victims, providing civic education to the public concerning this role and even leading the accountability process once the investigation and prosecution of the violations commenced at the ICC. These actions resulted in a backlash from the Kenyan state, the latest wave of which has included legislation attempting to limit the finances of these organisations. ${ }^{11}$ The troubled history of the ICC's intervention in Kenya is thus also one of domestic contestation between the state and CSOs.

Written from our perspective as two human rights practitioners who have been deeply engaged in the response of national-level CSOs to the ICC's intervention, this chapter examines the different roles played by civil society leading up to and including the trial phase of the Kenyan cases before the ICC. As the chapter will illustrate, Kenyan civil society has played a vital role in the context of the ICC's intervention, beginning with the establishment of Kenyans for Peace with Truth and Justice (KPTJ), a coalition of over thirty Kenyan and East African legal, human rights and governance organisations, that was convened in the immediate aftermath of the election debacle. ${ }^{12}$ Drawing upon direct experience of civil society advocacy and interviews with partner organisations, it illustrates the diverse practices of the Court's in-country partners, as well as their political implications.

\section{Pre-investigation period}

\section{Mapping}

On 28 February 2008, then-president Mwai Kibaki and opposition leader Raila Odinga signed a power-sharing agreement to attempt to bring an end to the post-election violence. ${ }^{13}$ The agreement, which was christened the 'Kenya National Dialogue and Reconciliation Process', contained terms for a 'Grand Coalition' government incorporating Kibaki's PNU

${ }^{11}$ Public Benefits Organisations Act of 2013, Miscellaneous Bill No. 18 of 2003, requires CSOs to declare their financial sources above 15 per cent. See R. Rajab, 'Kenyan NGOs Threaten More Protests Over Controversial Bill', Sabahi, 25 November 2013.

12 'Who is KPTJ?', Kenyans for Peace with Truth \& Justice, available at http://kptj.africog. org/who-is-kptj.

${ }^{13}$ See 'The Crisis in Kenya', International Coalition for the Responsibility to Protect, available at www.responsibilitytoprotect.org/index.php/crises/crisis-in-kenya. 
and Odinga's ODM. It also contained an agreement to immediately stop the violence and laid out a road map for humanitarian response, as well as institutional and legislative reforms aimed at preventing future atrocities. ${ }^{14}$ This was to be accomplished through institutional and legislative reform, as well as the establishment of several commissions of inquiry to investigate and address issues of justice, accountability, governance and the rule of law. ${ }^{15}$

It was apparent, however, that there was a lack of goodwill in judicial state organs in pursuing accountability for the electoral violence. In the aftermath, the office of the attorney general investigated and prosecuted a few cases before the law courts. ${ }^{16}$ However, these cases were not only of low-level perpetrators of the violence but were also limited to minor offences. The investigations and prosecutions eventually stalled altogether, supposedly for lack of evidence and/or in anticipation of the ICC or the establishment of a special tribunal. ${ }^{17}$

Prior to any national or international bodies being mandated to investigate the post-election violence, and before the degradation and adulteration of evidence and information, human rights organisations were on the ground collecting and collating data in the most affected regions. This 'mapping' exercise was intended to assist in preparing prosecutorial initiatives. It provided a sense of the nature of the crimes perpetrated, the geographical location of the crimes, who the victims were and the suspected identity of the perpetrators. The Kenya National Human Rights Commission (KNHCR) conducted one of the key mapping exercises, deploying teams of trained investigators to collect information from eight regions of Kenya that had been worst hit by the violence. ${ }^{18}$ These

14 'Kenya National Dialogue and Reconciliation Platform', www.dialoguekenya.org/agreements.aspx.

${ }^{15}$ N. Mue, 'Advocating Justice: Civil Society and Transitional Justice in Africa', Kenya Case Study: African Transitional Justice Research Network Workshop (Johannesburg, South Africa, 30-31 August 2010).

16 'Turning Pebbles: Evading Accountability for Post-Election Violence in Kenya', Human Rights Watch Report (December 2011) (HRW, 'Turning Pebbles'); 'Report to the Attorney-General by the Team on the Review of Post-election related violence in Western Nyanza, Central, Rift Valley, Eastern, Coast and Nairobi provinces' (February 2009) ('Report to the Attorney-General'), also cited in Request for Authorisation of an Investigation Pursuant to Article 15, Situation in the Republic of Kenya, ICC-01/09, PreTrial Chamber II, ICC, 26 November 2009 ('Prosecutor's Article 15 Request').

${ }^{17}$ HRW, 'Turning Pebbles'.

18 'On the Brink of the Precipice: A Human Rights Account Of Kenya's Post 2007 Election Violence', Kenyan National Commission on Human Rights (August 2008) (KNCHR, 'On the Brink of the Precipice'). 
teams sought to identify the specific human rights violations perpetrated and the responsibility of the state in response. The team also sought to analyse the criminal responsibility of the alleged perpetrators within the framework of Kenyan domestic law, as well as the state's international law obligations. This would later formulate the recommendations made to the national and international authorities for further action.

The information gathered only met a prima facie standard; however, the process gave a sense of the scale and pattern of the violations, and also identified potential leads and sources of evidence. It demonstrated the magnitude of the violence through introducing terminologies such as 'crimes against humanity'. Upon the establishment of the Commission of Inquiry into the Post-Election Violence (CIPEV), popularly referred to as the 'Waki Commision' after its chairperson, human rights organisations presented their findings before the commission. Part of these presentations included legal opinions and international best practices drawn from analogous situations and international human rights networks in order to accord the Waki Commission all options available towards ensuring accountability. ${ }^{19}$ The analysis of the raw data collected had indicated that the violations amounted to international crimes, and specifically, crimes against humanity. ${ }^{20}$ Presenting the results of the mapping therefore included a presentation of possible options for accountability within Kenya's legal framework, including international obligations drawn from international treaties like the ICC Rome Statute.

CSOs were concerned about the limited time available to the Waki Commission, whose mandate was only for three months, between May and August of 2008. ${ }^{21}$ They were further concerned about the nonenforcement of the outcome of previous commissions that had also investigated incidents of electoral violence. ${ }^{22}$ These presentations and recommendations to the Waki Commission included a recommendation for an ICC intervention, as Kenya had ratified the Rome Statute and bore an international obligation to domestically prosecute the international crimes committed on its territory.

These presentations bore fruit, as a key recommendation of the Waki Report was the establishment of a domestic special tribunal to try those responsible for the worst abuses. Failing that, the commission would submit its findings to the ICC prosecutor through the chief mediator of Kenya's

${ }^{19}$ Ibid. ${ }^{20}$ Ibid. ${ }^{21}$ CIPEV Report.

22 See 'Report of the Judicial Commission Appointed to inquire into Tribal Clashes in Kenya' (Akiwumi Report, 1999); 'Report of the Parliamentary Select Committee to investigate Ethnic Clashes in Western and other parts of Kenya' (Kiliku Report, 2006). 
peace process, former UN secretary-general Kofi Annan. ${ }^{23}$ The commission forwarded Annan a sealed envelope containing the names of the top alleged perpetrators of post-election violence, largely believed to be high-level politicians, along with numerous boxes of evidence. ${ }^{24}$ If the government did not follow the commission's recommendation to set up a hybrid 'Special Tribunal for Kenya' by 30 January 2009, Annan was requested to forward the envelope and the evidence to the ICC, which he eventually $\operatorname{did}^{25}$

\section{Options for accountability}

By the time of the ICC's involvement, a culture of impunity had become entrenched in Kenyan society. There was very little faith in the justice sector and many presumed the 2007-2008 violence could be swept under the carpet once the political power-sharing agreement had been signed. Part of the trigger to the violence was the refusal by the opposition leadership to seek resolution of electoral disputes in court, which resulted in its supporters seeking justice in the streets. ${ }^{26}$ The executive controlled the judiciary, determining appointments to and dismissal from this institution. ${ }^{27}$ The CIPEV findings also adversely implicated the police as having been part of the violence, even as they were mandated to carry out investigations for violations. ${ }^{28}$ The case of Edward Kirui is illustrative. ${ }^{29}$ In this case, a police officer was recorded on a national television camera shooting down two unarmed civilians in the course of the postelection violence. ${ }^{30}$ The case was dismissed, however, due to what has since been referred to as a 'mix up' in evidence. ${ }^{31}$

${ }^{23}$ C.L. Sriram and S. Brown, 'Kenya in the Shadow of the International Criminal Court: Complementarity, Gravity and Impact', International Criminal Law Review, 12 (2012), 219, 224 (Sriram and Brown, 'Kenya in the Shadow of the ICC').

${ }^{24}$ Ibid.; CIPEV Report, 18.

25 Sriram and Brown, 'Kenya in the Shadow of the ICC', 224. ${ }^{26}$ CIPEV Report.

27 Government of Kenya, 'Final Report of the Task Force on Judicial Reform' (Government Printer, 2010).

${ }^{28}$ CIPEV Report.

${ }^{29}$ Republic v. Edward Kirui, [2010] eKLR, High Court Criminal Case Number 9 of 2008.

30 C. Gitari, 'The Search for a Domestic Justice Process in Kenya', Rule of Law Report, The International Commission of Jurists - Kenya Section (2011).

${ }^{31}$ Proposed Amicus Curiae Observations by the Kenyan Section of the International Commission of Jurists Pursuant to Rule 103 of the Rules of Procedure and Evidence, The Prosecutor v. William Samoei Ruto, Henry Kiprono Kosgey and Joshua Arap Sang (The Prosecutor v. Ruto et al.), ICC-01/09-01/11, and The Prosecutor v. Francis Kirimi Muthaura, Uhuru Muigai Kenyatta and Mohammed Hussein Ali (The Prosecutor v. Muthaura et al.), ICC-01/09-02/11, ICC, 27 April 2011 ('Proposed Amicus Curiae Observations by ICJ-Kenya in Ruto et al. and Muthaura et al.'). 
The threat of an ICC intervention raised in the Waki Report resulted in the government publishing a bill to initiate a constitutional amendment that sought to entrench a special tribunal within the Kenyan Constitution. ${ }^{32}$ Parliamentarians quickly (if narrowly) thwarted this effort, defeating the bill on the floor of the National Assembly. ${ }^{33}$ Subsequent attempts to develop a legislative framework for a special tribunal were defeated at the deliberation stage within the national cabinet. ${ }^{34}$ Ministers rejected the proposed laws because the president would not be immune to the prosecutorial process, he would not have the prerogative to pardon accused persons, and the attorney general could not terminate proceedings within the proposed special tribunal. The Ministry of Justice, National Cohesion and Constitutional Affairs lobbied members of parliament to establish the tribunal, this time proposing it as a division within the High Court. ${ }^{35}$ This initiative also failed, as did a final attempt at establishing a special tribunal through a private member's motion. When one parliamentarian, MP Gitobu Imanyara, tabled a bill to establish a special tribunal for Kenya through a constitutional amendment, members of parliament walked out, ensuring an artificial lack of quorum. This happened on two occasions, after which the bill was never reintroduced in parliament. ${ }^{36}$

On the surface, it was presumed that the Waki Report would be shelved and the country would move on, as had been the case with previous reports. However, this time proved different: following the state's unwillingness to establish its own accountability mechanism, the ICC intervened. Even though Kofi Annan had granted two more extensions before submitting CIPEV's list of suspects and evidence to the ICC, the government did not, as noted, reintroduce legislation. The Office of the Prosecutor (OTP) also engaged in discussions with the government, in an attempt to convince the officials to initiate domestic proceedings with a carrot-and-stick approach. ${ }^{37}$ In the end, this proved unsuccessful:

32 The Special Tribunal for Kenya Bill, 2009.

33 J. Ngirachu, 'How MP's Frustrated All Efforts to Set Up Local Special Tribunal', Daily Nation, 13 February 2013.

34 'How Kenya Handled Local Tribunal Process', Daily Nation, 17 September 2013.

35 'Securing Justice: Establishing a Domestic Mechanism for the 2007/08 Post Election Violence in Kenya', Kenyans for Peace with Truth \& Justice and Kenya Human Rights Commission (May 2013).

36 'A Road Less Travelled: Parliamentary approaches to conflict prevention, reconciliation and peace building', Annual Parliamentary Hearing (United Nations Headquarters, 6-7 December 2012), available at www.ipu.org/splz-e/unga12/kenya.pdf.

37 Sriram and Brown, 'Kenya in the Shadow of the ICC', 224. 
Annan handed over the Waki envelope and evidence to the OTP in July 2009. Later that month, after the cabinet still failed to agree on a new legislation, the government announced it would dispense with plans for a hybrid tribunal and instead seek justice through the ordinary court system.

In large measure, then, civil society introduced the international criminal justice option into public discourse concerning accountability for the post-election violence. Indeed, human rights organisations responded to the violence by convening stakeholder forums in which options for justice were interrogated, including international options. A jurist colloquium brought together Kenyan jurists and international legal experts to generate possible road maps to justice. ${ }^{38}$ Furthermore, an emphasis on the large numbers of victims of sexual and gender-based violence drew female advocates to apply to be counsel before the ICC. ${ }^{39}$

\section{Witness protection}

Before 2010, the witness protection programme in Kenya was a minor department within the office of the attorney general. ${ }^{40}$ Potential witnesses to the violations in 2007-2008 therefore could not be safely protected under this regime. Several state officials and high-ranking political figures had been adversely mentioned both under the Waki Commission report as well as in the KNHRC report on the post-election violence. ${ }^{41}$ The latter also contained a list of suspected perpetrators and called on the state to follow through with the investigation and prosecution of perpetrators in line with its domestic and international obligations. ${ }^{42}$ Given the weaknesses of the Witness Protection Unit (WPU) as constituted, however, it was highly doubtful that it could offer any protection to persons under threat due to information they may have held against high-ranking officials.

Civil society groups adopted a dual approach to this challenge. First, the better-equipped organisations provided temporary protection to

${ }^{38}$ ICJ-Kenya conference series on options for justice culminated in the launch of a publication: G. Musila and W. Kaguongo (eds.), Judiciary Watch Report: Options for Justice in Kenya: Addressing Impunity and Options for Justice in Kenya - Mechanisms Issues and Debates (Nairobi: The Kenyan Section of the International Commission of Jurists, 2008),

39 Ibid. vol. III.

40 Witness Protection Act, 2006, No. 16 of 2006; 'Critique of the Witness Protection Act and Amendment Bill', The Kenyan Section of the International Commission of Jurists (ICJKenya) (2008).

${ }^{41}$ CIPEV Report; KNCHR, 'On the Brink of the Precipice'.

${ }^{42} \mathrm{KNCHR}$, 'On the Brink of the Precipice'. 
victims and potential witnesses pending comprehensive investigation and verification. Although such an action proved dangerous to members of staff of these institutions - in effect, they served as an informal network of protection providers - and some of the victims and witnesses proved unreliable, this action was a temporary measure aimed at providing safety for genuine victims and witnesses, some of whom were severely injured and required medical attention. As with the mapping exercise, the legal threshold used was one of prima facie, with the understanding that subsequent investigation by the ICC would establish the veracity of the evidence if it chose to proceed with those witnesses and secure them through their own witness support systems. Second, civil society engaged with the state by offering both technical and material support towards legislative reform to accord structural and financial independence to the national WPU. ${ }^{43}$ Through the establishment of a technical team drawing on expertise from the United Nations Office on Drugs and Crime, these organisations sought to implement international best practices and equip state officials who could potentially oversee such an agency.

The culmination of this effort was the Witness Protection Amendment Act 2010, which created a largely independent agency to oversee the protection of witnesses to the post-election violence, in addition to other grave crimes. The shortcomings of the legislation are still the subject of much advocacy among Kenyan civil society. The key drawback is the establishment of a board comprising key government officials to oversee the running of the agency. ${ }^{44}$ Such a structure risks compromising the security of the witnesses protected under this regime and has led to suspicions concerning the agency's viability.

\section{Pre-trial period}

\section{Intermediaries}

Human rights organisations played a key role as intermediaries in the pre-trial stage of the Kenyan cases before the ICC. ${ }^{45}$ Although the ICC only issued guidelines on intermediaries in $2014,{ }^{46}$ the Rome Statute makes no reference to third parties and their interaction with the ICC. Likewise, the Rules of Procedure and Evidence provide for non-

43 'Critique of the Witness Protection Act and Amendment Bill', ICJ-Kenya. ${ }^{44}$ Ibid.

${ }^{45}$ On this point, see further the discussion of intermediaries by Clancy in this volume.

46 'Guidelines governing the Relations between the Court and Intermediaries: for the Organs and Units of the Court and Counsel working with intermediaries', ICC (March 2014). 
governmental organisations to facilitate the registration of victims for participation in Court process, as well as providing protection to third parties at risk as a result of Court activities.

The work of civil society intermediaries has also guided the OTP, which relied heavily on the reports of human rights organisations in its application to the ICC to open investigations into Kenya. ${ }^{47}$ Once the OTP was authorised to investigate, human rights organisations continued to work as intermediaries, often providing social and political context for the investigations. To this end, a majority of human rights-oriented CSOs met annually with the panel of eminent persons, chaired by Kofi Annan, which had obtained an extension in its mandate. They also met regularly with stakeholders, including the government, media, citizen representatives and CSOs, in order to gauge the pace of implementing the relevant agenda items that had been agreed upon in the national accord.

These meetings provided an opportunity for Kenyan CSOs to update Court representatives on developments concerning the national accord agreements. The caucuses also included an assessment of accountability for perpetrators and protection of witnesses and victims of the postelection violence. It became apparent that, as the cases progressed, witnesses felt intimidated, having confided information to provincial administrators as well as grassroots civil society groups. These platforms allowed ongoing communication through the framework of KNDR and, from time to time, directly though the outreach wing of the ICC, which helped to provide the Court with social and political context. ${ }^{48}$ These communication channels proved particularly important where victims and witnesses could not access the ICC directly.

Kenyan CSOs have also worked as intermediaries between victim communities and relevant divisions of the Court. When the ICC prosecutor announced the list of individuals against whom charges would be brought in December 2010, Kenyan civil society groups such as Kituo cha Sheria and the International Center for Policy and Conflict embarked on the registration of victims for purposes of victim participation. ${ }^{49}$ The engagement of local civil society ensured the registration of most victims, who ordinarily would not be aware of the process. As a result, the number

47 Prosecutor's Article 15 Request, 3.

${ }^{48}$ See Kenya National Dialogue and Reconciliation Platform, available at www.dialoguekenya.org/index.php/reports/monitoring-reports.html.

49 'Victims' Rights to participate and seek reparations before the ICC', REDRESS, Information for Victims of Violence (10 June 2013). 
of victims registered in the Kenyan cases is relatively high in comparison to other cases before the ICC.

\section{Outreach programme}

Although the ICC invests in an outreach unit in Kenya, its impact is small in comparison to the size of the country, the target audience and the domestic appetite for information about the Court. This also provided an avenue for correcting misunderstandings about the role of the ICC. CSOs under the umbrella of KPTJ, as well as in their own individual capacities, undertook to educate the general population on the process and procedure of the ICC, as well as on the nature of the cases before the Court. ${ }^{50}$

After Prosecutor Moreno-Ocampo announced the investigation into the situation in Kenya, Kenyans largely believed that the ICC had the capacity to, and indeed would, investigate and prosecute all perpetrators of the 2007-2008 post-election violence. Civil society explained the statutory and financial constraints of the ICC, and the OTP's decision to prosecute only those bearing the greatest alleged responsibility for the post-election violence. Civil society thus had a role not only to 'manage' public expectations, but also to explain the enduring need for a domestic judicial mechanism to prosecute the mid-level and lower-level perpetrators. This role in civic education included partnerships with the media in order to have the widest reach possible, as well as to encourage a national debate on the intervention of the ICC, its possible impact and the function of its processes.

\section{Guardians of the ICC process}

After the prosecutor revealed the names of the six original accused, the Kenyan government began a concerted effort to prevent a trial from taking place. Four of the Kenyan government's larger efforts to thwart the ICC process were as follows. First, members of parliament passed a unanimous motion to withdraw Kenya from the Rome Statute. ${ }^{51}$ Although the motion was non-binding, it set the tone for the government's subsequent actions. Second, the government tried to rally countries within the African Union (AU) to request the ICC to defer the cases or to refer them back to Kenya. Part of the narrative before the AU was

50 See, e.g., 'ICC and Kenya - Understanding the Confirmation of Charges Hearing', KPTJ Report, Africa Centre for Open Governance (September 2011).

51 'Lawmakers vote to withdraw from Rome Statute', Coalition for the International Criminal Court. 
that, although Kenya had the ability to address the violations that had been perpetrated, the ICC was imposing its regime upon Kenya. The AU Summit first endorsed Kenya's deferral request on 14 January 2011 and subsequently made its own deferral request to the UN Security Council in July 2011, but its efforts were unsuccessful. ${ }^{52}$

The government also invoked Article 16 of the Rome Statute, directly requesting the Security Council to defer the cases based on the claim that they posed a threat to international peace and security. Prior to the filing of this application, the then vice president engaged in 'shuttle diplomacy', particularly in African countries that were members of the Security Council at the time, seeking to garner support for this application. Finally, in March 2011, the Kenyan government challenged the admissibility of the cases before the Court pursuant to Article 19 of the Rome Statute, requesting that the cases be declared inadmissible, and arguing that the adoption of the new constitution and associated legal reforms had opened the way for Kenya to conduct its own prosecutions for the post-election violence. ${ }^{53}$

In acting as the vanguard to the accountability process, civil society responded to each of these advances. Using its platform in the media, KPTJ member organisations explained that withdrawal from the ICC would not change the situation: a formal withdrawal would only take effect after a year and any case already within the ICC's ambit could not be withdrawn. ${ }^{54}$ The alternative for Kenyans would be impunity, not only concerning the immediate violations perpetrated in the post-election violence but also with any other equivalent violation. As a result, the larger public remained supportive of the ICC. ${ }^{55}$

Civil society used several platforms to respond to the government's efforts to obtain a deferral at the AU. In addition to the non-governmental

52 Despite the deferral request, the AU refrained from issuing a non-cooperation instruction to member states. Decision On The Implementation of the Assembly Decisions on the International Criminal Court - Doc. Ex.Cl/670(XIX)', AU Assembly: Assembly/Au/ Dec.366 (XVII) (Malabo, July 2011).

53 Application on Behalf of the Government of the Republic of Kenya Pursuant to Article 19 of the ICC Statute, The Prosecutor v. Ruto et al., ICC-01/09-01/11, and The Prosecutor v. Muthaura et al., ICC-01/09-02/11, ICC, 31 March 2011 ('Article 19 Application').

${ }^{54}$ Under Article 127 of the Rome Statute, withdrawal can only take effect one year after the receipt of notification of withdrawal by the UN Secretary-General and withdrawal does not discharge a state's obligations undertaken while a state was party to the Statute, including its duty of cooperation, in regard to criminal investigations and prosecutions begun prior to the withdrawal taking effect.

55 T. Maliti, 'Polls: Support for ICC remains high, but fear of violence has increased', International Justice Monitor (19 January 2012); T. Maliti, 'Two opinion Polls show support for ICC drops in Kenya', International Justice Monitor (31 July 2013). 
forum held prior to the AU's seventeenth summit, ${ }^{56}$ NGOs used their regional networks to circulate a memorandum/resolution explaining in detail the violations that had actually occurred in Kenya and the government's lethargic reaction to addressing any of the violations. Observations and recommendations were then sent to the governments under which the various CSOs were based. Using civil society in different countries, this network brought the circumstances in Kenya to the attention of various governments and called upon them to comply with their international obligations.

The request for a deferral required the prosecution of the cases to represent a threat to international peace and security under the UN Charter. ${ }^{57}$ CSOs embarked upon a diplomacy campaign of their own, specifically targeting members of the Security Council to inform them of the violations that had been perpetrated in Kenya and the impunity that had prevailed as a result of the high stature of the alleged perpetrators. In the end, the Security Council did not grant the deferral. A subsequent attempt, brought in November 2013, also failed. ${ }^{58}$

The fourth challenge by the Kenyan government to the ICC trial process was its admissibility challenge. This application broadly argued that, since Kenya had promulgated a new constitution in 2010, any effort to remedy the institutional failures that had led to the violence, the judiciary would be (and indeed was being) reformed. ${ }^{59}$ Police reform would also be undertaken along with the entire justice sector; as a result, Kenya was willing and capable to prosecute perpetrators of the postelection violence. In a bid to participate in this process and shed light on the factual position on the ground, the Kenyan section of the International Commission of Jurists (ICJ-Kenya) sought to be enjoined as amicus curiae to the admissibility challenge hearing. ${ }^{60}$ ICJ-Kenya's application was denied, although the ICC also ruled against the

${ }^{56}$ Observations and Recommendations on the International Criminal Court and the African Union in advance of the 17th African Union Summit (30 June-1 July); 'Advancing International Criminal Justice in Africa: State Responsibility, the African Union and the International Criminal Court Conference Report', Towards an Effective Advocacy Response, Centre for Citizens' Participation on the African Union, Trust Africa and MacArthur Foundation (Nairobi, 14-16 November 2011).

57 Article 16, Rome Statute.

58 Security Council: bid to defer International Criminal Court cases of Kenyan leaders fails', 15 November 2013, available at www.un.org/apps/news/story.asp? NewsID=46499\#. VF_H10vYTyB.

59 Article 19 Application.

${ }^{60}$ Proposed Amicus Curiae Observations by ICJ-Kenya in Ruto et al. and Muthaura et al. 
admissibility challenge. The Court found that whilst judicial reforms were indeed constitutionally mandated, a successful admissibility challenge requires the government to either have investigated or prosecuted, or be in the process of investigating or prosecuting, the same persons indicted before the ICC for 'substantially the same' conduct. ${ }^{61}$

In fact, the Kenyan government had only prosecuted a few cases of the mid-level and low-level perpetrators due to what it said was a 'lack of evidence'. While the Office of the Attorney General had investigated and prosecuted a few cases before the law courts immediately following the election violence, these cases were restricted to low-level perpetrators and the charges were also limited to simple offences. Subsequently, the investigations and prosecutions stalled altogether, supposedly for lack of evidence and in anticipation of the ICC or the establishment of a special tribunal. ${ }^{62}$ A broader picture is better given by an internal audit report conducted under the attorney general in 2009, which concluded that the office had shelved two-thirds of the cases under investigation. ${ }^{63}$

\section{Litigation as a civil society tool}

While the Kenyan government has insisted that it has and will continue to cooperate with the ICC, the OTP has consistently complained about state non-cooperation. ${ }^{64}$ The prosecutor has alluded to the fact that, while formally cooperating, the government has found sophisticated

${ }^{61}$ Judgment on the Appeal of the Republic of Kenya against the Decision of Pre-Trial Chamber II of 30 May 2011 entitled 'Decision on the Application by the Government of Kenya Challenging the Admissibility of the Case Pursuant to Article 19(2)(b) of the Statute', The Prosecutorv. Muthaura et al., ICC-01/09-02/11 OA, Appeals Chamber, ICC, 30 August 2011.

${ }^{62}$ HRW, 'Turning Pebbles'.

${ }^{63}$ Report to the Attorney General; also cited in Prosecutor's Article 15 Request. The report showed that, 'in Rift Valley Province, the investigating team had forwarded 504 cases to the Attorney General who ordered 42 of them be tried to logical conclusion. There was no further information concerning the 42 cases proposed for prosecution. In Western Province, 23 files involving 51 accused persons were forwarded to the Attorney General who decided 16 should proceed to trial and seven files be closed for lack of evidence. In Nyanza, 21 files were forwarded to the Attorney General. 18 were closed for lack of evidence. In Central Province, only two files were made available to the team to peruse. The Attorney General ordered that the cases be investigated and submitted to him afresh. Eastern Province had no case of post-election violence reported. In Nairobi the Police and Criminal Investigation Department curiously failed to submit any files. In the Coast province 6 files were perused involving 79 people.'

64 'Kenyan Government Not Cooperating with ICC - Bensouda', London Evening Times, 26 October 2012. 
ways of undermining the ICC's work. ${ }^{65}$ Early during the investigation, the OTP was denied access to relevant security officers for interviews when an injunction was obtained to block the process. The Kenyan government was slow to appeal the decision of the local court, and at the time of writing, the matter remained unresolved.

Early signs of impending non-cooperation were also evident when Kenya invited and hosted Sudanese president Omar al-Bashir, despite the Court having issued an arrest warrant against him for genocide and crimes against humanity. ${ }^{66}$ Having both ratified and domesticated the Rome Statute, Kenya had an international obligation to arrest Bashir, but the government failed to comply with its Rome Statute obligations by declining to enforce the standing arrest warrants. On a subsequent occasion, when President Bashir was expected in Nairobi for a meeting of a regional body, ICJ-Kenya filed an application before the Kenyan High Court, seeking the enforcement of the arrest warrant and was successful in this regard. ${ }^{67}$ President Bashir was prevented from visiting and the venue of the meeting had to be changed at the last minute. In addition to the immediate deterrent effect of this decision, it also established an important precedent in the country regarding the enforcement of decisions of international judicial organs.

\section{Trial phase}

\section{Advocacy}

Following the confirmation of charges hearing in late 2011, charges were confirmed against William Ruto and Joshua Sang and, in a separate case, against Francis Muthaura and Uhuru Kenyatta. ${ }^{68}$ Challenges were immediately apparent. At the time, Mr Muthaura (against whom the charges were later withdrawn) held the position of head of civil service, while $\mathrm{Mr}$ Kenyatta was deputy prime minister and finance minister. Other than sitting in cabinet, these two accused were also part of the government's organs determining national policy and responses on foreign relations, including cooperation with the ICC. ${ }^{69}$ Furthermore, their positions within

65 Ibid. 66 'Press Statement', KPTJ (2 December 2011).

${ }^{67}$ Kenya Section of The International Commission of Jurists v. Attorney General \& Another, [2011] eKLR, Misc. Criminal Application No. 685 of 2010.

68 Prosecutor's Article 15 Request. The charges against both Muthaura and Kenyatta were later withdrawn in March 2013 and December 2014, respectively.

${ }^{69}$ I. Ongiri, 'Pressure Piles on Kibaki to Let Go Muthaura Uhuru', Standard Media, 10 September 2011. 
government allowed them access to potential victims and suspects. As a member of the Witness Protection Agency board, the finance minister, in particular, could potentially access witness material.

Immediately after the charges were confirmed, CSOs began lobbying the government and garnering public support towards the resignations of both men. This process included writing open editorial articles in the national newspapers explaining the position to the public and elucidating the implications of the Kenyan state's activities. The momentum gained traction with some international institutions and foreign governments, indicating their reluctance to interact with government officials who were facing charges of crimes against humanity. Muthaura eventually resigned and while Uhuru Kenyatta retained his position as deputy prime minister, he relinquished his finance docket. ${ }^{70}$

There was also substantial civil society advocacy during the electoral campaign period in 2012 and 2013. Kenyatta and William Ruto came together in a political coalition platform to campaign for Kenya's 2013 presidential race as running mates for president and deputy president. The ICC became a key issue in the 2013 election, with Kenyatta and Ruto's Jubilee Alliance casting the Court as a tool of imperialism, bent on illegitimately seeking to influence the outcome of the Kenyan election at the behest of Western powers. Although civil society groups sought to legally challenge the viability of accused persons running for high government positions, the High Court refused to rule on the matter, stating that only the Supreme Court could rule on presidential election matters. ${ }^{71}$ Since the Kenyan cases before the ICC had barely begun at this stage, it was therefore not possible to bar Kenyatta and Ruto from holding public office. There was insufficient time between the ruling of the High Court and the election itself to properly adjudicate the matter.

In March 2013, Kenya held elections in which Kenyatta and Ruto were elected as president and deputy president, respectively. A petition was filed in the Supreme Court of Kenya challenging the results of the elections, but it declared that the elections were free, fair and credible, and that both men had been validly elected. ${ }^{72}$ From this new position of power, both the president and deputy president launched a renewed onslaught against their cases. While appearing to abide by their

70 'Kenya: Uhuru, Muthaura Bow to Pressure, Step Aside', allafrica, 26 January 2012.

71 'Uhuru Kenyatta Free to Run After Kenya Election Ruling', BBC News Africa, 15 February 2013.

72 Judgment of the Supreme Court of Kenya at Nairobi, Kenya Election Petition 2013, Petition No. 5 of 2013. 
obligations to the ICC, they nevertheless engaged in a series of diplomatic and judicial activities that have had the effect of undermining the ultimate objective: justice for victims.

In addition, the government continued to seek international support for its deferral campaign. By continuing to present a narrative of the ICC as a hegemonic tool of Western powers, ${ }^{73}$ the government succeeded in rallying African states gathered at the AU's Twelfth Extraordinary Summit in October 2012 to pass yet another resolution calling for sitting heads of state and senior government representatives to be exempt from criminal prosecution. ${ }^{74}$ Citing the selectivity of cases before the ICC, which to date have only been brought against African nationals, the Kenyan government attempted to cast itself as a victim. Part of the resolution, which was the outcome of the extraordinary session, reads:

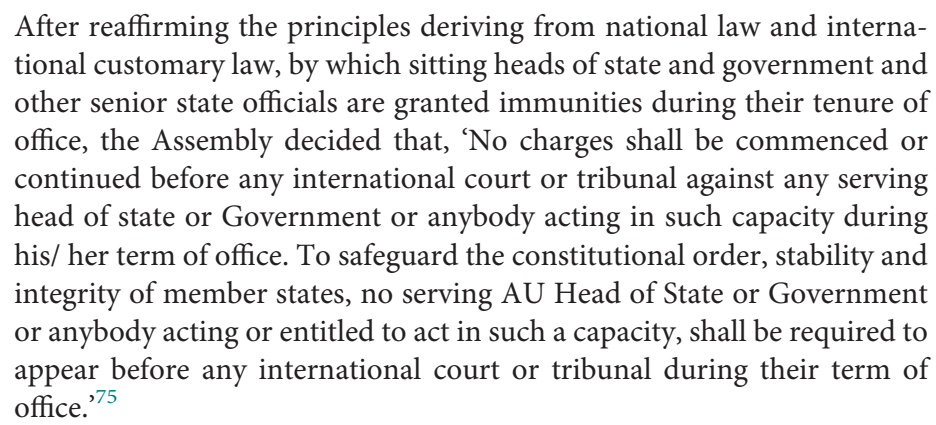

Once again, under a joint platform, CSOs lobbied against this position to their partners in different countries. Although Kenyan civil society was not granted an audience in the extraordinary session, it nonetheless developed a position paper arguing against the 'neo-colonial' narrative, and it shared this position throughout its networks for further advocacy with AU member states. ${ }^{76}$ The paper further argued that the resolution's stance on the immunity of sitting heads of state and government would

73 'The African Union, the International Criminal Court, and the United Nations Security Council', Background Paper, University of California, Irvine School of Law ICC-UNSC Workshop (November 2012).

${ }^{74}$ Extraordinary Session of the Assembly of the African Union (Addis Ababa, 11-12 October 2013).

75 Ibid.

76 'Kenyan Civil Society Letter and Memorandum to the UNSC on Deferral of ICC Cases', KPTJ (7 November 2013). 
undermine the international human rights system, and in particular the core objectives of the Rome Statute. ${ }^{77}$

In November 2013, the Kenyan government made an additional attempt to halt the cases before the ICC's governing body, the Assembly of States Parties (ASP), which was meeting in The Hague. The government sought to amend the rules of the ICC regarding prosecution of sitting heads of state, as well as their attendance at trial. ${ }^{78}$ Civil society present at the ASP made strong arguments against these proposed amendments. A coalition of organisations argued that the Rome Statute system deliberately ensured that there would be no immunity for any individual on the basis of official capacity. They contended that equality before the law for grave crimes is a fundamental tenet that is not only enshrined in the Statute but also recognised by international practice and, increasingly, adopted by national jurisdictions. Kenya therefore could not be an exception. Furthermore, while Article 143 of Kenya's Constitution provides immunity for the president from criminal prosecutions, such immunity does not extend to a crime under any treaty that prohibits it and to which Kenya is party. ${ }^{79}$ Kenyan representatives also argued that most victims and affected communities have supported the ICC because the Court is capable of dispensing justice even when the alleged perpetrators are the most powerful members of society. Alternative possibilities for accountability are often unavailable through the judiciaries of post-conflict states.

\section{Domestic litigation and reparations efforts}

Following the ICC's confirmation of the charges, Kenyan NGOs proceeded to file domestic cases to pursue justice for victims of post-election violence. Although these cases were not criminal in nature, they sought state responsibility for internal displacement, sexual violence and police shootings. ${ }^{80}$ One of the cases dealt specifically with victims of sexual and gender-based violence. The case was filed in February 2013 by a

\footnotetext{
77 The Kenyan government followed up the AU resolution with another deferral application to the UN Security Council. CSOs in turn wrote a letter to the Council conveying concerns regarding the deferral request, and the motion was again defeated. See 'Why the UN Security Council should Reject the Application for a Deferral of the Kenyan Cases before the International Criminal Court', A Memorandum from Kenyan Civil Society Organisations (23 October 2013).

78 'Kenya's "victory" at the Assembly States Parties meeting', RNW Africa Desk, 28 November 2013.

79 Article 143, Constitution of Kenya. ${ }^{80}$ HRW, 'Turning Pebbles'.
} 
consortium of civil society organisations comprising the Coalition on Violence against Women (COVAW), Independent Medico-Legal Unit (IMLU), ICJ-Kenya, Physicians for Human Rights (PHR) as well as eight victims of sexual and gender-based violence. ${ }^{81}$ There also has been litigation on behalf of internally displaced persons. ${ }^{82}$ In choosing to interpret the principle of complementarity as 'positive complementarity', where the ICC and the national government work jointly to ensure accountability for international crimes, CSOs have been using domestic legislation to push this agenda.

CSOs also developed a reparations framework to complement the ICC's Trust Fund for Victims (TFV). The framework, which was presented to the Truth, Justice and Reconciliation Commission and incorporated into its report, presents an option for the government to map victims of past violations, including of the 2007-2008 post-election violence. This is particularly important as the TFV has yet to make an assessment of the Kenyan situation as of the time of writing.

\section{Investigation and prosecution}

The KNHCR report on the post-election violence claimed that there may have been nearly 220 possible perpetrators. ${ }^{83}$ This could be a conservative estimate, and it demands developing either a prosecutorial strategy or judicial mechanism to prosecute these perpetrators and determine whether there may have been more. In tandem with the ICC's intervention, civil society groups have been at the forefront of advocating for such a domestic mechanism, though such advocacy had to take place after the commencement of the Kenyan cases. Given the pervasive climate of impunity, many organisations feared that any domestic accountability process might be hijacked to justify an admissibility challenge before the ICC.

The two government initiatives towards accountability have included a multi-agency task force, established by the Director of Public Prosecutions in April 2012, and a proposal, advanced by the Judicial Service Commission (JSC), for a new division of the High Court of Kenya with jurisdiction over international crimes. The task force's mandate was to review the 6,000 cases arising out of the violence that had been arbitrarily shelved by the Office of the Attorney General

81 'Hearing of the PEV Sexual Gender Based Violence case begins in Court', ICJ Kenya (26 March 2014).

${ }^{82}$ Federation of Kenya Women Lawyers (FIDA Kenya) \& 27 others v. Attorney General \& 3 others, [2011] eKLR, Petition No. 273 of 2011.

${ }^{83} \mathrm{KNCHR}$, 'On the Brink of the Precipice', 178-238. 
in $2009 .{ }^{84}$ The task force has reportedly reviewed all 6,000 cases and identified 1,716 suspects and 420 potential witnesses. ${ }^{85}$ It was also said to be prosecuting four murder cases, as well as preparing 150 files on sexual and gender-based violence for possible prosecution. However, the state has since announced a closure of all files due to insufficient evidence. $^{86}$

Kenyan CSOs have engaged in the rudimentary stages of a proposal to establish an International Crimes Division (ICD) of the High Court. The JSC mandated a study into the viability of establishing such a division; however, the policy framework enlarges the scope of the ICD to encompass transnational crimes and fails to clearly address the question on retrospective application of the law. ${ }^{87}$ The widening of the scope of the proposed ICD includes crimes ranging from terrorism to cybercrime. This undermines the intention for a concise temporary mechanism established to address the specific violations from the post-electoral violence period. This is particularly clear since Kenya already has a comprehensive legislative framework and institutions to address cybercrime. ${ }^{88}$ The International Crimes Act 2008 can also address any international crime that may occur after its enactment. Although CSOs are sceptical of the proposed division, they are, at the time of writing, still engaging with the process.

\section{Conclusion}

Gross human rights violations have become increasingly normalised in Kenya, particularly during or near election periods. Typically, those who came into power have had no interest in apprehending the perpetrators because they use violence to facilitate their access to power. In seeking to destabilise this equation, and in providing essential support to the ICC's intervention, human rights organisations have become the vanguard for justice in the country. The Kenyan government's efforts to thwart the legitimacy and financing of these organisations are a measure of civil society's success in this regard.

84 Report to the Attorney General; also cited in Prosecutor's Article 15 Request.

85 'Domestic Criminal Accountability Forum Report', ICJ-Kenya (12-13 June 2012).

86 'Kenya: Victims still seeking justice for post-election violence', Amnesty International (15 July 2014).

87 See Judicial Service Commission, 'Report of the Committee of the Judicial Service Commission on the establishment of an International Crimes Division in the High Court of Kenya', 30 October 2012. For further views on the proposed ICD, see 'A Real Option for Justice? The International Crimes Division of the High Court of Kenya', KPTJ Report (July 2014).

88 'New Court in Kenya to Focus on Maritime Piracy Cases', CNN Wire, 25 June 2010. 
The relationship between Kenyan civil society and the ICC brings together the Court's expertise regarding international criminal matters with the contextual knowledge of domestic advocates and practitioners. However, the relationship between the Court and its civil society partners needs further definition and refinement in ICC policies and guidelines. Lack of clarity regarding the role of intermediaries, especially during the early stages of mapping evidence and in witness protection, can damage the investigatory process, as the OTP's cases have increasingly revealed. Indeed, Kenyan politicians have seized on this lack of clarity, suggesting that the entire investigation and witness selection processes were undertaken by CSOs. Such rhetoric produces political vulnerabilities for civil society advocates, who are now accused of acting as conduits of foreign interests. In Kenya, being the vanguard for justice has come at a price. 


\title{
'They told us we would be part of history'
}

\author{
Reflections on the civil society intermediary experience \\ in the Great Lakes region
}

\author{
DÉIRDRE CLANCY
}

\section{Introduction}

The adoption of the Rome Statute marked the foundation of a new kind of international justice. With the elevation of victims as trial participants and the acknowledgement of the role of civil society, 'victims of unimaginable atrocity ${ }^{1}$ were no longer to be mere beneficial objects, but also, at least in theory, active subjects of international criminal justice. In the early years of the Court, generally enthusiastic engagement by local non-governmental organisations (LNGOs) and networks of civil society organisations around victim participation processes and investigations in the first situation countries in the Great Lakes region, with the exception of Uganda, seemed to confirm this vision. Often heavily encouraged and supported by international NGOs (INGOs), ${ }^{2}$ these local interlocutors took on more weight, importance and authority than they ever had in the context of the ad hoc tribunals for Rwanda and the former Yugoslavia. ${ }^{3}$ Against the background of the International Criminal Court's (ICC) constantly expanding jurisdiction, they collaborated intensively across the organs as mediators for, and 'interpreters' of, the work of the Court with, and in relation to, communities in situation countries.

1 Preamble, Rome Statute.

${ }^{2}$ INGOs such as Redress, Global Rights, Federation Internationale des Droits de l'homme, No Peace Without Justice, Human Rights Watch, the Women's Initiative for Gender Justice and the Open Society Justice Initiative were at the forefront of this groundbreaking work.

3 For an account of this latter engagement by intermediaries in the prosecutorial context, see E. Baylis, 'Outsourcing Investigations', UCLA Journal of International Law \& Foreign Affairs 14 (2009), 121, 126-130. 
The involvement of these local organisations and individuals quickly became critical to the evolution of a new type of actor on the ICC stage: the 'intermediary'. Despite their extensive engagement in operations, however, the role of intermediary was not explicitly envisaged in the Rome Statute. The word 'intermediaries' in fact appears only once in the core ICC framework documents. ${ }^{4}$ A comprehensive and precise definition of these 'informal agents of the Court' ${ }^{5}$ remains elusive. The most recent official attempt describes an intermediary as,

[S]omeone who comes between one person and another; who facilitates contact or provides a link between one of the organs or units of the Court or Counsel on the one hand, and victims, witnesses, beneficiaries of reparations or affected communities more broadly on the other. ${ }^{6}$

It is clear, however, that not all who fulfil this definition are considered to be 'intermediaries' in different contexts and for different purposes. As the discussion below will illustrate, there are fundamental conceptual, legal and perhaps ideological tensions, which make agreement on the definition of an intermediary and the implications of such a designation contentious both inside and outside the Court. As has been recognised, 'it is the complexity of the diversity of the situations with which the ICC is faced (rather than an ideological commitment to broader engagement as such) that has motivated the ICC's turn to intermediaries'?

The variety of roles played by intermediaries has particularly complicated efforts to encapsulate and manage their place in the process of investigation and trial. While the contours of individual participation as a victim or witness are ultimately controlled by the organs and judges of the Court,

${ }^{4}$ Regulation 97 (1) of the Regulations of the Registry refers to the Registry's obligation to take, 'all necessary measures within its powers to ensure the confidentiality of communications', including those 'between the Court and persons or organisations serving as intermediaries between the Court and victims'. In addition to this reference, the Regulations of the Trust Fund for Victims (TFV) provide that intermediaries may be used in facilitating the disbursement of reparations awards and the implementation of collective awards. Regulations 67 and 71, Regulations of the Trust Fund for Victims, Resolution ICC-ASP/4/Res.3, adopted 3 December 2005.

${ }^{5}$ C. De Vos, 'Case Note: "Someone who comes between one person and another": Lubanga, Local Cooperation and the Right to a Fair Trial', Melbourne Journal of International Law, 12 (2011), 1, 2.

${ }^{6}$ See 'Guidelines governing the Relations between the Court and Intermediaries: for the Organs and Units of the Court and Counsel working with intermediaries', ICC (March 2014), 5 ('Guidelines 2014').

7 E. Haslam and R. Edmonds, 'Managing a New "partnership": "Professionalization", Intermediaries and the ICC', Criminal Law Forum, 24 (2013), 49. 
engagement as an intermediary, as a critical valve between the ICC and the community, presents an opportunity to engage strategically before a case goes to trial. This potentially impacts both the course of investigations and the nature of victim participation, from the inside and from the outset. ${ }^{8}$ Through tasks such as sharing information on international crimes, identifying witnesses and facilitating victim participation, many intermediaries go beyond providing a mere 'link' to the ground, actively shaping the narratives emerging about the situation itself. ${ }^{9}$ Enjoying this locus of apparent agency vis-à-vis the Court in the early years, many local civil society intermediaries grew to see themselves as critical partners - and perhaps even as equal partners - in the international justice project.

Towards the end of 2007, however, as the ICC began to face increasing challenges both inside and outside the courtroom, intermediaries came under attack. As the most visible and accessible faces of the Court on the ground, these assaults on intermediaries came from all sides: not just from those hostile to the effort to hold perpetrators accountable, but also from victim communities frustrated and disappointed with the lack of change in their daily circumstances. When the conduct of intermediaries was placed under judicial scrutiny in the ICC's first trial of Thomas Lubanga, intermediaries also found themselves portrayed as betrayers of trust, both of local communities and of the cause of international justice itself. At the same time, in different situation countries on the ground, intermediaries and their families were facing assault, imprisonment, torture and exile. As intermediaries fled for their lives, the responsibility and capacity of the Court to protect those who had taken serious risks on behalf of its operations were called into question.

Civil society intermediaries in many situation countries felt abandoned and disappointed. Not only were they under attack, but also they were grappling with an inconsistent - and unwritten - Court policy and practice, and an institution that seemed reluctant to acknowledge the full extent of their suffering. Even in its public pronouncements, the Court strived to minimise the reality, with Prosecutor Luis Moreno-Ocampo

${ }^{8}$ Participating as a witness or victim can certainly shape the narrative at the Court in the early ICC cases; for example, a significant number of those who came to the court as participating victims were subsequently invited to become witnesses.

9 NGO intermediaries, for example, sometimes deliberately sourced certain categories of witnesses and victims. The work of the Women's Initiative for Gender Justice and the Sudan International Defence Group illustrate two modes of engagement in this regard. 
adamant in his assertion (as late as 2009) that 'no one ha[d] been harmed as a result of their work with the Court'. ${ }^{10}$

Eventually, the Court did begin an internal process to redress the gaps in the regulatory framework. In April 2012, the text of 'Draft Guidelines Governing the Relationship between the Court and Intermediaries for the Organs and Units of the Court and Counsel Working with Intermediaries' was agreed. It was only two years later, however, in April 2014 that a slightly amended version of this document (the 'Guidelines') was finally published on the Court's website. Although publication of the Guidelines is welcome, the circumstances and form in which they have been issued are unlikely to fully address the confusion that has plagued intermediary engagement to date. With new situations under examination and investigation, the circle of intermediary engagement is only going to expand. Deliberate and thorough 'road-testing' of the Guidelines, anchored to a transparent review procedure, is urgently needed.

This chapter overviews the evolution of the role of local intermediaries in ICC operations and their gradual emergence as players before chambers, eventually becoming the fulcrum upon which the very existence of the ICC's first trial turned. Drawing on aspects of the experience of intermediaries in the first five situation countries, it offers some reflections on the impact of this engagement upon intermediaries themselves, on their relationship with the Court and with their communities, and with the idea and reality of 'international criminal justice' more broadly. ${ }^{11}$ The chapter has three parts: it first sets out some of the key elements of the nature of ICC and intermediary engagement to date; it then traces a genealogy of this relationship with reference to key jurisprudence, policy and practice; and finally, it examines the framework that has been developed in response to this experience, namely the Guidelines. The chapter ends with some reflections on how the evolution of the intermediary role is challenging some of the assumptions underpinning international criminal justice itself.

This account of intermediary experiences does not purport to be comprehensive; it is grounded in observations gleaned during personal

${ }^{10}$ Notes of meeting attended by author in The Hague in October 2009. This was even after the prosecutor had made public reference in a speech to the UN Security Council to individuals who had been detained and tortured in Sudan 'on account of their work with my office'.

11 The reflections in this chapter were developed by the author while working at the International Refugee Rights Initiative (IRRI), in partnership with the Open Society Justice Initiative (OSJI). 
interaction with intermediaries in the Court's first five situation investigations between 2007 and 2013.

\section{New subjects of the international criminal justice process?}

The work of civil society across the globe was critical to the creation of the ICC and the first decade of its operation. Through coordinated advocacy and action, NGOs - almost wholly INGOs - were major players in the drafting of the Rome Statute and influenced the final version to a degree then unique in treaty negotiations. ${ }^{12}$ Since the Statute entered into force, NGOs, again particularly INGOs, have led and participated in intensive ratification and domestication campaigns and promoted the principle of complementarity. Groups of INGOs and local NGOs working together were at the origin of the first referrals and the evolution of the Court's caseload through vigorous human rights-monitoring initiatives and through sharing information with the Court and the international community.

Once proceedings began in The Hague, NGOs were successful in influencing the direction of investigations and trials through the submission of amicus curiae briefs and the identification of, and support to, victims as part of building the Court's arguably ground-breaking victim participation process. NGOs continue to work with victim groups and submit information on international criminal law violations as they are alleged, allowing the Court to respond quickly through preliminary analysis and examinations where appropriate, in theory, helping to prevent the escalation of situations where atrocities are occurring. As was made clear by the Office of the Prosecutor (OTP) in 2009,

None of the Office of the Prosecutor's objectives could be met without this permanent interaction with NGOs at all stages of its activities: development of policies and practices, crime prevention, promotion of national proceedings, monitoring, preliminary examinations, investigations, prosecutions, cooperation, and efforts to maximize the impact of its work and promote its understanding by victims and affected communities. ${ }^{13}$

The text of the Rome Statute itself recognises civil society as part of the community of actors charged with achieving its objectives. In the context

12 See M. Glasius, The International Criminal Court, A Global Civil Society Achievement (Abingdon: Routledge, 2005).

13 'OTP Prosecutorial Strategy 2009-2012' (Draft), 18 August 2009, para. 53. The final version of the strategy, published in 2010, contains a slight change in language at the equivalent para. 66: 'The Office's interaction with local and international NGOs is relevant at all stages of its activities.' 
of initiating proprio motu investigations, Article 15 (2) of the Statute, for example, permits the prosecutor to 'seek additional information from ... intergovernmental or non-governmental organisations, or other reliable sources'. Article 44 (4) notes that the Court may 'employ the expertise of gratis personnel offered by States Parties, intergovernmental organizations or non-governmental organizations to assist with the work of any of the organs of the Court'. The Court is also free to accept funds and voluntary contributions from 'international organisations, individuals, corporations and other entities' (Article 116). Where they have a representative function, civil society and NGOs can also be viewed as included within the references in the Statute to 'victims' and 'victim communities', in some circumstances. The requirement to take into account 'the interests of victims' pursuant to Article 53 (1)(c), for example, can be envisaged as involving consultations with local civil society. ${ }^{14}$

The role that NGOs and civil society play in terms of the daily operation of the Court - including taking on tasks that are conducted (or could be conducted) by Court staff - is little reflected, however, in the few references to NGOs or 'other entities' in the Statute. The reality is that civil society - most particularly local civil society organisations, often through the facilitation of an INGO partner - has been an essential partner for all organs of the Court, involved in outreach, investigations, victims' participation and even, in some cases, assisting with the protection of witnesses, victims and others at risk. NGOs and individual members of civil society have engaged with the organs of the Court across a broad spectrum of tasks: disseminating information on the Court's operations, collecting information on the commission of international crimes, advising on outreach strategy, helping defence counsel to locate experts, negotiating access to high-level insider witnesses, acting as 'first responders' for victims and witnesses under threat and participating in radio panels with Court staff.

This extensive engagement and its implications for the ICC's operations were little contemplated at the outset of the Court's work: as noted

14 The OTP acknowledged, for example, that in the context of Article 53, 'Understanding the interests of victims may require other forms of dialogue besides direct discussions with victims themselves. It may be important to seek the views of respected intermediaries and representatives, or those who may be able to provide a comprehensive overview of a complex situation. This may include local leaders (religious, political, tribal), other states, local and international intergovernmental and nongovernmental organizations.' See Section 5 (5), 'Policy Paper on the Interests of Justice', Office of the Prosecutor, ICC (September 2007). 
above, the word 'intermediaries' only appears once in its formal framework. Initially, when intermediaries were referred to in proceedings it was in discussions around the proper completion of victim participation applications or the context of applications for redactions of witness statements. It was the Lubanga trial, however, which brought to light the extensive the role that intermediaries have been playing on the ground in the conduct of essential tasks for the Court.

\section{The realities of intermediary engagement}

There are a number of key aspects of the intermediary role which are important for understanding how the relationship of intermediaries with the ICC unfolded and, indeed, subsequently, at least partially, unravelled.

Unlike the ad hoc tribunals, which were set up for particular situations and thus able to deepen their contextual knowledge and internal expertise over time, the ICC is constantly engaging in new places. The OTP preliminary analysis can one day be working on the situation in the two Koreas, and the next day in Mali. As it embarks on a new investigation with generally little background and few contacts on the ground, local interlocutors become essential to the Court's operations. ${ }^{15}$ At one point the prosecutor even called the use of intermediaries 'best practice', explaining that intermediaries could 'undertake tasks in the field that staff members cannot fulfil without creating suspicion; they know members of the community, and they have access to information and places that are otherwise unavailable. ${ }^{16}$ De Vos has argued that the OTP in fact deliberately designed its evidence-gathering practices, 'to minimize the time investigators spend in affected communities, and their degree of engagement with local actors. ${ }^{17}$ It is likely, therefore, that the ICC will increasingly rely on intermediaries as it increases its reach and its budget decreases in real terms in relation to the number of cases and situations before it.

As noted above, the current Guidelines definition of 'intermediary' pivots on the notion of a 'link' between the Court and others it must engage with on the ground. Although in many respects this conception is apt, the passivity of the notion fails to capture the variety of intermediary

15 There have nevertheless been suggestions that those who assist the OTP during the preliminary analysis stage cannot be considered intermediaries.

16 Redacted Decision on intermediaries, The Prosecutor v. Thomas Lubanga Dyilo ('Lubanga') ICC-01/04-01/06, Trial Chamber I, ICC, 31 May 2010.

17 See C. De Vos, 'Investigating from Afar: The ICC's Evidence Problem', Leiden Journal of International Law, 26 (2013), 1009. 
profiles and the breadth of tasks that they conduct. ${ }^{18}$ Intermediaries may come from all sides and strands of the community in a situation country. They can be political figures, rebel army representatives, local tribal leaders, teachers and professors, deserters from government forces or government officials acting in their private capacity. ${ }^{19}$ They will have a range of motivations from the politically partisan, to the ideological, financial and even, in some instances, revenge. Some intermediaries come to the ICC spontaneously (they may approach the Court to communicate on behalf of victim communities), while others are contacted by the Court because of their specific expertise. The majority of intermediaries, however, are staff of LNGOs or members of civil society networks working in the human rights or social justice field. These groups of intermediaries tend to identify most deeply with the ostensible objectives of the ICC and have also generally seen themselves as allied with the prosecution. It is local civil society and LNGO intermediaries who have also shouldered the greatest burdens as intermediaries, whether in terms of the multiplicity of tasks they have conducted, or through their position on the front lines of the broader national and regional battles around the legitimacy and impact of the Court.

The country and NGO contexts within which civil society intermediaries operate have been quite different: in Kenya, for example, the civil society movement has a very different history and set of capacities than its analogue in the Central African Republic. At the same time, where the pool of individuals with the necessary skills, interests and political courage to assist the Court is small, a few intermediaries often find themselves playing different roles for different sections and organs of the Court. This can complicate both the framework of the intermediary relationship with the ICC as well as relationships between the organs of the Court itself. It can also raise questions surrounding confidentiality and security. ${ }^{20}$ Multiple roles may also be played by intermediaries in the proceedings

18 This chapter does not address the critical ethical and accountability questions that arise for NGOs, both LNGOs and INGOs, in relation to their own communities and constituencies - and to each other - while performing the intermediary role. This issue requires urgent attention by civil society.

${ }^{19}$ Creating intermediary relationships with such individuals can raise complex conflict-ofinterest issues and can have political implications for the Court.

${ }^{20}$ In Lubanga, for example, the defence argued that the fact that one intermediary had worked for both the Victims Participation and Reparations Section (VPRS) and the OTP undermined his impartiality and independence. See Redacted Decision on the 'Defence Application seeking a permanent stay of proceedings', Lubanga, ICC-01/04-01/06, Trial Chamber I, ICC, 7 March 2011. 
themselves. In the Lubanga case, for example, a number of intermediaries eventually became key witnesses in the trial. Some were also victim participants, illustrating the close relationship between conflict-affected individuals and communities, and those who were carrying out work as 'intermediaries'.

Related to these realities, there is often a tension in the intermediary relationship between the Court's desire to benefit from local perspectives, access and expertise and its concern that local interests, whether political, financial, security-related or opportunistic, will tarnish the products of that relationship. The idea that local interlocutors should function as mere volunteers of the Court divested of their own politics or interests is prevalent. ${ }^{21}$ It would be natural that those working on behalf of the Court on the ground see financial or political opportunities in ICC interventions: the ICC generally arrives into situations of severe economic and conflict deprivation and Court staff and others in the international justice community enjoy relatively large salaries. These latter conditions of privilege are directly linked to the suffering of those whose cooperation they now seek. In this light, the extent to which local civil society intermediaries have been willing to engage without question of reward is remarkable. Indeed, intermediaries usually provide their services voluntarily to the Court. In certain circumstances, the basic costs associated with the intermediary task may be reimbursed, whether by the Court or one of its partners, such as, for example, an INGO through the operation of a special project. The Court directly remunerates intermediaries in extremely few circumstances. In the whole of 2012, for example, the total remuneration payments made to intermediaries by the OTP was $€ 5,490 .^{22}$ ICC judges have particularly lauded the cost-saving elements of the intermediary function, with Judge Ušacka declaring that intermediaries who assist [victim] applicants in accessing the Court are essential to the proper progress of the proceedings'. ${ }^{23}$

The role of local civil society in the work of the Court has sometimes been obscured by the need to maintain confidentiality in difficult security

${ }^{21}$ It is interesting that the political, ego or careerist ambitions of others in the international justice constituency do not appear to attract the same degree of suspicion and scrutiny.

22 See Second Report of the Court on the financial implications of the draft Guidelines governing the relations between the Court and Intermediaries, ICC-ASP/12/54, 30 October 2013, para. 9.

23 Decision on the Applications for Participation Filed in Connection with the Investigation in the Democratic Republic of Congo by Applicants, Situation in the Democratic Republic of the Congo, ICC-01/04, Pre-Trial Chamber I, ICC, 11 April 2011, para. 25. 
contexts, but also as a result of the more vocal public positioning of INGOs. INGOs have played very active intermediary roles themselves, in many cases initiating, bridging and directing the relationship between local NGOs and civil society and the Court. In these cases the INGO tends to take the role of principal interlocutor with the Court, reducing the risks that might be assumed by the local NGO but also helping to 'manage' what emerges from the ground. In this regard, INGOs are often viewed as the senior or lead intermediary, assumed to have the greater knowledge about the needs of the particular Court organ or process. ${ }^{24}$ This dislocation of the local from The Hague - however well intentioned - has sometimes created complications. Although NGOs may be united around the same general principles and objectives, how these are interpreted in the situation country may vary. Local civil society and INGOs will usually have very different interests in the dynamics of power, access and resources that attend the Court. These diverse dynamics have affected how elements of 'global civil society' have understood, and acted in relation to, the Court's activities and pronouncements, often with negative consequences for intermediaries on the ground.

\section{Tracing the relationship: from enthusiasm to stasis}

There are three main phases that can be discerned in the evolution of the relationship between local intermediaries and the Court in the first five situation countries. ${ }^{25}$ The first phase was generally characterised by enthusiasm and energy, the second by disappointment and retreat, and the third by mutual wariness and efforts to corral intermediaries through regulation.

During the first phase, with the OTP and other organs of the Court actively entreating partnerships, NGOs responded generously, little questioning the wisdom of participating in investigations or the possible consequences. ${ }^{26} \mathrm{In}$

${ }^{24}$ As Kendall and Nouwen have noted, 'Those who work in and around the Court are presented by the field of international criminal law as the field's actual agents. They consider themselves part of another abstraction: the "international community."' See S. Kendall and S. Nouwen, 'Representational Practices at the International Criminal Court: The Gap between Juridified and Abstract Victimhood', Law and Contemporary Problems, 76 (2014), 235.

25 This is despite the fact that in each specific country context, the political tone of investigations and the nature of the NGO community differed greatly.

${ }^{26}$ It should also be noted that the enthusiasm of local NGOs was sometimes driven by complex motivations and often shaped heavily by outside forces, financial and ideological. For an excellent exploration of these issues, see L. Hovil and M.C. Okello, 'Editorial Note, Civil Society, Social Movements and Transitional Justice', International Journal of Transitional Justice, 5 (2011), 333. 
parallel on the ground, in local communities where the ICC was focused, there was considerable expectation around the transformative potential of both investigations and the victim participation process. All this local support was infused with the ideological and financial commitment of a group of INGOs which had invested much in the creation of the Court and was now determined to see its first investigations bear fruit. ${ }^{27}$ The one exception to this atmosphere was Uganda, where local NGOs were overwhelmingly resistant to the entry of the Court into the conflict dynamic, despite considerable pressure by INGOs and others to promote the engagement of the Court. ${ }^{28}$

As a result of this sense of joint mission, intermediaries, their communities and sometimes even ICC staff saw intermediaries as emissaries of the Court on the ground. This identification with the Court would later prove problematic when the relationships fissured and it became clear that roles and responsibilities sometimes led in different directions. ${ }^{29}$ In this heady atmosphere there was also little reflection by intermediaries on the complexities and dangers of engaging as active partners with the Court, both personally and for their communities. International justice was invested with huge expectations, interwoven with assumptions about the capacity of the international community and its mechanisms to deliver political transformation. As one intermediary put it, 'they told us we would be part of history'. This fever of expectation not only seized local and INGOs but also affected the Court itself. As a result, at an operational level there was little sober assessment of risks, responsibilities and necessary mitigating measures. As the years went by and there was little movement in judicial proceedings, not least with respect to arrests, conflict-affected communities in many places became restive. As the on-the-ground interlocutors for the Court, intermediaries bore the brunt of the discontent, especially as tensions around the work of intermediaries also came to the fore in The Hague.

27 Baylis notes, for example, that one of the drivers for the 'increasing significance of third party investigations' is the fact that NGOs and the United Nations have consciously decided to 'train for and carry out extensive inquiries into atrocities specifically for the purpose of providing evidence for prosecutions in the new internationalized courts'. See, Baylis, 'Outsourcing Investigations', 126.

${ }^{28}$ See for example, 'A Poisoned Chalice? Local civil society and the International Criminal Court's engagement in Uganda', Discussion Paper 1: Just Justice? Civil Society, International Justice and the Search for Accountability in Africa, International Refugee Rights Initiative (October 2011).

${ }^{29}$ In one case encountered by the author, an intermediary who had assisted both the VPRS and the OTP was distressed when he discovered that the OTP had challenged the participation applications of certain victims. 


\section{Prosecutor $v$. Lubanga: intermediaries in the spotlight}

The management of the relationship between the Court and intermediaries threatened to derail twice in the ICC's first trial: first as a result of the debacle surrounding the use and disclosure of material received confidentially by the prosecutor under Article 54 (4)(e) and later with respect to allegations of intermediary misconduct and interference with witness testimony. ${ }^{30}$ The first issue that arose centred on the OTP's investigative strategy and the use of Article 54 (3)(e) confidentiality agreements under which the prosecutor can agree not to disclose information received in certain circumstances. ${ }^{31}$ As proceedings unfolded, it became clear that a significant amount of information had been collected by the OTP under the confidentiality seal of Article 54 (3)(e). The chamber found that the provision had been used to obtain evidence to be used at trial, rather than to generate new evidence. ${ }^{32}$ This, it said, constituted 'a wholesale and serious abuse, and a violation of an important provision which was intended to allow the prosecution to receive evidence confidentially, in very restrictive circumstances, ${ }^{33}$ In June 2008, the judges ordered the suspension of proceedings and the release of Mr Lubanga. It seemed very possible that the trial would collapse, causing huge concern on the ground for intermediaries and victim communities. ${ }^{34}$

${ }^{30}$ For an account of some of the key decisions dealing with intermediary issues in the Lubanga case, prior to the final judgment, see De Vos, 'Case Note, "Someone who Comes Between One Person and Another"'.

31 Article 54 of the Rome Statute addresses, 'the duties and powers of the Prosecutor with respect to investigations'. Sub-section (3)(e) particularly provides that the prosecutor may 'agree not to disclose, at any stage of the proceedings, documents or information that the Prosecutor obtains on the condition of confidentiality and solely for the purposes of generating new evidence, unless the provider of the information consents'.

32 By the end of the case it had emerged that the use of intermediaries in the case had been extensive: half of the OTP's witnesses had been contacted through seven intermediaries. The intermediaries employed had a wide variety of backgrounds from officers in the Congolese intelligence service to victims groups and they had engaged across various organs of the Court. A matter of grave concern for NGO intermediaries, it was also determined that three intermediaries might have persuaded a number of witnesses to provide partial or false evidence.

33 Judgment on the appeal of the Prosecutor against the decision of Trial Chamber I entitled 'Decision on the consequences of non-disclosure of exculpatory materials covered by Article 54 (3) (e) agreements and the application to stay the prosecution of the accused, together with certain other issues raised at the Status Conference on 10 June 2008', Lubanga, ICC-01/04-01/06 OA 13, Appeals Chamber, ICC, 21 October 2008, para. 12.

${ }^{34}$ See International Refugee Rights Initiative, 'ICC Decides to Release Lubanga; Prosecution Appeals', Refugee Rights News, 4:5 (July 2008). 
As the matter went on appeal, local intermediaries and others who had provided the material under Article 54 (3)(e) - primarily NGOs and the United Nations Mission in the Democratic Republic of Congo, under the United Nations' relationship agreement - became the focus of intense efforts by the OTP to secure confidentiality waivers which would permit transmission of materials to the defence. Suddenly, intermediaries, who until then had rarely figured in Court proceedings other than during examination of victim participation applications, became central to the continuation of the ICC's first case. Civil society intermediaries became the objects of strong pressure, not only from the OTP to waive confidentiality, but also from others demanding that they refuse to cooperate. Some intermediaries who were perceived to have assisted the prosecutor were attacked and others were driven into exile. Meanwhile, the Appeals Chamber upheld the suspension but stayed Lubanga's release. In November 2008, after the OTP had secured the necessary disclosure agreements, the trial commenced.

When the case moved into the defence phase of proceedings, however, the work of intermediaries was once again pushed centre stage as $\mathrm{Mr}$ Lubanga's counsel indicated that he would seek dismissal on grounds of abuse of process. In particular, it was claimed that intermediaries had been involved in making payments to witnesses to induce testimony and then issuing threats to cover up the fraud. ${ }^{35}$ As Judge Fulford noted in a rather testy exchange with the prosecutor's representative in 2010, 'The integrity of the intermediaries and their role is now a critical ingredient of this trial. ${ }^{36}$ Disclosure of the identity of intermediaries was sought, resisted and ultimately granted. Intermediaries ended up on the witness stand, becoming the pivot for the continuation of proceedings once again. In parallel use of intermediaries by the defence was also a focus of allegations by the OTP. ${ }^{37}$

Ultimately, the Court did order the disclosure of intermediary identities and requested the OTP to give evidence on the use of intermediaries by the prosecution, revealing for the first time the extent and nature of their role. The Court subsequently found that although the use of intermediaries had raised serious issues and the exclusion of testimony was

35 'Lubanga witness says he was paid \$200 to tell lies', International Justice Monitor, Lubanga Trial Website, 8 February 2010, available at www.ijmonitor.org/2010/02/ lubanga-witness-says-he-was-paid-us200-to-tell-lies/.

36 Trial hearing 12 March 2010.

37 The extensive use of intermediaries by the prosecution in the Chui and Katanga proceedings also drew censure from the Court and many of the same issues played out in defence and prosecution motions. 
ordered, the circumstances as a whole did not reach the threshold for a stay of proceedings. The centrality of the intermediary issue to the trial was starkly demonstrated in the 125 pages of the final judgment that were devoted to it.

\section{Attacks on intermediaries on the ground}

At the same time as intermediaries were in the judicial crosshairs in the Lubanga case, they were also coming under fire from their own communities. Some were concerned that the proceedings in The Hague had done little apart from emboldening the perpetrators. Intermediaries were also attacked by those hostile to efforts to seek accountability for heinous crimes. As a result, and despite the reluctance by the Court to acknowledge it, many LNGOs and civil society actors, and particularly civil society intermediaries, suffered greatly for their collaboration - perceived and actual - with the Court. This took the form of harassment, detention, torture, attacks and sexual crimes against family members, dissolution of organisations, forced displacement and killing. Instances of such conduct occurred in all five situation countries.

The increasingly poisoned atmosphere around intermediaries was also complicated by the bitter contestation under way within the African Union (AU) around the role of the ICC, spurred by the issuing of an arrest warrant for the Sudanese president Omar Al Bashir and, subsequently, the charges brought in the Kenya case. The opposition to the Court being fanned in Addis was a major reversal in the Court's fortunes in Africa, which had seen significant Rome Statute ratification, three state-initiated referrals and (at the time) was the site of all of the Court's situation investigations. The charged political atmosphere affected local civil society on the ground, with rifts deepening around the role of the AU, the political posturing of the then prosecutor, and the appropriateness of any criticism of the Court.

The debate among African civil society organisations working on the ICC, and particularly those engaging in regional and sub-regional debates, became polarised. There was significant pressure from some in the international justice community on local actors to 'toe the line' in Africa's struggle around the ICC, notwithstanding that some of the operational decisions being made on the ground and strategically in the courtroom were open to serious question. The quality of judicial decision-making on significant ambiguities in the Rome Statute was also a legitimate cause of concern. In the context of a Court under siege, however, 
any questioning of the ICC, whether in chambers or in terms of prosecutorial strategy, was viewed as a betrayal. As Chidi Odinkalu, one of the leading African human rights lawyers, acknowledged at the time, 'today mutual recrimination has replaced respectful dialogue, debates on the ICC often degenerate into epithets and supportive diplomacy is absent. Criticism of the court, no matter how constructive, risks being denounced as endorsing impunity; support for it, no matter how reasonable, is easily branded imperialism or its agent ${ }^{38}$ This atmosphere of 'international justice fundamentalism', alongside co-option of a coterie of international justice insiders, made it difficult for local civil society intermediaries to assert their own voices in demanding respect and clear dealing from the Court.

The power imbalances in the various relationships between the ICC and NGOs, and among NGOs themselves - particularly as intermediaries affected communication with those working on the ground, who feared that direct criticism would damage the fragile link civil society interlocutors had developed with The Hague. In one situation country, for example, a group of civil society intermediaries came together one evening to draft a letter to the then Prosecutor Moreno-Ocampo to explain the difficulty of their situation and seek help. In the morning, however, the letter was torn up. In their words, 'We thought he would be angry with us'.

\section{Confused ICC response and scarred relationships}

The response from the Court, albeit under huge pressure and subject to cross-cutting mandates and political pressures, was confused and inadequate, compounding the sense of dislocation and abandonment felt by many intermediaries on the ground. The ICC was fragmented, both in terms of the way in which it engaged across organs with intermediaries (and sometimes even within sections of the same organ), but also with respect to how policy towards intermediaries was articulated publicly. The central issue that overshadowed all others was the extent to which the Court had a responsibility to extend the explicit obligation to protect victims and witnesses to intermediaries. Although legal or procedural protection (redaction, non-disclosure of identities, etc.) had been granted to intermediaries in many cases, physical protection (the putting in place of safety and security measures outside the courtroom) had been much harder to access.

38 See C.A. Odinkalu, 'Saving International Justice in Africa', Oxford Transitional Justice Research Working Paper Series (August 2009). 
One of the major problems was the ambiguity of the Rome Statute when it came to the intermediary role. The Statue and the Rules of Procedure and Evidence provide that not only witnesses and victims but also 'persons at risk on account of the testimony of such witnesses' are entitled to be assessed for, and receive, procedural/legal and physical protection from the Court where required. The OTP itself is also required to take 'necessary measures, or request that necessary measures be taken, to ensure the confidentiality of information, the protection of any person or the preservation of evidence. ${ }^{39}$ The question was to what extent intermediaries could be interpreted as falling within the scope of these provisions.

In May 2008, two decisions were delivered by the Appeals Chamber, which confirmed that a broader category of persons than victims and witnesses could secure protection from the Court as 'persons at risk on account of the activities of the Court', or as potential prosecution witnesses. ${ }^{40}$ The Appeals Chamber ruled that 'the specific provisions of the Statute and the Rules ... are indicative of an overarching concern to ensure that persons are not unjustifiably exposed to risk through the activities of the Court'. ${ }^{41}$ This approach and formulation has been upheld in a series of decisions since that time.

Notwithstanding these decisions, intermediaries' access to physical protection from the Court continued to be difficult. It is generally the Victims and Witnesses Unit (VWU) that has the lead responsibility for making and operationalising security assessments, although the OTP and, more recently, the Registry's Security and Safety Section (SSS) also play a role. Individual risk assessments (IRAs) have certainly been carried out for intermediaries. Where an LNGO intermediary has ultimately fled his or her home, however, she/he has generally done so on her/his own steam or with the assistance of another partner, not the Court. The author did not come across any case where a decision was made by the Court to formally relocate an intermediary. ${ }^{42}$ At the same time, ICC staff members have acted informally in support

39 Article 54 (3) (f), Rome Statute [emphasis added]. In addition, Rule 59 (2) of the Rules of Procedure and Evidence addresses the issue of the provision of notice in certain situations requiring that the issue of such notice be consonant with the duty of the Court regarding, inter alia, 'the protection of any person'.

${ }^{40}$ Judgment on the appeal of the prosecutor against the decision of Pre-Trial Chamber I entitled 'First Decision on the Prosecution Request for Authorisation to Redact Witness Statements', The Prosecutor v. Germain Katanga, ICC-01/04-01/07 OA, Appeals Chamber, ICC, 13 May 2008.

${ }^{41}$ Ibid., para. 54.

${ }^{42}$ Of course, it may have been that in all cases where a risk assessment was conducted the facts did not require it. 
of relocation through encouraging, for example, a UN mission or other UN agency to take action within their area of competence. Steps to provide protection on the ground, however, have been taken by the Court such as reinforcing the safety features of an intermediary's home or office.

A range of justifications have been offered in different cases for this reluctance of the Court to act, some linked to legal determinations that purport to exclude the intermediary from the scope of responsibility, others on the basis of an alternative assessment of the facts. The biggest stumbling block has been the identification of a clear nexus between the apprehended threat and the engagement of the intermediary with the Court. Intermediaries often play many roles with respect to justice and peace in their communities and separating out a threat linked to ICC engagement has proven difficult. In some cases, for example, the responsible organ simply declared that as the individual's identity had not been disclosed formally in proceedings, the intermediary role could not have been known, and therefore no risk could have been created 'by the Court'. There are, of course, plenty of other ways for the work of an intermediary to be known beyond formal disclosure during proceedings.

Efforts to distance responsibility - through, for example, avoiding the conduct of a risk assessment - have also centred around suggestions that the individual was 'not an intermediary'. In one case it was claimed that the individual was not an intermediary as he had not been assigned an intermediary number. ${ }^{43}$ In other cases, distinctions were drawn between what was identified as the function of a 'lead' and an 'intermediary'. ${ }^{44}$ This distinction was deployed with some disingenuousness in one situation where an intense, repeated and directed relationship, over a long period around the conduct of a complex task, had been maintained with the intermediaries. It is hard to imagine how these interlocutors were anything other than 'intermediaries' (notwithstanding the questions as to whether the information gathered was eventually entered into evidence). In addition, strictly speaking, the concept of intermediary is irrelevant in terms of how the legal obligation to protect has been judicially formulated. The question is simply whether they are 'persons at risk on account of the activities of the Court'.

There were also internal tensions within the Court around how responsibilities for protection were to be shared across the organs. The

43 This is the number used in proceedings to maintain anonymity, a form of legal protection.

${ }^{44}$ It is interesting that, in Annex 1 of the Guidelines, working as a 'lead' is identified as coming within the scope of intermediary tasks. 
extent to which the OTP may be able to act independently of the VWU to protect individuals, for example, has been the subject of Court proceedings. A major challenge, particularly for the VWU, has also been resources and capacity: with literally thousands of victims and witnesses formally within its care, and potentially hundreds of thousands others, intermediary protection adds to an already great burden. ${ }^{45}$

As a result, other actors were called to fill the protection gap. INGOs and LNGOs came under particular pressure to provide solutions for the security and protection problems faced by their partners. Some even found themselves helping intermediaries deemed to be in danger to relocate. Indeed, it seemed that where INGOs could be relied on as proxy protectors, the Court was less likely to acknowledge responsibility. The part played by the INGO community in providing protection to intermediaries at risk was significant and lifesaving, reflecting the strong 'international justice constituency' that had grown up around the Court. At the same time it was also ad hoc, done almost always without the involvement of security experts, and raising questions of appropriateness, responsibility and sustainability in the long-term. Years after they had initially fled, some intermediaries are still without durable solutions to their plight, surviving through the grace of personal rather than institutional support.

The struggles by, and around, intermediaries inside and outside the courtroom resulted in disappointments on both sides, significantly damaging the relationship between NGOs and the Court. Local intermediaries discovered that the confidentiality and anonymity promised by the ICC was not absolute once trials got under way. They also found that the international community was generally unable to protect them from the consequences of their cooperation and often unwilling to even acknowledge their plight. This lack of recognition increased the feeling of abandonment for many who had viewed their engagement with the Court as one of joint enterprise. Some of the disappointment experienced by intermediaries was certainly rooted in a misunderstanding of the limited capacity of the Court and its 'international community' supporters. The situation was also little helped by those inside and outside the ICC, however, who unrealistically promoted - particularly in fragile situations where there was a desperate thirst for change - the potential

45 A rigid framework of physical protection responses also seems to curtail creative responses. For some intermediaries a period outside of the country on a reasonable premise, such as attending a course, would have been enough to diminish the risk level. Full-scale resettlement and relocation was not required. 
impact of investigations, as well as the extent to which their solidarity could translate into practical support when intermediaries came under attack. This misunderstanding may have encouraged intermediaries to take greater risks.

As the Lubanga case spluttered forward there was also concern about how intermediaries were being characterised at trial. Although it was the unacceptable behaviour of a small number of intermediaries that came under the spotlight, the judges' criticism stung. Intermediary disillusionment with the Court was heightened also by the growing sense that the sacrifice had been in vain: only a few cases moved forward to trial, and the situation on the ground in countries that were the focus of investigations had actually worsened in some places. At the same time, some intermediaries acknowledged that they should have expected to suffer for their engagement. As one intermediary said in conversation, 'Why did we think it would be any different? We should have known.' Others viewed the symbolic value of the initiation of investigations by the Court as sufficient in itself to have justified their sacrifice: the mere fact that investigations had taken place fundamentally altered the imbalances of power that had fuelled impunity and might, in the long term, bear fruit.

The ICC too was re-evaluating its relationship with NGO intermediaries. Since the halcyon early days of investigations, when the OTP could be found openly soliciting cooperation, the Court had now become increasingly wary. With a growing number of situation investigations, however, it was also likely that intermediaries were going to be increasingly vital to its work. Would intermediaries act ethically and accountably? Could they be trusted? How much would they cost and to what extent would the ICC have to extend them protection? A starting point for these questions seemed to be the formal regulation of the intermediary function.

\section{Developing a predicable framework for intermediary engagement}

Developing a consistent policy for the Court on intermediaries has proven difficult, both technically and politically. The diverse nature of the identity and function of intermediaries and the fact that they may play multiple roles with respect to different organs and parts of the Court make a 'one-size' approach impossible. Issues surrounding confidentiality and information sharing across organs have also impeded the development of a standardised set of practices. With the decision in Lubanga 
identifying 'lack of proper oversight' of intermediaries as a problem, however, the challenge became a judicial imperative.

In April 2012, a long and intensive Court-wide process ongoing since 2009 culminated with internal agreement on Draft Guidelines, a 'Code of Conduct' and a 'Model Contract'. NGOs and civil society had been invited to make detailed comments on previous drafts of the Draft Guidelines - although not on the Model Contract and Code of Conduct - through outreach to the Coalition for an International Criminal Court and the Victims' Rights Working Group. ${ }^{46}$ Two years later, in April 2014, an amended version of these documents appeared on the Court's website with the announcement that they had been 'in force' since 17 March 2014. ${ }^{47}$

It is heartening that the Guidelines have now been published. They contain a broad appreciation of the intermediary function and acknowledge the extensive tasks conducted. Alongside a framework for payment of expenses, it is also recognised that intermediaries can even be compensated for their work, in some circumstances. The Guidelines acknowledge the need for support, 'capacity building' and information sharing between the Court and intermediaries, including good practices on risk management. Critically for those on the ground, the Court's obligation to assess and to take into consideration the risks faced by the intermediary is clearly set out: 'The Court has a duty to prevent or manage security risk to intermediaries when those risks result from the intermediaries' interaction with the Court and the fulfilment of the intermediaries functions on behalf of the Court. ${ }^{48}$ An IRA is thus required before an organ or a party embarks on the intermediary

46 The Victim's Rights Working Group is a network of over 300 national and international civil society groups and experts created in 1997 under the auspices of the Coalition for the International Criminal Court (CICC). See www.vrwg.org. Two INGOs, IRRI and OSJI, also led a process that coordinated input from local civil society intermediaries across five situation countries in a detailed section-by-section analysis, including recommendations on the penultimate draft. See 'Commentary on the ICC Draft Guidelines on Intermediaries', International Refugee Rights Initiative and Open Society Justice Initiative (2011), available at www.opensocietyfoundations.org/publications/commentary-icc-draft-guidelines-intermediaries ('IRRI and OSJI Commentary').

47 Among the issues covered by the Guidelines are the definition and functions of intermediaries, formalisation of the relationship, support issues (materials, capacity building, compensation, psychosocial support), security (risk assessment, protective measures, confidentiality) and monitoring. The Guidelines contain a lengthy annex, setting out the main tasks conducted by intermediaries (by function and by unit/organ) and attach a Model Contract and a Code of Conduct.

${ }^{48}$ Guidelines 2014, 14. 
engagement, and it must be reviewed as circumstances change on the ground. ${ }^{49}$ Finally, it is acknowledged that there may also be a need for different organs or units of the Court to develop 'specialised policies in accordance with any specific obligations under the Statute'. ${ }^{50}$

At the same time, the Guidelines contain significant ambiguities, contradictions and potentially impractical elements. Divergent conceptions of the nature of intermediaries, their different functions and capacities, a bias against the bona fides of the local and fear of the 'dangerous intermediary', all permeate the Guidelines to some extent. Some reflections on the challenges to the workability and effectiveness of the Guidelines are offered here.

\section{Challenges for the Guidelines}

The Guidelines purport to create three categories of intermediaries 'contracted', 'unapproved' and 'affidavit' intermediaries 'approved by the Court' - but leave them undefined. With respect to 'unapproved intermediaries', for example, the Guidelines stipulate that the 'application of the present Guidelines is subject to determination on a case by case basis'. But the document fails to identify who makes this determination, and when. There is also no elaboration anywhere of the circumstances in which an 'affidavit' intermediary might come into being: the author has never heard of such an entity. To complicate the matter, attached to the Guidelines is a long list of tasks which are described as a 'summary of main tasks conducted by intermediaries. ${ }^{51}$ However, the Guidelines also provide that, 'not everyone who carries out these [listed] functions will be considered intermediaries for purposes of the Guidelines' ${ }^{52}$ The circumstances in which the relationships created by the performance of some of these tasks fall outside the scope of the Guidelines, and who makes this determination, are nowhere addressed. Meanwhile, the Code of Conduct appended to the Guidelines simply defines an intermediary as 'an individual or organisation who, upon request of an organ or unit of the Court or Counsel, conducts one or more of the activities mentioned in Section I of the Guidelines Governing the Relations between the Court and Intermediaries'. ${ }^{53}$

49

As noted below, however, conduct of an IRA in every instance prior to engaging with an intermediary may be impossible as a matter of practicality.

50

53 These ambiguities may mean less than they seem: as a matter of law the difference that being designated as an intermediary makes for critical issues, such as the extension of the Courts obligation to protect, may be little, in addition to the fact that the Guidelines are not considered to be legally binding. 
The Guidelines are more specific about who and what are not intermediaries for their purposes. The core group excluded are entities described as, 'covered by cooperation agreements (such as MoUs [Memoranda of Understanding] or national implementing legislation)'. These entities include, 'United Nations, inter-governmental organisations, international non-governmental organisations based in the field, government bodies, and national authorities. ${ }^{54}$ It is not clear if this formulation purports to create two tiers of interlocutor: intermediaries subject to the Guidelines 'regime' and others subject to specially drafted agreements. If a local civil society organisation, for example, offered to sign an MOU would it be 'exempt' from the Guidelines and, indeed, what would that mean? Excluding state and intergovernmental entities from the Guidelines ambit is understandable, as they may be bound by other obligations and frameworks that could complicate adherence. (Interestingly, the TFV explicitly recognises that, 'Intermediaries may include interested States, intergovernmental organizations' in the context of its work. ${ }^{55}$ ) INGOs, however, are frequently the lead partner and lead interlocutor in intermediary partnerships. It is hard to see the logic in exempting them from appropriate regulation where they play an operational role simply by virtue of their status as 'international'. Although they may not need the same support from the Court in terms of materials and protective measures, there would seem to be no reason why they should not come under the ambit of the Guidelines.

The second and rather confusing explicit exclusion from the ambit of the Guidelines is contained in the statement that, 'the services provided by an intermediary are generally provided on a voluntary basis and are distinguished from these provided through a contract between an organ or unit of the Court or Counsel and an individual or company'. ${ }^{56} \mathrm{~A}$ few sentences later, however, the Guidelines assert, 'the present policy applies to intermediaries working under a contractual relationship with an organ or Unit of the Court or Counsel'. The distinction intended by this phraseology is likely to be that between entities such as transport contractors providing logistics services, for example, and intermediaries providing support for investigations. The text, however, does little to assist and adds to the ambiguity.

The Guidelines in many respects embody the tension between the critical role intermediaries play in the functioning of the ICC and the desire to

\footnotetext{
${ }^{54}$ Guidelines 2014, 6. ${ }^{55}$ See Regulation 67, Regulations of the TFV.

${ }^{56}$ Guidelines 2014, 6.
} 
'ensure that intermediaries are not a substitute for staff for the implementation of the mandate of the Court'. ${ }^{57}$ While the Guidelines recognise, therefore, that intermediaries 'should not be called upon to undertake core functions' it is also recognised that this distinction can be 'blurred' ${ }^{58}$ On the ground, the delicacy and complexity of the tasks carried out by some intermediaries can look very much like those that staff conduct. In the Guidelines the onerous responsibilities placed on intermediaries are akin to those imposed on Court staff. For example, 'intermediaries must uphold the highest standard of confidentiality and respect the impartiality and independence of the Court while carrying out their activities in the same way as Court staff do ${ }^{59}$ The Code of Conduct further requires that an intermediary shall 'adhere to the polices of, and conduct practices in accordance with, Court decisions, applicable law and policies and practices of the Court and Counsel, as well as any instructions from the relevant organ or unit', albeit with the caveat of 'as far as he/she/it is reasonably aware'. ${ }^{60}$ Throughout the framework there is great emphasis placed on confidentiality and the non-disclosure of classified information, which, while understandable, may raise a conflict of interest and indeed obligations for intermediaries. ${ }^{61}$ Further, the Guidelines purport that such obligations are perpetual and do not cease upon completion of the intermediary's functions. ${ }^{62}$

Many of these obligations are not only onerous but also unrealistic. They seem to reflect the basic misunderstanding that was unfortunately articulated by the judges in Lubanga that, 'the intermediaries were activists, most of whom were fully aware of developments within the sphere of international criminal justice and the objectives of the investigators' ${ }^{63}$ This is rarely the case; not only will most local and international intermediaries find it hard to keep up with a rapidly evolving field of international criminal law, the objectives of the investigators may be particularly difficult to fathom. ${ }^{64}$ It is unlikely that a local intermediary's

57 Ibid., 3. ${ }^{58}$ Ibid., 2. ${ }^{59}$ Ibid., 3 [emphasis added].

60 Section 3.2, Code of Conduct, Guidelines 2014. The Guidelines note that the staff member appointed to supervise the work of the intermediary must ensure that the tasks are conducted consistently with the entire ICC legal framework, including 'all relevant orders or decisions of Chambers'. Guidelines 2014, 11.

61 See Section 5.4, Guidelines 2014.

62 See also for more detail Article 9, Model Contract, Guidelines 2014.

63 Judgment Pursuant to Article 74 of the Statute, Lubanga, ICC-01/04-01/06, Trial Chamber I, ICC, 14 March 2012, para. 184.

64 Indeed in those proceedings, the OTP had submitted to the Court that intermediaries were 'not supposed to know the objectives of the investigation team'. Ibid., para. 183. 
'objectives' in terms of his or her support to a particular investigation will be - or even should be - identical with the Court's. The obligation on the prosecutor to investigate exonerating evidence equally, for example, is not one with which all local NGOs may be always aware and comfortable. ${ }^{65}$ Further, and most importantly, there may also be conflicts between these and an intermediary's parallel obligations, mandates and functions, either professional or with respect to service to his or her community. Many local intermediaries are driven to engage with the Court out of political conviction, seeing the potential of international justice to redress the balance of power in their society. Efforts to 'professionalise' or co-opt intermediaries to adopt the attributes of ICC staff may not always be either appropriate or possible.

Although the introduction to the Guidelines lauds the role played by intermediaries, the legacy of the Lubanga case's unmasking of the 'bad' intermediary is also evident. The Guidelines require local intermediaries to disclose 'all relevant information covering their mandate, memberships or affiliations, sources of funding, links to parties or participants in the proceedings, potential legal issues/criminal record(s), and motivation to co-operate with the Court or Counsel'. ${ }^{66}$ However useful this range of information might be for the Court in assessing the nature of the information provided by an intermediary, it is overly broad and invasive and may even be contrary to national law if it were to be implemented.

The Guidelines also warn that protection may not be provided if an intermediary does not comply with good practices: 'The organ or unit should disengage or not proceed if an intermediary fails to observe and comply with best/good practices while engaged with the Court with the result that the intermediary falls outside of the framework of security measures for intermediaries.' Although adherence to good practice should be encouraged, whether this blanket exclusion from the ambit of the Court's protection is compatible with the Statute is questionable. The Model Contract further provides that non-compliance with the directions of the Court's staff or officials is a basis for breach of contract. ${ }^{67}$ There is unfortunately no 'reasonable grounds' caveat appended. Local interlocutors in fact have a much greater capacity to judge what is safe and appropriate conduct than ICC staff, who are rarely based on the ground where intermediaries work.

${ }^{65}$ See Article 54 (1) (a), Rome Statute. $\quad{ }^{66}$ See Guidelines 2014, 8.

67 There have been times when the judgments or actions of the staff of the Court have simply been wrong in the local context, including with respect to security and safety. 
Related to this, one of the key issues that intermediaries have emphasised is the importance of recognising the reciprocal nature of the relationship between the ICC and the intermediaries', including 'mutual respect and confidentiality' and the need to acknowledge their other roles and expertise. ${ }^{68}$ By enshrining the principle that the 'Court's engagement with intermediaries incurs rights and duties for both parties', the Guidelines do suggest that the relationship is between equal parties. Yet the Model Contract is clear at the same time that nothing 'shall be construed as establishing ... a partnership', and it goes on to create obligations almost entirely on the intermediary side of the relationship. Further, and unlike the Guidelines themselves, the contract makes no reference to duties of care such as the obligation to respond to threats experienced by the intermediary or to other forms of loss or injury. This latter provision is particularly troubling in that at least one of the forms of contract being currently used by the OTP does contain a reference to indemnification of death or injury in certain (albeit very narrow) circumstances. ${ }^{69}$

Some elements of the Guidelines, although laudable in ambition, are unrealistic in the context of complex day-to-day operations. The lengthy selection criteria if strictly applied, for example, would bar many current intermediaries. It may also be hard to do rigorous selection assessments in advance of the first engagement by the Court entity with an intermediary. Further, the greater the homogenisation of the category of those accepted to work as intermediaries, the less diverse the perspectives upon which the Court will be able to call. As Haslam and Edmunds have argued, professionalisation 'can work to the detriment of an ideologically-driven vision of broader participation, because it risks re-inscribing remoteness and hierarchies of knowledge. ${ }^{70}$ The requirement to conduct an IRA prior to working with an intermediary, while ideal, is also likely to be impractical. The VWU, for example, is often overwhelmed and unable

${ }^{68}$ IRRI and OSJI Commentary, 4.

69 See Clause 7, Conditions of Service - Independent Contractors/Consultants, Second Report on the draft Guidelines, 30 October 2013: 'Individual contractors and consultants who are authorized to travel at Court expense or who are required under the contract to perform their services in a Court office, or their dependants as appropriate, shall be entitled in the event of death, injury or illness attributable to the performance of services on behalf of the Court while in travel status or while working in an office of the Organization on official Court business to compensation equivalent to the compensation which, under Appendix D to the Staff Rules, would be payable to a staff member at step V of the First Officer (P-4) level of the Professional category.'

70 Haslam and Edmonds, 'Managing a New "partnership"'. 
to keep up with current obligations and requests. ${ }^{71}$ Without a radical change in resources and capacity, waiting for the conduct of an IRA before commencing work with an intermediary in every case would paralyse operations. The number of documents requiring signature or endorsement as part of the intermediary framework may also need review. ${ }^{72}$ Finally, on a practical note, some documents to which the Guidelines make reference, such as the Good Practices on Risk Management and its specific country application, do not yet seem to have been made available to those who are not Court staff such as counsel, let alone to intermediaries themselves.

There are also areas of the Guidelines that may need further elaboration. They do not address, for example, whether an intermediary has the right to have visibility on proceedings where they affect his or her essential interests. For example, the Model Contract includes an explicit undertaking by the intermediary that he/she agrees to the disclosure of his/her identity to the 'relevant judicial authority'. But there is no reciprocal obligation on the part of the ICC to either inform the intermediary that disclosure has occurred or to seek to mitigate the impact of such disclosure (although this latter duty is likely to be implied). ${ }^{73}$ It would seem reasonable that the Court could be required to advise if an intermediary becomes the subject of proceedings, so that he or she could make appropriate representations. ${ }^{74}$ Also not addressed is the right to be heard where matters such as physical safety are at issue.

Further, what about the right to representation? A victim has a representative, and, as an asset in the defence or prosecution's case, witnesses also enjoy some form of representation. In addition, witnesses have been permitted separate representation where questions relating to detention

${ }^{71}$ Other elements of the Court could take on this task, such as, for example, the Security and Safety Section (SSS) or the OTP. It is not clear, however, when the SSS would be called upon to take on such functions.

${ }^{72}$ For example, an intermediary may be required to sign multiple types of contracts, including an intermediary contract, agreement for the receipt and use of ICC assets, signed acknowledgement that information has been provided on possible disclosure or a confidentiality agreement (if no intermediary contract has been signed).

73 See Article 10, Model Contract, Guidelines 2014. It could also be argued, of course, that the presence of this clause implies a duty to inform the intermediary as to disclosure, especially where the effect may be to impact security or protection assessments. In terms of deliberate disclosure, the Court has set out quite a high threshold for disclosure of intermediary identities, including that it should only occur following a VWU assessment and the imposition of appropriate measures.

${ }^{74}$ This could include, for example, being advised of their intermediary number (where assigned), so that they can follow proceedings. 
and asylum are under consideration. In this regard, are there rights of action for intermediaries that could be construed within the framework of the Guidelines? As the role of intermediary is elevated to a new status, for example, can an administrative decision that a person is 'not an intermediary' (whatever the meaning of that decision in legal terms) be challenged, or indeed any other administrative determination that might be unreasonable or ultra vires? Might there be a role for an independent counsel, from whom intermediaries could seek advice before embarking on the intermediary role or thereafter?

\section{'Implementation' of the Guidelines}

For two years after they were agreed in 2012, the Draft Guidelines were not formally promulgated, although in practice some organs and units are understood to have applied their provisions. ${ }^{75}$ Politically, the operationalisation of the Guidelines was said to require explicit consent from the ICC's Assembly of State Parties (ASP). At two successive ASPs in 2012 and 2013, however, delegates simply 'took note' of the Guidelines, a half-hearted reference deemed insufficient to trigger implementation. While a fiscally sensitive ASP was clearly wary of institutionalising the intermediary role, reports by the Court to the ASP at the same time indicated that use of intermediaries was 'ultimately cost effective'. ${ }^{76}$ The ongoing stalemate suggested that there were deeper issues at play in how the Court's powerful constituencies viewed the intermediary role.

It is not clear what exactly caused the blockage to shift. When the Guidelines (including the Model Contract and the Code of Conduct) finally appeared on the Court's website in mid-April 2014 there was little fanfare, although a facilitator/focal point on intermediaries for the ASP had just been appointed shortly before. The brief text accompanying the posting declared that the documents would 'clarify the relationship of the Court and the Intermediaries, and their implementation will have a positive impact on the integrity of the Court's judicial proceedings by

${ }^{75}$ Conversation with the Deputy Registrar (The Hague, October 2012). At the same time it was clear that the text of the then Draft Guidelines was not to be distributed to intermediaries themselves. Further, it is clear that some victims' counsel, for example, had never seen copies of the Guidelines or were aware they existed until April 2014.

76 See, Second Report on the draft Guidelines (30 October 2013), para. 19: 'while there are unavoidable costs for the Court in implementing the draft Intermediaries Guidelines ... the use of intermediaries is ultimately cost effective for the Court. Intermediaries undertake work that would be extremely costly for the Court to perform.' 
ensuring the proper oversight of all intermediaries and also contribute to the safety of victims and witnesses'. After all the challenges surrounding their adoption and dissemination, however, the Guidelines themselves provide that they 'do not in any way bind or limit the Chambers' exercise of their powers'. ${ }^{77}$ Further, the text accompanying the website link describes the Guidelines simply as 'standards' to which the organs of the Court will 'aspire'. ${ }^{78}$ At the same time, the Guidelines provide that they 'enter into force on the 17 th March, 2014', indicating the existence of a timeline for the creation of obligations and expectations. ${ }^{79}$ It remains to be seen to what extent they may be relied upon in proceedings. Could they be used to found arguments based in administrative law principles around the creation of a legitimate expectation? This will all have to be judicially determined.

Despite all the challenges and new questions that have been raised by the Guidelines' current form, the mere fact that something has been put in writing on the intermediary relationship is a welcome development. In a best-case scenario their existence could give NGOs a baseline to negotiate their relationship with the Court on a more equal footing, provide critical information and set up more realistic expectations. This could result in safer and more effective engagements. Court staff may also be constrained to act in a more predicable way, thus shifting the balance of power. At the same time, there is a danger that the process will impact intermediary independence and freedom to act, as has been experienced by some intermediaries operating under contracts to date. In addition to the implementation of the Guidelines themselves, there are also additional framework issues to be ironed out: some of the organs such as the OTP, for example, are developing their own specialised regulations and it is not clear how these processes will interact and what visibility intermediaries will have on their development. There is much to be tested.

Fortunately, the Guidelines are intended to be a living framework and their review is integral to implementation. During the first two years, a

77 Guidelines 2014, section 4.

78 '[W]ith the exception of the model contract, Intermediaries guidelines are not legally binding, but represent standards for the Organs of the Court to aspire to in their interactions with intermediaries.' 'ICC adopts Guidelines on Intermediaries', Legal Texts and Tools-Strategies and Guidelines, International Criminal Court, available at www.icc-cpi.int/en_menus/icc/legal\%20texts\%20and\%20tools/strategies-and-guidelines/Pages/default.aspx.

79 It should be noted that they were only posted in mid-April 2014. ICC Weekly Update \#207 announced the publication of the Guidelines and provided the link in its 14-18 April 2014 edition. See www.icc-cpi.int/iccdocs/PIDS/wu/ED207_ENG.pdf, 5. 
six-month review will be carried out by the Working Group on Intermediaries and 'permanent observation mechanisms for reviewing recommendations and the exchange of experiences and information' will be established. A detailed review will also be conducted after 18 months of the Guidelines being in operation. ${ }^{80}$

\section{Conclusion}

The experience of local civil society intermediaries before the ICC is a microcosm of many of the challenges that are inherent to, and continue to thwart, the ambition of the Rome Statute. Setting forth on an experimental path of implementation, monitoring and review of the Guidelines will pose difficult, but necessary, questions about the Court and its relationship with 'victim communities', and more broadly, about the role of international criminal justice itself.

Intermediaries are needed by the Court for their intimate entwinement with, and capacity to mediate, interpret and influence, the local. At the same time they are expected to act as emissaries of an impartial global mechanism of international criminal justice corralled by contracts and codes that decontextualise and depoliticise. This austere vision of the intermediary role is juxtaposed with the reality that intermediaries usually have local responsibilities to bear witness and work as agents for change in a context where the ICC is conceived as a political instrument. ${ }^{81}$ Intermediaries and the Court may therefore sometimes share goals and ideological discourse, but almost always have divergent obligations and interests.

As one commentator has put it, 'whereas the International Court of Justice and other international authorities presuppose a community of nations, the ICC rests on an assumption of world citizenship and, as a result, its success depends on the cooperation of global civil society'. ${ }^{82}$ In many ways, the engagement of local intermediaries on the ground can be idealised as the manifestation of this vision of the Court: a democratic

${ }^{80}$ See Section 6.1, Guidelines 2014. It is likely also that the Guidelines will have to be amended in response to directions from chambers.

${ }^{81}$ Local intermediaries are not always representatives of the places where the ICC engages, but they are often, in how they work with the Court, the nearest communities may get to a relationship which those who are telling their story in the courtroom.

82 See A. Thomas, 'Non-governmental Organisations and the International Criminal Court: Implications of Hobbes' Theories of Human Nature and the Development of Social Institutions for their Evolving Relationship', Emory International Law Review, 28 (2014), 435, 437. 
mechanism, working with, and responsive to, local communities, challenging the powerful, and ensuring the existence of multiple truths through safeguarding, 'the delicate mosaic of humanity'. At the same time, the Court promotes itself as a strictly controlled criminal judicial mechanism, permitting and defining only certain categories of persons and story to be heard in the construction of its own singular narrative. ${ }^{83}$ ICC intermediaries are caught in the middle, occupying a space between what Emily Haslam has described as civil society as object and civil society as subject within the practice of international criminal law. ${ }^{84}$ More broadly, the intermediary struggle for recognition before the Court reflects the larger struggle around the question of 'what justice and whose justice' gets done by the ICC. Who mediates the activities of this chimera of 'impartial and universal' international criminal justice in the complex social, cultural and political realities of particular investigations, in the real world, on the ground?

${ }^{83}$ Kendall and Nouwen have described how the 'victim' before the Court has also become a depoliticised cipher. They have written of the 'overdetermined presence of the figure of "The Victims" as a rhetorical construct obscures the representative challenges faced by conflict-affected individuals in accessing the form of justice that is practiced in their (abstract) name'. S. Kendall and S. Nouwen, "Representational Practices at the International Criminal Court', 235.

${ }^{84}$ See E. Haslam, 'Subjects and Objects: International Criminal Law and the Institutionalization of Civil Society', International Journal for Transitional Justice, 5 (2011), 221. 


\section{P A R T I I I}

\section{Practices of inclusion and exclusion}




\title{
Challenges and limitations of outreach
}

\author{
From the ICTY to the ICC
}

\author{
MATIAS HELLMAN
}

\section{Introduction}

The communities directly affected by crimes against humanity and war crimes are among the primary stakeholders of an institution like the International Criminal Court (ICC), tasked as it is with holding the perpetrators of such crimes accountable and providing redress to victims. As the experience of other international or internationalised criminal courts has shown, providing accurate information in a timely manner to the communities affected by these crimes not only is responsible practice, but also shapes perceptions of a court's role, with implications for its broader legacy. In Bosnia and Herzegovina approximately a decade after the war in the country had ended, it was not uncommon for the first three or four topics on the evening news to all be related to war crimes, ranging from trials at the International Criminal Tribunal for the Former Yugoslavia (ICTY) to those before domestic courts, and from the discovery and exhumation of mass graves to exchanges and accusations between politicians related to war crimes.

'Outreach' has emerged in the last 15-20 years as both a concept and a set of practices that encompass interaction - related to but distinct from judicial activities - between an international court or tribunal (ICT) and local communities. While outreach is increasingly recognised as a necessary interface between an international court and local populations, it is still an underdeveloped (and frequently underfunded) area of operations. Indeed, outreach is not proscribed or defined in the statutes of any

The views contained herein are those of the author alone and in no way represent an expression of the institutional views of the ICC, the ICTY or the United Nations.

The author would like to thank Eva Jakusova, David Koller and Christopher Mahony for their helpful comments and suggestions. 
international criminal courts or tribunals, and has only recently been incorporated in the ICC's Regulations of the Registry.

This chapter addresses outreach practices of the ICC comparatively, by contextualising its work in relation to a broader genealogy of outreach practices and challenges at other international criminal courts and tribunals, particularly the ICTY. It will endeavour to demonstrate that outreach is not the sole or even decisive factor affecting the perceived legitimacy of international criminal proceedings among concerned local communities, whose perception of an ICT may remain negative (particularly in the short term), despite extensive outreach activities.

Furthermore, I argue that policy-makers should not expect international courts and tribunals to produce transformative and restorative societal effects unless other crucial factors are present, including complementary transitional justice measures and domestic political commitment to justice goals. While a strong outreach programme is crucial for making the extrajudicial impact of international justice institutions possible, there may be various factors - both internal and external - limiting an international court's impact that outreach cannot influence. Indeed, international courts and tribunals should be cautious with active involvement in socio-political processes because their legitimacy as judicial institutions - a primary condition for positive impact - depends on their perceived independence and impartiality.

\section{Outreach as an interface between courts and local populations}

\section{The origins of outreach}

The impact of international criminal justice on local populations surfaced as a policy question in the late 1990s after the initial institutionbuilding phase of the ICTY. ${ }^{1}$ The ICTY's outreach activities began in October 1998 with a two-day 'Outreach Symposium' held at the tribunal's seat in The Hague. ${ }^{2}$ The press release issued by the ICTY at the closing of the symposium described it as an opportunity to '[bring] together leading figures from the judicial and legal communities of the former Yugoslavia and [give] them the opportunity to listen to and question senior members of all sections of the Tribunal'. It went on,

${ }^{1}$ See, e.g., M. Klarin, 'The Tribunal's Four Battles', Journal for International Criminal Justice, 2 (2004), 546, 552.

2 Sixth Annual Report of the ICTY, UN Doc. A/54/187 \& S/1999/846 (1999), paras. 146-153. 
The Tribunal understands that there exist serious concerns about it among the population of the former Yugoslavia ... they have been and are still being exploited by those in positions of power in whose interest it is to block cooperation with the Tribunal. These concerns have to be addressed ... Direct communication and interaction is one of the most effective ways of doing so. ${ }^{3}$

As President Gabrielle Kirk McDonald had stated in her invitation letter, 'the Tribunal cannot contribute to the goals of peace, justice and reconciliation if its work is not only not known in the region but also actively misunderstood. ${ }^{4}$

In brief, then, outreach was conceived of as a vehicle for bringing about understanding of the ICTY's work in the region of the former Yugoslavia as a perceived precondition for achieving the tribunal's broader goals - in other words, those beyond the immediate results of judicial proceedings. Outreach was also expected to assist the investigative, prosecutorial and judicial work of the ICTY by reducing resistance to cooperation with the tribunal. It was this reasoning that provided the conceptual basis for the tribunal's early work when I joined the ICTY's outreach programme in October 1999.

Later descriptions of outreach programmes of international or internationalised justice institutions have largely followed the direction set by the ICTY. Disseminating information and raising awareness about institutional mandates and proceedings are perhaps the least controversial forms of outreach; indeed, they are contained in one form or another in the mission statements of all ICT outreach programmes. Other purposes have included more ambitious goals, including increasing institutional trust and gaining the support of local populations; promoting 'two-way communication' between the institution and the local population, as with the ICC; and promoting 'ownership' of the justice process. ${ }^{5}$ The goals of outreach have also increasingly dovetailed with broader goals, such as facilitating reconciliation, prevention, the restoration and maintenance of peace and institutional legacy and capacity building. ${ }^{6}$

${ }^{3}$ ICTY Press Release CC/PIU/355-E, 'Outreach symposium marks the first successful step in campaign for better understanding of the icty [sic] in the Former Yugoslavia', 20 October 1998.

4 Ibid.

${ }^{5}$ See, e.g., 'Outreach', Extraordinary Chambers in the Court of Cambodia (ECCC) webpage; 'Strategic Plan for Outreach of the International Criminal Court', ICC-ASP/5/12 (2006), para. 13 ('ICC Outreach Strategy'); 'Outreach and Public Affairs', Special Court for Sierra Leone (SCSL) webpage ('SCSL Outreach Description').

${ }^{6}$ See, e.g., 'Outreach Programme', ICTY webpage; 'ICTR Outreach Programme', in Symposium on the Legacy of International Criminal Courts and Tribunals in Africa (International Center for Ethics, Justice, and Public Life, Brandeis University, 2010), 34. 
The increasingly recognised connection between a local population's trust in and understanding of the work of international courts, and the courts' ability to contribute effectively to these extrajudicial goals - ownership, reconciliation, and capacity building - has often been expressed in terms of legitimacy. Jaya Ramji-Nogales, for instance, suggests that 'By increasing perceptions of legitimacy by as many players as possible, transitional justice mechanisms can ensure greater internalization of their findings and judgments, thereby becoming more effective at reconstructing social norms against mass violence. ${ }^{7}$

In sum, (1) ICTs form part of transitional justice measures intended to provide peace, stability and the reconstruction of the rule of law and social norms opposing mass violence; (2) for an ICT to contribute to these transitional justice goals, it needs to enjoy support of the population in the area(s) under its jurisdiction; and (3) outreach is one of the key measures for attaining such support, or perceived legitimacy. While outreach alone cannot secure the legitimacy of an international court or tribunal, it is a necessary companion of prosecutorial and judicial activities, and serves as the institution's interface with local populations. In this sense, outreach forms an integral part of court operations and a vital element for the achievement of policy goals.

\section{Development of outreach at the ICC}

Outreach, public information and communications activities are not referred to anywhere in the Rome Statute or in the ICC's Rules of Procedure and Evidence. ${ }^{8}$ What comes closest to outreach in the Statute is the reference to 'non-judicial aspects of the administration and servicing the Court', ${ }^{9}$ which forms part of the Registry's responsibilities. Nevertheless, owing largely to lessons learned about the importance of outreach from earlier tribunals, outreach was incorporated in the ICC's institution-building phase from the very beginning. Indeed, it was

Capacity building was featured most prominently in the ICTY and the ICTR as a consequence of their completion strategies endorsed by the UN Security Council (UNSC) and the language of the related UNSC resolutions.

7 J. Ramji-Nogales, 'Designing Bespoke Transitional Justice: A Pluralist Process Approach', Michigan Journal of International Law, 32 (2010), 1, 21.

${ }^{8}$ Rule 13 (1) of the RPE provides that 'Without prejudice to the authority of the Office of the Prosecutor under the Statute to receive, obtain and provide information and to establish channels of communication for this purpose, the Registrar shall serve as the channel of communication of the Court'.

9 Article 43 (1), Rome Statute. 
one of the essential functions provided for in the planning of the Court's operations.

The importance of outreach was formally recognised in a resolution adopted by the Assembly of States Parties (ASP) in 2005:

[The Assembly of States Parties] Recognizes the importance for the Court to engage communities in situations under investigation in a process of constructive interaction with the Court, designed to promote understanding and support for its mandate, to manage expectations and to enable those communities to follow and understand the international criminal justice process and, to that end, encourages the Court to intensify such outreach activities and requests the Court to present a detailed strategic plan in relation to its outreach activities. ${ }^{10}$

Following this mandate, the ICC submitted a Strategic Plan for Outreach, ${ }^{11}$ which the ASP acknowledged at its fifth session. ${ }^{12}$

In its introduction, the Strategic Plan notes that the document is the result of an assessment of the ICC's own experience since 2004, but that it also 'draws upon the achievements and lessons learned from the ad hoc tribunals - the International Criminal Tribunals for the Former Yugoslavia and Rwanda - as well as from the practice of the Special Court for Sierra Leone, which has been recognised as being particularly effective'.

While outreach cooperation with civil society was not a new idea - the ICTY's outreach programme had also relied heavily on collaboration with NGOs on the ground - the ICC's outreach strategy took the novel step of explicitly announcing a formal cooperative relationship with partners and 'culturally appropriate intermediaries, particularly where ICC staff is unable to contact the general public due to lack of resources, logistical or other constraints or security concerns. ${ }^{13}$ Such in-country presence is a fundamental but under-resourced aspect of the Court's work - in the words of former ICC President Sang-Hyun Song, it is 'indispensable' yet 'underappreciated'. ${ }^{14}$

10 'Strengthening the International Criminal Court and the Assembly of States Parties', ICCASP/4/Res.4 (3 December 2005), para. 22.

11 ICC Outreach Strategy.

12 'Strengthening the International Criminal Court and the Assembly of States Parties', ICCASP/5/Res.3 (1 December 2006), para. 20.

13 ICC Outreach Strategy', para. 66. In March 2014, the ICC adopted and publicised 'Guidelines Governing the Relations between the Court and Intermediaries', which regulates the ICC's interaction with intermediaries in this and other fields of activities. See further Chapter 9 by Clancy in this volume.

14 'Seminar on the ICC Review Conference: Key Challenges for International Criminal Justice', Seminar Report (New York, 30 April 2010). 
In an important normative development, reference to outreach has also been incorporated into the revised regulations of the ICC's Registry, approved in December 2013. Whereas the original regulations, adopted in 2006, contained no mention of outreach, the revised document incorporates a new regulation 5bis, which stipulates that 'the Registry shall ensure the public dissemination of appropriate, neutral and timely information concerning the activities of the Court through public information and outreach programmes'.

According to the regulation, which codifies existing working methods, several factors differentiate outreach from public information. While outreach specifically relates to 'making the Court's judicial proceedings accessible to those communities affected by the situations and cases before the Court', public information programmes 'shall be aimed at fostering public understanding and support for the work of the Court'. A non-exhaustive list of communication methods - including 'print and broadcast media, internet-based technologies, visits to the Court and public speaking engagements by Court officials' - may be used by the Registry as part of its publication information efforts; however, additional 'appropriate communication tools and strategies' are envisaged for outreach.

In addition to print and broadcast, possible methods of communication envisaged for outreach include 'consultation and townhall meetings', practices that would permit more 'two-way communication' between conflict-affected communities and the Court. Staff members from the ICC's outreach unit have long sought to develop practices that foster dialogue. The Court's second outreach report noted, for instance,

\begin{abstract}
New interaction techniques were developed and implemented in response to indications that a more participatory approach during outreach meetings was needed. Based on the data collected last year, participants claimed that more time needed to be allocated to the debates during the outreach activities. Therefore, the Outreach Unit shifted the communications approach from passive and informative meetings and workshops, with presentations about the Court by officials followed by a session of questions and answers, to more diverse, dynamic and engaging discussion where the participation of audiences is encouraged. ${ }^{15}$
\end{abstract}

One key outreach initiative developed through this 'two-way' communication is the ICC's 'Ask the Court' programme, where members of affected communities receive responses to questions that they have posed, through the outreach unit, to senior Court officials. Other important participatory

15 'Outreach Report 2008', Public Information and Documentation Section, 8. 
practices include consultative meetings with NGOs in planning outreach activities, interactive radio talk shows, listening clubs, outreach school clubs, facilitating peer-to-peer discussions, and moot court competitions.

Many of the above developments indicate a strengthened institutional position of outreach within the structure and operations of the ICC, acknowledging communication with conflict-affected communities as an essential part of the Court's mandate. As the following section discusses, however, there are a number of limitations that ICTs confront in their efforts to be more responsive to conflict-affected populations.

\section{Limitations of outreach}

Any positive societal impact of the ICC or other international tribunals is arguably based on their contribution to actually holding perpetrators accountable for their crimes. Consequently, the results of investigations, prosecutions and trials are among the most important factors determining the effects of international justice interventions. Where those results fall short of their intended goals, they present a serious obstacle that is difficult to overcome. If the prosecution or the court does not carry out their judicial mandate to a high standard, no amount of outreach and explaining will put it right. Typical reasons for disappointment (particularly for victims) in this respect include full or partial acquittals, low sentences and protracted proceedings. ${ }^{16}$ The first two of these are considered below in more detail.

\section{Results of judicial proceedings}

\section{Acquittals}

One of the scenarios most likely to disappoint conflict-affected communities and to distance them from the justice process is when the only case before an international court concerning certain crimes ends in an acquittal. The Halilovic case $^{17}$ at the ICTY is illustrative, as it was the only case in relation to two notorious incidents of mass murder against Bosnian Croat civilians committed in the villages of Grabovica and Uzdol. Following Halilovićs

${ }^{16}$ Diane Orentlicher writes that, 'a key area in which internationalized tribunals or domestic courts trying mass atrocities would benefit from improvement is in expediting trial proceedings without short-changing justice'. D. Orentlicher, That Someone Guilty Be Punished: The Impact of the ICTY in Bosnia (New York: Open Society Institute, 2010), 73.

17 Judgment, The Prosecutor v. Sefer Halilović, IT-01-48, Trial Chamber I, ICTY, 17 November 2005. 
acquittal, I was personally involved in outreach efforts towards the Grabovica community and found that even in-depth explanations about the judicial process would not offset the disappointment of the families of victims, who had invested time and, above all, mental strength in cooperating with the ICTY Prosecutor's Office (often in the face of general scepticism towards the tribunal in their community), in the hope that the case would give them a sense of closure. ${ }^{18}$ Even if the members of the victim community accepted - which they found difficult to do - that Halilović was not guilty, they felt that justice had not been done for them. In the words of a man who lost five family members, 'If he is guilty, he needs to be convicted. If he is not guilty, let him say who is guilty, let them investigate. Let the judiciary investigate who is guilty, they should answer [for the crime]. ${ }^{, 19}$

Another example of a similar outcome causing severe disappointment among victims is the ICC's case against Callixte Mbarushimana, whose confirmation of charges hearing was held in September 2011. In December 2011, the Pre-Trial Chamber declined to confirm the prosecutor's charges. At that time, Mbarushimana was the only person against whom the OTP had sought charges in connection with crimes allegedly committed in the provinces of North and South Kivu in the Democratic Republic of the Congo (DRC). ${ }^{20}$ A press release issued by the Congolese civil society organisation La Ligue pour la Paix et les Droits de l'Homme [The League for Peace and Human Rights] is indicative of the disappointment that often ensues when the outcome of judicial proceedings falls short of the expectations of conflict-affected communities:

Informed about the release of Mr. Callixte Mbarushimana ... plaintiffs and victims ... have expressed their total disappointment coupled with a sense of abandonment on them. They also fear for their security in the future ... They cannot understand that such a judicial body of the caliber of the ICC, with its material and human resources and in which they have placed their only hope for justice, because of the miscarriage of justice by the Congolese National judiciary, is about to fail in its mission. ${ }^{21}$

18 Disappointment of the family members of Grabovica victims described also in Orentlicher, That Someone Guilty Be Punished, 126-127.

19 Author's translation of comments attributed to Mr Anto Marić in a Bosnian-language media report. 'Halilović oslobođen optužbi', Radio Free Europe, 16 November 2005. Three persons have been subsequently convicted in the Bosnian courts for the murder of three victims in Grabovica.

20 The ICC prosecutor later pressed charges related to the same crime base against Sylvestre Mudacumura, who remains at large at the time of writing.

${ }^{21}$ English translation provided by the Coalition for the International Criminal Court. Original press release in French: 'Les graves violations des droits de l'homme commises 
These examples demonstrate that international criminal proceedings may end up severely disappointing victim populations; in such cases, outreach can, at best, reduce the negative impact. ${ }^{22}$ For instance, it is standard practice of the ICC's Outreach Programme to communicate actively and without delay to the affected communities that by entering a judgment of acquittal, or by rejecting to confirm charges, the judges are by no means belittling the suffering of conflict-affected communities.

An acquittal in an international trial is naturally the only correct outcome if the defendant is found to be not guilty, and certain parts of the affected communities, such as the ethnic group or immediate community of the defendants, may well welcome an acquittal if it concurs with their predominant narrative and understanding of the events in question. Furthermore, an acquittal may carry added value beyond the immediate question of individual responsibility if the judgment helps to clarify the historical record; for example, by determining that some of the alleged crimes or events did not take place at all. ${ }^{23}$ However, from a wider perspective, it may also be argued that an acquittal represents a failure on some level for the international court as a whole, since the main purpose of its costly existence is to be a forum for accountability.

\section{Low sentences}

Low sentences often have a similar effect as acquittals on conflict-affected populations, which attribute great significance to the length of prison sentences. In Refik Hodžić's words, 'The view shared by many victims is that low sentences imposed on war criminals amount to an implicit denial or to a failure to acknowledge the depth and gravity of their suffering. In an environment where such denial permeates their everyday life in the community, low sentences are seen as an act of betrayal by the courts, which in many cases was their only hope for acknowledgment. ${ }^{24}$

sur la population civile à l'Est de la République Démocratique du Congo ne doivent en aucun cas restées impunies', LIPADHO, 31 December 2011.

${ }^{22}$ Following the first-instance conviction of Germain Katanga at the ICC, a member of the local community from the area where the crimes took place was reported as saying that 'his acquittal would have felt like a knife thrust through the hearts of all the victims of the crimes he was on trial for'; 'What Do Ituri Residents Say About the Katanga Verdict', Radio Netherlands Worldwide, 12 March 2014.

${ }^{23}$ In most cases, however, the occurrence of the alleged crimes is not disputed, but rather the individual responsibility of the suspect or the accused.

${ }^{24}$ R. Hodžić, 'A Long Road Yet to Reconciliation: The Impact of the ICTY on Reconciliation and Victims' Perceptions of Criminal Justice', in R.H. Steinberg (ed.), Assessing the Legacy of the ICTY (Leiden: Brill, 2011), 115, 134. 
The ICTY has handed down sentences ranging from two to five years' imprisonment in several cases, on the grounds of the limited responsibility of the accused for the crimes in the indictment. ${ }^{25}$

Naturally, such an outcome may well be fully correct - for instance, when a court finds that the accused was responsible for only a small portion of the charges contained in the indictment, or that the accused was a passive rather than an active participant. Even if this is 'successfully' explained to victim populations, however, they may feel disappointed by the justice process, in particular if none of the perceived main culprits is successfully prosecuted.

While the ICC has not pronounced any sentences as short as some of those handed by the ICTY, the sentencing of Germain Katanga to 12 years in prison was similarly criticised by some as too lenient. The Court's outreach programme was credited, however, with preparing the affected populations in advance, which facilitated a positive reception of the judgment. ${ }^{26}$ Timely outreach that is sensitive to the expectations of the affected communities can thus, to some extent, pre-empt and mitigate negative reactions.

\section{Systemic obstacles}

\section{Individual responsibility in response to mass victimisation}

When assessing the satisfaction of victim populations with ICTs, it is important to remain mindful of the inherent limitations of criminal justice in providing remedies to victims of international crimes. Return of displaced persons and the reconstruction of destroyed houses may be possible, but the psychological effects of victimisation remain. Even with the best of efforts, victims of mass atrocities are unlikely to feel satisfied by the measure of justice provided by court proceedings involving a limited number of perpetrators. As a telling example, victim groups in Prijedor, Bosnia and Herzegovina, told me in 2006 that they felt that 'the ICTY had not done much for them'. This was despite the fact that the tribunal had more cases in relation to crimes committed in Prijedor than any other municipality in the former Yugoslavia; moreover, even though some defendants received relatively low sentences, all trials ended in convictions

25 See, e.g. Judgment, Prosecutor v. Enver Hadžihasanović \& Amir Kubura, IT-01-47, Appeals Chamber, ICTY, 22 April 2008; Judgment, Prosecutor v. Kvočka et al., IT-98-30/1 Appeals Chamber, ICTY, 28 February 2005.

26 'Reactions to the Sentencing of Germain Katanga: Some Comfort, Some Frustration', International Justice Monitor, 11 June 2014. 
and some of the ICTY's highest sentences were pronounced for Prijedor crimes. The local reactions in Ituri, DRC, to the second sentence pronounced by the ICC (in the Katanga case) reflected in a similar manner an impatient expectation that the Court must do more to provide justice. ${ }^{27}$

Another phenomenon illustrating the tensions between criminal and mass victimisation is the tendency to project collective traumas onto the trial of one, or a handful of, accused - especially if the communities perceive the trial as the first significant measure of justice for the crimes. In this context, it may be difficult to appreciate or explain that the sentence of a convicted person is determined in accordance with the level of his or her personal culpability and not (solely) according to the extent of the entire crime in connection with which he or she is convicted. While judges may impose a shorter prison sentence to reflect the extent of one's personal criminal liability, the public may interpret this as belittlement of the victims' suffering. This highlights the importance of outreach in communicating the parameters of the criminal justice process and 'managing expectations' from early on, as well as the significance of complementary transitional justice measures accompanying international criminal justice interventions.

\section{Prosecutorial choices}

A common form of criticism against international criminal courts is the claim that they are biased against a particular ethnic or national group because members of one national group are being disproportionately targeted for prosecution, or because the crimes committed against members of a group have not been adequately addressed (or both). In either case, the determining factor is case selection, which is the responsibility of prosecutors.

This was a common ground of criticism against the ICTY in Serbia, for instance, when the tribunal's prosecutor did not prosecute anyone for crimes allegedly committed by NATO (North Atlantic Treaty Organization) forces during the 1999 bombing campaign against the Federal Republic of Yugoslavia, and was seen as paying insufficient attention to crimes committed against Serbs in Kosovo. By contrast, a frequent claim among Bosnian Serbs has been that the ICTY largely ignored crimes committed against Serbs in Bosnia and Herzegovina and disproportionately targeted Serbs for prosecution.

27 Ibid. 
The ICC has dealt with this challenge repeatedly as well. In the context of the Court's first trials concerning crimes committed in the Ituri province of the DRC, where much of the conflict was between the ethnic Hema and Lendu communities, the cases initially concerned only to a very limited extent victims from the Lendu tribe. ${ }^{28}$ As a result, the International Center for Transitional Justice noted that 'the Lendu overwhelmingly believe the court is little more than an instrument in the hands of forces ranged against them', despite the fact that the ICC judges had been 'scrupulously fair. ${ }^{29}$ Subsequently, the case against Bosco Ntaganda - transferred to the ICC in March 2013 - has in fact been broadened to encompass a number of alleged crimes against Lendu victims. More broadly, the ICC has met extensive criticism on account of the fact that all of its investigations thus far have been restricted to the African continent.

Criticism of this sort is very difficult for outreach staff to counter if they do not represent the OTP; they are unfamiliar with, unauthorised and plainly unable to discuss the reasons for prosecutorial strategy and case (or situation) selections. Indeed, when working for ICTY outreach, I was often caught in the dilemma of whether to try to explain the OTP's policies with the information available from public statements, or whether to simply state that I was not able to answer the question, and that it should be put to the OTP. In practice, I would usually opt for the first course of action in an attempt to uphold the tribunal's overall reputation and integrity, and in hopes of not alienating the audience; however, this was a highly awkward position, not least for having to de facto speak for an organ that is not neutral in the same way that chambers or the Registry are meant to be. ${ }^{30}$

To that end, one should be cautious not to go too far with a 'One Court' approach. This principle, pronounced by the ICC in its 2006 Strategic Plan, foresees that the various organs and officials of the Court share a common mission and work together in coordination on matters of common concern. ${ }^{31}$ From an outreach perspective, the coordination of

${ }^{28}$ In the context of allegations against Mathieu Ngudjolo Chui relating to the use of child soldiers.

29 'ICC Asked Tough Questions by Historic First Judgment', International Center for Transitional Justice, 19 March 2012.

${ }^{30}$ In my personal experience as a staff member of ICTY outreach, failing to engage in substantive discussion on a question that the audience considers important is one of the surest ways to alienate them, and to reduce one's own legitimacy as a court representative.

31 'Strategic Plan of the International Criminal Court', ICC-ASP/5/6 (4 August 2006), paras. $14-15$. 
activities is certainly advisable, provided that the independence and specific roles of each organ are fully respected; however, insistence on representing a court like the ICC as an indivisible institution may compromise its perceived neutrality and that of the judges.

\section{Risk of perpetuating imbalances}

While prosecutors should endeavour to attend to the interests of all victims equally, ${ }^{32}$ in reality this is very difficult to achieve. It is highly likely that in situations of mass violence the investigation and prosecution of certain crimes will be left to the national judiciary, which may entail a significant delay, if the national jurisdiction is not yet capable of processing such cases. Some crimes may well remain unpunished due to the number and extent of the crimes committed, limited resources, the unavailability of sufficient evidence or a combination thereof. Accordingly, a certain degree of 'imbalance' - a lack of universal coverage - of prosecutions is inherent to international criminal institutions. Even a sound and logical decision of prosecutorial policy can lead to dissatisfaction, a perception of bias and reduced legitimacy amongst certain groups who see such decisions as ignoring the crimes committed against them. Particularly zealous attempts by an international court to inject information about its judicial proceedings into domestic public discourse - for instance, through statements of its principals may in some scenarios have the effect of perpetuating and amplifying the perceived imbalances.

\section{Judicial actors in socio-political processes}

There are also more general dilemmas concerning the engagement of judicial actors in socio-political discourse. First, as judicial institutions, ICTs are not well equipped for such tasks, which require political skill and a comprehensive understanding of the conflict and its societal context. In this respect, the knowledge possessed by judges of an international court is, in principle, limited to the evidence presented in the courtroom, primarily concerning the alleged criminality of the defendants. Judges would thus have to seek information and advice from other sources for the purposes of extrajudicial intervention, actions that would potentially be inconsistent with their judicial mandate.

32 Ramji-Nogales, 'Bespoke Transitional Justice', 18. 
Even if an extra-judicial role could be reconciled with a judicial mandate, for a court to engage extensively in socio-political activity would likely undermine its identity as a judicial institution. ${ }^{33}$ Furthermore, this could complicate the governance structure of a court like the ICC, which functions in a delicate balance involving judges who are independent by definition. Unless this structure were to be radically altered, any extrajudicial role would probably have to be placed in the presidency/registry pillar (as outreach functions usually are), which would be at odds with the fact that presidents are professional judges, and usually inclined to place emphasis on neutrality. As a 2010 report of the ICTY president notes, 'the Tribunal is and remains a criminal court. It should focus on its key expertise and make use of the possibility of cooperating with other actors who are best positioned to assist it. ${ }^{34}$ Often, however, it is outreach staff who participate in socio-political discourse through the media or public events, which requires careful balancing acts on their part.

\section{External obstacles}

Negative perceptions of ICTs in the communities of perpetrators

Even if an ICT performs to a high standard, this does not guarantee that it will be perceived well by the local population, since 'How a society responds to the work of an international tribunal is a function of myriad variables, ${ }^{35}$ with judicial proceedings and outreach being one among many. One of the rationales presented for international justice interventions is that they 'individualize guilt'. ${ }^{36}$ However, expecting that this logic will win the support of the communities from which an accused comes would be misguided.

My own experiences at the ICTY indicated that while some people might be receptive to information about crimes committed by members of their own community, they are often in the minority. In any case, a

${ }^{33}$ Orentlicher quotes a comment by Serbian journalist Filip Švarm that 'ICTY prosecutions veered too far into the realm of "social/political acts", which "undermines the legitimacy of the ICTY"'. D. Orentlicher, Shrinking the Space for Denial: The Impact of the ICTY in Serbia (New York: Open Society Institute, 2008), 77.

34 'Report of the President on the Conference Assessing the Legacy of the ICTY', ICTY Report (27 April 2010), para. 11(iv).

35 Orentlicher, Shrinking the Space for Denial, 12.

36 J.N. Clark, 'The ICTY and the Challenges of Reconciliation in the Former Yugoslavia', eInternational Relations, 23 January 2012. 
community's own, internal interpretations of events will often dominate their assessment of a court's findings about the crimes committed and the responsibility of those accused. Such dynamics partially explain the fervent reactions among some groups to charges brought against community or political leaders, for instance in the context of the ICC's operations in Côte d'Ivoire, Kenya or the Central African Republic. The supporters of Jean-Pierre Bemba and Laurent Gbagbo have staged frequent protests in The Hague, while, in Kenya, popular support for the ICC's involvement has declined following the confirmation of charges. The building of domestic political alliances and campaigning around the ICC - for instance, calling the elections 'a referendum on the ICC' - have also been notable consequences of the Court's intervention.

Furthermore, international criminal trials may have the effect of stigmatising groups; it has been noted that the 'trials support the underlying societal objective of conferring shame on a much larger body of people - bystanders and the lesser involved'. ${ }^{37}$ Frédéric Mégret has discussed this at length in the context of the ICC and even suggested that stigma could be a principal function of international criminal justice. ${ }^{38}$

\section{Rhetoric of political leaders}

Reluctance to amend popular narratives about conflict is even stronger when reinforced by political leaders, media reports and other major opinion-shaping factors. Refik Hodžić, for instance, suggests that 'political leaders who openly deny facts about crimes established by the ICTY judgments and who undermine its credibility with hostile and baseless accusations directed at the Tribunal must be called to account and not be ignored. ${ }^{39}$ It is important for policy-makers, however, to grasp the Sisyphean nature of the task that outreach faces if it is expected to transform the political discourse of a nation and alter deep-rooted, emotional views perpetuated by the domestic elites. Diane Orentlicher notes that 'With limited resources - the ICTY has only one outreach officer in all of Bosnia - the ICTY is vastly outmatched when it comes to creating a compelling narrative. ${ }^{40}$

\footnotetext{
37 L.E. Fletcher and H.M. Weinstein, 'A World Unto Itself? The Application of International Justice in the Former Yugoslavia', in E. Stover and H.M. Weinstein (eds.), My Neighbor, My Enemy (Cambridge: Cambridge University Press: 2004), 44.

${ }^{38}$ F. Mégret, 'Practices of Stigmatization', Law and Contemporary Problems, 76 (2014), 287.

39 Hodžić, 'A Long Road Yet to Reconciliation', 117.

40 Orentlicher, That Someone Guilty Be Punished, 104.
} 
Similarly, the ICC has only one outreach officer stationed in Kenya, where Court proceedings are a subject of enormous public interest and a heated topic of political discourse. The Kenyan government has a vested interest in the proceedings - not least due to the fact that two of the accused persons were the president and deputy president - and has engaged in advocacy regarding the ICC in the region and beyond. Developments since the confirmation of charges have included intensive discussions in the African Union (AU), a request by the AU (at the behest of the Kenyan government) to obtain a deferral of the proceedings from the UN Security Council, two attempts in the National Assembly of Kenya to effect withdrawal from the Rome Statute and amendments to the ICC's Rules of Procedure and Evidence that allow for partial absence of an accused from trial. All of these developments were closely covered by the media in Kenya, influencing the public's opinion of the ICC in the country.

Obviously, the imbalance is more than a question of numbers. Courts, even if equipped with large outreach teams, cannot impose a historical narrative on a society because changes ultimately have to come from within. Moreover, this should not be the task of ICTs. Confronting political leaders' public rejection of judicial findings about past crimes is a sensitive issue that raises fundamental questions about the relationship of judicial truths and historiography. As William Schabas argues, 'neither trials nor truth commissions should be allowed to stifle a constant reconsideration and reassessment of the past, something that is the essential contribution of professional historians'. ${ }^{41}$

From an outreach perspective, the ability of ICT officials to counter denial is also restricted by the nature of the judicial process and fair trial rights. International criminal proceedings typically take several years from surrender or arrest to final judgment, and as long as the case is pending, all matters are subject to dispute and have to be treated as such in any public statements. Even when a final judgment is issued in one case, the same facts may be disputed in another case before the same court. These factors are a very real concern for outreach staff.

\section{Challenges for outreach at the ICC}

As has been discussed previously, the ICC's outreach strategy and activities have in many ways drawn from the experiences of other courts and

${ }^{41}$ W. Schabas, Unimaginable Atrocities: Justice, Politics, and Rights at the War Crimes Tribunals (Oxford: Oxford University Press, 2012), 172. 
tribunals, and bear many similarities to the outreach programmes of the earlier tribunals. Fundraising for outreach activities, for instance, is a challenge that has been shared, to a varying extent, by all of these institutions. The ICTY, the ICTR and the Special Court for Sierra Leone (SCSL) all operated their outreach programmes with voluntary donations outside the regular budget of those institutions. Against this background, the inclusion of outreach in the main budget of the ICC, while still limited, was a major positive development. ${ }^{42}$ Provision of budgeted funds for outreach arguably reflects states parties' acceptance of the necessity and importance of outreach as a companion of investigative, prosecutorial and judicial activities.

That said, there have been persistent attempts by a number of states parties to reduce funding for outreach, under the pretext that it does not constitute a 'core' activity of the Court. Particularly during the tenth and eleventh sessions of the ASP in 2011-12, when a number of the largest budget-contributing states were pushing hard for a 'zero nominal growth' budget for the ICC, outreach came under a real threat of facing budget cuts. Much of these dynamics occurred in the informal talks in the lead-up to the assembly's annual sessions and is therefore not visible in the official documents of the ASP meeting. The seriousness of the threat is, however, well reflected in the recommendations of the Coalition for the International Criminal Court, which noted ahead of the eleventh session that 'a voluntary funding approach runs counter to lessons learned from previous international tribunals and courts'. ${ }^{43}$

While the number of situations subject to investigation and prosecution increased from four to eight between 2008 and 2014, funding for the Public Information and Documentation Section (which includes outreach) has only increased by 30 per cent during the same period. ${ }^{44}$ The ICC's mandate, which is not geographically limited like that of other ICTs, poses additional challenges for outreach. To begin with, the ICC deals with multiple situation countries as opposed to a single situation country, as

${ }^{42}$ It should be noted, however, that the ICC's outreach unit was not allocated the number of staff initially proposed by the Court.

${ }^{43}$ Coalition for the International Criminal Court, Comments and Recommendations to the 11th Session of the Assembly of States Parties, 9 November 2012, p. 7.

${ }^{44}$ While the ICC itself has not publicly complained about lack of resources for outreach, NGOs have been critical of the slow growth of the communications budget: 'Zero-growth in the Court's budget has resulted in an over-stretch in the limited resources available for PIDS ... Due to budgetary constraints, the Court has suspended several public information projects ... PIDS has had to shuffle resources - both human and material - available for outreach around to meet the increasing demand.' Ibid. 
at the SCSL or ICTR, or one region with closely related situation countries, as at the ICTY. Even equality of coverage within the same country can be an issue for the ICC. As noted in the Court's 2009 report,

Another challenge that has been identified and will require further consideration is related to geographic coverage and timing of Outreach operations. Due to constraints, the programme has prioritised communities affected by crimes currently heard before the Court. Hence, activities have been conducted in areas where crimes were committed or where communities that were affected by the crimes live. As a result, a communications gap is growing within the same countries of operations. ${ }^{45}$

New situations not only increase the number of local communities requiring the ICC's attention, but also frequently create the need for the translation of various information materials into additional languages. Re-allocating existing human resources may be complicated, as the cultural expertise and language skills fitting one situation may not be suitable for another. The strategic approach to outreach activities also has to be tailored anew for each situation. An initial assessment of political, cultural, historical and sociological factors must be carried out at the outset of operations in a new situation, as well as a mapping of the media environment.

Finally, a number of the ICC's situation countries remain in a state of armed conflict. As a result, the security situation is very difficult; indeed, in cases like Sudan, the Court has no access to the country whatsoever. To add to these challenges, the ICC's physical distance from the situation countries is far greater than what was the case with both the ad hoc tribunals and the SCSL, which was, uniquely, located in Sierra Leone.

\section{Reflections on methods for advancing the ICC's extrajudicial effects}

It has been noted that a 'realistic understanding of the possibilities and limitations of international justice is a prerequisite to its success ${ }^{46}$ and that raising expectations that subsequently cannot be met may lead to disappointment, frustration and apathy. ${ }^{47}$ Communication with the

${ }^{45}$ Public Information and Documentation Section, 'Outreach Report 2009', Executive Summary.

${ }^{46}$ ICC president Judge Sang-Hyun Song, 'From Punishment to Prevention: Reflections on the Future of International Criminal Justice', lecture held on 14 February 2012.

47 See J. Lincoln, Transitional Justice, Peace and Accountability: Outreach and the Role of International Courts after Conflict (London: Routledge, 2011), 90-91, 143. 
concerned societies and managing expectations is therefore crucial for the ability of ICTs to achieve their goals. The Strategic Plan of the ICC's outreach programme is in line with these considerations, as it is fundamentally based on the principles of neutrality and independence. Further, it places emphasis on the provision of information, promoting understanding of the ICC's mandate and its activities, as well as the 'management of expectations'. ${ }^{48}$

As argued above, judicial results form the fundamental basis of an ICT's legitimacy. In the words of a former ICC judge, 'The [ICC] will be judged by our ability to dispense international criminal justice at the highest level - that means securing those accused of the world's most egregious crimes before the court and delivering timely and fair justice. ${ }^{49}$ Accordingly, the quality of investigations, prosecutions and trials should be any court's primary preoccupation. Conversely, poor quality of judicial and prosecutorial activity would present a major obstacle for an ICT's ability to achieve its goals. ${ }^{50}$ This is the ICC's core challenge.

To that same end, however, it is vital that parent organisations provide international courts with the requisite resources and tools necessary for them to conduct their judicial mandate to a high standard. Furthermore, it is of critical importance that states respect their obligations to cooperate with investigations and prosecutions. The ICC's principals regularly seek to highlight the importance of these issues when addressing the Court's states parties, as well as the UN Security Council.

While acquittals are a natural phenomenon in any criminal jurisdiction, prosecutors should be particularly mindful of the negative societal impact that they are likely to carry and, accordingly, endeavour to pursue cases with overwhelming evidence establishing strong responsibility for grave crimes - in other words, cases with a high likelihood of a conviction and a substantial sentence. The new Strategic Plan of the ICC's Office of the Prosecutor, publicised in October 2013, represents a step in this direction, as it puts increased emphasis on ensuring the trial-readiness of cases before charging suspects and states that one of the expected

${ }^{48}$ ICC Outreach Strategy. See also Integrated Strategy for External Relations, Public Information and Outreach, International Criminal Court.

49 A. Fulford, 'The Reflections of a Trial Judge', Criminal Law Forum, 2 (2011), 215-216.

50 As reflected in the ICC's risk register, an internal draft document of the ICC, referred to with the permission of ICC management. 
results of the amended strategy will be 'an increased confirmation of charges and conviction rate. ${ }^{51}$

As this chapter has sought to illustrate, courts should also be equipped with a strong outreach programme from the outset to make their work fully accessible to local populations, as well as to promote a realistic understanding of their mandate. Outreach activities should be launched as early as possible for a variety of reasons, including trying to prevent inaccurate information from taking root. As the experience of the ICTY shows, the relatively late launch of the outreach programme left space for other stakeholders to steer the discourse freely and no doubt contributed to the negative views and prejudice towards the tribunal, much of which still endures. Outreach conducted by the prosecutor's office on its own account - for instance, to explain decisions not to investigate certain crimes - could also be considered a method for promoting transparency and preventing the alienation of affected communities. ${ }^{52}$

Outreach programmes should also include a strong field presence with sufficiently senior staff at the helm of the country teams. In my experience, seniority of outreach staff based in the field is crucial to allow them to liaise effectively with local authorities, as well as international organisations present on the ground. Similarly, only assigning junior staff to field positions may create a perception that the court is not paying due attention to the needs of the local population.

Lastly, policy-makers should address transitional justice needs in a comprehensive manner; international courts should not be relied on to conduct transitional justice tasks other than those that are clearly within their mandate. ICC interventions should therefore be supported with accompanying mechanisms to foster transitional justice processes related to criminal accountability, notably constructive socio-political discourse on atrocity crimes, as well as access to and public acknowledgment of facts about past atrocities. ${ }^{53}$ Robust outreach programmes can support these processes to an extent, but they should not be relied on as the main avenue for advancing transitional objectives.

51 'Strategic Plan June 2012-2015', Officer of the Prosecutor (11 October 2013), para. 23.

52 See M. Karwande, 'Implementing an Engagement Model: Outreach at the Special Court for Sierra Leone', in C. Ramírez-Barat (ed.), Transitional Justice, Culture, and Society: Beyond Outreach (New York: International Center for Transitional Justice, Social Science Research Council, 2014).

${ }^{53}$ See Fletcher and Weinstein, who note that, 'to reach these broader goals [of peace and stability], additional interventions are necessary to complement the work of criminal tribunals', 34 . 


\section{Conclusion}

Outreach is an integral element of international criminal justice, and it is crucial for enabling an affected society at large to benefit from accountability efforts in a wider socio-political context. ${ }^{54}$ Fortunately, the ICC outreach programme seems to have avoided the pitfall of 'overselling' the Court's mandate, having learned from the experiences of the ICTY and other ad hoc tribunals in this regard. The ICC's programme has focused on providing neutral information about the Court's activities through appropriate channels and facilitating dialogue between the Court and affected communities. Including references to outreach in the Regulations of the Registry of the ICC in 2013, as well as the adoption of guidelines governing the relations between the Court and intermediaries - including those assisting outreach - has further helped institutionalise and regulate outreach as an integral part of the Court's operations.

However, outreach cannot produce positive societal effects in the absence of other fundamental preconditions. The quality and integrity of investigations, prosecutions and trials should remain a central concern for ICTs, as well as for those actors on whose support they rely in the conduct of their judicial mandate. A political climate conducive to positive change is another critical factor for the extrajudicial impact of a court like the ICC, and this should be an essential consideration for transitional justice policy-makers.

Ultimately, domestic actors are the ones who should 'translate judicial findings of the tribunal into political facts', ${ }^{55}$ not only for the sake of 'local ownership', but also because this is the most effective way to entrench social norms prohibiting mass violence. Outreach should actively assist local society in accessing the ICC's work in a comprehensible and usable form, but it is the local stakeholders - civil society, politicians, the legal community, historians and the media - that can use that information for other extrajudicial purposes. If a court too actively tries to achieve effects such as reconciliation or satisfaction of victim communities, it risks undermining its own impartiality and integrity, which remain the cornerstones of its legitimacy.

${ }^{54}$ See, e.g., J.N. Clark, 'International War Crimes Tribunals and the Challenge of Outreach', International Criminal Law Review, 9 (2009), 99, 116.

55 Expression borrowed from comment of Emir Suljagić, quoted in Orentlicher, That Someone Guilty Be Punished, 98. 


\title{
'We ask for justice, you give us law'
}

\author{
The rule of law, economic markets and the reconfiguration
} of victimhood

\author{
KAMARI MAXINE CLARKE
}

I cannot and will not forget the innocent Kenyans who are no longer alive to tell their story. I will not forget those who did live to tell their stories of survival-and who have waited too long for justice. These survivors are crying out for more justice, not less. I will continue to fight for the justice they deserve.

Fatou Bensouda, ICC prosecutor

\section{Introduction}

These words of the prosecutor of the International Criminal Court (ICC) resound with conviction. They describe the way that the rule of law, in this case the Rome Statute for the ICC, has become a proxy for the defence of victims. But not all agree and some, like a prominent grassroots Latin American group, have pushed back with the observation, 'we ask for justice, you give us law' as a way to critique the contemporary conflation of justice with law. Similarly, among one of the most colourful controversies at the ICC was the counter-claim by deputy president of Kenya, William Ruto, during his pre-trial hearing for crimes against humanity in which he attempted to broaden the bid for justice through the broadening of the terms of victimhood. In a conciliatory, reflexive and assertive tone he argued that there were two types of victims following Kenya's post-election violence, and he was one of them. According to Ruto, there are 'the post-election violence victims, whose lives and property were destroyed and deserve justice and truth; and another set of victims which I belong to, victims of a syndicate of falsehood and a conspiracy of lies choreographed by networks that are obviously against 
truth and justice'. ${ }^{1}$ Ultimately, he claimed, he was a victim of structural violence at the hands of the ICC.

Some people received Ruto's remarks with affirmation and appreciation of his plight. To others, his claims to victimhood were laughable and defiled the very nature of suffering. The executive director of the NGOled Coalition for the International Criminal Court responded to Ruto's invocation of victimhood by insisting, 'States should not be distracted by the efforts of certain leaders to portray themselves as victims when the Court guarantees fair trial rights. The Assembly should stay focused on strengthening the Court's work and impact so that the actual victims of ICC crimes receive redress. ${ }^{2}$ A year earlier, the then deputy prosecutor Bensouda had responded to a similar sentiment in which members of the African elite claimed an impartial ICC had victimised them:

What offends me most when I hear criticisms about the so-called African bias is how quick we are to focus on the words and propaganda of a few powerful, influential individuals and to forget about the millions of anonymous people that suffer from these crimes ... because all the victims are African victims. Indeed, the greatest affront to victims of these brutal and unimaginable crimes ... women and young girls raped, families brutalised, robbed of everything, entire communities terrorised and shattered ... is to see those powerful individuals responsible for their sufferings trying to portray themselves as the victims of a pro-western, antiAfrican court. $^{3}$

The language Bensouda uses in these statements reflects a juridified ${ }^{4}$ notion of justice in which agents of the court equate justice with the exercise of law, with moral responsibility as its motivation. In this case, the narrative construction of justice-as-law invokes the mission of protecting victims against powerful perpetrators who have abused their impunity for too long.

The ICC's legal mission presumes that, in order to protect victims, justice must be understood as the objective manifestation of law. Bensouda's remarks also privilege those victimised according to popular definitions of suffering. For her, victims of 'brutal and unimaginable

${ }^{1}$ William Ruto, Transcript of ICC Status Conference, The Prosecutor v. William Samoei Ruto and Joshua Arap Sang, ICC-01/09-01/11, Trial Chamber V, ICC, 14 May 2013, 46-47.

${ }^{2}$ W. Pace, 'Assembly of State Parties Address', November 2013.

${ }^{3}$ F. Bensouda, deputy prosecutor of the ICC, The Guardian, 23 May 2012.

${ }^{4}$ S. Kendall and S. Nouwen, 'Representational Practices at the International Criminal Court: the Gap Between Juridified and Abstract Victimhood', Law and Contemporary Problems, 76 (2014), 235. 
crimes' represent a category of persons whom the law must protect. This sacred space of victimhood must not be open to expansion. But Ruto's statement, validity aside, offers a way of rethinking how the notion of the victim in Kenya's post-election context has become popularised to refer specifically to those subjected to violent attacks, economic loss or psychological harm. While ideas of structural, political and economic violence once had a place in progressive politics, today Ruto's remarks are a reminder of the narrowing of definitional spaces within which judicial processes are playing out. This delimitation of who is a 'victim' and what constitutes 'victimhood' came of age with the popularisation of a recently emergent victim-protection discourse.

The popular presumption today is that to utter the words 'victims want justice' is to assume that 'victims want adjudication' to address their grievances. This played out at a February 2014 status conference in the ICC case against Uhuru Kenyatta, now president of Kenya, whose charges were subsequently dropped in late 2014. Fergal Gaynor, the victims' case representative, told the following story about the victims he represents:

I referred earlier to a woman I met who was gang-raped by Mungiki attackers and then doused in paraffin and set alight. She was lucky to be rescued. Nine-months later she gave birth to a little boy. His biological father is a Mungiki rapist. The woman explained all of this to her husband - who, as you will recall, was himself hacked repeatedly by the Mungiki and left for dead that same day. He understood his wife's hellish predicament. And today they are raising together that little boy. Conceived through rape he is being raised in love. What does he (the husband) want - taking into account the horrors that he and his wife were subjected to? His answer is Justice. With justice, he told me, 'there can be reconciliation'. But if there is no justice he won't be able to find it in his heart to forgive. ${ }^{5}$

Gaynor concluded with the following:

For there to be true reconciliation there must be truth. For there to be truth, there must be evidence - all the evidence that is necessary to uncover the truth. For there to be evidence, there must be state cooperation and for that, the accused must give the order ... Justice ultimately is truth. It is the whole truth in all its measures. It is the rejection of those who try to create obstacles for reaching those truths ... They say in Kiswahili, 'haki huinua taifa.' In English, 'Justice elevates a nation.'

${ }^{5}$ Fergal Gaynor, Transcript of ICC Status Conference, The Prosecutor v. Uhuru Muigai Kenyatta, ICC-01/09-02/11, Trial Chamber V(b), ICC, 5 February 2014, 38. 
Here Gaynor attempts to connect the notion of true reconciliation with justice - fundamentally achieved through legal measures - and uncovering the truth of violence through juridical deliberations. This conception of justice, he argues, will produce the conditions for an elevated nation. This reduces 'justice' to 'law' as the precondition for reconciliation. Underlying this veneer of 'justice-as-law' is the narrowing of a particular language of justice, what I call 'legal encapsulation', that erases political and economic realities of violence and judicialises them. ${ }^{6}$ This is especially the case where poverty has contributed to vulnerabilities related to violence, such as Kenya, the Democratic Republic of the Congo (DRC) and the Central African Republic (CAR), all countries where the ICC has intervened. ${ }^{7}$

The form of sentimentality that we see in Gaynor's and Bensouda's rhetoric has its roots in the humanitarian ethos of 'giving', 'holding accountable', 'protecting' and 'saving', but it is tied to a profound form of judicialisation that was developed to build institutions, safeguard property and protect foreign investments. As the practice of justice has become aligned with both adjudicatory processes and humanitarian giving, it has propelled the support of state intervention, military action, economic assistance and health aid. ${ }^{8}$ Through this development, both the individualisation of criminal responsibility - meaning holding a figurehead like William Ruto responsible for mass crimes under his watch and possibly at his behest - and defence of a certain category of victim - the focus of this chapter - have become central to justice discourses in the contemporary period.

However, like many victims, Kiamu, a Kenyan victim of post-election violence, questioned the ability of the ICC to work on behalf of victims:

One of the biggest weaknesses of Kenyan criminal law, we do not have a scheme for compensating victims of crime and the idea that these people of the 2007 violence are the only victims of crime, they're not the only victims of crime, I'm also a victim of crime I lost ten teeth, I nearly died; the state isn't compensating me. The best the state will do if they find the guys who beat me they might even hang them but they'll never pay me a coin for the injuries I've suffered. We've had victims in this country since the colonial times so if you're going to address the system of victims of

${ }^{6}$ K.M. Clarke, 2015 (unpublished manuscript).

${ }^{7}$ N. Waddell and P. Clark (eds.), Courting Conflict? Justice, Peace and the ICC in Africa (London: Royal African Society, 2008), 11.

${ }^{8}$ U. Baxi, 'What May the "Third World" Expect from International Law?', Third World Quarterly: Reshaping Justice: International Law and the Third World, 27 (2006), 713. 
political violence in Kenya we do it holistically. We begin with the day the British landed here, the evictions that the settlers did - today the biggest land owners are settlers. All of these issues need to be addressed. We're not going to just come here and create a situation and it becomes an industry for everyone to make money and the reference point becomes 2007. My reference point is in the eighteenth century, and I think something needs to happen. If we're going to address the question of criminal politics of domination, exploitation and impoverishment and eviction then my reference point is not 2007 it goes much [further] back. And the ICC has no capacity to address that, so I'll not waste time on it.

Here we see not only a strong conviction about the limits of culpability in domestic and international criminal law, but also a critique concerning the inability of international law to adequately protect victims. ${ }^{9}$

In an attempt to understand how a particular narrative encapsulation of justice-as-law has gained influence in the definition and protection of victims, this chapter explores the judicialisation of politics in the late twentieth century to early twenty-first century. I detail the narrowing of a particular type of 'victim' subjectivity that has become increasingly aligned with the rise of the rule of law in order to demonstrate that a certain epistemology of victimhood has formed at the juncture of a new economic and political order: contemporary neoliberalism and the rise of 'good governance' indicators. By evaluating the impact of the World Bank structural adjustment policies of the 1990s and the institutionalisation of new strategies focused on liberalisation and privatisation, I examine how the rule of law has merged with a contemporary development theory focused on stabilising markets and argue that the post-Cold War political reorganisation of sovereignty, democracy and various neoliberal forms of economic expansionism is central to contemporary notions of justice, with the defence of the victim via liberal legality at its base. This construction represents a particular alliance between economics, politics and the law and reflects the link between justice and markets in postCold War processes of neoliberal globalisation. Through the use of statistical indicators to predict various outcomes ranging from state stability, state fragility and the probability of violence, such measures helped to propel new rule-of-law discourses around the protection of the victim through the encapsulation of the language of justice. As the justice discourse progressed as part of the rule of law directives, 'the victim' was

9 A. Franceschet, 'The Rule of Law, Inequality, and the International Criminal Court', Alternatives: Global, Local, Political, 29 (2004), 23. 
invoked not only as the subject to be saved by new judicial mechanisms, but also as the basis for the moral responsibility to protect.

Today, victims are popularly defined as those we have a responsibility to protect, justice is narrowly tailored in relation to legal processes, and law has increasingly become the domain for vetting socio-political issues. Both the figure of the victim and that of the perpetrator are central to the merger of humanitarianism with foreign-policy-making and international law mechanisms. The language of individualism rose in significance, while the focus on the individual criminal responsibility of commanders became central. The individual victim was, in turn, reduced to someone who suffered physical violence against his/her individual body, not structural forms of victimhood caused by the very conditions of economic or political disenfranchisement at the heart of the new justice discourse.

The discourses at the heart of this situation reflect a new international order in which the desire to manage violence and the need to mobilise extra state support for the defence of particular victims became part of a critical narrative triangulation - victims, justice and the law - deployed through the language of the law. Ultimately, this chapter seeks to show how the rule-of-law discourse of justice and individual criminal responsibility have actually narrowed the category of victim. This narrowing has resulted in a substantive disjuncture in which the new conception of victimhood is being propelled by various judicially driven institutions for victims - such as the Victim's Trust Fund - that, on one hand, claim to work on behalf of victims, but on the other hand are unable to provide victims with the basic necessities for addressing their suffering. By rethinking the unproblematised notion of the victim, the goal is to map a particular genealogy of victimhood through which to make sense of the contemporary alliance between the category of the victim and the workings of contemporary justice discourses.

\section{Neoliberalism, the Washington Consensus and the rule of law}

By the 1960s, as increasing numbers of African states had begun to gain independence and negotiate new terms for their independent states, a new trend had emerged in the West in which the market economy became the basis for state governance. So even as new African independent states attempted to establish social market principles carried over from earlier imperial governments, a new mechanism for economic reform involving the deregulation and the reduction of state influence, 
the elimination of price controls and the diminishing of trade barriers promoted the concept of market freedom. This new theory of neoliberal reform had consequences in African contexts.

Following African independence, the end of the Cold War period signalled a victory for democracy and neoliberal capitalism. To promote economic liberalisation, open markets and free trade, a particular type of liberal economic organisation arose to advocate for deregulation, privatisation and the enhancement of private-sector development. In 1981 the World Bank published what became known as the 'Berg Report' (named after its author) on Sub-Saharan Africa. Amongst the key recommendations were market-oriented policies and reductions in government expenditures. These recommendations were soon reflected in World Bank and International Monetary Fund (IMF) lending practices; loans were granted in exchange for commitments to neoliberal, marketstimulating reforms, such as structural adjustment policies.

In 1989, English economist John Williamson coined the term 'Washington Consensus' to refer to a strongly market-based approach to development. It highlights ten relatively specific economic policy prescriptions considered central to the 'standard' reforms for the economic and political crises in the South promoted by the IMF, the US Treasury Department and the World Bank. The prescriptions encompassed policies in such areas as macroeconomic stabilisation, economic opening with respect to both trade and investment and the expansion of market forces within the domestic economy. Themes such as 'stabilise, privatise, and liberalise' became the mantra of a generation of technocrats who came of age travelling to meet with political leaders in southern countries to offer economic development advice. ${ }^{10}$ The advice of many of these technocrats inspired a wave of reforms in Latin America and SubSaharan Africa that fundamentally transformed the policy landscape in these regions towards privatisation, deregulation and trade liberalisation. ${ }^{11}$

However, the market-oriented reforms proved to be ill-suited to deal with public-health emergencies, poverty and social inequality. ${ }^{12}$ This resulted in cycles of underdevelopment in which the most attractive avenues for profit were those involving extractive industries such

${ }^{10}$ D. Rodrik, 'Goodbye Washington Consensus, Hello Washington Confusion?', Journal of Economic Literature, 44 (2006), 973.

11 J.L. Mueller, 'The IMF, Neoliberalism and Hegemony', Global Society, 25 (2011), 377.

12 T. Krever, 'The Legal Turn in Late Development Theory: The "Rule of Law" and the World Bank's Development Model', Harvard International Law Journal, 52 (2011), 287. 
as oil, mining or plantation agriculture, which often involved violent and exploitative labour conditions. Newly independent African states and poorly functioning state institutions were increasingly incorporated into the international economy as they negotiated terms of extraction and compensation with former colonial powers. International organisations helping to facilitate transitional governments and corporations hoping to sustain extraction agreements negotiated with former military governments. But these extractive activities unfolded in contexts in which the armies and police were underpaid, educational and health institutions were dismally underfunded and courts and electoral politics were driven by economic opportunism.

Violence emerged as a response to social unrest and perceptions of inequality, with 12 civil wars in the last 25 years contributing to untold numbers of deaths, rapes and destruction on the African continent. Postindependence states attempted to control their capital cities and rural regions through takeovers and the autocratic suppression of opposition movements and democratic constitutionalism. This was enabled by successive military coups such as those in Nigeria, where ten successive coups ensued after the discovery of oil in $1966 .{ }^{13}$

The race for political control in Africa has led to the unfolding of electoral violence, and in some cases the development of rebel groups or ethnic patronage networks vying for political influence and/or the control of various extraction industries. The recent histories of the DRC, Somalia, Liberia, Nigeria, Kenya, Uganda, Sierra Leone and Congo-Brazzaville all followed this trajectory. Each country has various elite networks, international companies, rebel groups and governments deeply embattled in controlling resource extraction and political decision-making. This has led to a postcolonial condition in which political settlements and new and effective economic strategies are desperately needed. But, as noted above, neoliberal policies failed to result in economic development. Rather, social scientists have documented the extent to which they have actually exacerbated inequality in the Global South. ${ }^{14}$

${ }^{13}$ K. Clarke, 'Treat Greed as a War Crime', New York Times, January 2013.

14 B. Chalfin, Neoliberal Frontiers: An Ethnography of Sovereignty in West Africa (Chicago: University of Chicago Press, 2010); J. Ferguson, Global Shadows: Africa in the Neoliberal World Order (Durham: Duke University Press, 2006); J. Comaroff and J. Comaroff (eds.), Millennial Capitalism and the Culture of Neoliberalism (Durham: Duke University Press, 2001). 
In evaluating the failures of the 'stabilise, privatise, and liberalise' dictates, the World Bank turned its focus towards institutions. What resulted was the merger of a mainstream development theory with the rule of law. Technocrats recognised that economic growth also required the institutional transformation of property rights, legal institutions and the judiciary. The World Bank became central to the new rule-of-law discourse in which 'good governance' and the consolidation of democracy, human rights, reduction of corruption and secure economic growth became part of the new policy strategies. ${ }^{15}$ A range of scholars described the merger as the manifestation of a transformation from a focus on efficient markets as the path to growth and prosperity, to the new orthodoxy of good governance. ${ }^{16}$

Thus, good governance through legal predictability and propertyrights protections became part of the 2004 World Bank rule-of-law definition as outlined in the unveiling of its twenty-first-century development policies. ${ }^{17}$ The assumption was that if neoliberal policies had failed, it was because of the absence of a secure institutional environment, not the policies themselves. The law and various legal institutions were considered central to this new discourse. What was being signalled was that the rule of law required transparent legislation, fair laws, predictable enforcement and accountable governments to maintain order, promote private-sector growth, fight poverty and have legitimacy. ${ }^{18}$ Ultimately, ensuring predictable market conditions was key. The challenge was to measure governance and commitment through the development of predictive indicators.

The World Bank developed a Worldwide Governance Indicators ranking system in which it categorised countries in relation to six aspects of good governance: voice and accountability, political stability and violence, government effectiveness, rule of law, regulatory quality, and control of corruption. ${ }^{19}$ These indicators were used by foreign-aid

15 Krever, 'The Legal Turn'; A. Santos, 'The World Bank's Uses of the "Rule of Law" Promise in Economic Development', in D. Trubek and A. Santos (eds.), The New Law and Economic Development: A Critical Appraisal (New York: Cambridge University Press, 2006); I. Shihata, The World Bank in a Changing World (Leiden: Brill Publishing, 1991).

${ }^{16}$ Krever, 'The Legal Turn'; Santos, 'The World Bank's Uses of the 'Rule of Law; Promise in Economic Development', 253-300; Shihata, The World Bank in a Changing World.

17 Santos, 'The World Bank's Uses of the "Rule of Law" Promise in Economic Development'.

${ }_{18}$ Krever, 'The Legal Turn'.

19 D. Kaufmann, A. Kraay and M. Mastruzzi, 'The Worldwide Governance Indicators: Methodology and Analytical Issues', World Bank Policy Research Working Paper No. $5430(2010)$. 
donor agencies to allocate funding according to various predictions of compliance. ${ }^{20}$ As Sally Merry and others have described, 'An indicator is a named, rank-ordered representation of past or projected performance by different units that uses numerical data to simplify a more complex social phenomenon, drawing on scientific expertise and methodology. The representation is capable of being used to compare particular units of analysis (such as countries or persons), and to evaluate their performance by reference to one or more standards. ${ }^{21}$ The indicators are said to produce systems of knowledge in which various phenomena are measured and ranked, while particular claims are made according to legal, moral and scientific measures. ${ }^{22}$

Indicators have thus become part of the new democracy of the twentyfirst century. They reflect the development of measures of compliance as well as predictions of volatility, risk and economic viability. The shift to the rule of law and the support for its principles became part of the way that the notion of international justice was operationalised by the UN Security Council in the establishment of various ad hoc tribunals and, subsequently, the ICC. Accordingly, the World Justice Project Rule of Law Index is said to measure how the rule of law is experienced in daily life in a cross section of households. Based on data collected from over 100,000 households and 2,400 expert surveys in 99 countries worldwide, it highlights 47 indicators that are said to index the following themes: constraints on government powers, absence of corruption, open government, fundamental rights, order and security, regulatory enforcement and civil and criminal justice. ${ }^{23}$ It also produces data for analysing various challenges, regional strengths and best and worst practices.

In addition to serving as a measure for various state conditions and a predictor of a range of outcomes, including state stability, state fragility and the probability of violence, an important part of the new rule-of-law discourse was the development of a space for victims to be "protected" and encapsulated by the new provisions. As the discourse progressed, the figure of the victim was invoked as the subject to be saved by new judicial

${ }^{20}$ G. Safarty, 'Regulating Through Numbers: A Case Study of Corporate Sustainability Reporting', Virginia Journal of International Law, 54 (2013), 575.

${ }^{21}$ K. Davis, B. Kingsbury, and S. Engle Merry, 'Introduction: Global Governance by Indicators', in K. Davis, A. Fisher, and S. Engle Merry (eds.), Governance by Indicators: Global Power Through Classification and Rankings (Oxford: Oxford University Press, 2012), 3-28.

${ }^{22}$ M. Serban, 'Rule of Law Indicators as a Political Technology of Power in Romania' (unpublished manuscript).

23 'WJP Rule of Law Index', World Justice Project (Washington, DC, 2014). 
mechanisms, and as the basis for the moral responsibility to protect. Significantly, the moral register became critically relevant for African states following the Rwandan genocide, the long history of anti-apartheid struggle in South Africa, and Liberia and Sierra Leone's civil wars in which international intervention was late and marginal. And in that regard, African states signed on to the Rome Statute regime with the expectation that judicial mechanisms would ensure that the international community would never again just stand by and watch such violence on the African continent.

Yet, a more incipient reality was at play that connected the moral impetus for rule-of-law interventions with a pragmatic, expressive one: the new rule-of-law indexes mattered in post-colonial Africa because they ultimately played a critical role in the renewal of IMF and World Bank loans, as well as in ensuring the ongoing support of international donors. ${ }^{24}$ With the combined expressive and instrumental impetus behind Africa's participation in the Rome Statute system as well as the adoption of a range of other international treaties, African states inserted themselves and mobilised to build new institutions. These new institutions wed traditional approaches to domestic state action with the expansion of human rights and international criminal law that shifted the focus from states and state protection to the protection of persons and peoples. ${ }^{25}$ With the shift to individuals, the idea of the 'victim' to be protected emerged. This shift was accompanied by a new judicial discourse that expanded beyond that which was used with victims from African states. It was based on a parallel humanitarian regime guided by the law of war $^{26}$ that incorporated dimensions of democratisation and political and social transformations.

These changes in legal and moral discourses were propelled by the pressures of laissez faire globalisation and affected the ways that state sovereignty and state borders were being reconfigured. They also had implications for the way that domestic laws were being reformulated through the incorporation of international treaties, and national laws

${ }^{24}$ B. Oomen, 'Donor-Driven Justice and Its Discontents: The Case of Rwanda', Development and Change, 36 (2005), 887; J. Parsons et al., 'Developing Indicators to Measure the Rule of Law: A Global Approach. A Report to the World Justice Project', Vera Institute of Justice (July 2008).

25 R. Teitel, Transitional Justice (New York: Oxford University Press, 2002).

26 C. Focarelli, 'The Responsibility to Protect Doctrine and Humanitarian Intervention: Too Many Ambiguities for a Working Doctrine', Journal of Conflict \& Security Law, 13 (2008), 191. 
reworked with the introduction of bilateral agreements and new regional conventions and formations.

Alongside the earlier forms of economic neoliberal reconfigurations, pro-democracy developments, and World Bank-driven policy reformulations came the adoption of new humanitarian principles such as those embedded in various UN resolutions and international treaties. These shifts included the ICC Rome Statute, which reconfigured the reach of law and located the individual at the centre of foreign affairs. This figure of the individual was articulated through a discourse surrounding both the high-level 'perpetrator', criminally responsible for mass atrocities, and the 'victim' to be saved from the perpetrator's violence. Both figures - the perpetrator and the victim - were central to the merger of humanitarianism with foreign-policy-making and international law mechanisms. However, with the focus on the individual criminal responsibility of commanders, the space of the victim was reduced to someone who suffered physical violence against his/her individual body, not the larger structural forms of victimhood caused by conditions of economic or political marginalisation. With this focus on the individual victim to be protected from mass violence against an individual perpetrator, those at risk of what was seen as the worst forms of violence were entitled to legal protection through a new emergent discourse concerning the 'responsibility to protect'.

\section{Protecting (certain) victims: a core responsibility of the 'international community'}

In September 1999 in The Hague, on the centennial of the first International Peace Conference, Kofi Annan, the then secretary-general of the United Nations, delivered a critical speech in which he challenged states to address 'two equally compelling interests ${ }^{27}$ at once. Entitled 'The Effectiveness of the International Rule of Law in Maintaining International Peace and Security', Annan called for the production of an effective response to human rights abuses. The other interest was concerned with the development of a mechanism through which states could act with universal legitimacy. ${ }^{28}$ From this challenge, the Canadian

${ }^{27}$ K. Annan, 'The Secretary-General Address to the United Nations General Assembly' (1999).

28 S.J. Koulen, 'The Responsibility to Protect: A Critique of Motherhood and Apple Pie' (unpublished manuscript, 2009). 
government established the International Commission on Intervention and State Sovereignty (ICISS).

ICISS was set up to reconcile the relationship between state sovereignty and the responsibility of the international community 'to act in the face of mass violations of humanitarian norms' ${ }^{29}$ From this task, it published a final report in December 2001 entitled 'The Responsibility to Protect', ${ }^{30}$ which served as a critical doctrine for the development of the key principles of legality related to the protection of victims. The notion of the Responsibility to Protect (R2P or RtoP) emerged thereafter as a moral and political norm promoting the protection of life regardless of state citizenship or national identity. This notion led to the production of the terms for the expansion of global executive action ${ }^{31}$ in which the developing rule-of-law project led to the further institutionalisation of core principles that obligate persons in positions of power to act in particular ways.

In 2001, following the failure of the international community to act to prevent or stop the Rwandan genocide, the African Union (AU) reinforced the idea that the international community had a responsibility to protect its population in crisis situations. ${ }^{32}$ Article 4 of the AU's constitutive Act asserts 'The right of the Union to intervene in a Member State pursuant to a decision of the Assembly in respect of grave circumstances, namely war crimes, genocide and crimes against humanity'. Some four years later, the UN General Assembly produced a declaration clarifying the 'Principles and Guidelines on the Right to a Remedy and Reparation for Victims of Gross Violations of International Human Rights Law and Serious Violations of International Humanitarian Law'. This declaration articulated a universal set of guidelines for victims. By 2005, the AU had adopted the Ezulwini Consensus, which provided African states with an African regional tool to address mass atrocities.

The foundational pillars of RtoP involve the idea that a state has a responsibility to protect its population from gross human rights violations. These include crimes against humanity, war crimes, genocide and

29 'The Responsibility to Protect: Report of the International Commission on Intervention and State Sovereignty' (Ottawa: The International Commission on Intervention and State Sovereignty, 2001), 18.

${ }^{30}$ Ibid., 10.

31 A. Orford, 'On International Legal Method', London Review of International Law, 1 (2013), 166; A. Orford, 'Locating the International: Military and Monetary Interventions after the Cold War', Harvard International Law Journal, 38 (1997), 443.

32 B. Kioko, 'The right of intervention under the African Union's Constitutive Act: From non-interference to non-intervention', IRRC, 85 (2003), 807. 
ethnic cleansing. The second component involves the assumption that the international community has a responsibility to assist states in fulfilling that primary responsibility to protect its population. And finally, if a state fails to protect its citizens from the four crimes of concern, and if it has failed to maintain peaceful measures, the international community has a responsibility to intervene using the most effective and appropriate means, ranging from coercive measures to economic sanctions, with military intervention as a last resort. ${ }^{33}$

The RtoP discourse is not simply a moral architecture of the contemporary period. The notion of an obligation to protect the victim was driven by a force of law deployed across sovereign borders with expanded jurisdictional reach. This expansion of activity reflected a fundamental shift from the regulated affairs of the state to the expansion of global governance mechanisms known to operate from the north to the south, particularly in Africa and Latin America. These regions reflect the continuity of economic dependencies, and hence the need to manage political compliance with legal protections. The establishment of new ad hoc tribunals, international treaties, decrees and charters promoted the legal frameworks that made this possible. And the notion of the individual to be protected' joined with new international humanitarian and judicial mechanisms that provided the vocabulary for popularising these radically new and fundamentally transformative formations. ${ }^{34}$ Key to the development of these mechanisms was a deeply retributive justice system to punish the guilty, but with minimal restorative possibilities for the victims.

As we enter the second decade of this century, the plight of victims in post-violence conflict situations remains within the realm of retributivejustice approaches, such as criminal tribunals. International discourses about the victim began playing a critical role in establishing a profoundly astute justice discourse. But the formation of judicial mechanisms to protect victims was only part of the story. In shifting from development

33 'A more secure world: Our shared responsibility', Report of the Secretary-General's Highlevel Panel on Threats, Challenges and Change (2004), 56-57, paras. 201-203; C. Stahn, 'Notes and Comments. Responsibility to Protect: Political Rhetoric or Emerging Legal Norm?', American Journal of International Law, 101 (2007), 99.

34 Stahn, 'Notes and Comments. Responsibility to Protect'; C. Focarelli, 'The Responsibility to Protect Doctrine and Humanitarian Intervention: Too Many Ambiguities for a Working Doctrine', Journal of Conflict \& Security Law, 13 (2008), 191; N. Schimmel, 'The Moral Case for Restorative Justice as a Corollary of the Responsibility to Protect: A Rwandan Case Study of the Insufficiency of Impact of Retributive Justice on the Rights and Well-Being of Genocide Survivors', Journal of Human Rights, 11 (2012), 161. 
priorities to judicial measures, the popular definition of justice became narrower and far more restrictive and, with it, who counts as a 'victim' deserving of that justice.

\section{Retributive and restorative justice in the world of tribunals}

At both the Nuremberg and Tokyo tribunals, and the ad hoc tribunals for the former Yugoslavia and Rwanda, the interests of victims were to a large extent overlooked; their role was generally restricted to that of witnesses. However, as a result of the shift of the new governance architecture there has been a growing movement, supported by a range of non-governmental organisations as well as some states, to recognise the role of international justice in providing not only retributive justice but also restorative justice, by permitting victims to participate in proceedings and receive reparations for the harm they have suffered.

In 1985, the UN General Assembly first adopted the Declaration of Basic Principles of Justice for Victims of Crime and Abuse of Power (the Victims' Declaration), which revolutionised the ordinary usage of the term 'victim'. This declaration has been the 'cornerstone' of legal rights for victims under international law. It established victims' rights in the criminal justice process, including the right to access justice, to be treated with basic respect and dignity, to protection and assistance and to reparation. The restorative dimension came further into play in 1991, when a compensation system for victims of a war was created. And in the aftermath of the Gulf War, the Security Council set up a commission to deal with the requests originated by the occupation of Kuwait and to decide on the compensation.

The Victims' Declaration, alongside these developments, laid the foundation for the negotiations on how victim was to be defined in the ICC texts during the Preparatory Committee discussions, leading to the signing of the Rome Statute in 1998. Interestingly, after extensive debates on whether or not legal entities could also be included in the definition of the term 'victim', a compromise was reached in the Rules of Procedure and Evidence, which establishes that victims may include organisations or institutions. ${ }^{35}$ Despite this, the definition popularised by the ICC represents the consolidation of the notions of victims, justice and law.

After this period, international criminal law heralded a discourse driven by the Rome Statute's preambular conviction that 'all peoples

35 Rule 85 (b). 
are united by common bonds' that could be shattered at any time through violence, and that millions of children, women and men have been 'victims of unimaginable atrocities that deeply shock the conscience of humanity' ${ }^{36}$ During the negotiations on the Statute, emphasis was placed on ensuring that the core values of the Court - to promote greater peace and security through accountability for crimes, as well as the rights and the dignity of the victims - were to be respected. ${ }^{37}$ This issue was crucial, given the clear recognition by states that the ICC should not only be retributive, but also restorative.

In keeping with the rule of law momentum, the Rome Statute provides for the possibility of granting reparations to victims. In the negotiations that led to the formation of the Rome Statute for the ICC, two principal institutions were conceptualised: the International Criminal Court and the Trust Fund for Victims (TFV). The TFV was established in September 2002 by the Assembly of States Parties and complements the reparations functions of the Court. Its mission involves providing the advocacy and mechanisms for mobilising physical, material or psychological resources for individuals victimised by violence. It is administered by the registry but is independent from the ICC and is supervised by a board of directors. Articles 75 and 79 of the Rome Statute lay the foundation for this restorative, victim-centred element. ${ }^{38}$

The Trust Fund, funded through Court-ordered forfeitures and fines as well as voluntary contributions by states parties, has a two-pronged mandate. The first aspect of the mandate is the provision of general assistance to victims or communities of victims in ICC-situation countries. The second aspect involves the management and implementation of reparations to victims. Furthermore, in a novel phenomenon in international criminal proceedings, Article 68 (3) of the Rome Statute grants that victims of crimes under the jurisdiction of the Court may also make their views and concerns heard during a trial. Accordingly, the Office of Public Counsel for Victims was established in 2005. Since its inception, the office had, as of July 2010, represented approximately 2,000 victims and

36 Preamble, Rome Statute.

37 W. Schabas, An Introduction to the International Criminal Court, 4th Ed. (Cambridge: Cambridge University Press, 2011).

38 Articles 75 and 79, Rome Statute. Article 75 establishes that the Court 'may order reparations against a convicted person specifying appropriate reparations to, or in respect of, victims, including restitution, compensation and rehabilitation'. Article 79 establishes the Trust Fund 'for the benefit of victims of crimes within the jurisdiction of the Court, and the families of such victims'. 
submitted approximately 300 submissions in the various proceedings before the Court. The office has also assisted 30 external legal representatives in all situations and cases, and provided close to 600 legal advisors to them.

The Victims' Rights Working Group was also created in 1997 under the auspices of the NGO Coalition for the International Criminal Court in order to work with various victims' representatives to help them participate in the proceedings or to inform them of judicial developments as they relate to their case. The Victims Participation and Reparations Section (VPRS) of the ICC's Registry conducts regular assessments and evaluations of its work, and sees itself as committed to a reflective learning process as its staff implement the Court's mandate in situation countries. The mission is communicated in a prevailing discourse of defending victims and ending impunity through the rule of law. The centrality of victims at the centre of the Trust Fund's work is enabled through the mobilisation of ICC judicial proceedings. It is an example of the way that the law is actually a by-product of a changing world of neoliberal governance and the resulting forms of executive governance in the Global South, and Africa in particular.

Despite the initial revolutionary presumptions about the formation of the Trust Fund, various stakeholders on the ground have been rigorously debating whether international criminal trials should be subordinated to other justice-producing mechanisms available on the African continent. The arguments are broad, and concern the viability of the ICC and its ability to achieve justice, especially if driven by retributive motivations. The reality is that, in addition to the essentially punitive institution of the ICC, the drafters of the Rome Statute and a significant civil society lobby sought to include elements of restorative justice, focused on social repair and reconciliation. ${ }^{39}$ Yet various victims of violence, once enthusiastic about ICC adjudication, are now ambivalent about the work of the Court and its ability to achieve the type of justice that victims imagine. ${ }^{40}$ Two of the larger questions are how to define those on whose behalf the Court

39 'Victim Participation before the International Criminal Court', War Crimes Research Office (2007); Judge Sang-Hyun Song, President of the International Criminal Court, Opening Remarks at the 7th Consultative Assembly of Parliamentarians for the International Criminal Court and the Rule of Law \& World Parliamentary Conference of Human Rights, International Human Rights Day (10 December 2012).

40 'Kenyans set benchmarks for implementation of Jubilee Manifesto', prepared by Ipsos Synovate (13 July 2013). 
works, and has the Court been able to deliver on the many expectations of justice for victims? ${ }^{41}$

As a discourse, the provision of victim inclusion as a key component of international trials has become one of the key organising principles underlying the definition for international criminal justice. Though much has been achieved, the limitations and tensions of the system in practice have also become apparent. Allowing for the participation of victims of extreme forms of physical, sexual and psychological violence through the structure of the proceedings in the trials and for reparations through the Trust Fund were heralded as significant achievements, yet victims' applications to participate in a trial have at times been so voluminous that the VPRS data-management and registration systems have struggled to cope with these realities. And though the Court's promise has been articulated in the name of victims, the reality is that many victims complain of the lack of proportionality between its institutional force and its ability to produce substantive and tangible reparative justice for those in need.

ICC judge Christine van den Wyngaert has described the lengthy and cumbersome process of victim registration at the ICC. ${ }^{42}$ She concluded that the 'number of victims is becoming overwhelming ... The Court may soon reach the point where this individual case-by-case approach becomes unsustainable. It may well have to consider replacing individual applications with collective applications. ${ }^{43}$ ICC Judges have, since the start of trials, been grappling with a way to balance considerations of restorative justice for victims with expeditious and fair retributive justice. Indeed, a ruling by the judges of Trial Chamber $\mathrm{V}$ has led to the overhauling of victims' participation and representation in the case against Uhuru Kenyatta, and is an example of the need for rethinking the Court's restorative mandate. ${ }^{44}$

The very nature of the retributively driven judicial proceedings may at times deliver undesirable or incomprehensible results where victims are concerned. Due to a re-characterisation of charges, or a change in the temporal scope of cases, it is possible that from one day to the next,

41 Trust Fund for Victims, 'Mobilising Resources and Supporting the Most Vulnerable Victims through Ear-marked Funding', Programme Progress Report (Winter 2012).

${ }^{42}$ C. Van den Wyngaert, 'Victims before International Criminal Courts: Some Views of an ICC Trial Judge', Case Western Reserve Journal of International Law, 44 (2011), 482.

43 Ibid., 483.

44 Decision on Victims' Representation and Participation, The Prosecutor v. William Samoi Ruto and Joshua Arap Sang, ICC-01/09-01/11, Trial Chamber V, ICC, 3 October 2012. 
victims may find themselves ineligible for participation or even reparations. Despite this, ICC organs working with victims or the legal representatives of victims must deal with the challenges of communicating changing judicial decisions over who is selected as 'victim' and/or whose changing status has caused new forms of exclusion.

These competing demands continue to highlight the challenges as they relate to maintaining the equilibrium between the restorative mandate and the retributive, criminal justice mandate of the ICC. In this light, the following section demonstrates how, in Kenya, the DRC and CAR, the basis for justice for victims has remained in the judicial realm. Sara Kendall and Sarah Nouwen have called this juridified victimhood, in which justice exists with legality at its core. ${ }^{45}$ The chapter concludes by demonstrating how retributive justice has come to form the contemporary answer to various sites in which violence against individual victims came to be understood as the basis for defining victimhood. Through that definition, a new form of international judicialisation has been developed to build institutions dedicated to ensuring the protection of victims. However, this individualised focus has left mundane forms of structural suffering unattended.

\section{The delimited space of victimhood}

When you consider that the victims of the conflict did not have reparations and for me ... we talk and talk and talk about the accountability process but it will never be complete until we implement the recommendations of the TRC ... of the TRC reports ... We provide [legal] help to the perpetrators, why are we failing the victims? We have a lot of victims in Sierra Leone who are beggars today.

A front-line worker uttered the above words as he reflected on Sierra Leone's post-violence plight and anticipated the challenges of Kenya's post-election violence victims. Shortly after he shared his reflections, Kenya became an ICC situation country in 2012. Kenya is by far one of the most polarised countries as far as ICC activity is concerned. Today the cases are beset with controversies and complexities in which a portion of the population seems opposed to the Court's engagement, while the other part supports it.

According to the Kenyan Truth, Justice and Reconciliation Commission, the 2007 presidential elections were 'conducted in a volatile

45 Kendall and Nouwen, 'Representational Practices', 235-262. 
environment in which violence had been normalized and ethnic relations had become poisoned'. ${ }^{46}$ The groundwork had been laid for the eruption of violence such as delayed election results, reports of electoral vote rigging and ethnic incitements which ultimately led to a two-month period of violence, leaving more than one thousand dead, hundreds of thousands displaced, and large amounts of property destroyed.

Both the Party of National Unity led by sitting president Mwai Kibaki and the Orange Democratic Movement led by Raila Odinga claimed victory. ${ }^{47}$ Violence was seen in all but two regions of Kenya, with a heavy concentration in pro-Odinga areas, the slums of Nairobi, the Rift Valley (Eldoret), Nyanza (Kisumu) and the Coast Province (Mombasa). ${ }^{48}$ Patterns of violence included rioting, excessive use of force by members of the police and the security forces, the burning and looting of property, sexual violence and (ethnically motivated) murder. ${ }^{49}$ In November 2009, the ICC prosecutor requested authorisation from Pre-Trial Chamber II to open an investigation, submitting that there were reasonable grounds to believe that crimes against humanity had been committed, 'in particular crimes of murder, rape and other forms of sexual violence, deportation or forcible transfer of population and other inhumane acts'. ${ }^{50}$ The Pre-Trial Chamber granted the prosecutor's request to open an investigation on 31 March 2010.

In the Kenyan situation, at the time of writing, 233 victims had been authorised to participate in the case against Uhuru Kenyatta, which has since been dropped, with a further 327 included in the Ruto and Sang case. $^{51}$ Common legal representatives Fergal Gaynor and William Nderitu represented these groups of victims, respectively. The Kenya situation raises compelling questions with regard to victim participation and levels of support for the ICC. Reports of witness and victim intimidation in Kenya abound. On 5 June 2013, a letter began circulating in which ninety-three victims sought to withdraw from the ICC process, claiming they had lost faith in it, that they were no longer convinced that

${ }^{46}$ Report of the Truth, Justice and Reconciliation Commission (TJRC), Vol. I (2013), x.

47 'The General Elections in Kenya, 2007', Les Cahier d'Afrique de l'Est no. 38, Institut Français de recherché en Afrique (IFRA) (2008), 12; 'High Stakes: Political Violence and the 2013 Elections in Kenya', Human Rights Watch (HRW) (2013).

${ }^{48}$ IFRA, Ibid., 12; HRW, Ibid. ${ }^{49}$ HRW, Ibid.

${ }^{50}$ Request for authorisation of an investigation pursuant to Article 15, Situation in the Republic of Kenya, ICC-01/09, Pre-Trial Chamber II, ICC (26 November 2009), 3.

51 'Kenyan Victims withdraw from ICC Proceedings', Institute for War and Peace Reporting (7 June 2013). 
it would be beneficial to their interests and that they could not identify with the manner their interests had been represented in Court. ${ }^{52}$

When we interviewed one of the human rights workers for victims in Kenya we asked her if she thought that the ICC had done a good job with victims. She responded,

What's disheartening is that victims don't want to be a part of this anymore, this is like the latest that has not even gone to the media. It's like hush hush because who is going to say that Kenyan victims are saying they don't want to be part of ICC process ... In the cases of sexual violence what we know is that at some point when some of the field officers were having a conversation with me and saying please could you help, some women had disappeared. Some people were found dead, some people died from HIV which they acquired because you know ... it's 4-5 years down the line, with no medication and no proper food.

The above comment points to the ongoing decline of enthusiasm over the ICC process. Not only has the narrowing of the indictments led to the dropping of those eligible to be 'case victims', but the Trust Fund has yet to begin to implement projects in Kenya under its general assistance mandate. This has caused controversy and disappointment among victims and non-victims alike who are concerned with the absence of an ICC presence in the delivery of what they see as justice.

\section{The Democratic Republic of the Congo}

The history of violence in the DRC is long and complex. It is claimed that the Congolese civil wars caused the highest amount of deaths since World War II, with death tolls exceeding 5 million ( 3 million in conservative estimates). ${ }^{53}$ More than 2.4 million internally displaced persons have been reported. ${ }^{54}$ After two wars in the country in 1996 and 2003, and the government's failure to establish control and authority, the DRC has seen the proliferation of various armed groups, both local and foreign. These groups clash regularly with the Congolese army for power, in defence of their communities, and for the control of natural resources. ${ }^{55}$ All parties to the conflict have been implicated in committing human rights abuses, including torture, sexual violence and the

52 'Kenya: Victims want Uhuru's ICC Trial Hurried', allAfrica.com, 4 April 2013.

53 See 'US Congo Policy: Matching Deeds to Words to End the World's Deadliest War', Enough Project (2011); 'DR Congo war deaths "exaggerated"', BBC, 2010.

54 ' 10 facts you should know about the crisis in the DRC', Amnesty International (2013).

55 Ibid. 
recruitment of child soldiers. ${ }^{56}$ The DRC has been called the 'rape capital of the world', with various NGO reports commenting on what appears to be sexual violence committed on an unparalleled scale. ${ }^{57}$

In September 2003, the prosecutor informed states parties of his intention to open an investigation into the situation in the DRC using his proprio motu powers, but that a referral and the active participation of the authorities in the DRC would assist his office's work. In November 2003, the government of the DRC welcomed the Court's involvement in a letter, officially referring the situation to the Court in March $2004 .{ }^{58}$ One month later, the Office of the Prosecutor (OTP) announced a decision to open an investigation. ${ }^{59}$ As the first case to come before the ICC, in many ways Thomas Lubanga was a test case for victim participation. The Rome Statute defines 'victims' as 'natural persons who have suffered harm as a result of the commission of any crime within the jurisdiction of the Court'. ${ }^{60}$ In determining whether to grant victims status and to allow them to participate at trial (albeit through a common legal representative), judges must examine the link between the harm suffered, the victim's personal interests and the charges against the accused. The Appeals Chamber later used a slightly broader definition to include harm experienced collectively. ${ }^{61}$

In Lubanga, 129 victims participated in the proceedings through a large team of representatives. The majority claimed that the harms they had suffered resulted from the enlistment and conscription and use of children under the age of fifteen to participate actively in hostilities, as well as other crimes such as sexual violence and torture. ${ }^{62}$ Most of those who were classified as victims in the trial were former child soldiers. Notably, those who claimed to have suffered harm at the hands of these former child soldiers were not considered victims themselves for purposes of the trial. ${ }^{63}$ The Trial Chamber held that those who suffered harm due to the conduct of the direct victims (those who had been enlisted, conscripted and used in hostilities) were excluded and could not be

56 Ibid. $\quad 57$ TFV Programme Progress Report (Winter 2012), 16.

58 'The Office of the Prosecutor opens its first investigation', ICC Press Release (23 June 2004).

59 Ibid. ${ }^{60}$ Rule 85 (a), International Criminal Court, Rules of Procedure and Evidence.

61 Judgment pursuant to Article 74 of the Statute, The Prosecutor v. Thomas Lubanga Dyilo (Lubanga), ICC-01/04-01/06, Trial Chamber I, ICC, 14 March 2012, para. 14.

62 Ibid.

63 M. Pena, 'The Lubanga Case and Reparations for Victims of Sexual Violence', ijcentral, 2012. 
considered indirect victims, as only victims of the charged crimes may qualify for participation. ${ }^{64}$

Whether the ICC will adhere to this same division in its approach to reparations remains to be seen, although a landmark decision on reparations, issued in 2012, once again stated that they could only be granted to those who had suffered harm as a result of the crimes for which Lubanga had been convicted. ${ }^{65}$ A significant challenge for the Court to navigate will be the implementation of reparations and redress for victims while not contributing to further societal divisions or tension in the region. Child soldiers have been classified as the direct victims in the ICC's case, while locally, they may be perceived as perpetrators due to the oftenheinous acts they committed on the civilian population under duress, and certainly not deserving of what may be perceived as a reward from the international community. ${ }^{66}$

To date the TFV's projects involve northern Uganda ${ }^{67}$ and the DRC. The Court has approved 34 projects for both situations and some have either been phased out or completed. ${ }^{68}$ These projects are described as providing support for over 110,000 victims of crimes 'through integrated physical and psychological rehabilitation and/or material support at both the individual and community levels' ${ }^{69}$ TFV programming in DRC targets eastern DRC and victims of such crimes between 2002 and the present day in North and South Kivu, and through 2005 in the Ituri region. The TFV supports victims through activities focused on psychological rehabilitation and material support.

Following an assessment in 2007, the TFV submitted a filing to the Pre-Trial Chamber for 16 assistance projects in the DRC to focus on

64 Redacted Version of 'Decision on Indirect Victims', Lubanga, ICC-01/04-01/06, Trial Chamber I, ICC, 8 April 2009, para. 52.

${ }^{65}$ Pena, 'The Lubanga Case'.

${ }^{66}$ Decision establishing the principles and procedures to be applied to reparations, Lubanga, ICC-01/04-01/06, Trial Chamber I, ICC, 7 August 2012, paras. 44, 48.

67 The TFV's northern Uganda assistance program has been administered in eighteen subdistricts within Acholi, Lango, Teso and West Nile sub-regions and through partnerships has provided services to an estimated number of 39,750 victims of crimes against humanity and war crimes ranging from survivors of sexual violence and child mothers, former abductees, former child soldiers and returnee communities, as well as acutely impacted communities ranging from widows/widowers and surviving family members, disabled persons and amputees, and disfigured and tortured persons.

${ }^{68}$ For details of the activities and status of these projects, see Annex 7, 'External Evaluation of the trust Fund for Victims Programmes in Northern Uganda and the Democratic Republic of Congo', International Center for Research on Women (November 2013).

${ }^{69}$ Ibid., 15. 
psychological support, physical rehabilitation and material support for different categories of victims. ${ }^{70}$ Since 2008 to date, the TFV's partners in eastern DRC have provided services to 72,700 victims of war according to various categories, such as survivors of sexual violence, child mothers, former child soldiers (male and female), girls formerly associated with armed groups, returnee communities, acutely impacted communities, disabled persons and amputees, disfigured and tortured persons and other vulnerable children and young people. ${ }^{71}$ As Peter Dixon's chapter in this volume elaborates, the TFV identifies (or 'targets') its beneficiaries: It specifically identified victims within their mandate as individuals who have suffered gender-based violence including rape, forced pregnancy and sexual slavery, and has also involved the abduction and recruitment of girls, widows, orphans and vulnerable children into armed groups. ${ }^{72}$

As for the reparations mandate of the Trust Fund, it is likely that it will be implemented for the first time in the context of the DRC situation and the Lubanga conviction. With that judgment, not only are case victims expected to be awarded modest damages, but it will highlight the potential workings of a mechanism in which restorative justice can be observed alongside a judicial mandate. The challenge is that, as a result of the delays, many victims have complained that unmet expectations have produced a reality in which they fear that they have been used by the international system.

As a member of the OTP and the lawyer who represented nineteen victims from the DRC indicated in response to whether reparations should be given collectively or individually, 'Child soldiers are not a community ... It is not like a village that has been victimized. They are very often in conflict with their own families. I cannot see my clients as a group. They are really individuals.' This focus on the need to provide individual victims with the means for rebuilding their lives articulates the centrality of the individual in the work of the Trust Fund. But the Lubanga conviction also shows that the Trust Fund is not necessarily a fund that will be used to offer reparations to all victims of all crimes throughout the DRC. Rather, the Trust Fund is constrained by the Rome Statute's legal mandate. The second mandate - known as the 'general assistance' mandate - is the second component of the TFV, and those working in this arena have been working in the eastern DRC (and

70 Ibid., 16. ${ }^{71}$ Ibid., 19-20.

72 Trust Fund for Victims, 'Mobilising Resources and Supporting the Most Vulnerable Victims through Ear-marked Funding', Programme Progress Report (Winter 2012), 5. 
northern Uganda) since 2008. They have been offering trauma counselling, vocational training, reconciliation workshops and reconstructive surgery to over 80,000 victims.

Unlike the seeming success of the general assistance mandate in the DRC, the Trust Fund has discontinued its work in the CAR in early 2013. This delay and the ongoing violence in the region has had implications for how victims have engaged with the ICC and their prospects for future engagement. This calls into question the encapsulation of victimhood in contemporary justice discourses in situations where the protection of the victim is limited to either the narrow judicial case designations or particular mandates that provide limited compensation and exclude the possibility for reordering structural inequalities.

\section{Central African Republic}

A series of attempted and successful coups d'états and a subsequent series of crises have marked CAR's history since obtaining independence from France in $1960 .{ }^{73}$ Amnesty International has labelled CAR a 'volatile and unstable country', with the national security forces regularly clashing with various armed groups and factions. ${ }^{74}$ Reported crimes have included killings, torture, sexual violence, looting and destruction of property, many of which amount to war crimes or crimes against humanity. ${ }^{75}$ In 2002 several human rights organisations (both local and international) began to investigate the levels of violence and specific crimes committed in various regions in CAR, and relayed the evidence gathered to the ICC in February 2003. ${ }^{76}$ On 22 December 2004, the government referred the situation in CAR (since 1 July 2002) to the ICC. Two-and-a-half years later, in May 2007, the prosecutor opened an investigation.

The prosecutor had received allegations of attacks on the civilian population including looting, killing and rape, and alleged that high levels of sexual violence had been a central and distinctive feature of

${ }^{73}$ P. Vinck and P. Pham, 'Outreach Evaluation: The International Criminal Court in the Central African Republic', International Journal of Transitional Justice, 4 (2010), 421.

74 'Central African Republic: Action Needed to End Decades of Abuse', Amnesty International (2011).

75 Ibid.

76 M. Glasius, "We Ourselves, We Are Part of the Functioning": The ICC, Victims, and Civil Society in the Central African Republic', African Affairs, 108 (2009), 49; 'War Crimes in the Central African Republic: When the Elephants Fight, the Grass Suffers', International Federation for Human Rights (February 2003). 
the conflict. ${ }^{77}$ A record number of nearly 5,000 victims are participating in the case against Jean-Pierre Bemba Gombo, with the common legal representative team led by Edith-Marie Douzima-Lawson. ${ }^{78}$ Victims have identified murder, theft, destruction of property and sexual violence as the key crimes committed against the population during the various conflicts in the region since $2002 .{ }^{79}$ There are a reported 100,000 refugees from CAR in Cameroon, Chad and Sudan, and a further 100,000 internally displaced. ${ }^{80}$

Grave crimes falling within the jurisdiction of the ICC are seen to have been committed in CAR during 2002 and 2003 in particular. During this period, victims are alleged to have been raped and attacked by multiple assailants in public and in the presence of family members and some were subsequently killed. Ongoing violence has contributed to lengthy delays leading to questions about the viability of securing both restorative and retributive justice. In response to this problem with the delay, then prosecutor Luis Moreno-Ocampo insisted,

The people of Central African Republic need to know the world has not forgotten them ... Our investigative activities in CAR can bring to the attention of the international community the terrible problems facing the people here and the need to address them urgently. We need comprehensive solutions for CAR and the support of all. International justice is one part of the solution.

Security concerns have stalled implementation of the Trust Fund's projects in CAR, however, whereas the bulk of the funding has gone to projects in northern Uganda and the DRC.

In comparison to the controversies surrounding other ICC investigations, some observers have argued that the CAR has been relatively receptive to the Court and that this is due to the high level of local civil society involvement in instigating the cases. ${ }^{81}$ However, while the Trust Fund had planned to start activities in the CAR in 2013, it had to suspend all activities that year due to the political and security situation in the

77 'Background: Situation in the Central African Republic', Office of the Prosecutor, ICC (22 May 2007).

78 'Another 777 victims to participate in Bemba Trial', The Trial of Jean-Pierre Bemba Gombo, ijmonitor.org, 14 November 2013.

${ }^{79}$ P. Vinck and P. Pham, 'Building Peace, Seeking Justice: A Population-based Survey on Attitudes about Accountability and Social Reconstruction in The Central African Republic Reconstruction' (University of California, Berkeley Human Rights Center, August 2010).

80 'Trial Background', The Trial of Jean-Pierre Bemba Gombo, ijmonitor.org.

${ }^{81}$ Glasius, 'We Ourselves', 49. 
country. ${ }^{82}$ This delay and the ongoing violence in the region have had implications for how victims have engaged with the ICC and their prospects for future engagement. This calls into question the invocation of victim protection in contemporary justice discourses, especially in situations where the protection of those victimised by violence is limited to either the narrow judicial case designations or particular mandates that provide limited compensation and exclude the possibility for reordering structural inequalities.

In the Kenyan cases, victimhood is similarly based on clear violations against the human body. Through this conceptualisation of violence, it is the actual individual perpetrator of that violence that is the subject of the retributive mandate of the Court. In the case against Lubanga, the ICC's restorative mandate - a mandate whose reach might actually attend to the forms of structural and economic violence at the heart of various political contests - is significantly absent and not operating according to the structural needs of victims. These needs reflect a situation in which particular historical conditions of political marginalisation fostered particular types of vulnerable persons in the first place, and have become key to understanding the way that the contemporary neoliberal order has set in place the conditions for the individualisation of victimhood.

All of the foregoing examples of ICC cases under way highlight the way that the contemporary rule of law movement has worked through a particular window for parsing victimhood and a particular sentimentalism in the pursuit of justice through the defence of victims. Apart from the working of the TFV (which is operating only in select regions), this ethos of ICC justice today encapsulates the suffering of victims through a 'justice as the rule of law' discourse. This discourse motivates action through the defence of the indefensible - predominantly those victims of exceptional physical violence whose inflictions are related to those charges being pursued by the OTP against particular perpetrators. Through this constricted space of victimhood, ICC justice today has been propelled through an interest in the protection of the individual victim, and the merger of a new governance architecture with a new judicial mechanism for ensuring the institutionalisation of contemporary justice. It articulates expectations about our contemporary economy that clarify what our responsibilities are, what type of suffering is intolerable and how we can address those whose actions perpetrate violence.

82 'Trust Fund for Victims Suspends its Activities in the Central African Republic', Trust Fund for Victims, ICC (25 March 2013). 
Ultimately, because the protection of the victim has been driven by particular economic interests tied to the protection of private property, it has necessarily individualised responsibility as well as who and what qualifies as a victim, thereby narrowing the terms for victimhood. This reality represents the new justice discourse and presumes the need for a social order by which justice can be procured through judicialisation. This chapter has outlined the way in which the development of justice as a mechanism for dealing with gross violations represents a recent phenomenon in which individual rights are attended to through the law, thereby excluding the various ways that more mundane forms of violence have been removed from spaces of protective entitlement. Those claiming to be victims of an unequal social order are not considered victims and thus are not legally deserving of those protections by the law. This reality explains why William Ruto's claim to victimhood falls short of rule-of-law sympathies and how the moral sentimentalities that emerged with the figure of the victim brutalised by the African-leader-perpetrator have gained influence through a particular interest in the management of state borders and private property. This duality is propelled through various international forms of legality that reflect the norms of the contemporary judicial order.

\section{Juridified victimhood, juridification of justice - concluding thoughts}

Over the past five years we have seen a spectacular growth of justicerelated research, advocacy and funding to address the enormous gaps between the needs of post-violence victims and the provisions to meet them. Understanding how a domain of retributive justice meets the judicial and psycho-social-political and economic needs and expectations of various groups of victims is part of the challenge. ${ }^{83}$ Much of the scholarship on transitional justice - as a pragmatic and scholarly mechanism to deal with political transitions for societies needing to address past human rights abuses - has focused on the importance of implementing particular measures for addressing such abuses. These have ranged from criminal prosecutions to reparations programs, truth commissions and various kinds of institutional reforms concerned with

M. Mamdani, When Victims Become Killers: Colonialism, Nativism, and the Genocide in Rwanda (Princeton, NJ: Princeton University Press, 2001). 
democratic governance and rebuilding social trust, which are seen as necessary for repairing the social fabric of post-war-torn society. ${ }^{84}$

This literature has long been dominated by perceived dichotomies, such as that of peace versus justice, or retributive justice versus restorative justice. The debate, however, is now shifting towards an acceptance that it is not useful to ascribe either/or dichotomies to a rich, complex and, at times, seemingly contradictory reality. ${ }^{85}$ Recent scholarship has instead sought to make the case that retribution and restoration are not mutually exclusive. ${ }^{86}$ International courts and tribunals are not necessarily incapable of meeting the needs of victims, though there can at times be a vast difference between what victims need, expect or feel they are entitled to, and what the rigid framework of litigation can offer. ${ }^{87}$ Recent scholarship has also suggested that it may not be the outcome of a particular judicial intervention that matters, be it punishment for the perpetrator or reparations for the victims, but rather the process and structures of power that determine what acts constitute victimhood, and how to reconcile the challenges around how victims are included and excluded. How are their views represented ${ }^{88}$ How are their needs met, and on what terms, based on what principles?

Today, a growing number of scholars have begun re-conceptualising the terms of justice through a broadening of the terms of victimhood by which justice may be innovatively articulated. ${ }^{89}$ Some have pointed to ways in which the ICC could actually include more tangible

${ }^{84}$ Z. Miller, 'Effects of Invisibility: In Search of the "Economic" in Transitional Justice', International Journal of Transitional Justice, 2 (2008), 266.

85 W. Lambourne, 'Transitional Justice and Peacebuilding after Mass Violence', International Journal of Transitional Justice, 3 (2009), 28, 47-48.

${ }^{86}$ K. Daly, 'Revisiting the Relationship between Retributive and Restorative Justice', in H. Strang and J. Braithwaite (eds.), Restorative Justice: Philosophy to Practice (Aldershot: Ashgate Dartmouth, 2000).

87 T.M. Antkowiak, 'An Emerging Mandate for International Courts: Victim-Centered Remedies and Restorative Justice', Stanford Journal of International Law, 47 (2011), 279.

88 T.G. Okimoto, M. Wenzel and N.T. Feather, 'Beyond Retribution: Conceptualizing Restorative Justice and Exploring its Determinants', Social Justice Research, 22 (2009), $156,161$.

89 A. Boraine, 'Transitional Justice: A Holistic Interpretation', Journal of International Affairs, 60 (2006), 17, 19. See also J.N. Clark, 'The ICC, Uganda and the LRA: ReFraming the Debate', African Studies, 69 (2010), 141; Secretary-General Report, 'The Rule of Law and Transitional Justice in Conflict and Post-Conflict Societies', UN Doc S/ 2004/616 (2004). 
restorative-justice approaches, while others have shown that South Africa's Truth and Reconciliation Commission, though often seen as a model of restorative justice, included elements of retributive justice as well. ${ }^{90}$ Such examples highlight the reality that the juridification of justice in the defence of victims is only one of many starting points for making sense of the contemporary order.

${ }^{90}$ J. Sarkin, 'Enhancing the Legitimacy, Status and Role of the International Criminal Court Globally by Using Transitional Justice and Restorative Justice Strategies', Interdisciplinary Journal of Human Rights, 6 (2011-2012), 83, 84; L. Allais, 'Restorative Justice, Retributive Justice, and the South African Truth and Reconciliation Commission', Philosophy \& Public Affairs, 39 (2011), 331. 


\title{
Refracted justice
}

The imagined victim and the International Criminal Court

\author{
LAUREL E. FLETCHER
}

\section{Introduction}

Catastrophic violence seizes our imaginations. As observers and consumers of events taking place 'elsewhere', we try to picture what happened and to understand the effects of the violence. We make choices in interpreting events to create meaning from bloodshed. These choices implicate moral, political and legal considerations. Do we adopt the view of the combatants or victims? If we are the victims, are we innocent of wrongdoing and deserving of justice? Or are we complicit in creating conditions that permitted the atrocities to occur? These are questions that circulate in reporting and policy discussions of mass violence in armed conflict. In many conflicts, a consensus has now emerged among international observers that international criminal justice (ICJ) is a necessary response. The moral foundation of ICJ is based on the presumably unassailable premise that those responsible for atrocity crimes should be punished for their acts.

Demanding ICJ engages our imagination to these normative questions about who is responsible for the bloodshed through a particular understanding, or theory, of the innocent victim. Victims of mass atrocity crimes are invoked by the protagonists of ICJ as one of the primary moral justifications for this unique enterprise. Their suffering mobilises international politics and justice institutions to hold perpetrators accountable - to identify them, bring them to trial and punish those who are guilty. The theory of the victim constructed by ICJ and implemented most fully by the International Criminal Court (ICC) affords victims not only moral legitimacy but also legal rights. As figured by the field of ICJ, these 'imagined' victims demand accountability as the highest value pursued by justice institutions. 
Corporeal victims of mass atrocity crimes - those who exist outside of the ICJ discourse - may also want to see perpetrators held accountable for their crimes; however, they may not place the highest priority on retributive justice. They often demand other forms of justice as well, including material reparations and other redress associated with restorative justice. The dichotomy of imagined victims and real victims, while imperfect, captures the distance between the way in which international justice discourse constructs victims and the ways in which corporeal victims relate to ICJ. Employing the ICJ discourse on victims, international courts and tribunals almost unfailingly satisfies imagined victims while just as consistently frustrating the real ones. It is in the process of becoming 'real' with demands and desires that are distinct from the particular form of the international criminal trial - that the tensions between the imagined victim and the real victim surface. In making visible these frictions, a conflict in logics emerges: the logic of the victim theorised by ICJ that excludes the possibility of real victims with demands that diverge from the priorities of the international legal process.

Drawing on insights from critical theory and critical discourse analysis, this chapter contributes to critical reflection on transitional justice mechanisms, including the ICC, and aims to consider the political and social dimensions of ICJ. ${ }^{1}$ In so doing, it advances two arguments. First, it argues that the theory of the victim generated by ICJ produces a particular discourse around or a particular understanding of victims. This imagined victim works to mask the legal subordination of victims by the judicial institutions that derive their legitimacy, in part, through their service to this same constituency. Second, it argues that the imagined victim supports the logics of ICJ, which limit and render suspect, if not invisible, the particular meanings and desires of real victims for justice. The chapter thus contributes to international discussions of the values of ICJ and the ability of the ICC to live up to its moral commitments.

Inclusion of victims into the court is a defining feature of the ICC, and international justice supporters celebrate this newfound status of victims as rights-holders as codifying a broader trend in international law. ${ }^{2}$

${ }^{1}$ K. Clarke, Fictions of Justice: The International Criminal Court and the Challenge of Legal Pluralism in Sub-Saharan Africa (New York: Cambridge University Press, 2009); C. Moon, Narrating Political Reconciliation: South Africa's Truth and Reconciliation Commission (Lanham: Lexington Books, 2008).

2 'Policy Paper on Victims' Participation', Office of the Prosecutor, International Criminal Court, 12 April 2010, 1; B. McGonigle Leyh, Procedural Justice? Victim Participation in International Criminal Proceedings (Cambridge: Intersentia, 2011), 225; E. Haslam, 
Furthermore, envisioned as the leading edge in international justice, creators of the new court designed it to combine retributive justice (prosecuting offenders) and restorative justice (including victims in the legal process and authorising reparations) in a single institution. While a laudable goal, scholars have questioned the ability of the court to effectively 'manage the expectations' and experiences of these legal claimants. Critiques largely have emphasised the legal framework applicable to victims and the doctrinal tensions and implementation challenges that result. ${ }^{3}$ Consequently, prescriptions favour legal reform and rest on the premise that ICJ, if properly adjusted, can realise its moral promises to victims of mass atrocity.

This chapter's analysis is not as optimistic. The ICC seeks to satisfy multiple goals and constituencies. It aims to advance accountability, rule of law and reconciliation, and to serve the international community, national governments and civil society actors as well as victims. Yet, there are tensions among these goals and actors and limits to how well the institution may be able to resolve them. This chapter investigates how, in the case of victims, the root causes for the Court's shortcomings may be found in the logics of ICJ. Although victims are entitled to limited participation in the trial and to seek reparations after a sentence is reached, the legal structure of the ICC prioritises retributive over restorative justice, punishment over reparations, and the conviction of perpetrators over the character of the charges they face. Looking at trial procedures, victims are framed as a consideration against which other rights and values are weighed. Thus the real victims are subordinated to

'Victim Participation at the International Criminal Court: A Triumph of Hope Over Experience?', in D. McGodrick, P. Rowe, and E. Donnelly (eds.), The Permanent International Criminal Court: Legal and Policy Issues (Portland: Hart Publishing, 2004), $1,315-334$.

3 See, e.g., 'Obtaining Victim Status for Purposes of Participating in Proceedings at the International Criminal Court', War Crimes Research Office (December 2013); M. Tonellato, 'The Victims' Participation at a Crossroads: How the International Criminal Court Could Devise a Meaningful Victims' Participation While Respecting the Rights of the Defendant', European Journal of Crime, Criminal Law and Criminal Justice, 20 (2012), 315; C. Aptel, 'Prosecutorial Discretion at the ICC and Victims' Right to Remedy: Narrowing the Impunity Gap', Journal of International Criminal Justice, 10 (2012), 1357; 'Ensuring Effective and Efficient Representation of Victims at the International Criminal Court', War Crimes Research Office (December 2011); 'Victim Participation at the Case Stage of Proceedings', War Crimes Research Office (February 2009); 'Victim Participation Before the International Criminal Court, December', War Crimes Research Office (2007); C. Jorda and J. de Hemptinne, 'The Status and Role of the Victim', in A. Cassese, P. Gaeta, and J. Jones (eds.), The Rome Statute of the International Criminal Court: A Commentary (Oxford: Oxford University Press, 2002), 1, 1387, 1409-1416. 
the retributive justice aims of the ICC, and their desires are continually compromised despite their moral centrality to the integrated justice (retributive and restorative) mission of the Court. This account critically examines the ways in which the ICC discourse about victims facilitates this power dynamic.

The first part of this chapter introduces concepts from critical theory and critical discourse analysis and uses them to examine how courts, prosecutors and prominent international non-governmental organisations (INGOs) collectively create an international discourse on victims of international crimes. The second part turns our attention to what are termed 'real' or 'actual' victims ${ }^{4}$ and considers their treatment by the ICC at three points during the trial of Thomas Lubanga, the first case to reach a sentence and a decision on reparations. Through an analysis of the responses of the Court to demands by actual victims, the hierarchy of the imagined victims and the real victims is exposed. Part three employs a critical analysis of the trial proceedings to identify the competing logics at work in the ICJ theory of victims and adjudication of international criminal law. Part four discusses some of the implications of the gap between the imagined and real victims. This state of affairs presents normative and prescriptive challenges, which this chapter highlights but the resolution of which lies beyond its scope. What is at stake by an instrumental use of victims? What is lost and what might be gained by abandoning our promise to do more than symbolic justice? Part five concludes.

\section{The imagined victim}

The ICJ movement has flourished since the fall of the Berlin Wall and is legitimated through the experiences of victims. The logic of this movement is that atrocity crimes - crimes against humanity, genocide and war crimes - are harms committed against individuals, but are of such gravity that these crimes are considered an affront to humanity and, therefore,

4 This chapter will use the term 'real' or 'actual' victims to refer to embodied individuals who have suffered from atrocity crimes and who exist inside and outside the courtroom. This category is distinct from the way victims are constructed in the international criminal law discourse. This is not to suggest that real or actual victims are somehow authentic victims, or that such a category exists. While acknowledging that any understanding of victims always is mediated through acts of interpretation, the chapter adopts this dichotomy to expose the particular construction of the victim in the international criminal justice discourse and explore some of its implications. 
the international legal order vindicates humanity through punishment of the perpetrators. For these most serious crimes, justice for victims is a universal concern and where justice is not available domestically then justice will be provided through international institutions.

This understanding of victims as deserving recipients of legal justice and morally entitled to accountability has become hardwired into the norms, institutions and discourse of international justice. ICJ has normalised this theory of the victim. Identifying some of the processes through which this occurs reveals how power is deployed to generate a hegemonic, imagined victim. This discourse constructs the victim not only as deserving of justice, but also as demanding accountability. This understanding of the victim suppresses or deprioritises other understandings of the victim as demanding, for example, compensation, political participation or non-retributive measures.

\section{International criminal justice discourse of the victim}

Critical discourse analysis, like critical theory, is concerned with exposing the ways that power, ideology and discourse operate in unexpected ways. Claire Moon's theorisation of the role of discourse in reconciliation politics in South Africa is helpful here. ${ }^{5}$ She argues that there is a dynamic relationship between discursive practices - meanings generated through institutions and individuals who inhabit them - and the subjects of these practices such that discursive practices are acts of interpretation. ${ }^{6}$ These acts of interpretation shape or constitute the way we understand these subjects; subjects do not exist outside of, or independent from, acts of interpretation. Attention to the relationship between discursive practices and social practices reveals the way in which power operates to shape our conceptualisation of subjectivity, and therefore the possibilities for change. As described by critical discourse scholars,

[D]iscourse is socially constitutive as well as socially conditioned - it constitutes situations, objects of knowledge, and the social identities of and relationships between people and groups of people. It is constitutive both in the sense that it helps to sustain and reproduce the social status quo, and in the sense that it contributes to transforming it. Since discourse is so socially consequential, it gives rise to important issues of power. ${ }^{7}$

${ }^{5}$ Moon, Narrating Political Reconciliation. ${ }^{6}$ Ibid., 48-50.

${ }^{7}$ R. Wodak and M. Meyer, 'Critical Discourse Analysis: History, Agenda, Theory and Methodology', in R. Wodak and M. Meyer (eds.), Methods of Critical Discourse Analysis (London: Sage, 2009), 1, 5. 
Borrowing these insights, it is possible to study how victims are conceptualised and theorised in the ICJ discourse. This interpretation of the victim also tells us something about how these justice institutions understand victims should be treated. While a complete critical discourse analysis is beyond the scope of this chapter, legal texts, reports and policies by international courts and tribunals, speeches by their judges and prosecutors and statements by INGOs can serve to identify a common discourse about victims of atrocity crimes.

Victims are implicitly invoked in the Security Council resolutions leading to the establishment of UN-sponsored justice institutions that speak of the need to end impunity for atrocity crimes and to restore peace. ${ }^{8}$ The principal leaders of international justice institutions invoke victims as a category of meaning that instantiates the positive value of international justice for victims, as well as for humanity more generally. Victims, by virtue of suffering the wrongful acts of perpetrators, become defined as a group that deserves justice. Justice is always a virtue, a value as well as a tangible product (a conviction after trial) that all societies strive to achieve. ICJ stands outside of and above the response of any nation state to violence. It is uniquely capable of speaking in universal terms. The founding legal statutes of its institutions vest the protagonists of international justice - the judges and prosecutors - with symbolic and legal authority to speak on behalf of international justice. Indictments and court orders represent the considered judgments of these international actors about the nature, consequences and therefore the meaning of the acts for which the accused stand trial. These protagonists are capable of telling us what needs to be done to fulfil these universal goals of justice. As a result, the way in which these actors talk about victims is freighted with meaning.

By aligning the work of ICJ with victims, victims become a focal point around which the values and forms of universal justice revolve. Victims become symbolic targets of the observers' aspirations to righteousness. This merger between the values that victims represent and our aspirations to promote these values is potent. This allows the speaker to call upon our sense of moral urgency to respond to victims. The fusion between the imagined victims and the moral duty to punish perpetrators serves discursively to call upon international criminal law to do justice on behalf of each member of humanity as though the imagined injuries to the victim were our own.

${ }^{8}$ UN Doc. S/RES/827 (1993); UN Doc. S/RES/955 (1994); UN Doc. S/RES/1315 (2000) (on establishment of a Special Court for Sierra Leone); General Assembly Resolution 57/228 Khmer Rouge trials, UN Doc. A/RES/57/228 (2003). 
For example, successive presidents of the ICTY (International Criminal Tribunal for the Former Yugoslavia) invoke victims in the annual reports of the tribunal to the UN Security Council as a measure of the success of the institution; completed trials deliver justice to victims. ${ }^{9}$ The annual reports of the Rwandan tribunal are replete with references to victims. Victims define the social meaning of the tribunal, 'seeking justice for the victims continues to drive our commitment to the goal of ensuring that never again will such atrocities occur'. ${ }^{10}$ Other tribunals, such as the Extraordinary Chambers in the Courts of Cambodia, the Special Court for Sierra Leone and the Special Tribunal for Lebanon, also justify their work as providing 'justice to victims'. ${ }^{11}$ The convergence and consistency of the discourse of the imagined victim is further illustrated by a recent joint statement issued by prosecutors of the UN-sponsored criminal tribunals describing the meaning of their work as 'on behalf of the victims in the affected communities'.

Similarly, justice protagonists at the ICC - judges and prosecutors speak of the pursuit of justice by the court in terms of its service to victims. In his 2011 address to the UN General Assembly, ICC president Judge Sang-Hyun Song called upon states to 'redouble their efforts' to execute the court's arrest warrants because the failure to bring the indicted to justice was 'deeply distressing for the victims. ${ }^{13}$ He went on to state that his meetings with victims left him 'deeply moved' and

9 Twelfth Annual Report of the International Tribunal for the Former Yugoslavia, UN Doc. No. A/60/267 - S/2005/532 (2005); Tenth Annual Report of the International Tribunal for the Former Yugoslavia, UN Doc. No. A/58/297 - S/2003/829 (2003); Ninth Annual Report of the International Tribunal for the Former Yugoslavia, UN Doc. No. A/57/397 S/2002/985 (2002); Sixth Annual Report of the International Tribunal for the Former Yugoslavia, UN Doc. No. A/54/187 - S/1999/846 (1999).

10 Sixteenth Annual Report of the International Criminal Tribunal for Rwanda, UN Doc. No. A/66/209 - S/2011/472 (2011), 20; Eleventh Annual Report of the International Criminal Tribunal for Rwanda, UN Doc. No. A/61/265 - S/2006/658 (2006); Third Annual Report of the International Criminal Tribunal for Rwanda, UN Doc. No. A/53/ 429 - S/1998/857 (1998).

${ }^{11}$ Opening Speech by the Plenary's president Judge Kong Srim, during the Eighth Plenary of the Extraordinary Chambers in the Courts of Cambodia (13 September 2010); Statement by Prosecutor Brenda J. Hollis, Office of the Prosecutor, Special Court for Sierra Leone to the United Nations Security Council (9 October 2012); Ninth Annual Report of the President of the Special Court for Sierra Leone (2012); Second Annual Report of the President of the Special Court for Sierra Leone (2005); Annual Report, Special Tribunal For Lebanon (2009-2010).

12 SCSL OTP Press Release, Sixth Colloquium of International Prosecutors: Joint Statement (16 May 2011), 1.

13 J. S. Song, Address to the United Nations General Assembly (26 October 2011), 4. 
affected by their 'cries for relief and justice'. ${ }^{14}$ Luis Moreno-Ocampo, the first ICC prosecutor, frequently spoke of the centrality of victims to the work of international justice. ${ }^{15}$ His successor, Fatou Bensouda, continues in the same vein. She explained that her role is to investigate and prosecute those most responsible for the world's gravest crimes, where no-one else is doing justice for the victims. ${ }^{16}$

A critical analysis of the international justice discourse of victims also highlights how institutional actors at the ICC use the imagined victim simultaneously to legitimate and to garner support for their institutional roles. For example, in recent years, the ICC Assembly of States Parties (ASP) has effectively cut the ICC budget by not allocating increased funding as the number of investigations and cases increase. The ICC president regularly appeals to the ASP for increased financial support in part by making the case that the Court deserves funding to fulfil its mandate to provide justice to victims. ${ }^{17}$ Similarly, the Trust Fund for Victims (TFV), a non-judicial entity created under the ICC Statute with a dual mandate to provide assistance to victims and to implement Court-ordered reparations, frames appeals for support in terms of deserving victims and their centrality to the international justice. ${ }^{18}$ Although a part of the formal apparatus of the ICC, the TFV relies on voluntary contributions, rather than annual funding from the ASP, to carry out its general assistance mandate. Victims are not so much invoked as they are vividly described in terms of their suffering. Shattered, broken victims are depicted as struggling to rebuild their lives, and, with the help of TFV, their hopes for recovery are brighter. ${ }^{19}$ In short, victims are an instrumental funding appeal.

${ }^{14}$ Ibid.

15 See, e.g., L. Moreno-Ocampo, Prosecutor of the ICC, Seventh Diplomatic Briefing (Brussels, 29 June 2006), 8, 'At every stage of the judicial process, the Office [of the Prosecutor] will consult with the relevant victims and take their interests into account'; L. Moreno-Ocampo, Prosecutor of the ICC, Eighteenth Diplomatic Briefing (The Hague, 26 April 2010), 2.

${ }^{16}$ ICC Press Briefing, Nairobi, Statement by the Prosecutor of the International Criminal Court Mrs Fatou Bensouda (22 October 2012), 3.

17 See, e.g., J.S. Song, Remarks to the Eighteenth Diplomatic Briefing (The Hague, 26 April 2010), 3, wherein ICC president Judge Sang-Hyun Song stated, 'Victims, affected communities and communities under threat of future crimes should be the primary beneficiaries of the work of the Court and the entire Rome Statute system.'

18 See, e.g., 'Ten Years of International Criminal Court: A Focus on Victims', Keynote Speech Ms Elisabeth Rehn, Chair of the Board of Directors of the Trust Fund for Victims, Tallinn, Estonia (10 September 2012).

19 See, e.g., the video on the homepage of the website of the TFV, which includes film and testimony from survivors with visible, disfiguring, conflict-related injuries, available at www.trustfundforvictims.org. 
The indictment of notorious violators is vital, but indictments without trials leave international justice institutions impotent and potentially irrelevant. Judges and prosecutors at the ICC and other international criminal tribunals publicly hector states to cooperate with them by reminding states that victims are waiting for justice. For example, in addressing the UN Security Council, the ICC prosecutor reported on the lack of progress in cases, including those against Sudanese president Omar al-Bashir and other top officials, and argued for state action to effect arrests, by stating that, with the arrests, 'the victims will receive a clear message: they are not ignored. ${ }^{20}$

The constructed meaning of the victim serves to legitimate the normative claims of ICJ as well as the claims of institutional actors for greater financial and political support to implement their mandates. To acknowledge this instrumental use of the imagined victim clarifies what might be characterised as a self-interested political use of the category by institutional actors as distinct from how these same actors invoke victims to do other kinds of conceptual work. For example, the ICJ discourse on victims suggests that judges, TFV representatives and prosecutors also employ an understanding of victims as morally deserving and rightsbearing subjects. To point out that international justice protagonists deploy the imagined victim in multiple ways acknowledges the dynamic quality of legal discourse and the ways in which those who invoke it do so to legitimate moral values, as well as institutional needs.

\section{INGOs and the imagined victim as a challenge to international criminal justice discourse}

The dynamic quality of ICJ discourse towards victims also draws attention to resistance or challenges to its construction of imagined victims. The ICC discourse on victims maintains its own form and subjectivity victims are always the beneficiaries of international justice and the imagined victims are always served by it. However, because the category of the imagined victim is constructed by those who invoke it, its meaning is vulnerable to disruption.

A clear example of this process arises from INGOs that use imagined victims as a tool to hold the institutions of the ICC accountable in particular ways. INGOs participate in the construction of and, to some

${ }^{20}$ L. Moreno-Ocampo, Prosecutor of the ICC, Press Release, Statement to the UN Security Council on the Situation in Darfur UNSCR 1593 (2005) (5 June 2012), 4. 
extent, share the vocabulary of ICC protagonists with regard to the imagined victim. As captured by Human Rights Watch (HRW), 'Victims and affected communities are first among the court's many constituencies. ${ }^{21}$ HRW and other INGOs have urged the ICC to respond to their demands for reform that are framed as in the interests of victims. However, unlike the ICC-generated narrative, the INGO construction of the victim does not always assume that justice as implemented by the ICC is synonymous with the justice that victims seek and deserve. An examination of the public statements of INGO leaders in response to the Lubanga judgment illustrates how INGO advocates juxtapose the imagined victims as stakeholders - a constituency to which the court must answer - rather than as beneficiaries of the Court's justice.

In March 2012, the ICC Trial Chamber found Thomas Lubanga Dyilo, leader of the rebel group Patriotic Force for the Liberation of the Congo (FPLC), guilty of enlisting and conscripting child soldiers into his forces. The Lubanga case took eight years from when the Office of the Prosecutor (OTP) opened the investigation until the Court entered its judgment. Disappointing to many victims and their advocates, the prosecution brought a narrow set of charges regarding child soldiers and refused entreaties to include charges for sexual violence perpetrated by FPLC combatants. In response to the verdict, INGOs explicitly criticised as troubling the fact that the conviction did not reflect the full range of crimes that victims suffered and urged the Court to proactively address this gap by conducting outreach to victims and affected communities. ${ }^{22}$ One prominent INGO suggested that the ICC overlooked the victims in favour of technical aspects of justice administration to its detriment, 'It is when the quality of proceedings becomes the story over the vindication of victims' rights that serious concerns arise. ${ }^{23}$ By contrast, ICC prosecutor Luis Moreno-Ocampo claimed that the judgment served victims and justice, 'An international court investigated the suffering of some of the most vulnerable members of humanity - children in war zones ... The

${ }^{21}$ R. Dicker and E. Evenson, 'Letter to Prosecutor-Elect Fatou Bensouda: Priorities for the New International Criminal Court Prosecutor', Human Rights Watch (8 June 2012).

22 'First Verdict at the International Criminal Court: The case of Prosecutor vs. Thomas Lubanga Dyilo: Q\&A', Human Rights Watch (February 2012).

${ }^{23}$ P. Seils, 'ICC Asked Tough Questions by Historic First Judgment', International Center for Transitional Justice in Focus, 19 March 2012; see also 'Thomas Lubanga Sentenced to 14 Years Imprisonment in First ICC Trial', Coalition for the International Criminal Court Press Release (10 July 2012), 2-3. 
court provided a fair trial to the suspect and convicted him. It is a victory for humanity. ${ }^{.24}$

Victims, as imagined by these INGOs, are the abstracted personification of those to whom ICJ should answer; they are held up as a mirror to the ICC. In so doing, INGOs draw attention to ways in which international justice does not satisfy the demands of idealised victims. INGOs are not, in a legal sense, representing victims or their interests. These are organisations that are no more accountable to victims than the judges or prosecutors they criticise. Yet, by virtue of their status as independent organisations dedicated to promoting human rights and justice, they are able to claim the moral legitimacy to evaluate ICJ - to whom it should be accountable and the metrics by which it should be judged.

This example indicates a few important aspects of what the INGO discourse on victims reveals about the broader discourse of ICJ at the ICC. First, the manner in which INGOs invoke victims to challenge the legitimacy of the ICC points to the ways in which the subjectivity of victims is contested. INGOs inject the perspective of a victim that views justice differently from that which the ICC generates and celebrates; this victim is not satisfied with a verdict of the Court but names what is missing from the judgment - justice for sexual violence - and asserts a competing claim for what justice means and includes. Second, the ability of INGOs to contest the ICC's imagined victim is circumscribed by international criminal law. The law forecloses certain measures that victims might consider as justice - summary execution, performative atonement - so that the demands of the imagined victim never exceed the Court's mandate. Further, the ICC produces the authoritative, imagined victim through its judgments and statements; it is the Court, not INGOs, that is authorised by law to declare that justice has been done. Thus, the imagined victim of the ICC always legitimates the justice delivered by the Court and works to generate a hegemonic understanding of victims, even as counter-narratives of victims imagined by other stakeholders continue to circulate.

In sum, the major protagonists in ICJ - the judges, prosecutors and INGOs - claim the privilege of evoking and imagining victims. One might agree with the ways in which victims are imagined, just as one might think that atrocity crimes should be punished and perpetrators be

${ }^{24}$ International Criminal Court (ICC), 'Lubanga case: Press conference by ICC Prosecutor, 15 March 2012', YouTube: IntlCriminalCourt, 15 March 2012, available at www.youtube. $\mathrm{com} /$ watch?v=eoj_qCwHePk. 
sentenced. It is true that some real victims may share these beliefs and perspectives, but it is also true that others may not. The point is that those who invoke victims (including victim organisations) also construct them for particular purposes. It is the 'victim as imagined' that is able to carry a moral charge in arguments about what ICJ is and what values it serves.

\section{Victims in the International Criminal Court}

In its strategy statement, the ICC prides itself on its 'recognition of victims as actors within the international justice scheme greater than any previous international criminal tribunal. ${ }^{25}$ The Court formally combines retributive and restorative justice models. Prosecuting individuals responsible for atrocity crimes satisfies punitive goals, and restorative justice is promoted through victim participation in proceedings, as well as the reparations scheme. The OTP similarly celebrates that 'victims are actors of international justice rather than its passive subjects. Their participation is a statutory right, not a privilege bestowed on a case-bycase basis. ${ }^{26}$ The ICC justifies its inclusive approach on instrumental grounds - participation is good for victims because it improves the quality of their experience of justice and participation is good for justice as victims improve the work of the Court. ${ }^{27}$ When one examines how the ICC regime established and implemented this statutory regime of the rights of victims, the abstracted, imagined victim gives way to the actual victim. What does one learn about what victims want once they enter criminal proceedings and how do their preferences differ from what the Court and prosecutors imagined them to be?

The Rome Statute affords victims certain rights to participate in the proceedings. They may communicate to the prosecutor about alleged offences, they may participate in the judicial proceedings, they may provide evidence to the Court as a victim-witness and they may request reparations. Yet, these rights are qualified. While victims may present their 'views and concerns' to the ICC, ${ }^{28}$ judges have discretion as to when during proceedings victims may provide input, and the Statute stipulates that the judges control the manner in which

25 'Report of the Court on the Strategy in Relation to Victims', International Criminal Court ('ICC Report'), ICC-ASP/8/45, 18-26 November 2009, para. 1.

26 See OTP, 'Policy Paper on Victims' Participation', 1.

27 See ICC Report, paras. 2, 8, 44.

28 Article 68 (3), The 1998 Rome Statute of the International Criminal Court, 2187 UNTS 3 ('ICC Statute'). 
victims offer their views, so that their participation does not infringe on the fair trial rights of the accused. ${ }^{29}$ The legal framework for participation reflects competing views and tensions about the relationship of victims to ICJ. Advocates for a victim-centred or humanitarian approach pressed for the inclusion of victims' rights in the drafting of the Rome Statute. ${ }^{30}$ Arguments for victim participation drew on human rights principles regarding victims' rights to truth and justice, ${ }^{31}$ both elements of the imagined victim. Others adopted a utilitarian approach that viewed victim participation more sceptically, as a threat to judicial efficiency and as a detraction from the Court's central goal of convicting perpetrators - presaging fears that real victims are impediments to justice.

To some extent, these competing perspectives reflect different legal traditions. In the common law legal tradition, the interests of victims, as the injured parties, are represented by the prosecutor who has the sole responsibility to vindicate the crime as a breach of community norms; victims seeking money damages from a defendant generally must file a separate, private action, to do so. In the civil law tradition, the public law action of the state prosecutor and the private law action of victims to seek reparation for the harm caused by a wrongdoer may be joined in a single proceeding. While the ICC framework contains elements of each tradition within the victim participation provisions, as well as more generally, ${ }^{32}$ the Statute and Rules of Evidence and Procedure are the result of political negotiations among state representatives. The resulting regulatory regime owes perhaps as much to the process of negotiations as to a principled effort to integrate common law and civil law legal traditions. Commentators have noted that the inclusion of participation rights for

29 Ibid.

30 D. Donat-Cattin, 'Article 68: Protection of Victims and Witnesses and Their Participation in the Proceedings', in O. Triffterer (ed.), Commentary on the Rome Statute of the International Criminal Court: Observers' Notes, Article by Article (Munich: C.H. Beck, 2008), 1275, 1275-1281; G. Bitti and H. Friman, 'Participation of Victims in the Proceedings', in R. Lee (ed.), The International Criminal Court: Elements of Crimes and Rules of Procedure and Evidence (Ardsley: Transnational Publishers, 2001), 456, 456-459.

31 See Jorda and de Hemptinne, 'The Status and Role of the Victim'; see also McGonigle Leyh, Procedural Justice?, 269 n.256.

32 For example, the investigation stage employs procedures from the common and civil law traditions, while the trial phase more closely tracks common law procedures, and the rules of evidence and appeals follow civil law traditions. See K. Heller, 'The Rome Statute of the International Criminal Court', in K. Heller and M. Dubber (eds.), The Handbook of Comparative Criminal Law (Stanford, CA: Stanford University Press, 2011), 593, 599-601. 
victims was contentious and NGO advocates played an important role in securing victims' rights in the new Court. ${ }^{33}$

Nevertheless, victims and their advocates have rushed to test the limits of victim participation, and the Lubanga case offers some examples of this dynamic interaction between the imagined and actual victim at the ICC. Victims of Lubanga's forces sought to assert their rights to participate throughout the proceedings. Three junctures in particular - the adjudication of victims' requests to participate in investigations, the adjudication of standards for victim participation in judicial proceedings and the Court's ruling on reparations principles - illuminate this dynamic struggle between the imagined and actual victim.

\section{Victims and investigations}

Under the Rome Statute, the OTP is charged with investigating crimes within the jurisdiction of the Court. The question of the nature and extent to which victims may influence this process arose in the OTP investigation of the conflict in the Democratic Republic of Congo (DRC). A group of six victims filed applications with the Pre-Trial Chamber to participate in the investigation. The prosecutor objected to the applications, arguing that victims did not have the right under the Statute to participate in proceedings before a suspect is named. ${ }^{34}$ In other words, the role of victims - those with direct knowledge of the events under scrutiny - legally lies outside the decision-making process concerning which charges to pursue. ${ }^{35}$ The prosecutor saw victims as antagonists to the administration of justice. The Pre-Trial Chamber ruled against the prosecution, holding that the Statute afforded victims the right to participate and that considerations of efficiency and due process should be

33 See McGonigle Leyh, Procedural Justice?, 235-238.

34 Prosecution's Reply on the Applications for Participation, Situation in the Democratic Republic of Congo, 01/04-1/dp-6/dp, ICC-01/04, OTP, ICC, 15 August 2005, para. 14; see also Prosecution's Reply under Rule 89(1) to the Applications for Participation of Applicants a/0011/06, a/0012/06, a/0013/06, a/0014/06 and a/0015/06 in the Situation in Darfur, the Sudan, Situation in Darfur, Sudan, ICC-02/05, OTP, ICC, 8 June 2007.

35 The OTP more generally has favoured a restrictive view of victims' participation and has argued to maintain the exclusive purview of the prosecutor to search for the truth, 'That crimes should be effectively investigated and prosecuted is the core of the Prosecutor's mandate.' OTP, 'Policy Paper on Victims' Participation', 10, quoting Prosecution's Document in Support of Appeal Against the 6 December 2007 Decision on the Victims' Applications for Participation in the Proceedings, Situation in Darfur, Sudan, ICC-02/05, OTP, ICC, 18 February 2008, para. 24. 
taken into account on a case-by-case basis. ${ }^{36}$ The Pre-Trial Chamber drew on human rights principles and jurisprudence in its reasoning, placing the ICC legal framework in the context of international trends expanding the rights of victims. ${ }^{37}$

Despite grounding its decision in the international legal framework of victims as rights-holders - the imagined victim - the ICC limited the extent of their participatory rights. The judges ruled that victims would not have access to the investigation files or be able to attend closed sessions; what 'participation' of victims in the investigation meant was that they would be notified of proceedings and could have access to the public documents. ${ }^{38}$ In other words, victims had no greater access to information in the possession of the OTP than the general public. The Court, while formally siding with victims, in fact offered a hollow victory. Its decision did nothing to give effect to what victims purportedly wanted: the ability to influence the direction of the investigation and the decision of the prosecutor regarding which crimes to charge. At the conclusion of the investigation, the prosecutor did not refer charges for crimes of sexual violence as advocated by many victims' groups, but rather focused on crimes related to Lubanga's conscription and use of child soldiers, prompting a furious and public response from victims and NGO advocates. ${ }^{39}$ The Court has subsequently ruled in several cases, and on appeal, that the charges against defendants define the limits in which victims have standing to participate in judicial proceedings. Therefore,

${ }^{36}$ Public Redacted Version of Decision on the Applications for Participation in the Proceedings of VPRS 1, VPRS 2, VPRS 3, VPRS 4, VPRS 5 and VPRS 6, Situation in the Democratic Republic of the Congo, ICC-01/04, Pre-Trial Chamber I, ICC, 17 January 2006, paras. $57-58,70$.

37 Ibid., paras. $50-54$.

38 Ibid., paras. 59, 74, 76. The narrow normative victory for victims was curtailed further. In a subsequent ruling, the Appeals Chamber agreed, in part, with the position of the prosecutor and held that investigations are not 'judicial proceedings', within the meaning of Article 68 (3), and therefore victims are not entitled to participate. Judgment on Victim Participation in the Investigation Stage of the Proceedings in the Appeal of the OPCD Against the Decision of Pre-Trial Chamber I of 7 December 2007 and in the Appeals of the OPCD and the Prosecutor Against the Decision of Pre-Trial Chamber I of 24 December 2007, Situation in Democratic Republic of the Congo, ICC-01/04, Appeals Chamber, ICC, 19 December 2008, para. 45.

39 On the narrow scope of the charges brought against Mr Lubanga, see 'Joint Letter to the Chief Prosecutor of the ICC, Luis Moreno Ocampo' from Avocats Sans Frontières, Center for Justice and Reconciliation, Coalition Nationale pour la Cour Pénale Internationale RCD, Fédération Internationale des Ligues des Droits de l'Homme, Human Rights Watch, International Center for Transitional Justice Redress and the Women's Initiative for Gender Justice (1 August 2006). 
only victims of the criminal conduct relating to Lubanga's recruitment and use of child soldiers could participate, and only the experiences related to those charges would be relevant to the Court.

\section{Victims and participation in proceedings}

The discrepancy between the desires of some victims of the conflict in the DRC to see justice for crimes of sexual violence and the decision by the prosecutor to focus on the use of child soldiers led to repeated efforts by victims to have their views taken into account by the Court. Victims participating in the Lubanga trial requested that the Court re-characterise the legal charges against Lubanga to include sexual slavery. ${ }^{40}$ The Trial Chamber agreed with the victims, but the Appeals Chamber unanimously reversed that decision, ruling that the Trial Chamber had committed a legal error by effectively circumventing the charging documents in order to admit new facts after the charges had been confirmed. ${ }^{41}$ In the end, the Court sided with the prosecutor and legally subordinated victims to the vision of justice that the OTP decided to pursue.

\section{Victims and reparations}

Following its judgment against Lubanga, the Trial Chamber issued its decision on the principles and procedures to be applied to reparations in the case. ${ }^{42}$ Unlike the guilt phase of the trial, victims are parties, not 'participants', in these proceedings. During the reparations phase, the Court determines the harm for which the convicted perpetrator is responsible and the measures to address these wrongs. Reparations encompass a variety of interventions, such as compensation, physical and psychological rehabilitation and other measures to repair the social

40 Joint Application of the Legal Representatives of the Victims for the Implementation of the Procedure under Regulation 55 of the Regulations of the Court, The Prosecutor v. Thomas Lubanga Dyilo ('Lubanga'), ICC-01/04-01/06, 22 May 2009, paras. 4, 11, 17, 41 ('TFV Submission, Lubanga').

41 Judgment on the Appeals of Mr Lubanga Dyilo and the Prosecutor against the Decision of Trial Chamber I of 14 July 2009 entitled 'Decision giving notice to the parties and participants that the legal characterization of the facts may be subject to change in accordance with Regulation 55(2) of the Regulations of the Court', Lubanga, ICC-01/ 04-01/06 OA 15 A 16, Appeals Chamber, ICC, 8 December 2009, para. 88.

42 Decision Establishing the Principles and Procedures to be Applied to Reparations, Lubanga, ICC-01/04-01/06, Trial Chamber I, ICC, 7 August 2012 ('Decision Establishing Principles and Procedures of Reparations, Lubanga'). 
consequences of atrocity crimes. The Lubanga decision on reparations principles was another jurisprudential first, and the Trial Chamber considered a number of issues regarding the principles that should guide the Court, as well as the procedures that will apply in implementing its reparations order. This analysis focuses on the Court's decision as to whether reparations should be awarded on an individual or collective basis, as this debate illustrates tensions between the imagined and the actual victim. ${ }^{43}$

What did actual victims want reparations to be and do? Two groups of victim participants filed separate submissions on reparations. Each group favoured individual reparations to the participants and advocated that awards should take into account the particular needs of individual victims for economic and psychological assistance. ${ }^{44}$ The victim participants acknowledged that child soldiers had different experiences, had suffered a range of harms and had received different types of assistance post-conflict, all of which the Court should take into account. Their submissions emphasised that variability in benefits might be based on categories of experience (child soldiers who had been raped, those infected with HIV, those injured), the length of time spent as a child soldier and their level of education, among other factors. ${ }^{45}$

Collective reparations are not defined in the Rome Statute or Court regulations but, as explained by the TFV, collective reparations may include measures that are provided to groups. Some measures may be exclusive, like providing health care to members of a specific group (former child soldiers), or may be provided to a group on a non-exclusive

43 While the Appeals Chamber later amended the Trial Chamber's decision, it affirmed that the determination to award reparations on a collective basis, and not to rule on the merits of individual reparation requests, did not undermine the objectives of the reparations proceedings. See Judgment on the appeals against the 'Decision establishing the principles and procedures to be applied to reparations' of 7 August 2012 with AMENDED order for reparations (Annex A) and public annexes 1 and 2, Lubanga, Appeals Chamber, ICC, 3 March 2015.

44 One group asserted that only victim participants should receive individual reparations, while the other groups stated that former child soldiers who did not participate nonetheless should be able to receive individual awards, even if such amounts were modest. Observations on the Sentence and Reparations by Victims ('V01 Group'), Lubanga, ICC01/04-01/06, 18 April 2012, paras. 24-27.

45 Ibid., paras. 28-29; Observations of the V02 Group of Victims on Sentencing and Reparations ('V02 Group'), Lubanga, ICC-01/04-01/06, 18 April 2012, para. 27. Some victim participants felt that they should receive individual awards, in part, because they had assumed a risk to take part in the proceedings. See V01 Group, para. 24. 
basis, such as schools. ${ }^{46}$ Collective reparations, however, should 'address the harm the victims suffered on an individual and collective basis' ${ }^{47}$ Victim participants supported collective reparations in addition to individual reparations. They stressed that collective reparations were needed to reduce the stigma of former child soldiers in their communities, if measures could be issued in a manner that would avoid inadvertently 'benefiting' this group and potentially encouraging other youth to enlist in the future. ${ }^{48}$

While acknowledging that the ICC framework permitted the award of individual, as well as collective reparations, ${ }^{49}$ the Trial Chamber exclusively adopted the community-based approach put forward by the TFV. The judges agreed that in light of the limited TFV funds from voluntary contributions, a community-based approach emphasising collective awards would have 'greater utility' and reduce the administrative costs associated with individual awards. ${ }^{50}$ Under this plan the TFV would conduct outreach and consultation with victims and communities from which child soldiers were recruited to develop reparations proposals for Court approval. ${ }^{51}$ Victims might still receive individual benefits, but only if this was included in the community proposal and approved by the ICC. ${ }^{52}$

The imagined victim worked again here to justify abstracted, collective forms of repair and obscured the particular and disparate preferences of individual victims for reparative justice. In adjudicating a reparations framework, the Court could not rely on the trope of an imagined victim who desired simply that the guilty be punished. Rather, it had to deliberate among competing claims and visions of adequate repair being advanced both by victims who participated in the proceedings and by entities, like the TFV, vested with power to speak on their behalf. The Court accepted that collective reparations promising large-scale change

46 Observations on Reparations in Response to the Scheduling Order of 14 March 2012, Lubanga, ICC-01/04-01/06, 25 April 2012, paras. 173-174.

47 See Decision Establishing Principles and Procedures of Reparations, Lubanga, para. 221.

48 See V01 Group, paras. 17-18; see V02 Group, paras. 17-18.

49 See Decision Establishing Principles and Procedures of Reparations, Lubanga, paras. 217-221.

50 Ibid., para. 274. Lubanga was declared indigent and therefore he would not pay reparations. The award would be financed through the voluntary contributions made to the TFV.

51 See TFV Submission, Lubanga, paras. 190-201 and 215-219; see Decision Establishing Principles and Procedures of Reparations, Lubanga, para. 282.

52 See Decision Establishing Principles and Procedures of Reparations, Lubanga, para. 217. 
were the priority: promoting reconciliation, decreasing the stigma of former child soldiers and working to change cultural attitudes that support the practice of child soldiers. ${ }^{53}$ The victim participants were a fraction of all those who consider themselves victims of the conflict and they may or may not hold views representative of the collective. Adopting an exclusively community-based reparations framework may result in providing greater benefit to a greater number of victims. It also avoided the Court having to decide among competing claims and being seen as making political choices about which victims to favour. This argument does not seek to deny these legitimate justifications for the decision. The point is that, by ignoring the victim participants in the proceedings, the Court imagined victims only in a reductive, collective form that elided their individualism. Once again, the imagined victim - one who will participate in a community deliberation that was assumed capable of promoting social change - was satisfied by the Court's utilitarian approach.

The persuasive power of individual victims was negligible by comparison; the submissions of victim participants were not cited in the operative sections of the ruling. How is it that the ICC, which congratulated itself on the pride of place it gives to victims, so neatly has avoided any direct response to them? The Court eschewed a principle of individual awards and outsourced its authority to implement individual benefits. Given how tightly the OTP and the Court guarded their prerogatives to determine retributive justice, the willingness of the judges to divest themselves of power to consider the needs of real victim participants suggests, once again, that the power of imagined victims outstrips their own.

\section{Conflicting logics of international criminal justice}

The contrast between the ways in which ICJ protagonists such as judges, prosecutors and INGOs invoke victims and the treatment of claims by actual victims who seek to participate in ICC proceedings is striking. Given that ICJ discourse presents victims as requiring justice, and calls on states and citizens to support the ICC to fulfil this moral promise, it may be surprising that real victims have so little power in an institution celebrated as giving them agency and voice. The clash may be explained, in part, by a clash in logics: the logic of the imagined victim and the logic

53 See TFV Submission, Lubanga, paras. 145-146, 150, 169, 178. 
of international criminal law. These two orderings have fundamentally different relations to victims, even as the same actors are protagonists in each system. The contradiction revealed between the imagined and actual victims thus is embedded in the ICJ project.

The imagined victim invoked by the ICC's president, its prosecutor and INGO representatives justifies the moral and legal mandate of the Court to hold perpetrators responsible for their crimes. Yet, the logic of the narrative of the imagined victim also contains an unspoken but limiting moral commitment to victims: the idea that punishment is a measure for the victims. For the imagined victim invoked by the Court, the conviction of the perpetrator completes the moral promise of ICJ. The bad actor is called out as a villain on the world stage. The perpetrators did not evade justice; they received their just desserts. The moral and legal tasks thus are seen to be complete.

To some extent, this normative assessment may reflect the desires of real victims. Available survey data of victims of atrocity crimes in multiple conflicts indicate that victims believed it was important to hold accountable those who committed crimes. ${ }^{54}$ For example, in one study of the DRC, when asked what should happen to those who committed war crimes, 69 per cent of victims surveyed said perpetrators should be punished. ${ }^{55}$ The idea that those who attack civilians, force communities to flee and whose acts disrupt the social fabric of communities should be made to answer for their crimes may be a powerful and common sentiment. However, the survey data also indicated that, while accountability may be held in high regard as a principle or ideal goal, it appears to occupy a lesser priority than measures designed to improve the immediate, material concerns of victims. When researchers asked respondents to list what were their priorities for the government, justice measures were mentioned by only a small fraction of victims. In eastern DRC, only 1 per cent of respondents felt that the government should direct immediate attention to accountability and justice. ${ }^{56}$ Respondents overwhelmingly cited the need for improvements to economic and social welfare

54 See, e.g., P. Vinck and P. Pham, 'Building Peace Seeking Justice: A Population-Based Survey on Attitudes About Accountability and Social Reconstruction in the Central African Republic' (2010); P. Pham and P. Vinck, 'Transitioning to Peace: A PopulationBased Survey on Attitudes About Social Reconstruction and Justice in Northern Uganda', Human Rights Center University of California, Berkeley (2010).

${ }^{55}$ P. Vinck et al., 'Living with Fear: A Population-Based Survey on Attitudes About Peace, Justice, and Social Reconstruction in Eastern Democratic Republic of Congo' (2008), 1,43 . The term 'war crime' was not defined.

56 Ibid., 27. 
conditions - job creation, education, health care and peace - as top priorities. Retributive justice was never strongly expressed as a priority among victims.

These data may not be inconsistent. The moral and material demands of victims are linked: the harms victims suffered and for which they seek justice are directly related to their ability to re-establish stability. Victims may believe that they deserve more than seeing those accountable punished; they deserve material measures that will address their personal losses. These are not inconsistent demands, but rather dual aspirations for how a society will respond to violence. The behaviour and views of actual victim participants in Lubanga are consistent with these data: those victims who joined the proceedings wanted to see the defendant held responsible for his crimes and they wanted individual, material redress for the harms they suffered.

While victims may see retributive and restorative justice as inextricably linked, the ICC does not, despite the lip service it pays to victims. The reparations regime is additive, not essential, to justice defined as punishment of perpetrators. The TFV is financed by voluntary contributions rather than from the core budget of the Court. The organs of the Court define reparations as a separate moral and legal category, belonging to the domain of restorative justice, distinct from its retributive justice mandate. The institutional design features of the ICC reflect the legal values ascribed to victims by its creators.

Justice thus becomes synonymous with retributive justice. The logic of international criminal law, an adaptation of municipal criminal law, vests a prosecutor and a court with the responsibility of administrating justice. The victims may have a discretionary right to participate, as they do at the ICC, but the prosecutor has responsibility for seeing that justice is delivered. Imagined and actual victims are instrumental to securing justice - defined as a 'conviction' - and the judges and prosecutor use them as such. For actual victims to assert otherwise invites the ICC - its judges, prosecutor and TFV - to instantiate their subordinated status anew, as it did throughout the legal proceedings in Lubanga. The moment that victims become parties is in the reparations phase. Yet, here too, victims find their needs are contingent and redefined by a different logic: the logic of scale.

Under the ICC's approach, individual victims will have to persuade their communities that they deserve individual benefits. It is possible that these victims may receive a benefit from collective reparations, or that their preferences as expressed to the Court were shaped by their legal 
representatives and are not authentic; in other words, the interests of victims' may, in fact, be served by collective reparations. Nevertheless, the logics of scale work against the ICC adopting an individualised process that seeks to respond to the interests of individual victims. The chamber was persuaded that individual awards were both infeasible and impracticable in Lubanga. Yet, it also had convicted an individual of crimes involving thousands of victims. This suggests that ICJ is able to master complexity if given enough time and resources. While there are important differences between adjudicating individual criminal liability and thousands of damages claims, the ease with which the Court disposed of the possibility of individual awards implies a cost-benefit calculus that privileges retributive justice. Though costly, retribution serves unnumbered imagined victims; by contrast, individual reparations awards require a degree of precision and resources that are greater than the Court can afford.

Such material considerations generally lie outside the normative judgments that criminal courts are required to make. Here, the imagined victim obscures the juridical switch from normative to distributive concerns. Individual reparations were not morally required by the (retributive) justice that the ICC claims imagined victims deserve. The Court thus could dismiss the request of victim participants - and by extension the requests of any victim for individual awards - without violating its moral promise to imagined victims. As of this writing, the reparations decision is being appealed and how reparations are ultimately implemented remains to be seen.

Yet the real victims, the ones who stand outside the international justice discourse, cannot be satisfied even as the discourse of ICJ legitimates itself as serving their interests. The scale of the crimes defeats their aspirations for a richer understanding of justice that could include both retributive and restorative dimensions in equal measure. The Lubanga case suggests that ICJ may be a process of continual diminishment with regard to real victims. The scale of the crimes is what makes them subjects of concern to the ICC and what activates the moral attention of a world audience. Yet the administration of justice requires the prosecutor to narrow the legal response to a scale that can be managed. What begins as a call for justice for all victims winds up as retributive justice for select crimes. Furthermore, to manage its inability to provide individual awards of reparations to all victims of the select crimes, the Court eliminates individual reparations altogether. Individual victims are subsumed as a category within their communities. 
Whether or not one believes that victims should be treated as a single category for purposes of restorative justice measures, the logic of scale upon which this treatment is based is not explicit in the ICJ discourse. Mass violence generates populations of victims who believe that retributive justice and compensation are important priorities. The ICC framework promises to respond to both, but the logics of scale overwhelm the institutional capacity to deliver fully on either. Not all crimes will be prosecuted and not all victims will be eligible for reparations. Yet, the ICC continues to rely on the imagined victim to do important political work to support and legitimate ICJ, including soliciting the support of actual victims. This gap between what the discourse promises and what the Court delivers has reputational costs. Therefore it is important to appreciate how the conflict between the logic of retributive justice and the logic of scale threatens the moral legitimacy of the ICJ enterprise.

\section{Conclusion}

Victims of atrocity crimes are central to the project of ICJ. They provide the moral urgency to mobilise political will and resources to punish perpetrators and provide redress to victims. The ICC has been celebrated as the first permanent international criminal tribunal that embodies the trends in international law to affirm victims as agents of the global campaign against impunity of atrocity crimes. In the discourse of ICJ, victims of mass violence are abstracted and constructed with particular characteristics. This imagined victim always demands retributive justice and therefore is always satisfied by a conviction, regardless of what real victims believe the most blameworthy conduct is or who is responsible for it. In contrast to the embrace of the imagined victim, the way in which the ICC judges, the OTP and TFV treated victims in Lubanga highlights the instrumental use of actual victims in international criminal law. Actual victims have limited rights and power to influence justice; they are recipients of retributive justice as defined and secured by the ICC. The scale of mass crimes means that criminal charges will be selective and that reparations will only ever be partial, and therefore unlikely to meet the expectations of victims of the violence for redress.

This analysis suggests that the contradiction between the promise to victims of ICJ and what the field is capable of delivering is generated by the politics of law. The ICC relies on a legitimating discourse that places victims as deserving beneficiaries of justice, even though as a legal institution it cannot deliver justice to all victims. The gap between the 
discourse of the imagined victim and the administration of international justice in turn generates dashed expectations. To narrow this gap means promising less at the risk of losing support from communities on the ground as well as among states and the public or providing more to actual victims at the risk of bogging down legal proceedings, jeopardising due process rights of defendants and becoming unaffordable to the states parties and donors that finance the Court. This chapter does not offer a prescriptive solution. Rather, it calls for sustained attention to this clash of logics and the gap between the imagined victim and the actual victim. Victims are indeed central to justice efforts for atrocity crimes but because some victims support some forms of justice does not mean that all victims support ICJ. How the ICC defines justice and its beneficiaries is critical to its success; if the Court makes the promise of justice, it must be capable of fulfilling it. 


\title{
Reparations and the politics of recognition
}

\author{
PETER J. DIXON
}

\section{Introduction}

There is an enduring tension in the distribution of international criminal reparations. On the one hand, awards for reparations are at heart a form of recognition that entails including certain people and excluding others. On the other hand, this is very hard to do in contexts of mass atrocity with a system limited to individual criminal responsibility. With its reparations award in The Prosecutor v. Thomas Lubanga Dyilo (Lubanga), Trial Chamber I of the International Criminal Court (ICC) acknowledged this tightrope and attempted to walk it through principles of flexibility and inclusivity. ${ }^{1}$ These principles alone, however, are not sufficient, as was underlined by the Appeals Chamber's judgment of March 2015. ${ }^{2}$ The provision of international criminal reparations is an inherently political act through which the ICC will necessarily become a player in local power relations. In this chapter, I seek to unpack one key dimension of these relations - the 'politics of recognition' - and offer strategies to navigate them.

Unlike the politics of distribution, which entail struggles over the allocation of goods, recognition entails interpreting, representing and rendering visible (and invisible) categories of people. ${ }^{3}$ Reparations

${ }^{1}$ Decision establishing the principles and procedures to be applied to reparations, The Prosecutorv. Thomas Lubanga Dyilo ('Lubanga'), ICC-01/04-01/06, Trial Chamber I, ICC, 7 August 2012 ('Reparations Decision, Lubanga, 7 August 2012').

2 Judgment on the appeals against the 'Decision establishing the principles and procedures to be applied to reparations' of 7 August 2012 with AMENDED order for reparations (Annex A) and public annexes 1 and 2, Lubanga, Appeals Chamber, ICC, 3 March 2015 ('Reparations Judgment, Lubanga, 3 March 2015').

3 On the politics of recognition and its relationship to the politics of distribution, see N. Fraser, 'Social Justice in the Age of Identity Politics: Redistribution, Recognition, and Participation', in L. Ray and A. Sayer (eds.), Culture and Economy after the Cultural Turn (London: Sage, 1999), 25-52. 
involve both, which makes them an authoritative form of recognition in international criminal justice, and an especially political process. My argument in this chapter is as follows: compared to assistance or development or humanitarian aid, reparations are particularly marked by the politics of recognition, which manifest themselves on the ground in affected communities in at least two ways. One was partly acknowledged in the Trial Chamber's reparations decision: the risk of subjecting already vulnerable groups to forms of interpretation that are foreign or even hostile. This is particularly dangerous for reparations to victims of grave crimes, for whom the stigma attached to a crime can be as harmful as the original act itself, or even more harmful. ${ }^{4}$ Second, there is a risk that the reparations process will be captured by elites and subsumed to local power struggles as communities contest the right to legitimately claim particular identities and characterisations of the conflict. While the way an award is designed can help ameliorate these tensions, I focus here on the importance of project implementation and the process through which an award's ultimate beneficiaries are targeted. The targeting process, I argue, is integral to how victims and affected communities experience the reparations process and therefore deserves careful consideration by the ICC.

To illustrate, this chapter draws on experiences from some of international criminal justice's neighbouring fields - development, assistance and reconstruction - and on personal research conducted in the Ituri region of the eastern Democratic Republic of the Congo (DRC), where the Lubanga reparations will be distributed. This research suggests that the politics of recognition demands more than combining individual and collective reparations, as the Trial Chamber proposed, and more than field-based expertise, which it believes will enable the ICC's Trust Fund for Victims (Trust Fund or TFV) to successfully manage the process. ${ }^{5}$ Rather, these politics demand one or both of the following: (1) a participatory approach to defining the criteria by which reparations will be distributed and identifying those who will benefit - what practitioners call 'targeting'; and/or (2) close involvement by the Trial Chamber throughout the targeting

4 'Report of the Panel on Remedies and Reparations for Victims of Sexual Violence in the Democratic Republic of Congo to the High Commissioner for Human Rights', United Nations High Commissioner for Human Rights (2011) (OHCHR, 'Report of the Panel on Remedies and Reparations').

5 Reparations Decision, Lubanga, 7 August 2012, para. 266. 
process. ${ }^{6}$ The Appeals Chamber's judgment, which scaled back several of the Trial Chamber's attempts at flexibility and inclusivity, underscores the importance of such strategies,

Targeting is among the most powerful mechanisms through which the individuals and communities to whom goods are distributed (and not distributed) experience the meaning attached to them. This is particularly important for reparations because they are at heart a symbolic good. Targeting should therefore not be relegated to a seemingly apolitical, technical phase of project 'implementation'. Yet, by relinquishing to the Trust Fund its authority over these details, Trial Chamber I (as well as subsequent chambers) risks diminishing the potential significance of reparations and increasing the risk that the process may be captured by local politics. This not only risks causing further injury to communities and individuals harmed by grave crimes, but it also risks compromising the ICC's legitimacy. At the same time, I propose, the politics of recognition can also be leveraged to repair grave harms, a claim to which I return in the chapter's conclusion.

This argument is divided into five sections. The first explains why the politics of recognition matters for reparations in general, and for international criminal reparations in particular. The second briefly reviews the Ituri conflict and the Trial and Appeals Chambers' reparations decisions in Lubanga, including their approach to targeting and the potential role given to the TFV. The third section draws on the experiences of international criminal justice's neighbouring fields - development, assistance and reconstruction - to reflect on the risks that reparations pose to vulnerable groups and communities if targeting is not handled carefully. In the fourth section I use my personal research in the DRC to analyse what these risks could mean for Ituri specifically. The fifth and concluding section proposes a potential resolution, drawing on promising work in the area of community-driven reconstruction and arguing for a targeting process that is closely linked to the judicial process.

My research in Ituri involved several trips to the region, the last of which spanned eight months in 2013. ${ }^{7}$ This was a significant time for Ituri, ten years after Luis Moreno-Ocampo first announced his interest in

${ }^{6}$ There is currently a debate over the precise nature of the legal relationship between the ICC and the TFV, which I do not enter into here. For more, see C. McCarthy, 'Reparations under the Rome Statute of the International Criminal Court and Reparative Justice Theory', International Journal of Transitional Justice, 3 (2009), 250-271.

7 This research was conducted with Maria Elena Vignoli and the Ituri-based NGO, Réseau Haki na Amani, supported by PAX. See P. Dixon and M.E. Vignoli, Le Droit De Connaître: Vérité Et Réconciliation En Ituri (Amsterdam: PAX, 2014). 
the region and his intention to begin investigations there. ${ }^{8}$ My arrival followed Lubanga's guilty verdict and the subsequent reparations decision; the acquittal of one of his alleged enemies, Mathew Ngudjolo; and the arrest and transfer to The Hague of Lubanga's alleged partner in Ituri, Bosco Ntaganda. ${ }^{9}$ In collaboration with the Ituri-based NGO, Réseau Haki na Amani, we interviewed a broad selection of Ituri's traditional leadership, including village and regional chiefs (chefs des villages, chefs des collectivités); 'notables', who are considered representatives of the different ethnic groups; and leaders from civil society groups, including the directors of non-governmental peace, justice and development organisations. In total, we spoke to 182 individuals in fifty-five interviews across three of Ituri's five territories: Djugu (where the capital Bunia is located), Irumu and Mahagi. These interviews involved the two main ethnic groups in Ituri - the Hema and Lendu - as well as the Bira, Alur and others. ${ }^{10}$ We also conducted a randomised, representative survey of Djugu and Irumu on attitudes about possibilities for truth and reconciliation in Ituri.

My observations in this chapter draw mostly on our qualitative data. While these data are not representative of all Iturians, they serve to illustrate and elaborate on Ituri's contemporary political climate. Finally, this chapter also draws on policy reports, case studies and evaluations from international organisations and agencies. These are useful to illustrate the practical challenges to implementing reparations, particularly around issues of targeting and the stigmatisation of victims.

\section{Reparations and the politics of recognition}

According to the ICC's registrar, 'victims have indicated they want to be recognized'. ${ }^{11}$ To that end, I seek to unpack the discretion, idiosyncrasies, assumptions, politics and power dynamics that make certain forms of

${ }^{8}$ International Criminal Court, 'Press Release: Communications Received by the Office of the Prosecutor of the ICC', No. pids.009.2003-EN (The Hague: International Criminal Court, 16 July 2003) ('ICC Press Release, 16 July 2003').

9 Reparations Decision, Lubanga, 7 August 2012; Judgment pursuant to Article 74 of the Statute, The Prosecutor v. Mathew Ngudjolo Chui, ICC-01/04-02/12, Trial Chamber II, ICC, 18 December 2012; Decision on the Prosecutor's Application under Article 58, The Prosecutor v. Bosco Ntaganda, ICC-01/04-02/06, Pre-Trial Chamber II, ICC, 13 July 2012.

10 The interviews were conducted in French or in local languages with the help of a translator. The translations provided in this chapter are my own from French.

11 'Turning the Lens: Victims and Affected Communities on the Court and the Rome Statute System', RC/ST/V/INF.2 (The Hague: Registry, International Criminal Court, 2010). 
victimisation recognisable and others less so. These issues are not unique to reparations. Development initiatives, humanitarian assistance and reconstruction projects all entail particular methods of targeting through which they define, measure and act upon the world, often obscuring the politics behind them. ${ }^{12}$ Simply analogising ICC reparations to the politics of development assistance and humanitarian aid, however, misses what is 'legal' about the Court and Court-ordered reparations. Where the politics of development, assistance and reconstruction might tend more towards struggles over distribution, Court-ordered reparations distinguish themselves through the very act of recognition - a 'technology of truth' through which the truth is identified, measured, represented and, ultimately, objectified. ${ }^{13}$ This makes ICC reparations political not in the sense of interest groups politics, but through their introduction of such a technology into the social relations and power struggles of the places where the Court intervenes - in other words, into the politics of recognition.

For the ICC, whose Trust Fund is already distributing goods to victims in Ituri under the label of 'assistance', distinguishing reparations from assistance is particularly important. This section analyses the similarities between reparations and development and reflects on how international criminal reparations are entangled in such politics.

\section{Distinguishing reparations from assistance}

The ICC has thus far worked primarily in resource-deprived contexts, where many people live in need of food, shelter, health care and security. ${ }^{14}$ Not surprisingly, these immediate needs often take priority. ${ }^{15}$ In these contexts, reparations can be seen as a means of satisfying basic ends,

12 J. Ferguson, The Anti-Politics Machine: 'Development', Depoliticization, and Bureaucratic Power in Lesotho (Cambridge: Cambridge University Press, 1990).

13 See S. Engle Merry, 'Anthropology and International Law', Annual Review of Anthropology, 35 (2006), 99-116; S. Engle Merry and S. Bibler Coutin, 'Technologies of Truth in the Anthropology of Conflict: Aes/Apla Presidential Address, 2013', American Ethnologist, 41 (2014), 1-16.

14 The following description fits the ICC's situation countries well: 'poverty, huge inequalities, weak institutions, broken physical infrastructure, poor governance, high levels of insecurity, and low levels of social capital.' P. de Greiff, 'Articulating the Links between Transitional Justice and Development: Justice and Social Integration', in R. Duthie and P. de Greiff (eds.), Transitional Justice and Development: Making Connections (New York: International Center for Transitional Justice, 2009), 28-75, 29.

15 Patrick Vinck, Phuong Pham and colleagues have conducted representative surveys in a number of conflict and post-conflict settings, all of which underscore the diversity of people's priorities and the importance of basic needs. 
no matter the reasoning behind them. Equally importantly, the awarding of reparations will rarely go unnoticed by a recipient's broader community, even in the case of individual reparations. Lawyers and transitional justice scholars are well aware of these similarities. In more than one case, prosecution witnesses have been accused of providing their testimony only in exchange for assistance. In such contexts, distinguishing reparations and assistance through the former's symbolic element is particularly important, both for the court issuing them and for the affected communities. Indeed, reparations can look very similar in form to development, assistance and reconstruction projects, particularly when the organisational provenance of the two does not necessarily distinguish them.

This is the case in Ituri, as it will likely be for many of the situations when and if ICC trials reach the reparations phase. The TFV is mandated by the Rome Statute system to provide both 'reparations' and 'assistance' and has been providing the latter in northern Uganda and eastern DRC since 2009. ${ }^{16}$ This assistance can only be given to victims of crimes under the jurisdiction of the ICC, as they are defined in the Rome Statute, but it is provided prior to and separate from any particular criminal proceedings. In practice, however, the line between reparations and assistance can be unclear. In Ituri, for instance, the Trust Fund is providing assistance to former child soldiers, some of whom may have participated in the war under the leadership of Thomas Lubanga. What, then, distinguishes reparations from assistance when the same Court can provide both to the same group of beneficiaries?

To answer this, lawyers and scholars stress the symbolic element of reparations. In the words of two commentators, 'What distinguishes reparations from assistance is the moral and political content of the former, positing that victims are entitled to reparations because their rights have been violated. ${ }^{17}$ This then implies that, 'those receiving reparations are by definition rights holders'. ${ }^{18}$ Morally, reparations are given to a recipient because she has been wronged, not because she is in need or is vulnerable. Politically, reparations are awarded because a

${ }^{16}$ Rule 98, ICC Rules of Procedure and Evidence. For more on the TFV's legal basis, see www.trustfundforvictims.org/legal-basis.

${ }^{17}$ N. Roht-Arriaza and K. Orlovsky, 'A Complementary Relationship: Reparations and Development', in P. de Greiff and R. Duthie (eds.), Transitional Justice and Development: Making Connections (New York: International Center for Transitional Justice, 2009), 170-213, 179.

Ibid. 
recipient's rights have been violated. Together, both dimensions are meant to (re)establish what Pablo de Greiff has called 'inclusive citizenship' and what Brandon Hamber calls 'social recognition'. ${ }^{19}$ Both terms denote the social and political integration of victims back into society. In theory, the intended symbolism of a reparations award is thus potentially far more valuable than the particular good or service actually being distributed.

\section{Recognition and targeting}

That such subtlety is effectively communicated to, and understood by, the recipient herself and by her broader community is central to the intended mission of reparations. In this context, outreach is clearly crucial. The judgment from which a reparations award stems must be effectively explained to an award's ultimate beneficiaries. Furthermore, the particular targeting strategy through which reparations are distributed will influence their meaning on the ground. As de Greiff writes, 'the element of recognition that is part and parcel of reparations ... will typically require targeting victims for special treatment'. ${ }^{20}$

Targeting has been of particular concern to fields like international development for several decades, particularly since development scholars like Amartya Sen began to examine the importance of participation, consultation and dialogue in the development process. ${ }^{21}$ One problem with traditional, criteria-based methods of targeting is that beneficiaries 'do not share the same targeting concerns as the national level or donor agencies.' ${ }^{22}$ This is of particular concern for international criminal reparations.

Compared to reparations from domestic and international human rights courts, international criminal reparations will tend to communicate the meaning attached to them more exclusively via the particular targeting

19 de Greiff, 'Articulating the Links', 62. Hamber writes, 'without social recognition, their suffering runs the risk of continuing to exist only in their internal world where it can be acute and isolating'. B. Hamber, 'Narrowing the Micro and Macro: A Psychological Perspective on Reparations in Societies in Transition', in P. de Greiff (ed.), The Handbook of Reparations (New York: Oxford University Press, 2006), 560-589.

${ }^{20}$ P. de Greiff, 'Establishing Links between DDR and Reparations', in A. Cutter Patel et al. (eds.), Disarming the Past (New York: International Center for Transitional Justice, 2009), 132-159, 151.

21 A. Sen, Development as Freedom (New York: Anchor, 2000). See also J. Van Domelen, 'Reaching the Poor and Vulnerable: Targeting Strategies for Social Funds and Other Community-Driven Programs', The World Bank (2007); G. Mansuri and V. Rao, 'Community-Based and -Driven Development: A Critical Review', The World Bank Research Observer, 19 (2004), 1-39.

22 J. Van Domelen, ibid. 
strategy through which they are distributed. In domestic criminal proceedings, which are likely to play out closer to the victims themselves than international proceedings, outreach by itself may go a long way. In cases where the state is ordered by an international human rights court to pay for and implement awards, the state can directly manage communication, for better or worse. In either case, it is easier to communicate 'the seriousness of the state and their fellow citizens [to] re-establish relations of equality and respect', which reparations are meant to convey. ${ }^{23}$

But international criminal reparations face a more daunting task. They come from the ICC, a court that is far removed from the local context and which has little authority over the state in question. Furthermore the simultaneous reliance of international criminal reparations on symbolism and targeting makes them vulnerable to the local politics of recognition in significant ways. Here, I am concerned with two aspects of these politics in particular: (1) the subjection of victimised groups to forms of interpretation that may do them harm, or which they may reject, and (2) the struggle over interpretations and characterisations of the conflict and its victims.

I do not argue that domestic or international human rights reparations are immune from such struggles over recognition, but they are on average better equipped to manage them. State-based reparations, for example, can coordinate with other programmes to fill in the gaps that reparations will miss, thus ameliorating some of the distributive tensions that can exacerbate the politics of recognition. De Greiff explicitly supports such coordination. ${ }^{24}$ But the ICC cannot count on states or other international agencies to complement or coordinate with its plans for reparations, and the Trust Fund's assistance resources are limited. The politics of distribution are also a concern for reparations; indeed, the two can never be completely separated. But because recognition is fundamental to what makes reparations meaningful, the politics of recognition are of particular concern.

To briefly illustrate, the ICC's Office of the Prosecutor (OTP) has thus far characterised the Ituri war as a fundamentally ethnic conflict played out between two ethnic groups: the Lendu and the Hema. ${ }^{25}$ In the OTP's four Ituri-based cases, both the alleged crimes and the categories of

${ }^{23}$ de Greiff, 'Articulating the Links', 145. ${ }^{24} \mathrm{Ibid}$.

${ }^{25}$ For example, Smith writes, '[Bosco Ntaganda] persecuted civilians on ethnic grounds, through deliberate attacks, forced displacement, murder, rape, sexual enslavement and pillaging.' David Smith, 'Congo Warlord Bosco Ntaganda Led Ethnically Motivated Murder, ICC Told', The Guardian, 10 February 2014. 
victimisation are thus structured accordingly. In my own research, however, both Lendu and Hema often rejected this characterisation. This was not because they denied either the legitimacy of Lendu and Hema as categories of identity or that there was significant conflict between them, but because they tended to see the conflict in more fluid terms, where violence was also economically, politically and geo-politically motivated.

The next section describes the Iturian context and reviews prior and ongoing debates over the characterisation of the Ituri war in Lubanga. These debates highlight that the ICC is aware of the challenges that reparations are likely to encounter in the field, which the Trial Chamber has tended to cast in terms of a tension between inclusivity and exclusivity. I agree with such a characterisation, but see this tension as fundamentally political in nature. In later sections, I draw on the targeting experiences of development, assistance and reconstruction projects and on my personal research to illustrate what these politics of recognition look like in practice.

\section{The Ituri war and The Prosecutor v. Thomas Lubanga Dyilo}

In its reparations decision, the Trial Chamber embraced reparations as a path to include those who were not recognised during the trial process, due to the idiosyncrasies of the OTP's case strategy and/or the limits of international criminal law. The chamber's proposed solutions call for flexibility and a combination of collective and individual awards. These are a good start, but more is needed to realise the Court's restorative potential. Measures of inclusivity can still rely on top-down targeting strategies and can still ignore, rather than manage, the politics of recognition. The Appeals Chamber's judgment also scaled back several of the Trial Chamber's attempts at inclusivity, underscoring that reparations cannot necessarily be used to fill in the gaps left by the trial process. Rather, a more participatory approach to targeting and/or closer involvement by the chamber will help.

\section{The Ituri war}

Ituri is a relatively small and picturesque district in northeastern DRC, bordering Uganda and South Sudan. Like much of eastern DRC, it is particularly rich in natural resources, including gold, diamonds, timber and oil. It is also home to numerous ethnic groups, although the two largest are by far the Lendu, who are mostly farmers, and the Hema, more 
often pastoralists. The Lendu and Hema have lived together since before colonial times, but Belgian policy favoured the Hema and exacerbated tensions. Henry Morton Stanley, an Englishman working for the Belgian King Leopold, described the Hema as 'amiable, quiet and friendly neighbours ... with whom we have never exchanged angry words' and the Lendu as 'abrasive and violent'. ${ }^{26}$ Nevertheless, the two groups lived together relatively peacefully until 1999, when a series of small land conflicts led to some of the bloodiest fighting of the DRC's many conflicts. Through 2004, it was the scene of massacres, rapes, mass child abductions and other serious crimes, in which an estimated 60,000 people were killed. At the conflict's peak, between 20,000 and 25,000 children and adults were involved in the fighting. ${ }^{27}$

On the radio, Lendu leaders accused the Hema of orchestrating the war to complete their subjugation of the Lendu people. Hema leaders accused the Lendu of attempting genocide against them, fuelled by bitterness and jealousy. Allusions to the Hutu and Tutsi of Rwanda were occasionally made. ${ }^{28}$ On the surface, it seemed an apt comparison - a group subjugated by the Belgians and then relegated to poverty, finally reaching the breaking point. But the comparisons were not accurate. The chain of events that ignited such conflicts cannot be boiled down to ethnic hatred; rather, the full causes are simultaneously economic, political, geo-political and ethnic. ${ }^{29}$ Many Iturians, in fact, believe that Uganda, Rwanda and Kinshasa manipulated and took advantage of ethnic grievances. ${ }^{30}$ Subjects we interviewed in 2013 would ask, rhetorically, 'Where did the guns come from?', referring to the thousands of weapons believed to have been brought into Ituri from outside to arm both Hema and Lendu militias. Both sides thus claim victim status, but as I will return to below, the notion of outsider manipulation is central to Ituri's local politics of recognition.

Despite these complexities, the OTP pursued an essentially ethnic framing of the Ituri war. In 2003, the prosecutor saw Ituri as 'the most urgent situation to be followed'. ${ }^{31}$ Following President Joseph Kabila's

${ }^{26}$ D. Fahey, Ituri: Gold, Land, and Ethnicity in North-Eastern Congo (London: Rift Valley Institute, 2013), 17.

27 Dixon and Vignoli, Le Droit De Connaître.

28 'DRC: Special Report on Ituri District, Northeastern DRC', UN Integrated Regional Information Network (18 December 2002).

${ }^{29}$ D. Fahey, 'The Trouble with Ituri', African Security Review, 20 (2011), 108-113; K. Vlassenroot and T. Raeymaekers, 'The Politics of Rebellion and Intervention in Ituri: The Emergence of a New Political Complex?', African Affairs, 103 (2004), 385-412.

30 Personal interviews with local leaders (Ituri, 2013).

31 ICC Press Release, 16 July 2003. 
referral of the DRC situation to the Court, the OTP has since charged four of the conflict's alleged leaders, two from the Hema side and two from the Lendu side. Three are originally from Ituri, including Thomas Lubanga Dyilo (who is Hema), while one, Bosco Ntaganda, is a Tutsi from Rwanda. In all four trials, the OTP has repeatedly focused more on the ethnic nature of Ituri's violence than on its economic or geo-political dimensions. ${ }^{32}$ While the Trial Chamber in Lubanga acknowledged the observation that Ituri's ethnic tensions would not have 'turned into massive slaughter' without the involvement of Kinshasa, Rwanda or Uganda, it fundamentally agreed with the OTP's characterisation. ${ }^{33}$

\section{The definition of 'victims' in The Prosecutor $v$. Thomas Lubanga Dyilo}

The OTP's framing of the conflict also influenced the definition of 'victims' in Lubanga, for both participation and reparations. As the first of the ICC's trials, participation was a vexed issue since the Rome Statute system defines 'victims' quite generally. ${ }^{34}$ In the beginning, attempts were made to define 'eligibility for participation' in rather inclusive terms, but these were ultimately unsuccessful. This left the definition of 'victims' quite narrow during Lubanga's trial. In its first ruling on victim participation, for example, the chamber determined that victims of any crime under the Court's jurisdiction could theoretically participate. ${ }^{35}$ The Appeals Chamber disagreed, however, noting that, 'the purpose of trial proceedings is the determination of the guilt or innocence of the accused person of the crimes charged. ${ }^{36}$

In Lubanga, the only confirmed charge was that of enlisting and conscripting child soldiers, so only victims of this particular charge could participate in the Appeals Chamber's view. The Rome Statute, however, allows for both direct and indirect harm. Were, then, the

32 On the ethnic dimensions of the OTP's investigations in the DRC, see further Chapter 7 by Kambale in this volume.

33 Judgment pursuant to Article 74 of the Statute, Lubanga, ICC-01/04-01/06, Trial Chamber I, ICC, 14 March 2012 ('Article 74 Judgment, Lubanga, 14 March 2012').

${ }^{34}$ Rule 85 (a) of the Rules of Procedure and Evidence states that the term "Victims" means natural persons who have suffered harm as a result of the commission of any crime within the jurisdiction of the Court.'

35 Decision on victims' participation, Lubanga, ICC-01/04-01/06, Trial Chamber I, ICC, 18 January 2008, para. 95 [emphasis added].

${ }^{36}$ Judgment on the appeals of The Prosecutor and The Defence against Trial Chamber I's Decision on Victims' Participation of 18 January 2008, Lubanga, ICC-01/04-01/06, The Appeals Chamber, ICC, 11 July 2008, para. 62 [emphasis added]. 
victims of crimes committed by child soldiers the indirect victims of Thomas Lubanga? ${ }^{37}$ Again, the definition was left quite narrow. Drawing on the Appeals Chamber, the Trial Chamber ruled that, to count as an indirect victim, a person must have a close personal relationship to a direct victim, such as that between parent and child. Those harmed by the child soldiers, it followed, could not count as indirect victims. ${ }^{38}$

Three years later, similar questions about the definition of 'victims' emerged for the purposes of reparations. Again, the prosecutor and the Trial Chamber favoured inclusivity. The OTP had already noted that it 'must necessarily limit the incidents selected in its investigation and prosecution', and that the reparations phase should therefore take a broader approach. ${ }^{39}$ In its reparations decision, the Trial Chamber wrote that reparations require a 'broad and flexible' approach, which can 'avoid further stigmatisation of the victims and discrimination by their families and communities' ${ }^{40}$ It underlined the value of a collective award and later introduced for these purposes a distinction between 'victims' and the 'beneficiaries' who reside in the communities where collective reparations programmes will be developed but who will not be granted 'victim status'. ${ }^{41}$ Victims of crimes for which Lubanga was not convicted (including victims of sexual violence) could thus theoretically benefit from a reparations award.

This distinction, and the Trial Chamber's endorsement of collective reparations, reflects an attempt to manage the inherent tension between inclusivity and exclusivity that is attached to reparations. As described in the reparations decision, such an award could seemingly impart the meaning that makes reparations symbolically valuable, while simultaneously filling in the gaps left by the selective recognition of forms of victimisation. Yet this says nothing of the actual targeting strategy needed

37 Because Rule 85 (a) makes no mention of 'direct' harm to natural persons (as 85 (b) does for organisations and institutions), the Trial Chamber found, and the Appeals Chamber confirmed, that people can suffer either 'direct' or 'indirect' harm and thus stand as either 'direct' or 'indirect' victims before the Court.

38 Redacted version of 'Decision on "indirect victims"', Lubanga, ICC-01/04-01/06, Trial Chamber I, ICC, 8 April 2009, para. 52.

39 Office of the Prosecutor, 'Policy Paper on Victims' Participation' (The Hague: International Criminal Court, 2010), 9.

40 Reparations Decision, Lubanga, 7 August 2012, paras. 180, 192.

${ }^{41}$ Such a distinction was not introduced outright in the original 7 August decision but clarified later in reply to the defence's request for leave to appeal. Decision on the defence request for leave to appeal the decision establishing the principles and procedures to be applied to reparations, Lubanga, ICC-01/04-01/06, Trial Chamber I, ICC, 29 August 2012, para. 29. 
to strike such a balance. Both individual and collective reparations, for instance, can still rely on bureaucratic, top-down targeting measures.

Furthermore, the Appeals Chamber eventually determined that, while 'an award of collective reparations to a community is not necessarily an error, ... the scope of the convicted person's liability for reparations in respect of a community must be specified'. ${ }^{42}$ In other words, collective reparations can only make a reparations order more inclusive to the extent that the convicted person is found to be specifically liable for the crimes addressed by the award. Victims of crimes of which Lubanga was not found guilty - notably crimes of sexual violence - can thus only benefit from assistance in the Appeals Chamber's view, not reparations. ${ }^{43}$

The Appeals Chamber's decision underscores that efforts at inclusivity are not sufficient to manage the delicate politics of recognition. Rather, the particular targeting strategies through which victims are identified, selected and verified are integral to the process. The Trial Chamber left such responsibilities to the field-based expertise of the TFV. ${ }^{44}$ Yet relegating these details to a 'technical' phase of implementation, in place of managing them through the Court's legal processes, leaves the reparations process particularly vulnerable to Ituri's politics of recognition, regardless of how inclusive the process might be. At the same time, it risks relegating reparations to little more than long-delayed assistance.

\section{The recognition of vulnerable groups}

There is much that the ICC can learn about the politics of recognition, both from the experiences of neighbouring fields and from first-hand research in the contexts where Court-ordered reparations will be distributed. The next two sections draw on these to unpack two key dimensions of these politics: the subjection of vulnerable populations to forms of recognition that are foreign or hostile and local power struggles over claims to certain forms of identity and characterisations of violence.

42 Reparations Judgment, Lubanga, 3 March 2015, para. 212.

${ }^{43}$ Ibid., para. 198-199. This, however, would not disqualify victims of sexual violence from benefitting from 'assistance'.

44 On appeal, however, the Appeals Chamber ruled that the decision did indeed count as an 'order for reparations'. Decision on the admissibility of the appeals against Trial Chamber I's 'Decision establishing the principles and procedures to be applied to reparations' and directions on the further conduct of proceedings, Lubanga, ICC-01/04-01/06, The Appeals Chamber, ICC, 14 December 2012, para. 64 ('Appeal Decision on Reparations, Lubanga, 14 December 2012'). 
To the first point, the Trial Chamber in Lubanga recognised the risk of stigma and discrimination for vulnerable groups. Such risk is well established in academic and policy literature on two groups to whom the ICC will likely be distributing reparations, if not in Lubanga then likely in other trials: child soldiers, or children associated with armed forces, and victims of sexual and/or gender-based violence (SGBV). But the risk of discrimination also runs deeper. Here, I draw on case studies from a variety of countries and contexts to show that while the 'best practices' and 'lessons learned' around stigma are important, they do not necessarily capture the political nature of representation that underlies stigmatisation. What is at stake in the recognition of certain forms of victimisation is the right to legitimately name and objectify particular categories of identity. For those who belong to the more vulnerable of these groups, sometimes not recognising them, or letting them define the terms of their recognition, is best.

\section{Children associated with armed forces}

As the sole crime charged in Lubanga, the enlistment of children associated with armed forces (CAAF) has received considerable attention. There is already an extensive body of literature on the challenges of defining, identifying, rehabilitating and reintegrating such children and young adults. ${ }^{45}$ For the ICC, one of the greatest challenges will be deciding how to identify and target them in ways that reflect their reality and do not risk further stigmatisation. Many CAAF, for instance, do not self-identify as 'child soldiers'; many are no longer children; many were not abducted, but volunteered themselves or were volunteered by their families; and females, especially, may avoid the label because they are more often harmed by sexual violence and the resulting stigma than males. Moreover, there are many other ways young people can be made vulnerable by war. They can be orphaned, displaced, forced into camps, forced into prostitution, seriously injured and more. CAAF can be in better economic situations than their peers precisely because of their association with armed groups, which is often an incentive behind enlisting in the first place.

45 M.A. Drumbl, Reimagining Child Soldiers in International Law and Policy (New York: Oxford University Press, 2012); L. Stark, N. Boothby, and A. Ager, 'Children and Fighting Forces: 10 Years on from Cape Town', Disasters, 33 (2009), 522-547 (Stark et al., 'Children and Fighting Forces'). 
There is a wealth of information available from disarmament, demobilisation and reintegration (DDR) programmes around the world, all with significant warnings and lessons. They unanimously reinforce the value of inclusive programming as a method to target child soldiers without stigmatising them. ${ }^{46}$ When applied, though, inclusive programming generally means not recognising CAAF. To do so, DDR projects thus blend child soldiers together with other 'waraffected children', who, in programming parlance, are often narrowed down to 'orphans and vulnerable children' (OVC). Different agencies use different ratios of CAAF to OVC, including the Trust Fund in Ituri. ${ }^{47}$ The key, though, is that 'community-based programming that applies to a wider group of vulnerable children is more effective than assistance targeted at a specific group identified by one experience alone'. ${ }^{48}$

To this end, integration is considered a major step in the rehabilitation process, if not the most important one. ${ }^{49}$ Many note that girls may not want to participate in projects publicly labelled as DDR because they do not want to self-identify as 'child soldiers' or do not self-identify as such in the first place. Instead, girls may 'perceive themselves as "wives" or "cooks" and prefer these social categories' ${ }^{50}$ For these girls, integration might mean losing the social label 'child mother' and becoming a 'student' in the eyes of her peers. These lessons around inclusivity for female CAAF have been significant for the ICC. In one Trust Fund assistance project for female CAAF, for example,

46 UNICEF, Children and DDR: Integrated Disarmament Demobilization and Reintegration Standards (New York: United Nations Children Fund, 2006); UNICEF, The Paris Principles: Principles and Guidelines on Children Associated with Armed Forces or Armed Groups (Paris: UNICEF, 2007); C. Blattman and J. Annan, 'The Consequences of Child Soldiering', Review of Economics and Statistics, 92 (2010), 882-898; J. MacVeigh, S. Maguire, and J. Wedge, 'Stolen Futures: The Reintegration of Children Affected by Armed Conflict', Save the Children (2007).

47 TFV, Learning from the TFV's Second Mandate: From Implementing Rehabilitation Assistance to Reparations (The Hague: Trust Fund for Victims, International Criminal Court, 2010).

${ }^{48}$ MacVeigh et al., 'Stolen Futures'.

49 S. McKay and D. Mazurana, Where Are the Girls? Girls in Fighting Forces in Northern Uganda, Sierra Leone and Mozambique: Their Lives During and After War (Montreal: Rights \& Democracy - International Centre for Human Rights and Democratic Development, 2004).

${ }^{50}$ And economically, DDR programmes can often inadvertently discriminate against girls, reducing the economic incentives to present themselves as eligible for the assistance: 'that community markets can only absorb a limited number of tailors, for instance, often limits livelihoods options for girls'. Stark et al., 'Children and Fighting Forces'. 
providing girls with a school uniform to wear was among its most powerful interventions. ${ }^{51}$

\section{Victims of sexual and/or gender-based violence}

For victims of sexual violence more generally, lessons about inclusivity are less clear than for CAAF, but are still significant. On the one hand, that victims of SGBV are specifically targeted is itself an accomplishment given the historic lack of public recognition of and resources devoted to sexual violence in and after war. However, experts in the field also recognise the risks of stigmatising through overly restrictive approaches to targeting. In August 2010, for instance, a high-level panel convened to assess existing judicial mechanisms for victims of sexual violence in eastern DRC concluded that targeting reparations to victims of sexual violence can further stigmatise them - a particularly troubling idea, they noted, as 'the reparation needs of victims of sexual violence may be caused more by the stigmatisation than the sexual violence itself.$^{52}$ The report quotes the coordinator of a Congolese NGO supporting victims of sexual violence, who herself requested that donors actually stop targeting SGBV exclusively, since 'much attention given to sexual violence victims is fuelling jealousy and further stigmatisation'. ${ }^{53}$ Other agencies have come to similar conclusions. ${ }^{54}$

Like the Trial Chamber in Lubanga, the panel suggested that both collective and individual reparations are necessary. It found that individual and collective targeting can respond to different needs and demand different screening requirements and burdens of proof, providing the flexibility needed to adapt to different local conditions and needs. As for CAAF, proactively not recognising victims of sexual violence for the harm they suffered can be a valuable part of the process. Rehabilitation projects, that is, provide vulnerable groups not only with valuable

51 TFV, Reviewing Rehabilitation Assistance and Preparing for Delivering Reparations (The Hague: Trust Fund for Victims, International Criminal Court, 2011), 26.

52 OHCHR, 'Report of the Panel on Remedies and Reparations', March 2011.

53 Ibid., 24-25.

${ }^{54}$ SIDA, for instance, has recently begun to emphasise the value of programmes to empower and expand women's choices, preferably not only targeting victims of genderbased violence'. Sida, 'The Democratic Republic of Congo: Country Gender Profile' (Sida: Department for Conflict and Post-Conflict Cooperation and Gender Equality Team, 2009). See also 'Sierra Leone: Getting Reparations Right for Survivors of Sexual Violence', Amnesty International (2007). 
material and social services, but also with social identities that are often rooted in projects' eligibility criteria and targeting strategies.

This is not meant to suggest that CAAF, especially female CAAF, or other victims of sexual violence, do not have specific needs that are unique to their experiences. Rather, I draw on these literatures to highlight here that certain needs of vulnerable groups can be met through targeting strategies that do not impose or reinforce identities that are harmful or irreconcilable with local realities, or which the intended beneficiaries themselves may reject.

\section{Whose war? Representations of war in Ituri}

The second dimension of the politics of recognition that will influence the provision of reparations is the identity and power struggles rooted in how conflicts, and their victims, are socially represented. Iturian politics are complicated. ${ }^{55}$ I do not attempt to exhaustively review these struggles here, but rather seek to present two examples that illustrate the complex political terrain on which the ICC's reparations process will play out. First, the OTP has focused not only on a limited time frame and set of crimes, but also on a limited number of locations, which has in turn encouraged inter-village competition over 'legitimate' claims to victimisation. Second, the prosecutor's characterisation of the conflict as an essentially ethnic war has excluded other explanations, inspiring local leaders on both sides to reject the ICC's framing.

At the outset, some general context is warranted. Even though Ituri is considered among the more pacified regions of north-eastern DRC, especially when compared to the Kivus to the south, it is still very much marked by lingering tensions. ${ }^{56}$ In interviews, leaders referred often to the district as a 'ticking time-bomb', repeatedly returning to the same issues: severe poverty and hunger, entrenched land conflict, ethnic mistrust, rumours and political manipulation, conflicts over natural resources, thousands of hidden weapons and tens of thousands of former young combatants who are now in their twenties with no education and bleak job prospects. 'The war is not over!' was a common refrain across our interviews. To many observers, peace is only held together by

55 See Fahey, 'The Trouble with Ituri'; Dixon and Vignoli, Le Droit De Connaître; S. Hellmüller, 'The Power of Perceptions: Localizing International Peacebuilding Approaches', International Peacekeeping, 20 (2013), 219-232.

${ }^{56}$ Fahey, ibid. 
Ituri's patchwork of NGOs, UN agencies, and the United Nations' peacekeeping mission in the Congo, known as MONUSCO. ${ }^{57}$

Furthermore, while scholars have now studied the Ituri war and recorded its history, Iturians themselves remain relatively unaware about the war's events and origins. ${ }^{58}$ People know it began with historic grievances over land between the Hema and Lendu in Djugu territory, for example, but they cannot explain how these grievances turned into years of bloodshed that pitted neighbour against neighbour. Many suspect the conflict was partly due to outside manipulation. Many also suspect that at least some of their neighbours benefitted from the war. The schools in Ituri, however, do not teach this history, relying on a curriculum designed in Kinshasa that teaches children about the independence leader Patrice Lumumba, but not their own war. ${ }^{59}$ Instead, we were told, children learn ethnic hatred from their parents. Aside from a few small NGOs, Ituri lacks the sort of public space that is needed to engage in dialogue about this history. This gap is filled by rumours, suspicion and lies.

Many community leaders thus felt the region needed its own smallscale truth and reconciliation process - something more locally run than the DRC's failed 2003 attempt at a national Truth and Reconciliation Commission following the Inter-Congolese Dialogue. ${ }^{60}$ Unlike the international community, which overwhelmingly expressed scepticism and fear over Ituri's 'internal time bomb', these leaders generally felt that public dialogue about the war could help. Our survey data from Irumu and Djugu indicate the general population feels similarly. Over 80 per cent of local respondents said it was either 'important' or 'very important' that the history of the war be made public. An equal number responded that if there were an opportunity to speak publicly about the war, they would share their story. ${ }^{61}$ These data inform my analysis of the quotes shared below. In sharing them, I suggest that Iturians generally want recognition for their suffering, but not necessarily according to the categories that have informed the ICC's judicial proceedings and, it

57 Personal interviews with members of international community (Ituri, 2013).

58 Personal interviews with local leaders (Ituri, 2013).

59 Personal interview with local leader (Ituri, 2013).

${ }^{60}$ Personal interviews with local leaders (Ituri, 2013).

${ }^{61}$ Dixon and Vignoli, Le Droit De Connaître. See also P. Vinck et al., 'Living with Fear: A Population-Based Survey on Attitudes About Peace, Justice, and Social Reconstruction in Eastern Democratic Republic of the Congo' (University of California, Berkeley Human Rights Center, 2008). 
follows, reparations. Here, though, categories refer not to vulnerable people - for whom, as noted, recognition can bring harm - but to geographies, for example, via community leaders from towns devastated by the war where the OTP has paid relatively little attention.

\section{Competing for victim status}

Such desire for recognition, coupled with the lack of faith in external representations by institutions like the ICC, motivates the first of the two struggles I focus on here: competition over legitimate victimhood. Vis-à-vis reparations, this competition expresses itself primarily in questions about collective and individual reparations. Overall, there was a strong preference for collective reparations. This would seem to fit with the Lubanga Trial Chamber's emphasis on collective reparations, but not with its linguistic distinction between victims and beneficiaries. Many subjects, for instance, expressed that it would be unfair to draw lines through individual awards because the OTP only investigated a subset of the towns and villages that were devastated by the war:

Here, there is truly the need for collective reparations. Because, as I said, even if some were not chosen [for investigation by the prosecutor], there were grave crimes affected almost everyone in Ituri ... Even if Bunia was not chosen, the war affected all, and we need collective reparations, something from which the whole population can benefit. ${ }^{62}$

The emphasis here is on 'chosen' localities; that is, the towns and villages officially sanctioned by the ICC as having suffered. Others added, along these lines, that it would simply be impractical to repair victims individually when everyone had suffered.

There isn't a single village, a single person who escaped. So if everyone is to be awarded individually, where is that money going to come from? ... It is important to recognize the victims, very important, but practically, in practice it is difficult to distribute reparations individually. ${ }^{63}$

Many also expressed a lack of faith in the ICC's objectivity, recalling the 'fake victims' that beleaguered the prosecutor's case in Lubanga. ${ }^{64}$ How, they asked, can we trust that someone is really the victim they claim to be?

62 Personal interview with local leader (Ituri, 2013). ${ }^{63} \mathrm{Ibid}$.

${ }^{64}$ Personal interviews with local leaders (Ituri, 2013). See Article 74 Judgment, Lubanga, 14 March 2012. 
There are fake victims, like, for example, we can say that there are fake victims or falsified testimonies there at the ICC. Really, individual reparations will not be easy. ${ }^{65}$

One leader, in particular, offered an interesting case study. He is the leader of the town of Nyankunde, which endured one of the deadliest massacres of the Ituri war, but which has not received significant attention from the ICC. Nyankunde is ethnically Bira and therefore is difficult to place in the Hema-Lendu dichotomy, although the Bira were alleged to have supported the Hema in the ICC trials against Lendu leaders Germain Katanga and Mathieu Ngudjolo Chui. He recounted how at one point he had personally begun to collect the skulls of those killed in his town, after an international church group brought him to Kigali to see a monument built for the Rwandan genocide. He believed something collective like a monument could help his town as well. 'People must know what happened here,' he said, 'so it does not happen again. ${ }^{.66}$

The Nyankunde chief's perspective is significant because it differs quite sharply from those expressed in the town of Bogoro, a day's drive away and also the site of a brutal massacre. Unlike Nyankunde, Bogoro has played a key role in ICC proceedings as it is the town where Ngudjolo Chui and Katanga were alleged to have carried out an attack against the predominantly Hema population. Indeed, Bogoro is the only town in Ituri to have received such sustained focus, including a visit from former prosecutor Moreno-Ocampo and from ICC trial judges.

Community leaders in Bogoro expressed the strongest desire for individual reparations of all our interviewees. Some NGOs in Bunia even suspected them of trying to turn their fellow villagers against the idea of collective reparations. 'It is clear' who the victims are, one Bogoro leader told us, 'because the ICC has a list' - a reference to the list of victims approved to participate in the Ngudjolo and Katanga trials. ${ }^{67}$ 'Others,' one added, 'were trying to generalize this list.' These leaders recognised that other towns had also suffered during the war - including other Hema towns - and might be upset by Bogoro's individualised recognition, but this did not seem to matter. 'The ICC talks about Bogoro,' one village elder concluded. Such attitudes can also be seen in some of the submissions from those victims participating in the ICC's trials. Some of the participating victims in Lubanga, for example,

\footnotetext{
65 Personal interview with local leader (Ituri, 2013). $\quad{ }^{66}$ Ibid.

67 Personal interviews with local leaders (Ituri, 2013).
} 
suggested that they could receive a 'war victim' certificate from the Court, designating their official status and providing them access to services. ${ }^{68}$

\section{Framing the Ituri war}

The desire for individualised reparations in Bogoro was more of an expression of solidarity along geographic, not necessarily ethnic, lines. This reflects the second element of the struggle over representations on which I focus: contest over the legitimate characterisation of the conflict itself, particularly over the Court's framing of it as essentially ethnic. The great majority of leaders with whom we spoke acknowledged the ethnic nature of the conflict, and many expressed ethnic bias and hatred during interviews, but both Hema and Lendu (and the other groups with whom we spoke) took issue with the ICC's account. While each group felt they alone were the true victims of the war, leaders from all sides felt strongly that the Court had mischaracterised their grievances, with which they had managed to live since long before war broke out in Ituri.

'We are condemned to live together,' subjects frequently said. Often they followed with rhetorical questions such as, "Whose were the hands that manipulated us?', 'Where did the guns come from?' and 'Why are they not in The Hague?', referring to the Ugandans, Rwandans and Congolese from Kinshasa who, in their mind, fuelled the conflict and gained from it. Moreover, subjects repeatedly noted that Ituri has more than two ethnic groups and that they were all somehow involved in the conflict.

I would like to add something. It was not simply that the war was between two tribes. No! Because I know that the international community ignores that. The great majority of communities were victims during that war. ${ }^{69}$

Competition over the characterisation of the war plays into contemporary Iturian power struggles, where ethnicity is used to divide and motivate constituencies. The 'extremists' in Ituri are well known and have the power to block initiatives where they are not sufficiently implicated, or which they feel may not be in their best interests. One international NGO, for instance, found its reconciliation project ground to a halt when Hema and Lendu notables demanded, as a precondition for their cooperation, that their 'brothers in The Hague' be released. ${ }^{70}$ Yet,

${ }^{68}$ Observations sur la fixation de la peine et les réparations de la part des victimes, Lubanga, ICC-01/04-01/06, Trial Chamber I, ICC, 18 April 2012, para. 23.

${ }^{69}$ Personal interview with local leader (Ituri, 2013). ${ }^{70} \mathrm{Ibid}$. 
virtually all with whom we spoke, whether ethnic community leaders or civil society leaders, agreed that the extremists must be implicated, and that attempting to forge ahead on a project about the war without them would go nowhere.

These narratives are not meant to argue for or against the veracity of the different claims our subjects made about the truth of the Ituri war. Rather, I cite them to illustrate the struggles over recognition that are likely to influence how the ICC's reparations process will be received. The key issue will not only be who gets what, but what does this distribution mean for the myriad categories and frames through which the conflict can potentially be represented. Opening up the process to both 'victims' and 'beneficiaries', as the Trial Chamber in Lubanga has proposed, could in theory be one way to make the process inclusive, although the Appeals Chamber's judgment appears to limit such inclusivity. But there is more to claiming victim status than the benefits it might yield. The truth of what happened is also at stake.

Ultimately, such challenges cannot be managed through technical means alone. The truth implied in a reparations award is received and interpreted through the means and categories by which the award is targeted. This demands sustained involvement from ICC chambers and meaningful participation from Iturians themselves throughout the reparations process. Moreover, where technical expertise does matter, it is not necessarily the kind that the TFV has exhibited in its provision of assistance projects. Rather, the provision of reparations demands a very particular form of expertise about how to carry out meaningful participation in charged circumstances, like the politics of recognition in Ituri, described above. The concluding section considers some potential ways forward.

\section{Conclusion: unlocking restorative justice in international criminal law}

Reparations are a potentially restorative tool of transitional justice, but the restricted framing imposed by a system of individual criminal responsibility harbours a fundamental tension. In my view, though, the ICC's reparations regime still offers restorative potential. As a first and crucial step, the Court has acknowledged some of the resulting gaps and indicated that reparations and assistance could be used to bridge them, although not as easily as the Trial Chamber originally envisaged. The OTP's plan to begin realising more expansive investigations, 
notwithstanding its perennial resource and time limitations, could indicate similar acknowledgement. ${ }^{71}$ Indeed, the Ituri trials were particularly limited in scope - Lubanga in terms of the charges and Katanga and Ngudjolo in terms of their geography.

Second, notwithstanding the Appeals Chamber's judgment, the Trial Chamber in Lubanga at least recognised the importance of inclusion, embracing the idea of collective reparations and an expanded class of beneficiaries, in addition to the category of victims. Such inclusive measures could do much to ameliorate the distributive tensions that any reparations reward will cause. At the same time, the Appeals Chamber's judgment suggests that attempts at inclusivity will always be limited, and that the distinction between reparations and 'assistance' could be increasingly eroded, especially in the absence of sustained involvement by the ICC itself.

The Court, then, should play a sustained role in the reparations process, from the reparations decision to the targeting of awards. Those on the receiving end of the ICC's technologies of truth, particularly its reparations regime, will not simply accept reparations at face value but will challenge, adapt and incorporate them. This gives the ICC significant potential to play a restorative role in these processes, but it must embrace this potential. It can do so through two ways in particular: first, the Court could adopt a participatory and consultative approach to the entire reparations process, drawing on the experience of community-driven reconstruction; second, the chambers could play a more active role in beneficiary identification and verification, helping to guide the meaning that recipients and their communities will attach to reparations.

International criminal reparations can look to the experience of community-driven development and reconstruction - particularly in lessons drawn from working with CAAF and SGBV victims - which utilise participatory approaches to targeting by incorporating local definitions of need and deprivation into programme design. ${ }^{72}$ Proponents cite a

71 OTP, Strategic Plan, 2012-2015 (The Hague: International Criminal Court, 11 October 2013).

${ }^{72}$ J. Conning and M. Kevane, 'Community-Based Targeting Mechanisms for Social Safety Nets: A Critical Review', World Development, 30 (2002), 375-394; T. Slaymaker, K. Christiansen and I. Hemming, Community-Based Approaches and Service Delivery: Issues and Options in Difficult Environments and Partnerships (London: Overseas Development Institute, 2005). For work on targeting in conflict and post-conflict contexts, see S. Jaspars and J. Shoham, 'Targeting the Vulnerable: A Review of the Necessity and Feasibility of Targeting Vulnerable Households', Disasters, 23 (1999), 359-372; K. Kuehnast, J. de Berry and N. Ahmed, Community-Driven Development in the 
number of potential advantages to this approach: lower costs, more community accountability, better information about and adaptation to realities on the ground, harnessing and strengthening of social capital as a positive external effect, more programme legitimacy and the empowerment of disadvantaged groups. Community-driven reconstruction thus holds particular promise. These projects 'support the democratic selection of local community councils, including measures on the representation of women, youth or other disadvantaged groups', and then provide them with grants to implement local priorities. ${ }^{73}$ Indeed, communities receiving this type of support have reported less social tension and greater acceptance of vulnerable groups as a result. ${ }^{74}$ Moreover, marginalised groups, including women and CAAF, have been found to be better informed, more actively involved in reconstruction activities and more likely to trust their community representatives when compared to control communities. ${ }^{75}$

Such projects, however, demand specific forms of expertise that neither the ICC nor the TFV is likely to have. The experts that Trial Chamber I discussed in the Lubanga reparations decision could thus include those who do possess such experience. ${ }^{76}$ Indeed, 'communitybased' or 'community-driven' approaches entail significant risks. In one such example from South Sudan, for instance, 'relief committees and other community representatives put on a show for [the donor] which gave the appearance of targeting. In reality, "targeted" women were chosen to carry food to a site where it was then redistributed by local chiefs. ${ }^{77}$ Close monitoring and oversight by organisations with specific experience in this area are essential to avoid such scenarios.

Context of Conflict-Affected Countries: Challenges and Opportunities (Washington, DC: The World Bank: Social Development Department and Environmentally and Socially Sustainable Development Network, 2006); World Bank, World Development Report 2011: Conflict, Security, and Development (Washington, DC: The World Bank, 2011).

73 S. Cliffe, S. Guggenheim, and M. Kostner, Community-Driven Reconstruction as an Instrument in War-to-Peace Transitions (Washington, DC: The World Bank: Conflict Prevention and Reconstruction Unit and Social Development Department, 2003), 2; 'IRC's Approach to Community-Driven Reconstruction: A Basic Primer for First Generation Programming', The International Rescue Committee (2007).

74 J.D. Fearon, M. Humphreys, and J.M. Weinstein, Evaluating Community-Driven Reconstruction Lessons from Post-Conflict Liberia (Washington, DC: The World Bank Institute, 2009).

75 J.D. Fearon, M. Humphreys, and J.M. Weinstein, 'Can Development Aid Contribute to Social Cohesion after Civil War? Evidence from a Field Experiment in Post-Conflict Liberia', The American Economic Review, 99 (2009), 287-291.

${ }^{76}$ Reparations Decision, Lubanga, 7 August 2012, para. 263.

77 Jaspars and Shoham, 'Targeting the Vulnerable'. 
Regardless of whether the ICC utilises such an approach, trial chambers should involve themselves more closely in overseeing the entire reparations process. This chapter has argued that much of the meaning attached to a reparations award will be communicated through its targeting strategy. In practice, the dichotomy between 'design' and 'implementation' is thus false; rather, the former depends upon the latter. ${ }^{78}$ In an ideal world, Trial Chamber I, or even a separately constituted reparations chamber, could hold hearings to oversee this 'implementation' phase, which will be fundamental to the very design of the award itself.

Whether or not such hearings are feasible, the chamber should stay involved to provide an authoritative forum through which Iturians can engage in debate over the categories and representations that make reparations symbolically powerful. Without the involvement of the ICC in such a role, the danger is that either the politics of recognition will overwhelm the reparations process or the process itself will become little more than long-delayed assistance, stripped of the meaning that makes reparations powerful beyond their material value. ${ }^{79}$

Ultimately, international criminal law can transform social relations and identities through official designations of 'truth'. Through reparations, categories of crime and victimisation in the courtroom become social categories of people on the ground. This is part of what makes them symbolically powerful. But it also entails great risk. For vulnerable groups, the need for reparative justice can stem more from the social exclusion resulting from crimes than from the crimes themselves. In post-conflict settings like Ituri, the truths determined in a courtroom in The Hague, manifested through reparations, can interact with existing power relations in ways that antagonise social cohesion and promote competition.

Given these complexities, some might argue that international criminal reparations should perhaps be left entirely to non-legal agencies, with more relevant resources and experience. Indeed, scholars have warned that 'many involved with international justice have lost sight of its goals in favour of developing and maintaining an international system of criminal law over and above what might be the needs and desires of the

78 The use of such a dichotomy can be seen in the Appeals Chamber's ruling, Appeal Decision on Reparations, Lubanga, 14 December 2012.

79 The Rome Statute system provides for such a role. If the experience of the Trial Chamber in Lubanga's case is any indication, the real hurdle will be the length of trials versus the term limits of the judges. 
victims of abuse ${ }^{80}$ In my view, relegating reparations to an entirely nonlegal body also sells the ICC short and overlooks the fact that it is already involved in the distribution of recognition, which is rooted in its power to issue definitions of crime, responsibility and victimisation. Reparations are one form of this power, and the targeting strategies used to distribute them are its manifestation on the ground. By focusing on these strategies, and carefully managing them, the Court can more fully embrace its restorative potential.

${ }^{80}$ See H.M. Weinstein, et al., 'Stay the Hand of Justice: Whose Priorities Take Priority?', in R. Shaw et al. (eds.), Localizing Transitional Justice: Interventions and Priorities after Mass Violence (Stanford, CA: Stanford University Press, 2010). 


\title{
Beyond the restorative turn
}

\author{
The limits of legal humanitarianism
}

\author{
SARA KENDALL
}

\section{Introduction}

International criminal law has been historically concerned with individual accountability, informed by a punitive conception of justice designed to hold perpetrators accountable for crimes. As a sub-field within the broader discipline of public international law, with its focus on the agency of states, international criminal law's emphasis on the individual has been interpreted as indexing a shift from a paradigm of state sovereignty to human security, in terms of both accountability (of perpetrators) and rights (of victims). ${ }^{1}$ This shift has been furthered by an emerging recognition of the figure of the victim, with links to the broader conflict-affected communities to which individual victims belong. In the case of the permanent International Criminal Court (ICC), the moral call to alleviate suffering is translated into participatory rights for individual victims before the Court, as well as the mandate of its affiliated Trust Fund for Victims to provide medical and livelihood assistance to conflict-affected communities. As an ICC guidebook explains, 'victims at the ICC enjoy rights that have never before been incorporated in the mandate of an international criminal court'.

Yet the Court's claim to alleviate suffering brings its work into a relationship with other humanitarian discourses and practices outside of international law. How might this inclusion of relief to conflictaffected communities be related to shifts in governance and development

I thank Christian De Vos, Nesam McMillan and Sarah Nouwen for their comments on this chapter, as well as the Netherlands Organisation for Scientific Research (NWO) for funding the field research that informs this account.

${ }^{1}$ R. Teitel, Humanity's Law (Oxford: Oxford University Press, 2011).

2 'Victims Before the International Criminal Court: A Guide for the Participation of Victims in the Proceedings of the Court', www.icc-cpi.int/NR/rdonlyres/8FF91A2C-5274-4DCB9CCE-37273C5E9AB4/282477/160910VPRSBookletEnglish.pdf. 
beyond the juridical field, as with development aid and the provision of medical assistance? Can a body of law that has been traditionally oriented towards accountability through punishment - 'ending impunity' - be recast as a site of restorative justice, and with what expressive and material effects?

This chapter locates the restorative work of the ICC against the backdrop of humanitarianism: the transformation of moral sentiment into material practices that seek to reduce suffering. ${ }^{3}$ Such a reading draws upon critiques of humanitarianism from beyond the legal field, including anthropology, history and political theory, which seek to diagnose its theoretical and material effects. International criminal law's restorative turn harbours common sentiments that link it to broader forms of humanitarian government, which anthropologist Didier Fassin defines as 'the set of procedures established and actions conducted in order to manage, regulate, and support the existence of human beings' ${ }^{4}$ The ICC's practices of victim participation and aid provision operate as forms of what can be termed 'legal humanitarianism', which seeks to alleviate conflict-affected suffering and assert rights claims through international criminal law. Legal humanitarianism routes its governance objectives through humanitarian logics, yet it is limited by the framework of law, which provides jurisdictional constraints that other humanitarian forms do not encounter to the same degree.

The chapter seeks to illustrate the limits of routing restorative justice practices through a historically punitive legal field. These limits - and the injustices they produce - are not necessarily a product of the ICC as an institution, but are rather a by-product of trying to bend a retributive field to suit restorative aims. Asking a field oriented around judgment and punishment to provide recognition and redress to conflict-affected communities leads to a form of justice that might be better described as liminal rather than transitional, unintentionally producing exclusions, deferrals and marginalisations that have been largely neglected in the literature on the ICC's restorative mandate. In this sense legal humanitarianism operates as a form of governance, mobilising ICC states parties

3 See generally M. Barnett, Empire of Humanity: A History of Humanitarianism (Ithaca, NY: Cornell University Press, 2011); D. Fassin, Humanitarian Reason: A Moral History of the Present (Berkeley: University of California Press, 2012); and I. Feldman and M. Ticktin (eds.), In the Name of Humanity: The Government of Threat and Care (Durham: Duke University Press, 2010).

${ }^{4}$ Fassin continues: 'government includes but exceeds the intervention of the state, local administrations, international bodies, and political institutions more generally'. Fassin, Humanitarian Reason, 1. 
and in-country donor states, non-governmental and community-based organisations and the Court itself in projects of classifying and categorising conflict-affected populations through legal logics.

The chapter first takes up the contested figure of the human in international law, which carries resonances in contemporary legal humanitarianism. It then locates international criminal law's 'restorative turn' in relation to the broader rise of human rights discourse towards the end of the twentieth century. Reading legal humanitarianism in relation to other critiques of humanitarian practice, the following section brings international criminal law's restorative turn into dialogue with historical and anthropological literature. Moving from a theoretical consideration of legal humanitarianism, the two sections that follow draw upon empirical material, both from official ICC literature and from observations of Court practice, to consider the Court's victim participation regime and the ICC Trust Fund's assistance mandate. The chapter concludes by considering the implications of reading international criminal law's restorative turn as a novel form of post-conflict governance, and what the risks and limitations may be of routing restorative justice through a retributive legal frame.

\section{Between triumph and scepticism}

Despite more than half a century separating them from our 'humanitarian present', ${ }^{5}$ two claims mark competing poles in contemporary debates about the role of international law in securing the figure of the human. On one side of the spectrum, the Nuremberg Military Tribunal declared that '[h] umanity can assert itself by law', already suggesting the foundational role that will be ascribed to post-World War II trials by contemporary proponents of international criminal tribunals. ${ }^{6}$ Here the tribunal conflates its own agency in prosecuting those suspected of international crimes with another actor, 'humanity', which can now 'assert itself by law' and enforce its own (inherent) human rights. On the other side, Hannah Arendt's well-known account of the vulnerability of refugees and stateless people continues to inform sceptics who question the viability of human rights claims in a world where rights are still largely civil and

${ }^{5}$ See E. Weizman, The Least of All Possible Evils: Humanitarian Violence from Arendt to Gaza (London: Verso, 2011).

${ }^{6}$ United States v. Ohlendorf (The Einsatzgruppen Case), reprinted in 4 Trials of War Criminals before the Nuremberg Military Tribunals under Control Council Law No. 10, 411 (1946-1953) 112. As cited in Teitel, Humanity's Law, 77. 
political creatures, existing between a state and its citizens rather than inherent to humanity itself. ${ }^{7}$

Half a century later, scholarship on international criminal law and human rights continues to inhabit a spectrum between these poles of triumph and scepticism, moving between a 'utopian' cosmopolitan vision of law and an 'apologist' deference to state sovereignty. ${ }^{8}$ The main points of contention have remained more or less the same, focusing on the extent to which human rights can be protected at the international level through prosecuting international crimes. What has changed is a developing claim that different sub-fields of international law, such as human rights law and international humanitarian law, are growing closer together at a normative level and in legal practice. ${ }^{9}$ This normative convergence is explained in different ways, though increasingly the ideal of 'human security' and related references to humanity or humanitarianism have appeared within the discourse of international criminal law. ${ }^{10}$ In its landmark jurisdictional decision in Tadic, for example, the International Criminal Tribunal for the Former Yugoslavia (ICTY) claimed that the dichotomy between interstate and intrastate conflicts was being broken down in international law, and 'the State-sovereigntyoriented approach ... has been gradually supplanted by a human-beingoriented approach. ${ }^{11}$ Distinctions between conflict and peacetime and between international and internal conflicts have been unsettled by an international criminal law jurisprudence that at times overtly references humanity both as its beneficiary and as its ground.

Expressions of humanitarian sentiment in the discourse of international criminal law have become commonplace. They are threaded throughout official ICC statements as well as in commentary from civil society organisations and diplomats who promote the ICC's work. Even representatives from the United States, a state not party to the ICC, have linked humanitarianism with state security in expressing support for

${ }^{7}$ H. Arendt, The Origins of Totalitarianism (San Diego: Harcourt, 1968), 279.

8 M. Koskenniemi, From Apology to Utopia: The Structure of International Legal Argument (Cambridge: Cambridge University Press, 2006).

9 T. Meron, The Humanization of International Law (Leiden: Martinus Nijhoff, 2006).

${ }^{10}$ For links between human security and international criminal law, see L. Axelworthy, 'Human Security and Global Governance: Putting People First', Global Governance, 7 (2001), 19-23.

11 Appeal on Jurisdiction, Prosecutor v. Tadic, IT-94-1-AR72, Appeals Chamber, ICTY, 2 October 1995. 
international criminal legal institutions. ${ }^{12}$ Others have pressed farther, contending that this traditionally retributive field works to alleviate the suffering of conflict-affected populations. A representative from a European state's claim to the president of the ICC's Assembly of States Parties offers a telling example of how criminal justice's traditional concerns with accountability and deterrence have become bound up with the more abstract aims of human security and social repair:

A substantial number of victims have already been uplifted because they believe in your ability to deliver justice. And more victims will benefit in the future, not only thanks to the Court's reparative mandate, but mainly because of its firm effect to deter grave crimes against humanity. ${ }^{13}$

This claim from a state representative reflects a common sentiment expressed by other states supporting what is referred to as the ICC's 'restorative mandate'. ${ }^{14}$ In this account of the Court's work, victims are 'uplifted' through a belief in the form of justice that the ICC dispenses, which is seen to be both reparative and deterrent. Court proponents frequently describe accountability, deterrence and reparation as forming a constellation of objectives that are thought to be attainable through the field of international criminal law.

In addition to linking the field to human and state security, tribunal observers and officials have claimed that international criminal law institutions can lessen the suffering brought about through mass conflict. The language of bearing witness has been supplemented with claims about 'giving voice', rehabilitating and repairing the harms done to victims of international crimes through criminal processes. These claims suggest that the field has turned towards restorative forms of justice to supplement its objectives of holding individual perpetrators of grave crimes to account.

12 Harold Koh has claimed that 'the United States has long recognized that international criminal justice, and accountability for those responsible for atrocities, is in our national security interests as well as in our humanitarian interests'. H. Koh, 'International Criminal Justice 5.0', New York City, 8 November 2012, available online at www.state. gov/s/1/releases/remarks/200957.htm.

13 Statement by Swedish Ambassador Per Sjögren, Deputy Director-General, Ministry for Foreign Affairs, at the 12th Session of the Assembly of States Parties to the Rome Statute, The Hague, 21 November 2013.

${ }^{14}$ For example, at the 12th ASP, the representative from Finland noted that 'reparations are at the heart of the restorative mandate of the Court'. Victim plenary, 12th Session of the Assembly of States Parties to the Rome Statute, 22 November 2013, author's notes. 


\section{International criminal law's 'restorative turn'}

Understanding the contemporary interest in restorative justice and the figure of the victim in international criminal law entails placing it in the broader historical context of this retributive legal field. Proponents of what is now called international criminal law draw a line back to the post-World War II military tribunals constituted by the allied powers at Nuremberg and Tokyo. ${ }^{15}$ The field of international criminal law expanded in the period following the Cold War, contributing to the 'tribunalisation' of conflict. ${ }^{16}$ As critics have noted, however, privileging criminal accountability comes at the expense of alternate political values, such as inclusion and membership. ${ }^{17}$ Negotiated political settlements would permit perpetrators to become part of a new regime, whereas the logic of international criminal law entails casting perpetrators as criminals and excluding them from the future formation of a polity. The field privileges punishment over reconciliation, producing what Sarah Nouwen and Wouter Werner have referred to as a kind of Schmittian distinction between 'friends' and 'enemies' of the 'international community'. ${ }^{18}$

It would seem that such a focus on the figure of the criminal in need of punishment cuts against more transitional objectives of reconciliation and repair, as accountability begins from a premise of isolating individuals and attributing blame rather than reconciling communities. In this sense the restorative turn, emerging through the Rome Statute negotiations of the mid-1990s, harbours more of a humanitarian objective than an alignment with the aims of transitional justice. As the reach of international criminal law has extended, the field has become increasingly bound up with humanitarian logics and a focus on the figure of the victim in need of care. In her contribution to this volume, anthropologist Kamari Clarke explains that the UN General Assembly's 1985

${ }^{15}$ Most standard textbooks of the field typically begin from Nuremberg, though these origin myths are unsettled by an emerging strand of literature on this field's history; see for example K.J. Heller and G. Simpson, The Hidden Histories of War Crimes Trials (Oxford: Oxford University Press, 2013).

${ }^{16}$ On what she terms the 'tribunalization of African violence', see K. Clarke, Fictions of Justice: The International Criminal Court and the Challenge of Legal Pluralism in SubSaharan Africa (New York: Cambridge University Press, 2009).

17 M. Mamdani, Saviors and Survivors: Darfur, Politics, and the War on Terror (New York: Doubleday, 2010); A. Branch, Displacing Human Rights: War and Intervention in Northern Uganda (Oxford: Oxford University Press, 2011).

18 S. Nouwen and W. Werner, 'Doing Justice to the Political: The International Criminal in Uganda and Sudan', European Journal of International Law, 21 (2010), 941-965. 
'Declaration of Basic Principles of Justice for Victims of Crime and Abuse of Power' provided a foundation for Rome Statute negotiations concerning victims' participatory and reparative rights at the ICC. When the Security Council invoked 'the responsibility to protect' in its resolution referring the Libyan conflict to the ICC, the growing relationship between humanitarian discourse and criminal accountability was made explicit. ${ }^{19}$

As restorative aims become formalised, international criminal law is now regarded as a site of humanitarian practice as well as a means of accountability and deterrence. Recent scholarship has argued that different bodies of law have become more consolidated around a notion of 'humanity' as a legal subject - a subject that, in the words of the Nuremberg Military Tribunal, 'is able to assert itself by law'. David Luban points out the plurality of meanings now attributed to the work of international criminal law:

\begin{abstract}
in addition to the familiar quartet of retribution-deterrence-incapacitation-rehabilitation, ICL recognizes other purposes, and these raise problems of their own. The curious feature about ICL is that in it the emphasis shifts from punishments to trials. Thus it is often said that the goal of ICL lies in promoting social reconciliation, giving victims a voice, or making a historical record of mass atrocities to help secure the past against deniers and revisionists. ${ }^{20}$
\end{abstract}

The ICC has gone the farthest among hybrid and international courts and tribunals in institutionalising restorative objectives. It has adopted statutory provisions establishing participatory and reparatory rights for victims of international crimes, thus formalising the presence of humanitarian objectives in this retributive legal frame. ${ }^{21}$

Court proponents invoke conflict-affected communities and what Kamari Clarke calls 'the specter of the victim' as normative justifications for their work. ${ }^{22}$ ICC prosecutor Fatou Bensouda has claimed that 'the sole raison d'être of the Court's activities ... is the victims and the justice they deserve, ${ }^{23}$ suggesting that the telos of the ICC's work is oriented towards restorative rather than retributive purposes. Meanwhile, the

19 UNSC Res. 1970, 26 February 2011.

${ }^{20}$ D. Luban, 'Fairness to Rightness: Jurisdiction, Legality, and the Legitimacy of International Criminal Law', Georgetown Law Faculty Working Papers, 67 (2008), 8.

${ }^{21}$ Article 63, Rome Statute. Article 75(2) empowers the Court to make a reparations order against a convicted person; Article 79 establishes the Trust Fund for Victims. These rights are taken up in greater detail in Chapter 13 by Dixon in this volume.

${ }^{22}$ Clarke, Fictions of Justice, 22-23. ${ }^{23}$ OTP Press Release, 20 July 2013. 
ICC's president has stated that 'the Rome Statute and the ICC bring retributive and restorative justice together with the prevention of future crimes. ${ }^{24}$

Within international law there have been some efforts to account for a more sanguine reading of the rise of the figure of the human. For example, Ruti Teitel has argued that there is a legal conception of humanity at play in the overlapping spaces between the law of war, human rights law and international criminal law. Building upon the ICTY appellate chamber's assertions in the Tadic decision, Teitel claims that ' $[t]$ he normative foundations of the international legal order have shifted from an emphasis on state security - that is, security as defined by borders, statehood, territory, and so on - to a focus on human security: the security of persons and peoples'. ${ }^{25}$ Elaborating upon what she terms a nascent 'humanity law', Teitel's work offers an extended argument about the growing commonalities between these legal fields since World War II. $^{26}$ The ICC features in this account as a vehicle through which international criminal law is brought into a closer relationship with conflict management, forging connections between punishment and international security. ${ }^{27}$ This account of the ICC does not take up other humanitarian aspects of its work, however, such as the role of victim participants and the Court's Trust Fund, but instead claims a growing convergence between different bodies of law. Read through the 'humanity law' frame, victim redress amounts to holding individual perpetrators criminally accountable for human rights violations and violations of international humanitarian law. Punishment itself is seen as a form of redress.

In international criminal law more specifically, dominant interpretations of including restorative justice regard it as a progressive legal development - a shift to incorporating victims' needs within a field that has historically relegated them to its margins. Much like progressive histories of the field itself, this interpretation presumes a kind of humanitarian teleology, where these practices are taken as signs that

${ }^{24}$ Statement of President Song, 10 December 2012. ${ }^{25}$ Teitel, Humanity's Law, 4.

${ }^{26}$ Richard Ashby Wilson also uses the 'humanity law' appellation to describe a cosmopolitan universalist jurisdiction; see 'When Humanity Sits in Judgment: Crimes Against Humanity and the Conundrum of Race and Ethnicity at the International Tribunal for Rwanda', in Feldman and Ticktin, In the Name of Humanity, 27-57.

27 Teitel argues that the ICC is 'aimed at managing conflict worldwide' - an objective that 'links it to the prevailing interstate security regime', particularly through the use of UN Security Council referrals as a trigger for ICC jurisdiction. Teitel, Humanity's Law, 89-90. 
international criminal law is becoming more responsive to conflictaffected communities. In this account, victims have been traditionally excluded from international criminal trials, with the ICC offering something of a paradigm shift in the recognition of victims' rights and the inclusion of restorative justice. ${ }^{28}$ As some observers have argued, the involvement of victims 'not only is a "right" but also appears indispensable if post-conflict justice processes are to be restorative and capable of building the foundations for a strong transition through empowerment of those who were victimized during conflict. ${ }^{29}$

Rather than reading the emergence of these practices as they relate to the field's development, I contend that the ICC's restorative dimension should be interpreted within a wider frame, in relation to the rise of humanitarian discourse across a range of different fields of knowledge and sites of engagement. The discourse of restorative justice before the ICC stretches beyond the framework of positive law. Claims about hearing the voices of victims, restoring lost dignity and reconciling populations in the wake of conflict through the vehicle of international criminal law exceed the terms available through the very law that supposedly sustains these objectives.

\section{Restorative justice in the humanitarian continuum}

The ICC's framework of restorative justice can be related to what has been described above as 'humanitarian government ${ }^{30}$ and elsewhere as 'humanitarian compassion' ${ }^{31}$ that may be deployed through various 'regimes of care'. ${ }^{32}$ These terms have been used to refer to a diverse set of practices, including pardons from truth commissions and the provision of medical assistance to asylum seekers, but these disparate practices

28 Conor McCarthy's work on the role of victims at the ICC notes that 'the idea of bringing "justice to victims" was not of central concern to international criminal law at the formative stage of its development'. See C. McCarthy, 'Victim Redress and International Criminal Justice: Competing Paradigms, or Compatible Forms of Justice?', Journal of International Criminal Justice, 10 (2012), 351-372; and C. McCarthy, Reparations and Victim Support in the International Criminal Court (Cambridge: Cambridge University Press, 2012).

${ }^{29}$ M. Pena and G. Carayon, 'Is the ICC Making the Most of Victim Participation?', The International Journal of Transitional Justice, 7 (2013), 519, 518-535.

${ }^{30}$ Fassin, Humanitarian Reason.

31 R. Meister, After Evil: A Politics of Human Rights (New York: Columbia University Press, 2011), 73.

32 M. Ticktin, Casualties of Care: Immigrants and the Politics of Humanitarianism in France (Berkeley: University of California Press, 2011), 3. 
share underlying commonalities with the restorative turn in international criminal law. Adequately grasping the stakes of the restorative turn and its relation to humanitarianism thus requires taking up scholarship that has addressed its historical emergence and its manifestation in other fields, such as humanitarian assistance to conflict-affected populations and the provision of medical care to refugees. The restorative turn can be seen as another site where humanitarian sentiment assumes institutional and material forms. This wider optic helps to illustrate some of humanitarianism's presumptions and unintended consequences, providing a way of viewing restorative justice in international law as part of a constellation of activities - what we might think of as a humanitarian continuum. ${ }^{33}$

Humanitarianism can be understood as the manifestation of compassionate or moralising sentiments as political forces that appear through practices, such as the provision of medical care to conflict-affected communities. These practices produce effects among populations that are perceived as vulnerable, whether due to their exposure to armed conflict, poverty or repressive governments. Humanitarian sentiments appear explicitly at the nexus of legal and policy discourse through doctrines authorising the use of armed force, such as 'humanitarian intervention' and the 'responsibility to protect', which permit military intervention where a state is seen to be manifestly failing to protect its population. ${ }^{34}$ These justifications for intervention are a more extreme consequence of routing humanitarian logics through international law, but legal humanitarianism also assumes more subtle forms, such as regimes of care directed at conflict-affected populations. At all points on the continuum, from military intervention to care provision, humanitarianism operates as a form of governance: evaluating, deciding and implementing its objectives, and producing divisions between selected and 'untreated' populations.

33 As with Michel Foucault's notion of the 'carceral continuum', which contended that the disciplinary techniques developed in prisons expanded throughout society, we might think of a humanitarian continuum as the expansion of humanitarian logics into other areas, such as international criminal law. See M. Foucault, Discipline and Punish: The Birth of the Prison (New York: Vintage Books, 1977). I thank Nesam McMillan for her insights on this point.

34 See generally A. Orford, International Authority and the Responsibility to Protect (Cambridge: Cambridge University Press, 2011). For a historical account of humanitarian intervention, see B. Simms and D.J.B. Trim (eds.), Humanitarian Intervention: A History (Cambridge: Cambridge University Press, 2011). 
The historical rise of humanitarianism predates the post-Cold War expansion of international criminal law. Some accounts have located its emergence in the late eighteenth and early nineteenth centuries, when what was previously taken as private acts of compassion emerged into the public realm, animated by Enlightenment notions of progress and the idea that the human condition could be taken as an object of improvement. ${ }^{35}$ As Michael Barnett writes, ' $[\mathrm{w}]$ hat distinguishes humanitarianism from previous acts of compassion is that it is organized and part of governance, connects the immanent to the transcendent, and is directed at those in other lands. ${ }^{36}$

Humanitarianism is torn between the desire to universalise on the one hand and the attention to particular circumstance on the other. For example, reports of the ICC's Trust Fund emphasise the importance of context in its work at the same time as they portray an abstract 'African victim'. The reports proclaim a kind of emancipation through the Trust Fund's regime of care - restoring dignity, acquiring knowledge about rights - while also requiring individuals to accept and submit themselves to the Trust Fund's logic for targeting individuals and conflict-affected communities, as Peter Dixon's contribution to this volume illustrates in greater detail.

While there is much emphasis on the emancipatory potential in Court discourse and in the language of its proponents, international criminal law's restorative turn has hardly been considered as a form of governance in the scholarship of international criminal law. Most work on the inclusion of victims and conflict-affected communities in ICC jurisprudence and practice regard it as falling somewhere along a spectrum of efficacy, ranging from a welcome development for the field through extending victims' rights on one end, to generating policy problems and fair trial rights concerns on the other. ${ }^{37}$ Understanding the ways in

35 On the emergence of humanity as 'sentiment', see T. Laqueur, 'Bodies, Details and Humanitarian Narrative', in L. Hunt (ed.), The New Cultural History (Berkeley: University of California Press, 1989), 176-204; and T. Laqueur, 'Mourning, Pity, and the Work of Narrative in the Making of "Humanity", in R. A. Wilson and R. Brown (eds.), Humanitarianism and Suffering: The Mobilization of Empathy (Cambridge: Cambridge University Press, 2009), 31-57.

${ }^{36}$ M. Barnett, Empire of Humanity, 21. The work of Didier Fassin and Miriam Ticktin tracks how humanitarianism is deployed domestically as well, thus challenging Barnett's claim that it is directed outward as a form of governance.

37 See generally L. Moffet, Justice for Victims before the International Criminal Court (London: Routledge, 2014); C. van den Wyngaert, 'Victims Before International Criminal Courts: Some Views and Concerns of an ICC Trial Judge', Case Western 
which it governs individual survivors of mass violence as well as the conflict-affected populations to which they belong calls for a broader contextual view, locating its rootedness in liberal forms.

Our humanitarian present is marked by a liberal form of humanitarianism that closely meshes with the discourse of human rights. ${ }^{38}$ Barnett argues that contemporary humanitarianism is a liberal humanitarianism' that began in the wake of the Cold War, characterised by efforts to protect vulnerable populations and to prevent conflict through extending democratic governance. The post-Cold War ascendance of international criminal law can then be located in relation to its contemporary form of liberal humanitarianism, both of which developed against the backdrop of a particular human rights discourse that emerged during the Cold War period. ${ }^{39}$ As Kamari Clarke's contribution to this volume elaborates, the field expanded in conjunction with a liberal understanding of legality, accompanied by 'rule of law' and 'good governance' initiatives. International criminal law's restorative turn sits within a broader field of humanitarian activity, with links to concrete practices of intervention, such as the 'responsibility to protect' and development agendas of donor states.

This broader humanitarian continuum has also been subject to critique. Alex de Waal's work on the paradoxes of humanitarianism illustrates how 'the impulse to ameliorate suffering leads humanitarian workers into the unwelcome situation of acting cruelly. While professional standards are increasing, thereby reducing suffering, some cruelties are intrinsic to the humanitarian predicament - hence the humanitarians' tragedy. ${ }^{40}$ De Waal elaborates that the 'tragedy' results from irreconcilable goals and the constraints brought by the conditions in which humanitarianism is carried out; cruelty is inevitably tied to

Reserve Journal of International Law, 44 (2011), 425; S. Vasiliev, 'Article 68(3) and personal interests of victims in the emerging practice of the ICC', in Carsten Stahn and Göran Sluiter (eds.), The Emerging Practice of the International Criminal Court (Leiden: Brill, 2009).

38 Barnett, Empire of Humanity, 167. David Chandler makes a similar claim, arguing that the 'transformation of humanitarianism from the margins to the centre of the international policy-agenda has been achieved through the redefinition of humanitarian policy and practice and its integration with the fast growing agenda of human rights'. See D. Chandler, 'The Road to Military Humanitarianism: How the Human Rights NGOs Shaped A New Humanitarian Agenda', Human Rights Quarterly, 23 (2001), 678, 678-700.

39 See S. Moyn, The Last Utopia: Human Rights in History (Harvard: Harvard University Press, 2012); as well as Meister, After Evil.

40 A. de Waal, 'The Humanitarians' Tragedy: Escapable and Inescapable Cruelty', Disasters, 34(2) (2010), 130, 131-37. 
decision-making in the face of suffering, where some lives will be saved and others will be lost. Sarah Nouwen picks up this point specifically in relation to the field of international criminal law when she argues that it also harbours a certain cruelty: it overstates its own ability to bring about an end to conflict; it operates according to logics of selection that belie its presumed political neutrality; and it necessarily privileges accountability over negotiated settlement, an aim that may itself beget further violence. $^{41}$

As the following sections illustrate, the gap between the rhetorical promise and material practice of international criminal law as a form of restorative justice produces new divisions: between court-recognised victims and general (unrecognised) victims of a conflict, and between beneficiaries of ICC 'targeting' and those whose suffering falls outside selected categories of assistance. By extension, such divisions may form the basis for new forms of grievance when they are mapped across conflict-affect communities.

\section{Victim participation as legal humanitarianism}

The most apparent forms of legal humanitarianism at the ICC appear in the Court's efforts to engage with victims. Here the link between international criminal law and human rights law is made explicitly, as some commentators have claimed that the appearance of victims' rights in the ICC statute shows a 'complementarity between international criminal law and international human rights law'. ${ }^{42}$ The restorative mandate of the ICC's work, considered in the following section, provides another location for an emergent legal humanitarianism. Here recognition by and inclusion within the legal process is presented as a form of empowerment - indeed, as a right - as well as a humanitarian practice of alleviating suffering. As one ICC representative suggested publicly, victim participation can be regarded a form of reparation or redress. ${ }^{43}$

${ }^{41}$ S. Nouwen, 'Justifying Justice', in J. Crawford and M. Koskenniemi (eds.), The Cambridge Companion to International Law (New York: Cambridge University Press, 2012), 327-351.

${ }^{42}$ FIDH, 'Enhancing Victims' Rights Before the ICC: A View from Situation Countries on Victims' Rights at the International Criminal Court' (November 2013), 8, referencing ICJ Judge A. Trinidade, The Access of Individuals to International Justice (Oxford: Oxford University Press, 2011), 201-204.

${ }^{43}$ Paolina Massida, Head of the ICC Office of Public Counsel for Victims, presentation at conference 'Reparations before the International Criminal Court', The Hague, 12 May 2011, author's notes. 
Yet the field of potential beneficiaries of the ICC's restorative work is circumscribed from the moment the Court intervenes in a situation country. When the prosecutor determines what crimes to investigate and what arrest warrants to issue, there are effects at the level of jurisdictional criteria and evidentiary assessments. For the Court's restorative mandate, or what some official ICC documents have termed its mandate regarding victims', ${ }^{44}$ this manifests as restrictions on who qualifies as a court-recognised victim for purposes of participation. This leads to a form of 'juridified victimhood' - namely, the use of legal criteria to determine an individual's status as a victim. ${ }^{45}$ Victimhood in this sense becomes an identity that is regulated through jurisdictional standards, such as time and place and the subject matter of crimes. When charges are dropped, as was the case against Uhuru Kenyatta in the Kenyan situation, this has broader implications for victim participation: former 'case victims' are then regarded as 'situation victims', with fewer participatory rights. From the standpoint of conflict-affected communities, the use of legal categories to determine one's qualification as a victim may seem arbitrary at best, and quite possibly as manifesting an institutional indifference to suffering.

Some critical scholarship has noted the shortcomings of the Court's victim participation regime. ${ }^{46}$ Others have welcomed victim participation in principle, offering suggestions for greater inclusion. ${ }^{47}$ To be sure, there could be ways of modifying the ICC's practices within its existing legal frameworks that may assist it in achieving greater recognition of those who have suffered the effects of the crimes it seeks to prosecute. However, what I contend here is that the Court's very point of departure - its work within legal and jurisdictional categories produces institutional limitations to the recognition that it might grant.

${ }^{44}$ ICC-ASP/11/38, 'Court's Revised Strategy in Relation to Victims', 5 November 2012, 2.

${ }^{45}$ See generally S. Kendall and S. Nouwen, 'Representational Practices at the International Criminal Court: The Gap Between Juridified and Abstract Victimhood', Law and Contemporary Problems, 76(3-4) (2014), 235-262.

46 See note 37 for examples of this literature.

47 J. Wemmers, 'Where Do They Belong? Giving Victims a Place in the Criminal Justice Process', Criminal Law Forum, 20 (2009), 395-416; M. Pena, 'Victim Participation at the International Criminal Court: Achievements Made and Challenges Lying Ahead', ILSA Journal of International and Comparative Law, 16 (2010), 497-516; S. Garkawe, 'Have Recent Changes Designed to Benefit Victims of International Crimes Added to the Legitimacy of International Criminal Justice?', in G. Boas, W. Schabas, and M. Scharf (eds.), International Criminal Justice: Legitimacy and Coherence (Cheltenham: Edward Elgar, 2012), 269-303. 
The way in which victim participation is enacted in practice illustrates some of these shortcomings, which are not only matters of policy but also inherent to the juridical form.

Implementing the Rome Statute's victim participation provisions has involved a considerable amount of reflexivity among actors, who have adjusted and re-adjusted their practices in relation to resource constraints and other challenges that they have faced sur le terrain. In order to be granted status as victim participants, conflict-affected individuals must first be informed of the possibility that they may seek recognition before the Court. This assumes a number of prior interventions: interaction with the Court's outreach section, for example, as well as contact with members of the ICC's Victim Participation and Reparations Section (VPRS) or their 'intermediary' partners. ${ }^{48}$ It is only through these channels that the conflict-affected individual will come into contact with the participation forms that will enable his or her claim to the participatory rights to be adjudicated before the Court. As the head of VPRS has noted, '[a] major challenge is how to inform victims about the ICC in general as well as about their own possible role as participants', and 'how to process potentially large numbers of application forms from victims. ${ }^{49}$ Judges in the Kenyan situation instituted an alternative model for attaining recognition as a victim participant, which they claimed they made 'for practical reasons'; ${ }^{50}$ however, as the majority of situations to date require the adjudication of individual victim participation forms, most individuals receive (or are denied) recognition by the ICC through the process described here.

Victim participation forms must be filled out in such a way that the individual is able to establish a nexus between the harms she or he has suffered and the charged crimes. ${ }^{51}$ Forms work as 'actants' in the sense that they produce effects; ${ }^{52}$ through the very act of filling in a form,

48 On the role of intermediaries in the ICC's work, see Dierdre Clancy's contribution to this volume.

49 F. McKay, 'Victim Participation in Proceedings Before the International Criminal Court', Human Rights Brief, 15(3) (2008), 4-5.

50 Decision on Victims' Representation and Participation, The Prosecutor v. William Samoi Ruto and Joshua Arap Sang, Case No. ICC-01/09-01/11, Trial Chamber V, ICC, 3 October 2012, para 30.

${ }^{51}$ For an elaboration of the role of the form in the production of victimary identity at the ICC, see S. Kendall, 'Archiving Victimhood: Practices of Inscription in International Criminal Law', in S. Motha and H. van Rijswijk (eds.), Law, Memory, Violence: Uncovering the Counter-Archive (London: Routledge, 2016).

52 B. Latour, Politics of Nature: How to Bring the Sciences into Democracy (Harvard: Harvard University Press, 2004). 
conflict-affected individuals are brought into a state of waiting. The Court's Rules of Procedure and Evidence requires that applications must be submitted to the prosecution and the defence before a judicial determination is made, and sometimes the relevant chamber can take years to provide applicants with a response. The VPRS section has publicly explained that ' $\mathrm{v}$ ] arying types of application form and application process [sic] have been adopted by different Chambers. Responding to these is, in the short term, having an impact on the workload of the section as it involves designing different forms and processes and modifying the reporting system and database each time. ${ }^{53}$ As one experienced commentator who worked extensively with VPRS has noted, 'the application process has been long and cumbersome for all parties involved, including victims'. ${ }^{54}$ Backlogs are widely reported by Court staff, and are even noted in official Court documents. ${ }^{55}$ These backlogs can have chilling effects on the efforts by potential participants to exercise their participatory rights under the Rome Statute. For example, the inability to process and adjudicate forms before significant events on the judicial calendar has resulted in hundreds of individuals not receiving a determination from the Court before the confirmation of charges hearing in the Mbarushimana case in 2011. ${ }^{56}$

In the Ugandan situation, over eight years after arrest warrants were issued as of the time of writing, Court-recognised victims have not been able to actively exercise their participatory rights apart from at a confirmation of charges hearing in 2008. Many applicants for participant status have not heard back about their applications after years of waiting. In December 2013, field office staff members undertook a 'mission' to northern Uganda for several weeks to engage with conflict-affected communities. Before the trip, an outreach officer described this as a 'commemoration ceremony' in northern Uganda for all individuals who had applied for victim participant status or had communicated with the Court. The term was later abandoned, as some judges

53 Proposed programme budget for 2014 of the International Criminal Court, ICC-ASP/12/ 10, Included in Assembly of States Parties to the Rome Statute of the International Criminal Court, Twelfth Session, Official Records Volume II, para 537.

54 Pena, 'Victim Participation', 511.

55 For example, a 2012 ASP resolution noted 'with continued concern reports from the Court on the persistent backlogs the Court has had in processing applications from victims seeking to participate in proceedings'; see Resolution ICC-ASP/11/Res.7, 'Victims and Reparations', 21 November 2012.

56 REDRESS, 'Hundreds of Victims Prevented from Participating in Crucial Court Hearings Due to lack of Resources at the International Criminal Court', Press Release, 15 July 2011. 
purportedly did not think the language of 'commemoration' was appropriate. Another staff member who had participated in the meetings said that they were intended to 'celebrate [the victims'] resilience in this process', but that the purpose of the meeting was primarily directed toward clarifying the Court's 'maintenance strategy' as it decreased its field presence in Uganda rather than towards commemorating victims. ${ }^{57}$ Meanwhile, intermediaries were discouraged from submitting more participation forms although the Court was technically still required to accept new participant applications. There was a general impression that the Court was at capacity, unable to take on more potential victim participants in the Ugandan situation in light of the other contexts where it had intervened.

In conversations over the past several years, members of civil society organisations have noted the frustrations of conflict-affected communities who had been hearing the same messages since the Court had started working in Uganda - the promise of participatory rights, assistance and reparation that were always over the horizon and rarely materialising in practice. Meanwhile, in the Kenyan context, changes to the system of victim participation have resulted in the creation of a twotiered system of Court-recognised victims: those entitled to participate, as in other situations, and those whose details are noted in a 'register' maintained by the Court, which operates rather like a closed archive. Inaccessible to relief agencies and to the Court's affiliated Trust Fund, the register contains identifying details of individuals as well as information about their suffering. Common legal representatives for victims have access to information from registered victims and may use this as a basis for identifying potential victim participants; the information gathered about individuals who are not candidates for participation form part of a mass of information to be used by legal representatives in making general claims regarding victims' interests and concerns. Ultimately, however, the language used by the decision renders even this information potentially irrelevant; in specifying that 'all victims, regardless of whether they have registered or not, will be represented through common legal representation ${ }^{58}$ while the case is at trial, the decision at least discursively collapses the distinction between registered and non-registered victims. While individuated guilt remains at the centre of international criminal

57 Interview with ICC field office staff, Kampala, 6 February 2014.

58 Proposed programme budget for 2014 of the International Criminal Court, ICC-ASP/12/ 10 , para 52. 
law, it would seem that individuated suffering - a premise of legal humanitarianism - is more tenuous than it may appear in claims made through ICC documents.

Official texts reveal the tensions in translating the ambitions of legal humanitarianism into practice. For example, the ICC's 2012 'revised strategy in relation to victims' maintains that it incorporates a 'rights based perspective' that 'reconfirms and empowers the victim as a vital actor in the justice process rather than a passive recipient of services and magnanimity'. ${ }^{59}$ The text contains an extensive annex listing the 'rights and prerogatives' of victims at various stages of the Court process, enumerated under a heading entitled 'right or possibilities'. The list of nearly 100 items reinforces the difficulty of carrying out the 'strategic objective' of communicating 'rights as victims in relation to the elements of the ICC system and at all steps of the judicial process' ${ }^{60}$ Furthermore, given the Court's shifting jurisprudence on precisely these rights and prerogatives/possibilities, how can the ICC ensure that the individual victim remains a vital actor rather than a passive recipient of legal recognition and assistance?

Such observations are not meant to diminish the extensive efforts by some members of Court staff to produce a system in line with this rightsbased perspective, nor the efforts by non-governmental organisations and ICC 'intermediaries' to improve the system through Court channels or through informal attempts to compensate for formal shortcomings. The overarching issue is more systemic, in the sense that the legal field itself is bound by restrictions that undergird its efforts to engage in humanitarian practices. This is more evident with the Court's most overt attempts to engage in legal humanitarianism through the work of its Trust Fund.

\section{Producing productive subjects: the ICC Trust Fund's assistance mandate}

Even more than victim participation, which is largely articulated as a matter of rights grounded in the Rome Statute, the ICC's Trust Fund serves as an exemplary instance of legal humanitarianism, providing selective assistance to conflict-affected individuals and populations that

59 ICC/ASP/11/38, 'Court's Revised strategy in relation to victims', 5 November 2012, para. 6.

60 Ibid., para. 18. 
fall broadly within the Court's jurisdiction. The Trust Fund is not technically located within the ICC's institutional structure; rather, the ICC and TFV are regarded as 'complementary institutions'. ${ }^{61}$ The Trust Fund claims its institutional mission is 'to support programs, which address the harm resulting from the crimes under the jurisdiction of the ICC by assisting victims to return to a dignified and contributory life within their communities', with an overarching goal 'to relieve the suffering of victims'. ${ }^{62}$ This relief is carried out through two distinct mandates: first, through implementing reparations awards (not considered here, but taken up in Peter Dixon's contribution to this volume); and second, 'to provide victims and their families in situations under Court jurisdiction with physical rehabilitation, psychological rehabilitation, and/or material support'. ${ }^{63}$

Taken together, the contributions from Kamari Clarke, Laurel Fletcher and Peter Dixon in this volume cover significant aspects of the Trust Fund's work in practice, including the kinds of programmes it supports in select ICC situation countries as well as the politics of 'targeting' beneficiaries. They illustrate the risks of re-inscribing categories of identity by privileging certain communities over others, a concern that was also voiced by non-governmental organisations working in the Democratic Republic of Congo, whose representatives claimed that among the local population the Court was seen to be favouring certain communities. ${ }^{64}$ Building upon the observations from previous chapters, this section seeks to show how the provision of assistance to conflictaffected communities, as a form of legal humanitarianism, is constrained by juridical logics that limit its work. If the Trust Fund is 'like a donor', ${ }^{65}$ in the words of one of its representatives, what kind of donor might it be? Reading the Trust Fund's work in relation to critical literature on the provision of humanitarian assistance reveals the ways in which legal humanitarianism works to govern conflict-affected populations.

Anthropologists studying the practices of humanitarianism have shown how efforts to alleviate suffering are bound up with relations of power and interest. Didier Fassin's scholarship provides a grounded account of the work of the humanitarian organisation Médecins sans Frontières (MSF), illustrating the unintended consequences of decisions to prioritise certain forms of assistance over others (the provision of food

61 TFV Programme Progress Report, Summer 2014, 3, emphasis added. ${ }^{62}$ Ibid., 4.

${ }^{63} \mathrm{Ibid} . \quad{ }^{64}$ Interview with representatives of an INGO, Kinshasa, 20 June 2011.

${ }^{65}$ Interview with Trust Fund representative, Kampala, 25 October 2011. 
over medical treatment, for example) and valuing certain lives over others (those of the humanitarian care providers over the populations they are treating). Fassin points to a paradox that he claims is embedded within humanitarianism:

Humanitarianism is founded on an inequality of lives and hierarchies of humanity. This profound contradiction between the noble goals of humanitarian action (saving endangered others and alleviating suffering everywhere in an indiscriminate manner) and the concrete terms under which humanitarian agents have to operate (producing inequalities and hierarchies) is not the result of dysfunction of the humanitarian organizations or the misbehavior or their agents: it is an aporia of humanitarian governmentality. ${ }^{66}$

Fassin's critique of humanitarianism begins from noting its point of departure within a framework of inequality. Those who carry out the work of humanitarianism are structurally separated from those who are thought to benefit from this work, a fact that is most starkly illustrated when the lives of humanitarian aid providers are prioritised over those they treat when situations relapse into conflict. This has been the case at the ICC, as when staff members have ceased implementing Trust Fund assistance in the Central African Republic at various points due to security concerns. In Kenya the Trust Fund's presence has been deferred for years, with prospects of a preliminary 'assessment mission' discussed as early as 2011 and slated for early $2012,{ }^{67}$ whereas a 2014 programme progress report asserted that 'an assessment mission to Kenya is planned for 2015 depending on security protocols and travel guidelines'. ${ }^{68} \mathrm{~A}$ representative of the Trust Fund explained that the delay was first due to jurisdictional issues and then continued due to security concerns, noting that Kenya has become a very dangerous environment for human rights defenders. ${ }^{69}$ Meanwhile, domestic civil society partners have continued to work in support of the ICC's presence in Kenya, with one member of a leading non-governmental organisation remarking that 'everybody's life in the Court becomes more precious than is ordinarily the case'. ${ }^{70}$

${ }^{66}$ D. Fassin, 'Inequality of Lives, Hierarchies of Humanity: Moral Commitments and Ethical Dilemmas of Humanitarianism', in Feldman and Ticktin, In the Name of Humanity, 239.

${ }^{67}$ Interview with Trust Fund representative, Kampala, 25 October 2011.

68 TFV Programme Progress Report, Summer 2014, 35.

${ }^{69}$ Interview with Trust Fund representative, Kampala, 6 February 2014.

${ }^{70}$ Interview with member of Kenyan NGO, Nairobi, 30 November 2012. 
In addition to privileging some lives over others, humanitarian actors further inscribe the division between themselves as agentic subjects and the suffering populations whom they seek to treat through making the very assessments that are necessary for targeting beneficiaries. By classifying and categorising populations based upon treatment priorities, humanitarianism produces hierarchies and inequalities that belie its egalitarian ambitions, as the work of Alex de Waal and Didier Fassin has shown. Fassin claims that rather than a product of individual decision-making ('dysfunction' or 'misbehavior'), this contradiction between humanitarianism's 'noble goals' and its work in practice is instead an 'aporia', an impasse or doubt, intrinsic to humanitarian governance. Relatedly, Ilana Feldman and Miriam Ticktin have argued that 'humanitarian organizations often find themselves in the business of governing managing, servicing - the populations they seek to aid'. ${ }^{71}$

Much like humanitarian aid provision, the restorative turn in international criminal law also harbours a contradiction between its ambitious goals of redressing wrongs on a broad scale and its relatively limited manifestations at the level of practice. To be sure, some issues arise from limitations that appear as products of institutional practice, particularly among large multi-sited institutions like the ICC, with field offices maintaining reporting relationships with The Hague, where most policy decisions are taken. As Trust Fund representatives have pointed out, the process of selecting proposals for recipients of funding is 'bureaucratic' and time-consuming. ${ }^{72}$ For example, the Trust Fund's activities in the Democratic Republic of Congo does not have a physical rehabilitation mandate because it was not originally requested from the chamber; to attempt to add one would take considerable time. ${ }^{73}$ However, what Fassin notes regarding the work of MSF holds for the ICC as well: rather than merely a product of bureaucratic dysfunction or staff decisions within the Court, the contradiction between legal humanitarianism's ambitious goals and limited practices is intrinsic, arising from a more fundamental tension between international criminal law and restorative conceptions of justice. Just as the universalist sentiment undergirding humanitarian assistance - to aid all those who suffer - runs up against

${ }^{71}$ I. Feldman and M. Ticktin, 'Government and Humanity', in Feldman and Ticktin (eds.), In the Name of Humanity, 13.

${ }^{72}$ Interview with Trust Fund representative, Kampala, 6 February 2014.

73 To add a physical rehabilitation mandate would require filing a request with the Court, which would then have 45 days to decide on the proposal, and observations would need to be made by all parties. Interview with Trust Fund representative, Kampala, 12 July 2012. 
practical constraints, producing hierarchies and exclusions along the way, the restorative sentiment at play in the 'victims' mandate' of the ICC meets the juridical constraints of a field that is fundamentally designed to classify and categorise.

In international criminal law, such acts of classification and categorisation typically entail affixing criminal labels to forms of behaviour and locating individuals within hierarchies of command. Juridical classification ascribes modes of liability, differentiates forms of crime and determines what subjects, acts and periods of time fall within the scope of an institution's jurisdiction. The form of governance performed here entails sorting and differentiation, distinguishing which deeds amount to 'crimes of greatest concern to the international community' and which bodies will appear before the law. When directed at the level of the population, however, these categories perform additional forms of governance. Borrowing from Michel Foucault, we can conceptualise such governance as a kind of 'biopower', intervening at the collective level (here, among conflict-affected populations) to promote life and health. ${ }^{74}$ Unlike other theorisations of 'biopower' that would regard it as a repressive form of power, such as the sovereign power to suspend the law, ${ }^{75}$ Foucault regarded biopower as productive power, in the sense that it was oriented towards producing greater vitality in the populations towards which it was directed. ${ }^{76}$ Eighteenth- and nineteenth-century forms included developing biopolitical strategies for intervening to improve birth rates and control epidemics; we might regard twentieth- and twenty-first-century humanitarian practices that seek to alleviate suffering through providing medical care and livelihood support as contemporary forms. Generally biopower sought to 'produce and regulate ways of maximizing the capacities of both the population and the individual as the target of power'; ${ }^{77}$ similarly, according to the official Trust Fund narrative, the purpose of physical rehabilitation is 'to address the care and rehabilitation of those victims who have suffered physical injury, in

74 See M. Foucault, The History of Sexuality, Vol. 1: The Will to Knowledge (London: Penguin, 1978); and M. Foucault, Society must be defended: Lectures at the Collège de France, 1975-76 (New York: Picador, 2002).

${ }^{75}$ G. Agamben, Homo Sacer: Sovereign Power and Bare Life (Stanford, CA: Stanford University Press, 1998).

${ }^{76}$ Foucault's work historicises this form of power, beginning with its emergence in the seventeenth century and consolidation in the nineteenth century. There is a vast secondary literature on Foucault's notion of biopower and biopolitics, and addressing it is beyond the scope of this chapter.

77 P. Rabinow and N. Rose, 'Biopower Today', Biosocieties, 1 (2006), 199, 195-217. 
order to recover and resume their roles as productive and contributing members of their societies' ${ }^{78}$

Through reading Trust Fund interventions in this light, as forms of governance, we can see the ways in which legal humanitarianism seeks to support and manage the lives of those who fall within its jurisdiction. A telling example is the case of Mary, a pseudonym used to designate a woman from northern Uganda, whose narrative is recounted in a Trust Fund annual report. According to the report, Mary 'became actively involved in economically-productive activities' following Trust Fundsupported counselling. ${ }^{79}$ Here the Trust Fund's embeddedness in a liberal conception of subjectivity - the norm of the productive, selfreliant subject - reveals the broader backdrop of 'liberal humanitarianism', in Barnett's words, in which Trust Fund interventions transpire. This focus on economic productivity is coupled with an emphasis on psychic well-being: '[e]ngaging herself in defence of her own rights has strengthened her sense of purpose and happiness and has been an important part of her remarkable recovery. ${ }^{80}$ All Trust Fund interventions include a 'psychosocial' dimension, such as counselling, in addition to medical or livelihood support. ${ }^{81}$ In this way the Trust Fund draws upon therapeutic discourse, casting suffering as trauma and thereby extending the reach of psychological responses to material harm.

Finally, as Peter Dixon's chapter recounts, the Trust Fund operates through practices of 'targeting' that direct care towards particular individuals and communities. In the case of the Trust Fund's medical interventions, a representative explained that the Trust Fund tries to address individuals who have injuries that are 'emblematic of the conflict', such as burn victims and amputees in the context of northern Uganda. ${ }^{82}$ A Gulubased observer of the Trust Fund's work noted that the Trust Fund was known for supporting reconstructive surgery and prosthetics, but was not well known for treating other conflict-related conditions. ${ }^{83}$ Here conflict-related suffering is placed on a spectrum of what can be regarded as most 'emblematic', and treatment priorities are determined in relation to that spectrum. As a second Trust Fund staff member observed, 'we are not a humanitarian body'; ${ }^{84}$ legal humanitarianism faces the constraints of the juridical form. Even the Trust Fund, whose work is not restricted

\footnotetext{
78 TFV Programme Progress Report, Summer 2014, 5. $\quad{ }^{79}$ Ibid., $32 . \quad{ }^{80}$ Ibid.

${ }_{81}^{81}$ Interview with Trust Fund representative, Kampala, 9 December 2011. ${ }^{82}$ Ibid.

${ }^{83}$ Interview with Justice and Security Research Programme researcher, Gulu, 8 February 2014.

${ }^{84}$ Interview with Trust Fund representative, Kampala, 12 July 2012.
} 
by the need to establish a nexus to charged crimes, still regards its interventions as responding to harms rather than to needs.

\section{Conclusion: beyond humanitarian governance}

The globalization of compassion meant a view of humanity based on the figure of the victim. ${ }^{85}$

In Discipline and Punish, Michel Foucault argued that ' $\mathrm{t}$ ] $\mathrm{oday}$, criminal justice functions and justifies itself only by this perpetual reference to something other than itself, by this unceasing reinscription in nonjuridical systems' ${ }^{86}$ In the case of international criminal law, this 'something other' appears increasingly as the figure of the victim, the object of legal humanitarianism. It would seem that the logic of punitive justice is not enough to legitimate the political and material investments of states in the field of international criminal law, requiring a humanitarian supplement to the objectives of institutions such as the ICC.

As a form of humanitarian governance, the ICC's victim mandate produces a regime of care - an institutionalisation of what Judith Butler calls 'precarious life', which is then governed and managed and attended to (or not). ${ }^{87}$ Governance is not always carried out by states (or by the Court), but also by non-state actors, by technologies of inscription such as victim participation forms, and through practices of adjudication, with their associated deferrals in line with the slow pace of juridical time. The conduits of legal humanitarianism are diverse, as the Court describes:

A wide range of actors including States Parties, local authorities, nongovernmental and community based organisations, as well as international organisations have been and continue to be instrumental in bringing about an increased awareness of victims' rights, as well as in enabling them to realise their rights. Wherever possible the Court seeks to identify a common approach and to coordinate with the above actors. ${ }^{88}$

A plurality of actors participate in implementing the Court's 'victim mandate' and, by extension, in disseminating its associated views about

${ }^{85}$ Weizman, The Least of All Possible Evils, 38.

${ }^{86}$ M. Foucault, Discipline and Punish: The Birth of the Prison (New York: Vintage Books, 1977), 22.

${ }^{87}$ Judith Butler, Precarious Life: The Powers of Mourning and Violence (London: Verso, 2004).

${ }^{88}$ ICC-ASP/11/38, 'Court's Revised Strategy in Relation to Victims', 5 November 2012, 4. 
the utility of routing restorative justice through retributive law. As this chapter has illustrated, these interventions are consequential: they produce expectations about what the field of international criminal law enables; expectations that are to be 'managed', according to official ICC documents, ${ }^{89}$ but which nonetheless may be experienced as a form of institutional indifference bordering on cruelty. Staff working for the VPRS section must explain that specific forms of suffering will not be compensated, as when an aspiring victim participant requests compensation for lost livestock in response to a query on the participation form. Some applicants for victim participation in the Ugandan situation have filed forms in 2006 and continue to await formal recognition. ${ }^{90}$ Others in the Kenyan situation must be informed by Court staff that their status has changed from case to situation victim, with an attendant loss of participatory rights.

These practices of participation and assistance, animated by humanitarian sentiments and seeking to carve out a space for restorative justice within a retributive legal framework, are themselves modes of governance. They classify conflict-affected populations; for example, into groups with participatory rights at the ICC and those who fall outside its jurisdiction, and those whose wounds are regarded as emblematic and those whose are not. The Court has recognised the perils of implementing victims' rights through the Rome Statute, arguing that it needs to exceed the Hippocratic imperative to 'do no harm' and address the conflict-affected individual as 'a rights-holder to whom the duty-bearer in this case, the Court, the TFV, and the Rome Statute system - owes an obligation it must fulfil'. ${ }^{91}$ Yet in spite of these aspirational sentiments, the Court is constrained by its innate identity as a legal institution, bound to perpetually reinscribe the categories and classifications that inform its very being. To overcome this requires a step beyond the positivism of the Rome Statute system towards a broader notion of equity and responsiveness to the communities who most directly experienced the suffering wrought through the crimes the Court seeks to adjudicate - a step that may not be possible within the juridical frame of the ICC.

89 A policy document on external relations includes among its goals 'managing expectations'; see ICC, 'Integrated Strategy for External Relations, Public Information and Outreach'.

${ }^{90}$ Interview of VPRS staff member, Kampala, 6 February 2014.

${ }^{91}$ ICC/ASP/11/38, 'Court's Revised strategy in relation to victims', 5 November 2012, 3. 


\section{Politics and legal pluralism}




\title{
All roads lead to Rome \\ Implementation and domestic politics in Kenya and Uganda
}

\author{
CHRISTIAN M. DE VOS
}

\section{Introduction}

The adoption of the International Criminal Court's (ICC) founding treaty, the Rome Statute, formally initiated the ratification process that brought the ICC into existence. Perhaps more significantly, it also inaugurated a far-ranging effort to embed the Statute in the domestic legal framework of states. As one legal scholar has ambitiously characterised it, the Statute was a 'quasi-legislative event that produced a criminal code for the world'. ${ }^{1}$ Conceived and led largely by the same global civil society network that had pressed for the Court's establishment, ${ }^{2}$ these campaigns for national implementation have been intimately linked to the principle of complementarity. The Coalition for the International Criminal Court (CICC) notes that, 'For the principle of complementarity to become truly effective, following ratification, States must also implement all of the crimes under the Rome Statute into domestic legislation.' ${ }^{3}$ Similarly, Amnesty International claims that a state that fails to enact national legislation 'would risk being considered unable and unwilling genuinely to investigate and prosecute crimes within the Court's jurisdiction'. ${ }^{4}$ By

Thanks to Abigail Baim-Lance, Erika Dailey, Sara Kendall, Carsten Stahn and Larissa van den Herik for their helpful comments in the writing of this chapter. The support of the Netherlands Organization for Scientific Research (NWO) for enabling the field research on which this chapter draws is also gratefully acknowledged.

${ }^{1}$ L. Nadya Sadat, The International Criminal Court and the Transformation of International Law: Justice for the New Millennium (Leiden: Martinus Nijhoff, 2002), 263.

2 See M. Glasius, The International Criminal Court: A Global Civil Society Achievement (Oxfordshire: Routledge, 2006).

3 See '< A Universal Court with Global Support > Ratification and Implementation', Coalition for the International Criminal Court webpage ('CICC webpage'), www.iccnow.org.

4 Amnesty International, 'The International Criminal Court: Checklist for Effective Implementation' (July 2000), 2. The 2010 'updated' version of the checklist reiterates 
connecting complementarity to implementation, the ICC, it is thought, will catalyse the development of a more robust national framework for prosecuting international crimes. ${ }^{5}$

This chapter undertakes a close examination of the Rome Statute's implementation in the domestic jurisdictions of Kenya and Uganda. ${ }^{6}$ Its contention is two-fold. First, implementation has become an increasingly sophisticated exercise in applying the Statute as a 'global script' to a diverse array of national contexts. ${ }^{7} \mathrm{NGOs,}$ advisors and legal consultants who offer counsel to states on how to reform their domestic legal and constitutional frameworks have each developed Rome Statute 'model laws' and implementation 'toolkits'. This growing 'transnational expert community ${ }^{8}$ has, in turn, engendered an increasingly strict interpretation of what complementarity purportedly requires: it reflects a desire for uniformity between the Statute and its application at the domestic level.

Second, the ICC itself did not catalyse the passage of national implementation legislation in Kenya or Uganda. Rather, implementation of the Statute in both countries was accelerated in order to 'perform' complementarity for predominantly international audiences. In Uganda, the country's role as host of the 2010 Review Conference of the Rome Statute ('ICC Review Conference') hastened a legislative process that had long stagnated, while, in Kenya, the desire to publicly demonstrate a departure from the election violence of 2007-2008 'fast-tracked' implementation of the Statute there. In Uganda, however, subsequent efforts to abandon the country's long-standing amnesty program have been met with strong opposition, signalling significant discomfort with the

this same claim. See Amnesty International, 'International Criminal Court: Updated Checklist for National Implementation' (May 2010) ('AI Updated Checklist').

5 See, e.g., J. Kleffner, 'The Impact of Complementarity on National Implementation of Substantive International Criminal Law', Journal of International Criminal Justice, 1 (2003), 86-113.

6 This chapter forms part of a broader project on whether or under what circumstances ICC interventions can, as its supporters have assumed, catalyse progressive change in postconflict countries' domestic institutions and legal frameworks. I focus here on Kenya and Uganda in light of their similar experiences and shared common-law tradition. While the conclusions advanced may be relevant in other contexts, I do not suggest that they are representative of all ICC interventions or post-conflict countries.

${ }^{7}$ My use of 'global script' borrows from Carruthers and Halliday's use of the term as a 'formalized expression or codification of global norms'. See B. Carruthers and T. Halliday, 'Negotiating Globalization: Global Scripts and Intermediation in the Construction of Asian Insolvency Regimes', Law \& Social Inquiry, 31(3) (2006), 535-536.

${ }^{8}$ M. Drumbl, Atrocity, Punishment, and International Law (New York: Cambridge University Press, 2007), 135. 
domestic ICC legislation's retributive framework. Similarly, in Kenya, the initiation of ICC investigations in 2009 fractured the apparent unanimity of the country's political class over the desirability of the domestic legislation it had ratified only one year prior, even as they united former political rivals Uhuru Kenyatta and William Ruto. ${ }^{9}$

The union of these two factors - uniformity of application and the power of external constituencies - was largely responsible for driving the implementation process in both countries, but it glossed over deeper political fissures about the desirability of international criminal law as a framework for domestic accountability. These political contestations were subordinated in the short term, but have never abated. Further, the focus on identical implementation of the Rome Statute at national level raises troubling questions about the African continent's equal and consensual participation in the creation of this body of law. Rather than focusing on implementation as a 'catalytic effect" ${ }^{10}$ in itself, then, this chapter queries the costs that 'a liberal orthodoxy about what international criminal law should be ${ }^{11}$ might pose to other normative ideals, such as legal pluralism or deliberative, democratic debate.

This chapter proceeds in four parts. It first briefly identifies the arguments that have animated why implementation of the Rome Statute's substantive and procedural provisions should be understood as a duty of ICC member states, even when, as a legal matter, it is not clear that such an obligation exists. The second section focuses on how international NGOs and the capacity-building sector - communities of practice with a shared interest in implementation - have drawn on these arguments in their promotion of implementation guidelines and 'model laws'. I suggest that these tools have contributed to a view of implementation as an increasingly disciplinary exercise, one that privileges conformity with the Rome Statute. Through process tracing, part three turns to the particular experiences of Uganda and Kenya to show how, in each country, it was not the ICC, but the mediated influence of external actors

9 On shifts in the Kenyan political order, see S. Kendall, "UhuRuto" and Other Leviathans: the International Criminal Court and the Kenyan Political Order', African Journal of Legal Studies, 7 (2014), 399-427.

10 See S. Nouwen, Complementarity in the Line of Fire: The Catalysing Effect of the International Criminal Court in Uganda and Sudan (New York: Cambridge University Press, 2013), 194.

${ }^{11}$ F. Mégret, 'Too Much of a Good Thing?: Implementation and the Uses of Complementarity', in C. Stahn and M. El Zeidy (eds.), The International Criminal Court and Complementarity: From Theory to Practice (New York: Cambridge University Press, 2011), 386. 
and events that pushed the implementation process forward. However, as the fourth section illustrates, key political questions that were overlooked in this process soon re-emerged. Based on these histories, the chapter concludes by focusing on three dimensions of implementation: as purity, as politics, and as a form of political theatre.

\section{A duty to implement?}

The incorporation of treaty protections is one form that the legal protection of human rights may take at the domestic level. Implementation thus reinforces not only the primacy of states in international law but also a general rule: states, in general, have far-going freedom as to the manner in which they give effect to their international obligations. As Ward Ferdinandusse argues, however, the extent of this freedom can be 'easily overestimate[d]', particularly in the context of international criminal law. ${ }^{12}$ Many scholars have argued that the special character of international humanitarian law distinguishes it from other crimes, thus requiring greater fidelity to the manner of its implementation at the national level. Similar arguments point to the uniquely expressivist function of international criminal law as requiring its identical enunciation in national law. ${ }^{13}$

The Rome Statute has become a growing site of contestation over the duty and scope of states to implement its provisions in their own domestic legal orders. Many commentators root a duty to implement in a purposive reading of the Rome Statute, particularly its preambular language, which recalls 'that it is the duty of every State to exercise its criminal jurisdiction over those responsible for international crimes'. ${ }^{14}$ For example, David Donat Cattin, secretary-general of the influential Parliamentarians for Global Action (PGA), argues that the principle of complementarity 'implies that States shall fully implement the Rome Statute in their domestic legal orders in order to comply with their primary responsibility to realize the object and purpose of the treaty (and [Rome Statute] system)', which is 'to put an end to the impunity of the [individual] perpetrators of the most serious crimes of concern to the international community as a whole and to contribute to the prevention of such crimes. ${ }^{15}$

12 W. Ferdinandusse, Direct Application of International Criminal Law in National Courts (The Hague: T. M. C. Asser Press, 2006), 148.

13 See, e.g., Drumbl, Atrocity, Punishment, and International Law, 173-179.

${ }_{14}$ Preamble, Rome Statute.

15 D. Cattin, 'Approximation or Harmonisation as a Result of Implementation of the Rome Statute', in L. van den Herik and C. Stahn (eds.), The Diversification and Fragmentation of 
Yet the text of the Statute requires only that a country's domestic law facilitate cooperation with the ICC and that it criminalise offences against the 'administration of justice'. ${ }^{16}$ There is no obligation as such to implement its substantive (or procedural) provisions. As Alain Pellet notes, 'neither the signatory States nor even the States Parties have any clear obligations to bring their domestic legislation into harmony with the basic provisions of the Rome Statute. ${ }^{17}$ Furthermore, as a matter of treaty interpretation, the preambular recital is not part of the Statute's operative text; rather, it merely 'recalls' a suggested pre-existing duty, not one arising from the treaty itself. ${ }^{18}$ Thus, while states may be obliged to investigate or prosecute crimes based on other rules of international law, it would appear, as Sarah Nouwen has argued, that the recital 'merely reflects an aspiration, just like many of the other preambular considerations'. ${ }^{19}$

The difference between 'ordinary' and international crimes has also been advanced as a basis for domestic implementation. In the context of the ICC, the academic Jann Kleffner has been one of the strongest proponents of this position. He argues that, 'Implementation can only be considered satisfactory if it comprehensively and effectively covers the entire range of conduct criminalized by the Rome Statute, without adversely affecting preexisting obligations under international law that go beyond the Rome Statute, and while taking into account the need to fill gaps in the legislation that may lead to impunity, such as those resulting from the absence of universal jurisdiction. ${ }^{20}$ ICC actors have endorsed Kleffner's view. Sylvana Arbia, the ICC's former registrar, writes that, 'Without [implementing legislation], states could be left in the position of prosecuting only for some of the constitutive acts of the crimes, such as murder and rape. This could undermine the basis of national prosecutions, and may invite the ICC's Judges to take jurisdiction where this might not be needed. ${ }^{21}$

International Criminal Law (Leiden: Martinus Nijhoff, 2012), 361-362 (quoting combined paras. 4 and 5 of Rome Statute Preamble).

${ }_{16}$ Article 88, Rome Statute.

17 A. Pellet, 'Entry Into Force and Amendment of the Statute', in A. Cassese, P. Gaeta, and J. Jones (eds.), The Rome Statute of the International Criminal Court: A Commentary, Vol. 1 (Oxford: Oxford University Press, 2002), 153.

18 D. Robinson, 'The Mysterious Mysteriousness of Complementarity', Criminal Law Forum, 21(1) (2010), 94-95.

${ }^{19}$ Nouwen, Complementarity in the Line of Fire, 39.

${ }^{20}$ J. Kleffner, Complementarity in the Rome Statute and National Criminal Jurisdictions (New York: Oxford University Press, 2008), 112.

21 S. Arbia and G. Bassy, 'Proactive Complementarity: A Registrar's Perspective and Plans', in C. Stahn and M. El Zeidy (eds.), The International Criminal Court and Complementarity: From Theory to Practice (New York: Cambridge University Press, 2011), 65. 
Distinguishing between ordinary and international crimes was critical to the criminal tribunals for Rwanda and the former Yugoslavia, both of which, unlike the ICC, enjoy primacy over national jurisdictions. ${ }^{22}$ The Rome Statute, however, makes no such distinction: states are permitted to prosecute international crimes as ordinary crimes, provided that their doing so is not deliberately designed to shield perpetrators from criminal responsibility. Indeed, during the drafting of Article 20(3) on ne bis in idem (the principle that a person should not be prosecuted more than once for the same criminal conduct), states explicitly rejected a proposal that would have made a case admissible before the ICC where the national proceeding failed to consider the international character or grave nature of a crime. ${ }^{23}$ For this reason, the Statute instead refers to the 'same conduct' of an accused, 'to make clear that a national prosecution of a crime - international or ordinary - did not prohibit ICC retrial for charges based on different conduct'. ${ }^{24}$ Article 93(10) further supports this interpretation, as it refers to the Court providing assistance to a state party 'conducting an investigation into or trial in respect of conduct which constitutes a crime within the jurisdiction of the Court or which constitutes a serious crimes under the national law of the requesting State. ${ }^{25}$

Finally, implementation discourse reflects anxieties about fragmentation in international law more generally. ${ }^{26}$ As Carsten Stahn and Larissa van den Herik note, 'One of the inherent features of international criminal law is a desire for uniformity', which 'flows from the need for "certainty, stability and predictability" [that] is required in criminal

22 Both of the ICTY and ICTR statutes explicitly allow for the retrial of persons who had already been tried by a national court if 'the act for which he or she was tried was characterized by an ordinary crime'. See Prosecutor v. Michel Bagaragaza, Decision on the Prosecution Motion for Referral to the Kingdom of Norway, Rule 11 bis of the Rules of Procedure and Evidence, ICTR-05-86, Trial Chamber III, ICTR, 19 May 2006.

${ }^{23}$ Article 20(3), Rome Statute. As Jo Stigen notes, the 'ordinary crime' criterion, initially endorsed by the [ILC], 'was proposed but rejected [in the negotiations] as it met too much resistance'. J. Stigen, The Relationship between the International Criminal Court and National Jurisdictions: The Principle of Complementarity (Leiden: Martinus Nijhoff, 2008), 335.

${ }^{24}$ K. Heller, 'A Sentence-Based Theory of Complementarity', Harvard International Law Journal, 53(1) (2012), 224. For a similar conclusion, see Nouwen, Complementarity in the Line of Fire, 50.

25 Article 93(10), Rome Statute (emphasis added).

${ }^{26}$ See Conclusions of the Work of the Study Group on the Fragmentation of International Law, 'Difficulties arising from the Diversification and Expansion of International Law', UN Doc. A/61/10 (2006). 
proceedings ${ }^{27}$ A related concept is that the Statute establishes a common criminal floor. Cattin, for instance, sees the Statute as posing a 'minimum standard for national criminal justice systems exercising their primary responsibility: States can do more, but shall do no less, than what the Rome Statute prescribes, so as to ensure that all crimes against humanity, war crimes and acts of genocide be duly incorporated in the relevant legal order and not left unpunished. ${ }^{28}$ The fact that international criminal law enforcement is increasingly migrating from international tribunals to national courts makes the idea of minimum standards (often referred to as 'international standards') particularly attractive when the 'landscape of domestic justice is diverse and partly schizophrenic'. ${ }^{29}$ To that end, 'the play between ... unity and diversity, is one of the discursive patterns used by the [legal] discipline to deploy criticism and propose reform projects'. ${ }^{30}$ Faithful domestication of the Rome Statute, as the following section details, is one such project.

\section{Implementation and standardisation}

While implementation is itself a political process - an act of state - human rights NGOs, particularly international ones, have played a significant role in influencing debates about what domestication of the Rome Statute requires. ${ }^{31}$ Many of these organisations maintain offices in ICC situation countries, creating a vital, vertical network between those sites where international criminal law is produced - The Hague, Brussels, Geneva, New York - and enacted. There now exists an array of implementation materials prepared by these organisations. As early as 2000, Amnesty International created a 'Checklist for Effective Implementation', while Human Rights Watch and the International Centre for Criminal Law

27 C. Stahn and L. van dan Herik, "Fragmentation", Diversification and "3D" Legal Pluralism: International Criminal Law and the Jack-in-the-Box?', in L. van den Herik and C. Stahn (eds.), The Diversification and Fragmentation of International Criminal Law (Leiden: Martinus Nijhoff, 2012), 58 (citing Prosecutor v. Aleksovski, Judgment, IT-9514/1-A, The Appeals Chamber, ICTY, 24 March 2003, para. 101).

${ }^{28}$ Cattin, 'Approximation or Harmonisation as a Result of Implementation of the Rome Statute', 373

29 Stahn and van dan Herik, "Fragmentation", Diversification and "3D" Legal Pluralism', 39.

30 A.C. Martineau, 'The Rhetoric of Fragmentation: Fear and Faith in International Law', Leiden Journal of International Law, 22(1) (2009), 2-3.

31 The CICC is one international NGO that has made implementation a centrepiece of its work; however, others like Amnesty International, Avocats Sans Frontiers, the International Federation for Human Rights (FIDH), No Peace Without Justice, PGA, and Human Rights Watch have all been similarly engaged. 
Reform published similar manuals shortly thereafter. ${ }^{32}$ As part of its 'Global Advocacy Campaign for the International Criminal Court', the CICC maintains a detailed, on-going chart of those states that have either enacted, or are in the process of enacting, 'Rome Statute Crimes Legislation' and/or 'Cooperation Legislation'. ${ }^{33}$ The coalition also includes a resource page with links to 'model' national implementation laws, as well as 'template statutes' endorsed by various regional organisations like the Commonwealth Secretariat. ${ }^{34}$

The Commonwealth's Model Law - of particular relevance to Kenya and Uganda - is a 58-page document with prepared language that closely tracks the text of the Rome Statute. While noting that, 'there is no "onesize-fits-all" solution to the complex process of domestic implementation', the Law presents itself as 'model legislation (i.e. a textual basis to be modified and adapted to a given national system)'. ${ }^{35}$ Interested states are invited to insert the name of their country at relevant points throughout the document, and to include select optional additional provisions, ranging from the appropriate penalties for crimes ('imprisonment for a term not exceeding 30 years or a term of life imprisonment when justified by the extreme gravity of the crime') to extending the law's coverage to violations of the Geneva Conventions. ${ }^{36}$

Various 'best practice' tools for implementation supplement such material. One such tool is the National Implementing Legislation Database (NILD). NILD seeks to provide users with 'access to a fullysearchable, relational database of national implementing legislation'. ${ }^{37}$

32 AI Updated Checklist; Human Rights Watch, 'Making the International Criminal Court Work: A Handbook for Implementing the Rome Statute' (September 2001) ('HRW Handbook'); ICCLR, 'International Criminal Court: Checklist of Implementation Considerations and Examples Relating to the Rome Statute and the Rules of Procedure \& Evidence' (April 2002).

33 See CICC webpage.

34 The Secretariat describes itself as 'provid[ing] guidance on policy making, technical assistance and advisory services to Commonwealth member countries'. For further information, see http://thecommonwealth.org/organisation/commonwealth-secretariat.

35 Commonwealth Secretariat, 'Cover Note: International Criminal Court (ICC) Statute and Implementation of the Geneva Conventions', SOLM(11)10, May 2011, para. 3(a).

${ }^{36}$ Ibid., Annex B, Model Law to Implement the Rome Statute of the International Criminal Court. See, e.g., Part II ('International Crimes and Offences Against the Administration of Justice').

37 National Implementing Legislation Database of the International Criminal Court Statute ('NILD Database'), www.nottingham.ac.uk/hrlc/documents/projectsummaries/pdfs/ projectnild.pdf. The legal academic Olympia Bekou, who has also contributed an extensive literature on complementarity and implementation, manages NILD. See, e.g., O. Bekou and S. Shah, 'Realising the Potential of the International Criminal Court: The 
Part of the ICC's Legal Tools project, ${ }^{38}$ NILD describes itself as 'an invaluable tool for national legislators who have not yet adopted, but are considering or drafting implementing legislation, enhancing their capability to draft effective legislation drawing upon previous experience of fellow State Parties' ${ }^{39}$ NILD further allows states that have adopted legislation to 'monitor the impact of their legislation on other States and undertake necessary amendments if the content of the Rome Statute changes, or if improvements are deemed necessary. ${ }^{40}$ One publication highlights not only NILD but also other Legal Tools projects as well Case Matrix, a Means of Proof Digest - as examples of access to legal information. It notes that such access 'should be provided in line with this new paradigm shift towards positive complementarity that focuses on strengthening domestic capacity and empowering national actors'. ${ }^{41}$

These tools accompany the literature of NGOs, which endorses a similarly maximalist approach to implementation. According to Amnesty's implementation checklist, 'principles of criminal responsibility in national legislation should be at least as strict as ... the Rome Statute'. ${ }^{42}$ This includes, for instance, that 'all crimes of accessory criminal responsibility such as aiding, abetting, and direct and public incitement as contained in Article 25 [of the Statute] should be punishable under national law, ${ }^{43}$ Conformity with the Statute has also been presented as encompassing far-reaching procedural requirements: Human Rights Watch notes that states 'should guarantee the highest international standards for fair trials at the national level', as 'these rights will ... be important in the determination of the admissibility of a case by the ICC ${ }^{44}$ Such standards would include not only programs of victim and witness protection but even procedural regimes unique to the Rome Statute, such as a trust fund for victims or provisions for victim participation. A related issue is punishment: effective implementation, it is strongly suggested, would be inconsistent with the death penalty. ${ }^{45}$

African Experience', Human Rights Law Review 6(3) (2006); O. Bekou, 'Crimes at Crossroads: Incorporating International Crimes at the National Level', Journal of International Criminal Justice 10(3) (2012).

${ }^{38}$ See 'ICC Legal Tools', www.legal-tools.org/en/go-to-database/. $\quad{ }^{39}$ NILD Database.

40 Ibid.

${ }^{41}$ M. Bergsmo (ed.), Active Complementarity: Legal Information Transfer (Torkel Opsahl Academic EPublisher, 2011), vi.

42 AI Updated Checklist, 17. ${ }^{43}$ Ibid. ${ }^{44}$ HRW Handbook, 19.

45 In Amnesty's words, 'it would be inappropriate for national courts to impose a more severe penalty for a crime under international law than the one chosen by the international community itself. AI Updated Checklist. 
These documents illustrate that even where commentators and NGOs acknowledge that the Rome Statute contains no positive obligations to implement its substantive (or procedural) law provisions, the principle of complementarity is presented in a manner that nevertheless compels it. As a technique of governance, the approach to implementation is thus increasingly disciplinary: failure to abide by the purported requirements of the Rome Statute opens states up to the risk that the ICC will intervene. This view has been furthered by much academic commentary on implementation (noted above), which overwhelmingly focuses on fidelity to the Rome Statute's text. ${ }^{46}$ Thus, just as the coercive pull of complementarity - welcomed by those who see its outcome as salutary - could encourage national proceedings, it might also induce national courts ... to conform to a variety of modalities that mimic those found in international criminal law regarding sanction (i.e., no death penalty) and procedure (i.e., a fair trial)'. ${ }^{47}$ The proliferation of 'model laws' abets this process. Indeed, as will be seen, the Kenyan and Ugandan ICC laws are themselves largely identical, insofar as they are both drawn from the Commonwealth Secretariat's model legislation.

\section{Implementation in practice: Uganda and Kenya}

Uganda: the ICC's host state

Like many treaties that Uganda has signed but not domesticated, Nouwen argues that the government ratified the Rome Statute in June 2002 because it was 'internationally fashionable and improved the [government's] image in the eyes of European donors'. ${ }^{48}$ The adoption of implementing legislation at the time appeared 'bleak', however, as it was not seen as a priority for either the executive or the legislature. Nevertheless, as a result of the attention increasingly paid to the government's conflict with the Lord's Resistance Army (LRA), and following

${ }^{46}$ As an example, see the articles gathered in the 'Symposium on National Implementation of the ICC Statute', which appeared in two parts in the Journal of International Criminal Justice, 2(1), March 2004 and 5(2), May 2007. In the second installment, editor Luisa Vierucci notes that, 'states tend to stick to the definition of the crimes as contained in the ICC Statute' and that this 'seems ... to be a response to the states' inherent concern to avoid the risk of possibly adverse decisions on complementarity by the ICC'. L. Vierucci, 'National Implementation of the ICC Statute (Part II): Foreword', Journal of International Criminal Justice, 5(2) (2007), 419-420.

47 Drumbl, Atrocity, Punishment, and International Law, 139.

48 Nouwen, Complementarity in the Line of Fire, 194. 
President Museveni's referral of that situation to the ICC in 2003 (making it the first country to come under the Court's jurisdiction), international human rights organisations and their national-level partners prioritised implementation of the Statute there.

After receiving authorisation to prepare a draft implementation bill, Uganda's Ministry of Justice and Constitutional Affairs assembled a first draft in 2004. It used Canada's and New Zealand's ICC legislation as examples, and the Commonwealth Secretariat reportedly provided 'technical support' and 'drafting assistance'. ${ }^{49}$ Groups like PGA also 'conducted seminars and workshops on the Rome Statute for MPs, and facilitated relevant contacts for them with others, including the European Union, the ICC and local civil society'. ${ }^{50}$ Yet political developments on the ground soon stalled any desire to press for the ICC Bill's passage. After the ICC's warrants for the LRA's leaders were unsealed in mid-2005, the legislation was seen, much like the Court itself, as a hindrance to the advancement of peace negotiations. As explained in a letter by the Uganda Coalition for the International Criminal Court (UCICC) for its 'Domestication Campaign 2008', the bill had 'been proposed and has lapsed in Parliament before because too many legislators feared that adopting these laws means that the ICC would take jurisdiction away from Uganda and potentially interrupt the peace process' ${ }^{51}$ Preparations for multi-party elections in 2006, along with 'backlogs in Parliament', ${ }^{52}$ further delayed consideration of the bill and it ultimately lapsed with the prorogation of parliament.

A substantially similar version of the bill was reintroduced in late $2006 .{ }^{53}$ The executive, however, 'prioritised commercial laws for debate' and commentators have noted that parliament was instructed to 'go slow' with the legislation because its passage was still 'thought to send the wrong message in relation to the ongoing Juba talks'. ${ }^{54}$ As the then

49 International Criminal Court Bill, XCVII(26), Uganda Gazette, 28 May 2004; e-mail communication from Ministry of Justice, Uganda (on-file).

50 Putting Complementarity Into Practice, Open Society Foundations (2010), 61-62. See also remarks of Mr Wacha in The Eighth Parliament of Uganda, Third Reading, The International Criminal Court Bill, 2006, 10 March 2010, 10950 ('ICC Bill Third Reading').

${ }^{51}$ UCICC, Domestic Campaign 2008, 10 July 2008 (letter on-file).

52 B. Afako, 'Country Study V: Uganda', in M. du Plessis and J. Ford (eds.), Unable or Unwilling? Case Studies on Domestic Implementation of the ICC Statute in Selected Africa Countries (ISS Monograph Series, 2008), 94.

53 International Criminal Court Bill, XCVIX(67), Uganda Gazette, 17 November 2006.

${ }^{54}$ Nouwen, Complementarity in the Line of Fire, 197. Ugandan jurist Barney Afako also describes the 'prospects of Uganda implementing a suitable national scheme in the next 
deputy attorney general Freddie Ruhindi testified during parliamentary debate over what would become the 2010 act:

[T] he long time taken on deliberating on this matter was not by accident. Interestingly, we are not even recalling that the first one was a 2004 Bill, which lapsed with the Seventh Parliament. Then we came out with the Seventh Parliament. Then we came out with the 2006 Bill and at one point, you may recall that we were in very serious negotiations with the Kony group and everyone of us was actually quite reluctant to disturb that process by coming on the Floor of the House and at the end of the day derailing the process. But as we speak, that has gone bad and there is nothing to stop us from going ahead with the enactment of this law in full swing. ${ }^{55}$

Thus, whereas there were a variety of competing and superior interests during the previous six years that implementation of legislation was pending, this calculus had shifted by 2010. Peace negotiations were no longer a confounding variable, while the imminent arrival of delegates from around the world to Kampala for the first-ever 'Review Conference of the Rome Statute' provided the necessary push for adoption. ${ }^{56}$

The significance of Uganda's hosting the conference is evident from public documents. During the bill's second reading, Ruhindi noted that, 'on the sidelines of the substantive debate on this Bill, Uganda is privileged ... [to] be hosting the first ever review conference'. ${ }^{57}$ In its annual report, the Justice Law and Order Sector (JLOS) - a government mechanism operating a 'sector-wide approach' to donor-driven judicial reform stated that, 'one of the conditions that was set by the ICC to allow [Uganda] to host the conference was domestication of the Rome Statute. ${ }^{58}$ Mirjam Blaak, Uganda's ambassador to The Hague, confirms

two years ... as "low" (on a scale of 'unlikely - low - fair - good - highly likely')'. See B. Afako, Country Study V: Uganda.

55 The Eighth Parliament of Uganda, Second Reading, The International Criminal Court Bill, 2004, 10 March 2010, 10941 (Mr F. Ruhindi) ('ICC Bill Second Reading'). Notably, although the title of the second reading is 'The International Criminal Court Bill, 2004', the MPs clarified that 'the committee chairman [was] reading a report entitled, "The International Criminal Court Bill 2006"'. Ibid., 10932 (remarks of Mr Kawuma).

56 Nouwen, Complementarity in the Line of Fire, 198; see also C. Mbazira, 'Prosecuting International Crimes Committed by the Lord's Resistance Army in Uganda', in C. Murungu and J. Biegon (eds.), Prosecuting International Crimes in Africa (Cape Town: Pretoria University Law Press, 2011). Mbazira argues, 'It appears that the hasty passing of the overdue Bill was catalyzed by Uganda's hosting of the ICC Review Conference from 31 May to 1 June 2010', 215.

57 ICC Bill Second Reading, 10931.

58 'JLOS Annual Performance Report 2009/2010' (September 2010), 65. 
this view: in her words, 'It was important to have the bill signed before the review conference took place. They wouldn't have cancelled the review conference if it hadn't been, but it was an understanding that we would. ${ }^{59}$

In the end, the act as passed in 2010 was nearly identical to the version that was put forward almost six years before ${ }^{60}$ Substantively, the ICC Act proscribes war crimes, genocide and crimes against humanity in a manner identical to the Rome Statute; the latter's definitions were incorporated by reference into the act, as were the modes of responsibility and the Statute's 'general principles of criminal law'. ${ }^{61}$ This mirror imaging belied the concerns of some parliamentarians, however, who in an otherwise non-contentious debate raised questions about the scope of the Rome Statute's protection and whether Uganda was entitled to amend it. Geofrey Ekanya, an MP from Tororo County, asked:

I want to find out from the Attorney-General and the committee chairperson, what harm would it cause to expand the definition of the Bill as regards the crimes against humanity, to include plunder. As we speak now, the international community has been facilitating some countries to plunder natural resources in Africa and I think this should be part of the crimes against humanity. I am talking about DRC, for example; I am talking about the conflicts we had in other parts of Africa. The guns come from the West to facilitate conflicts; to plunder Africa and then they take the minerals; but the Bill does not talk about those who facilitate plundering because this is what leads to conflict and finally crimes against humanity. So, would it be wrong for us to expand the definition of crimes against humanity to include the agents who facilitate plunder? ${ }^{62}$

Ekanya also expressed concern that 'certain provisions within the Rome Statute' - particularly concerning presidential immunity - were 'not in

59 B. Oketch, 'Uganda Set for First War Crime Trial', Institute for War \& Peace Reporting, 14 July 2010.

60 See, e.g., ICC Bill Third Reading, 10950 (remarks of Mr Wacha). Mr Wacha notes that, 'the two Bills: the 2004 Bill and this particular Bill were not any different, they were the same'.

${ }^{61}$ International Criminal Court Act, 2010, Uganda Gazette No. 39, Vol. 103, 25 June 2010, sections 7-9; 19. Those amendments that were made focused on minor procedural issues. For instance, the act states that consent for prosecution under the ICA would be required from the Department of Public Prosecutions, rather than the attorney general. Further, jurisdiction was to vest with the Ugandan High Court, not the Magistrate Court. See Report of the Sessional Committee on Legal and Parliamentary Affairs on the International Criminal Court Bill, 2006 ('Sessional Committee Report'), March 2010, $4-5$.

${ }^{62}$ ICC Bill, Second Reading, 10935. 
consonance' with Ugandan law, and urged that these questions be 'taken care of so that we and innocent people are not used as guinea pigs'. ${ }^{63}$ Other MPs raised similar concerns: John Kawanga agreed that, 'at another stage we shall have to deal with commercial crime, corruption and things of the kind', while Alice Alaso asked what passage of the law would 'mean with our amnesty law', whether it would 'put the final nail on the peace process', and 'the place of traditional justice vis-à-vis the ICC Bill'. ${ }^{64}$

The interventions of these MPs raised questions about the place of the ICC Act within Uganda's broader transitional justice architecture, as well as the state's ability to tailor the Statute to suit its particular national context. In reply to Ekanya's concerns, MP Stephen Tashobya, who chaired the Committee on Legal and Parliamentary Affairs, replied (incorrectly) that 'you may not actually go beyond what [the Rome Statute] says and, therefore, you have to confine yourself to its text. ${ }^{65}$ Furthermore, as Ms Alaso's comments indicate, the bill as passed offered no provisions on alternative criminal justice proceedings, nor did it address the role of Uganda's Amnesty Committee, which had been issuing amnesties to former combatants, including those from the LRA, for the past 10 years. ${ }^{66}$ Indeed, whereas the 2004 version of the ICC Bill included a proposed amendment by MP Jacob Oulanyah that would have recognised 'alternative criminal justice proceedings' in addition to 'formal' criminal proceedings, ${ }^{67}$ no such proposals were later considered or debated. This suggests that, by 2010, an increasingly Hague-centric framework for punishment had taken hold, hastened by a perceived

63 Ibid., 10936.

64 Ibid., 10938-30 (remarks of Messrs Kawanga and Kyanjo); see also 10934 (remarks of Ms Alaso).

65 Ibid., 10936. MP Tashobya added, 'But as to whether we can amend the Rome Statute, I do not know. You are intending to expand and that will be an amendment of the Rome Statute.'

66 In January 2000, Uganda adopted an Amnesty Act that provided amnesty for anyone who had engaged in armed rebellion against the government since the '26th day of January 1986 ' and who agreed to renounce and abandon such rebellion. The conditions for amnesty were broadly conceived, with the declaration that 'amnesty means a pardon, forgiveness, exemption or discharge from criminal prosecution or any other form of punishment by the State'. See Amnesty Act, 2000.

67 J. Oulanyah, 'Proposed new Part to ICC Bill; Part X - Alternate Proceedings', 12 December 2004 (proposed amendments on file). Oulanyah's proposal suggested a possible truth commission model, not unlike that adopted in South Africa. The 'alternative proceedings' would, for instance, 'provide a system of individual accountability', including 'public and open hearings', 'participation of victims and affected persons', 'full disclosure of all relevant facts', a 'written determination of the case', and 'sanctions'. 
need to pass the legislation prior to the start of the ICC Review Conference.

A similar mindset informed the influential network of Ugandan justice sector donors. Stephen Oola notes, for example, that an initial agreement by JLOS to present to parliament in 2009 the ICC Bill together with a proposed National Reconciliation Bill - in order to generate a 'comprehensive national discussion on Uganda's justice needs' - was scuttled when donor governments made it clear that they wanted the ICC Bill fast-tracked. ${ }^{68}$ As a result, Oola argues that 'the ICC Act was rushed through Parliament with little consultation and without much-needed acknowledgment of the domestic legal reality, given the existence of the Amnesty Act. ${ }^{69}$

\section{Kenya: 'becoming a global village'?}

As in Uganda, international pressure was a key dynamic that drove the passage of Kenya's domestic implementing legislation. Following the election of President Mwai Kibaki in 2002, the government ratified (as an executive act) the Rome Statute in 2005. Little is known about the administration's intentions in choosing to do so other than that, in the wake of an ostensibly reformist political moment, ratification of the Statute was seen as a positive step by the new administration. One prominent Kenyan activist described the ratification as 'one of those things you do to look good', ${ }^{70}$ while Yvonne Dutton's analysis suggests that Kenya's classification as a democracy in the post-Kibaki era played a role in the government's decision to join the Court. ${ }^{71}$ International NGOs also seized on the moment. The CICC, for instance, chose Kenya as a target country on which to focus its efforts, noting that ratification would send an 'important signal to other African states who have yet to ratify about Africa's growing commitment to international justice and the rule of law. ${ }^{72}$

68 The bill proposed, in part, the establishment of a National Truth and Reconciliation Commission to 'facilitate the process of reconciliation within the country and to investigate the circumstances under which the gross violations and abuses of human rights were committed, including their motives, perpetrators and victims and to disclose the truth with respect to the violations in order to prevent a repeat of the violation or abuses in future'. National Reconciliation Bill, draft of 10 June 2011 (copy on file).

69 See further Chapter 6 by Oola in this volume.

${ }_{70}$ Personal interview conducted in Nairobi, Kenya, 30 November 2012.

${ }^{71}$ See Y. Dutton, Rules, Politics, and the International Criminal Court: Committing to the Court (Oxon: Routledge, 2013).

72 CICC, 'Global Coalition Calls on Kenya to Ratify International Criminal Court' (11 January 2005). 
At the time, Kenya did not have any laws in place that would have enabled it to prosecute international crimes as such. Neither the Kenyan Penal Code (KPC) nor the Armed Forces Act, which governs the Kenyan military, contained any such provisions, nor had a Kenyan court ever dealt with crimes against humanity, war crimes and genocide. ${ }^{73}$ Following ratification, then, the Kenyan National Commission on Human Rights began drafting a bill that sought to implement provisions of the Statute domestically. At the time, however, the country was also undergoing its constitutional review process, with a referendum set for November 2005. As a result, the draft International Crimes Bill was temporarily shelved. It went through an initial reading in parliament in June 2006 but, before it could proceed further, the 2007 elections had arrived.

In the wake of the electoral violence, a process that might have otherwise proceeded as a quiet, internal manner was quickly internationalised. Following its hearings, a key recommendation of the Commission of Inquiry on Post-Election Violence (known also as the 'Waki Commission') was that implementation of the Rome Statute be 'fast-tracked for enactment by Parliament to facilitate investigation and prosecution of crimes against humanity'. ${ }^{74}$ Likewise, as Antonina Okuta notes, the commission's recommendation that a special local tribunal be created to try the alleged perpetrators brought 'into sharp focus the country's national legislation as well as its capacity to handle the investigation and prosecution of international crimes'. ${ }^{75}$

As in Uganda, the Commonwealth Secretariat played an influential role in the drafting process. At the bill's second reading in May 2008, Kenya's then attorney general Amos Wako stated that the government had been 'well guided' by the United Nations and the Commonwealth Secretariat, which had 'developed model legislation to guide the countries'. ${ }^{76}$ He continued:

73 A. Okuta, 'National Legislation for Prosecution of International Crimes in Kenya', Journal of International Criminal Justice, 7 (2009), 1063. The one exception was Kenya's Geneva Conventions Act, which, like Uganda, incorporated into Kenyan law the 'grave breaches' provisions of the Geneva Conventions. This act would not have been applicable for Kenya's post-2007 election violence, however, as it did not occur in the context of an international conflict.

${ }^{74}$ Report of the Commission of Inquiry into Post-Election Violence (2008), 476.

75 A. Okuta, 'National Legislation for Prosecution of International Crimes in Kenya', 1065.

${ }^{76}$ Kenya National Assembly Official Record (Hansard), The International Crimes Bill, Second Reading, 7 May 2008, 907 ('ICA Second Reading'). 
Mr. Speaker, Sir, we talk about the world being a global village. It is, indeed, becoming a global village, whether it is from the perspective of communications; that is telephones, mobile phones, television and so on, but for institutions such as the national State and so on. Also, from the point of view of issues relating to law and order, there can be no state as such which does not have a criminal justice system. Therefore, to the extent that the international community is developing an international criminal justice system, we are indeed and truly becoming a global village. $^{77}$

Reflecting the perception that states are legally bound to implement the Statute, Wako added in his remarks that, '[B]y the mere fact we have ratified this Rome Treaty, we are, as a State, under an obligation to domesticate the Treaty, so that it has a force of law in Kenya., ${ }^{, 8}$

Remarkably, the parliamentary debate on the International Crimes Act (ICA) records no opposition to its passage. The attorney general's proposal was supported by MP Martha Karua, then minister for Justice, National Cohesion and Constitutional Affairs, as well as MP Danson Mungatana, who '[took] the opportunity to thank the Attorney-General for, once again, rising to the occasion and bringing our country's laws in line with the international community, especially in criminal jurisprudence'. ${ }^{79}$ MP Farah Maalim, a leading figure in the Orange Democratic Movement and himself a member of PGA, made the most extensive remarks on the bill, supporting its passage but expressing scepticism about the limitations of international criminal law. In particular, Maalim endorsed the 'need to redefine ... the definition of the UN of what genocide is', calling for it to encompass 'cultural' and 'economic' genocide. ${ }^{80}$ In his words:

It is easier for the West to arm, facilitate and finance the warlords, while they take away the timber from the Congo Forest. All these raw materials end up in the West. The money [that] is stolen from the continent often ends up in Switzerland, American and European banks. ... Economic genocide should have been included in the Statute more than anything else. The permanent impoverishment of the black man, the slavery and the colonization that we suffered is still what keeps us where we are. There has been no compensation and responsibility for what happened. The context of the Statute tells us how little the black continent participated in the formulation of this Statute. ${ }^{81}$

77 Ibid., 906. ${ }^{78}$ Ibid., $907 .{ }^{79}$ Ibid., $913 . \quad{ }^{80}$ Ibid., 917.

${ }^{81} \mathrm{Ibid}$., 918. In response to MP Maalim, the attorney general replied: 'Sir, a lot was spoken about economic genocide. This Bill is not concerned with what one may call 'economic genocide'. Important as it is, it is only concerned with criminal genocide,' 927 
Maalim further lamented the absence of Kiswahili 'as one of the languages of the ICC'. He opined: 'I have seen that they have included Russian, Spanish, Arabic, English and Chinese. There are more speakers of Kiswahili than Russian. Our own Governments, and the continental body, would have been done a lot of pride if we also had Kiswahili as one of the languages in the ICC. ${ }^{82}$

Despite MP Maalim's remarks, the ICA, as a model for the Ugandan legislation that followed, imports directly almost all provisions of the Rome Statute. It refers entirely to the Statute's definition of international crimes, ${ }^{83}$ while provisions on command responsibility, statutes of limitation and superior orders are likewise directly imported. ${ }^{84}$ Similarly, the act provides that the maximum penalty for Rome Statute crimes is life imprisonment, even though the penal code maintains the death penalty for ordinary crimes such as murder, armed robbery and treason. ${ }^{85}$

The ICA was tabled and passed with remarkable speed, coming into operation on 1 January 2009. As in Uganda, it is one of the few international treaties to be domesticated into Kenya's national law. Standing in support, MP Ekwee Ethuro took note of the ICA's rapid passage:

I am aware of many of the international protocols and statutes that have been consented to by the Government, that have not seen the Floor of this House. That is not the proper way to do it. I want to believe the business of knee-jack reaction-Maybe the greatest motivation of the International Crimes Bill to even see the walls of this House, is a consideration of what we have gone through in terms of the Waki Report. ... All the protocols and any other international protocols that the Government of Kenya has committed itself to should be domesticated. ${ }^{86}$

${ }^{82}$ Ibid., 917.

83 The International Crimes Act, 2008 ('ICA 2008'), Art. 6(4). One significant difference between Kenya's ICA and the Rome Statute is its provisions on immunity. Rather than incorporate Article 27 of the Rome Statute, which makes official capacity irrelevant to immunity, the ICA's Section 27 only provides that the official capacity of a person shall not be used as a reason to refuse a request for the surrender of that person to the ICC. Thus, while there is no immunity for purposes of transfer or surrender to the Court, the president's constitutional grant of immunity would prevail for the purpose of domestic prosecutions in Kenya under the ICA. A similar immunity exception was also debated in the Ugandan context; however, the provision there was ultimately defeated, again owing largely to the vigorous efforts of civil society. See M. Ndifuna, J. Apio, and A. Smith, 'The Role of States Parties in Building the ICC's Local Impact: Findings from Delegates' Visits to Uganda' (2011), which notes that the ICC Bill 'faced delays throughout 2009-2010, reportedly in part due to efforts ... to provide immunity for Heads of State', 11 (on-file).

${ }^{84}$ ICA 2008, Art. 7(1)(f), (g), (k). ${ }^{85}$ Ibid., Art. 7(5)(b0).

${ }^{86}$ Kenya National Assembly Official Record (Hansard), The International Crimes Bill, Third Reading, 11 December 2008, 4084. MP Githae (now the Kenyan ambassador to 


\section{Surfacing political discomforts: post-implementation domestic politics}

\section{Uganda: the end of amnesty?}

In Uganda, parliament's rushed support for the ICC Act's passage - seen at the time as a symbolic precondition for hosting the 2010 Review Conference - soon gave way to a deeper set of political concerns over the future of the Amnesty Act and, by extension, to the dominance of the complementarity framework. This was not surprising. Uganda had passed the Amnesty Act in 2000, within a year of its first signing the Rome Statute, but 'without considering any possible inconsistency in obligations' ${ }^{87}$ Furthermore, while some MPs had raised questions about amnesty's future in light of the ICC Act, at the time Attorney General Ruhindi had assured them that, 'International criminal justice does not throw away our own initiatives to try some of these renegades.' He noted, correctly, that 'you can actually have amnesty internally or domestically under the complementarity principle'. ${ }^{88}$ Nevertheless, the possibility of conflict was apparent. What might happen, for instance, if an amnesty applicant became a target for domestic prosecution under Ugandan law?

This precise question confronted parliament only one month after the ICC Act's passage, when the executive sought a 'carve out' declaration for the eligibility of four individuals to receive amnesty: Thomas Kwoyelo, a former LRA combatant, and three of the ICC's named suspects. The Minister of State for Internal Affairs purportedly sought the exemption because these individuals 'have been engaged and continue to engage in acts that are contrary to international standards and are rebellious and injurious to the citizens of this country and the neighbouring states' ${ }^{89}$ At this point Ugandan authorities had already seized Kwoyelo and he had in fact applied for amnesty under the existing law. This led one MP who opposed the government's motion to note that it was in a 'catch-22' situation:

The minister is telling us that the fourth person [Kwoyelo] is already in the hands of the security agencies; they do not know what to do with him.

the US) likewise took the occasion to state, ' $[\mathrm{N}]$ ow that the Attorney-General is in the mood of domesticating international agreements, we have so many of them that we have not domesticated in this country, which Kenya has ratified. I would like to ask him to bring them to this House so that we can domesticate them.' Ibid.

${ }^{88}$ ICC Bill Second Reading, 10942.

89 Request for Parliament to Approve the Declaration of Named Individuals as Persons Not Eligible for Amnesty, 13 April 2010 (on file); remarks of Mr M. Kasaija, 785. 
Actually, they just want us to pass this request so that they can have this person prosecuted, because they can't grant him amnesty; they can't release him, and they can't take him to court while the peace process is going on. Why should we operate like that? ${ }^{90}$

Another MP from northern Uganda raised similar objections, expressing confusion as to the criteria used in selecting Kwoyelo for prosecution. ${ }^{91}$ She added:

Now, I want to know the effects of the declaration beyond the indictment. Suppose tomorrow, Kony comes out and says, 'I want to sign for amnesty and I will stop all this suffering for the people of Sudan, DRC and for the people of Central African Republic.' What will be the political decision of Uganda, DRC and Sudan for the sake of their people, what will be the effect of this? Is this decision written in stone, or can it be undone? ${ }^{92}$

In the end, the Ministry withdrew its motion; however, the failed attempt soon inaugurated a more concerted effort to cease the issuing of amnesties entirely. Indeed, although amnesty remained strongly supported by Ugandans in the north and amongst their political representatives, its continuance increasingly conflicted with Uganda's carefully crafted image as a 'complementarity state'. JLOS, for instance, which was meant to act as a 'neutral' justice coordinator, undertook a more aggressive effort to discontinue the act, arguing that it was incompatible with Uganda's obligations under international law. ${ }^{93}$

A more urgent crisis thus presented itself in late 2012, when the Ministry of the Interior did not renew Part II of the Amnesty Act, which was the provision that empowered the commission to grant amnesties. The provision's lapsing - largely understood as a response to the Ugandan Constitutional Court's halting of Kwoyelo's trial in September 2011, on the grounds that he was entitled to amnesty ${ }^{94}$ was met with intense opposition. Oola notes that it 'angered many victims and leaders from the conflict affected sub-regions in northern

90 Ibid., 787 (remarks of E. Lukwago). Notably, Hon. Lukwago (now mayor of Kampala) had also served as a member of the Committee of Legal and Parliamentary Affairs that considered the ICC Bill before it went to the floor of Parliament. See Sessional Committee Report.

91 Ibid., 788 (remarks of B. Amongi). ${ }^{92}$ Ibid.

93 See, e.g., The Amnesty Law (2000) Issues Paper, Review by the Transitional Justice Working Group, JLOS (April 2012).

94 Constitutional Petition No. 036/11, arising out of HCT-00-ICD-Case No. 02/10, 22 September 2011 (on-file). In April 2015, the Ugandan Supreme Court overturned the Constitutional Court's decision, effectively bringing Kwoyelo's case back before the International Crimes Division for further proceedings. 
Uganda', so much that local leaders and domestic civil society groups petitioned the Speaker of Parliament, condemning the 'illegal and unconstitutional manner' in which the amnesty provision had been removed. ${ }^{95}$ Ultimately, the matter was referred to the Parliamentary Committee on Defence and Internal Affairs, which proceeded to undertake extensive consultations with key stakeholders.

In its final, 45-page report, published in August 2013, the committee concluded that the lapsing of Part II of the Act was 'premature and out of step with the sentiments of affected communities', and recommended that it be 'restore[d] in its entirety'. ${ }^{96}$ Far more than the debate over the ICC Act, the committee's report surfaces the complexity of Uganda's post-conflict landscape. It reviews, for instance, the arguments in favour of amnesty - the fact that 'the vast majority of rebels were forcibly abducted, many at a very tender age'; the concern that there is 'now no legal protection for returnees from prosecution' - and assesses the executive branch's contention that the granting of amnesty 'was inconsistent with the Rome Statute of the International Criminal Court (1998) (domesticated in Uganda in 2010) ${ }^{9} .{ }^{97}$ It notes that JLOS and the UCICC played a leading role in advancing this argument, along with 'diverse external pressure from some of Uganda's development partners as well as agencies of the United Nations and other international commentators who have policy objections to the amnesty'. ${ }^{98}$ In the committee's view, these external actors 'appear to have exerted a disproportional influence on the Executive's approach to the amnesty issue, by promoting their own policy preferences..$^{99}$

The committee's conclusions also dispel a number of the misconceptions about complementarity's obligations. It notes, for instance, that there is in fact no provision of [the Rome Statute] which outlaws amnesties, neither does the Statute impose any express obligations upon states to prosecute relevant crimes'. ${ }^{100}$ It further notes the common view encountered by committee members that the Statute imposes upon states parties a general obligation to establish international crimes courts

95 Oola notes that, in addition to the suspicious manner of the lapsing, it was procedurally improper: Under the Amnesty Act, the decision to renew or lapse any part of the law is at the discretion of the Minister of the Interior. Here, the chief justice and attorney general both were alleged to have improperly intervened in the process. For a more detail account of this episode, see Oola (Chapter 6).

96 Report of the Committee on Defence and Internal Affairs on the Petition on the Lapsing of Part II of The Amnesty Act ('Committee Report - Amnesty Lapse'), August 2013, para. 13.1.

97 Ibid., para. 9.8. $\quad{ }^{98}$ Ibid., paras. 9.4, 9.6. $\quad{ }^{99}$ Ibid., para. 9.38. ${ }^{100}$ Ibid., para. 9.18. 
and to introduce criminal legislation in order to prosecute ICC crimes nationally'. ${ }^{101}$ In perhaps its strongest passage, the report concludes:

There is ... a broader political issue at stake here, which relates not only to Uganda, but generally to the African continent: it concerns the extent to which African values and priorities inform the content of international law. There is a greater need for African states to be more assertive in ensuring that their values are reflected in the development of international law. ${ }^{102}$

Following the committee's conclusions, the Amnesty Act was reinstated in its entirety (at the time, through May 2015).

\section{Kenya: a return to the political}

The politically contested nature of amnesty in Uganda, and the relative detachment of that debate from the ICC Act's passage, resonates in the Kenyan context as well. There, the swift approval of the ICA was soon followed by political stalemate on an attendant institutional question: whether or not to establish a Special Tribunal for Kenya (STK), which would be empowered to retroactively judge alleged perpetrators of the election violence. Unlike the ICA, which saw minimal debate as to the incorporation of its substantial obligations into Kenya's legal framework, the STK Bill was deeply contested. Parliamentarians rejected the overt directives of the executive to vote in favour of the tribunal's establishment, raising questions about its comportment with the Kenyan Constitution as well as the risk of creating a parallel structure to the country's broader legal system. ${ }^{103}$

The defeat of the STK Bill was largely the product of an 'unholy alliance' between politicians who feared that genuine, independent domestic proceedings would never be possible through Kenyan courts, and those who saw such a tribunal, at the time, as a greater threat than the ICC itself. ${ }^{104}$ As Lydiah Kemunto Bosire notes, the failure of the Waki Commission's report to trigger a domestic judicial response 'resulted in part from the fact that domestic actors perceived the ICC to be a remote

101 Ibid., para. 9.21. ${ }^{102}$ Ibid., para. 9.39.

103 See Kenya National Assembly Official Record (Hansard), The Constitution of Kenya (Amendment) Bill, Second Reading, 3 February 2009.

104 For a more detailed discussion of these dynamics, see M. Wankeyi, 'The International Criminal Court's Cases in Kenya: Origin and Impact', Institute for Security Studies Paper (No. 237, August 2012), 8-9; S. Brown with C. Sriram, 'The Big Fish Won't Fry Themselves: Criminal Accountability for Post-Election Violence in Kenya', African Affairs, 111 (2012), 252-254. 
threat'. ${ }^{105}$ The phrase 'Don't be vague, go to The Hague' emerged as part of the country's political lexicon, ostensibly signalling a preference for the ICC's involvement, even if it signalled that the Court was seen to be the more limited threat. ${ }^{106}$

Repeated attempts by the Kenyan Parliament to withdraw from the Rome Statute and to repeal the ICA also reflect the deeply contested nature of the ICC's intervention. ${ }^{107}$ At the time of the Court's summons, domestic legislation was, in fact, tabled seeking to repeal the ICA. Although the government took no action on the bill, only one parliamentarian (former justice minister Karua) opposed the motion. ${ }^{108}$ Furthermore, in contrast to the 'global village' invoked by Attorney General Wako only three years before, at a special session of the Senate in December 2013 (and following a similar debate by the National Assembly in September ${ }^{109}$ ), senators spoke of cooperation with the ICC as 'singing the tune of the whites'; of 'playing politics with the boundaries of this country and the flag and the national anthem of our nation'; and of an 'unsupervised prosecutor who can .... arrest people who he thinks do not suck up to international neo-colonial ideology'. ${ }^{110}$

105 L. Kemunto Bosire, 'Misconceptions II - Domestic Prosecutions and the International Criminal Court' (11 September 2009), in Debating International Justice in Africa: OTJR Collected Essays, 2008-2010 (Oxford: The Foundation for Law, Justice and Society, 2010), 125-128. In the wake of the government-sponsored bill's failure, one parliamentarian, Gitobu Imanyara, tried repeatedly to bring forward a private members' bill to establish an accountability mechanism, but his efforts never advanced to the parliamentary floor.

106 While a majority of parliamentarians in fact voted in favour of the tribunal (101 to 93), passage of the bill required a two-third majority given that it necessitated a constitutional amendment. See F. Mureithi, 'How MPs Rejected the Proposed Special Tribunal for Kenya Bill', The Star, 12 March 2011.

107 See, e.g., N. Kulish, 'Legislators in Kenya Vote to Quit Global Court', International Herald Tribune, 5 (6 September 2013).

108 See P. Opiyo, 'Isaac Ruto: Kenya Should Pull Out of ICC', Standard Digital, 15 December 2010; T.O. Hansen, 'Transitional Justice in Kenya? An Assessment of the Accountability Process in Light of Domestic Politics and Security Concerns', California Western International Law Journal, 42(1) (2011), 1-35.

109 The National Assembly is the lower house of the Parliament of Kenya, while the Senate is the upper house. Prior to the structural reforms laid out in the 2010 Constitution, the Assembly served as the country's unicameral legislature; hence, debates on the ICC Act and the establishment of a domestic tribunal only took place there. The 11th Parliament, which began in March 2013, was the first to incorporate the constitutional reforms; since that time, the various Rome Statute withdrawal motions have been debated in both houses.

110 Parliament of Kenya, Convening of Special Sitting of The Senate to Debate Motion on Withdrawal of Kenya from the Rome Statute, Official Record (Hansard) ('Senate Debate'), 10 September 2013, 46 (Sen. Keter); ibid., 14 and 16 (Sen. (Prof.) Kindiki). 
This discourse has further cast Kenyan civil society as shadowy hands conspiring against the state and its people - 'evil society' in the words of Kenyatta's 2013 presidential campaign. ${ }^{111}$ Furthermore, according to the Senate Majority Leader:

What has happened ... is that a few people especially from the NonGovernment Organisations (NGOs) world decided to convert the misery and the tragedy that befell our country into a money-minting business where a few citizens have converted themselves into running rings and organisations in the name of victims support. These are people who have been responsible and have been used by foreigners to cook up the stories and bring up the kind of friction that is now being witnessed before the [ICC]. As I said, we should be all ashamed as Kenyans. ${ }^{112}$

The Senate ultimately passed a motion expressing its intention to bring forward a bill that would compel the government to withdraw from the ICC. Like the ICA's passage, however, this motion may be largely symbolic: to date, no such bill has been tabled.

\section{Implementation as purity, as politics and as 'performance'}

The histories recounted herein suggest three tentative fault lines around implementation of the Rome Statute and its relationship to complementarity.

\section{Implementation as purity}

Rather than a catalyst, the ICC is better understood as the axis around which much advocacy for implementation of the Rome Statute has turned. Domestic NGO coalitions were stimulated and supported by larger, international organisations who saw implementation not only as a way to facilitate cooperation with the ICC, but also as a broader step in criminal justice reform. Abolition of the death penalty and the introduction of victim participation regimes are perhaps the clearest illustration

111 J. Githongo, 'Whither Civil Society?', The Star, 6 April 2013.

112 Senate Debate, 22. See also Parliamentary Debates, National Assembly Official Report (Hansard), 15 October 2014, in which one MP suggests that the Open Society Initiative in East Africa is a 'terrorist organisation', and that NGOs such as the Africa Centre for Open Governance, Kenyans for Peace Truth and Justice, and the Kenya Human Rights Commission 'bears the greatest responsibility for the post-election violence'. In his words, 'The forest might be different at different times but the monkeys are always the same' (remarks of Hon. Moses Kuria). 
of such reform. The normative stake of many of these actors, however, as well as many legal academics, is to preserve the Rome Statute in its technically correct or 'pure' form, transplanting its complex substantive and unique procedural provisions into national legal frameworks. The proliferation of 'model laws' and legal tools - most of which copy the Statute in content and form - are a means towards this end.

Yet 'distortions' in implementation are an issue of legal pluralism: they are an inevitable product of importing new legal principles into an established legal system. In her work on the 'translation' of international law into local justice, Sally Engle Merry contends that the efficacy of human rights depends on their 'need to be translated into local terms and situated within local contexts of power and meaning'; they need 'to be remade in the vernacular'. ${ }^{113}$ Merry helpfully defines translation as 'the process of adjusting the rhetoric and structures of ... programs or interventions to local circumstances', ${ }^{114}$ but she notes that the process can also yield replication: rather than a merger of global frames with local forms (hybridisation), they are appropriated wholesale. Similarly, Mark Drumbl notes that, 'Pressures emanating from dominant international norms [can] narrow the diversity of national and local accountability modalities.'115

Analogised to the implementation efforts detailed herein, there is little evidence of 'vernacularisation' in either Uganda or Kenya. In both countries, the Statute's core substantive and procedural provisions were copied, based almost entirely on 'model' ICC legislation that had been prepared for export. Rather than an opportunity to tailor domestic legislation to reflect more localised concerns and desires - to encompass, for instance, suggestions that it incorporate the crime of pillage or corporate liability, or to accommodate other transitional justice measures - implementation appeared instead as an exercise in mimicry. This is not accidental: as noted above, much of the academic literature has deliberately presented complementarity as requiring uniformity with the Rome Statute, while NGO implementation materials and other capacity-building programs have been similarly designed. Thus, even though international law certainly permits amendments in the form of broader protection at the national level few (if any) of these materials encourage them. ${ }^{116}$

113 S.E. Merry, Human Rights and Gender Violence: Translating International Law into Local Justice (Chicago: University of Chicago Press, 2006), 1.

114 Ibid., 135. ${ }^{115}$ Drumbl, Atrocity, Punishment, and International Law, 121.

116 Indeed, the expectation that implementation must preserve the international text from distortions arising from domestic politics belies the fact that fragmentation is itself a constitutive element of treaty making. As Immi Tallgren, a diplomatic representative to 


\section{Implementation as politics}

While often presented as a seemingly technical exercise, implementation is fundamentally a political process. In both countries, the passage of implementing legislation was alternately delayed because it was not a sufficient political priority, or passed swiftly, with large majorities, because it became important enough to external constituencies and carried little political cost. In Kenya and Uganda, the politics that predominated was initially one of wanting to be seen as compliant states: implementation was evidence of putting complementarity 'into practice' and a means of signalling to external constituencies the governments' purported commitment to accountability.

At the time the acts were enacted, these priorities briefly outweighed other domestic concerns. In Uganda, what passage of the ICC Act might mean for the continued practice of granting amnesties was glossed over, but quickly returned to the political fore. Similarly, Kenya's charged domestic politics are largely absent from the 2008 parliamentary debate on the ICA's passage, yet the unexpected swiftness of the ICC's intervention there radically altered the political landscape; indeed, most 'regard the leadership of the Jubilee Alliance as a political marriage forged to protect' Kenyatta and Ruto. ${ }^{117}$ This, in turn, has led to repeated efforts to nullify the domestic legislation, withdraw from the Court and derail its proceedings.

Yet the intensity of these debates, and their relative absence from earlier discourse, suggests a decoupling from the politics of the Rome Statute's enactment and the text of the implementation legislation itself. A focus on the 'ceremonial conformity ${ }^{118}$ of Uganda's ICC Act and Kenya's ICA with the Rome Statute - an exact mapping of the latter's substantive and procedural provisions - can be understood as a desire to gain or maintain international legitimacy, but it also reflects the power and authority of particular non-state actors - influential NGOs, legal

Rome in 1998, writes, ' $[\mathrm{H}]$ ere in Rome we are slowly constructing articles by putting bits and pieces together, solving the lack of consensus by lukewarm compromises about how a particular matter should be addressed, deferring the most controversial questions in strategic choices of terms to the "application." I. Tallgren, 'We Did It? The Vertigo of Law and Everyday Life at the Diplomatic Conference on the Establishment of an International Criminal Court', Leiden Journal of International Law, 12 (1999), 689.

118 M. Fourcade and J. Savelsberg, 'Global Processes, National Institutions, Local Bricolage: Shaping Law in an Era of Globalization', Law \& Social Inquiry, 31(3) (2006), 516 (citing J. Meyer and B. Rowan, 'Institutionalized Organization: Formal Structure as Myth and Ceremony', American Journal of Sociology, 83 (1977)). 
academics, the ICC itself - to mediate the relationship between the international and national spheres. It also underscores their influence in the social construction of a new norm of complementarity, one that is increasingly freed from its legal constraints as an admissibility principle in the service of broader governance goals.

These goals may be normatively desirable; however, they also risk supplanting democratic deliberation with 'a treaty-centred international administrative bureaucracy', contributing to a 'whittling down of democratic input in important aspects of national lawmaking. ${ }^{119}$ The presentation of implementation as an international duty rather than a choice (or even a priority) amongst domestic political actors has arguably contributed to such 'whittling down'.

\section{Implementation as 'performance'}

Contrary to popular accounts, the ICC itself was not a catalyst for implementation of the Rome Statute in either Kenya or Uganda. The passage of the ICC Act did not come until eight years after the Court had formally intervened in Uganda, bringing with it an array of other transnational actors whose focus and interests were significantly broader than the ICC's alone. Moreover, since the act's passage, there is increasing evidence to suggest that it was the country's role as host state for the ICC Review Conference, part of an orchestrated performance for the 'international community' which pushed forward legislation that had otherwise languished.

The desire to be seen as a compliant, cooperative state in the eyes of international actors likewise motivated Kenyan politics, at least in the early phase of the post-election violence. At that stage, in 2008, the imminence of ICC intervention still appeared relatively remote - indeed, it was its remoteness that led many MPs to reject the Special Tribunal bill - but passage of the ICA was seen as a politically strategic move. As a stand-alone recommendation of the Waki Commission it was an opportunity to signal a break with the past, even as the act's own retrospective applicability to those events appeared doubtful. The ICA may have been, in the words of the director of a leading Kenyan NGO, the country's

119 Drumbl, Atrocity, Punishment, and International Law, 135. For a similar critique in the context of constitutional drafting, see S. Kendall, "Constitutional Technicity": Displacing Politics through Expert Knowledge', Law, Culture and the Humanities 11 (3) (2015). 
'never again' moment but, unlike the STK, it came at a sufficiently low political cost. ${ }^{120}$

These histories suggest that, rather than a deliberative, democratic process, implementation in Uganda and Kenya is better understood as a form of political theatre. In both countries, passage of domestic ICC legislation was hailed for its swift passage with large majorities, demonstrating the entrenchment of global norms domestically and vindicating the ICC's catalytic potential. In fact, however, implementation of the Statute was accelerated in order to 'perform' complementarity for predominantly international audiences, and to signal, in the Kenyan context, a return to the 'global village'. Much like the international criminal trial itself, then, implementation of the Rome Statute served a symbolic function, even as the post-implementation domestic politics of both countries remain deeply contested. ${ }^{121}$

\section{Conclusion}

Implementation narratives typically present the process as part of a march towards global consensus - as something above the state, rather than a part of it. 'Model' laws and toolkits facilitate this process; however, as this chapter has suggested, such questions of technique overwhelmingly privilege uniformity with the Rome Statute, often stifling deeper political debates within the state itself. Moreover, the outsized role of external actors and constituencies in these processes - most of whom regard deviation from the Statute with suspicion - raises questions about who the agents of implementation are, as well as the content and form of the domestic legislation that is enacted. Efforts to progressively narrow discussions about alternative forms of justice from the Ugandan ICC Act, or the mistaken belief that a domestic Rome Statute could not incorporate economic crimes in Kenya, suggest a view of implementation driven less by domestic political interests than in replicating the Statute as a 'global script'.

120 Personal interview conducted in Nairobi, Kenya, 30 November 2012.

121 On the symbolic function of the criminal trial, see M. Koskenniemi, 'Between Impunity and Show Trials', in J.A. Frowein and R. Wolfrum (eds.), Max Planck Yearbook of United Nations Law, Volume 6 (The Netherlands: Kluwer Law International, 2002), 1-35. On ritual and 'performance' in the context of state transition, see also J. Borneman, Settling Accounts: Violence, Justice, and Accountability in Postsocialist Europe (Princeton, NJ: Princeton University Press, 1997), 20-25. 
Thinking of implementation as beyond fidelity to the Rome Statute could free a space in which to think more critically about its productive potential. As this chapter has illustrated, implementation is a politically fraught and dynamic process; it continues long after legislation is formally passed. In Uganda, domestic debates over the fate of Thomas Kwoyelo and the future of the country's transitional justice process continue to evolve; in Kenya, threats by parliamentarians to repeal the ICA or withdraw from the Court reflect deeper contestation over the ICC's selective geographies and Western origins. These uneven trajectories suggest that implementation is a site for contestation but, equally, for experimentation and innovation as well. In short, implementation can be a site for states to also develop this dynamic body of law in a manner that better reflects their national interests and local contexts. All roads need not lead to Rome. 


\title{
Applying and 'misapplying' the Rome Statute in the Democratic Republic of Congo
}

\author{
PATRYK I. LABUDA
}

\section{Introduction}

The Democratic Republic of Congo's (DRC) ratification of the Rome Statute in 2002 created expectations in a country devastated by years of war. Several national armies and multiple militia and rebel groups had committed atrocities in a territory the size of Western Europe without a properly functioning justice system. ${ }^{1}$ Proponents of the newly established International Criminal Court (ICC) hoped that it would be able to hold perpetrators accountable for war crimes, crimes against humanity and genocide.

A decade later, the ICC's involvement in the DRC is a tale of symbolic achievements and difficult compromises. The country has been one of the most active situations for the Court, with the cases of Germain Katanga, Mathieu Ngudjolo, Bosco Ntaganda and Thomas Lubanga all coming before the ICC's chambers. However, the government's promises of 'ending impunity' ring hollow to many Congolese. Atrocities continue to be perpetrated in some regions, and parliament has failed to meaningfully reform the domestic justice system. There is also a glaring impunity gap for past crimes: the United Nations has documented over 600 unresolved cases of serious human rights violations committed between 1993 and $2003 .^{2}$

This chapter examines how international criminal justice has been interpreted, implemented and contested within the DRC. Rather than

${ }^{1}$ See G. Prunier, Africa's World War: Congo, the Rwandan Genocide, and the Making of a Continental Catastrophe (New York: Oxford University Press, 2009), 257-283.

${ }^{2}$ Haut Commissariat des Nations Unies pour les Droits de l'Homme, Rapport du Projet Mapping concernant les violations les plus graves des droits de l'homme et du droit international humanitaire commises entre mars 1993 et juin 2003 sur le territoire de la République démocratique du Congo (2010) ('UN Mapping Report'). 
focusing on the trials of Congolese nationals in The Hague, it shifts the geographical frame to the DRC to the domestic level, given that efforts at national level to secure accountability for international crimes have received less scholarly attention. The chapter explores how the Congolese authorities have invoked, applied and 'misapplied' the Rome Statute to support the government's policy of la lutte contre l'impunité amidst the broader context of the ICC's intervention in the country. Importing international norms and standards into the Congolese legal system has produced contestation between various institutional actors over: (1) who controls the process (the Ministry of Justice, the Senate, the National Assembly?), (2) where justice should be administered (civilian or military tribunals?), and (3) how to interpret international criminal law (according to the aspirations of conflict-affected communities or the expectations of international actors?). While the chapter draws attention to the achievements of the Congolese authorities in prosecuting grave crimes, it also suggests that the political and legal conflicts over implementing the Statute have led to some distortions ('misapplications') of the legal framework applicable to international crimes at the domestic level.

The chapter begins with a brief overview of the Congolese legal system, followed by an assessment of the Congolese Parliament's attempts, over the course of 2010 and 2011, to overhaul the legislative framework for international crimes, in particular through Rome Statute implementing legislation and a government-backed hybrid court. ${ }^{4}$ It then considers how Congolese courts have used the Statute to reinterpret and change domestic criminal law.

\section{The Congolese legal system: institutional framework and substantive law}

President Joseph Kabila and his ministers of justice have stressed on a number of occasions that strengthening the rule of law and the 'struggle

${ }^{3}$ In English, 'struggle against impunity'.

${ }^{4}$ While this chapter focuses on the 2010-2011 parliamentary period, there have been other efforts to pass such legislation. In May 2014, the National Assembly rejected another proposal that envisaged setting up special chambers within the DRC's existing court system. More recently, in June and November 2015 the Congolese Parliament provisionally endorsed an amended version of the bill domesticating the Rome Statute. Negotiations on the amended bill are underway and it is now possible the Congolese Parliament will domesticate the Rome Statute by the end of 2015. See P. Labuda, 'Whither the Fight Against Impunity in the Democratic Republic of Congo?' (24 June 2015), http://justicehub.org/ article/whither-fight-against-impunity-democratic-republic-congo. 
against impunity' are among the government's most important objectives. ${ }^{5}$ The Congolese Constitution of 2006 laid the groundwork for a number of sweeping reforms in the domestic justice system. The principle of the separation of powers was introduced for the first time, and several individual rights gained constitutional status, in particular the right to a fair trial, the presumption of innocence and the principle of legality. ${ }^{6}$ The Constitution also created a new institutional hierarchy in the justice sector: the bifurcated system of justice, in which military and civilian courts co-exist on an equal footing, was to be gradually phased out. The High Military Court (Haute Cour Militaire) was to remain the supreme military jurisdiction, but its decisions would be subject to judicial oversight by the (civilian) Court of Cassation (Cour de Cassation). Thus, military tribunals would be made accountable to civilian (democratically accountable) authorities.'

However, years after the enactment of the Constitution, only some of these institutional reforms have been implemented. The Court of Cassation has not been established. Its functions are still performed by the Supreme Court of Justice (Cour Supreme de la Justice), which is also acting as the Constitutional Court (Cour Constitutionnelle) and the State Council (Conseil d'Etat). ${ }^{8}$ Furthermore, depriving the military of its institutional powers and shifting them to new and inexperienced civilian bodies has proved easier on paper than in practice.

Despite efforts to give civilian courts jurisdiction over international crimes, at the time of writing Congo's military courts retain authority over the prosecution of international crimes. ${ }^{9}$ Genocide, war crimes and crimes against humanity are not criminalised by the regular criminal code (code pénal ordinaire), which is applicable to civilians. Enacted in 1886 and substantially revised in 1940, its provisions predate international crimes as a legal category. The new draft criminal code

${ }^{5}$ See Plan d'Action pour la Réforme de la Justice (2007); Ministry of Justice, Feuille de Route du Ministère de la Justice pour l'année 2009; Ministry of Justice and Human Rights, Preamble of Projet de loi relative aux Chambres spécialisées pour la répression des violations graves du droit international humanitaire: création, organisation, fonctionnement, droit applicable, compétence et procédure (2011).

${ }^{6}$ See Articles 149-151, 17, 19 and 20, DRC Constitution 2006.

7 Article 153, DRC Constitution 2006.

8 Articles 153, 154, 157, DRC Constitution 2006. At the time of writing, legislation establishing the three courts remained blocked in parliament.

9 See M. Wetsh'okonda Koso, 'République Démocratique du Congo. La justice militaire et le respect des droits de l'homme - l'urgence du parachèvement de la réforme', Open Society Initiative for Southern Africa (2009), 17-22. 
integrates verbatim the Rome Statute's definitions of international crimes, but it remains to be seen whether this legislation will be enacted. ${ }^{10}$

International crimes were first criminalised in the 1972 Code of Military Justice or CMJ (code de justice militaire). ${ }^{11}$ The Military Criminal Code or MCC (code pénal militaire) and the Military Judicial Code (code judiciaire militaire) were enacted following a series of legislative reforms undertaken towards the end of the Second Congolese War. ${ }^{12}$ None of these military codes have statutes of limitations for international crimes, which means that, at least in theory, crimes extending as far back as the early Mobutu era can still be charged under domestic military criminal law. ${ }^{13}$

As a monist legal system, international treaties can be applied directly by Congolese courts without further enabling legislation at the national level. ${ }^{14}$ The 2006 Constitution allows courts and tribunals to apply 'international treaties duly ratified', and the supremacy of international law over regular laws - but not the Constitution itself - is also recognised. ${ }^{15}$ The Rome Statute, like other international treaties, can thus be invoked and applied (subject to further legal requirements) by Congolese national courts. Given that the Mobutu regime acceded to many international humanitarian law (IHL) and human rights treaties, and that customary rules of IHL were in force throughout this period, international crimes have been part of the Congolese legal framework in a broader sense for a relatively long time. ${ }^{16}$

However, in a country where a significant proportion of such crimes has been and continues to be perpetrated by the armed forces, it appears unlikely that key perpetrators will be held accountable within the existing institutional framework. The entire Congolese judicial system suffers from a lack of resources and personnel. These difficulties are further

10 The Commission Permanente de Réforme du Droit Congolais (CPRDC) is working on the draft criminal code since 2006. Chapter IV, Draft Criminal Code.

11 See Articles 502, 505, 530, Ordonnance-loi $\mathrm{n}^{\circ} 72 / 060$ du 25 septembre 1972 portant institution d'un Code de justice militaire, with subsequent amendments.

12 Code judiciaire militaire, Loi $\mathrm{N}^{\circ} 023 / 2002$ du 18 novembre 2002; Code pénal militaire, Loi $\mathrm{N}^{\circ} 024 / 2002 \mathrm{du} 18$ novembre 2002, and subsequent amendments.

13 Article, 166 MJC; Article 10, MCC. Joseph Désiré Mobutu ruled the DRC (then Zaire) from 1960-1961 to 1997.

14 See W. Ferdinandusse, Direct Application of International Criminal Law in National Courts (The Hague: T.M.C. Asser Press, 2006), 129-171.

15 Articles 153, 215, 216, DRC Constitution 2006.

${ }^{16}$ For details on conventions to which DRC is a party, see UN Mapping Report, 383-385. 
amplified within the military justice system, ${ }^{17}$ whose hierarchical command structure leads to political interference and institutional pressures, and curtails a number of due process rights. ${ }^{18}$ There are also legal obstacles to trying some members of the military. For one, under Congolese military law at least one member of the judicial panel must be of equal or superior military rank to that of the accused. ${ }^{19}$ Furthermore, amnesty bills, though formally inapplicable to international crimes, have been interpreted broadly to shield some members of the military from prosecution. ${ }^{20}$ Lastly, the Congolese military's sweeping powers also extend to trials of civilians, ${ }^{21}$ which is considered a violation of international custom. ${ }^{22}$

This brief overview of the Congolese legal system suggests that international crimes have been criminalised in the DRC for the past forty years through a patchwork of domestic military criminal law, international treaties and customary international law. However, the institutional framework, in particular the military's control of prosecutions of international crimes, has made enforcement of these norms very difficult. Thus, while the Rome Statute's entry into force in 2002 altered the landscape of international criminal justice, has yet to bring about a radical re-articulation of the domestic legal framework for prosecuting international crimes in the DRC.

17 'Rebuilding Courts and Trust: An Assessment of the Needs of the Justice System in the Democratic Republic of Congo', International Bar Association and International Legal Assistance Consortium (2009), 19-24 ('Rebuilding Courts and Trust').

18 UN Mapping Report, 439-444. See also Report of the Special Rapporteur on the Independence of judges and lawyers, Leandro Despouy, Promotion and Protection of All Human Rights, Civil, Political, Economic, Social and Cultural, Including the Right to Development, Mission to the Democratic Republic of Congo, UN Doc. A/HRC/8/4/ Add.2 (2008), paras. 22-40.

19 Articles 25 and 34, MJC 2002. ${ }^{20}$ UN Mapping Report, 454-455.

21 The MJC has been interpreted broadly to give military tribunals the power to try civilians, including for international crimes. This undermines the strict separation between civilian and military authority in the DRC as required by the 2006 Constitutions. Article 111.2, MJC 2002 (and 106, 108, 112, MJC). See also Wetsh'okonda Koso, 'La justice militaire et le respect', 45-47.

22 See Principle 9, Economic and Social Council, Report submitted by the Special Rapporteur of the Sub-Commission on the Promotion and Protection of Human Rights, Emmanuel Decaux, Civil and Political Rights, Including the Question of Independence of the Judiciary, Administration of Justice, Impunity, UN Doc. E/CN.4/ 2006/58 (2006) ('Decaux Principles'). This has raised many criticisms from international actors and domestic civil society groups. See, e.g., the former UN High Commissioner for Human Rights, Louise Arbour, in 'UN High Commissioner Concerned at Kilwa Military Trial in the Democratic Republic of Congo', UN Press Release, 4 July 2007. 


\section{Implementation}

\section{La loi de mise en cuvre: 2010-2011}

The legislative history of efforts to implement the Rome Statute illustrates the political stakes of judicial reform in the DRC. Such legislation would better align the Congo's domestic legal framework with international standards and help empower judicial institutions to cope with the challenges of prosecuting international crimes. However, despite the Congolese government's professed support for the 'struggle against impunity' and the intense lobbying efforts of Congolese civil society groups and international organisations, Rome Statute implementing legislation (la loi de mise en oeuvre du Statut de Rome) remained elusive for over a decade.

A number of implementing bills have been considered during this time. Two draft bills were discussed between 2001 and 2002, but they never received the approval of President Kabila. ${ }^{23}$ (It is worth remembering that the political situation in the DRC was extremely volatile in 20012002, with Kabila's Kinshasa-based government controlling only parts of the country.) Different versions of a governmental projet de loi $i^{24}$ were prepared together with members of civil society between 2003 and 2004, and finally brought before parliament in 2005. But the bill was never put to a formal vote in the National Assembly or in the Senate, presumably because of the government's lukewarm support. ${ }^{25}$ In 2008, two members of the National Assembly, Professor Nyabirungu and Honourable Mutumbe, drafted a revised version of the law (une proposition de loi). ${ }^{26}$ Though negotiations reached an advanced stage, parliament did not pass the bill during its five-year term, which expired in November 2011. ${ }^{27}$

${ }^{23}$ G. Musila, 'Between Rhetoric and Action: The Politics, Processes and Practice of the ICC's Work in the DRC', Institute for Security Studies (2009), 16-17; see also footnotes and Annex II.

24 The distinction between a proposition de loi and a projet de loi is significant. The latter is a government-endorsed legislative bill, usually drafted and sponsored by the Ministry of Justice. The former is a legislative bill submitted by either an individual MP or a group of MPs, but it usually does not have the executive's approval.

25 The 2005 projet de loi can be found in L. Stone and M. du Plessis (eds.), 'The Implementation of the Rome Statute of the International Criminal Court in African Countries', Institute for Security Studies (2008), 114-139.

${ }^{26}$ See 'Plaidoyer pour l'adoption de la loi de mise en ouvre', International Center for Transitional Justice.

${ }^{27}$ In the current legislature (2012-2016), Honourable Balamage has sought to revive the implementing bill, but as of the time of writing it had not reached a vote in Parliament. 
The 2008 version of the draft legislation would have introduced a series of technical reforms to harmonise the relationship between the ICC and the Congolese domestic system. It had four main objectives: ${ }^{28}$ first, it would textually incorporate the Rome Statute's classification of international crimes into domestic criminal law. ${ }^{29}$ Congolese courts would no longer have to choose the applicable law each time, which would ultimately lead to a more unified and coherent case law in this area. Second, civilian courts - not military tribunals - would have sole jurisdiction over international crimes. This would include trials of members of the military or the police. ${ }^{30}$ The (civilian) Courts of Appeal would be competent in the first instance, with appeals adjudicated directly by the Supreme Court (or the Court of Cassation, if and when the judicial reforms of the 2006 Constitution are implemented). Third, a number of fair trial guarantees, especially relating to defendant rights, victim participation and witness protection, would be guaranteed at the domestic level for the first time. ${ }^{31}$ Lastly, a coherent framework regulating collaboration between the ICC's field units and domestic Congolese judicial and governmental authorities would be established. ${ }^{32}$

Yet these seemingly technical reforms have encountered considerable political resistance. After March 2008, when it was first presented before the National Assembly, the implementation bill did not come up for

See 'Statut de Rome: Les parlementaires congolais appeles a acceler le proccessus de mise en "œuvre"', Le Potentiel, 18 June 2013.

28 See La Proposition de loi modifiant et complétant le Code Pénal, le Code de procedure pénale, du Code de l'organisation et de la compétence judiciaires, le code judiciaire militaire et le code penal militaire en vue de la mise en oeuvre du Statut de Rome de la Cour Pénale Internationale ('Loi de mise en œuvre'). The March 2008 version of the draft bill will be referenced in this chapter, unless otherwise stated. The 2012 version of the bill replicated the earlier proposition in most regards.

29 Article 9, Loi de mise en oeuvre. A workshop of the PAJ Committee (Commission Politique, Administrative et Judiciaire) of the National Assembly agreed on a revised text of the bill in June 2011.

30 Articles 10-12, Loi de mise en oeuvre. Trials of members of the military or police would require at least one member of the judicial panel to be coopted from the defendants' respective organisation. This solution aimed to shield the implementation bill from a potential claim of unconstitutionality, in line with Article 156, DRC Constitution 2006.

31 The 2008 version of the implementation bill is less explicit about defendants' and victims' rights. In response to lobbying from civil society groups, the PAJ Committee agreed upon a revised version of the bill, with more procedural safeguards for victims, witnesses and defendants.

32 On the challenge of cooperation between the national institutions and the ICC see further Chapter 7 by Kambale in this volume. 
discussion for over two years. ${ }^{33}$ During that period, the president of the National Assembly declined to place the law on the parliamentary agenda despite the efforts of international actors and local civil society groups. For reasons that are not entirely clear, in November 2010 a preliminary debate on the bill was finally scheduled in the lower chamber of parliament.

Many parliamentarians opposed the bill, and the aims of implementing Rome Statute legislation were marginalised by a debate about the status of the death penalty in the DRC. Many MPs argued (incorrectly) that incorporating the Rome Statute into domestic law would force Congo to abolish the death penalty. ${ }^{34}$ Other objections concerned the involvement of outside actors in advocating for the bill's passage, which was described as a form of neo-colonialism and as a threat to national sovereignty. Only after the bill's drafters returned the discussion to substantive issues relating to the proposed reforms did the National Assembly address issues such as the bill's handling of sexual violence, the privileges and immunities of Congolese officials, amnesty provisions, universal jurisdiction and the age of criminal responsibility. After a heated and fractious debate, the National Assembly's members voted to declare the implementation bill 'admissible' (recevable).

The Congolese media hailed the vote as a major achievement, but in fact it had little practical significance at that stage. The bill was only transferred to the Political, Administrative and Judicial (PAJ) Committee for further discussion. Admissibility votes are usually a formality in the legislative process, and so despite the optimistic rhetoric of many NGOs surrounding the vote, ${ }^{35}$ the debate made it clear that implementing the Statute could not be taken for granted. ${ }^{36}$ The vote also illustrated that the

33 Why and how certain legislative proposals find their way onto the parliamentary agenda is not clear. The Speaker of the Congolese National Assembly wields disproportionate power in this regard, but other countries have the same or similar rules.

34 Article 80 of the ICC Statute provides that 'Nothing ... affects the application by States of penalties prescribed by their national law.' This point was raised by several MPs during the parliamentary debate.

35 See, e.g., Coalition Nationale pour la Cour Pénale Internationale CN-CPI RDC, La Coalition Nationale Salue la Recevabilité de la Proposition de loi de mise en œuvre du Statut de Rome de la Cour Pénale Internationale (2011).

36 This was borne out by the debate on 18 and 19 November 2011 when a separate bill on abolishing the death penalty was voted down by the National Assembly. See 'L'Assemblée Nationale rejette la proposition de loi sur l'abolition de la peine de mort', Le Potentiel, 26 Novembre 2011. 
challenge of incorporating the Statute into domestic criminal law is primarily political. In a country with a troubled history of colonial exploitation, some lawmakers had reservations about the international community's efforts to promote justice. Some political parties were also aware that adjusting the legal framework put their representatives at direct risk of prosecution. Another challenge lay in the Congolese military's reluctance to relinquish jurisdiction over international crimes. The DRC remains a country in which the military and the government have close ties, and there is a mutual interest in being able to exercise control over prosecutions of international crimes. ${ }^{37}$

The Congolese chapter of the Coalition for the International Criminal Court sought to address these concerns by organizing a workshop for members of the PAJ Committee, in which it addressed the bill's aims and the need for swift action. This was strengthened by the government's claims that justice reform would be one of the main items on the parliamentary agenda for the spring legislative session. However, two issues hindered further progress: the looming national elections scheduled for November 2011 and the government's rival projet de loi establishing 'special chambers' in the Congolese courts.

\section{Specialised chambers, the Special Court and the ICC}

In October 2010 the United Nations published a 'mapping report' documenting several hundred instances of unresolved crimes and human rights violations in the DRC. One of its recommendations was the establishment of hybrid chambers in the Congolese courts. ${ }^{38}$ Though the possibility of creating an international or hybrid court had already been mooted after the 2002 peace accords, this time the idea was taken up with more enthusiasm. The MoJ prepared a projet de loi on establishing 'specialised chambers' in the Congolese courts with jurisdiction over international crimes, whose preamble acknowledged that the Rome Statute was inoperative for crimes committed before 2002, and that the government had fallen short in its efforts to combat impunity. ${ }^{39}$

37 See Wetsh'okonda Koso, 'La justice militaire et le respect', 71-77.

38 See UN Mapping Report, 480.

39 Ministry of Justice and Human Rights, Avant Projet de loi portant création, organisation, fonctionnement, droit applicable, compétence et procédure des Chambres spécialisées pour la répression des violations graves du droit international humanitaire (2010). 
The draft bill (as well as its subsequent amended versions) ${ }^{40}$ raised a number of intriguing questions about the principle of complementarity. ${ }^{41}$ Hybrid tribunals and internationalised courts had been tried elsewhere, but not in countries with ongoing ICC investigations. Among other things, the draft bill sought to clarify the relationship between domestic governmental authorities and the proposed court, as well as between the proposed court and the ICC. But two issues proved more difficult to resolve.

First, the chambers' proposed jurisdictional ambit waxed and waned over the course of the bill's drafting. At one point it was mandated to investigate all crimes 'ever committed' in Congo; ${ }^{42}$ it then shrank to a far more limited ten-year timeframe (1993-2003, in line with the scope of the UN Mapping Report), only to expand again to cover crimes committed from 1993 to the present. ${ }^{43}$ In doing so, it created a novel legal situation, in which the 'specialised chambers' would exercise primary jurisdiction over international crimes, with secondary jurisdiction devolved to Congo's civilian courts, and the ICC enjoying (presumably) tertiary jurisdiction. ${ }^{44}$ The complementarity principle thus broke new ground under the proposed legislation, with a mixed national-international jurisdiction co-exercising judicial powers over cases within the ICC's remit.

Second, the MoJ struggled to find a viable legal basis for prosecuting acts committed over such a long period of time. Drafts of the specialised chambers' bill incorporated the Rome Statute's definitions of international crimes, and applied them retroactively to crimes committed before

${ }^{40}$ Subsequent drafts no longer used the term 'specialised chambers'. Due to constitutional issues, the government agreed to elevate the proposed jurisdiction to the status of a 'Special Court' within the Congolese judicial system.

41 The enabling law had to resolve a number of logistical and legal issues, in particular the court's organisational and administrative structure, the participation of international and national staff, victim and witness protection mechanisms, and funding issues. See 'Commentaires sur l'avant-projet de loi portant création de chambres spécialisées' (a shortened version is available at www.hrw.org/fr/node/97326).

42 Article 15, Avant-projet de loi (first draft).

43 The UN Mapping Report compiles data about crimes and human rights violations committed up to June 2003. Not coincidentally, this is the beginning of the transitional period and Kabila's consolidation of power.

44 The ICC is mentioned only in the exposé des motifs. While the bill did not call into question the ICC's jurisdiction, it did not seek to regulate the courts' concurrent powers. The bill also assumed that the Rome Statute implementing bill would be adopted, and civilian courts would acquire jurisdiction over international crimes. See Article 14 (3), Avant-projet de loi, 25 November 2011 (first draft). 
2002, which would have violated the principle of nullum crimen sine lege. ${ }^{45}$ The bill's reference to the implementing bill among the chambers' sources of law - in addition to the Rome Statute's definitions of international crimes incorporated directly into the bill - only added to the confusion: it unnecessarily duplicated references to the same definitions of crimes, and incorrectly assumed that the two bills could be passed simultaneously.

The politics surrounding the two bills compounded these legal difficulties. The discussion about the DRC's legacy of impunity unfolded against the backdrop of the country's democratic elections scheduled for November 2011. In a paradoxical turn of events, parliament refused to endorse the government-backed bill, while the government obstructed parliament's efforts to enact the Rome Statute implementing bill. The Minister of Justice, Luzolo Bambi Lessa, defended the Special Court (as it was then called) in parliament in June and August of that year. ${ }^{46}$ But parliamentarians from all sides of the political spectrum criticised the government's proposal, arguing that it would be dependent on external aid and cast Congo's own justice system in a negative light. It is also likely that many parliamentarians resented the MoJ's project, which would have marginalised parliament's implementing bill. ${ }^{47}$

The fraught legislative histories of these two bills illustrate how efforts to incorporate international criminal law at the national level produce both legal difficulties and political resistance. In the DRC the seemingly technical task of transposing the Rome Statute's principles

45 The Rome Statute's provisions cannot be applied retroactively to offences committed before 2002; however, in the initial draft of the specialised chambers' bill, the Statute would have served as the basis of prosecution for all crimes ever committed in the DRC.

46 Articles 16-26, Projet de loi portant création, organisation et fonctionnement de la Cour spécialisée de la répression des crimes de génocide, crimes de guerre et crimes contre l'humanité, approved by the Conseil des Ministres, 2 August. The revised legislation, in an effort to devise a more coherent basis of the Court's jurisdiction, split the applicable law into two separate sections. The Special Court would adjudicate international crimes committed before 2002 according to one standard, and subsequent crimes pursuant to the Rome Statute, whose definitions were transposed and codified verbatim.

47 Once the Senate conclusively rejected the revised Special Court (after months of wrangling), the implementing bill was not even put to a vote in parliament. Though there was no official explanation for this, parliamentarians presumably had little appetite for another protracted debate just months before the country's second democratic elections. See P. Labuda, 'The Lubanga Trial: The Democratic Republic of Congo's Failure to Address Impunity for International Crimes. A View from Inside the Legislative Process 2010-2011', Open Society Justice Initiative (2011). 
into domestic law occurred in the shadow of a number of institutional conflicts between competing repositories of power. The MoJ represents the interests of the president and the executive, which is in turn closely tied to the military establishment. On the other hand, some political parties had little incentive to support initiatives that could implicate their own members, while other parliamentarians balk at legislative proposals that could strengthen the government's role in administering justice for international crimes. These and other institutional conflicts are the hidden dimension of seeking accountability for international crimes in the DRC. ${ }^{48}$

\section{Military justice: the Rome Statute and domestic criminal law}

Aside from the political contestations surrounding the implementing bill and the Special Court, there is also the legal dimension of holding individual perpetrators to account. Prosecutions of international crimes at the national level produce a variety of challenges; to that end, the second part of this chapter explores why and how the military judicial authorities in the DRC have turned to the Rome Statute to support domestic trials. Observers have lauded these trials as a breakthrough, but they have also generated their own institutional and interpretive conflicts within the domestic justice system as to the relationship between national law and international norms. ${ }^{49}$

\section{A new interpretive tool}

The Congolese legislature enacted the new MCC several months after President Kabila ratified the Rome Statute. ${ }^{50}$ Given the temporal proximity of the two events - March and November 2002 - one might expect

48 These conflicts will likely continue to play out at the domestic level in the current legislature and executive. A new version of the implementing bill was tabled in the current legislature, while the MoJ recently revived the idea of a mixed jurisdiction.

49

G. Mattioli and A. van Woudenberg, 'Global Catalyst for Prosecutions? The ICC in the Democratic Republic of Congo', in P. Clark and N. Waddell (eds.), Courting Conflict? Justice, Peace and the ICC in Africa (London: Royal African Society, 2008), 55-62.

50 While beyond this chapter's scope, it is worth noting that the constitutionality of the Rome Statute's rapid ratification has been called into question. See M. Wetsh'Okonda Koso, 'Le malaise soulevé par l'application directe su Statut de Rome par le jugement n RP 084/2005 du 12 avril 2006 du Tribunal Militaire de Garnison de Mbandaka', Revue Horizons, 2 (2006), 154-157. 
the definitions of international crimes in the military code to reflect the definitions contained within the Statute. Quite the opposite is true. The definitions not only diverge, they also conflict with principles of customary international law, and in some cases are less clear than the $1972 \mathrm{CMJ}$. These differences raise questions as to why the Congolese legislature enacted the MCC in its current form.

Among these divergences, perhaps the most striking is the definition of crimes against humanity, which the MCC conflates with war crimes. ${ }^{51}$ For instance, while IHL is the body of law applicable to armed conflict, according to the MCC, 'crimes against humanity are grave breaches of [IHL]', which can be '... committed against all civilian populations before or during war'. In fact, it is not possible to commit violations of IHL 'before ... war', as the MCC suggests. There are also two separate lists of acts constituting crimes against humanity in the MCC but, unlike the loi de mise en cuvre, neither one replicates the acts criminalised in the Rome Statute. The first list invokes the Geneva Conventions, and enumerates acts that are usually considered war crimes in international law. ${ }^{52}$ The second list resembles the notion of crimes against humanity in the Rome Statute, ${ }^{53}$ but with several intriguing differences: apartheid and forced disappearances do not appear in the MCC, but 'serious devastation of wildlife, plant life, soil and subsoil resources' and 'destruction of natural and cultural universal heritage' are criminalised. It also makes a pioneering attempt to criminalise aggression as a crime against humanity. ${ }^{54}$ In short, while the MCC's concept of crimes against humanity departs from accepted norms of international law and the definitions established in the Rome Statute, in certain areas it is also more expansive than the Statute itself.

The level of detail with which the MCC defines crimes against humanity (albeit incorrectly in many instances) stands in marked contrast with its laconic regulation of war crimes. In one short provision, the MCC says: 'War crimes should be understood as any transgression of the law of the Republic committed in time of war and contrary to the laws and customs of war. ${ }^{55}$ It is significant that there is no penalty for

51 Article 165, MCC 2002. ${ }^{52}$ Article 166, MCC 2002.

53 Article 169, MCC 2002 and Article 7, Rome Statute.

54 Article 169, MCC 2002: '. . . against the Republic'. The crime of aggression was not part of the Rome Statute's original jurisdiction.

55 Article 173, MCC 2002. This provision is almost a carbon copy of its counterpart in the 1972 CMJ. 
war crimes in this provision. Under Congolese criminal law and in line with the continental tradition of criminal law, there is no crime without a specific penalty (nulla poena sine lege, the principle of legality of penalties). ${ }^{56}$ This means that, in theory at least, any prosecution of war crimes in the DRC would violate this fundamental principle of criminal law.

It is unlikely that the MCC's textual ambiguities are accidental given the intense discussions surrounding international criminal law at the time of its drafting. ${ }^{57}$ The Congolese legislature enacted the MCC just six months after President Kabila ratified the Rome Statute and three weeks before the Rome Statute was promulgated in the Journal Officiel. ${ }^{58}$ Two separate parliamentary bills incorporating the Rome Statute into domestic law had already been proposed in 2001 and 2002. In these bills the Rome Statute's definitions of international crimes were replicated at length, with only minor variations. Moreover, two high-level conferences organised by the MoJ in Kinshasa and Lubumbashi discussed these matters in late 2002, and the preamble to the MCC also expressly invokes the Statute. ${ }^{59}$

Thus, the MCC's distortions may well have been deliberately introduced by the Congolese legislature. For instance, the decision not to provide penalties for war crimes suggests that the military authorities remained wary of drastic reform and the threat of accountability. ${ }^{60} \mathrm{~A}$ resumption of hostilities was not out of the question as much of the DRC remained under de facto military rule in 2002; indeed, the ink was still drying on the Sun City accords. ${ }^{61}$ In sum, despite some of the MCC's

56 Article 2, MCC: 'Nulle infraction ne peut être punie de peine qui n'était pas prévue par la loi avant que l'infraction fut commise.'

57 The definition of genocide enacted by the Congolese legislator is almost identical to that that of the Genocide Convention and the Rome Statute, but the DRC code is notable for its inclusion of political groups as a protected class.

58 The Rome Statute was published in the Journal Officiel on 5 December 2002. See P. Kambale, 'L'application du Statut de Rome était-elle correctement faite? Une brève réplique a Marcel Wetsh'okonda', Revue Horizons, 2 (2006), 202-203.

${ }^{59}$ Exposé des motifs, MCC 2002.

${ }^{60}$ See 'Etude de Jurisprudence: L’Application du Statut de Rome de la Cour Pénale Internationale par les Juridictions de la République Démocratique du Congo', Avocats Sans Frontières (2009), 22-24, 27. Article 174 of the MCC seems to give military courts jurisdiction over enemy combatants only, which would strengthen this argument.

${ }^{61}$ However, some believe institutional inertia may have contributed to the poor drafting of the MCC and MJC. Drafts of both codes could have been prepared in advance (perhaps years before 2002), and nobody noticed the contradictions during parliamentary debate. Author's interview with M. Wetsho'konda Koso (Kinshasa, DRC, 24 April 2011). 
progressive provisions, it appears that the Code's regulation of international crimes primarily reflected the entrenched interests of the Congolese military, which had little interest in aligning it with the ICC.

\section{Case law: using the Rome Statute to interpret domestic law}

The military justice system began investigating international crimes around the time that the ICC's first arrest warrants were issued. Though there was no direct causal relationship between these investigations, since then the Rome Statute and international criminal law have been a source of inspiration for Congolese military tribunals. Confronted with the MCC's inconsistencies and a lack of prosecutorial and judicial experience, the military authorities have turned to international practices to fill these gaps. Applying the Statute to domestic trials in the DRC has produced a number of progressive developments, such as increased protection of victims and witnesses, as well as innovative interpretations of the definition of rape. However, it has also led to some misapplications of other legal norms and principles, notably with respect to the relationship between domestic and international law or the fair trial rights of defendants. This section explores how the Rome Statute has featured in the case law of domestic military tribunals.

Despite the DRC's conflict-ridden past, no judicial decision on international crimes was made under the 1972 JMC. $^{62}$ In fact, only two international crimes trials have ever addressed events preceding the entry into force of the revised MCC and the transitional constitution of 2003, and neither has dealt with the atrocities of the First and Second Congo Wars. ${ }^{63}$ The pro-Kabila Court of Military Order (Cour d'Ordre Militaire), which operated during this time (1997-2003), made little effort to ground its judgments in sound domestic criminal law, let alone in international law. ${ }^{64}$ Likewise, other de facto jurisdictions

62 UN Mapping Report, 425.

63 In the Ankoro case the Military Court of Katanga province declined to uphold charges of crimes against humanity under the 1972 CMJ (Article 505) relating to events in November 2002. See Association Africaine de Defense des Droits de l'Homme, Représentation du Katanga, 'Rapport sur le procès de Ankoro'; A. Katanga, 'Lutte contre l'impunité, mots vains pour le gouvernement de la RDC' (2005). The other trial relating to events before May 2003 - when a new constitutional and military legal order entered into force - is the MILOBS prosecution for the murder and torture of two United Nations peacekeepers in 2003. In this case, which began only in 2007, the judges applied the Rome Statute.

64 'Cour d'ordre militaire: un instrument de répression et de mort en RDC: Proces Olenga Nkoy', Association Africaine de Défense des Droits de l’Homme (1998). 
administered by rebel groups, such as the military courts of RDC-Goma and MLC, were more concerned with political contingency and shortterm gain than substantive criminal law and due process. ${ }^{65}$ The situation began to change towards the end of the transitional period and shortly before the entry into force of the 2006 Constitution. In March 2006, Lubanga, a militia leader from Ituri province, was arrested and transferred to The Hague. Shortly before that, charges of international crimes were also brought against him within the DRC's military justice system.

The Military Tribunal in Equatorial Province was the first to make use of the Rome Statute in an international crimes trial. ${ }^{66}$ Since then, military tribunals in four other provinces - Katanga, Oriental Province, South Kivu and North Kivu - have also applied the Statute to clarify points of law and procedure in around fifteen separate trials for war crimes and crimes against humanity. ${ }^{67}$ In the absence of institutionalised case reporting in the DRC it is not possible to establish a comprehensive list of such cases. Tribunals are reluctant to share information about prosecutions of members of the military, and while the media tries to keep the public aware of such developments, many court documents and trial transcripts remain inaccessible or lost; in some instances, the documents may not have existed in the first place. ${ }^{68}$

The MCC's definitional flaws seem to lie at the heart of the military justice system's embrace of the Rome Statute. In Mutins de Mbandaka, the judges candidly explained that the MCC 'conflates crimes against humanity with war crimes, which, incidentally, is clearly defined by the Rome Statute of the International Criminal Court'. ${ }^{69}$ In Bongi, the tribunal was equally clear that 'this internal legislation, namely the military criminal code ... has, however, a glaring loophole and does not criminalise war crimes, which are left with no sanction ... in this situation, a remedy to these loopholes must be found by invoking the Rome Statute. ${ }^{70}$

65 UN Mapping Report, 408-409.

66 Tribunal Militaire de Garnison, Mutins de Mbandaka ('TMG de Mbandaka'), jugement avant dire droit, 12 January 2006, RP 086/05.

67 To date, no genocide cases have been brought, although Thomas Lubanga was initially indicted for genocide (alongside other crimes). The main trials in the DRC are described chronologically in UN Mapping Report (n 2), 410-421.

68 Some transcripts were compiled by the International Center for Transitional Justice in Recommandations de l'atelier sur l'évaluation de la justice militaire comme mécanisme de répression des crimes internationaux (2009).

69 TMG de Mbandaka, Mutins de Mbandaka, 20 June 2006, RP 101/06, 16.

70 TMG de l'Ituri, Bongi, paras. 66 and 71. Other judgments also mention the MCC's conflicting definitions; See TMG de l'Ituri, Bavi, 19 February 2006, 37; TMG de l'Ituri, 
The courts have also articulated other rationales for applying the Rome Statute. In Songo Mboyo, the tribunal noted that 'the Rome Statute of the ICC is very favourable to the suspects eliminating capital punishment and providing efficient protection mechanisms for victims [meriting] its application in the ongoing proceedings. ${ }^{71}$ The tribunal in Oriental Province argued in similar terms that, 'the provisions of the Rome Statute are more humanitarian, in effect, less severe with respect to its penalties, there being no capital punishment'. ${ }^{72}$ In the Kibibi decision, these various strands of argumentation were brought together: 'This legal instrument [i.e., the Rome Statute] is more explicit with respect to the definition of concepts, more favourable to suspects in that there is no death penalty and better adapted in that it foresees clear mechanisms for victim protection. ${ }^{73}$

While the military tribunals are fairly clear about why it makes sense to apply the Rome Statute - an international treaty - to domestic prosecutions, they have more difficulty explaining how this is possible in legal terms. ${ }^{74}$ Some tribunals have quoted Articles 153 ('courts may also apply international treaties') and 215 ('international treaties have superior authority [autorité supérieure] over regular laws') of the 2006 Constitution, but the judges seem to view these provisions as self-explanatory. There is little legal analysis of how an international treaty can or should displace domestic law. The theory of monism, arguably the strongest argument in favour of the Rome Statute's direct application, is mentioned only in the Bongi decision. ${ }^{75}$ Notably, the majority of tribunals make only passing and incomplete references to the DRC's ratification of the Rome Statute, or to its self-executing character in Congolese domestic law. ${ }^{76}$

Kahwa, 2 August 2006, RP 039/2006, 24. TMG de Mbandaka, Songo Mboyo, 12 April 2006, RP 084/2005, 12.

71 TMG de Mbandaka, Songo Mboyo, 2.

72 Cour Militaire ('CM') de la Province Orientale, Bongi, 4 November 2006, RPA 030/2006, $15-16$.

${ }^{73}$ CM du Sud Kivu, Daniel Kibibi et autres, 21 February 2011, RP 043/2011, 16.

${ }^{74}$ Usually, these arguments appear alongside those concerning definitional gaps and constitutional arguments. But see CM de la Province Orientale, Bongi, 15-16.

${ }^{75}$ Ibid., para. 74.

76 The Rome Statute's self-executing character and its reciprocal application (or lack thereof) by other states parties are never raised. There is no proper legal analysis of the legality of the ratification of the Rome Statute, or its entry into force (significant for the principle of non-retroactivity). See Etude de Jurisprudence, 14-16. 
The legality of the direct application of the Rome Statute's Elements of Crimes (EoC) and Rules of Procedure and Evidence (RPE) to displace binding domestic law is equally problematic. None of the judgments examine the legal status of the EoC under international law or its relationship to Congolese criminal law and procedure. For instance, the Bavi and Kahwa decisions determine culpability on the basis of the EoC, but fail to mention it as a source of law. ${ }^{77}$ Likewise, the Bongi decision, which rigorously analyses the constitutive elements of pillage and homicide as war crimes by applying the five-pronged test from the EoC, fails to acknowledge it as the source of this new legal standard. ${ }^{78}$ Some judgments go even further and make direct use of the Rome Statute's RPE. ${ }^{79}$ For instance, in Kibibi the Military Court of South Kivu, after endorsing the Songo Mboyo and Mutins de Mbandaka decisions, applied the rules relating to victim protection and testimony. ${ }^{80}$

While it is clear that, in instances like these, the tribunals are filling significant gaps in the Congolese criminal procedure, the questionable legality of transposing an international criminal tribunal's internal set of rules to displace binding domestic law seems somewhat lost in the excitement surrounding international criminal justice. For instance, the Kibibi trial lasted just two weeks, which raises questions about the tribunal's respect of fair trial standards and defendants' rights. The military judges administering international crimes trials in the DRC have also struggled to articulate a coherent legal basis for the Rome Statute's application to Congolese law. Although this, on its own, does not undermine the legitimacy of the tribunals' judgments, it does point to a flexible understanding of how international law can be used - and potentially abused - to enhance domestic justice. ${ }^{81}$

Thus far, the Rome Statute has been applied to a variety of charges in both war crimes and crimes against humanity trials; there have been no

77 Ibid., 25-34. TMG de l'Ituri, Bavi, 37-43, CM de la Province Orientale, Bavi, 28 July 2007, RPA 003/07, 30.

${ }_{78}$ Art, 8(2)(c)(i) ICC EoC.

79 Rules 70 (in particular) and 66(4) ICC RPE. See also Etude de Jurisprudence, 42-48.

${ }^{80}$ Rules 68(2) and 87(3) ICC RPE. See Avocats Sans Frontières, Le Lieutenant-Colonel Daniel Kibibi Mutware condamné à 20 ans de prison pour crimes contre l'humanité (2011).

81 The direct application of international law in a domestic court is a threshold legal question, which gives rise to divergent solutions depending on the type of legal system. To date, no Congolese military tribunal has performed a comprehensive analysis of the applicability and enforceability of the Rome Statute at the domestic level. See CM du Katanga, Kilwa, 28 June 2007, RP 010/2006. 
trials of genocide. Application of the Rome Statute has proved more successful in trials involving crimes against humanity. On several occasions, tribunals have referred to the Statute and the case law of the International Criminal Tribunal for Rwanda (ICTR) to interpret the notion of 'systematic' and 'widespread' attacks against civilians. ${ }^{82}$ By contrast, the military justice system has had more difficulty prosecuting war crimes cases. In fact, indictments for war crimes have been thrown out in the majority of cases (with only the charges concerning ordinary crimes or crimes against humanity upheld). ${ }^{83}$ The Mitwaba trial illustrates these challenges: the civil parties brought war crimes charges, ${ }^{84}$ while the prosecutors, who doubted it would be possible to convince the judges that an armed conflict was still ongoing in 2005, opted for crimes against humanity. ${ }^{85}$

The notion of armed conflict has also been a recurring and contentious issue. The tribunals have struggled with the threshold questions of whether the DRC continues to be in a state of war after the 2002 peace accords (and the Rome Statute's ratification), and if so, whether the armed conflict should be classified as international or non-international. In the Bongi trial, the judges performed a thorough analysis of the legal framework applicable to international and domestic conflicts, and conceded that 'foreign armies, including those of Uganda and others have aggravated this situation by providing war materials, funds and personnel to one or other armed group'; yet the tribunal concluded that 'all hypotheses of war crimes committed in the context of an international armed conflict are to be excluded because the FRPI [Patriotic Resistance Forces of Ituri], the UPC army [Union of Congolese Patriots], the FNI army [National and Integrationist Front], the PUSIC army [Party for Unity and Safeguarding of the Integrity of Congo] are, in fact, only

82 See Article 7(1), ICC Statute and Article 169, MCC 2002. Both the Songo Mboyo and Mutins de Mbandaka decisions require - for reasons that remain unclear - that weapons of war (armes de guerre) be used to commit crimes against humanity. See TMG de Mbandaka, Songo Mboyo, 26.

${ }^{83}$ CM du Katanga, Ankoro, 20 December 2004, RP 02/2004. See also, TMG de l'Ituri, Kahwa; TMG de l'Ituri, Mutins de Bunia, 18 June 2007, RP 008/2007; TMG du Haut Katanga, Gédéon Kyungu, 5 March 2009, RP 0134/2007; CM du Katanga, Kilwa, 28 June 2007, RP 00/2006.

${ }^{84}$ CM du Katanga, Mitwaba, 25 April 2007, RP 011/2006, 7.

${ }^{85}$ In the end, the court threw out all charges relating to international crimes, and punished the suspect only for failing to assist a person in danger: an ordinary military crime under the MCC. In this trial - as in many others - prosecutors had presented ample proof of ongoing hostilities amounting to a domestic, or even an international, conflict. Etude de Jurisprudence, 54-58. 
domestic militias or armed groups fighting against the Congolese armed forces'. ${ }^{86}$ In the Bavi case, the judges cited both the ICTY's Tadic and the ICTR's Akayesu and Bagilishema jurisprudence, and also concluded that there was an internal conflict in Ituri. ${ }^{87}$ Notably, none of the tribunals have looked to the ICC's confirmation of charges against Lubanga to help circumscribe the parameters of armed conflict in Congo, which is surprising given the tribunals' general willingness to refer to Court practice. $^{88}$

The tribunals' reluctance to detail the causal link between military activities and armed conflict, or to re-consider the duration of 'international armed conflict' in the country (June 2003 being the cut-off point suggested in the ICC's Lubanga decision), ${ }^{89}$ has several consequences. For victims there is little guidance as to which charges and claims to pursue before the Congolese tribunals. ${ }^{90}$ It would also suggest that the military justice system is invested in downplaying the continued existence of hostilities in the country, as this would be a tacit acknowledgment of the government and military's failures. It could also be interpreted as an effort to shield members of the military from war crimes prosecutions. The reluctance to extend the duration of international armed conflict makes prosecution of foreign perpetrators or linking atrocities to foreign armies more difficult.

The relationship between the ICC and national jurisdictions is governed by the principle of complementarity. Although it forms part of the admissibility criteria for adjudicating crimes before the ICC, complementarity has also been understood more broadly as a burden-sharing relationship in which the ICC can and should encourage domestic

86 TMG de l'Ituri, Bongi (n 56) 13-14 and para. 93, and 5 and para. 7. Confirmed by CM du Province Orientale, 4 November 2006, RPA 030/06, 19. The judges amended the prosecutor's act of indictment, which was based on Article 8 (2) (b), Rome Statute, to reflect the non-international character of the war crimes (Article 8 (2) (e)). Ibid., paras. 75-80.

87 Article 29, MCJ 2002. TMG de l'Ituri, Bavi (n 70), 37-41. The same tribunal reached an analogous decision in the Kahwa trial, though its legal rationale is incomplete; TMG de l'Ituri, Kahwa, 28-29.

88 The International Court of Justice's judgment condemning Uganda for its intervention in eastern Congo has not been cited either: Case Concerning Armed Activities on the Territory of the Congo (Democratic Republic of the Congo v. Uganda), Judgment of 19 December 2005, [2005] ICJ Rep. 168.

89 Décision sur la confirmation des charges, Lubanga, Situation in the DRC, ICC-01/04-01/ 06, Pre-Trial Chamber I, ICC, 29 January 2007, para. 240.

90 The military tribunal in the Bongi case began addressing some of these questions. See TMG de l'Ituri, Bongi, paras. 79-97. See also Etude de Jurisprudence, 58-59. 
prosecutions. ${ }^{91}$ The trial of Lubanga is interesting because of its purported 'catalysing' effect on domestic prosecutions of analogous cases. The suspect was transferred to The Hague to stand trial for conscripting and enlisting child soldiers, which was an offence that the MCC does not criminalise. According to the Office of the Prosecutor (OTP), it stepped in because the Congolese military tribunals were unable to prosecute. ${ }^{92}$ Since then, two domestic trials have included charges of child conscription. In Biyoyo the tribunal refused to apply the Rome Statute's definition of this crime, and instead convicted the defendant for ordinary crimes, including 'illegal detention of a person' and 'kidnapping. ${ }^{93}$ In Gedeon $K u n g u$, prosecutors requested an indictment for the war crime of 'enlisting ... about 300 children below the age of 15 , among whom 150 have been identified and demobilized'; ${ }^{94}$ but the military tribunal threw out these charges, and issued a conviction only for ordinary military crimes, terrorism and crimes against humanity. ${ }^{95}$

In light of eastern Congo's reputation as the 'rape capital of the world', it would seem reasonable to expect many cases involving charges of rape. Surprisingly, rape as a war crime has been sanctioned in only a handful of cases: in Bavi, for instance, the tribunal applied the Rome Statute's EoC and used international case law to establish the defendant's command responsibility for ordering his soldiers to commit rape. ${ }^{96}$ In Kilwa the judges rejected all charges of war crimes, including rape. ${ }^{97}$ But this low figure is misleading. So far, Congolese military tribunals have been more willing to classify rape, and especially mass rape, as a crime against humanity. This trend began in 2006 with Songo Mboyo, one of the earliest judgments, and continued through 2011, with the Kibibi verdict (which found eleven members of the Congolese armed forces guilty of raping eighty-nine women) and the

91 On complementarity and its different meanings, and especially the ICC's 'catalytic effect' on domestic prosecutions, See S. Nouwen, Complementarity in the Line of Fire. The Catalysing Effect of the International Criminal Court in Uganda and Sudan (New York: Cambridge University Press, 2014), 34-110, 337-410.

92 The DRC's authorities had issued an arrest warrant charging Lubanga with crimes against humanity and genocide. The ICC stepped in because the Congolese prosecutors did not bring charges of child conscription and enlistment as a war crime, which was impossible because the MCC does not criminalise these acts. See W. Schabas, 'Prosecutorial Discretion v. Judicial Activism at the International Criminal Court', Journal of International Criminal Justice, 6 (2008), 731-761.

93 TMG de Bukavu, Biyoyo, 17 March 2006, RP 101/2006, 7-10.

94 Auditorat militaire près le TMG du Haut Katanga, Gédéon, 20 July 2007, RMP 0468/ MAK/2007, 5.

95 TMG du Haut Katanga, Gédéon Kyungu, 5 March 2009.

96 TMG de l'Ituri, Bavi, 42-43. $\quad 97$ CM du Katanga, Kilwa, 28 June 2007. 
conviction of two members of the Democratic Forces for the Liberation of Rwanda (FDLR) of, among others, rape as a crime against humanity. ${ }^{98}$

Cases involving charges of rape have featured progressive and unconventional uses of international law and the Rome Statute. ${ }^{99}$ In Songo Mboyo, the Rome Statute served to advance a novel legal interpretation of ' $\mathrm{r}$ ]ape as an inhuman act [which] is defined differently under domestic and international law. In fact, the interpretation provided by the Elements of Crimes ... considerably extends the notion of rape to also include any other inhuman act with gender-specific connotations. ${ }^{100}$ The EoC allowed the judge to criminalise all forms of rape, including against men, ${ }^{101}$ and to give greater weight to the testimony of rape victims than is usually permitted in the Congolese justice system. ${ }^{102}$ Both Songo Mboyo and the Mutins de Mbandaka decision, another case involving charges of rape, ${ }^{103}$ assess the credibility of rape victims' firsthand testimony and conclude that it should usually be privileged over that of other trial participants. ${ }^{104}$ These are creative and progressive instances of judicial decision-making, though - as explained above the legality of the tribunals' direct application of the EoC to displace binding domestic law raises questions.

A growing body of case law has matured in the last few years. The attention surrounding the ICC's work in the DRC, and the transfer of a few militia leaders to stand trial in The Hague, have made the Rome Statute a source of inspiration for Congolese judges and prosecutors. The military judicial system has drawn original insights from the Statute and ICL jurisprudence to supplement the domestic legal framework, and to address its lack of experience in dealing with complex international crimes trials. It is also encouraging that the military has begun holding members of its own armed forces (not just militias) accountable.

98 CM du Sud Kivu, Daniel Kibibi et autres; 'Deux elements FDLR comdanés pour crimes contre l'humanité en RDC', Avocats Sans Frontières (2011).

99 In August 2006, a new law on sexual violence was enacted, aligning Congolese criminal law with international standards in this area: Loi no. 06/18 du 20 juillet 2006. Many of the Rome Statute's progressive institutions relating to rape and victim protection were incorporated into this law.

100 TMG de Mbandaka, Songo Mboyo, 27. ${ }^{101}$ Ibid., 32.

102 Ibid., 27. This decision is examined by J.-P. Fofe Djofia Malewa, 'Commentaire du Jugement Songo Mboyo: Une illustration de l'eclairage de la justice nationale par les textes et la jurisprudence penaux internationaux', Revue Horizons, 2 (2006), 119-140.

103 TMG de Mbandaka, Mutins de Mbandaka and, on appeal, CM de l'Equateur, Mutins de Mbandaka, 15 June 2007, 12-14.

104 TMG de Mbandaka, Songo Mboyo, 27-34. CM de l'Equateur, Mutins de Mbandaka, 15. 
But serious challenges remain: in some trials there have been evidentiary deficiencies, and facts are not always construed in the light of the applicable law. Judges have also evinced a rather liberal understanding of how and why international law should displace domestic legislation, leading to both progressive interpretations of some legal norms (for instance, the definition of rape) and regressive infringements of others (fair trial rights of defendants). Victim and witness protection is still in its infancy, and the penitentiary system allows too many perpetrators to escape. Lastly, international crimes are prosecuted in an uneven and selective manner, and some perpetrators, especially high-ranking members of the Congolese military, remain beyond the reach of the judicial system. ${ }^{105}$

\section{Conclusion}

In 2003, President Joseph Kabila argued that, 'because of the specific situation in my country, the competent authorities are unfortunately not capable of investigating [international] crimes or undertaking the required inquiries without the participation of the International Criminal Court'. ${ }^{106}$ While some authors have criticised the self-serving nature of Kabila's self-referral and the selectiveness of the OTP's investigations in the DRC, ${ }^{107}$ there is little doubt that the Congolese justice system still faces daunting challenges. The inconsistent codification of international crimes in the MCC and the military tribunals' historical jurisdiction over such offences reflect the military's disproportionate influence on criminal justice, and remain a compelling reason for aligning the domestic legal and institutional framework with internationally recognised standards.

The Rome Statute has played an important role during the last ten years as a catalyst for judicial and legal reform at the domestic level. In over a dozen trials, the military tribunals have drawn on the Statute and applied the case law of international tribunals, leading to many important

105 See Etude de Jurisprudence, 42, 68, 106-109; 'Putting Complementarity Into Practice: Domestic Justice for International Crimes in DRC, Uganda, and Kenya', Open Society Foundations (2011), 35-36.

106 Kabila's letter is available in Musila, 'Between Rhetoric and Action'.

107 See P. Clark, 'Law, Politics and Pragmatism: The ICC and Case Selection in the Democratic Republic of Congo and Uganda', in P. Clark and N. Waddell (eds.), Courting Conflict?, 37-42; N. Jurdi, The International Criminal Court and National Courts. A Contentious Relationship (Surrey, UK: Ashgate, 2011), 173-180; P. Gaeta, 'Is the Practice of Self-Referrals a Sound Start for the ICC?', Journal of International Criminal Justice, 2 (2004), 949-952. 
convictions. The legal framework of the Statute was also the driving force behind two important initiatives: the specialised chambers, which initially sought to establish a domestic mechanism with international elements for adjudicating international crimes, and implementing legislation, which could put in place a robust accountability framework for the future. Thanks to the efforts of Congolese civil society and the work of international organisations, knowledge about the ICC and international criminal justice increased considerably during this time.

However, the history of these two initiatives also speaks to the political dimensions of the international justice project. The political context of the ICC's intervention in the DRC (and increasingly in other African countries) has made international actors - NGOs and donor states alike - uneasy bedfellows for some Congolese parliamentarians, and undermined the viability of more sweeping judicial reform in the country. For some military judges, the role of international law in addressing mass atrocities remains vague. These difficulties should be borne in mind as the DRC continues to search for viable ways to ensure accountability for past and continuing human rights violations. 


\title{
Beyond the 'shadow' of the ICC
}

Struggles over control of the conflict narrative in Colombia

\author{
JENNIFER EASTERDAY
}

[Paths to international justice] can be the production not only of justice itself but of the indirect and direct control of the terms by which decisions are made, naturalized, and controlled. ${ }^{1}$

\section{Introduction}

This chapter considers how the International Criminal Court (ICC) and Colombia employ international criminal justice towards different political and normative objectives. It attempts to show how Colombia has adopted and 'vernacularised' international justice to assert control over the terms by which the Colombian conflict is understood and represented. $^{2}$ I argue that this process, in turn, seeks to entrench the Colombian government's power domestically and internationally.

Colombia has been in the midst of an ongoing conflict between paramilitary groups, guerrilla groups and the national army for over fifty years. The conflict has been marked by extreme violence, including massacres, torture, forced disappearance, forced displacement, sexual violence and other war crimes and crimes against humanity. Colombia signed the Rome Statute in December 1998 and deposited its instrument of ratification in August 2002. The state has been under preliminary examination by the Office of the Prosecutor (OTP) since June 2004, which makes it the oldest situation classified as such. Since then, the Colombian government has developed a new approach to the conflict,

${ }^{1}$ K. Clarke, Fictions of Justice: The International Criminal Court and the Challenge of Legal Pluralism in Sub-Saharan Africa (New York: Cambridge University Press, 2009), 146.

${ }^{2}$ On the idea of the 'vernacular' in relation to accountability projects, see P. Levitt and S. Merry, 'Vernacularization on the Ground: Local Uses of Global Women's Rights in Peru, China, India and the United States', Global Networks, 9 (2009), 441, 444. 
adopting the normative frameworks of international criminal law and transitional justice, actively cooperating with the ICC in developing legislation, and conducting national trials for war crimes, crimes against humanity and genocide.

It has been argued that the best way of achieving the primary goal of the ICC - fostering accountability for serious international crimes - is through 'positive complementarity', whereby the Court encourages or assists national prosecutions. ${ }^{3}$ This has been a cornerstone of the ICC's approach in Colombia. ${ }^{4}$ The OTP has been active in consultations with Colombian actors and has followed the domestic legislative progress, which has had an impact on the development of the country's transitional justice legal framework. It has also influenced the evolving narrative of the conflict itself.

There is a growing body of literature analysing the influence of the ICC in situation countries and its impact on domestic procedures and conceptions of justice. ${ }^{5}$ However, most literature regarding the ICC's work in Colombia focuses on issues of compliance and complementarity. Little has been written about the broader effects of ICC involvement in Colombia, including its normative, expressive and discursive dimensions. This chapter explores the 'vernacularisation', or uptake, of international justice norms in Colombia and the expressivist goals of criminal justice in that context. In particular, it will explore how the ICC and the Colombian government take different approaches to theories of justice, which in turn have had an impact on the government's conflict narrative. An important distinction exists between narratives created out of popular memory and those created out of representations of the past adopted by state institutions. ${ }^{6}$ This chapter posits that the narrative being asserted by

${ }^{3}$ W. Burke-White and S. Kaplan, 'Shaping the Contours of Domestic Justice: The International Criminal Court and an Admissibility Challenge in the Uganda Situation', Journal of International Criminal Justice, 7 (2009) 257; W. Burke-White, 'Proactive Complementarity: The International Criminal Court and National Courts in the Rome Statute', Harvard Journal of International Law, 49 (2008), 53.

4 'Report on Preliminary Examination Activities 2013', Office of the Prosecutor, International Criminal Court (November 2013), para. 131 ('OTP 2013 Report').

${ }^{5}$ See, e.g., S.M.H. Nouwen, Complementarity in the Line of Fire: The Catalysing Effect of the International Criminal Court in Uganda and Sudan (New York: Cambridge University Press, 2013); Clarke, Fictions of Justice.

${ }^{6}$ See, e.g., R. Nets-Zehngut, 'Israeli Memory of the Palestinian Refugee Problem', Peace Review, 24 (2012), 187; P. Riaño-Alcalá and E. Baines, 'The Archive in the Witness: Documentation in Settings of Chronic Insecurity', International Journal of Transitional Justice, 5 (2011), 412; C. McGrattana, 'Explaining Northern Ireland? The limitations of the ethnic conflict model', National Identities, 12 (2010), 181. 
the Colombian government seeks to entrench state power using the terms of international justice; in so doing, it threatens to reproduce historic societal inequalities.

\section{'Vernacularisation' and customisation}

Social scientists have explored how 'international' ideas are disseminated in domestic contexts. Finnemore and Sikkink, for example, focus on the important role of transnational advocacy networks in what they call a 'justice cascade'. ${ }^{7}$ Others have focused on the idea of the 'diffusion' of international concepts to domestic levels, explaining a 'top-down' transfer from the international to the national. ${ }^{8}$ These theories focus on the adoption of legal norms.

Looking beyond the strictly 'legal', Peggy Levitt and Sally Merry describe the process of local interpretation and adoption of international ideas as 'vernacularisation'. 'They argue,

[As international ideas] connect with a locality, they take on some of the ideological and social attributes of the place, but also retain some of their original formulation. ... Vernacularizers take the ideas and practices of one group and present them in terms that another group will accept. This is not the work of a single person. Chains of actors stretch from the sites of the global production of human rights documents and ideas (in New York, Geneva and Vienna) to localities where ordinary people around the world adopt them. ${ }^{10}$

The process of vernacularisation depends on a number of factors, including the position of 'vernacularisers' within hierarchies of power and institutional positions. In Colombia, transitional justice norms have been invoked by various actors, including victims, as well as armed groups such as the Revolutionary Armed Forces of Colombia (Fuerzas Armadas Revolucionarias de Colombia), also known as FARC. ${ }^{11}$ The focus here, however, is primarily on 'elite actors' - the Colombian government and the ICC - as opposed to what Levitt and Merry call

7 M. Finnemore and K. Sikkink, 'International Norm Dynamics and Political Change', International Organization, 52 (1998), 887, 895.

8 T. Ginsburg, S. Chernykh, and Z. Elkins, 'Commitment and Diffusion: Why Constitutions Incorporate International Law', University of Illinois Law Review (2008), 201; Levitt and Merry, Vernacularization, 441, 444.

${ }^{9}$ Ibid., $446 .{ }^{10}$ Ibid., 446-447.

11 'Transitional Justice and Colombia's Peace Talks', International Crisis Group (29 August 2013), 6, 9-10 (International Crisis Group, 'Transitional Justice'). 
'marginal actors'. ${ }^{12}$ According to Levitt and Merry, elite actors are more likely to adopt international ideas early on, making them culturally legitimate through customisation. ${ }^{13}$ The uptake and vernacularisation of international norms, especially through state administrative functions, can be a mechanism through which states seek to entrench state power. ${ }^{14}$

In Colombia, the government drew ideas and practices from the field of international justice and presented them in terms that elite networks in Colombia would accept. The government has thus vernacularised these norms in ways that ensure it can control the conflict narrative while purportedly working on behalf of conflict-affected victim communities. However, as I discuss below, this customisation has also produced contestation with the ICC, has served as a mechanism to entrench state power, and has perpetuated political inequalities in Colombian society.

The ICC and its complementarity regime heavily influence the terms through which the conflict is addressed in Colombia. Under the Rome Statute's legal framework, national courts are ostensibly allowed to pursue a case before the ICC can act. However, the ICC, particularly through the OTP, retains influence over the domestic process through its ability to monitor, evaluate and, ultimately, judge what it deems the correctness or appropriateness of the Colombian government's investigatory and prosecutorial approach. ${ }^{15}$ To that end, the OTP has adopted the practice of opening 'preliminary examinations' before deciding whether to open an investigation. ${ }^{16}$ The OTP also influences the process of vernacularisation

12 Levitt and Merry, Vernacularization, 446. ${ }^{13} \mathrm{Ibid}$., 444.

14 Specifically, 'symbolic' state power. 'Symbolic' power is constitutive of the power of the state to naturalise and depoliticise issues that are the product of historical struggle. M. Loveman, 'The Modern State and the Primitive Accumulation of Symbolic Power', American Journal of Sociology, 110 (2005), 1651, 1655. Loveman argues that 'to begin to accumulate symbolic power, the state must carve out a new domain of social life to administer, co-opt the administrative practices of others, or wrestle existing administrative functions away from their traditional executors, imbuing them with new meanings in the process'. Ibid., 1657-1658. For a discussion of how Argentina adopted human rights discourse and norms to entrench its symbolic power, see M.F. Carmody, 'Never Again! Human Rights and the Construction of Stable Post-Authoritarian States', presented at ISA Human Rights Joint Conference 2014 (17 June 2014, Istanbul, Turkey) (on-file).

${ }^{15}$ See, e.g., 'Policy Paper on Preliminary Examinations', OTP, ICC (November 2013), 7 ('OTP Policy Paper'). The Policy Paper notes that, 'The ability of national and international courts to define their own jurisdiction within statutory parameters - compétence de la compétence - is well established ... it is the ICC that ultimately determines when and where the Court should intervene in accordance with the statutory criteria, which are the essence of the Office's preliminary examination process'.

${ }^{16}$ See generally, ICC website on situations and cases, www.icc-cpi.int/Menus/ICC/ Situations+and+Cases/. 
through its positive complementarity policy, by which it seeks to promote national proceedings through capacity building, sharing information and promoting support for accountability efforts with international donors. ${ }^{17}$ As argued here, the interpretation of prosecutorial strategy has been one site of vernacularisation and customisation.

Another way in which international legal discourse and its attendant norms have been taken up in Colombia is through the stated value of criminal prosecutions. The ICC and Colombia take two distinct approaches to the value of criminal prosecutions. The ICC focuses on the retributive value of trials; the Colombian government, on the other hand, focuses more on their expressive value. According to Mark Drumbl, 'expressivism ... transcends retribution and deterrence in claiming as a central goal the crafting of historical narratives, their authentication as truths, and their pedagogical dissemination to the public'. ${ }^{18}$ As discussed below, the Colombian government has repeatedly emphasised the value of trials for providing truth to victims, but seems to specifically avoid punitive rhetoric.

Ultimately, atrocity crimes trials produce sites of contestation in addition to expressing messages about political power. These messages arise out of the manner in which trials are designed, implemented and defended or attacked. In the Colombian context, these contestations over narratives reflect power differentials between the domestic and the international. Also, and perhaps more importantly, they reflect uneven power relations between members of Colombian society - in particular, the frequently invoked but historically disenfranchised 'victim' of atrocity. As the following section shows, recourse to the framework of international criminal law and its discourse of accountability narrows the narrative of Colombia's conflict history.

\section{A brief history of Colombia's conflict}

The modern Colombian conflict emerged from an ideological battle dating back to La Violencia, a violent struggle between liberals and conservatives between 1948 and 1957. A power-sharing agreement called the National Front attempted to resolve that conflict. After the National Front was established in 1958, far-left groups who had been excluded

'Prosecutorial Strategy 2009-2012', OTP, ICC (February 2010), 5.

${ }^{18}$ M. Drumbl, Atrocity and Punishment, and International Law (New York: Cambridge University Press, 2007), 173. 
from the political process formed small armies of guerrilla soldiers in the vast remote regions of the country. The FARC and the National Liberation Army (Ejército de Liberación Nacional, or ELN) were among the largest of these groups. ${ }^{19}$ In the 1970s, wealthy landowners and drug lords formed their own private armies with the assistance of the government and military, to protect their interests from expropriation by the guerrillas. ${ }^{20}$ These paramilitary groups eventually joined forces under an umbrella organisation, the United Self-Defence Forces of Colombia (Autodefensas Unidas de Colombia, or AUC). ${ }^{21}$

Despite its origins in ideological differences between paramilitary groups and the government, the current conflict is based on battles for land, money and control over drug routes. It has been well established that the guerrillas, paramilitaries and the government have all committed gross human rights abuses throughout the country. The state and paramilitary forces have worked together closely, with the paramilitary forces responsible for a large majority of human rights abuses. These abuses include massacring villages, torture, extrajudicial killings, kidnapping and forced displacement, amongst others. The government has adopted a variety of policies - inconsistently fluctuating between amnesty and military power - to fight the leftist guerrillas, with limited success. ${ }^{22}$

Exclusion and inequality have also pervaded the Colombian conflict, sustained by the absence of the state in many parts of the country and its inability to effectively govern in areas where it is present. ${ }^{23}$ In remote areas, which make up the large majority of the state, the judiciary is weak. (It is, for instance, often unwilling or unable to enforce or impartially

19 D. Bushnell, The Making of Modern Colombia: A Nation in Spite of Itself (Berkeley: University of California Press, 1993), 201-248.

${ }^{20}$ W. Tate, 'Paramilitaries in Colombia', Brown Journal of World Affairs, 8 (Winter/Spring 2001), 163, 165; W. Avilés, 'Paramilitarism and Colombia's Low-Intensity Democracy', Journal of Latin American Studies, 28 (2006), 379, 394.

${ }^{21}$ Informe sobre el Proceso de Desmovilización en Colombia, Comisión Interamericana de Derechos Humanos, OEA/Ser.L/V/II.120 Doc. 60 (13 December 2004), para. 42.

22 J.L. Esquirol, 'Can International Law Help? An Analysis of the Colombian Peace Process', Connecticut Journal of International Law, 16 (Fall 2000), 23, 28; N. Springer, 'Colombia: Internal Displacement - Policies and Problems', Writenet Report (June 2006), 1; C. Diaz, 'Colombia's Bid for Justice and Peace', International Center for Transitional Justice (May 2007), 2.

${ }^{23}$ Historically, the state has been absent from these regions, including a lack of public works, teachers, police and a diffuse judicial order. 'Callejon sin Salida', Programa de las Naciones Unidas para el Desarrollo Informe Nacional de Desarrollo Humano Colombia (2003), 28, 44. Even where local residents did not support guerrilla groups' political views, often these groups provided more support and services than distant government officials. Bushnell, The Making of Modern Colombia, 244. 
interpret contracts.) This lack of connection between the state and the everyday lives of citizens enhances the social and legal exclusion experienced by many Colombians. ${ }^{24}$

Developing a shared notion of justice and an authoritative narrative of the Colombian conflict is a process that challenges deeply entrenched understandings of the conflict. Communism, drugs, state power and terrorism have all been considered causes of the conflict; indeed, the very notion of conflict itself has been contested. The Colombian government previously denied the existence of an armed conflict, instead treating it as a state of emergency or as a series of terrorist attacks. ${ }^{25}$ 'Solutions' to the conflict have included numerous attempts at negotiations with the various armed groups and have generally included amnesties. Under the 'shadow' of the ICC, however, that has evolved into a narrative that readily acknowledges violence as a product of internal armed conflict, that focuses on victims and victims' rights to the truth and that moves away from total amnesties to a sense that at least a limited form of accountability is necessary.

\section{ICC involvement in Colombia}

The ICC has been involved in Colombia for over a decade. Since March 2005, after the then-ICC prosecutor Luis Moreno-Ocampo informed the Colombian government that he had received information about alleged international crimes committed in the country, the OTP has requested and received information from the Colombian government about crimes within the jurisdiction of the Court and the status of national proceedings. The OTP claims that it has taken a very active role in communicating with Colombian authorities about their domestic proceedings. Moreno-Ocampo visited Colombia on missions in October 2007 and August 2008, and other senior OTP staff members have conducted separate trips. The OTP has also maintained ongoing communication with Colombian judicial authorities and civil society groups. $^{26}$

The OTP has taken a generally supportive stance toward Colombian domestic prosecutions, but has consistently intervened with its views on

${ }^{24}$ J.M.J. Cepeda-Espinosa, 'Judicial Activism in a Violent Context: The Origin, Role and Impact of the Colombian Constitutional Court', Washington University Global Studies Law Review, 3 (2004), 529, 541.

${ }^{25}$ See, e.g.,'State of commotion', The Economist, 15 August 2002.

${ }^{26}$ OTP 2012 Report, paras. 27-28. 
how those prosecutions should be carried out. ${ }^{27}$ In 2005, the OTP told the Colombian government that it had already concluded that crimes against humanity had been committed in the country, and that the only things preventing it from opening an investigation were national proceedings. ${ }^{28}$ As early as 2007 , Moreno-Ocampo said that he needed to see rapid progress in the prosecution of paramilitary leaders. He repeated this message in late $2008 .^{29}$

The OTP has suggested through its preliminary examination reports of Colombia that it would focus primarily on government and military leaders. ${ }^{30}$ With respect to prosecutions, the OTP would realistically only open a case in Colombia if it were reasonably certain that the case would be admissible. Under Article 17 of the Rome Statute, to preclude admissibility, Colombia would need to pursue charges against the same accused, and for 'substantially the same' conduct, as the ICC had brought in its arrest warrant. If it has, the Court must then determine whether the prosecution is 'genuine' in order to ensure that it is not being undertaken to shield the individual from prosecution, amongst other reasons.

As the ICC has worked through its analysis of these tests, Colombia has continued its domestic prosecution efforts. A dynamic relationship has thus emerged between the OTP and the Colombian government. For the OTP, this relationship is the cornerstone of its 'positive complementarity' strategy and a way to help mould national prosecutions according to its retributive approach to justice. For Colombia, crafting this relationship and adopting the ICC's forms of justice represents a way for the government to further entrench its sovereignty and power. The following section describes how Colombia has customised international justice norms for this purpose.

${ }^{27}$ P.F. Seils, 'Making Complementarity Work: Maximizing the Limited Role of the Prosecutor', in C. Stahn and M.M. El Zeidy (eds.), The International Criminal Court and Complementarity: From Theory to Practice (New York: Cambridge University Press, 2011), 1010-1011.

28 In order to open an investigation, Article 53 of the Rome Statute states that the prosecutor must consider whether there is a reasonable basis to believe that a crime within the jurisdiction of the Court has been committed, whether the case is admissible and whether there are substantial reasons to believe that an investigation would not serve the interests of justice. In its reports on Colombia, the OTP stated that there is a reasonable basis to believe state and non-state actors have committed crimes against humanity and war crimes within the ICC's jurisdiction. Therefore, the key issue at stake is whether a case would be admissible under Article 17 of the Rome Statute. If the OTP determines a case would be admissible, it would then formally open an investigation.

29 Seils, Making Complementarity Work, 1009.

30 OTP 2013 Report, para. 120. 


\section{Colombia's vernacularisation of international justice norms}

Many sectors of Colombian society have adopted and translated the language and norms of transitional justice and international criminal law to characterise the conflict. The government, in particular, has vernacularised international justice norms as victim-oriented, broader than criminal trials and part of an expressive 'transitional justice' that will help establish the 'truth' about the conflict. Through importing international legal discourse into the Colombian political context, the government has crafted a narrative that depicts non-state perpetrators as the main actors that abuse the rights of otherwise passive victims. At the same time, this detracts from instances of state violence and avoids punitive discourse.

The adoption of such a framework is not surprising in a state with a deep tradition of legalism. ${ }^{31}$ Historically, judicial formalities and language have had a strong impact on social interactions among Colombians. ${ }^{32}$ Legalism has been used as an ideological pretext for exclusion and impunity, and to derail social movements and reduce their potential transformative value. ${ }^{33}$ The law has also influenced how the conflict in Colombia was fought. Armed groups adjusted their tactics away from large massacres to selective and smaller acts to make legal investigations within the framework of international humanitarian law and human rights more difficult. ${ }^{34}$ Colombia has continued to adapt this legalist tradition to the language of international justice by passing numerous laws and decrees - which can be referred to collectively as Colombia's 'international justice framework' - after the government signed the Rome Statute. The following section outlines the main contours of this framework.

${ }^{31}$ L.E. Nagle, 'Colombia's Faceless Justice: A Necessary Evil, Blind Impartiality or Modern Inquisition?', University of Pittsburgh Law Review, 61 (2000), 881, 895. Although many laws are not applied, they reinforce a culture of legalism in Colombia. For a discussion of how this is representative of Latin America in general, see J.A. Couso, 'The Changing Role of Law and Courts in Latin America: From an Obstacle to Social Change to a Tool of Social Equity', in R. Gargarella, P. Domingo, and T. Roux (eds.), Courts and Social Transformation in New Democracies: An Institutional Voice for the Poor? (Hampshire/ Burlington: Ashgate, 2006), 62.

32 'Basta Ya! Colombia: Memorias de Guerra y Dignidad', Grupo de Memoria Histórica (2013), 197.

33 Ibid., 197; Cepeda-Espinosa, 'Judicial Activism', 529, 541; Nagle, 'Colombia's Faceless Justice', 893-894.

34 Grupo de Memoria Histórica, Basta Ya!, 199. 


\section{Colombia's Justice and Peace Law}

In 2003, after a number of failed peace agreements, the Colombian government and the paramilitary groups reached a peace agreement known as the Ralito Accord. ${ }^{35}$ In 2005, after extensive debate with the paramilitary groups, the government passed the Justice and Peace Law (JPL) in an attempt to provide accountability for crimes committed by the leaders of the paramilitary groups. ${ }^{36}$

The JPL resembles a quasi-amnesty for crimes including genocide, crimes against humanity or war crimes committed by members of armed paramilitary groups. It provides significantly reduced sentences to combatants that demobilise and confess to their crimes. ${ }^{37}$ Procedure under the JPL differs from normal criminal proceedings in Colombia, as it employs an inquisitorial model and relies on the confession of an accused. ${ }^{38}$ Combatants who participate in the JPL and are found guilty receive full sentences, which are then suspended and substituted with reduced conditional sentences of between five and eight years. ${ }^{39}$ By contrast, 'normal' sentences for similar crimes run from fifty to sixty years of imprisonment. ${ }^{40}$

This lowered sentence is possible for all participants, regardless of the gravity, context, quantity or scale of crimes committed, and regardless of the rank or role of the participant in the paramilitary group. ${ }^{41}$ Although there is a large disparity between sentences under the JPL and the normal criminal justice system, the Colombian Constitutional Court has held that this does not violate the right to justice, and is not considered an amnesty or pardon because the normal sentences are only 'suspended' under the JPL; they are not replaced. ${ }^{42}$ The Court noted that although the

35 J. Easterday, 'Deciding the Fate of Complementarity: A Colombian Case Study', Arizona Journal of International and Comparative Law, 26 (2009), 49, 71-72.

36 Ley 975 de 2005, Ley de Justicia y Paz [Law 975 of 2005, Law of Justice and Peace], Diario Oficial [D.O.] 45.980 (25 July, 2005) (Colom.); Easterday, 'Deciding the Fate of Complementarity', 75-76. Law 782/2002 and Regulatory Decree 128/03 are also part of the JPL legal framework.

37 Artículo 17, Ley 975 de 2005 (full and truthful confessions).

38 Easterday, 'Deciding the Fate of Complementarity', 77-79.

39 Artículo 29, Ley 975 de 2005.

${ }^{40} \mathrm{~K}$. Ambos, The Colombian Peace Process and the Principle of Complementarity of the International Criminal Court: An Inductive, Situation-based Approach (Heidelberg: Springer, 2010), 4.

41 Ibid.

42 Corte Constitucional [C.C.], Gustavo Gallón Giraldo y Otros v. Colombia, Sentencia No. C-370/2006, May 18, 2006, VI.3.3.3; Ambos, The Colombian Peace Process, 72-73. 
JPL gives 'less rigorous' sentences, it requires cooperation with the justice system and with the victims, which makes the sentences conditional. ${ }^{43}$

The JPL also regulates the investigation and prosecution procedures for these crimes. Under its legal framework, investigations and prosecutions should focus on crime patterns in the context of alleged war crimes and crimes against humanity, the structural and organisational aspects of armed groups and external support given to the paramilitaries. A 2012 directive from the attorney general ordered all of its units to prioritise investigations of crimes committed by large criminal organisations and those most responsible for these crimes. ${ }^{44}$ This was further reflected in a December 2012 legislative reform to the JPL, ${ }^{45}$ which has led to investigations of paramilitary group leaders. ${ }^{46}$ The December reform also limited the ability for demobilised paramilitaries to be released from jail. Under its terms, if the state determines that an individual had not told the full truth, collaborated with the justice system or compensated their victims by 2014, their case will be transferred to regular courts. There, the conditional sentence suspension could be lifted. This reform also ended the victim's reparations program under the JPL. ${ }^{47}$

There have been significant problems with the execution of the JPL. In 2014, some 400 former paramilitaries were released from detention without a sentence because the process had taken so long that they had already been detained for the maximum eight-year sentence. ${ }^{48}$ Another serious problem arose when the Colombian authorities extradited twenty-nine high-level paramilitary leaders to the United States, ostensibly on drug-related charges, between September 2008 and March 2009. ${ }^{49}$ Their extradition came just as

43 Corte Constitucional [C.C.], Gustavo Gallón Giraldo y Otros v. Colombia, Sentencia No. C-370/2006, May 18, 2006, VI.3.3.3.

44 Attorney General of Colombia, Directiva No. 0001, 4 October 2012; available at www. fiscalia.gov.co/colombia/wp-content/uploads/Directiva-N\%C2\%B0-0001-del-4-de-octubre-de-2012.pdf; on how 'most responsible' is defined and applied by international courts, see X. Agirre Aranburu, 'Gravity of Crimes and Responsibility of the Suspect', in M. Bergsmo (ed.), Criteria for Prioritizing and Selecting Core International Crimes Cases (Oslo: Torkel Opsahl Academic EPublisher, 2010), 223; S. SáCouto and K. Cleary, 'The Gravity Threshold of the International Criminal Court', American University International Law Review, 23 (2008), 807, 813.

45 Artículo 16A, Ley 1592 de 2012, D.O. 48.633, 3 December 2012.

${ }^{46}$ OTP 2012 Report, para. 145. ${ }^{47}$ International Crisis Group, Transitional Justice, 5.

48 "'Estamos intentando desatascar los procesos": Hinestrosa', VerdadAbierta.com, 31 January 2014.

49 'Truth Behind Bars', International Human Rights Law Clinic (February 2010), 1 (International Human Rights Law Clinic, 'Truth Behind Bars'); '14 Members of Colombian Paramilitary Group Extradited to the United States to Face U.S. Drug 
they had started to divulge close links between the paramilitaries and the Colombian government and elected officials, and before prosecutors and victims could interrogate them about their crimes. ${ }^{50}$ Although officially these individuals can still participate in the JPL, in practice their participation has been limited and is now controlled by the US government. ${ }^{51}$

The JPL process has also been plagued by a critical congestion and backlog of cases. ${ }^{52}$ Collective confession hearings have alleviated some of these concerns, but the procedural framework could be more streamlined to improve the speed and efficiency of the process. ${ }^{53}$ Victims have had limited access to the hearings, which are held in locations and cities far from where the crimes were committed, and have difficulty participating in the process. ${ }^{54}$

Given these difficulties, some have questioned whether the JPL constitutes a genuine willingness of the Colombian state to prosecute Rome Statute crimes. ${ }^{55}$ The process has additionally demonstrated implementation challenges and shows how, in practice, the government attempts to maintain control over the portrayal of the conflict. This can be seen, for example, by the inquisitorial structure of trials, reliance on confessions, limited victim participation and the silencing of controversial voices through extradition.

\section{Other domestic trials and transitional justice reforms}

In addition to the JPL, other accountability measures also represent opportunities for the Colombian government to shape the portrayal of

Charges', United States Drug Enforcement Administration, 13 May 2008, available at www.justice.gov/dea/pubs/states/newsrel/mia051308.html.

50 International Human Rights Law Clinic, 'Truth Behind Bars', 5. This report notes that 'most Defendants avoided testifying about certain categories of crimes, such as forced recruitment of child combatants, forced displacement, sexual violence, kidnapping, torture, voter intimidation, and smuggling'. Ibid., citing 'Breaking the Grip? Obstacles to Justice for Paramilitary Mafias in Colombia', Human Rights Watch (2008), 37-39.

${ }^{51}$ International Human Rights Law Clinic, 'Truth Behind Bars', 3.

52 'Unidad Nacional de Justicia y Paz: arduo trabajo en un pais en conflicto', Fiscalia General de la Nacion, 3 October 2011.

${ }^{53}$ K. Ambos and F. Huber, 'The Colombian Peace Process and the Principle of Complementarity of the International Criminal Court: Is there sufficient willingness and ability on the part of the Colombian authorities or should the Prosecutor open an investigation now?', Extended version of the Statement in the 'Thematic Session: Colombia', ICC OTP - NGO roundtable, 19-20 October 2010 (The Hague, January 2011), 8.

${ }^{54}$ Ibid., 9.

55 See Easterday, 'Deciding the Fate of Complementarity'; Ambos and Huber, 'Thematic Session: Colombia', 6. 
the conflict. Trials taking place before the Colombian Supreme Court are investigating links between the government and paramilitaries. Paramilitary leaders divulged these links during their JPL confessions. Known as 'parapolitics', this scandal implicated congressmen, public officials, military, police and private entities. ${ }^{56}$ The Supreme Court, empowered to investigate public officials, opened investigations of members of Colombia's Congress. They are generally charged with concierto para delinquir, or agreeing to commit criminal activities with other persons. A small number of public officials have also been convicted on charges of committing violent crimes such as murder, enforced disappearances, kidnapping and torture.

While the link between paramilitary groups and state officials has long been known, these cases present an opportunity to develop this aspect of the story through criminal trials. However, the Colombian government has also attempted to control these proceedings. Former president of Colombia, Alvaro Uribe, exerted pressure against the judiciary while he was in office. Uribe's supporters were implicated in the parapolitics scandal and he proceeded to mount a campaign to delegitimise the judicial process. This prompted the Supreme Court to publish a communique denouncing the 'recurrent, systematic and even orchestrated' campaign of 'malicious and deceptively perverse comments designed exclusively to delegitimise the judicial investigations or to undermine their credibility. ${ }^{5}$

Finally, in 2011, the Colombian government passed a law known as the 'Victim's Law and Property Restitution'. This law is a historic development for victims of the Colombian conflict, as it focuses on providing truth, justice and reparations for victims, and includes a guarantee of non-repetition. ${ }^{58}$ The law treats victims broadly and provides benefits to victims of disappearances, murder, displacement and other human rights violations. They can receive damages, restitution, social services

56 OTP 2012 Report, para. 175.

57 'La Corte Supreme se pronuncia en pleno', Semana.com, available at www.semana.com/ on-line/corte-suprema-pronuncia-pleno/114499-3.aspx. The original text reads, 'La Corte ve con preocupación cómo de manera recurrente, sistemática e inclusive, orquestada se deslizan malintencionada y engañosamente comentarios malsanos, orientados exclusivamente a deslegitimar las investigaciones de los servidores judiciales o a minar su credibilidad' [author's translation]. See also 'Colombia: Proposal Threatens 'Parapolitics' Investigations, Proposed Constitutional Changes Harm Accountability, Favor Uribe Allies', Human Rights Watch (4 August 2008); Ambos and Huber, 'Thematic Session: Colombia', 10.

58 Law 1448 of 2011 , Arts 1, 8. 
and legal protection. The law also provides rights related to the victims' role in shaping the conflict narrative, including the creation of a national day of memory and the collection of victim testimonies.

Colombia has also taken steps to amend its constitution to include transitional justice provisions known as the 'Legal Framework for Peace'. Under this framework, prosecutors would prioritise investigations and prosecutions against those bearing the greatest responsibility for crimes against humanity and war crimes. Those cases not selected would be conditionally dropped. Some sentences could be suspended. The amendments passed in Congress, which still needs to pass implementing legislation at the time of writing. In August 2013, the Constitutional Court upheld the constitutionality of the amendments. ${ }^{59}$ The Constitutional Court also set out parameters that the Colombian Congress must adhere to when it adopts implementing legislation. One of these stipulates that a completely suspended sentence cannot be applied to those who have been convicted as 'most responsible' for genocide, crimes against humanity or war crimes that were committed in a systematic manner. ${ }^{60}$

Members of the Colombian military are also facing trial for crimes that fall within the ICC's jurisdiction. In particular, members of the military are being investigated for involvement in 'false positives' incidents, where members of the military killed civilians and counted them as combat deaths in exchange for rewards such as vacation time, medals and promotions. ${ }^{61}$ In December 2012, the Colombian Congress passed a bill amending three constitutional provisions to reform the military justice system. ${ }^{62}$ Known as the 'Military Justice Reform', the bill gave jurisdiction to military courts to investigate and prosecute military and police on active duty for crimes 'related to acts of military service'. All alleged violations of humanitarian law are to be tried in military courts, with the exception of a number of crimes that can only be tried in civilian courts: torture, extrajudicial killings, forced disappearance, sexual violence, crimes against humanity and enforced disappearance. In a contentious October 2013 decision, the Constitutional Court struck down the law on procedural grounds. ${ }^{63}$

These additions to the Colombian legal framework reflect a clear adoption of international justice norms. The ICC has had significant input into this process and has helped to shape Colombia's justice project. Through its public and private reports, the ICC is helping to

${ }^{59}$ Corte Constitucional [C.C.], Sentencia C-579/13 (28 August, 2013).

${ }^{60}$ OTP 2013 Report, para. 133. ${ }^{61}$ OTP 2012 Report, paras. 102, 180.

62 The bill amended articles 116, 152 and 221 of the Colombian Constitution.

${ }^{63}$ Corte Constitucional [C.C.], Sentencia C-740/13 (23 October 2013). 
shape the terms of the conflict narrative and maintain authority over international crimes. As can be seen in the interactions between the Court and the Colombian government, however, there is a tension between the ICC's retributive approach and Colombia's transitional justice approach.

The influence of the law, and specifically international criminal law, on the conflict appears to be growing. ${ }^{64}$ For example, in 2011, for the first time, the president publicly characterised it as an internal armed conflict, as opposed to a state of emergency. He specifically noted that Colombia was part of the ICC and therefore is obliged to recognise the laws and procedures of the Rome Statute, including those related to internal armed conflicts. However, he was careful to note that this recognition of an internal armed conflict in no way meant that the government was granting political or belligerent status to the armed groups, which he said were simply terrorists and drug traffickers. ${ }^{65}$ This forms one example of how the state is adopting the language of international law, but translating it to meet its own objectives.

\section{The 'shadow' of the ICC}

An examination of the Colombian framework, beyond its strictly legal components, shows ongoing power struggles over Colombia's sovereignty and its role in shaping the conflict narrative. Colombia's approach to the ICC has been relatively accommodating: it publicly acknowledges its relationship with the OTP and the importance of working together. The reach of this message of cooperation extends both externally and internally. Colombia's president has made a point of the state's cooperation with the ICC at the highest levels of international politics, including at the UN General Assembly. ${ }^{66}$ Significantly, the government has acknowledged the Court's role in the historic peace agreements with the FARC. ${ }^{67}$ Bringing the ICC into this delicate situation shows a deep level of engagement. By adopting and strategically employing the ICC's

64 Ibid., 226.

65 Article 3, Law No. 1448; See Presidencia República de Colombia, 'Reconocer conflicto armado interno no les da estatutos político a los terroristas', 6 May 2011, available at http://wsp.presidencia.gov.co/Prensa/2011/Mayo/Paginas/20110506_10.aspx.

66 Statement by the President of the Republic of Colombia, Juan Manuel Santos, Before the General Assembly of the United Nations in its Sixty-Eighth Session, 24 September 2013.

67 'Corte Penal Internacional, “aliada del proceso de paz”: Santos', Elespectador.com, 24 September 2013 (unofficial translation). 
normative framework, however, the Colombian government can further entrench its influence at the national level.

The Colombian government has largely taken up the ICC's terminology for framing crimes, but it has appropriated these terms in order to exert its own authority over the justice process and to reassert its sovereignty. This can be seen in Colombia's adoption of a similar prosecutorial strategy as the ICC. Faced with a burdened JPL process and a growing number of cases in the normal courts, as well as pressure from the ICC to investigate those 'most responsible', Colombia has adopted a prosecutorial strategy that prioritises the prosecution of leaders over the rank and file. The ICC has reacted negatively to this policy, and has suggested that, should Colombia fail to investigate lower-level perpetrators as well, it could violate its obligations under the Rome Statute. The Court thus appears to be pushing back against Colombia's assertion of sovereignty over its domestic proceedings, as is made particularly clear through the behaviour of the OTP vis-à-vis domestic initiatives.

It appears that the OTP is attempting to control the scope, content and goal of the prosecutions through evaluating the Colombian national proceedings and assessing whether its criminal justice framework fits within the normative vision of the ICC. The OTP has commented on nearly every piece of Colombian legislation dealing with atrocity crimes and has even been involved in discussions about the current peace talks with the FARC. ${ }^{68}$ Members of its staff have conducted multiple trips to the region, holding public and private meetings with government officials. ${ }^{69}$ The OTP has issued several press releases about Colombia and, exceptionally, released a report in 2012 on its activities there. ${ }^{70}$ The report asserted that there were reasonable grounds to believe that both non-state and state actors had committed war crimes and crimes against humanity. It also stated that its priorities will be to focus on the continuation of national proceedings, particularly proceedings related to those 'most responsible' and to crimes including forced displacement, sexual crimes and the false positive cases. ${ }^{71}$

68 OTP 2013 Report, paras. 131-2; see also 'Delegación de la CPI avaló proceso de paz', Semana.com, 15 April 2013; 'La CPI tiene interés en las ejecuciones extrajudiciales', El Espectador, 16 April 2013; 'Justicia transicional: la búsqueda de penas alternativas', Semana, 30 November 2013.

${ }^{69}$ OTP 2012 Report, para. 131; OTP 2013 Report, para. 147.

70 The OTP explicitly recognised that the report was exceptional, produced 'in recognition of the high level of public interest generated by this examination'. OTP 2012 Report, para. 1.

71 Ibid., paras. 22, 159. 
The prosecutor's report reveals the way in which the ICC exercises various oversight practices over the Colombian process. The OTP evaluated the national proceedings, labelling the JPL a 'transitional justice mechanism' and noting that it was 'designed to encourage paramilitaries to demobilise and to confess their crimes in exchange for reduced sentences'. ${ }^{72}$ The report's language implies that how the OTP evaluates whether proceedings are genuine will involve analysing information about the specific crimes allegedly committed by each accused, so as to understand the operational behaviour of the leadership of each group. It also suggests that sentencing will inform its evaluation of genuineness. The report reiterated that Colombian trials should prioritise those most responsible, and stated that information and evidence concerning the origins, promotion, consolidation and expansion of paramilitary groups is spread out among courts and prosecutors in a way that may hamper the proper contextualisation of the crimes committed and a comprehensive understanding of the complexity of the phenomenon'. ${ }^{73}$ This suggests that describing the context of the conflict is important to the ICC and that there exists a 'proper' way to do this, including by altering the local jurisdiction of the cases.

In addition to asserting oversight over the domestic process through public reports, the OTP has attempted to engage directly with actors in the domestic judiciary. In late 2013, Prosecutor Bensouda sent two letters to the Colombian Constitutional Court about the Legal Framework for Peace. The letters touched on two of the most controversial aspects of the legislation: alternative sentencing ${ }^{74}$ and prosecutorial strategy. ${ }^{75}$ One letter stated that a complete suspension of incarceration for those most responsible for atrocity crimes - even if they had been tried and convicted - would constitute a violation of international law and of Colombia's obligations under the Rome Statute.

The prosecutor also carved out specific roles for domestic courts and the ICC, qualifying her prosecutorial discretion to try only those 'most responsible' as something unique to the ICC. She clarified to the Colombian courts that, although her office focused on investigating and trying the 'most responsible', this should not be interpreted as a

${ }^{72}$ Ibid., para. $11 .{ }^{73}$ Ibid., para. 210.

${ }^{74}$ Letter from ICC OTP to the President of the Colombian Constitutional Court, 26 July 2013, available at www.semana.com/upload/documentos/Documento_354581_20130817.pdf.

${ }^{75}$ Letter from ICC OTP to the President of the Colombian Constitutional Court, 7 August 2013, available at www.semana.com/upload/documentos/Documento_354436_20130817.pdf. 
precedent that authorises states to follow the same strategy. ${ }^{76}$ Rather, the OTP works with a focus on two levels of combating impunity, first by initiating processes against those most responsible for the crimes, and second by promoting domestic processes against those that have 'lesser responsibility'. ${ }^{77}$ These letters appear to contradict the OTP's previous message to Colombia about focusing its proceedings on those who bear the greatest responsibility for the most serious crimes. Furthermore, while the OTP seeks to foster a kind of legal 'mimicry' by promoting its form of international criminal law, it discourages the independent exercise of a domestic prosecutorial strategy. As another example of the OTP's retributive focus, it requires Colombia to impose at least some term of imprisonment in order to comply with the Rome Statute.

The response to the OTP's efforts to exert influence was direct: Colombia's prosecutor general, Eduardo Montealegre, defended the state's position and challenged Bensouda's position. Montealegre maintained that the government's proposed policy adheres to the letter of the law and follows the most recent developments in international law; further, he claimed that international law has adapted itself to transitional justice. He also noted that the OTP's position followed retributive theories of criminal justice, which he distinguished from Colombia's transitional justice approach. Under a transitional justice theory, the state can try those 'most responsible' and also impose alternative sentences. $^{78}$

The message from The Hague thus appears to be mixed: on the one hand it supports the Colombian proceedings and the state's transitional justice initiatives, but on the other it signals to domestic authorities that the Court should maintain influence over domestic prosecutions. In particular, while stating that it was satisfied with Colombia's prioritisation of the prosecution of those 'most responsible', it continued to emphasise that the investigations needed to dig deeper. The ICC asserts this pressure through a call to broaden Colombia's conflict narrative - for instance, by highlighting connections between the state and paramilitaries that have historically been overlooked in the conflict. The Court also wants trials to focus on crimes against women and girls, including rape and forms of

76 Ibid. 77 Ibid.

78 'Fiscal rechaza críticas de la Corte Penal Internacional al proceso de paz', Elespectador. com, 23 October 2013. 
sexual violence, which it views as a gap in the conflict narrative as revealed through domestic charging practices. ${ }^{79}$

\section{Expressivism, victims and the notion of 'truth'}

While the ICC's approach has focused on punitive aspects of justice, the Colombian government's use of international justice discourse can be read through the optic of what some scholars have termed legal 'expressivism'; namely, that laws reflect and endorse certain values or messages. ${ }^{80}$ Expressivist approaches to criminal law focus on trials and punishment as a vehicle to strengthen respect for the rule of law. ${ }^{81}$ In this light, it is evident that the Colombian state has sought to craft a historical narrative through a transitional justice legal framework: the government has sought to authenticate its depiction of the conflict through a victim-centred discourse focusing on the value of the 'truth'. The state has also embarked upon a pedagogical dissemination of international justice norms through public statements and by constitutionalising these norms within its domestic legal framework.

The Colombian government's narrative position, then, emphasises the recognition of crimes and discovery of the truth over trying individual cases. Some politicians have argued that the truth can serve as a form of justice. $^{82}$ To be sure, there are multiple versions of the 'truth' of the conflict, and this is especially the case with regard to judicial truth. The fact that there are multiple versions of a conflict is not itself inherently problematic; however, there is a risk in Colombia that the state's 'official' narrative will reproduce structural inequalities and maintain historical silences around certain conflict-affected communities and individuals. Some have argued that conflict narratives that fail to adequately recognise victims of violence can detract from peace efforts and contribute to continued injustice. ${ }^{83}$

79 L. Chappell, R. Grey, and E. Waller, 'The Gender Justice Shadow of Complementarity: Lessons from the International Criminal Court's Preliminary Examinations in Guinea and Colombia', International Journal of Transitional Justice, 7 (2013), 455.

80 M.D. Rosen, 'Establishment, Expressivism, and Federalism', Chicago-Kent Law Review, 78 (2003), 669.

${ }^{81}$ Drumbl, 'Attrocity and Punishment', 173.

82 'La verdad puede ser una forma de justicia', Semana.com, 29 July 2013, available at: www. semana.com/nacion/articulo/la-verdad-puede-forma-justicia/352504-3.

83 E. Stanley, 'Truth commissions and the Recognition of State Crime', British Journal of Criminology, 45 (2005), 582. 
As previously noted, Colombia has a long legalist tradition and a history of using legal frameworks in response to conflict. One thing that has changed significantly is the role of victims in the Colombian legal vernacular. Previously, it was only either the government or the leaders of illegal armed groups that featured in the conflict. ${ }^{84}$ The emergence of the figure of the victim has changed the conflict discourse and, for the first time, victims may feature more prominently as agents in its development. ${ }^{85}$ Indeed, until recently, victim organisations have voluntarily excluded themselves from the transitional justice initiatives, because 'they doubted that conditions would allow for public clarification and recognition of the crimes committed. ${ }^{86}$

Victims have also become more prominent in Colombia's transitional justice legislation. International and domestic pressure in favour of victim's rights has influenced the balance between amnesties and criminal justice in Colombia's legal response to the conflict, beginning with the debate over the JPL. ${ }^{87}$ The JPL included 'victim' as a legal subject for the first time in Colombian law. ${ }^{88}$ Critics of the JPL and its implementation were then able to push for the passage of the Victim's Law, which in turn created the National Commission of Reparation and Reconciliation as well as the Historical Memory Group. More recently, victims have appeared on the agenda of peace talks between the FARC and the government.

However, the invocation of the victim has also served as a platform for Colombia to defend its position and strategy. This victim-centred rhetoric is historically unprecedented. In 2010, Colombia's President Santos addressed the Ninth Session of the ICC's Assembly of States Parties (ASP). He discussed the success of the JPL and how it had enabled cases against government officials, as well as the prosecution of a military official. He contended that the victims were at the 'centre' of Colombia's efforts, but noted the cost of implementing the Victims Law. ${ }^{89}$ In a speech before the UN General Assembly in 2013, Santos asked the international community to respect Colombia's right to pursue peace and claimed there was no way it could investigate all of the crimes committed during the conflict. Santos asserted that victims are the priority: 'If we

${ }^{84}$ C. Rojas, 'Las víctimas del conflict, o nuevo protagonista de la historia colombiana', RazonPublica.com, 26 August 2013.

${ }^{85}$ Ibid. ${ }^{86}$ M.V. Uribe, 'Memory in Times of War', Public Culture 21 (2009), 6.

87 Rojas, 'Las víctimas del conflict'. ${ }^{88}$ Ibid.

89 'Reparación a las víctimas será un esfuerzo de 22 mil millones de dólares, dice Santos en la CPI', Semana.com, 6 December 2010. 
understand justice and the fight against impunity - in a transition - as a set of measures aimed at satisfying the victims and not just as the administration of criminal processes, it is possible to find a comprehensive solution for all. ${ }^{90}$ UN Resident and Humanitarian Coordinator in Colombia, Fabrizio Hochschild, stated that it was the first time he remembers a president beginning a speech before the United Nations that focused on victims. ${ }^{91}$

The vernacularisation of international justice norms in Colombia has thus translated 'justice' as victim-oriented and as something broader than the administration of criminal processes. By focusing on the rights of victims, the government emphasises the expressive value of atrocity crimes trials and the importance of establishing the 'truth' about the conflict. However, the government avoids speaking of the direct responsibility of the state for crimes committed against those victims. ${ }^{92}$ In addition, although Colombia's vernacularisation of international criminal justice places great emphasis on victims, they remain relatively absent from legal practice. The development of the narrative thus continues to be top-down, negotiated by those in power who have been the architects of the conflict.

Colombia's focus on the expressive value of trials and, in particular, on the role of the victim is to the government's advantage. This focus might arise out of the complicated national context, and the fact that the conflict is ongoing; a focus on retribution can complicate peace negotiations. As the government and the FARC work through a delicate negotiation process, this is an important factor. In addition to providing an alternate understanding of justice that may conflict with or contest the normative values of the ICC, the expressive value of trials in Colombia may also help reinforce the rule of law internally. This is important where large swathes of the country still have little government presence, and where people have turned away from formal legal structures in dispute settlement. ${ }^{93}$ It also sends a message of the central role of the government to areas of the country that were previously controlled by the FARC, ELN or paramilitaries.

90 Statement by the president of the Republic of Colombia, Juan Manuel Santos, Before the General Assembly of the United Nations in its Sixty-Eighth Session, 24 September 2013.

91 'ONU califica de 'histórico' discurso de Santos en Nueva York', Elespectador.com, 24 September 2013.

92 N.C. Sánchez, 'Santos y su bipolaridad con las víctimas'; see also "'Le pido perdón al Presidente Betancur a nombre de los colombianos”: Santos', Semana.com, 1 February 2012.

93 Nagle, Colombia's Faceless Justice. 
However, there are risks associated with a focus on the expressive value of trials - especially when undertaken to protect state power. Judicial trials do not necessarily provide an adequate site of narrative development. Many have argued that law is poorly suited to writing history. ${ }^{94}$ As Clifford Geertz famously noted, 'whatever the law is after, it is not the whole story'. ${ }^{95}$ This is even more salient when the focus of investigations is narrowed.

The trials and hearings conducted under Colombia's international justice framework could thus lead to skewed or partial versions of the conflict. ${ }^{96}$ Selective trials - reflected in Colombia's new prosecutorial strategy of focusing on those 'most responsible' - can lead to selective truths. Criminal trials are dominated by complex rules of procedure and evidence. Such rules can bolster the seeming 'authenticity' of the narrative, but they can also detract from it.

Trial management strategies, like the ones implemented in Colombia in efforts to streamline and reduce trial time, can also 'flatten' narratives. Interrupted performances are another risk: trials that end abruptly because an accused is no longer 'available' create partial narratives. This is especially true for processes that focus on a few select individuals, and where there is a risk that high-level perpetrators could be extradited to the United States on drug charges. Indeed, there is a real possibility that the Colombian government might act on other extradition requests for several high-level FARC members, including those participating in peace negotiations.

Another risk of the Colombian process is the fact that, while parties to the conflict have negotiated the international justice framework, victims and other constituencies of Colombian civil society have been largely absent from these negotiations. In some ways, this version of the truth might pose an obstacle to peace, as it arises out of a bargain between historically empowered actors and marginalises the grievances and roles of the un-empowered. The narrative that these trials produce may be incomplete or may reduce or eliminate uncomfortable facts. These risks might ultimately detract from the overall expressive value of the trials in addition to minimising their potential benefit. As Drumbl argues,

94 R.A. Wilson, Writing History in International Criminal Trials (New York: Cambridge University Press, 2011), 6.

95 C. Geertz, 'Fact and Law in Comparative Perspective', in C. Geertz, Local Knowledge: Further Essays in Interpretative Anthropology (New York: Basic Books, 1983), 167234, 173.

96 Uribe, 'Memory in Times of War', 5. 
'flattening the narratives to protect power drains some of their transformative content'. ${ }^{97}$ Flattening or transforming the conflict narrative is, I argue, a key aspect of the Colombian state's approach in its domestic uptake of the ICC's normative framework.

\section{Conclusion}

This chapter has explored how the Colombian government is using a vernacularised discourse of international justice to assert control over how the country's conflict is portrayed. The government's actions mirror a number of larger socio-legal effects, including externalised contestations over Colombian sovereignty and internalised contests over the other parties to the conflict. By controlling the forms of narration, there is a risk that the government's narrative will embed understandings of justice that are incommensurate with the lived experience of many sectors of society, thereby exacerbating existing societal exclusions and reinforcing powerful networks.

Tensions concerning how the conflict is presented reflect broader tensions over competing conceptions of sovereignty. The Colombian approach to transitional justice entails signalling to the ICC and other global actors that it retains its sovereignty and political supremacy. This is apparent through Colombia's statements before the United Nations and the ASP. Yet, internally, Colombia presents a complicated picture of rivalries and struggles for power. Although this chapter has focused on the Colombian government, there are other micro-contestations and active participants, including a vibrant victims' movement, and contestations between the executive and the judiciary. There has also been a striking difference of approach and rhetoric between the Santos government and its predecessor, with the current administration taking advantage of an opportunity to develop an authoritative conflict narrative. The government is also asserting its powers over other parties to the conflict and the political opposition. As discussed above, this includes a victim-centred rhetoric and a focus on expressivism over retribution. This approach further enables the government to solidify its position as 'victor', even in the case of a negotiated end to the conflict.

However, in application of the law, victims appear to have a more marginal role than the government's discourse would imply. For example, the JPL gave a central voice to perpetrators, that is, paramilitary

97 Drumbl, 'Atrocity and Punishment', 178. 
leaders who confessed to their crimes. In practice, this process has been criticised for not facilitating broad victim participation and for limiting the voices of victims. Although the JPL did give rise to the Historical Memory Group, which has investigated massacres and crimes, this 'voice' is distinct from what victims might have in the judicial context. It also reflects a historical lack of access to justice for those with little political capital. Thus, although the ICC's relationship with Colombia has led to victims playing a more central role in the conflict narrative and the development of victim-centred legislation, a closer look suggests that they have remained on the sidelines, as subjects of the state's political and judicial control. This, ultimately, could undermine the authority that the state struggles to maintain. ${ }^{98}$

Beyond the shadow of the ICC and its normative discourse, Colombian society faces broader challenges in resolving what has proven to be an intractable conflict. The Court's involvement in Colombia has had far-reaching effects that have extended beyond what legal tests and normative impositions could adequately address. Rather, the ICC has become an active participant in contestations surrounding the Colombian conflict narrative. The interaction between the Court and the Colombian government has given rise to a broader discursive struggle over the terms through which political power is exercised.

98 Clarke, Fictions of Justice, 146. 


\title{
Between justice and politics
}

The ICC's intervention in Libya

\author{
MARK KERSTEN
}

\section{Introduction}

Prior to the Arab Spring, there were few signs or predictions that the Arab world would attract the attention of the International Criminal Court (ICC). The events that unfolded and the effects of the Court on developments in conflict and post-conflict Libya speak to the tension between the vision of an apolitical pursuit for accountability and the deeply political work of the Court in practice. This chapter critically examines the effects of the ICC on the conflict in Libya and on the pursuit of international criminal accountability since the beginning of the Arab Spring in February 2011. It considers both the impact of the ICC on conflict and post-conflict Libya as well as the impact of the Court's intervention on the institution itself, and suggests that this reciprocal relationship epitomises the politics of international criminal justice. The central argument of the chapter builds upon a growing body of scholarship that recognises the role of political interests on international criminal justice and on the work of the ICC in particular. ${ }^{1}$ The Court's effects in Libya have ultimately been determined not by the ICC itself but rather by political actors and the political contexts in which it operates.

The chapter first contextualises the Court's intervention in Libya, followed by an examination of the politics of the UN Security Council's referral to the ICC. In the third section, the chapter focuses on the socalled peace versus justice debate as it pertains to Libya. The effects of the ICC's intervention on efforts to establish and negotiate peace and

Thanks to Kirsten Ainley and Elke Schwarz who generously took the time to read drafts of this chapter and offer their invaluable insights.

${ }^{1}$ See, e.g., G. Simpson, Law, War and Crime: War Crimes Trials and the Reinvention of International Law (Cambridge: Polity Press, 2007); A. Branch, Displacing Human Rights War and Intervention in Northern Uganda (New York: Oxford University Press, 2011). 
stability in Libya are assessed. The fourth section discusses the political instrumentalisation of the ICC's work by the 'international community' and intervening North Atlantic Treaty Organization (NATO) forces. Part five offers an assessment of the sharply dichotomous debate over where to try Saif Al-Islam Gaddafi and Abdullah Al-Senussi, the two surviving members of the Gaddafi regime against whom arrest warrants were issued. This leads to an analysis of the politics and law of Libya's admissibility challenges at the ICC. The chapter concludes by offering some reflections of the Court's role and its impact on conflict and postconflict Libya.

\section{The ICC's Libya intervention in context}

Few could have foreseen that Libya would be the target of an ICC investigation, that arrest warrants would be issued against its head of state, Muammar Gaddafi; his heir apparent, Saif Al-Islam Gaddafi; and his head of intelligence, Abdullah Al-Senussi - let alone that it would be the locus of a NATO military intervention drawing upon the doctrine of the 'Responsibility to Protect'. As Alex Bellamy points out, no crisis or conflict-monitoring group had Libya on its 'at risk' lists. ${ }^{3}$ On the contrary, just months before Gaddafi's crackdown on protesters, a number of states had praised Libya's human rights record during the country's Universal Periodic Review, while Foreign Policy's 2010 Failed States Index ranked Libya ahead of India, Turkey, Russia and Mexico - none of which would generally be considered candidates for foreign military intervention. ${ }^{4}$

In 2011, however, fissures in the four-decade-long rule of Muammar Gaddafi began to appear. Emboldened by events in neighbouring 'Arab Spring' states in the early months of the year, protesters, primarily in the eastern part of the country, took to the streets to voice ongoing socioeconomic concerns and demand reform. In response, the regime moved to crush what until then were largely peaceful demonstrations. Protests escalated in the eastern capital of Benghazi and quickly transformed into a full-scale rebellion, seeking the overthrow of the Gaddafi government. Increasingly fervent, organised and armed groups began clashing with the regime's feared security forces. The opposition also set up the

2 A. Bellamy, 'Libya and the Responsibility to Protect: The Exception and the Norm', Ethics \& International Affairs, 25 (2011), 263-269.

3 Ibid.

${ }^{4}$ The concept of failed states is controversial but oft-evoked in discussions regarding candidates for humanitarian intervention. 
National Transitional Council (NTC) to manage political objectives and present a political face to the people of Libya and the international community. As violence escalated, a consensus began to emerge among states at the UN Security Council and beyond: in order to prevent Gaddafi from indiscriminately slaughtering any challengers to his regime, concerted international action was needed. ${ }^{5}$

The situation in Libya was remarkable for the pace with which seemingly peaceful protests deteriorated into mass violence as well as the extent of the threat to civilian lives posed by the Gaddafi regime. ${ }^{6}$ Equally significant was the speed with which states reacted and responded by turning towards the ICC. Amongst others, the Organization of the Islamic Conference, the Arab League and the African Union called on the international community to become involved. The UN's High Commissioner for Human Rights likewise added her support for an investigation of what she declared were crimes against humanity being committed by Gaddafi forces. ${ }^{7}$ If detractors of international intervention had reservations, Libya's deputy permanent representative to the United Nations, Ibrahim Dabbashi, encouraged them to take action. On 21 February 2011 he declared:

We call on the UN Security Council to use the principle of the right to protect to take the necessary action to protect the Libyan people against the genocide ... We also call on the prosecutor of the International Criminal Court to start immediately investigating the crimes committed by Gaddafi. ${ }^{8}$

Emboldened, if not pressured, by support from key regional and international organisations and leaders, on 26 February 2011 the UN Security Council passed Resolution 1970, a package of sanctions aimed at pressuring the Gaddafi regime to desist in its violent crackdown on civilians in Libya. ${ }^{9}$ Amongst its measures was the Security Council's second-ever referral of a situation to the ICC.

${ }^{5}$ S. Chesterman, "Leading from Behind": The Responsibility to Protect, The Obama Doctrine, and Humanitarian Intervention after Libya', Ethics \& International Affairs, 3 (2011), 279-285.

${ }^{6}$ Ibid., 4.

7 See statement by Navi Pillay, UN High Commissioner for Human Rights, to the Fifteenth Special Session of the Human Rights Council, 'Situation of Human Rights in the Libyan Arab Jamahiriya' (25 February 2011).

${ }^{8}$ See M. Du Plessis and A. Louw, 'Justice and the Libyan Crisis: The ICC's Role under Security Council Resolution 1970', ISS Africa Briefing Paper (2011), 1-2.

9 UN Doc. S/RES/1970 (2011). 
The referral was roundly praised. Human rights groups highlighted, in particular, that it had been passed with unprecedented speed and was authorised unanimously by all members of the Council. ${ }^{10}$ For advocates and proponents of the Court, Resolution 1970 contained many important advances for the ICC and for the project of international criminal justice. A number of countries who are not ICC member states and which had, to varying degrees, opposed the ICC all voted in favour of the resolution. ${ }^{11}$ Despite these 'triumphs', however, it would be dangerous to overstate international support for the referral or the extent to which it was a 'victory' for international criminal justice. Indeed, the litany of celebratory statements obscured the deeply political and politically controversial contours of the referral.

\section{Mixing justice and politics: Security Council Resolution 1970}

Despite the violence of Libyan state forces, it was not clear that the Security Council would seek the ICC's intervention. A number of states on the Council were ambivalent about the prospect of the Court's involvement. However, when the Arab League issued a statement condemning the Gaddafi regime, the balance appeared to tip: a strong resolution and referral to the ICC became a political possibility. Still, even with the unanimous referral, statements by Security Council members revealed their anxiety. Following the passing of Resolution 1970, both the Chinese ambassador and his Russian counterpart avoided any mention of the ICC in explaining their decisions to support the resolution. Moreover, neither directly criticised Gaddafi or his government. China claimed that it was only because of 'special circumstances' that the resolution was passed while Russia took the opportunity to highlight that it 'opposed counterproductive interventions'. ${ }^{12}$ Meanwhile, the Indian ambassador suggested that India would have 'preferred a "calibrated approach" to the issue', suggesting that the state had its concerns as well. ${ }^{13}$

10 'UN: Security Council Refers Libya to ICC', Human Rights Watch (27 February 2011); 'United Nations Security Council Refers Libya to the ICC', Coalition for the International Criminal Court (27 February 2011); 'Unanimous Security Council vote a crucial moment for international justice', Amnesty International (27 February 2011).

11 This includes China, Russia, the United States and India.

12 See 'In Swift, Decisive Action, Security Council Imposes Tough Measures on Libyan Regime, Adopting Resolution 1970 in Wake of Crackdown on Protesters', UN Doc. SC/ 10187/Rev.1 (2011).

${ }^{13}$ Ibid. 
Nevertheless, an agreement was brokered. One consequence of the referral was to expose issues in the relationship between the Security Council and the Court and, in particular, the proximity of the Council member states' political interests with the supposed apolitical justice served by the Court. A key issue of contention for drafters of the ICC's Rome Statute had been the role of the Security Council in the Court's mandate. ${ }^{14}$ Proponents of the ICC were determined to avoid giving the Council too much influence over the functioning of the Court for fear it would result in politicisation of its work and would place international criminal justice at the whim of the Council's five permanent members. ${ }^{15}$ In Libya, however, this fear appeared to largely evaporate.

Yet the high politics of Resolution 1970 made the referral a matter of the political prerogatives of the Security Council's members as much as one of international criminal accountability. Three aspects of the resolution highlight the politicisation of the ICC's mandate: the exclusion of non-state parties from the jurisdiction of the Court, the inclusion of a reference to Article 16 of the Rome Statute and the temporal limitations imposed on the ICC's jurisdiction. Each will be considered in turn.

Similar to Resolution 1593 (2005), which referred the situation in Darfur to the ICC, Resolution 1970 precludes the ICC from investigating or prosecuting citizens of states that are not members of the Court. Operative paragraph 6 of the Resolution 1970 reads:

[The Security Council] ... Decides that nationals, current or former officials or personnel from a State outside the Libyan Arab Jamahiriya which is not a party to the Rome Statute of the International Criminal Court shall be subject to the exclusive jurisdiction of that State for all alleged acts or omissions arising out of or related to operations in the Libyan Arab Jamahiriya established or authorized by the Council, unless such exclusive jurisdiction has been expressly waived by the State. ${ }^{16}$

The exclusion of non-states parties in Resolution 1970 exposes a paradox in the treatment of the ICC by powerful states. This is particularly true of the United States, which insisted on the exclusion of non-states parties as a pre-condition for supporting the referral. ${ }^{17}$ Commentators have noted the paradox of having 'the United States putting forward a resolution to

${ }^{14}$ See M. Glasius, The International Criminal Court: A Global Civil Society Achievement (Oxford/New York: Routledge, 2006), 47-60.

15 Under Article 16 of the Rome Statute, negotiators eventually achieved a compromise that allowed the UN Security Council to defer investigations and prosecutions for twelve months, renewably.

${ }^{16}$ See Resolution 1970. ${ }^{17}$ See du Plessis and Louw, 'Justice and the Libyan Crisis', 2. 
the Security Council in support of a referral to a court from which it had insisted its military personnel and political elite were immune.' ${ }^{18}$ Moreover, the exclusion of non-states parties undermines a key goal of the Court: the achievement of universal jurisdiction. Brazil was the only ICC state party to openly express its reservations with expanding the Court's jurisdiction through the referral. ${ }^{19}$

The legality of excluding non-states parties from the ICC's jurisdiction is also highly questionable. In the context of the Security Council's referral of Sudan, Robert Cryer argued that the exclusion of non-states parties was legally dubious. Cryer's critique is equally applicable to Resolution 1970. As he argues, 'the exclusion of some states' nationals fails to respect the Prosecutor's independence and makes it difficult to reconcile the resolution with the principle of equality before the law. Some states' nationals, it would appear, are more equal than others. ${ }^{20}$ In short, the political tailoring of the referral to exclude non-states parties from the ICC's jurisdiction both undermines the Court's stated aim to achieve universal justice and suggests a hierarchy wherein similar crimes within the same context will not be similarly investigated and prosecuted.

A second controversial feature of the referral was the inclusion of a preambular reference 'recalling article 16 of the Rome Statute under which no investigation or prosecution may be commenced or proceeded with by the International Criminal Court for a period of 12 months after a Security Council request to that effect'. Article 16 of the Rome Statute can be invoked by the Council to suspend an investigation or prosecution by the Court for up to twelve months, renewable yearly, if either is deemed to pose a threat to international peace and security. The reference to Article 16 was almost certainly included in order to assuage the concerns of states that the ICC could complicate attempts to negotiate a political settlement to the conflict. ${ }^{21}$ In this context, the prospect of an Article 16 deferral can be seen as a concession to efforts to negotiate peace.

On the surface, the inclusion of Article 16 may be unproblematic. After all, it is part of the Rome Statute and it had previously been

18 T. Dunne and J. Gifkins, 'Libya and the State of Intervention', Australian Journal of International Affairs, 65 (2011), 515-529.

19 See UN Doc. SC/10187/Rev.1.

${ }^{20}$ R. Cryer, 'Sudan, Resolution 1593, and International Criminal Justice', Leiden Journal of International Law, 19 (2006), 195-222.

21 This is also suggested by Du Plessis and Louw, 'Justice and the Libyan Crisis', 2. It has further been suggested that the inclusion of the reference to Article 16 was part of a compromise necessary to have Resolution 1970 pass. See 'UNSC refers situation in Libya to ICC, Sanctions Gaddafi and Aides', Sudan Tribune, 27 February 2011. 
included in Resolution 1593 (2005). However, many international criminal justice scholars had expected - and perhaps hoped - that Article 16 would never become relevant in practice. ${ }^{22}$ The invocation of Article 16 would undoubtedly run contrary (at least temporarily) to attempts to end impunity and is certainly an uncomfortable proposition for those who fear manipulation of the ICC's work by the Security Council. The concern and controversy of the reference in the referral, then, lies both in the possibility that it would set a precedent for subsequent referrals and that it may indicate that states consider Article 16 a viable option where political prerogatives would trump the aims of justice and accountability.

The third notable element of Resolution 1970 is the restriction placed on the temporal jurisdiction of the ICC. Article 11 of the Rome Statute provides the ICC with jurisdiction for crimes allegedly perpetrated after 1 July 2002, the date the Court came into existence. ${ }^{23}$ Operative Paragraph 4 of the Security Council's resolution, however, reads that it: 'Decides to refer the situation in the Libyan Arab Jamahiriya since 15 February 2011 to the Prosecutor of the International Criminal Court. ${ }^{24}$ To date there has been no official explanation by states or by the United Nations as to why the ICC's jurisdiction was restricted to events post-February 15 . The Court has also remained silent on the subject. But it is clear that Security Council members negotiated this temporal limitation on the Court's jurisdiction.

It would appear that the restriction to events after 15 February 2011 was included in order to shield key Western states from having their affairs and relations with Libya come under judicial scrutiny. In the years preceding the intervention, many of the same Western states that ultimately intervened in Libya and helped overturn the regime had maintained close economic, political and intelligence connections with the Libyan government. These connections helped legitimise and sustain Gaddafi's regime. ${ }^{25}$ During the NATO intervention itself, the head

22 See, e.g., J. Gavron, 'Amnesties in the Light of Developments in International Law and the Establishment of the International Criminal Court', The International and Comparative Law Quarterly, 51 (2002), 91-117; C. Stahn, 'Complementarity, Amnesties and Alternative Forms of Justice: Some Interpretative Guidelines for the International Criminal Court', Journal of International Criminal Justice, 3 (2005), 698-699; M. Freeman, Necessary Evils - Amnesties and the Search for Justice (New York: Cambridge University Press, 2009), 81.

${ }^{23}$ Article 11, Rome Statute. ${ }^{24}$ See UN Doc. SC/10187/Rev.1.

25 See, e.g., R. St John, Libya - From Colony to Revolution (Oxford: Oneworld, 2011), 225-278; J. Wright, A History of Libya (London: C. Hurst \& Co., 2010), 221-229. 
rebel commander in Tripoli, Abdel Hakim Belhadj, declared that he was seeking to sue the British and American governments for their complicity in his extraordinary rendition and torture. ${ }^{26}$ Meanwhile, the disruption stemming from the conflict resulted in abandoned political offices flush with confidential government files. In September, documents found by officials from Human Rights Watch in the office of Gaddafi's defected foreign minister, Moussa Koussa, detailed American and UK engagement with Libyan intelligence and anti-terrorism practices, including the extraordinary rendition of individuals to be interrogated and tortured. ${ }^{27}$ In short, there is ample evidence to suggest that the ICC's temporal jurisdiction was curtailed to prevent investigators from shedding light on damaging relations between the Gaddafi regime and the same states that engineered its collapse.

\section{Peace versus, or with, justice in Libya?}

Just two weeks after the Security Council's referral, ICC prosecutor Luis Moreno-Ocampo opened an investigation into alleged crimes committed in Libya. On 16 May 2011 he requested that the Court issue the three arrest warrants; two months later, the Pre-Trial Chamber approved warrants against all three. This represented a remarkable turnaround from the time of the referral to the issuance of warrants, especially in comparison to previous ICC interventions. In Darfur, the Court took two years to move from accepting the Security Council's referral to issuing arrest warrants. Not unlike other contexts in which the ICC has intervened, a debate ensued as to the effects of the ICC's involvement on developments during the Libyan conflict, most notably on efforts to transition the country from conflict to peace. ${ }^{28}$ This is often referred to as the 'peace versus justice' debate. ${ }^{29}$

Numerous commentators claimed that the ICC's involvement would make a transition to peace in Libya less likely. It was proclaimed that the ICC's intervention would give Gaddafi an incentive to 'fight to the death and

${ }^{26}$ See 'Libya commander Abdel Hakim Belhaj to sue UK government', BBC News, 19 December 2011.

27 'Libya: Gaddafi regime's US-UK spy links revealed', BBC News, 4 September 2011.

${ }^{28}$ In particular, debates on the effects of the ICC on peace negotiations and peace processes have characterised analyses of the Court's involvement in northern Uganda and Darfur.

29 See R. Kerr and E. Mobekk, Peace and Justice - Seeking Accountability after War (Cambridge: Polity Press, 2007); C. L. Sriram and S. Pillay (eds.), Peace versus Justice? The Dilemma of Transitional Justice in Africa (Scottsville: University of KwaZulu-Naatal Press, 2010). 
take a lot of people down with him', ${ }^{30}$ that the ICC 'may have perpetuated, rather than ended, [Gaddafi's] crimes', ${ }^{31}$ and that Libya was mired 'in a civil war in large part because of Gaddafi's international prosecution.. ${ }^{32}$ Concerns that the ICC would obstruct a resolution to the conflict only increased later, when it appeared increasingly likely that the conflict would become a long, protracted civil war, and that the ICC would reinforce a military and political stalemate. There were two primary options of conflict resolution highlighted by observers during the conflict that could have been pursued by the ICC's intervention: the negotiation of a peace agreement between Gaddafi and the rebels, or the removal of Gaddafi by negotiating his exile or asylum. This section explores the possible effects of the ICC on both options. The analysis offered suggests that political actors and dynamics ultimately precluded any non-military solution to the war.

\section{Peace agreement between Gaddafi and the Libyan opposition}

It was not always clear that Gaddafi's removal from power was a necessary condition for a transition in Libya. Resolution 1973, authorising the establishment of a no-fly zone in Libya, said nothing that could justify outright regime change. ${ }^{33}$ While some states, including the United States and the United Kingdom, almost immediately called on Gaddafi to relinquish power, ${ }^{34}$ others worked to find a negotiated compromise between the rebels and his regime.

In April 2011, a five-member African Union (AU) High-Level Panel, led by South African president Jacob Zuma, travelled to Libya in an attempt to broker an end to hostilities. In addition to a cessation of all hostilities - including NATO airstrikes - the AU's peace plan included allowing the unimpeded delivery of humanitarian aid, the protection of

${ }^{30}$ M. Boot, 'Qaddafi Exile Unlikely', Commentary Magazine, 23 March 2011.

31 D. Saunders, 'When Justice Stands in the Way of a Dictator's Departure', Globe and Mail, 2 April 2011.

32 See, e.g., P. Sands, 'The ICC Arrest Warrants Will Make Colonel Gaddafi Dig in His Heels', The Guardian, 4 May 2011.

33 The targeting of Gaddafi himself, however, became a topic of heated debate and an area of much confusion. By June 2011, NATO officials admitted that they did see Gaddafi as a legitimate military target as the head of the regime's military command and control. Importantly, however, this is not spelled out in UN Security Council Resolution 1970. See 'Libya: Removing Gaddafi not allowed, says David Cameron', BBC News, 21 March 2011; and F. Townsend, 'NATO official: Gadhafi a legitimate target', CNN, 10 June 2011.

${ }^{34}$ E. O'Brien and A. Sinclair, 'The Libyan War: A Diplomatic History, February - August 2011', Center on International Cooperation (2011), 9-10. 
foreign nationals and official peace talks between rebels and the Gaddafi regime. On 11 April, it was announced that Gaddafi had accepted the AU road map. However, on the very same day, the rebels rejected the AU's plan. As Zuma and the AU delegation reached rebel-held Benghazi, they were greeted with slogans that declared 'African Union take Gaddafi with you'. Mustafa Abdel Jalil, who subsequently became the chair of the NTC, made it clear why the rebels rejected the plan: 'The African Union initiative does not include the departure of Gaddafi and his sons from the Libyan political scene, therefore it is outdated. ${ }^{35}$ In short, for the Libyan opposition, a peace negotiation that in any way legitimised Gaddafi, or that included provisions for him to maintain a position of power, would have been rejected as a condition to peace talks.

For his part, Gaddafi did not show any indication that he would step down as a precondition to talks. Moreover, there is no evidence that he sought to address the ICC's investigation as an issue at the negotiating table. Thus, it can neither be said that the Court's intervention gave Gaddafi an incentive to negotiate a peaceful resolution to the conflict, nor that it prevented negotiations from taking place. Furthermore, it is not possible to suggest that the arrest warrant against Gaddafi led to the failure of the peace negotiations. Rather, the preliminary talks consistently failed to move forward because a pre-condition for negotiations taking place could not be met: an agreement on the fate of Gaddafi. Indeed, the rebels went so far as to reject any negotiations that included Gaddafi. The ICC may have bolstered the ability of the NTC to reject negotiations, but, even if this is the case, it is difficult to imagine that the NTC could have persuaded the various militias to accept a deal. This is an important finding: the ICC cannot have a negative or a positive effect on a peace process if the parties in conflict are either unwilling or unable to negotiate peace.

\section{Negotiated exile/asylum for Gaddafi}

Reflecting the importance of Gaddafi's personal fate as a dynamic in resolving the conflict, the possibility of his going into exile was a key topic of contention throughout the civil war. Numerous states were reported to have offered Gaddafi exile. ${ }^{36}$ Western states were reportedly focused on

35 'Libyan Rebels Reject African Union Peace Plan', The Independent, 11 April 2011.

36 This included Uganda, Chad, Malawi, Venezuela and Zimbabwe. See D. Smith, 'Where Could Colonel Muammar Gaddafi Go If He Were Exiled?', The Guardian, 21 February 2011; and D. Sanger and E. Schmitt, 'U.S. and Allies Seek a Refuge for Qaddafi', The New York Times, 16 April 2011. 
non-ICC member states as possible targets. During attempts to re-ignite peace talks between the rebels and the Gaddafi regime led by Turkey, it was reported that NATO had privately acknowledged that it would approve of Gaddafi's exile to non-ICC-member states. ${ }^{37}$

Despite pleas from his closest advisors that he leave Libya, Gaddafi was steadfast in his refusal to accept any such deal. By contrast, many senior members in Gaddafi's coterie defected beginning just days after the conflict erupted in February $2011 .{ }^{38}$ It is difficult to attribute the defections of senior officials to any single aspect of the conflict including the ICC's intervention, investigations or arrest warrants. Such causal claims risk overly and inappropriately simplifying the multiple dynamics at play and the complexity of the conflict. (A fear of being killed by siding with Gaddafi - and perhaps losing the war - is likely to have played as much, if not more, of a role in the decision-making of former Gaddafi loyalists to defect.) Still, the apparent correlation between the ICC's involvement and Gaddafi's subsequent abandonment by his allies deserves careful analysis. In the end, however, assertions that the ICC closed the space available for Gaddafi to accept an offer of exile are misplaced. There is no evidence that he was ever interested in exploring that space in the first place.

\section{Instrumentalisation of the ICC in Libya}

In the wake of the unanimous vote to refer the situation in Libya to the ICC, Western states voiced their support for the Court and its role in the crisis. In a joint letter, UK prime minister David Cameron, French president Nicolas Sarkozy and US president Barack Obama expressed their confidence in the ICC's work, declaring that the Court 'is rightly investigating the crimes committed against civilians and the grievous violations of international law, ${ }^{39}$ In early May 2011, the US ambassador to the United Nations reaffirmed support for the ICC, stating that the administration 'welcome[d] the swift and thorough work the Prosecutor has done ... The specter of ICC prosecution is serious and imminent and should again warn those around Qadhafi about the perils of continuing to

37 These states included Sudan, Belarus and Zimbabwe. See I. Black, 'Turkey Asks Libya Summit to Back Peace Negotiations', The Guardian, 14 July 2011.

38 R. Spencer, 'Libya: Five Generals Defect as Pressure Mounts on Muammar Gaddafi', The Telegraph, 30 May 2011.

39 B. Obama, D. Cameron, and N. Sarkozy, 'Libya's Pathway to Peace', The New York Times, 14 April 2011. 
tie their fate to his. ${ }^{40}$ As the organisation leading the military intervention, NATO also similarly supported the work of the ICC. ${ }^{41}$

These statements made clear that the ICC's intervention was, in the eyes of intervening powers, singularly about targeting Gaddafi and his regime. Additionally, this language was critical in framing the intervention in Libya as one that was fundamentally about justice. ${ }^{42}$ Yet this lofty rhetoric obscured the fact that Western intervening forces were instrumentalising the ICC for political purposes such that, when it became a potential obstacle to shifting political goals, the Court's role in trying Gaddafi was largely abandoned. Indeed, attempts by intervening forces to push Gaddafi into exile as a tactic of conflict resolution ran contrary to the ICC's involvement insofar as they posed additional (and intentional) barriers to enforcing the Court's arrest warrants. Thus, there appears to have been significant double-speak by the intervening powers. They invoked and supported the ICC while exploring possible states for Gaddafi to permanently or temporarily evade prosecution.

As the conflict continued and it became clear that Gaddafi would not leave Libya, Western states increasingly accepted the possibility of the Libyan leader remaining in country. In response, Human Rights Watch argued that Security Council members 'should be reaffirming the message that impunity is no longer an option, instead of proffering a get out of jail free card to end a military stalemate'. ${ }^{43}$ The ICC's Office of the Prosecutor (OTP) also voiced concern, maintaining that Gaddafi could not remain in Libya. ${ }^{44}$ But these remarks coincided with an important shift in the rhetoric of Western states. When faced with questions about Gaddafi's fate, officials increasingly suggested that what happened to him was not a matter of international criminal law but 'up to the Libyan people'. Gaddafi's future was thus re-branded as a question of respect for the sovereign wishes of the Libyan people. Asked in late August 2011 where the 'Tripoli Three' should be tried, the US ambassador declared:

40 See remarks by Susan Rice, US Permanent Representative to the United Nations, to the Security Council, 'Briefing on Libya and the International Criminal Court' (4 May 2011).

${ }^{41}$ See press briefing on Libya by Oana Lungescu, NATO Spokesperson, and Wing Commander Mike Bracken, Operation Unified Protector Spokesperson (17 May 2011).

42 See D. Kaye, 'Wanted: Qaddafi \& Co. Can the ICC Arrest the Libya Three?', Foreign Affairs, 19 May 2011.

${ }^{43}$ R. Dicker, 'Handing Qaddafi a Get-Out-Of-Jail-Free Card', The New York Times, 1 August 2011.

${ }^{44}$ R. Taylor and C. Stephen, 'Gaddafi Can't be Left in Libya, Says International Criminal Court', The Guardian, 26 July 2011. 
This is something that must be decided not by the United States or any other government, but by the people of Libya and by the interim transitional government that we expect will soon be constituted ... These are all choices that the Libyan people will ultimately have to make for themselves. ${ }^{45}$

This shift in rhetoric also coincided with changes in the nature of the conflict. As noted above, during the summer of 2011, the stalemate between the rebels and pro-Gaddafi forces began to falter. By late August, Tripoli fell and the same NATO states that had intervened to support the opposition began to position themselves to benefit from the presumed economic windfall that an NTC-controlled Libya would enable. ${ }^{46}$

In this context, the calculus of Western states reverted from backing international criminal justice to other political interests in a post-Gaddafi Libya. The utility of the ICC - to frame the intervention in the name of justice and to marginalise and pressure Gaddafi - had been exhausted. In the context of building strong relations with a post-Gaddafi Libya, the shift towards employing language of ownership - that 'it was up to Libyans' was politically cunning. To argue against it would patronise Libyans, deny them a right to establish their own accountability mechanisms and potentially undermine the intervening powers' future economic and political role. Similarly, there was little incentive for the international community to insist that Gaddafi's death was a missed opportunity for accountability. ${ }^{47}$

The lack of commitment amongst intervening states to the obligations spelled out both in Resolution 1970 and in the Rome Statute was also made evident through two additional developments: the surrender of AlSenussi to Libya from Mauritania and the visit by Sudanese president Omar al-Bashir. In March 2012 it was confirmed that Al-Senussi had been arrested in a joint operation of French and Mauritanian officials in Nouakchott, Mauritania. ${ }^{48}$ Immediately following his arrest, Al-Senussi's

45 See C. Lynch, 'Rice Says Libyan People Can Decide Whether to Try Qaddafi; ICC Says Not So Fast', Foreign Policy, 23 August 2011.

${ }^{46}$ R. Cornwell, 'World Powers Scramble for a Stake in Future of the New Libya', The Independent, 23 August 2011.

${ }^{47}$ Despite the ICC prosecutor's belief that his death 'create[d] suspicions' that a war crime had been committed, the matter has never been investigated. The attitude of Western states following Gaddafi's death can thus be seen as an abrogation of responsibility to the very mandate they gave to the ICC. See 'ICC Says Muammar Gaddafi Killing May Be War Crime', BBC News, 16 December 2011.

${ }^{48}$ It is widely believed that intelligence officials from numerous states, primarily from the West, interrogated him while in detention. See L. Hilsum, 'Abdullah al-Senussi, Gaddafi's "Black Box"', FT Magazine, 2 June 2010; L. Prieur, 'Libya Steps Up Call for Senussi 
fate emerged as the centrepiece in an extradition dispute between Libya, France and the ICC. France had long sought custody of Al-Senussi for his role in the 1989 bombing of UTA Flight 772 in which 170 passengers, including 54 French citizens, had perished. ${ }^{49}$ The French government maintained that its role in capturing him gave it a privileged position in requesting his surrender to France. ${ }^{50}$ There is no evidence that France pushed for Al-Senussi's surrender to the ICC, despite the fact that it is a member state. The ICC was effectively cut out of the picture. ${ }^{51}$

In January 2012, Sudanese president Omar al-Bashir visited Tripoli. Bashir remains wanted by the ICC, yet he had also provided significant material support to the rebels during their fight against Gaddafi, whose removal Bashir called the 'best piece of news in Sudan's modern history'. ${ }^{52}$ Predictably, no Western state admonished Bashir's visit. Only the United States stated (two days after the visit) that it had brought the issue up with the NTC and disagreed with Bashir's visit, but that ' $[t]$ his is the first time as a free government [the NTC] have had to encounter these issues'. ${ }^{53}$ ICC member states, including France and the United Kingdom, remained silent, suggesting that their priorities, too, had shifted.

The possible effects and contributions of the ICC during the Libyan Revolution were ultimately shaped and even determined by the political prerogatives and interests of the Security Council and NATO powers. Commitment to the ICC's mandate was heeded only insofar as it advanced the political aims of the intervening powers, namely the marginalisation of Gaddafi. Once the Court stopped serving these interests, its work was of limited value. The relationship between the ICC and those who invoked it was thus not one of legal obligation, but rather political convenience.

\section{The ICC, Libya and 'local ownership'}

The decision of where to hold post-conflict judicial proceedings has always been politically charged. Gerry Simpson notes that the question

Transfer', Reuters, 19 March 2012; 'Mauritania Agrees to Extradite Senussi: Libya vice PM', RNW: International Justice Desk, 21 March 2012

49 L. Prieur and H. al Shachi, 'Mauritania Agrees to Senussi Extradition, Libya Says', Reuters, 20 March 2012.

50 Ibid.

${ }^{51}$ L. Harding and I. Black, 'Mauritania Extradites Gaddafi Spy Chief Senussi to Libya', The Guardian, 5 September 2012.

52 'Bashir Denounces Gaddafi During Libya Visit', ABC News, 8 January 2012.

53 'US opposes Sudan's Bashir visit to Libya', AFP, 9 January 2012. 
and controversy of where to adjudicate international crimes has coloured international criminal justice since its inception. 'Law's place' is complicated by the tension between the internationalisation of criminal justice and the fact that justice is best served at the local level where the crime has taken place, where the evidence is located, and where the witnesses live'. ${ }^{54}$ Simpson's observation points to the fact that the decision of where to serve justice for atrocities is rarely obvious and often rife with political manoeuvring. The case of Libya affirms this point.

Even before Gaddafi's demise, questions abounded about where the defendants could and should be tried. The debate was largely framed in dichotomous terms: either a trial would be conducted in Libya by Libyans or in The Hague by the ICC. This obscured middle-ground options and left the OTP with little choice but to support Libya's intentions to try Saif Al-Islam Gaddafi and Abdullah Al-Senussi in Libya.

If a trial in The Hague by ICC judges was ever a real possibility, it was short-lived. There was little-to-no apparent will on the part of the NTC or the international community to arrest any of the 'Tripoli Three' and surrender them to the Court. Nevertheless, a legal debate ensued over whether Libya was under an obligation to surrender Gaddafi or AlSenussi before bringing its admissibility challenge under the Court's complementarity regime. Human rights groups were adamant that they should be transferred to the ICC. ${ }^{55}$ This, in combination with concern that other Gaddafi-era officials would be physically abused and perhaps even tortured and killed if tried in Libya, belied scepticism amongst groups that Libya had the capacity to try key figures of the former regime. ${ }^{56}$ It remained clear, however, that Libyan authorities in the NTC had no interest in transferring either defendant to The Hague and that the Security Council had little interest in pressuring them to do so. As Ahmed Jehani, Libya's representative to the Court, declared: 'No amount of pressure will push Libya' to surrender Gaddafi or Senussi. ${ }^{57}$

Some observers suggested that a middle ground be pursued: holding an in situ trial in Libya or sequencing prosecutions between Libya and

${ }^{54}$ Simpson, Law, War and Crime, 30.

55 'Saif Gaddafi Must be Transferred Safely to ICC', Amnesty International (28 October 2011); 'Parliamentarians for Global Action (PGA) Calls for the Prompt Surrender of Saif Al Islam Gaddafi and Abdullah Al-Senussi to the International Criminal Court', Parliamentarians for Global Action (21 November 2011).

56 'Tunisia to Extradite Libya ex-PM if Fair Trial Possible', BBC News, 2 January 2012.

57 See 'Saif al-Islam to be Moved to Tripoli: Officials', AFP, 7 April 2012. 
The Hague. ${ }^{58}$ An in situ trial would have had numerous advantages: being in closer proximity to the victims, witnesses and evidence; contributing, perhaps, to building of the rule of law in Libya and providing a material legacy; and upholding 'international standards' for criminal justice. The latter concern was particularly salient amidst growing concerns that Libyan authorities would apply the death penalty against those convicted of crimes during the conflict.

The Rome Statute envisages the possibility of a travelling Court. ${ }^{59}$ Article 3(3) of the Statute notes that proceedings may take place 'elsewhere, whenever it considers it desirable' and the idea has been explored by the ICC in other contexts. It further appears that the OTP saw the option of an in situ trial favourably, as the OTP reported that it had offered the option of a trial by ICC judges to the NTC. ${ }^{60}$ However, while its reasoning remains unknown, the NTC rejected the possibility of an in situ trial. It became increasingly clear that the new Libyan government wanted local proceedings, with the support of the majority of Libyans and the acquiescence (or lack of interest) of much of the international community. ${ }^{61}$

The prosecutor also suggested that the ICC and the NTC could sequence prosecutions. Sequencing, envisioned under Article 94 of the Rome Statute, would entail Libya trying Gaddafi and Al-Senussi and subsequently transferring them to the ICC to be tried over the alleged crimes outlined in their indictment (or vice versa) ${ }^{62}$ Importantly, a trial at the ICC might have given time for the Libyan government to stabilise and to build an independent judiciary capable of trying Gaddafi and AlSenussi domestically for crimes other than those charged by the Court. Indeed, sequencing could have ensured that alleged crimes committed before and after 15 February 2011 were investigated and prosecuted by Libya before (or after) Gaddafi and Al-Senussi faced charges relating to their conduct during the uprising.

58 See D. Kaye, 'What to Do with Qaddafi?', The New York Times, 31 August 2011.

${ }^{59}$ For an analysis of this issue, see S. Ford, 'The International Criminal Court and Proximity to the Scene of the Crime: Does the Rome Statute Permit All of the ICC's Trials to Take Place at Local or Regional Chambers?', John Marshall Law Review, 43 (2010), 715.

${ }^{60}$ Prosecutor's Submissions on the Prosecutor's recent trip to Libya, Prosecutor v. Gaddafi and Al-Senussi, Situation in Libya, ICC-01/11-01/11, Pre-Trial Chamber I, ICC, 25 November 2011.

${ }^{61}$ See F. Murphy, 'Libya Vows It, Not ICC, Will Try Saif, Senussi', Reuters, 20 November 2011; C. Stephen, 'Saif Gaddafi Sets Libya's New Rulers a Test of Commitment to Human Rights', The Guardian, 7 January 2012.

62 See C. Stahn, 'Libya, the International Criminal Court and Complementarity - A Test for "Shared Responsibility", Journal of International Criminal Justice, 10 (2012), 325-349. 
The role of Western states that had invoked and supported the ICC's involvement in Libya helped to determine these outcomes. It is a distinct possibility that had these states used their influence to support the Court's mandate, the ICC would have had more leverage either to gain custody of accused, to negotiate with Libyan authorities to establish an in situ proceeding or at the very least to participate in the process. By the same token, it is important to consider the possibility that the lack of willingness on the part of Libyan authorities for these options was at least partly due to the fact that the Court did very little to communicate or demonstrate its work locally or to establish any kind of local presence during the conflict. ${ }^{63}$ The ICC thus appeared foreign and removed, and Libyans understandably felt reluctant handing over key individuals from the Gaddafi regime to a Court they hardly knew. As the executive director of Lawyers for Justice in Libya noted:

The press and NGOs were in Libya and were gathering evidence but there was no visible presence of the ICC. People were not clear as to what should happen after the indictments and did not understand why, for example, the BBC was in Libya but the ICC was not. That the words of the ICC and the international community were not backed up by the actions in the country and the lack of communication was a real problem. ${ }^{64}$

With a minimal presence in the country during the war, the ICC likely hampered the possibility of playing a more proactive role in prosecuting the accused. Combined with insufficient interest from the international community, this difficult situation left the OTP with little choice but to support the NTC's desire to try the accused in Libya. ${ }^{65}$

\section{Libya's admissibility challenge(s)}

On 1 May 2012, Libya officially filed its admissibility challenge at the ICC. Lawyers representing the new regime in Tripoli argued that the case was inadmissible on the grounds that its national judicial system is 'actively investigating Mr. Gaddafi and Mr. Al-Senussi for their alleged criminal responsibility for multiple acts of murder and persecution, committed

${ }^{63}$ See E. Saudi, 'Milestones in International Criminal Justice', Chatham House Meeting Summary: International Law Programme (2011), 10.

${ }^{64}$ Ibid.

65 Timothy William Waters has argued that Moreno-Ocampo's acquiescence was pragmatic and a response to needing the cooperation of Libyan authorities 'to have any hope of influencing the process'. See T. Waters, 'Let Tripoli Try Saif al-Islam - Why the Qaddafi Trial is the Wrong Case for the ICC', Foreign Affairs, 9 December 2011. 
pursuant to or in furtherance of State policy, amounting to crimes against humanity' ${ }^{66}$ The resultant legal battle created acrimonious divisions within the ICC and, more specifically, between the OTP and the Office of Public Counsel for the Defence (OPCD).

Despite widespread concerns that holding fair trials may be impossible in Libya, the OTP has sided with Libya's insistence upon trying Gaddafi and Senussi itself. In Moreno-Ocampo's words, 'The standard of the ICC is that it has to be a judicial process that is not organised to shield the suspect ... and I respect that it's important for the cases to be tried in Libya ... and I am not competing for the case. ${ }^{67}$ Rather than holding up the orthodox standard of complementarity, whereby a state has to persuade ICC judges that it is actively and genuinely able and willing to prosecute the same individuals for the same crimes, the OTP apparently calculated that it was better to argue that its initial investigation had contributed positively to Libya's pursuit of justice. ${ }^{68}$ There are a number of plausible reasons for this leniency.

First, the OTP's position can be seen as paying respect to the obvious interest and willingness of Libyans - not just the government - to hold trials themselves. In this context, denying that Libya had any right to investigate or prosecute Gaddafi or Al-Senussi would have been tantamount to declaring that Libya's interest and efforts were irrelevant. Relatedly, there was a risk of conflating the previous, autocratic regime with the new transitional one.

Other reasons contributed to the OTP's position towards Libya's admissibility challenges. It was not a given that the OTP would be able to successfully convict Gaddafi. The Libya Working Group noted in February 2012 that ' $t$ t here is speculation that the ICC does not want Saif to be put on trial in The Hague as they do not have a strong case against him'. ${ }^{69}$ Timothy William Waters has argued, alternatively, that Moreno-Ocampo's acquiescence was a pragmatic response aimed at ensuring the cooperation of Libyan authorities

66 Application on Behalf of the Government of Libya Pursuant to Article 19 of the Rome Statute, Prosecutor v. Gaddafi and Al-Senussi, Situation in Libya, ICC-01/11-01/11, PreTrial Chamber I, ICC, 1 May 2012, para. 1.

67 'No Libyan Response on Gaddafi Son as Deadline Nears', BBC News, 10 January 2012.

${ }^{68}$ It should be noted that, in response to Libya's admissibility challenge, the OTP has expressed some concern about the fact that Saif is not in the custody of Libya. See Prosecution response to Application on behalf of the Government of Libya pursuant to Article 19 of the Rome Statute, Prosecutor v. Gaddafi and Al-Senussi, Situation in Libya, ICC-01/11-01/11, Pre-Trail Chamber I, ICC, 5 June 2012.

${ }^{69}$ See 'Libya's Recovery: Prospects and Perils', Chatham House MENA Programme: Libya Working Group Meeting Summary (2012), 6. 
so as 'to have any hope of influencing the process'. ${ }^{70}$ The ICC has received limited support from the Security Council as well, which appeared largely uninterested in the pursuit of post-Gaddafi accountability. The international community's disinterest in pressing for trials at the ICC has acted as a virtual endorsement of Libya's intent to prosecute both of the accused.

Not long after the civil war concluded, the OTP shifted its focus away from seeking custody of Gaddafi or Al-Senussi towards framing the Court's role in Libya as contributing to 'positive complementarity'. ${ }^{71}$ The prosecutor argued that 'the ICC is still providing an important service, because we will ensure justice in Libya, whoever will do it. ${ }^{72}$ Moreover, he appeared on numerous occasions with NTC leaders, reaffirming the perception that his office's role is to support rather than to compete with Libya. This may have also been a pragmatic framing on Moreno-Ocampo's part. It does not appear that the Court will have much, if any, impact on the prosecution of Gaddafi or Al-Senussi, irrespective of Libya's admissibility challenges. Claiming a degree of responsibility by couching arguments in terms of positive complementarity may thus have served to avoid the ICC from appearing impotent.

The attitude of the OTP led to tensions within the Court, especially between the OTP and the OPCD, which has insisted that both men be tried in The Hague. In November 2011, the OPCD claimed that the OTP was employing a double standard in its application of complementarity in the context of Libya, ${ }^{73}$ and it later filed a motion with the ICC's Appeals Chamber to disqualify Moreno-Ocampo due to 'an objective appearance that the Prosecutor is affiliated with both the political cause and legal positions of the NTC government'. ${ }^{74}$ The application was ultimately dismissed but not before judges admonished the prosecutor, declaring that his 'behaviour was clearly inappropriate in light of the

70 T. Waters, 'Let Tripoli Try Saif al-Islam - Why the Qaddafi Trial is the Wrong Case for the ICC', Foreign Affairs, 9 December 2011.

${ }^{71}$ See C. Stahn, 'Taking Complementarity Seriously: On the Sense and Sensibility of "Classical", "Positive" and "Negative" Complementarity", in C. Stahn and M. El Zeidy (eds.), The International Criminal Court and Complementarity: From Theory to Practice (Cambridge: Cambridge University Press, 2011), 233-282.

72 See T. Papenfuss, 'Interview with Luis Moreno Ocampo, Chief Prosecutor of the International Criminal Court', Global Observatory, 25 January 2012.

73 See OPCD Request for Authorisation to Present Observations in Proceedings Concerning Mr Saif Gaddafi, Prosecutor v. Gaddafi and Al-Senussi, Situation in Libya, ICC-01/11-01/ 11, Pre-Trial Chamber I, ICC, 28 November 2011.

${ }^{74}$ See Request to Disqualify the Prosecutor from Participating in the Case Against Mr Saif Al Islam Gaddafi, Prosecutor v. Gaddafi and Al-Senussi, ICC-01/11-01/11, The Appeals Chamber, ICC, 3 May 2012, para. 28. The application was subsequently dismissed. 
presumption of innocence' and 'may lead observers to question the integrity of the Court as a whole. 75

As time passed, it became clear that the key to the admissibility challenges was whether Libya could demonstrate that it had custody of the accused. With Al-Senussi in the custody of the Libyan government and Tripoli having begun proceedings against the former intelligence chief, the judges in Pre-Trial Chamber I ruled that the case against him was inadmissible before the ICC. ${ }^{76}$ Ultimately, the chamber found that 'the same case against Mr. Al-Senussi that is before the Court is currently subject to domestic proceedings being conducted by the competent authorities of Libya - which has jurisdiction over the case - and that Libya is not unwilling or unable genuinely to carry out its proceedings in relation to the case. ${ }^{77}$ In response, one of Libya's legal representatives declared that the ruling 'vindicates the efforts [the Libyan government] has made to give effect to the principle of complementarity, which allows Libya to conduct the trial of Mr. Senussi if it satisfies the court, as it has done, that it can conduct a fair trial." ${ }^{78}$

By contrast, because Gaddafi is not in the custody of the national authorities, Libya has had a more difficult time convincing the Court that he too should be prosecuted there. The government sought to publicly demonstrate its preparations to try Gaddafi: it unveiled a refurbished courtroom in Tripoli and a personal prison for him. However, despite numerous announcements suggesting that Gaddafi would be transferred from Zintan to Tripoli, the government has been unable to gain custody of him. In line with Article 17(3) of the Rome Statute, the OPCD put this argument forward in claiming that Libya's admissibility challenge should be rejected. ${ }^{79}$

Ultimately, the Libyan government's failure to gain custody of Gaddafi meant that the OPCD 'won' the admissibility challenge. In May 2013, ICC judges ruled that Gaddafi's case was admissible before the Court because, in part, the state was unable to prosecute him so long as he remained outside the

75 Application on behalf of the Government of Libya pursuant to Article 19 of the Rome Statute, Prosecutor v. Gaddafi and Al-Senussi, Situation in Libya, ICC-01/11-01/11, PreTrial Chamber I, ICC, 3 May 2012.

${ }^{76}$ See Decision on the admissibility of the case against Abdullah Al-Senussi, Prosecutor v. Gaddafi and Al-Senussi, Situation in Libya, ICC-01/11-01/11, Pre-Trial Chamber I, ICC, 11 October 2013.

77 Ibid., para. 311

78 'Gaddafi-era spy chief al-Senussi to be tried in Libya', BBC News, 11 October 2013.

79 Public Redacted Version of the Corrigendum to the 'Defence Response to the "Application on behalf of the Government of Libya pursuant to Article 19 of the Rome Statute"', Prosecutor v. Gaddafi and Al-Senussi, Situation in Libya, ICC-01/11-01/11, PreTrial Chamber I, ICC, 31 July 2012, paras. 358-368. 
custody of Libyan authorities. It found that the 'national system cannot yet be applied in full in areas or aspects relevant to the case, being thus "unavailable" within the terms of article 17(3) of the Statute'. As a consequence, the chamber held, "Libya is "unable to obtain the accused" and the necessary testimony, and is also "otherwise unable to carry out [the] proceedings" in the case against Mr. Gaddafi in compliance with its national laws. ${ }^{80}$

Libya appealed the judgment, continuing to contend that Gaddafi should be tried domestically. Libya's justice minister responded that ' $[w]$ e will give what is needed to convince the ICC that Libya is capable of conducting a fair trial in accordance with international standards ${ }^{81}$ It appears unlikely, however, that Gaddafi will be transferred from Zintan into the custody of central authorities. Fearing for Gaddafi's security and potentially his life if transferred to Tripoli, the Zintani militia holding him has claimed that it will host his trial. The Zintani brigade has benefitted from leveraging its custody of their prized prisoner. Indeed, Zintani defence minister Osama al-Juwali's surprise appointment to his post was reportedly linked to Zintan's continued custody of Gaddafi. ${ }^{82}$

Libya has thus been partially successful in its admissibility challenges. However, the nature of the admissibility hearings was not about where Gaddafi and Al-Senussi would be tried; that question had been answered before the Libyan uprising had even concluded. Emboldened by a mixture of support and silence from the international community, Libya was clear that it would try Gaddafi and Senussi. The admissibility challenges were instead about whether or not the ICC would endorse Libya's intentions. Furthermore, it remains difficult to see what ultimate effect the ICC will have on criminal accountability in post-Gaddafi Libya: regardless of what the Court has said, it does not appear that Libya would surrender either of the accused to The Hague.

\section{Concluding reflections}

This chapter has sought to demonstrate that the effects of the ICC in Libya have been bound, mitigated and, in some instances, determined by

${ }^{80}$ Decision on the admissibility of the case against Saif Al-Islam Gaddafi, Prosecutor v. Gaddafi and Al-Senussi, Situation in Libya, ICC-01/11, Pre-Trial Chamber I, ICC, 31 May 2013, para. 205.

${ }^{81}$ M. Gumuchian and G. Schennib, 'Libya to Appeal ICC Ruling to Hand Over Gaddafi's Son', Reuters, 2 June 2013.

82 C. Stephen and L. Harding, 'Libyan PM Snubs Islamists with Cabinet to Please Western Backers', The Guardian, 22 November 2011. 
the political actors and political context in which the ICC intervened. From its inception, the political considerations and interests of the UN Security Council's major stakeholders tailored Resolution 1970. The ICC's intervention at the behest of the Council then left the Court vulnerable to instrumentalisation: after the ICC had served the political goals of NATO states, support for its mandate rapidly dwindled. Once willing to back its role in Libya in order to legitimise the intervention and marginalise the Gaddafi regime, intervening states quickly abandoned the Court. This volte face has left the ICC in a difficult position. Demanding the surrender of individuals knowing that it would never happen, and where there was virtually no political support for such an outcome, risked creating an impression of impotence. The OTP has instead sought to claim a victory for 'positive complementarity', but it had little other choice. ${ }^{83}$

The Court's experience in Libya points to a central tension facing the Court: on the one hand, there is an obvious desire to investigate crimes committed in non-member states. Doing so, however, requires playing by the political rules set by the Security Council. On the other hand, tethering the politics of the Council with the accountability sought by the ICC guarantees that the interests of the most powerful states will mould the scope of the Court's work. Resolution 1970 ensured that atrocities in Libya would be investigated but guaranteed that this would be done selectively. ${ }^{84}$ Libya may thus teach the ICC a harsh lesson: Security Council referrals come at too large a cost to its own legitimacy.

The Court's ongoing relationship with the Security Council demands greater scrutiny - from scholars as well as from proponents of the ICC. The relationship will continue to shape the potential for the Court to investigate some of the worst human rights violations. Amongst the most pressing is the situation in Syria. However, even if a referral of Syria becomes a possibility, unless there is a greater political commitment to the Court's mandate from the Council, there is good reason for the ICC to be wary of engaging in yet another highly volatile conflict. Ultimately, the Court's intervention in Libya has had mixed effects. In a

83

On a visit to Tripoli, Luis Moreno-Ocampo, for example, declared, 'In May, we requested a warrant because Libyans couldn't do justice in Libya. Now, as soon as Libyans decide to do justice they could do justice and we'll help them to do it.' See 'Saif al-Islam Gaddafi Can Face Trial in Libya - ICC', BBC News, 22 November 2011.

84 As Carsten Stahn writes, 'The language of the SC Res. 1970 stands as an unfortunate precedent for future practice'. See Stahn, 'Libya, the International Criminal Court and Complementarity', 348. 
situation as complex as that of the Libyan revolution, civil war and transition, such an outcome is unsurprising. But, as this chapter has argued, the effects of the ICC's intervention were shaped and determined not only by the Court's decision-making and behaviour, but also by the constraints imposed upon it, given the broader political context in which it operates. 


\title{
Peace making, justice and the ICC
}

\author{
JUAN E. MÉNDEZ AND JEREMY KELLEY
}

\section{Introduction}

Many accounts of the International Criminal Court (ICC) treat it as an isolated legal institution tasked with adjudicating international crimes. The project of international criminal accountability is taken to be separate from peace processes, entrenching a binary distinction between peace and justice. By contrast, this chapter locates the work of the ICC within the broader context of peace making, as its founding documents had envisioned. The Court's governing Statute recognises the intrinsic link between international criminal justice and peace. By consenting to this treaty, the Court's states parties recognised that 'grave crimes threaten the peace, security and well-being of the world' and expressed determination 'to put an end to impunity for the perpetrators of these crimes and thus to contribute to the prevention of such crimes'. ${ }^{1}$ To achieve this they agreed 'that it is the duty of every State to exercise its criminal jurisdiction over those responsible for international crimes' ${ }^{2}$ and established an institution that would intervene when states cannot or will not exercise that responsibility themselves.

States party to the Statute recognised that this obligation is not limited solely to its signatories. Under international humanitarian law and human rights law, states are required to investigate, prosecute and punish international crimes. This obligation originates in the genocide and torture conventions, in the legacy of Nuremberg, in the notion of 'crimes against humanity', in the Geneva Conventions with respect to war crimes and in the jurisprudence of all major human rights tribunals in the last quarter century. After the Nuremberg and Tokyo trials there was an early emphasis on criminal accountability and punishment during a period when the first human rights treaties were also being drafted. The Genocide Convention of 1948 and the four Geneva Conventions of

\footnotetext{
${ }^{1}$ Preamble, Rome Statute. ${ }^{2}$ Ibid.
} 
1949 emphasised the obligation to investigate, prosecute and punish the most severe crimes. Human rights standard-setting in the mid-twentieth century abandoned the emphasis on individual criminal liability in favour of state responsibility. Despite references to the need for universal jurisdiction, for multilateral commissions of inquiry, and for international tribunals, when it came to atrocity crimes the human rights canon seemed to yield to notions of national sovereignty and non-intervention in internal affairs.

The Rome Statute revives the recognition that accountability and punishment are essential to the establishment of lasting peace. Building upon the legacy of the post-World War II tribunals, a novel framework has been developed to enforce individual accountability for perpetrators of mass crimes with the aspiration of deterring future violations and encouraging peaceful solutions to international and internal conflicts. Through placing the work of the ICC in the broader context of peace making, this chapter argues that justice complements efforts at conflict resolution. Ultimately, it contends that international criminal justice should be situated in relation to other post-conflict transitional mechanisms, which should work towards harmonised social and political objectives.

\section{The role of the 'justice track'}

Drawing upon the experience of Darfur, four approaches or 'tracks' of conflict resolution form distinct aspects of peace-building processes. ${ }^{3}$ The 'political track' involves peace negotiations and mediation. The 'security track' emphasises the protection of civilian populations from attack and deploying military units if necessary. The 'humanitarian track' works to deliver relief supplies and assistance. Finally, the 'justice track' seeks to break the cycle of impunity for crimes already committed and works towards deterring future violations.

The 'justice track' forms an essential aspect of the peace-building process. It refers to the investigation, prosecution and punishment of those most responsible for violence and victimisation of civilian populations. Without confronting the crimes of the past, individual victims and communities struggle to obtain closure and move on to a lasting peaceful solution. Some well-meaning advocates of 'peace' argue that seeking

${ }^{3}$ In the early stages of the crisis in Darfur, Sudan, Juan Méndez was the Special Advisor to the UN Secretary-General on the Prevention of Genocide. He visited Darfur twice in that capacity. 
criminal accountability hampers the peace process. The ICC's intervention in Uganda has produced a large body of literature arguing for the priority of one value over the other, presuming that peace and justice are dichotomous choices. ${ }^{4}$ While it may be true that the demands of justice may complicate peace negotiations, it also creates a more sustainable solution at the end of the process by laying the foundation for a culture of accountability. Negotiations that sacrifice accountability for an immediate peace create obstacles to redress for victims and communities, which is needed to create a fair and lasting resolution to violent tensions.

Justice, understood here as criminal accountability, forms one of the available measures or policies that can lead to conflict resolution, but in almost every case it cannot be the only one. Mediators, conflict resolution specialists, the parties to the conflict and victims and civil society working together will have to come up with a combination of measures most appropriate to the unique circumstances of each conflict. As a conflict evolves through different phases, initiatives in each of the four tracks need to be adapted and combined in a dynamic and anticipatory response to events.

Breaking the cycle of impunity is central to the 'justice track' of peace making, as it is necessary to prevent the repetition of violations and to dismantle the structures that enable violence in the first place. Of course, nothing can provide a guarantee against the re-articulation of these structures in the future or the formation of new ones that lead to abuses. This does not mean that prevention is not a proper motive for justice measures. We may not have empirical proof that prosecution of international crimes prevents their recurrence in the future, but we do know that a climate of impunity is an invitation to perpetrators to commit new abuses and perhaps even to escalate existing conflicts.

Criminal prosecution is an essential ingredient of any effort, but it should never be contemplated as the only response. In the early 1990s, some observers interpreted the creation of the International Criminal Tribunal for the Former Yugoslavia (ICTY) as a token gesture by an international community that could not manage a more robust response to the genocidal campaigns in the Balkans. To the credit of the ICTY, its impartiality and independence - as well as the continuation of atrocities

${ }^{4}$ For different positions on this debate, see T. Allen, Trial Justice: The International Criminal Court and the Lord's Resistance Army (London: Zed Books, 2006); A. Branch, Displacing Human Rights: War and Intervention in Northern Uganda (New York: Cambridge University Press, 2011); P. Hazan, Judging War, Judging History: Behind Truth and Reconciliation (Palo Alto, CA: Stanford University Press, 2010). 
in the region - soon prompted other actions, albeit never enough and never on time. In fact, criminal accountability can serve to prevent future atrocities only if it is seen as one dimension of a larger peace-making objective that needs to be coordinated with effective armed protection of civilian populations, with distribution of humanitarian assistance, and with genuine, comprehensive efforts at resolving conflict. At the same time, actors must ensure that they do not permit the parties to the conflict to condition their consent to any one of these four components upon progress on any other. If each aspect is contingent upon another, the risk of failure increases considerably. All four must be pursued individually, yet in a coordinated fashion and in good faith.

The risks of an uncoordinated approach are substantial. In the Darfur conflict, for example, the Sudanese government played the different processes against each other, often holding hostage the access of humanitarian organisations to conflict zones in retaliation for peacekeeping and justice interventions. The international community acceded to Khartoum's demands on a number of occasions, possibly prolonging the move towards a peaceful resolution. In Uganda, delivering humanitarian assistance directly into the hands of the Lord's Resistance Army (LRA) leadership as a means to encourage engagement in the Juba peace talks had the effect of emboldening the LRA leadership to defy the ICC arrest warrants and demand more concessions during negotiations. International actors should be encouraged to support peace efforts, including the provision of incentives to the parties of a conflict. At the very least, those measures should not work at cross-purposes with judicial efforts and should be carefully coordinated to integrate peace with justice.

\section{Case study: Ahmed Harun}

The case against Ahmed Harun in the Darfur situation illustrates the need for an integrated approach. For three years, mediators and political leaders ignored the arrest warrant against Harun as they pursued a threetrack approach that included political negotiation, peacekeeping and humanitarian aid, but excluded accountability. While the first substantial steps towards resolving the Darfur situation were the establishment of the UN Mission in Sudan and the ICC referral in March 2005, ${ }^{5}$ in practice the use of peacekeeping, political negotiation, and humanitarian aid dominated the process. The Bashir regime refused to cooperate with ICC

5 See UN Doc. S/RES/1590 (2005) and UN Doc. S/RES/1593 (2005), respectively. 
investigations and threatened to withdraw its consent to the other three tracks if the warrants were not dropped.

Harun played a role in hindering the provision of humanitarian assistance, and as a member of the African Union/United Nations hybrid operation in Darfur (UNAMID) oversight committee he also hindered the deployment of peacekeepers. In June 2007, one month after the arrest warrant against Harun was issued, the UN Security Council visited Khartoum and failed to raise the matter of enforcing the warrant with the Sudanese government. In 2008, Harun intervened in Abyei on the border between North and South Sudan, leaving 60,000 people displaced. For three years, the Security Council failed to remind Sudan that the referral, a decision under Chapter VII, was binding on all member states. This was not an oversight, but rather a deliberate decision to sequence peace first followed by justice. As a result, neither peace nor justice was attained.

Despite Harun's indictment by the ICC, he continued to serve as the Minister of State for Humanitarian Affairs and later as the governor of South Kordofan. In early 2011, with escalating tensions in the Abyei region on the border between North and South Sudan, the United Nations decided to fly Harun to the region to serve as a mediator in the crisis. While this act may have been practical under the circumstances, and although the United Nations is not required to assist the ICC in apprehension of wanted persons, it undermined the UN commitment to cooperate with the ICC and harmed efforts to disarticulate the cycle of impunity stemming from the crimes committed in the Darfur region.

The Harun case illustrates that justice cannot be subject to bargaining, nor should it be subjected to the vagaries of peace processes. To maintain legitimacy, it must be allowed to work in its own separate channel, albeit one that interacts with, supports and requires support from the other channels to peace. As the UN Secretary General has noted,

Ignoring the administration of justice ... leads to a culture of impunity that will undermine sustainable peace. Now that the ICC has been established, mediators should make the international legal position clear to the parties. They should understand that if the jurisdiction of the ICC is established in a particular situation, then, as an independent judicial body, the Court will proceed to deal with it in accordance with the relevant provisions of the Rome Statute and the process of justice will take its course. $^{6}$

${ }^{6}$ Report of the Secretary-General on Enhancing Mediation and its Support Activities, UN Doc. S/2009/189 (2009), 37. 
The ICC and other international justice mechanisms are foremost instruments of justice, and only secondarily instruments of peace or of prevention. However, these mechanisms do not operate in apolitical or decontextualised settings, as they are sometimes depicted. Political, security and humanitarian concerns often form part of the contextual backdrop in which justice mechanisms operate, and a more effective peace-building strategy should seek to understand the complex network of relationships between these different tracks.

\section{Acceptance of the 'justice track'}

States made a conscious decision in Rome to connect peace and justice, as is reflected in the Rome Statute preamble. By providing for interaction between the Court and the UN Security Council, the 'justice track' has been envisioned as a complement to political, security and humanitarian 'tracks' in international peace processes. This vision was put into practice as early as March 2005 with Security Council Resolution 1593 on Darfur, which invoked peace and security concerns as a basis for referring the situation to the ICC. ${ }^{7}$ The Rome Statute has created new rules to which actors involved in conflict management must adjust. The new framework and specific provisions - such as Article 27(2), which negates claims for immunity based on a suspect's official capacity - are already factored into contemporary peace efforts.

Justice through the Rome Statute framework has affected the dynamics of peace making at the United Nations. There are many indications that the ICC has received increasing attention from the United Nations. For example, the UN General Assembly debates and adopts an annual resolution expressing support for the ICC and encouraging participation by member states. ${ }^{8}$ Furthermore, states parties to the ICC that are members of the Security Council keep ICC issues on the agenda. ${ }^{9}$ Meanwhile, UN Secretary General Ban Ki Moon has stated that '[i]nternational criminal justice, a concept based on the premise that the achievement of justice provides a firmer foundation

${ }^{7}$ UN Doc. S/RES/1593 (2005), 1, 'Determining that the situation in Sudan continues to constitute a threat to international peace and security.'

${ }^{8}$ See, e.g., Report of the International Criminal Court, UN Doc. A/RES/65/12 (2011).

9 'States Parties that are members of the Security Council should ensure that the Court's interests, need for assistance and mandate are taken into account.' Recommendation 51, Strengthening the International Criminal Court and the Assembly of States Parties, Resolution ICC-ASP/6/Res.2 (2007). 
for lasting peace, has become a defining aspect of the work of the organization'. ${ }^{10}$

In addition to receiving significant expressions of support from the United Nations, the Rome Statute system has enjoyed widespread ratification by states and increasing support from non-state parties. Since 2002, when the Rome Statute entered into force with the ratification of sixty states, more than sixty other states have joined the ICC. Its jurisdiction covers all of Western Europe, all of South America and the majority of African states. Evolution of the role of states that are not parties to the Statute has also been significant. In an address to the Council on Foreign Relations, Luis Moreno-Ocampo, former prosecutor of the ICC, discussed the shadow the ICC throws over all states, even non-state parties. He commented that:

In my 6-year tenure, I saw a great evolution. I just mentioned the case of Turkey, a State not party. The Chinese authorities describe themselves as a 'Non State Party partner of the Court'; Russia sent more than 3000 communications to my Office on alleged crimes committed in Georgia; my Office regularly interacts and cooperates with Qatar, Egypt, Rwanda, and regional organizations such as the League of Arab States. Since 2005, the United States has followed a similar policy of constructive engagement with the ICC ... Today, the new administration is also very supportive, including on our efforts to open an investigation in Kenya. US cooperation is important to arrest individuals protected by militias as Joseph Kony or to isolate others such as President $\mathrm{Al}$ Bashir. ${ }^{11}$

Collaboration between the ICC and individual states as well as regional actors is also an indication of the Court's growing presence within the broader field of peace making. The ICC's Office of the Prosecutor (OTP) has worked with African Union (AU) mediators in Kenya, Darfur and Guinea; with the Organization of American States regarding Colombia and Honduras; and with the League of Arab States. All European Union states are states parties, and to date they have consistently insisted on implementation of the Court's decisions. The ICC and the justice track it elicits have shaped how states and intergovernmental organisations have come to conceptualise peace making. The following section illustrates some concrete examples of the Court's effects upon the geopolitics of peace making.

${ }^{10}$ Report of the Secretary-General on the Work of the Organization, UN Doc. A/62/1 (2007), para. 81.

11 Keynote speech by L. Moreno-Ocampo, Prosecutor of the ICC, to the Council of Foreign Relations (4 February 2010), 12-13. 


\section{Implementing the 'justice track'}

\section{Referrals and other decisions}

Where it has been impracticable to implement justice in domestic circumstances, many states have voluntarily involved the ICC in an attempt to resolve ongoing conflicts. In mid-2003, the prosecutor reported that crimes in the Ituri region of the Democratic Republic of Congo (DRC) appeared to fall within the jurisdiction of the Court. Almost 5,000 persons were killed after 1 July 2002 (the date in which the Rome Statute went into effect), and the Congolese government recognised its inability to control the area. There appeared to be no pending domestic judicial proceedings concerning these crimes, nor was it thought they could truly be undertaken. The prosecutor selected the DRC situation as the first to investigate, expressing his intention to use his proprio motu powers if necessary, but at the same time inviting the DRC to proceed with a referral, which it eventually did on 3 March 2004. Following a similar invitation from the prosecutor, President Museveni of Uganda also decided in December 2003 to refer the situation concerning the LRA.

In the search for peaceful solutions to conflicts, the UN Security Council has issued resolutions referring situations to the ICC. On 31 March 2005, it referred the Darfur situation to the Court, 'determining that the situation in Sudan continues to constitute a threat to international peace and security'. ${ }^{12}$ The Security Council subsequently used its referral power to open an investigation into the crackdown on protesters in Libya in an attempt to prevent further escalation of the violence. ${ }^{13}$ This resolution was quickly followed by other measures, including the use of military force to restore peace, but justice was central to the UN plan to end the conflict in Libya. As Gaddafi lost power in Libya, calls from inside and outside the country for the capture and transfer to the ICC of the deposed leader, his son Saif Al-Islam Gaddafi and Abdullah Al-Senussi underscore how accountability was considered central to creating greater stability in Libya. ${ }^{14}$ The Libyan referral was also the first time that the 'responsibility to protect' was invoked in relation to the ICC, suggesting that judicial institutions could be used as a means of strengthening prevention. As the UN Secretary General noted in a 2012 report, 'the threat of referrals to the ICC can undoubtedly serve a preventative purpose and the engagement

12 UN Doc. S/RES/1593 (2005). ${ }^{13}$ UN Doc. S/RES/1970 (2011).
14 See further Chapter 18 by Kersten in this volume. 
of ICC in response to the alleged perpetration of crimes can contribute to the overall response'. ${ }^{15}$

\section{Exclusion of amnesties from peace processes}

Not only is the granting of amnesty for crimes antithetical to the ideal of accountability, it can also be counterproductive to the reconciliation of a society to its past wrongs. This has been increasingly recognised in peacemaking practices, where criminal accountability has been favoured over the granting of amnesties. In the DRC, for example, there were discussions in 2007 of possible amnesties for senior commanders to encourage the demobilisation of armed groups. Following contacts between the OTP and the mediators, an 'ICC clause' excluding amnesties for Rome Statute crimes was incorporated in the Goma Agreement of January 2008. ${ }^{16}$ The former militia group leader, Mathieu Ngudjolo, was arrested and transferred to the Court by the Congolese authorities in the following month. Ngudjolo had agreed to be integrated into the Congolese Armed Forces and was in Kinshasa for training at the time of his arrest. Some observers claimed that his surrender could jeopardise the on-going demobilisation. It did not, however, and in February 2008, when the amnesty issue was raised again at a political dialogue in the Central African Republic, the ICC prosecutor was invited to brief participants in the dialogue. The resulting Global Peace Agreement of June 2008 excluded amnesty for war crimes, crimes against humanity and genocide. $^{17}$

In Colombia, prosecutors, courts, legislators and members of the executive branch explicitly mentioned the prospect of the ICC attaining jurisdiction as an important reason to implement Colombia's Justice and Peace Law, ensuring that the main perpetrators of crimes would be prosecuted. ${ }^{18}$ In Kenya, former Secretary General Kofi Annan, on behalf of the AU, maintained at all times that post-election violence had to be prosecuted in order to avoid recurring violence during the next election cycle, either through mechanisms established by the Kenyans or by the ICC. ${ }^{19}$

15 Report of the Secretary-General, Responsibility to Protect: Timely and Decisive Response, UN Doc. A/66/874-S/2012/578 (2012), para. 29.

16 'DR Congo: Cautious Welcome for Kivu Peace Deal', IRIN, 29 January 2008.

17 'Background Paper on Inclusive Political Dialogue', UN Peacebuilding Commission, Country-specific configuration on the Central African Republic (2008), para. 13.

18 See further Chapter 17 by Easterday in this volume.

19 'Kenya Needs Reforms to Avoid 2012 Violence - Annan', Reuters, 31 March 2009. 


\section{Integrating accountability into mediation efforts}

The requirements of accountability form part of any lasting peaceful solution. Other aspects of transitional justice are also fundamental for establishing peace, but the inclusion of measures ensuring accountability for those most responsible for international crimes has become a necessary part of any successful mediation effort. As shown above, seeking criminal accountability is one aspect where justice arises in negotiations. Yet, successful peace mediation will include both judicial and non-judicial elements.

The situation in Darfur illustrates the significant incentive that judicial interventions can provide for mediation efforts. Before the ICC prosecutor's application for an arrest warrant in 2008, the peace process had stalled; UN and AU envoys Jan Eliasson and Salim Salem, respectively, had resigned. The ICC indictment revived the negotiations. The AU and Arab League increased efforts to achieve peace, creating a committee headed by Qatar. A new UN-AU mediator was appointed. The United States, a non-state party to the Rome Statute, took a leading role.

President al-Bashir was effectively cornered through these developments. His government then engaged with the UN's Department of Peacekeeping Operations more actively than at any time before, and 65 per cent of UNAMID was deployed in the following six months. AlBashir's efforts to appear constructive led to renewed negotiations with the rebels, and the UN-AU mediator, Djibril Bassole, brought the parties to the negotiating table without ever challenging the ICC's independent work. ${ }^{20}$ In short, efforts to bring President al-Bashir before the ICC did not hamper the peace process; to the contrary, they may have had a decisive role in fostering it.

\section{Evaluating the impact of justice on peace and stability}

Implementing justice measures does not guarantee that the desired outcome will be achieved. This is true of all peace measures. The importance of justice does not stem from thinking of it as an instrument for the pursuit of social goods (such as stability, peace and legitimacy), but rather from the idea that benefits to conflict-affected communities and building the rule of law are ends in themselves.

20 The AU eventually called upon the Security Council to suspend the ICC actions under Article 16 of the ICC Statute, which the ICC has not done. Otherwise, the AU has never acceded to Khartoum's demand that it put pressure on the ICC to drop charges. 
Such claims about the worth of international justice efforts are difficult to demonstrate empirically. This may especially be the case with demonstrating deterrence - namely, that further violence has been prevented through judicial interventions - and with demonstrating that alleged perpetrators have been marginalised. The following sections address these two aims of international criminal accountability. Drawing upon specific examples from the experience of the ICC, they show how justice can be used to promote peace and stability through preventing further conflict and marginalising alleged perpetrators.

\section{Preventing violence}

It will always be difficult to establish a causal connection between a certain act of justice and its deterrent effect upon criminal conduct that did not take place by virtue of that act. However, this does not disprove the claim that punishment has preventative effects. In essence, attempting to measure international justice is a process of measuring the counterfactual. Specific penalties may not have a deterrent effect, but there is deterrence in the likelihood of punishment. The deterrent effects of international and domestic criminal justice efforts can be more reliably assessed once the system is more developed and its results more reliably predicted. Meanwhile, the certainty of criminal investigation and prosecution is central to achieving deterrent effects. Now that a permanent institution exists to prosecute international crimes, there are increasing signs of the justice track's deterrent effects.

Although the deterrent effects of judicial interventions may be generally difficult to measure, these claims can be substantiated in specific cases. Drawing upon one of the authors' experience as Special Advisor to the UN Secretary General on the Prevention of Genocide, the following examples illustrate the importance of integrating accountability measures into conflict prevention. In the first instance, during two official UN visits to Darfur in 2004 and 2005, it was evident that the circumstances of protracted impunity were complicating peace-building efforts. The fact that crimes committed against the civilian population of Darfur remained unpunished had a paralysing effect upon other measures taken by the international community to prevent the conflict from escalating. The perpetrators were still armed and active in the region, and their supporters in the Sudanese government were still ready to unleash the janjaweed and to provide them with logistical and combat support. Within that context, international observers strained to conduct serious 
monitoring on the ground, and armed peacekeeping contingents could not distinguish between people armed in self-defence and militias that used their weapons to commit atrocities.

Likewise, the presence and activity of the perpetrators seriously impaired the delivery of relief assistance, making it more difficult to prevent violence through a cease-fire, let alone a comprehensive peace accord. Equally important, the widespread impunity made it impossible for internally displaced populations to make their own decisions about whether to return to their villages. The fact that millions of individuals were dependent on others for even their most basic needs and were still threatened made peacekeeping, humanitarian assistance and peace negotiations more difficult. All four tracks of conflict prevention - political, security, humanitarian and justice - require the active participation of victims and their community representatives.

Meanwhile, the threat of prosecution can contribute to preventing further conflict. In November 2004, the conflict in Ivory Coast escalated to the scale of mass atrocities based upon ethnicity or national origin of groups considered 'non-Ivoirien' by the Gbagbo government. Armed militias in the countryside and mobs of 'Jeunes Patriotes' in Abidjan threatened to attack those considered non-citizens even if they had been born in the country. The Ivorian airwaves were filled with hate speech. As Special Advisor, I urged action by Kofi Annan and the Security Council. Because Ivory Coast had accepted the jurisdiction of the ICC in 2002 and the Statute included instigation to commit genocide as a crime under its jurisdiction, it could be announced publicly that those responsible for incitement to violence could face prosecution in The Hague. The press release was widely publicised in Abidjan, and after 48 hours, the racial hatred being expressed on radio and TV ceased; calm returned to the capital. It was later established that individuals in authority and their legal advisors had carefully analysed the prospect of ICC prosecution.

Based upon such experiences of the potential preventative force of the threat of prosecutions, the OTP's strategy commits to providing early information on its activities and to alert states and organisations of the commission of Rome Statute crimes. In Georgia, for example, the OTP made public statements affirming that it had jurisdiction over alleged crimes as soon as violence started in August 2008. Both parties pledged cooperation with the Court. The OTP visited Georgia in November 2008 and Moscow in February 2010, following the governments' invitations. The fact that these two countries chose to resolve the remaining issues of the 2008 conflict lawfully is an important step. In Guinea, the OTP 
announced in mid-October that it was monitoring the allegations of crimes committed against civilians on 28 September 2009. Six days later, Guinea's minister of foreign affairs met with the OTP to offer cooperation, and the OTP visited Conakry in February 2010. In Kenya, the OTP stated as early as January 2008 that it had jurisdiction over alleged crimes. All actors then committed to addressing and preventing political violence. In all three examples, it is plausible to assert that the decision to cooperate with the investigation and punishment of crimes had an important effect on the reduction of violence and on the reduced scope and extent of new violations. The OTP continues to assert its commitment to prevention, as reflected in its 2012-2015 Prosecutorial Strategy.

Finally, the events of the 'Arab Spring' may provide further support for claims regarding the deterrent effects of the justice track. Even though it is not possible to say with certainty that the threat of ICC prosecution has played a role in avoiding greater loss of life, some relationships are clear. The new Tunisian government has signed and ratified the Rome Statute. It is also investigating human rights crimes of the 'revolutionary period' from December 2010 to January 2011. Opening a regional seminar on the ICC in Tunis, Mohammed Charef, attorney general and director of Judicial Services of the Ministry of Justice, encouraged more states to join the ICC. ${ }^{21}$ As the Court's jurisdiction is extended through further ratifications of the Statute, the possibility of preventing violence through the threat of international criminal accountability continues to increase.

\section{Marginalising alleged perpetrators}

Justice can also contribute to peace building through isolating and marginalising alleged perpetrators and violent regimes. International and domestic allies will often distance themselves from those who stand accused of violating international law, thus weakening the support that repressive regimes depend upon to maintain their power. Marginalisation builds upon itself: as more allies turn away from a regime, more are inclined to do the same. As a regime is weakened, incentives - in the form of both showing international goodwill and deferring to international pressures - arise for other states to aid in the detention and transfer of alleged criminals. Although some commentators have argued that this has effectively politicised the ICC's work and

21 'Opening of the Regional Seminar on the ICC in Tunisia', ICC Press Release, 19 September 2011. 
tends to reinforce the power of strong states, such critiques do not account for the constructive effects that marginalising alleged perpetrators may have on ongoing peace processes. ${ }^{22}$

Several examples illustrate how this marginalisation can contribute to peace building. At the time of the Dayton agreement for the former Yugoslavia, there were pressures on the ICTY to revoke the arrest warrants against Radovan Karadžić and Ratko Mladić so that they could participate in negotiations. There were fears that criminal prosecution would be an obstacle to a negotiated end to the conflict. Despite this pressure, ICTY president Antonio Cassese and Prosecutor Richard Goldstone refused to suspend actions against the accused. The exclusion of both suspects from the talks contributed to the successful end of the conflict. Based on such experience, the ICC's OTP has called on states to 'eliminate non-essential contacts with individuals subject to an arrest warrant issued by the Court' and to 'contribute to the marginalization of fugitives', while 'tak[ing] steps to prevent that aid and funds meant for humanitarian purposes or peace talks are diverted for the benefit of persons subject to a warrant. ${ }^{23}$

Meanwhile, President al-Bashir of Sudan has been isolated through the issuance of an ICC arrest warrant against him. Legally, he cannot travel to states parties to the Statute. South Africa informed him in 2009 that although he was invited to the inauguration of President Zuma, he would be arrested upon entry into the country. ${ }^{24}$ Uganda and Nigeria did the same. Presidents Lula of Brazil and Fernández de Kirchner of Argentina refused to approach him in an Arab-South America summit in March 2009. President Sarkozy took the unprecedented decision to postpone and relocate a French-African summit rather than run the risk of meeting him in a corridor. Turkey had him cancel an appearance at an Organisation of the Islamic Conference meeting in Ankara. Al-Bashir did visit Kenya, a state party to the ICC, in August 2009. While the Kenyan government did not uphold its obligation to arrest the Sudanese president, the episode resulted in much international embarrassment

${ }^{22}$ See, e.g., S. Nouwen and W. Werner, 'Doing Justice to the Political: The International Criminal Court in Uganda and Sudan', European Journal of International Law, 21 (2010), 941-965.

${ }^{23}$ Office of the Prosecutor, 'Prosecutorial Strategy 2009-2012' (2010), 48.

${ }^{24}$ In an apparent reversal, Bashir was subsequently allowed to attend an African Union summit in South Africa in 2015 and later permitted to depart, in violation of an order from the South Africa High Court that he not leave the country. See M. Cohen, 'Al-Bashir Sets Up High Court and Zuma Administration Clash’, Mail \& Guardian, 23 June 2015. 
(including the summoning of Kenyan ambassadors to explain the failure), extensive complaints from civil society and a rift in the coalition government. A year later, in August of 2010, an International Authority on Development conference that was to be attended by al-Bashir was moved from Kenya to Ethiopia (a non-state party) under pressure from the ICC that the Kenyan government fulfil its obligations both under the Rome Statute and under Kenyan law. ${ }^{25}$ Al-Bashir's capacity to travel has been restricted, and the Sudanese government now deploys fighter aircraft to escort his plane on any trip. The ease with which South Sudan's secession occurred may have been influenced by the fact that al-Bashir's regime, isolated and weakened from the pressure of the ICC warrants, must act reasonably on the international stage in order to retain its remaining power and alliances.

The Libyan situation provides another example of the power of marginalisation. Colonel Gaddafi's Libya had been considered a pariah state for many years before Gaddafi lost power during the 'Arab Spring'. After the ICC issued an arrest warrant against him, his remaining supporters distanced themselves. Referring to the warrant, the spokesman for the Transitional National Council claimed, 'This is very important. These people have caused nightmares over the last 42 years. This sends a very clear signal to all those around Gaddafi that no one is exempt. It will speed defections and desertions, and minimise deaths as much as possible. ${ }^{26}$

\section{Conclusion}

At the international level, the ICC serves as the sole permanent institution where international crimes are adjudicated. Its contribution to peace building is tied to the deterrent and marginalising effects of its capacity to prosecute crimes and, by extension, to contribute to international security. As the Court's current prosecutor maintained, 'Since the International Criminal Court became operational in 2002, we have witnessed an unprecedented integration between peace and security and international justice. ${ }^{27}$ The Court's impact in deterring violence will emanate from the certainty of application of its law. Commentators have observed that 'trials deter future human rights violations by

25 'IGAD Summit Moved From Kenya As ICC Demands Arrest of Sudan's Bashir', AllAfrica, 26 October 2010.

${ }^{26}$ A. Gilligan, 'Libya: Col Gaddafi regime dismissed ICC arrest warrant requests', The Telegraph, 16 May 2011.

27 F. Bensouda, 'International Justice and Diplomacy', The New York Times, 19 March 2013. 
increasing the perception of the possibility of costs of repression for individual state officials' ${ }^{28}$ The impression that they will be held to account for their acts will compromise the calculus of leaders seeking to use violence to gain or retain power.

Defining the conflict as a dilemma of peace versus justice, some commentators have argued that by pressing for justice, the rational calculus of any violent regime is to hold on to power so as to avoid prosecution. However, the ultimate goal is not just the immediate end to hostilities, but the establishment of lasting peace. Certainty that law will be applied is therefore a key means of contributing to this goal. The calculus of a regime changes when, because of the pressures of international justice, it becomes isolated and has less power or credibility in negotiations. As was seen with the resolution of conflicts in Sierra Leone and the former Yugoslavia, international justice mechanisms can contribute to the peace process by marginalising offenders from other actors who can be brought into the process.

For justice to have an impact, it must be able to preserve the integrity of its objectives. Prosecutor Bensouda has maintained that the ICC's work must remain independent of other interests, yet in working towards its objective of criminal accountability, it still contributes to peace and security:

As the [ICC] is an independent and judicial institution, it cannot take into consideration the interests of peace, which is the mandate of other institutions, such as the United Nations Security Council. However, justice can have a positive impact on peace and security: this is what the U.N. Secretary General, Ban Ki-moon, calls the 'shadow of the Court' - its preventative role, and its capacity to diffuse potentially tense situations that could lead to violence by setting a clear line of accountability. ${ }^{29}$

As the prosecutor claims, justice contributes to conflict prevention when it is pursued for its own sake. If the ICC is contemplated simply as a lever, however, it will be undermined, as some will expect it to be turned on and off as political circumstances dictate. Justice contributes to peace precisely by concentrating on its own specific role for the benefit of victims and for the contribution that it makes to the long-term stabilising effects of the rule of law.

The 'justice track' thus complements political, humanitarian and security objectives, and it is a necessary dimension of post-conflict

${ }^{28}$ K. Sikkink and H. Kim, 'Do Human Rights Trials Make a Difference?', American Political Science Association annual meeting (Chicago, August 2007).

${ }^{29}$ F. Bensouda, 'International Justice and Diplomacy'. 
peace building. Persuasive scholarship has argued that creating cultures of accountability is instrumental in establishing the basis for peaceful societies. ${ }^{30}$ Although the precise relationship between cause and effect may not be fully understood, the examples taken up through this chapter illustrate how justice encourages the prevention of further conflict and the marginalisation of alleged perpetrators by disarticulating structures of violence. In considering the ICC as an element of the 'justice track', it should not be regarded as an isolated legal institution but rather as part of a dynamic and multi-tracked peace-making process.

${ }^{30}$ See, e.g., K. Sikkink, The Justice Cascade (New York, NY: W.W. Norton \& Company, 2011). 


\section{INDEX}

accountability

and conflict prevention, 489

and international criminal law, 352

and the the International Criminal Court (ICC), 433

rationale of, 70

Acholi ethnic group, 149, 155

acquittals

in international trials, 257-259, 269

admissibility, 3

challenge by Kenyan government, 210-211

challenge by Libyan government, 475 criteria for, 125

Afako, Barney, 168

Afghanistan

community-based justice, 135-137

interests of justice

rationale for, 137-139

Ministry of Justice of, 135

post-Taliban, 123

African states

and neoliberalism, 277-283

and rule of law, 277-283

African Union (AU)

and Arab League, 458, 488

roadmap, 465

Twelfth Extraordinary

Summit, 214

high-level panel, 464

UNAMID, 483, 488

Al-Bashir, Omar, 179, 212, 232, 468, $469,485,488,492,493$

Al-Senussi, Abdullah, 66, 457, 469, 470, $471,472,473,475,486$

amnesty, 140-142

Amnesty International, 26, 379, 385
Annan, Kofi, 203, 204, 207, 283, 487, 490

Arab League, the, 458

Arab Spring, 456

and Libya, 457

events of, 491

Arab states

and request for ICC help, 458

Arbia, Sylvana, 383

Arendt, Hannah, 354

Armed Forces Act, 394

Assembly of States Parties (ASP), 16-17, 287, 309

Bensouda, Fatou, 273, 275, 309, 358

bespoke transitional justice, $112-117$

Bongi trial, 426

Brahimi Report, 46

Brahimi, Lakhdar, 123

Branch, Adam, 29, 62

Butler, Judith, 375

Case Matrix, 464

Cassese, Antonio, 55, 492

Central African Republic (CAR), 296-299

Chieftaincy of Military Intelligence, 217

child soldiers, 199, 293

conscripting and enlisting of, 179

civil society intermediaries, 247-248

Coalition for the International Criminal Court (CICC), 238, 267, 273, 379

Coalition on Violence Against Women (COVAW), 216

Cold War, 357

Colombia

and peace agreements, 441-443 
and the International Criminal

Court (ICC), 432-434, 438-439

approach to the ICC, 446-450

Colombian conflict, history of, 436-438

Constitution of, 441

Constitutional Court of, 448

FARC negotiation process, 434,437 , $446,447,451,452,453$

history of conflict, 432, 436-438, 444, 455

impact of conflict on, 455

international justice discourse / norms, 450

legal vernacular in, 451

National Commission of Reparation and Reconciliation, 451

Supreme Court trials, 444

the Santos government and, 454

transitional justice legal framework, 433,450

trials of the military in, 445

Victim's Law and Property Restitution, 451

Victims Law, 451

community based organisations (CBOs), 4, 354, 375

Commission of Inquiry into the PostElection Violence (CIPEV), 202, 394

Commission on Peace and Reconciliation, 254-257

Commonwealth's Model ICC Law, the 460

complementarity, 177, 216

and community-based justice, 124-127

and implementation of the Rome Statute, 380

and the ICC, 147-148

challenges facing the ICC, 102

'positive complementarity', $11,154,173,177,179,196,216$, 433, 439, 474, 477

conflict prevention

and accountability, 489

conflict-affected communities and acquittals, 257

cooperation, state, $12,100,103,143$, 191, 194, 196, 446

cosmopolitanism

theories of, 28

courts

military, 17, 178, 187, 410, 423, 425,445

Darfur conflict, 482-484

de Greiff, Pablo, 74

de Waal, Alex, 363

Declaration of Basic Principles of Justice for Victims of Crime and Abuse of Power, 286

Democratic Republic of the Congo (DRC), 292-296, 315, 327

1972 Judiciary Military Code, 422

AFDL (Alliance des forces démocratiques pour la libération du Congo), 173

and the Rome Statute, 408

and the Trust Fund for Victims, 372

Congolese war, 179 peacekeeping mission, 343

Congolese armed forces (FARDC), 412,487

Congolese legal community international support for, 185-189 and the Military Criminal Code

(MCC), 419-422

Constitution of, 410

Cour de cassation, 171

crimes in Ituri region, 486

domestic trials and the Rome Statute in the DRC, 422-430

ratification of the Rome

Statute, 419

FARDC, 411, 427, 428, 487

FRPI (Forces de résistance patriotique de l'Ituri), 183

Goma Agreement, 487

Hema, 334-336, 343, 345-347

Hema population, 67

High Military Court of, 410

human rights violations, 416, 431-432, 444

Inter-Congolese Dialogue, 177, 343 
Democratic Republic of Congo (cont.) implementation of the Rome Statute, 413-416

Ituri wars, 333-335, 343, 345-347

military tribunals, 428

and the Rome Statute, 422

peacekeeping, 482, 490

Procureur général de la République, 186

Rassemblement Congolais pour la Démocratie - Mouvement de Libération

(RCD-ML), 179, 183-184

role of the ICC and, 292-296

Rome Statute, 412-416

the legal system of, 408-409

Truth and Reconciliation

Commission, 176, 343

UN Mission, 189-192, 235

Union des patriotes congolais

(UPC), 67, 179

development, 254-257

dispute mechanisms

community-based, 123

Dolan, Chris, 155

Drumbl, Mark, 403, 436

Dyilo, Thomas Lubanga, 15, 188, 293, $311,331,336,408$

ICC charges and, 179-182

emancipation, ethics of, 72-74

EMOI ('Integrated Operational Head Command'), 184

expressivism, 450-454, 382-385

Extraordinary Chambers in the Courts of Cambodia, 308

FARC negotiation process, 446, 452

Fassin, Didier, 353, 370, 372

field offices, 292, 367, 372

Finnemore, Martha, 434

Foucault, Michel, 373, 436-438

Gaddafi, Muammar, 66, 457, 471, 486

possibility of exile, 465-466

removal of, 464-465
Gaddafi, Saif Al-Islam, 66, 101-102, 457, 470, 486

Gaynor, Fergal, 274, 275, 291

Gbagbo Laurent, 490

Geertz, Clifford, 453

Genocide Convention of 1948, 479

global governance, 4, 20, 69, 285

global institutionalism

criticisms of, 68-69

global justice

and the ICC, 107-108

Global Peace Agreement, 487

Goldstone, Richard, 131, 492

Goma Agreement, 487

gross human rights violations

in Kenya, 217-218

Halilović case, 257

Harun, Ahmed, 482-484

Historical Memory Group, 451

Holocaust, 27, 29

human rights, 66, 206-207, 217-218, 354-356, 382-385, 416

legal protection of, 382

protection at the international level, 354-356

human rights organisations

as intermediaries, 206-208

human rights standards

and the ICC, 66

Human Rights Watch, 385, 387

humanitarian government, 360

humanitarian sentiments and international criminal law, 355

humanitarianism, 361-364, 371-373

'legal humanitarianism', 16-17, 353,372

the Court's description of, 375

hybrid tribunal, 17, 205, 417

International Criminal Court, 2, 352, 173-176, 408

African countries and, 34, 36

and the role of civil society, 223-225

and Libya, 458-462

history of, 97-101

Assembly of States Parties (ASP), 451 
civil society, 247-248

compulsory power, 5

effects in African states, 8

European influence, 35

genesis of, 2-5

historical event analysis, 65-66

human rights standards and, 66

in Colombia, 432-434

in Libya

the West's support of, 466-469

institutional structure of, 4

intermediaries relationship, 233-237

international bodies and the, 4

International Criminal Court (1998), 399

international justice, 55-60

juridified diplomacy, 108

Kenyan govenment failure to cooperate with, 211-212

Kenyan government efforts against, 208-211

Legal Tools project, 463-465

legitimacy of, 117, 120

limitations of outreach, 257

local connections and, 79-81

Lubanga case

and intermediaries, 230-232

mandate of, 3, 70-72

Office for Public Counsel of Victims, 119

Office of Public Counsel for the Defence (OPCD), 473-475

Office of the Prosecutor (OTP), 485

outreach development and, 254-257

Outreach Programme of, 260

outreach programmes and, 266-268

Outreach Unit of, 7

outreach

challenges to, 251-252

patrons of, 31-36

proceedings and delocalisation, 64

proceedings and social engineering, 64

restorative work of, 353

Review Conference, 17

role of, 137

criticism of, 144

roles of, 479-480
Rules of Procedure and Evidence, 14, 254, 367

the Arab world, 456

the role of intermediaries, 225-230

the role of NGOs, 223

transitional justice, 106-107

Trust Fund for Victims, 4, 219, 287, 359

Trust Fund for Victims (TFV), 216, 287

victimhood, 272-277

victims rights, 302

'imagined victim', 15, 310-313

Inter-Congolese Dialogue (ICD), 175

intermediaries, 206-207, 219, 225-230, 237-239, 247-248

framework, 237-239

guidelines, 239-245

international criminal tribunals

history of, 90-101

International Center for Transitional Justice, 159

International Commission of Jurists, (ICJ-Kenya), 210

International Commission on Intervention and State Sovereignty (ICISS), 284

International Crimes Act (ICA), the in Kenya, 395

International Crimes Division (ICD), 11

International Criminal Tribunal for Rwanda, 1, 90, 426

ICTR, 1, 90, 93-97 political functions of, 94

ICTR's Statute, 94

International Criminal Tribunal for the former Yugoslavia (ICTY), 90, 251, 308, 355, 481

ICTY, 1, 90, 93-97, 251

as token gesture, 481

political functions of, 94

ICTY's outreach, 333-335

international criminal tribunals

and cosmopolitan arguments, 29-30

and criminal trials, 89

and justice, 87

and legitimacy of, 23 
international criminal tribunals (cont.) and restorative justice, 286-290 and retributive justice, 286-290 as instruments of diplomacy, 89 as judicial institutions, 263 as tools of diplomacy and politics, 88 expectations of outreach programmes, $268-270$ means of understanding them, 86

perceptions of, 264-265 vs. truth commissions, 87

International Military Tribunal for the Far East, 90, 157, 286

International Monetary Fund (IMF), 354

International Peace Conference, 283 international trials and acquittals, 257-259 low sentences, 259-260 Ituri conflict, 67 Ivory Coast, 490

Jirga, 203

Juba Accords, 133, 134, 155-158, 482

Jubilee Alliance, 213

judicialisation criticism of, 68-69

juridical classification and international criminal law, 373

juridified diplomacy, 85, 88-89, 112 and international criminal courts and tribunals, 86 and the ICC, 106, 108 and the ICTR, 93 and the ICTY, 93 paradigms of, 89-90 Jurisdiction, Complementarity and Cooperation Division (JCCD), 177

justice, 87 community-based, 124-127 criminal accountability, 481 importance for peace, 488 interests of, $130-132,137$ rationale for, 137-139 local ownership of, 132 restorative, 376

justice cascade, 434

Justice Law and Order Sector (JLOS), 159,390

and the Amnesty Act, 167-169

Justice and Peace Law (Colombia), 17, 441, 487

justice sector

formal vs. informal, 136

Kabila, Joseph, 335, 409, 413, 419, 430

Kabila, Laurent-Desire, 173

Kahwa decisions, 425

Kampala Review Conference, 49, 159

Katanga, Germain, 67, 81, 182-185, $187,260,345,348,408$

Kenya

attack on intermediaries, 232-233

civil society advocacy, 213

Commission of Inquiry on Post-

Election Violence, 202, 394

domestic litigation, 215-216

election violence, 198

gross human rights violations, 217-218

ICC outreach programmes in, 208

implementation of the Rome Statute, 380-381

International Commission of Jurists-Kenya, 210

International Crimes Division, 11

international crimes, 394

Judicial Service Commission (JSC), 216

National Dialogue and Reconciliation Committee, 199

National Human Rights Commission (KNHCR), 201, 216, 292, 394, 485

Penal Code, 394, 483

reparations, 216

Special Tribunal for Kenya (STK), 203, 204, 400

the International Crimes Act (ICA), 217, 395

Truth Justice and Reconciliation Commission, 216, 290 
Waki Commission, 202, 205, 394, 405

witness protection programme,

$$
\text { 205-206 }
$$

Kenyan cases

in Kenya, 205-206

pre-trial stage

intermediaries and, 206-208

Kenyatta, Uhuru, 12, 110, 212, 213, 274, 365,381

Kibaki, Mwai, 200, 291, 393

Kibibi trial, 425, 428

Ki-Moon, Ban, 484, 494

Kituo cha Sheria, 207

Kony, Joseph, 150

Koskenniemi, Martti, 18, 26

Kosovo, 97

Kwoyelo, Thomas, 11, 148, 149, 161, 163-170, 397-400

Constitutional Court and Kwoyelo's trial, 163

League of Nations, 69

'legal encapsulation', 15, 275

legal humanitarianism, 353-354, 369,410

legal pluralism, 8, 16-17, 63, 381, 403

and victim participation, 364-369

Libya

history of conflict, 463-465

Libya Arab Jamahiriya, 460,462

Libya Working Group, 473

Organisation of the Islamic

Conference, 492

the ICC in, 456-459

unrest in, 457-458

local non-governmental organisations (LNGOs), 219

Lord's Resistance Army (LRA), 111, 133, 148, 388

Lubanga case, 54, 76, 80, 119, 227, 241 , $293,315,323,336-338,344,348$

and intermediaries, 230-232

judgment, 311 reparations, 327

Lumumba, Patrice, 343

mass atrocity crimes

victims of, 77-79

Mbarushimana case, 432

Mbarushimana, Callixte, 258

Médecins sans Frontières (MSF), 434

medical interventions, the Trust

Fund's, 374

memorialisation, 17,157

military courts, 17, 178, 410, 423, 445

Merry, Sally Engle, 403, 434

Military Court of South Kivu, 425

Military Justice Reform, 445

military justice system

in the DRC, 422

Military Tribunal in Equatorial Province, 423

Milošević, Slobodan, 97

Mitwaba trial, 426

MONUSCO, 343

Moreno-Ocampo, Luis, 3, 149, 172, $176,177,178,185,189,208,221$, 297, 309, 311, 438, 463, 473, 474,485

request to disqualify, 474

Moscow Declaration, 91, 99, 127

Museveni, Yoweri, 111, 149, 151, 160, 389, 486

Muthaura, Francis, 212, 213

National Implementing Legislation Database (NILD), 386

National Resistance Army/Movement (NRM), 153

NATO airstrikes, 464

NATO military intervention in Libya, 457

Nazi atrocities criminal trials for, 92

Ngiti fighters, 67, 185

NGOs and the International Criminal Court (ICC), 223-225

neoliberalism, 14, 276-283

non-governmental organisations

(NGOs), 223-225 
Ngudjolo case, 348

Ngudjolo, Mathieu 'Chui', 182-185, 187, 408, 487

Nouwen, Sarah, 20, 24, 290, 357, 383, 388

Ntaganda, Bosco, 181, 408

Nuremberg Military Tribunal, 354, 358

Nuremberg trials, 479

Odinga, Raila, 199, 291

Office of the Prosecutor (OTP)

Kenyan government issues, 211

intermediaries, 206-208

investigative failures, 189-192

Policy Paper on Victims' Participation, 14

Ongwen, Dominic, 216

Orange Democratic Movement (ODM), 199, 291

ordinary and international crimes, 384

Orentlicher, Diane, 265

Organization of the Islamic Conference, 458, 492

orphans and vulnerable children (OVC), 340

Otti, Vincent, 150

outreach, 7, 30-36, 63, 251-252, 254-257, 260, 268, 271

Palestine, xvii

Parliamentarians for Global Action (PGA), 382

Party of National Unity (PNU), 199, 291

peace-building process, 480-482

Permanent Cease Fire and Disarmament, Demobilisation and Reintegration, 156

perpetrators marginalisation of, 491-493 guidance for amnesty and, 141-142

Policy Paper on Victims' Participation, 14

political office

and accused persons, 212-215 political settlements, 20, 279, 357 post-election violence, $12,17,112$, 198-203, 206, 208-209, 215-217, 272, 275, 290, 394, 405, 487

politics of recognition, 342-344

positive complementarity, 3,433

in Libya, 474

post-World War II military tribunals, 357

Potsdam Declaration, 91

Project Rule of Law Index, 281

Public Information and

Documentation Section, 267

referrals

state, 4, 8, 176, 194

United Nations Security Council, 458

reparations, 216, 226, 317-320, 326-329, 334, 338-339, 342, 346-351, 366

and international criminal justice, 347-351

and the Ituri war, 346-347

as a form of power, 351

international criminal reparations, 326-329

vs. assistance, 330-332

Report on the Rule of Law and Transitional Justice in Conflict or Post-Conflict Societies (UN), 86

Responsibility to Protect, 52, 284, 457

restorative justice, 360-364, 376

and international criminal law, 357-360

'restorative turn', 354, 357-360

Review Conference of the Rome Statute, 390

Revolutionary Armed Forces of Colombia, 434

rights-based approach, 76

Rome Statute, 4, 15, 61, 69, 97, 402, 480, 484

Article 11 of, 462

Article 16 of, 461-462

Article 20(3) of, 384

Article 25 of, 387

Article 53, 128-129, 130-132

reciprocal rights and, 142-143 
Article 93 of, 143

Article 93(10) of, 384

as 'system of justice', 57

domestic implementation, 16-17, 382-385

negotiations, 357

principle of complementarity, 388

victim participation, 366

victims' rights, 376

Ruto, William, 110, 212, 213, 272, 273, 274, 381

Rwandan Defense Force, 179

Rwandan genocide, 28, 284

Schabas, William, 132

Second Congolese War, 411

Sen, Amartya, 332

sexual and gender-based violence, 16-17, 205, 215-217

Simpson, Gerry, 10, 85, 88, 108, 469

Special Court for Sierra Leone, 2, 267, 141

Special Tribunal for Kenya (STK), 400

Strategic Plan of the ICC's Outreach Programme, 269

Tadic decision, 422

Teitel, Ruti, 148, 359

Refugee Law Project (RLP), 210

Tokyo trials, 479

transitional justice, 85-91, 101-102, 106-107, 112-120, 450

and cultural experts, 118

and juridified diplomacy, 88-89

and Moscow and Potsdam

Declarations, 91

and peaceful solutions, 488

bespoke, 112-117, 118

and the ICC, 117-120

integration of with juridified diplomacy, 101-102

legitimacy of, 117

paradigm of, 89-90

transitional justice theory, 111

trial management strategies and associated risks, 453-454

Trust Fund for Victims, 4, 13, 76, 309, 340, 362, 368, 369 in Kenya, 371

in the DRC, 326, 372

in Uganda, 374

Uganda, 155

Acholi ethnic group, 149

Agreement on Accountability and Reconciliation (AAR), 157, 201, See also Juba Accords

Amnesty Act, 133, 159-161, 163, 167-169, 397-400

renewal of Part II, 398

Amnesty Committee, 482

as an ICC host state, 388-393

Committee on Legal and Parliamentary Affairs, 392

Commonwealth Model Law

complementarity in, 155, 159

conflict-affected communities, 152-153

Constitutional Court, 134

domestic war crimes division, 148 , 158-159

domestication campaign, 389

implementation of the Rome Statute, 389-390

internally displaced persons (IDP), 149

Juba Accords [Agreement on Accountability and Reconciliation], 133-134, 140

Juba peace process, 149, 155-158

Justice Law and Order Sector (JLOS), 159, 163, 165-170, 390, 393, 398-399

Kampala Review Conference, 49

legacy of violence, 153-155

Lord's Resistance Army (LRA), 42, 73, 111, 133, 139, 148, 193, 388,482

National Reconciliation and Transitional Justice Audit, 154-155

National Reconciliation Bill, 393

Penal Code Act, 162

Refugee Law Project, 148

Thomas Kwoyelo, 11, 148, 149, 161, 163-170, 397, 398 
Uganda (cont.) transitional justice, 165-167

Ugandan People's Defense Force (UPDF), 151

war crimes, 150

Uganda Coalition for the International Criminal Court (UCICC), 389

UN Basic Principles and Guidelines on the Right to a Remedy and Reparation, 75

UN Convention against Torture, 171

UN General Assembly

support of the ICC, 484

UN Mission in Congo, 189

UN Mission in Sudan, 482

UN peacebuilding and local ownership, 47

UN Secretary-General on the Rule of Law and Transitional Justice, 47

UN Security Council, 4, 8, 19

in Khartoum, 483

referral of Libya to ICC, 458-459

Resolution 1593 (2005), 99, 460, 461, 462,484

Resolution 1970, 459, 460, 462, 468,477

Resolution 1973, 464

UN Women and the UN Office of the High Commissioner of Human Rights, 167

UN's Department of Peacekeeping Operations

in Darfur, 488

UNAMID, 483, 488

United Nations Charter, 60, 93

United Nations Office on Drugs and Crime, 206

United Nations Secretary-General, 86

United Nations Security Council referrals, 459

Universal Periodic Review, 457

van den Wyngaert, Christine (Judge), $67,68,289$

vernacularisation, 434-435

Victim Participation and Reparations Section (VPRS), 366 victims

and international courts,

313-320

and reparations, 317-320

critical discourse, 306-310

'imagined victim', 15, 305

importance to international criminal justice, 324-325

individual responsibility, 260-261

'juridified victim', 39, 290, 299-301

legal rights, 302-305

livelihood assistance, 4, 16-17, 352

participation, 4, 13-14, 16, 19, 39, 49, 54, 65, 207, 219, 221, 223, 225, 229, 231, 291, 293, 313-315, 336, 353-354, 364-369, 375-376, 387, 414, 443, 455

protection, 283-286

reparations, 62, 326

targeting, 341-342

Victims and Witnesses Unit (VWU), 234

Victims Participation and Reparations Section (VPRS), 288

Victims' Rights Working Group, 288

violence

post-election, $12,17,112,198-203$, 206, 208-209, 215-217, 272, $275,290,394,405,487$

sexual and gender-based, 16-17, 205, 215-217, 341-342

structural, 15, 273

Waki Commission, 202, 205, 394, 400

Washington Consensus, 278

witness protection

and fair trials, 387

World Bank, 278, 280, 353

World Governance Indicators, 280

World War II trials, 354

World War II tribunals

legacy of, 480

Zintani militia, 476

Zuma, Jacob, 464, 465, 492 